\title{
Rescaling conflictive access and property relations in the context of REDD+ in Jambi, Indonesia
}

\author{
Dissertation \\ zur Erlangung des mathematisch-naturwissenschaftlichen Doktorgrades \\ "Doctor rerum naturalium" \\ der Georg-August-Universität Göttingen \\ im Promotionsprogramm Geowissenschaften / Geographie \\ der Georg-August University School of Science (GAUSS) \\ vorgelegt von
}

Dipl. Geogr. Jonas Ibrahim Hein

Geboren in Berlin

Göttingen 2016 
Betreuungsausschuss:

Prof. Dr. Heiko Faust

Abteilung Humangeographie, Geographisches Institut, Fakultät für Geowissenschaften und

Geographie, Georg-August-Universität Göttingen

Dr. Fariborz Zelli (Associate Professor)

Department of Political Science, Environmental Politics Research Group, Lund University (Sweden)

Prof. Dr. Christoph Dittrich

Abteilung Humangeographie, Geographisches Institut, Fakultät für Geowissenschaften und Geographie, Georg-August-Universität Göttingen

Mitglieder der Prüfungskommission

Referent: $\quad$ Prof. Dr. Heiko Faust, Abteilung Humangeographie, Geographisches Institut, Fakultät für Geowissenschaften und Geographie, Georg-August-Universität Göttingen

Korreferent: Dr. Fariborz Zelli (Associate Professor), Department of Political Science, Environmental Politics Research Group, Lund University (Sweden)

2. Korreferent: Prof. Dr. Christoph Dittrich, Abteilung Humangeographie, Geographisches Institut, Fakultät für Geowissenschaften und Geographie, Georg-August-Universität Göttingen

\section{Weitere Mitglieder der Prüfungskommission:}

Prof. Dr. Michael Flitner, Artec, Forschungszentrum Nachhaltigkeit, Universität Bremen

Dr. Lukas Giessen, Abteilung für Forst- und Naturschutzpolitik und Forstgeschichte, Fakultät für Forstwissenschaften und Waldökologie, Georg-August-Universität Göttingen

Dr. Markus Keck, Abteilung Humangeographie, Geographisches Institut, Fakultät für Geowissenschaften und Geographie, Georg-August-Universität Göttingen

Tag der mündlichen Prüfung: $\quad$ 15.04.2016 


\section{Summary}

Deforestation and forest degradation are contributing approximately $10 \%$ to $15 \%$ to global greenhouse gas emissions (Van der Werf et al. 2009). The Reducing Emissions from Deforestation and Forest Degradation (REDD+) mechanism, as an international payment for ecosystem service scheme, aims to create financial incentives for expanding protected areas in the Global South. REDD+ has been framed as a "win-win"-solution by donors, conservation organizations and corporate actors facilitating simultaneously forest conservation, rural development and cost-effective climate change mitigation (Allianz 2014; Angelsen et al. 2012; Pagiola 2011; Virgilio et al. 2010). But the expansion of protected areas is seldom a conflict-free process, especially when local communities have to cope with the simultaneous expansion of large-scale agro-industrial estates (Brad et al. 2015; Eilenberg 2015; Fairhead, Leach, and Scoones 2012; Hein et al. 2015; Zimmerer 2006; Kelly 2011).

A fundamental requirement for REDD+ is "good governance" and an unambiguous, clearly defined and preferably individualized and western-oriented understanding of property (Doherty and Schroeder 2011: 66; Larson et al. 2013: 678; Zelli et al. 2014: 37). However, exactly the carbon- rich tropical frontier forests are located in regions where forest and land tenure are highly contested (NaughtonTreves and Wendland 2014: 1). In particular Indonesia's last remaining frontier areas are heavily contested spaces that are witnessing violent conflicts on access and control of forest land (Hein et al. 2015; Tsing 2005).

This dissertation aims to unravel the causes and the scalar dimension of conflictive and unequal access and property relations in the context of an emerging transnational framework for forest conservation to mitigate climate change (REDD+). While empirically focusing on conflictive forest and land tenure in Indonesias REDD+ pilot province Jambi (Sumatra) this dissertation seeks to contribute to the deconstruction of REDD+ as a "win-win" solution. The overarching research question of this dissertation is: How are multi-scalar land conflicts on access and property in REDD+ target areas structured and how can this be explained? Conceptually this study is guided by political ecology and by the interrelated politics of scale literature. The study seeks to bring forward empirical and conceptual discussions within political ecology on the roles of scale and power for accessing land and property.

For investigating multi-scalar land conflicts on access and property in REDD+ pilot areas this study builds on a multi-sited qualitative approach (multi-sited ethnography). Different qualitative techniques such as semi-structured interviews, expert interviews, participatory observation, group interviews and document analysis have been used at different field sites. Empirical research has been conducted mainly in villages' located within or adjacent to two REDD+ pilot projects and at transnational nodes 
of REDD+ and land tenure governance in the province of Jambi (Sumatra), in Jakarta, Germany and elsewhere. Nodes of REDD+ governance include actors such as the Ministry of Forestry (MoF) in Jakarta, provincial authorities, transnational NGOs, donor agencies and companies that are linked through transnational scalar networks to REDD+ pilot sites.

The findings show that social conflict has changed scales of meaning and regulation and led to the construction of new scales (e.g. village scales of land tenure regulation). In Indonesia resistance was made possible because of changing power constellations after regime change at the end of the 1990s and has further changed the power constellation in place. Changing power constellations and rescaling facilitated access to the state forest (kawasan hutan) for local elites.

The studied conflicts on access and control of forests within REDD+ projects in Jambi indicate that REDD+ has transnationalized and has changed meanings and implications of pre-existing land conflicts. REDD+ links greenhouse gas emitters in the global North to peasants and indigenous groups struggling for land and property in the global South. REDD+ rescales conflicts and provides entry points for a spatial expansion of resistance linking peasants to transnational climate justice groups in North and South.

Thus, REDD+ pilot projects in Jambi financed by private and public donors changed the dialectical relationships between structure and agency. They reduced the ability to access land for some actors, provided additional opportunities for others and provided additional agency for transnational resistance campaigns of peasant movements allied with climate justice organizations. Moreover, the findings of this study explain in detail what it means that transnational conservation initiatives and market-based conservation instruments such as REDD+ are not acting in a social and political vacuum. Understanding the historical context is of key importance for solving land conflicts in the context of conservation interventions. In landscapes characterized by historically contingent structural inequality caused by the neglect of customary land rights expanding conservation areas might reinforce inequality, existing power asymmetries and social conflict.

The ongoing land conflicts on access and control of forests in Jambi as well as experiences from other countries implementing REDD+ such as Peru (Zelli et al. 2014) indicate that forest carbon offsetting is a very risky strategy to mitigate climate change. Instead of avoiding emissions forest carbon offsetting could lead to additional greenhouse gas emissions if conflictive access and property relations undermine the integrity of forest areas designated for conservation and carbon offsetting. 


\section{Zusammenfassung}

Entwaldung und Walddegradation verursachen ca. 10\% bis $15 \%$ der globalen Treibhausgasemissionen (Van der Werf et al. 2009). REDD+ (engl. Abkürzung Reducing Emissions from Deforestation and Forest Degradation) ist ein internationaler Mechanismus, der finanzielle Anreize für die Ausweitung von Schutzgebieten im globalen Süden schaffen soll. Geber, Umweltschutzorganisationen und Unternehmen bezeichnen REDD+ als eine „win-win“ Lösung. Es wird argumentiert, dass REDD+ Waldschutz, ländliche Entwicklung und eine kosteneffiziente Reduktion von Treibhausgasen ermöglicht (Allianz 2014; Angelsen et al. 2012; Pagiola 2011; Virgilio et al. 2010). Die Ausweitung von Schutzgebieten geschieht jedoch selten konfliktfrei. Dies gilt im besonderen Maße, wenn die ländliche Bevölkerung mit der gleichzeitigen Ausweitung von agro-industriellen Großplantagen konfrontiert ist (Brad et al. 2015; Eilenberg 2015; Fairhead, Leach, and Scoones 2012; Hein et al. 2015; Zimmerer 2006; Kelly 2011).

Als wesentliche Voraussetzung für eine erfolgreiche Umsetzung von REDD+ gilt gute Regierungsführung (good governance), eine klar definierte Bodenordnung und ein individualisiertes westliches Verständnis von Eigentum (Doherty and Schroeder 2011: 66; Larson et al. 2013: 678; Zelli et al. 2014: 37). Die besonders kohlenstoffreichen tropischen Regenwälder liegen jedoch meist in Regionen in denen die Bodenordnung umkämpft ist (Naughton-Treves and Wendland 2014: 1). Insbesondere Indonesiens Waldrandlagen gelten als umkämpfte Räume. Der Zugang und die Kontrolle von Land und Wäldern ist durch fortlaufende, teils gewalttätige Aushandlungsprozesse gekennzeichnet (Hein et al. 2015; Tsing 2005).

Diese Dissertation untersucht die Ursachen für und die skalare Dimension von konfliktiven und ungleichen Eigentums- und Landzugangsverhältnissen im Kontext eines entstehenden transnationalen Regelwerks für den Waldschutz. Durch eine Untersuchung von Land- und Forstkonflikten, die im Zusammenhang mit zwei REDD+ Pilotprojekten in der indonesischen Provinz Jambi stehen, versucht diese Dissertation zur Dekonstruktion von REDD+ als „win-win“ Lösung beizutragen. Die übergeordnete Fragestellung des Dissertationsvorhabens lautet: Wie sind multi-skalare Landkonflikte um Eigentum und Landzugang in REDD+ Pilotregionen strukturiert und wie sind diese zu erklären?

Konzeptionell orientiert sich die vorliegende Dissertation an der politischen Ökologie und der eng damit verknüpften Literatur zu politics of scale. Sie versucht Fragen der sozialen Konstruktion und Produktion von Eigentum anhand sich verschiebender räumlicher Maßstabsebenen (scale) und dynamischer Machtverhältnisse zu erklären und bestehende Ansätze einer political ecology of scale (Neumann 2009) konzeptionell zu erweitern. 
Die Dissertation stützt sich auf verschiedene Methoden der qualitativen Sozialforschung und orientiert sich an den Prämissen der multi-sited ethnography. Halb-strukturierte Interviews, Experteninterviews, Gruppeninterviews, teilnehmende Beobachtung an verschiedenen Standorten und die Analyse von Dokumenten bilden die empirische Grundlage dieser Arbeit. Qualitative Interviews wurden vor allem in Dörfern, die innerhalb oder in unmittelbarer Umgebung von REDD+ Pilotprojekten liegen, durchgeführt. Darüber hinaus wurden Interviews an den transnationalen Knoten der REDD+ Governance und den nationalen waldpolitischen Knotenpunkten durchgeführt. Als nationale und transnationale Knotenpunkte gelten die Zentralen von Gebern, Nichtregierungsorganisationen, Unternehmen, Ministerien und Forstverwaltungen. Die jeweils involvierten Akteure sind im Rahmen von transnationalen Netzwerken miteinander verbunden und an der Implementierung von REDD+ Pilotprojekten beteiligt.

Die Ergebnisse dieser Dissertation zeigen auf, dass Widerstand und politische Aushandlungsprozesse bestehende Bedeutungs- und Regulationsskalen verändern. In Indonesien führte dies zur Konstruktion von neuen politischen Ebenen der Bodenordnung und Forstverwaltung. Die Organisation von skalenübergreifendem Widerstand wurde in Indonesien erst durch den Regimewechsel und die veränderten Machtkonstellationen Ende der 1990er Jahre möglich. Der Regimewechsel führte zu einer Reskalierung der Bodenordnung und ermöglichte so lokalen Eliten den Zugang zum Staatswald (kawasan hutan). Skalenübergreifender Widerstand kann so als Folge von sich verändernden Machtverhältnissen angesehen werden, aber impliziert auch Prozesse der Veränderung räumlicher Maßstabebenen und Machtkonstellationen.

Die untersuchten Landkonflikte in Jambi zeigen, dass die Umsetzung von REDD+ Politiken zur Transnationalisierung von vermeintlich lokalen und bereits bestehenden Konflikten um Landzugang führt. REDD+ Projekte verbinden Emittenten von Treibhausgasen im globalen Norden mit Kleinbauern und indigenen Gruppen im globalen Süden. Lokale Aushandlungsprozesse um den Zugang zu natürlichen Ressourcen bekommen so globale Relevanz. REDD+ kann so zu einer räumlichen Ausweitung von Protest und politischem Widerstand führen. REDD+ verbindet zunehmend diese lokalen Gruppen mit transnationalen Bewegungen und Netzwerken zur Klimagerechtigkeit. Damit führt die Implementierung von REDD+ Pilotprojekten auch zu einer Veränderung von Maßstabsebenen und Machtkonstellationen. Die untersuchten Pilotprojekte in Jambi haben das dialektische Verhältnis zwischen strukturellen politökonomischen Bedingungen und dem Handlungsspielraum (agency) verschiedener Akteursgruppen verändert. So beschränken neue Regelsysteme den Zugang zu Land für bestimmte Akteure, während sie anderen Gruppen im Rahmen von vertraglichen Vereinbarungen zum Naturschutz Zugang gewähren. 
Des Weiteren zeigen die Ergebnisse dieser Studie, dass transnationale Instrumente wie REDD+ nicht in einem politischen und sozialen Vakuum agieren. Die Ausweitung von Waldschutz durch REDD+ führt zu Konflikten bzw. ändert deren Bedeutung. Ein verbessertes Verständnis der historischen Ursachen von Konflikten kann helfen, Landkonflikte im Rahmen der Ausweitung von Schutzgebieten zu lösen bzw. zu vermeiden. In Regionen, die sich durch strukturelle und sich fortlaufend reproduzierende Ungleichheit auszeichnen und durch die Missachtung von traditionellen Landrechten und Enteignungen von indigenen Gruppen gekennzeichnet sind, kann die Erweiterung von Waldschutzgebieten bestehende Ungleichheiten und Machtasymmetrien verschärfen und Konflikte verstärken.

Zu dem verdeutlichen die Konflikte um den Zugang zu Land und natürlichen Ressourcen in Jambi als auch Erkenntnisse aus anderen Ländern, dass Projekte zur Reduktion von $\mathrm{CO}_{2}$-Emissionen in Waldgebieten eine sehr risikoreiche Strategie zur Emissionsminderung sein können. Wenn Landkonflikte die Integrität solcher Projekte gefährden, tragen diese nicht zur Reduktion von Treibhausgasen bei, sondern produzieren zusätzliche Emissionen. 


\section{Table of Contents}

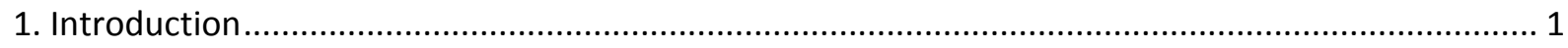

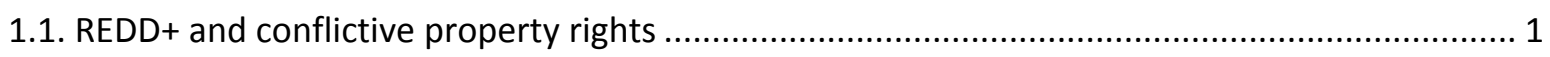

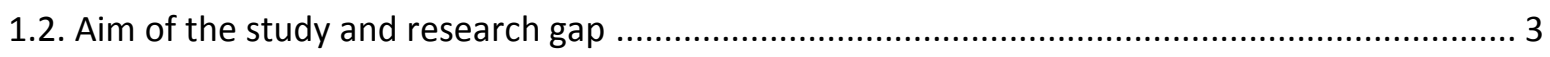

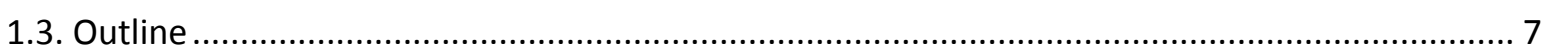

2. Conceptual Framework: towards scalar politics of conflictive access and property relations .......... 9

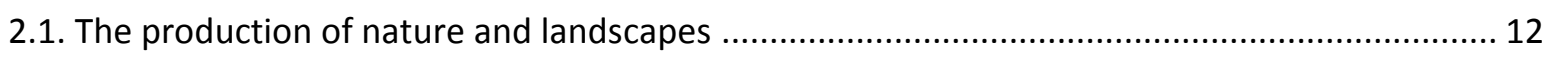

2.2. Politics of scale and the social production of space and scale ............................................ 13

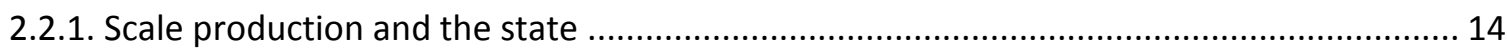

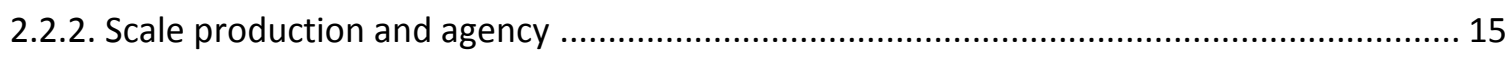

2.2.3. State transformation and rescaling of environmental governance .................................... 16

2.2.4. Socio-ecological rescaling and the production of scales of meaning and regulation ......... 19

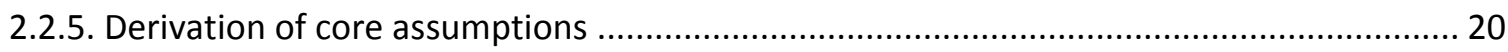

2.3. Conceptualizing power and resistance for analyzing conflictive access and property relations

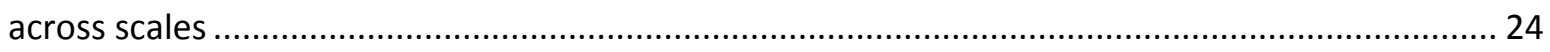

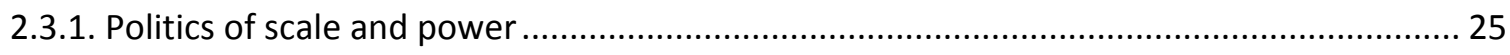

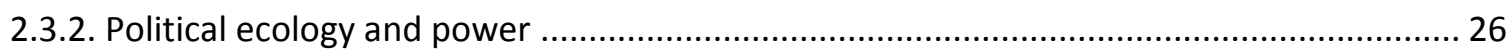

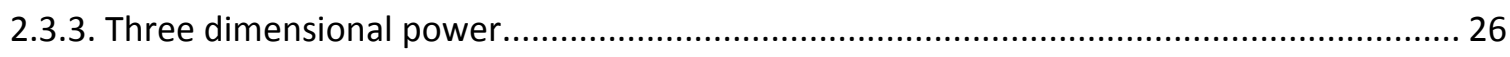

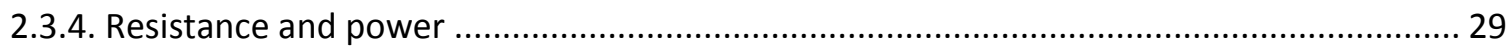

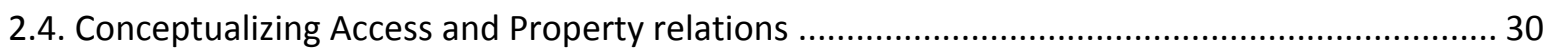

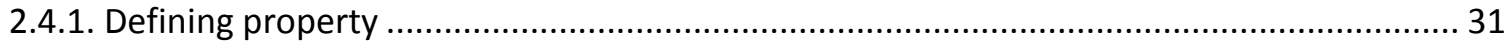

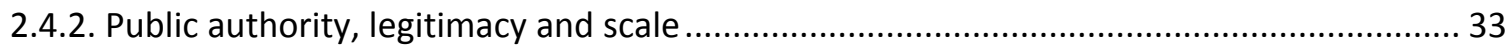

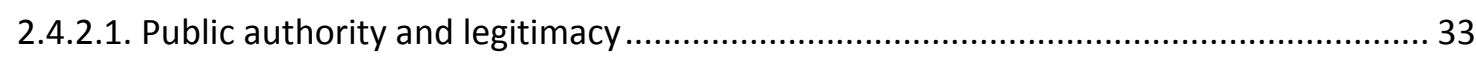

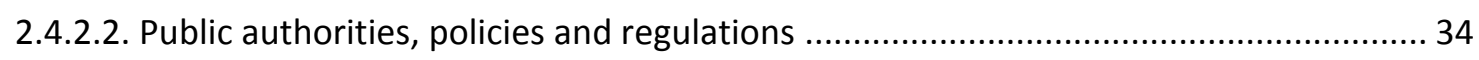

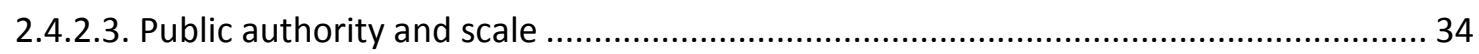

2.4.3. Ethnicity and social identity mediating access to public authority and property ............... 35

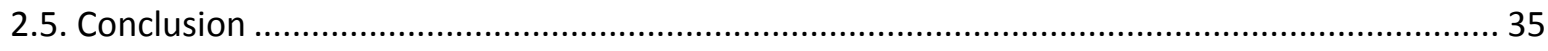

3. Methods, research design and locating the main sites of investigation ....................................... 38 
3.1. Reflexive science model, political ecology and qualitative research 38

3.2. Doing multi-sited fieldwork for analyzing land conflicts in the context of REDD+ across scales... 40

3.3 Selection of the main sites of investigation 41

3.4. Description of research methods and field research 44

3.4.1. Applied qualitative techniques 44

3.4.2. Time frame of empirical investigation 46

3.5. Qualitative research with different actors at different field sites 48

3.5.1. Interviews at the village scale 48

3.5.2. Interviews with NGOs, companies, academia, staff of state agencies and donor agencies... 51

3.5.3. Role and background of research assistants 51

3.6. Data analysis 52

3.7. Reflection, limitations and challenges 53

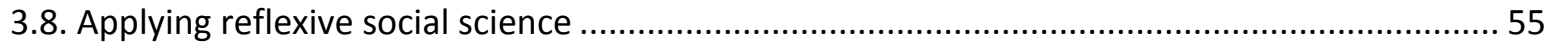

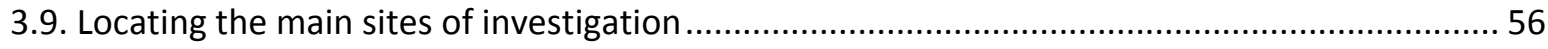

3.9.1. Transnational, national and local nodes of decision making ........................................... 56

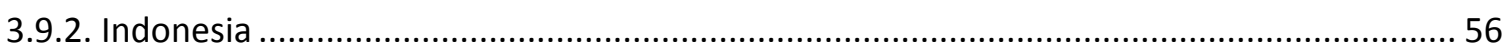

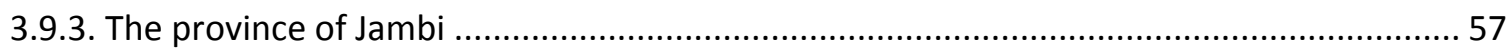

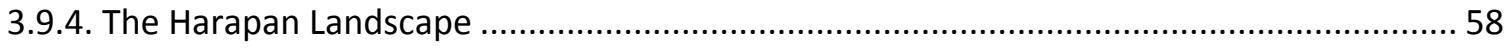

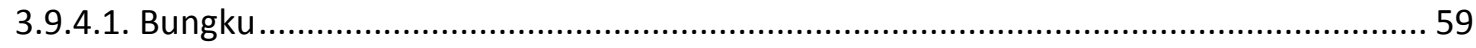

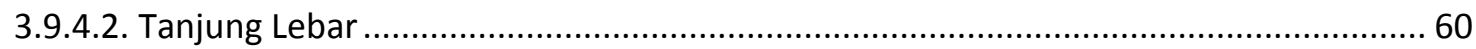

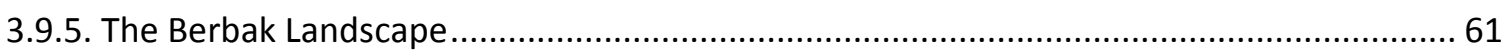

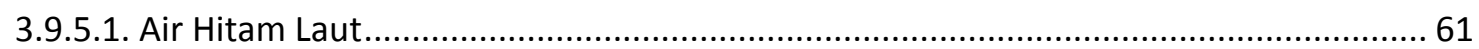

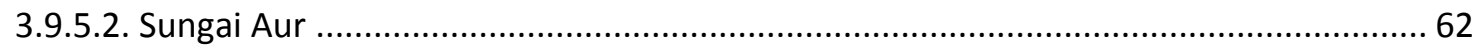

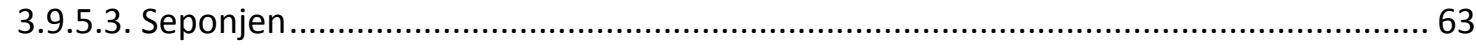

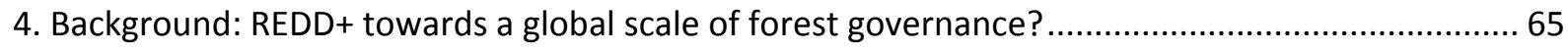

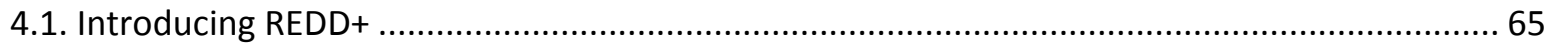

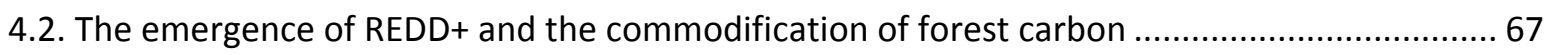




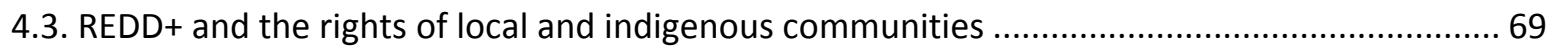

4.4. National REDD+ and land-based mitigation policies and land tenure .............................. 73

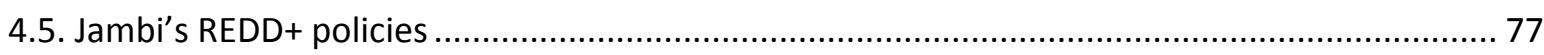

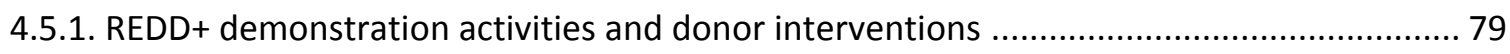

4.5.2. The Harapan Rainforest Project ................................................................... 81

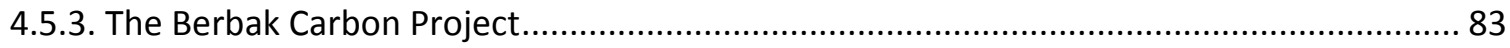

4.5.4. Actor mapping: state and non-state actors involved in REDD+ in Jambi .......................84

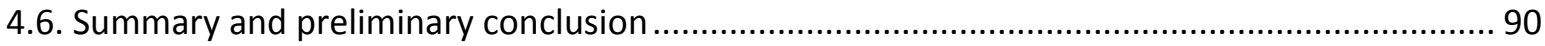

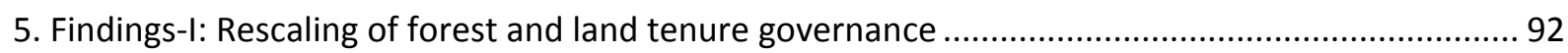

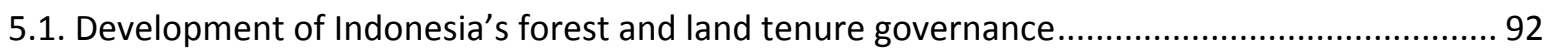

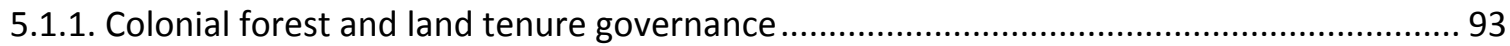

5.1.2. Nationalization: introduction of new laws and rescaling for development? ..................96

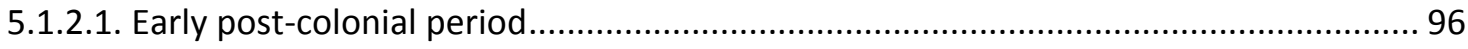

5.1.2.2. The Basic Agrarian Law towards social justice and agrarian reform? ..................... 96

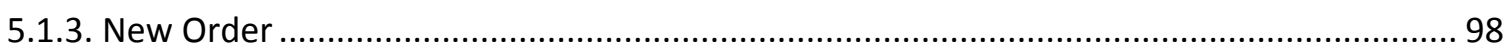

5.1.3.1. Reestablishing dualistic land and forest governance ......................................... 98

5.1.3.2. Adjusting village governance ............................................................ 100

5.1.3.3. Transmigration, new property and modernization ......................................... 101

5.1.4. Reformasi: rescaling through democratization and decentralization........................ 103

5.2. Different types of de jure land and forest rights................................................... 106

5.3. The formation of resistance movements and alternative scales of meaning and regulation . 111

5.3.1. Reemergence of Adat

5.3.2. Re-emergence of the Agrarian Movement 114

5.3.3. Concluding remarks on peasant and indigenous rights movements

5.4. The province of Jambi: shifting scales of meaning and regulation inscribed in two frontier landscapes 116

5.4.1. A brief history of Jambi

5.4.2. Harapan landscape, the Batin Sembilan and processes of dispossession 118

5.4.3. Berbak landscape: in-migration, drainage and logging. 126 
5.5 Summary and preliminary conclusion 130

6. Findings-II: Historically contingent access and property relations in REDD+ target areas 132

6.1. Customary and colonial access and property relations 133

6.1.1. The Harapan Landscape and the Batin Sembilan 133

6.1.2. The Berbak Landscape. 136

6.2. Different actors and different access patterns 137

6.2.1. Access to land and property for the purpose of conservation and REDD+ 138

6.2.1.1. Burung Indonesia, PT REKI, and the Harapan Rainforest... 138

6.2.1.2. The Zoological Society of London and the Berbak Carbon Project 140

6.2.2. Access to land and property for oil palm companies 142

6.2.3. Access to land and property for peasant migrants 144

6.3. The "making" of new property challenging REDD+ and conservation: State policies, rescaling and legal mimicry 147

6.3.1. State-based settlement and land allocation schemes 149

6.3.2. Village-scale land-titling and the role of local public authorities 151

6.3.3. Village-scale settlement schemes and land occupations in the Harapan Landscape 155

6.3.3.1. Transwakarsa Mandiri/Kunangan Jaya I 160

6.3.3.2. Camp Gunung/ Kunangan Jaya II: Land for second-generation transmigrants. 161

6.3.3.3. Tanjung Mandiri: Migrants as model farmers and conflictive boundaries 163

6.3.3.4. Land occupation by SPI: The settlements of Sungai Jerad and Bukit Sinjal 166

6.3.4. Village-scale settlement schemes in the Berbak Landscape 169

6.3.4.1. Bugi colonization in the Berbak Landscape: Commercial land reclamation and villagescale settlement projects 171

6.3.4.2. Farming groups for collective forest conversion 172

6.4. "Making" of new property and new regulations by REDD+ and conservation initiatives 173

6.4.1. The Harapan Rainforest: New regulations and new properties and community benefits 174

6.4.1.1. Conditional land tenure and conservation agreements. 176

6.4.1.2. Other rights and community benefits provided by the Harapan Rainforest project. 178 
6.4.2. Berbak Carbon Project: New regulations and new property and access to community benefits 179

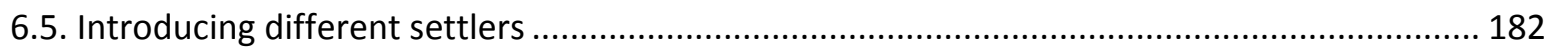

6.5.1. A migrant household in the TSM settlement within the Harapan Rainforest .................. 182

6.5.2. A migrant household in a SPI settlement in the Harapan Rainforest ............................. 182

6.5.3. A Batin Sembilan household displaced by PT Asiatic Persada that lives in the mitra settlement of the Harapan Rainforest

6.5.4. A Malay family in the transmigration settlement in the Berbak Carbon Project.

6.6. Summary and preliminary conclusion: Power and the scalar politics of de facto property rights and land titles

7. Findings-III: Transnational resistance and multi-scalar land conflicts in the context of REDD+ .... 190

7.1. General overview of land conflicts in the research villages (conflict mapping)

7.2. Peasant resistance, climate justice and agrarian reform: conflict between SPI and the Harapan Rainforest 196

7.2.1. Conflict history 198

7.2.2. Actor mapping. 199

7.2.3. A multi-scalar conflict on meanings, access and control of the Harapan Rainforest. 201

7.3. The conflict on Kunangan Jaya I 203

7.3.1. Conflict history and conflict mediation 204

7.3.2. Actor mapping. 206

7.3.3. Competing scales of regulation, conflicts between state apparatuses and the role of social identity and indigenous rights.

7.4. Conflicts between different state apparatuses: a transmigration site within the Berbak Carbon Project

7.4.1. Conflict history and the formation of the transmigration settlement 213

7.4.2. Competing state apparatuses, rent-seeking and new property 215

7.4.3. Competing state apparatuses and implications for REDD+

7.5. Summary and preliminary conclusion

8. Discussion and conclusion 220

8.1. Elements of a political ecology of scale and property in the context of REDD+ 
8.1.1. Spatial implications of conflictive modes of production

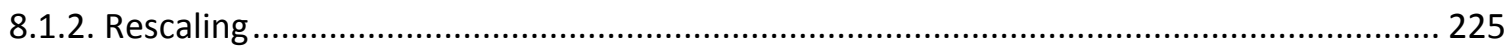

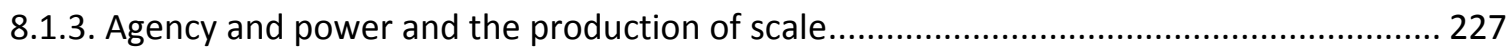

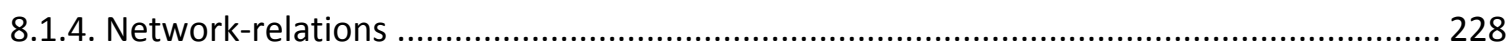

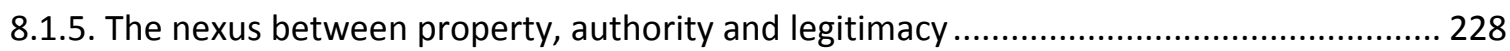

8.1.6. Contributions to political ecology: revisiting guiding assumptions and analytical criteria.....

8.2. Limitations, challenges and open issues

8.3. Concluding remarks: relevance for REDD+ and climate justice and future directions of research for development geography. 235

References. 238

Acknowledgments . 259

Annex I: List of interviews, meetings and discussions 261

Annex II: Interview guides. 266

Annex III: CV 273 


\section{Figures:}

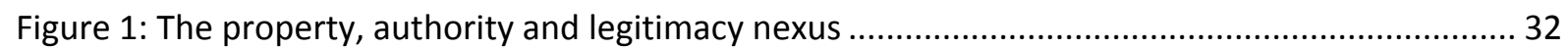

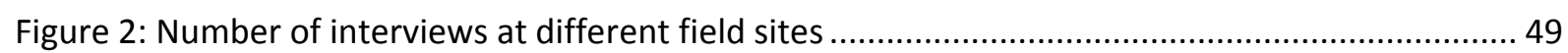

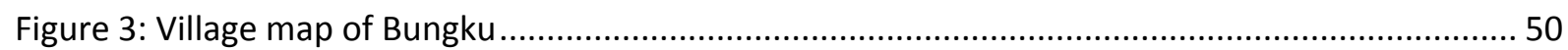

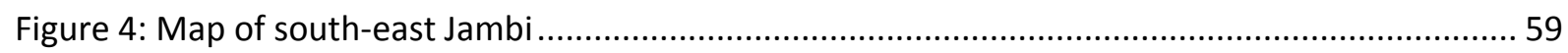

Figure 5: Statement on a placard found in a household in settling in the Harapan Rainforest............ 66

Figure 6: Map of the planned concession of PT BDU/ PT Asiatic Persada and adjacent logging

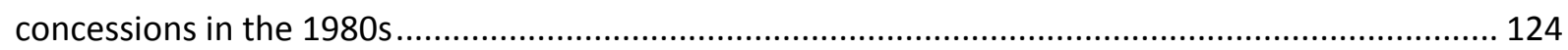

Figure 7: Different thematic maps of the Harapan Rainforest and its surroundings......................... 125

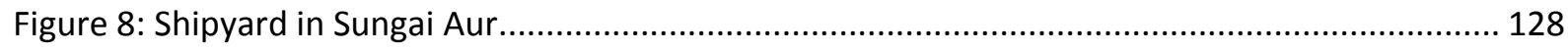

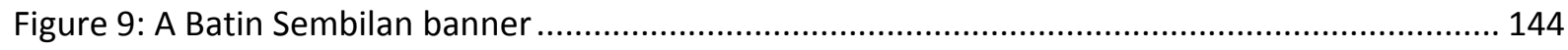

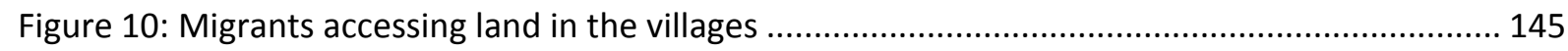

Figure 11: Village-scale land-titling in the villages and the changing meaning of sporadik across scales

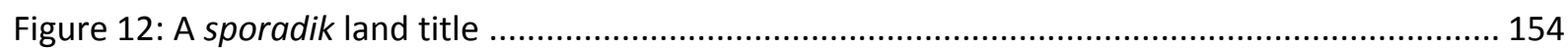

Figure 13: Schematic representation of settlement formation ....................................................... 157

Figure 14: Location of settlements within the Harapan Rainforest ............................................... 159

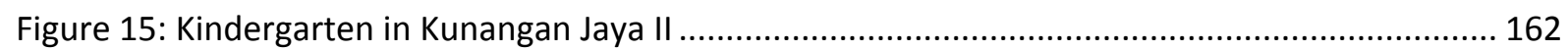

Figure 16: Sign of the elementary school of Tanjung Mandiri ........................................................... 165

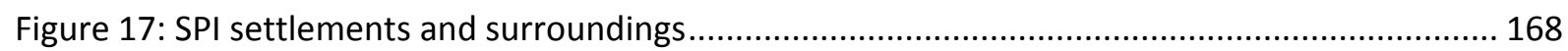

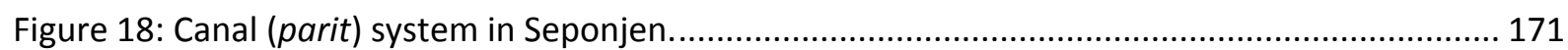

Figure 19: Large trench as border fortification of the concession of PT Asiatic Persada in Bungku... 191

Figure 20: Deforestation in the northern Harapan Rainforest until 2013 ........................................ 197

Figure 21: Timber ready for floating within the Harapan Rainforest............................................... 198

Figure 22: Actor mapping of the conflict between SPI and PT REKI on access and control of the Harapan

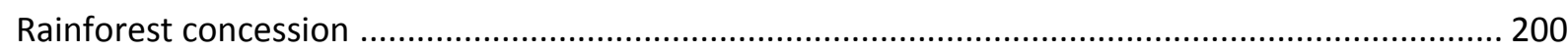

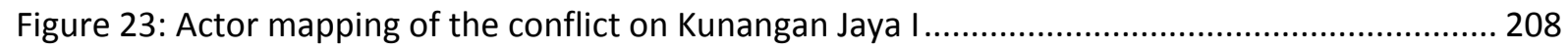

Figure 24: Berbak Landscape and the location of the Transmigration Settlement of Sungai Aur ...... 213 


\section{Tables:}

Table 1: Guiding assumptions derived from the politics of scale literature .................................... 24

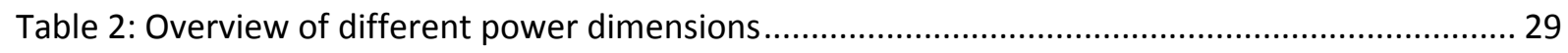

Table 3: Research villages and REDD+/ conservation projects ................................................. 43

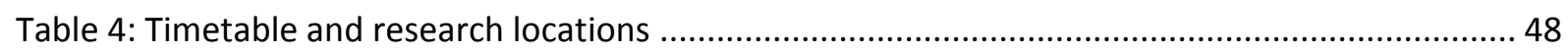

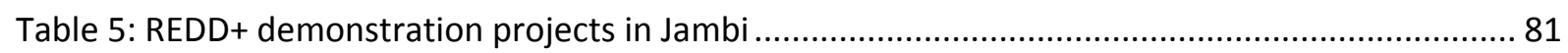

Table 6: Actors involved in REDD+ and land tenure conflicts in REDD+ target areas in Jambi ............ 90

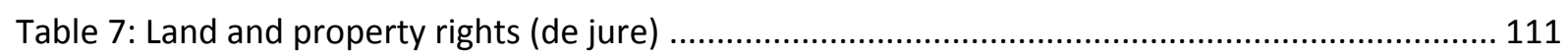

Table 8: Lineages of the Batin Sembilan and their settlements................................................ 119

Table 9: Land allocated to companies, total village territory, and land used by farmers in the study

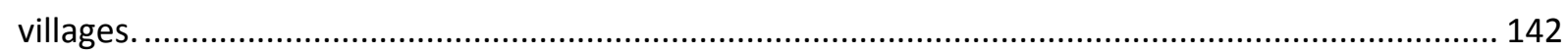

Table 10: Different formal land allocation schemes .......................................................... 150

Table 11: Village-scale land titles used in the study villages ...................................................... 155

Table 12: Settlements within the Harapan Rainforest ...................................................... 158

Table 13: Organized peat-swamp-forest conversion initiatives in Berbak Landscape villages.......... 170

Table 14: Conditional land tenure and community benefits of the Berbak Carbon and the Harapan

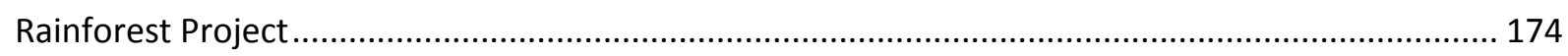

Table 15: Access and property relations in the different study landscapes ................................ 185

Table 16: De facto authority, property and scale relations in a historical perspective ................... 187

Table 17: Land conflict mapping in the study villages............................................................ 194

Table 18: Revisited guiding assumptions and analytical criteria as elements of a political ecology of scale for investigating land conflicts 



\section{Introduction}

\subsection{REDD+ and conflictive property rights}

Climate change has put tropical forest conservation back on the political agenda. Deforestation and forest degradation are contributing approximately $10 \%$ to $15 \%$ to global greenhouse gas emissions (Van der Werf et al. 2009). Indonesia has one of the highest deforestation rates and one of the highest greenhouse gas emissions caused by peat land and forest conversion globally (Margono et al. 2014; Weisse and Petersen 2015). In 2007 the Reducing emissions from deforestation and (forest) degradation (REDD+) mechanisms became part of the official policy mix of the United Nations Framework Convention on Climate Change (UNFCCC). The idea of REDD+ gained rapidly political traction, especially in Indonesia (Brockhaus et al. 2012: 31). REDD+ aims to create financial incentives for forest rich developing countries to avoid deforestation through putting a value on standing forests. REDD+ has been framed as a "win-win"-solution by donors, conservation organizations and corporate actors facilitating forest conservation, rural development and cost-effective climate change mitigation (Allianz 2014; Angelsen et al. 2012; Pagiola 2011; Virgilio et al. 2010). Critical voices warn that REDD+ policies increase the existing pressure on land, challenges customary forest tenure and consequently lead to additional exclusions of marginalized groups instead of fostering rural development (Gupta 2012; Hein 2014; McAfee 1999; Phelps et al. 2010).

The concept of REDD+ is based on the economistic and simplistic logic of market environmentalism ignoring the complexity of place-based historically rooted social and environmental relations. Forests are conceptualized as quantifiable carbon pools, assuming that attributing monetary value to standing forests would halt deforestation almost automatically, and that environmental problems can be outsourced, geographically transferred and solved at low cost locations (McAfee 2012a: 112-113; Kosoy and Corbera 2010: 1229; Lohmann 2008: 362). Yet, environmental blueprints and financial incentives provided for forest conservation in the global South are not operating in a social and political vacuum. A fundamental requirement for REDD+ as an international payment for ecosystem service scheme are good governance and an unambiguous, clearly defined and preferably individualized and western understanding of property (Doherty and Schroeder 2011: 66; Larson et al. 2013: 678; Zelli et al. 2014: 37). However, exactly the carbon rich tropical frontier forests are located in regions where forest and land tenure are highly contested (Naughton-Treves and Wendland 2014: 1). Frontier forests are transitional spaces where policy narratives (e.g. conservation vs. agricultural expansion), public authorities and different understandings of property compete (Fold and Hirsch 2009: 95; Hein et al. 2015: 2; Peluso and Lund 2011: 668). 
In Indonesia, the large highly biodiverse archipelago with the third largest tropical forest cover, the situation is notably conflictive. One the one hand, Indonesia claims to be a global leader in REDD+ on the other hand, local realities such as land tenure conflicts and the rampant 2015 forest fires stand in sharp contrast to Indonesia's announced forest governance reforms (Finlayson 2014; Hein et al. 2015: 1; Toumbourou 2015). In particular Indonesia's last remaining frontier areas are heavily contested spaces that are still witnessing violent conflicts on access and control of forest land (Hein et al. 2015; Tsing 2005). Caused by historically contingent structural inequality land conflicts "became chronic" (Rachman 2013: 3) in Indonesia. Colonial and post-colonial governments have appropriated vast forest areas for conservation and resource exploitation (ibid.). The amount of land conflicts in Indonesia is steadily increasing reaching a new record high in 2013 with 12816609 ha land in conflict involving 139874 households (Konsorsium Pembaruan Agraria 2013: 3). Today, indigenous communities and peasant organizations consider the occupation of corporate and state-owned plantation estates and conservation areas as legitimate responses to the dispossessions of the colonial and post-colonial state (Hein et al. 2015; Peluso, Afiff, and Rachman 2008; Lukas 2014).

The expansion of protected areas is seldom a conflict-free process, especially when local and indigenous communities have to cope with the simultaneous expansion of large-scale agro-industrial estates (Brad et al. 2015; Eilenberg 2015; Fairhead, Leach, and Scoones 2012; Hein et al. 2015; Zimmerer 2006; Kelly 2011). From 1990 to 2010 the province of Jambi on the island of Sumatra has witnessed a tenfold increase of the land area used for oil palm ${ }^{1}$ cultivation. During the same period at least four larger conservation areas have been established by public and private actors.

The REDD+ mechanism changes the politics of scale of apparently local land conflicts. Scale is defined here as manifestations of power relations and as the outcome of social and ecological dynamics (Swyngedouw 2010: 8 ; Hein et al. 2015: 1). Context specific apparently local land conflicts on access and control of forests become transnationalized in the context of REDD+ and forest carbon offsetting. The basic idea of offsetting emissions at low cost locations links not only emitters in the North with project implementers and land users in the South. Offsetting also links local struggles on access and control of forest and land resources to transnational activists networks that provide land users the opportunity to resist against land claims of private or public conservation agencies (Chatterton, Featherstone, and Routledge 2013; Hein et al. 2015; Hein and Faust 2014; Hein and Garrelts 2014).

But for all that, REDD+ can be many different things for different actor coalitions and their respective storylines and discourses. REDD+ is not only a market-based forest conservation instrument, REDD+ can also be considered as an attempt of a strong actor coalition to establish a global scale of forest and

\footnotetext{
${ }^{1}$ Elaeis guineensis
} 
land tenure governance for supporting climate change mitigation, biodiversity conservation, sustainable development and the rights of local and indigenous communities (Gupta 2012: 622). The Province of Jambi on the island of Sumatra, which is since 2012 one of Indonesia's REDD+ pilot provinces, has announced the designation of new community forest concessions in the provincial REDD+ strategy. Furthermore, the provincial government declared to map land claimed by local and indigenous communities for solving land conflicts (Perbatakusuma et al. 2012: 4f).

The social consequences of REDD+ are closely linked to the above mentioned agrarian questions and consequently to the politics of scale of land and forest tenure. REDD+ as new global scale of forest regulation and as a market-oriented conservation mechanism encounters historical contingent structural inequality and politics of appropriation in many tropical frontier areas (Hein et al. 2015; Kelly 2011). Alice B. Kelly (2011: 694) for instance argues "[...] that conservation by dispossession may actually threaten the environment more than it preserves it".

\subsection{Aim of the study and research gap}

This dissertation aims to unravel the causes and the scalar dimension of conflictive and unequal access and property relations in the context of an emerging transnational framework for REDD+. While focusing on conflictive forest and land tenure in the REDD+ pilot province of Jambi (Sumatra, Indonesia) this dissertation contributes to the deconstruction of REDD+ as a "win-win" solution. The starting assumption of this study is that historically contingent political rescaling processes are altering access and property relations. Rescaling processes such as colonization, nationalization, decentralization and more recent attempts to establish a transnational (or global) scale of forest governance (e.g. REDD+) are challenging preexisting access and property relations. I argue in line with Erik Swyngedouw (2010: 13) that socio-ecological scales "[...] shape in important ways who will have access to what kind of nature $[\ldots]]^{\prime \prime}$. Socio-ecological scales are the outcome of social and physical processes thus shaped by actors and structuring the social practices of actors. In this section I will outline research gaps, central aims and the guiding research questions of this dissertation.

Despite the REDD+ rush (McGregor 2010: 23) and the growing popularity of market- and result-based conservation instruments the amount of studies focusing on social implications, especially conflictive access and property relations in the context of the implementation of these instruments, is rather small. Especially multi-level and multi-sited studies covering conflictive dynamics at the transnational, national and the REDD+ project scale are still rare. Most of the existing studies on Indonesia focus rather on the national scale (e.g. Indrarto et al. 2012; Astuti and McGregor 2015; Brockhaus et al. 
2012), on the project scale (e.g. Howson and Kindon 2015; McGregor 2010; Resosudarmo et al. 2014) or on social and political conditions facilitating a successful implementation of REDD+ (Larson et al. 2013; Resosudarmo et al. 2014; Sunderlin et al. 2014; Vorlaufer et al. 2015).

Scholars have highlighted that clear forest and land tenure are a precondition for REDD+ implementation in the global South (Awono et al. 2014; Larson et al. 2013; Naughton-Treves and Wendland 2014; Resosudarmo et al. 2014). It is widely argued that clear property rights are associated with better forest conditions (Lambini and Nguyen 2014: 189). Overlapping or competing forest and land tenure have been identified as causes of conflict and as factors limiting the effectiveness of conservation initiatives (Resosudarmo et al. 2014: 76; Lambini and Nguyen 2014: 178; Hein et al. 2015; Awono et al. 2014). Especially competing customary and state law or inconsistencies between de jure and de facto tenure are considered as common sources of conflict in REDD+ target areas as case studies from Indonesia, Cameroon and Kenya indicate (Atela 2015; Resosudarmo et al. 2014; Awono et al. 2014). Nevertheless, studies on property relations in Indonesia have found that a simple differentiation between customary and state law or between de jure and de facto rights cannot fully reflect the myriads of different types of property negotiated by actors at different scales (van Meijl and von Benda-Beckmann 1999: 19; von Benda-Beckmann, von Benda-Beckmann, and Wiber 2009; von BendaBeckmann 1981; Kunz et al. submitted).

In a seminal monograph Derek Hall and colleagues (2011) have identified different historically contingent processes that have changed access and property relations across Southeast Asia. First, formalization of land tenure created benefits for some groups to the expense of other groups. Second, the expansion of protected areas has limited access to land. At the same time community conservation projects created new opportunities to legitimize community claims. Third, the introduction of new boom crops (e.g. cocoa $^{2}$, oil palm and rubber ${ }^{3}$ ) transformed former kin-ship and family based land rights used for shifting cultivation to individualized tree property. Furthermore, land occupations and informal land allocations by agrarian reform movements emerged as forms of resistance constituting new types of access and property relations (ibid. 170). Agrarian movements and indigenous rights movements have occupied vast forest areas in Indonesia (Peluso, Afiff, and Rachman 2008: 388; Hein et al. 2015: 7; Hein and Faust 2014: 23; Tuong 2009: 183). Yet, the role of transnational peasant movements in land conflicts in REDD+ target has not been comprehensively analyzed so far.

Political ecologists have shown that REDD+ and other conservation projects are introduced to preexisting social and political settings and might reinforce existing power asymmetries (Rodríguez de Francisco 2013; McGregor 2010; Zimmerer 2006; Zulu 2009). A number of recent studies have stressed

\footnotetext{
${ }^{2}$ Theobroma cacao

${ }^{3}$ Hevea brasiliensis
} 
that investigating the historical context is highly relevant for understanding access and property relations and the outcomes of conservation interventions (Eilenberg 2015; Galudra et al. 2014; Galudra et al. 2011; Hein et al. 2015; Howson and Kindon 2015; McGregor 2010). Using political ecology based approaches Mc Gregor (2010) and Eilenberg (2015) showed for different parts of Indonesia how REDD+ is translated and transformed to local action creating mainly benefits for local elites. Esteve Corbera and Karina Brown (2010) have analyzed forest carbon offsets in China, Ecuador and Mexico. They showed that existing property rights determine the ability of actors to benefit from these projects (Corbera and Brown 2010: 1757). For Indonesia, Galudra and colleagues (2014; 2011) have unraveled how autocratic frontier expansion, spontaneous migrants and ongoing processes of re- and decentralization have shaped access and property relations. They conclude that carbon rights are linked to existing property rights, authorities and power relations (Galudra et al. 2011: 440).

Access and property relations reflect state-community relations (Sikor and Lund 2009). Nancy Peluso and Peter Vandergeest (2001) have shown how colonial forest authorities in Malaysia and Indonesia have invented "state" and "customary forest" as legal concepts politizing forest and limiting access to forests (ibid. 765). Colonial forest administrations established access and property regimes based on ethnic categories and fostered legal pluralism (Peluso and Vandergeest 2001: 801). The impacts of Indonesia's decentralization on state-community relations and access to natural resources has been investigated by a number of geographers, political ecologists, and anthropologists (Beckert, Dittrich, and Adiwibowo 2014; McCarthy 2004, 2005c, 2005b; Pichler 2014; Steinebach 2013b). McCarthy (2004: 1215) for instance has shown how decentralization has diversified authorities legitimizing access to resources and legal frameworks regulating access. A more recent article of Barbara Beckert and colleagues (2014: 87) goes in the same direction and argues that conflictive access to natural resources is caused by "ambivalent institutional regimes".

Beyond enriching the politics of scale and political ecology literature the study aims to contribute to the broader field of development geography (German: Geographische Entwicklungsforschung). Development geographers use transdisciplinary, theory-oriented and multi-scalar approaches for applied research focusing on the socio-spatial consequences of uneven human development and on the social construction and deconstruction of the term development as such (Bohle 2011: 745; Dittrich 2012: 5; Müller-Mahn and Verne 2011: 775). As a multi- and transdisciplinary field, development geography is located at an intersection between political geography, political ecology, development studies and development cooperation. Contemporary development geography is actor-centric considering tensions between structure and agency (Bohle 2011: 749). Development geographers argue that the agency of actors is structured by power asymmetries, political interests and socially produced space (ibid. 750). 
Richard Peet (2011: 8) and colleagues have argued that "the entire debate - both in terms of assessing costs and policy solutions [...]" on climate change mitigation "[...] has been dominated by economics [...]". Against this backdrop this dissertation seeks to unravel the conflictive scalar politics of access and property in the context of REDD+ focusing on two REDD+ pilot projects in the Indonesian province of Jambi. This study aims to contribute to ongoing conceptual discussions within political ecology and politics of scale on the role of scale for property formation and land conflicts (Hein et al. 2015; Zulu 2009; Kunz et al. submitted). For investigating conflictive access and property relations the study investigates the complex rules and social, political and economic processes that mediate access to natural resources (McCarthy 2006: 3). The respective rules in use reflect hidden power relations that need to be unraveled for understanding differentiated abilities of actors to access land and property (ibid. 11). This study investigates the formation of property in a historical perspective and unravels the relevance of scale and power for the ability of actors to access land and property. Understanding the historical context of the making and unmaking of rules, property and scale is highly relevant for investigating present conflicts on access and control of land and forests. Environmental history provides valuable insights on how ideas of nature, conservation and property from the global North have shaped environmental and agrarian change in peripheral frontier landscapes (Zimmerer and Bassett 2003a: 13).

In the context of REDD+ and the broader environmental globalization of "planetary support services" (Zimmerer and Bassett 2003a: 4) the basic agrarian questions as James Fairhead and colleagues (2012: 241) have (re-) formulated recently: "Who owns what? [...] and who gets what?" are (re-) gaining importance. The overarching research question of this dissertation is: How are multi-scalar land conflicts on access and property in REDD+ target areas structured and how can this be explained? This question then leads to three sub-ordinated research questions:

1. In how far are rescaling processes (e.g. decentralization, REDD+) altering the ability of different actors to access land and property, and it how far are actors shaping rescaling processes?

2. Which historically contingent access and property relations explain struggles over land in REDD+ target areas in Jambi?

3. Which multi-scalar resistance strategies do local actors employ to defend claims over land and natural resources?

For investigating and answering these questions this study builds on political ecology and the interrelated politics of scale literature. Political ecology seeks to explain socially differentiated abilities to access and benefit from land and natural resources. Political ecologists argue that nature is socially produced (Peet, Robbins, and Watts 2011: 29). Moreover, trade-offs between different actors and 
different natural resource use practices characterize human-environmental interactions (ibid.). The politics of scale literature has its roots in socio-spatial theory (Lefebvre 1976b; Soja 1980) and builds on the premise that space and scale are neither given nor a natural phenomenon (Sayre 2005: 283), they are socially produced and contain social and ecological processes (Swyngedouw 2010: 12).

Methods and research design are guided by the reflexive science model developed by Michael Burawoy (1998: 5). For considering the transnational linkages and chains of interactions between different actors within and between scales this dissertation employs a multi-sited qualitative approach building on George E. Marcus (1995) and Sally E. Merry (2000). Marcus argues that (1995: 79f) research which is "embedded in a world system [...] cannot be [...] focused on a single site of intensive investigation". Research sites for this study are primarily two REDD+ pilot projects in the province of Jambi - the Harapan Rainforest project and the Berbak Carbon Project and actors and locations in Jambi, Indonesia, Germany and beyond such as the Ministry of Forestry (MoF) in Jakarta, provincial forest agencies, transnational NGOs, donor agencies and companies that are linked through transnational scalar networks to the Harapan Rainforest and the Berbak Carbon Project.

\subsection{Outline}

The outline of this study is as follows. Chapter two presents the analytical framework of this dissertation project. The chapter outlines the specific attractiveness of political ecology and politics of scale, and the specific attractiveness of applying these approaches to a study on conflictive land tenure in the context of REDD+. Secondly the chapter defines the key concepts, scale, power, access and property which are guiding this study. In chapter three the research design and the used methods are outlined and the mains sites of empirical investigations are introduced. Research design and methods build on the notion of REDD+ as a multi-sited arena of negotiation (Klepp 2011; Benda-Beckmann, Benda-Beckmann, and Griffiths 2005).

Chapter four describes first the transnational REDD+ governance framework, referring to decisions of the UNFCCC, to carbon standards of private actors and second to the emerging national Indonesian and Jambi's provincial REDD+ governance. Furthermore, the chapter gives an overview of REDD+ pilot and private conservation projects in Jambi, and introduces the Harapan Rainforest and the Berbak Carbon project. In addition, an actor mapping of actors involved in REDD+, conservation and related conflicts in Jambi is given.

The chapters five to seven present the main empirical findings of this study. Chapter five investigates rescaling and state transformation and intertwined reforms of forest and land tenure governance as 
the dynamic context of REDD+ implementation in Indonesia. The chapter shows how different political regimes facilitated the construction of specific scales of meaning and regulation governing access to land and forests. Some of them outlived the historical conditions that led to their construction. They are still inscribed in Jambi's remaining frontier landscapes. Furthermore, this chapter gives an overview over de jure forest and land tenure regulations.

Chapter six unravels historically contingent access and property relation in REDD+ target areas, more specifically in the landscapes adjacent to the Harapan Rainforest and to the Berbak Carbon Project in Jambi. It indicates how rescaling processes have changed power relations and the property authority nexus expanding the agency and thus the abilities of actors to access land and property. Actor coalitions formed by traditional elites, village governments, migrants and peasant movements have been able to resist against conservation companies and forest authorities and managed to established informal settlements within REDD+ pilot projects. Anyhow, the relations between local and customary communities and conservation companies and forest authorities are not only conflictive. The conservation initiatives provide benefits for some actors by allocating new conditional property rights, community benefits and by providing employment. Furthermore, this chapter gives an overview over de facto forest and land tenure regulations.

Chapter seven focuses on the multi-scalar and transnational dimensions of land conflicts and peasant resistance. It provides first a general overview and categorization (conflict mapping) of ongoing land conflicts in in the landscapes adjacent to the Harapan Rainforest and to the Berbak Carbon Project in Jambi. Second it investigates three specific multi-scalar land conflicts characterized by different conflict histories, scalar arrangements and different actor constellations employing multiple strategies for legitimizing land claims. The three selected land conflicts can be considered as a consequence of rescaling processes described in chapter five and of conflictive property rights described in chapter six. Moreover, the conflicts have induced further rescaling of access and property relations.

Chapter eight summarizes and discusses the main findings, outlines the contribution of this study to a political ecology of scale of access and property and identifies implications for climate justice and future directions of research for development geography. The study concludes by arguing for a development geography that unravels the interests of actors investing in climate protection (e.g. REDD+), power asymmetries between actors and the legitimacy of private actors taking over former state functions. Development geography and political ecology could help to reduce the impact of climate change and climate policies on the worst-off members of society. 


\section{Conceptual Framework: towards scalar politics of conflictive access and property relations}

I argue that REDD+ and broader processes of state transformation have induced significant rescaling processes within the governance of land tenure, forests and ecosystems (Castree 2008; Cohen and McCarthy 2014; Reed and Bruyneel 2010). Decision making power has shifted upwards (e.g. producing a global scale of governance), downwards (e.g. producing a landscape, community scale and a REDD+ project scale of governance) or outwards (e.g. towards non-state actors (Reed and Bruyneel 2010: 651; Cohen and McCarthy 2014: 2)) altering the abilities of different social actors to access land and property ${ }^{4}$. For investigating transnational conflicts on access and property in REDD+ target areas, the conceptual framework of this thesis is based on the broader scholarship of political ecology and on the interrelated politics of scale literature.

Political ecology emerged out of critique towards neo-Malthusian and euro-centric approaches for analyzing environmental degradation (Bryant 2001: 152). The pioneers of the field Piers Blaikie and Harold Brookfield (1987: 17) have defined political ecology as a research field that "[...] combines the concerns of ecology and a broadly defined political economy. Together this encompasses the constantly shifting dialectic between society and land-based resources and also within classes and groups within society itself" (ibid). Contemporary political ecology is rather a broad scholarship that focuses on the interrelations between political economy, ecological processes and power relations than a single theory (Köhler 2008: 214). Political ecologists built on wide range of schools of thought coming from very different epistemological perspectives (e.g. (critical realism, hermeneutics / social constructivism, post-structuralism) approaches loosely stuck together by at least five central assumptions ${ }^{5}$ :

- social relations are organizing access to natural resources (Gezon and Paulson 2004: 2);

- trade-offs between different actors and different types of natural resource use characterize human-environmental interactions (ibid.);

- nature is negotiated in different arenas and on different socially produced and interconnected scales (Bryant 2001: 153; Gezon and Paulson 2004: 13; Tsing 2000);

\footnotetext{
${ }^{4}$ Property is simply defined as socially legitimate relationship to objects of value (Sikor and Lund 2010: 3-5), a more comprehensive discussion of property will be described in section "Defining Property".

${ }^{5}$ In "Place, Power, Difference - Multiscale Research at the Dawn of the Twenty-first Century" Lisa I. Gezon and Susan Paulson (2005: 2) identify five core concepts of political ecology: first: "[...] resource use is organized and transmitted through social relations [...]", second: acceptance of trade-offs, different interests and positions, third: "global connectedness", fourth: "[...] political, economic, and ecological expressions may be mutually reinforcing" marginality. For this purpose here I have modified and expanded their definition drawing mainly on Peet et al (2011), Bryant (2001), Ribot and Peluso (2003) and Tsing (2000).
} 
- power differentials and social identity are important explanations for socially differentiated abilities to benefit from natural resources (Gezon and Paulson 2004; Ribot and Peluso 2003);

- last but not least political ecologists have a clearly normative goal, which is environmental justice (Blaikie 2012: 2).

Research of political ecologist is qualitative, participatory and evidence-based. Evidence-based political ecology is characterized by "progressive contextualization" through linking local environmental dynamics with local, regional and global chains of interaction (Bryant 2001: 153).

In German speaking countries the concept of societal relationships with nature (Gesellschaftliche Naturverhältnisse) based on the Frankfurt School of thought has been quite influential for scholars of political ecology (Görg 2011: 416; Köhler 2008: 210; Pichler 2014: 19). The concept of societal relationships with nature developed by Christoph Görg $(1999,2011)$ goes to some extend beyond the Anglo-Saxon political ecology stressing the importance of institutions and different state agencies. The concept explicitly considers that "[...] conflicts over societal relationships with nature are closely interlinked with spatio-institutional transformations of the state" (Brand, Görg, and Wissen 2011: 150).

The politics of scale literature, as the second strand of literature relevant for this thesis has been influential in critical human geography and has its roots in socio-spatial theory developed by Henry Lefebvre (1976a) and Edward Soja (1980). Socio spatial theorists argue that:

- " "[...] relations of production are social and spatial" (Soja 1980: 208).

- Capitalist development is uneven (Smith 2008) leading to "[...] division of organized space into dominant centers and subordinate peripheries, [...]" (Soja 1980: 209).

- Space is a social product (Lefebvre 1976: 31, Soja 1980: 209), "space itself may be primordially given, but the organization, use, and meaning of space is a product of social translation, transformation and experience" (Soja 1980: 210).

- "Space is political and ideological" (Lefebvre 1976: 31), socially produced space reflects the dominant ideologies and modes of production (Lefebvre 1976: 31, Soja 1980: 210).

- Scale is a socially produced and a dynamic spatial element within socially produced space (Brenner 1998; Towers 2000; Wissen 2008).

Moreover, the politics of scale literature has been influenced by the world system theory of Immanuel Wallerstein (1974). Immanuel Wallerstein assumes that the world economy is s single system consisting of a disadvantaged semi-periphery and of advantaged core countries (ibid. 3-4).

Scale theorists and political ecologists share many theoretical and empirical concerns and have been recently more and more engaged in an intense dialog (Neumann 2009: 398-400). Early political 
ecologists such as Blaikie and Brookfield (1987: 79) already highlighted the interconnectedness "[...] of political economic relationships at the local, regional and international scales which determine the actions of land-user [...]". Authors such as Erik Swyngedouw (2010) and Karl Zimmerer $(2000,2006)$ have bridged both strands of literature drawing on socio-spatial theory for analyzing the production of specific natures (Neumann 2009: 402). The societal relationships with nature literature also explicitly stress the relevance of scale production and rescaling for accessing natural resources (Wissen 2008: 168; Brand, Görg, and Wissen 2011).

Following Roderick P. Neumann (2009: 403) and Bettina Köhler (2008: 216-20), I argue for an approach for investigating access and property that explicitly theorizes scale relations, processes of rescaling considering power imbalances and agency (ibid.). In this chapter, I will first establish key theories, and I will derive and further develop core assumptions (table 1) guiding my research. Second, I facilitate the application through developing major concepts such as power, property and authority. For defining these concepts, I have to rely to some extent on other theories since politics of scale is underspecified with regard to power, authority and property rights.

In the next section, I will briefly illustrate how geographers and political ecologists understand the terms nature and landscape. I consider nature, landscape and scale as closely entangled terms. Landscapes as the materialization of social processes can be considered as being part of what Lefebvres (1991, 1976b) describes as "second nature". Scale delimits landscapes and the second nature. Moreover, scales are investing landscapes with meanings and regulations (Towers 2000: 26). Second, I will review the theoretical and political economy oriented politics of scale literature and the growing body of the politics of scale literature focusing on environmental politics. Third, the concepts of power and resistance will be discussed and defined in a emprically applicable way. Fourth access and property concepts and the relevance of scale for anayzing access and property relations will be outlined. Finally, I will outline the synthesized conceptual framework including key arguments and guiding assumptions for a historically contingent investigation of transnationalized access and property conflicts in REDD+ target areas.

Finally yet importantly, it is worthwhile to mention that the conceptual framework of this study has not been developed a priori. It has been developed in an active and intense dialog between empirics and theoretical concepts. 


\subsection{The production of nature and landscapes}

Nature and especially human-nature or human-environmental interactions have always been central to geographical research. In recent debates within the discipline, scholars argue that nature is either socially constructed or produced (Demeritt 2001). Political ecologists research starts with the basic assumption that the appropriation and transformation of the biophysical environment through labor produces a "second nature" (Lefebvre 1976b: 15) or "social nature" (Castree 2001). This study builds on a dual understanding of nature based on the societal relationships with nature concept (Görg 2011: 416). First, a material dimension refers to economic and technical forms of appropriation (ibid.). Second, a symbolic dimension refers to nature as a cultural construction (ibid.). Both dimensions are no binary opposites, they are intrinsically linked to each other. Nature is produced by society through practices, through linguistic and scientific meanings but nature still has a biophysical and material basis with inherent physical processes (Escobar 1999: 3; Görg 2011: 417). In more illustrative terms, the social practices of smallholders, conservationists and logging companies transform the meanings of nature but at the same time they transform the biophysical materiality of nature. The biophysical materiality of nature is rather shaped by social practices and discourses than determined by its materality (ibid.). Thus, the very same nature, or more specifically a forest can be experienced differently "[...] according to one`s social position" (Escobar 1999: 5). For a logging company a forest is primarily a source of timber. The semi-nomadic Batin Sembilan in the Harapan Rainforest might conceive the same forest as a fruit garden whilst a frontier migrant might consider the forest as empty space for agriclutural expansion. A REDD+ project developer in contrast might conceive the forest as a carbon storage and as source of forest carbon credits.

As nature, the term landscape is widely used in geography. According to George Towers (2000: 26) landscapes are the starting point for "the political geography of scale". The term landscape usually seeks to encompass social and biophysical aspects in a more or less well defined space (Duncan 1995; Görg 2007; Potschin and Haines-Young 2006). Landscapes are spatial units of nature that have been created by the "[...] human gaze that divide things up and forms the separated parts into specific units" (Simmel 2007: 22). Thus, landscapes are distinct socially produced spatial elements of the broader social or second nature (Görg 2007: 960). Landscapes are not constant socio-ecological spaces, they reflect different succeeding, competing and overlapping historical societal relationships with nature and continuous processes of socio-political transformation (Lefebvre 1976a: 31; Görg 2007). Specific individuals, actor groups and broader societal processes are driving landscape transformation (Faust and Kreisel 2006: 234). 
Recently the term landscape gained importance in policy debates on conservation and REDD+. Scholars from the influential Center for International Forestry Reseacrh (CIFOR) argue that so called "landscape approaches" are needed to manage trade-offs between conservation, climate change mitigation and development goals (Sayer et al. 2013). They define landscapes in a rather technical way "[...] as an area delineated by an actor for a specific set of objectives" (Sayer et al. 2013: 8350).

\subsection{Politics of scale and the social production of space and scale}

In cartography and remote sensing, the scale refers to the spatial resolution of maps or satellite images. Almost in all sciences, the term refers to the spatial level of analysis. Environmental scientists use the term for describing the spatial extend of ecosystem dynamics, environmental problems and disasters. The politics of scale literature argues that self-evident and daily used terms with socio-spatial and territorial implications such as the household or the nation state only appear as given (Sayre 2005: 283). They are the outcome of very social processes and are consequently socially produced (Brenner 2001; Cox 1998; McCarthy 2005a; Towers 2000).

First, the politics of scale literature focuses not on scale as such but seeks to explain processes that lead to the construction of different forms of (hierarchical) socio-spatial organizations such as Indonesia's nested administrative system (with its neighborhoods (rukun tetangga), hamlets (dusun), and villages (desa)). For describing the socio-spatial organization of institutions, e.g. of Indonesia's nested administrative system again, the term scalar structure is often used by authors of the politics of scale literature (Brenner 1998; Purcell 2002).

Second, the politics of scale literature focuses on the social and ecological consequences of scale construction or reconstruction. For instances, the construction of a REDD+ project as a new scale of forest governance may enhance forest protection but may also exclude certain actors e.g. shifting cultivators and logging companies from accessing the project area. Third the politics of scale literature seeks to explain dialectical relationships between structure and agency (Marston 2000: 220; Towers 2000: 26). Actors may actively alter the configuration of existing scales and seek to produce new scales. But existing scales may also structure the livelihoods of actors (Wissen 2008: 20). Questions of power are explicitly mentioned by authors such as Neil Smith (1992, 2008), James Meadowcroft (2002) and Leo Charles Zulu (2009) as important factor constituting different scalar arrangements. However, most authors are not clearly defining power. A more detailed conceptualization of power is therefore part of a separate section (see section 2.3). 
The politics of scale literature stands in the tradition of historical-materialist approaches towards sociospatial theory (Wissen 2008: 19). Starting point is the basic argument formulated by the socio-spatial theorists Edward Soja (1980) and Henry Lefebvre (1976a) that space is socially produced (Lefebvre 1976a; Marston 2000; Soja 1980; Towers 2000). Soja (1980: 210) argues that “[...] space in its purest physical sense [...] may be primordially given, [...]" but what he then calls social space or created space is socially produced through transforming "[...] the given conditions inherent in life-on-earth" (ibid.). Socially produced space reflects modes of production, political organization and ideology (Soja 1980: 210; Lefebvre 1976a: 31). In this sense, the social production of space is a dialectical process. Space, political organization and relations of production mutually depend on each other. Space is the outcome of social relations. At the same time, space is structuring and mediating social relations (Soja 1980: 211). The concept of scale expands the socio-spatial theory of Lefebvre and Soja since it locates social practices not as fixed within space but within dynamic socially produced scales (Brenner 1998: 459, Wissen 2008: 19). Starting point is the premise that scale as space is socially produced (Towers 2000 : 26).

In the next paragraphs I will intensively review the political economy oriented approaches of Neil Brenner $(1997,2001)$ and Neil Smith $(2008,1992)$ for developing elements for a politics of scale informed conceptual framework for analyzing transnational conflicts on access and property in REDD+ target areas.

\subsubsection{Scale production and the state}

The focus of Brenner's work is to conceptualize the role of the state in the production of scale (Marston 2000: 226). Drawing on Lefebvre he argues "[...] that the territorial state has played a crucial role in constructing a worldwide 'second nature' of sociospatial configurations organized on multiple, overlapping spatial scales" (Brenner 1997: 149). He further argues that globalization, as ongoing rescaling processes of the world economy is associated with state interventions that support the expansion of capitalistic modes of production (Brenner 2001: 594; Marston 2000: 227). Brenner claims that the "geoeconomic project of neoliberalism" which goes hand in hand with processes of commodification have transformed the scalar organization and scales of "sociopolitical regulation" (Brenner 2001: 594).

State interventions facilitated privatization and scalar re-structuring that might have territorial and tangible outcomes inscribed in the landscape (Marston 2000: 221-227). In Indonesian forest landscapes the so called sector laws (e.g. forest law, in more detail in chapter five) have promoted investment in natural resource exploitation by establishing a concession system with far reaching territorial consequences challenging established modes of production (e.g. shifting cultivation 
practices conducted by customary communities), scales of meaning and scales of sociopolitical regulation (Elmhirst 2001; Peluso, Afiff, and Rachman 2008; Pye 2012; Rachman 2011: 30-36). Tangible outcomes of rescaling process might be direct changes in land use, for instance a shift from shifting cultivation to commercial large-scale oil palm plantation estates. A national concession system is a new scale regulating access to land for the purpose of facilitating forest exploitation and plantation developments thus changing the character and the meaning of a landscape previously used for other purposes. Brenner proposes to use the concept of politics of scale in a process-based sense, e.g. referring to political processes (e.g. decentralization of forest governance or the construction of a new transnational scale of forest governance) which may lead to the production of new scalar configurations and those altering existing scalar configurations and scalar hierarchies (Brenner 2001: $600)$.

\subsubsection{Scale production and agency}

Neil Smith (2008: 229) uses the politics of scale concept in a broader sense defining scale as "[...] the most elemental form of spatial differentiation, from the demarcation of the home to the globe". He argues that the production of scale is not only the outcome of state interventions and modes of production but also of human agency and social and cultural practices which are embedded in the context of the broader political economy (Marston 2000: 223). He conceptualizes politics of scale as the frictions and contestations within scales and between scales (Marston 2000: 228; Smith 1992: 64). Scale, according to Smith's understanding demarcates arenas of political contest. Scale in this sense "[... ] both contains social acitivity, and at the same time provides already partioned geography within which social acitivity takes place" (Smith 1992: 66). Smith argues that any hierarchical and nested scalar configurations are neither ontological given nor strictly demarcated they are" [...] produced as part of the social, cultural and political landscapes [...]" (Smith 1992: 66).

In Smith's understanding social conflicts take place on more than one scale. Especially subaltern groups, marginalized at the local scale might seek to "jump" (Smith 2008: 232) to a more promising scale. Scale jumping, Smith argues is used as a resistance strategy that might facilitate alliances between actors or which might provide access to resources or to political decision making at higher or lower scales. Sucessful actors are consequently those that are able to choose the scale of political struggle for achieving their interests, this might include the deconstruction of scales serving the intests of political oponents (Smith 2008: 232). Active scale choices can be used in order to in-or exclude actors from access to political resources, natural resources and land (Lebel, Garden, and Imamura 2005: 1). Section 2.3.4 will provide a more detailed discussion on forms of resistance beyond scale jumping that are relevant for this study. 
The approaches of Brenner and Smith and the broader historical-materialist theory on statehood form the conceptual basis of most of the later writings. Recently the politics of scale concept is becoming increasingly popular for studies investigating the social production of environmental problems. The 'environmental' politics of scale literature builds explicitly on Brenner and Smiths approaches but aims to shift the focus of the debate from labor relations, and modes of production towards conflicts and contradictions inherent in the social production and appropriation of nature (McCarthy 2005a: 735; Swyngedouw 2010: 12). The politics of scale concept has been applied in different cultural contexts and in different fields. It has been used: for analyzing the consequences of a changing role of the state in environmental governance (Bulkeley 2005; Cohen and McCarthy 2014; McCarthy 2005c, 2005b; Reed and Bruyneel 2010; Brand et al. 2008); for analyzing natural resource and land conflicts (e.g. Agius et al. 2007; Burlando 2012; Lebel, Garden, and Imamura 2005; Perreault 2003; Swyngedouw 2010; Zulu 2009); and for analyzing struggles over conservation and environmental justice (Towers 2000; Zimmerer 2000; Zulu 2009).

\subsubsection{State transformation and rescaling of environmental governance}

Ongoing and historically contingent state transformations (e.g. colonization, decolonization, neoliberalism) and the increasingly transnationalized environmental and forest governance induced significant rescaling processes affecting access and property relations. The politics of scale literature and the broader materialistic state theory argues that the state and its role in governing the environment is embedded in and the result of broader societal processes (Brand and Görg 2003: 221).

In broader terms materialistic state theory argues that the state, is not a homogenous actor (Brand and Görg 2003: 226). Ulrich Brand and Christoph Görg (2003: 226), based on Nicos Poulantzas conceptualize the state as a "[...] power-based social relation which creates, in the form of apparatuses $^{6}$, a materiality which by itself is full of conflicts and contradictions". The different apparatuses of the state have different sometimes competing or contradictive interests and projects e.g. agricultural agency might push agricultural expansion while the forest agency is expanding protected areas. As the statement of Brand and Görg indicates, the state and its different apparatuses are characterized by contradictive social relations of conflict and cooperation (Brand and Görg 2003: 226; Poulantzas 1978: 131). Different apparatuses of the state are mediating between different actors (e.g. private sector and the civil society) embedded in specific power constellations; actors that are more powerful have more direct access to the regulatory power of the state. The state reflects

\footnotetext{
${ }^{6}$ The state apparatus is defined based on Poulantzas as the "[...] ensemble of the structures of a social formation $[\ldots]$ " including "[....] the personnel of the state, the ranks of the administration, bureaucracy, army, etc. Thus the state apparatus is a "[....] network of institutions and personnel through the state function is executed" (Barrow 1993).
} 
"societal relationships" and is part of society. In this sense "[...] are the 'state' and '(civil)' society formally separate, at the same time they form a contradictory unity" (Brand et al. 2008: 35).

The contradictive activities of different apparatuses of the state are relevant variables for understanding rescaling processes (e.g. because of decentralization) and their impacts on conflictive access and property relations. Different local state apparatuses such as Indonesian village governments, sectoral state agencies and informal public authorities might legitimize overlapping and conflictive property rights with reference to the state (for sub-saharian Africa Lund 2008: 7). Section 2.4 will provide a more detailed conceptual discussion on the role of competing authorities providing legitimacy for different types of property.

Ulrich Brand and colleagues (2011: 150) argue "[...] that conflicts over societal relationships with nature are closely interlinked with spatio-institutional transformations of the state". The recent changes can be explained with the transformation towards post-Fordism ${ }^{7}$ in the developed world and the global rise of neoliberalism ${ }^{8}$ and its disruptive structural adjustment programs in the global South (Brand and Görg 2003: 222-223; Elmhirst 2001: 287; Nevins and Peluso 2008: 8-11; Peet, Robbins, and Watts 2011: 21; Brand et al. 2008: 4-6). Neoliberalism and a post-Fordist mode of regulation increased competition between states fostering structural change to enhance profit options for private investors (Brand and Görg 2003: 222). Furthermore, in the course of neoliberal reforms the nation state has given up authority to scales above the nation state (e.g. UNFCCC, ASEAN, WTO), below the nation state (e.g. district and provincial governments) ${ }^{9}$ and to non-state actors (e.g. conservation companies such as PT $\mathrm{REKI}^{10}$ ) (Cohen and McCarthy 2014; Hein and Garrelts 2014).

In Indonesia as in other post-colonial societies, the modern state and its bureaucracy have been established in a process of colonial subjection. The colonial state reflected tensions between different actors within the colony and within the state of the overseas colonizer ${ }^{11}$ (Alavi 1972: 61; Schiel 2001:

\footnotetext{
7 The regulation school of thought emerging in 1980s in France has introduced the term post-fordism for describing transitions of capitalism starting in the 1970s. A post-fordist mode of regulation refers to new patterns of socio-technical and institutional organization (e.g. network society, just-in-time production, flexible specialization) characterizing contemporary capitalism (Fürst 2001; Amin 2008).

${ }^{8}$ Neoliberalism according to David Harvey (Harvey 2005: 2) "[...] is in the first instance a theory of political economic practices that proposes that human well-being can best be advanced by liberating individual entrepreneurial freedoms and skills within an institutional framework characterized by strong private property rights, free markets, and free trade". Neoliberal thinking has influenced political practices since the 1970s across the globe leading to deregulation, privatization, state transformation and to the creation of new markets for noncommodified goods and services e.g. health care, water, environmental pollution (e.g. carbon credits) and land (ibid. 3).

${ }^{9}$ For a more detailed discussion of decentralization processes, in particular in Indonesia's forest sector consider section 5.14 .

10 PT, acronym for Perseroan Terbatas (limited liability company), REKI, acronym for Restorasi Ekosistem Indonesia.

${ }^{11}$ Conflicts within the forest apparatus of the colonial state are mentioned in section 5.1.1.
} 
106). Moreover, many post-colonial societies inherited an overdeveloped state that weak post-colonial civil societies were not able to control (Alavi 1972: 61) leading to the rise of a military dominated state bureaucracy such as the New Order regime of Suharto in Indonesia (Mochtar 1995; Ufen 2002).

In Indonesia and in other emerging economies, the interventionists development state has been transformed into the "national competition state" (Brand and Görg 2003: 222; Heigl 2011: 132; Hirsch and Kannankulam 2011) supporting privatization, commercialization and transnationalization of natural resources (Pye 2012: 202). In Indonesia, this transformation occurred not unidirectional reflecting tensions between protectionists and world-market oriented actors (Ufen 2002: 120). Andreas Ufen (2002: 124) has identified three phases of state transformation since Suharto came to power: first a period of economic liberalization between 1965-1974, second a period of petro-dollar financed interventionists development policies between 1974-1983, and third again and still ongoing a period of economic liberalization associated with deregulation, privatization, decentralization and market opening (ibid.).

National competition states are increasingly considering the opportunities of carbon, biodiversity and conservation markets and seek to provide perfect framework conditions for private investors, and for interventions of transnational NGOs and international donors (Brand and Görg 2003; While, Jonas, and Gibbs 2010). Biodiversity offsets, genetic resources, privatized conservation and forest carbon offsets constitute the "ecological phase" of capitalism (Escobar 1996: 326). They become increasingly relevant for states in the context of market-based climate change mechanisms such as REDD+ and for accessing other sources of climate finance (e.g. Green Climate Fund).

In Indonesia, first market-based conservation policies delegating protected area management to private actors came up in the 2000s permitting private conservation concessions and payment for ecosystem service projects. REDD+ accelerated the process. First regulations permitting private actors to run REDD+ offsets have been issued in 2008 (Hein 2013b; Hein and Faust 2014; Walsh, Asmui, and Utomo 2012).

Based on the above mention spatio-institutional transformations and based on Maureen G. Reed and Shannon Bruyneel (2010: 651) I deviate three rescaling processes relevant in the context of REDD + implementation in Indonesia:

- up-scaling of state functions towards international state apparatuses (e.g. UNFCCC, FCPF);

- down-scaling of state-functions towards regional state apparatuses and local communities (e.g. local governments, community-based conservation projects) 
- scaling-out or delegating state functions towards non-state actors (e.g. conservation companies running REDD+ projects, transnational carbon standards certifying forest carbon offsets).

\subsubsection{Socio-ecological rescaling and the production of scales of meaning and regulation ${ }^{12}$}

The historically contingent social transformation and appropriation of nature produces specific social and material natures (Swyngedouw 2010: 11). Scales as a geographical construction divide sociomaterial natures (ibid. 12). Consequently, scales can be understood as particular spaces containing social processes and biophysical processes (ibid). Culture and social practices provide meanings for physical, ecological and material phenomena such as climate change, droughts and forest fires. Furthermore, cultural and social practices produce different scales for different or for the very same physical and ecological phenomena. Some phenomena are constructed as being active at a global scale (e.g. climate change); others are constructed as local phenomena. The 'environmental' politics of scale literature describes the construction and configuration of scales, including those that might appear as biophysically given as the outcome of socio-ecological dynamics structured by power relations (Sayre and Vittorio 2009; Swyngedouw 2010; Zimmerer 2000; Zulu 2009).

George Towers (2000: 26) drawing especially on Soja, Lefebre and Brenner extends the discussion and argues that, "the social production of space invests the landscape with meaning and regulation [...]" dividing social and biophysical procsses within "[...] landscapes into scales of meaning and regulation". Both scales are produced through social struggle and may overlap spatially and institionally (ibid.). Scales of regulation refer to spatial entities with specific rule systems governed by state authorities or in the case of non-state actors by regional divisions of NGOs or businesses (Towers 2000: 26). Scales of meaning, according to Towers refer to constructed socio-cultural meanings of ecosystems, of a wider landscape or a nation (ibid.).

Different conflictive scalar narratives attributing different meanings to places and landscapes express social conflict on scales of meaning. I will pick up an example I have provided in the section "the production of nature and landscapes". Forest in Jambi can be considered as one specific occurrence of "second nature", they had been transformed through specific modes of production entangled with modes of social spatial organization. In pre-colonial times, the most relevant modes of production were shifting cultivation and gathering of non-timber forest products. These practices transformed nature and produced (cultural) landscapes invested with distinct scales of meaning e.g. community

\footnotetext{
12 Parts of this section have been published in Hein et al. (2015) "Rescaling of access and property relations in a frontier landscape: insights from Jambi, Indonesia", The Professional Geographer.
} 
forest as hunting grounds, community forests as spaces for shifting cultivation and community forests as sources of non-timber forest products. Dutch colonization introduced new scales of meaning constructing Jambi's forest as source of colonial wealth linking Jambi's forests with the colonial administration in Jakarta and the Dutch government in the Netherlands. Different conceptualizations of nature and landscape lead to different scalar configurations and vice versa. The specific outcomes e.g. Jambi's forest as source of colonial or of community wealth might contradict each other inducing social conflict. Conservationists, may refer to the particularities of a specific landscape - e.g., a habitat of the endangered Sumatran Tiger or the carbon storage capacity of peat swamp - and, consequently construct a scalar narrative for creating a new scale of meaning (Kelly 1997; Swyngedouw 2010; Towers 2000; Hein et al. 2015: 2). In contrast, indigenous groups construct scales of meaning based on their ancestral lands that offer alternative boundaries for legitimizing their presence in a landscape (Hein et al. 2015: 2).

In contrast, social conflicts on scales of regulation are expressed by attempts of actors to limit or expand the applicability of specific regulations to existing higher or lower scales or by constructing additional scales (ibid.). Scales of regulation are defined as social spatial entities (e.g. jurisdictions) with a specific legal order (Flitner and Görg 2008: 170; Hein et al. 2015: 3; Towers 2000: 26). Picking up the conservationists' example again, if conservation campaigns are successful in transforming a scalar narrative into a scalar practice e.g. through the establishment of a reserve for protecting the Sumatran Tiger, the established scale of meaning might be complemented by a new scale of regulation. The new conservation scale might exclude actors and may challenge preexisting scales of meaning and regulation (Cohen and McCarthy 2014: 8; Hall, Hirsch, and Li 2011: 60; Zimmerer 2000: 359). Socioecological rescaling processes, e.g. through the decentralization of forest governance and implementing protected areas might have an important influence on, among others, the ability of actors to acces land (Swyngedouw 2010: 12, Ribot and Peluso 2003: 154) and to participate in decisionmaking processes regarding natural resource use (Larson and Ribot 2004: 5).

\subsubsection{Derivation of core assumptions}

Political scales, as mentioned above demarcate arenas of political contest (Smith 1992: 66). Thus, scales are arenas of political struggle which are not fixed and which are linked through actor networks and scale jumping (Bulkeley 2005; Flitner and Görg 2008; Swyngedouw 2010). Social conflict visible through competing scalar narratives and practices might alter the scalar configuration (e.g. deconstruct pre-existing scales, widen existing scales or construct additional scales) and the material and biophysical content of a specific scale. 
Most of environmental politics of scale literature focuses on conflicts and contradictions in the course of watershed management projects. Only few scholars have applied the politics of scale concept for analyzing natural resource conflicts beyond the water sector yet. Zimmerer for instance (2000) analyzed the implementation of protected areas. He claims "[...] scale is central to today's conservation boom" (Zimmerer 2000: 360). He identifies strong analogies between the production of scales in the context of economic globalization and between the production of protected areas as scales of conservation. Both processes involve different actors from different places linked through networks and the active "containing of space" (ibid. 361). The produced new conservation scales are restricting access, may threaten livelihoods and might produce a new community scale neglecting power asymmetries and the heterogeneity of communities ${ }^{13}$ (Cohen and McCarthy 2014: 6; Hall, Hirsch, and Li 2011: 60; Zimmerer 2000: 359). Leo Charles Zulu (2009) argues in the same direction. He analyzed the implementation of a community-based natural resource management project in Malawi. Project implementation induced different rescaling processes of decision making towards traditional elites altering land tenure arrangements and reducing the ability of non-elite households to benefit from the resources of the community forest significantly (Zulu 2009: 695f). As response land user jumped to the lower household scale and started to manage individual tree plantations (ibid.).

In many cases, powerful groups are able to actively choose or alter the scale of regulation for achieving specific interests. Subaltern groups seek to jump to higher or lower scales or seek to establish networks across scales for achieving their interests (Perreault 2003: 65; Zulu 2009: 695). Thomas Perreault (2003: 68) investigated the role of "multi-scalar networks" and the politics of "place-based" community organizations for legalizing customary land claims. Community based organizations based on social and ethnic identity contributed significantly to the reconstruction of a common and shared community heritage and served as focal points for external support. Furthermore, actor coalitions across scales, involving local, provincial, national and transnational allies contributed significantly to the ability of indigenous communities to legalize land claims and to access benefits from national and multilateral development projects (ibid.).

In the water sector, the politics of scale literature has contributed towards an understanding of watershed management as a contested political rescaling process (Houdret, Dombrowsky, and Horlemann 2014; Swyngedouw 2010). Swyngedouw for instance (2010: 15ff) analyzed the establishment of watershed management agencies in Spain in the $20^{\text {th }}$ century. Spanish modernizing elites sought to transform the territorial structure of the country through the establishment of new political boundaries based on 'natural' watershed boundaries (ibid.). The reterritorialization attempts,

\footnotetext{
${ }^{13}$ This might occur for instance through implementing so-called community benefits.
} 
argues Swyngedouw (2010: 17) had been part of a broader strategy to challenge the existing territorial claims of the traditional Spanish elite.

In table 1 below, I will list the main guiding assumptions derived from politics of scale and socio-spatial theory. The table lists assumptions on how scales are constructed, causes of scalar change, and implications of scalar structure and scalar change for different actors, scalar change and conflict and scale relations. 


\begin{tabular}{|c|c|c|}
\hline & Guiding assumptions & Additional illustration and/ or empirical examples \\
\hline \multirow{4}{*}{$\begin{array}{l}\text { Construction/ } \\
\text { production of } \\
\text { scales }\end{array}$} & $\begin{array}{l}\text { Socially produced space } \\
\text { reflects modes of } \\
\text { production, political } \\
\text { organization and } \\
\text { ideology (Soja 1980: } \\
\text { 210; Lefebvre 1976a: } \\
\text { 31). }\end{array}$ & $\begin{array}{l}\text { Specific modes of production e.g. agro-industrial plantations } \\
\text { produce specific spaces, political organization and ideology } \\
\text { are reflected in spatial institutional structure (e.g. central or } \\
\text { decentralized state) (Soja 1980: 249; Lefebvre 1976a: 31). }\end{array}$ \\
\hline & $\begin{array}{l}\text { Scale as space is } \\
\text { socially produced } \\
\text { (Towers 2000: } 26 \text { ). }\end{array}$ & $\begin{array}{l}\text { Scale as the most elemental form of spatial differentiation } \\
\text { (Smith 2008: 229). Scale as the outcome of modes of } \\
\text { production, human agency and cultural practices. }\end{array}$ \\
\hline & $\begin{array}{l}\text { Dynamic scales reflect } \\
\text { the dialectical } \\
\text { relationships between } \\
\text { structure and agency } \\
\text { (Marston 2000: 220; } \\
\text { Towers 2000: 26). }\end{array}$ & $\begin{array}{l}\text { Actors produce scales and scales structure at the same time } \\
\text { the activities of actors (Smith 1995: } 60) \text {, for instance } \\
\text { protected areas and REDD+ projects are constructed by } \\
\text { actors shaping social activities of peasants by prohibiting } \\
\text { access. }\end{array}$ \\
\hline & $\begin{array}{l}\text { Socially produced } \\
\text { scales contain social } \\
\text { acitivties and } \\
\text { ecological processes } \\
\text { (Smith 1992, Reed and } \\
\text { Bruyneel 2010, } \\
\text { Swyngedouw 2010). }\end{array}$ & $\begin{array}{l}\text { Socially produced scales such as the Harapan Rainforest } \\
\text { Project and the Berbak Carbon Project contain social } \\
\text { processes (e.g. land conflicts) and ecological processes (e.g. } \\
\text { carbon storage capacity of forest ecosystems). }\end{array}$ \\
\hline \multirow[t]{2}{*}{$\begin{array}{l}\text { Causes of } \\
\text { scalar change }\end{array}$} & $\begin{array}{l}\text { State transformations } \\
\text { lead to scalar } \\
\text { restructuring (Brenner } \\
\text { 2001) }\end{array}$ & $\begin{array}{l}\text { Broader processes of state transformation alter the scalar } \\
\text { structure (Brenner 2001), for instance decentralization } \\
\text { changes the scalar structure, in particualar the structure of } \\
\text { scales of regulation and associated repsonsabilities of local } \\
\text { state apparatuses e.g. in legitimizing land claims as property. } \\
\text { Delegating of state functions to non-state actors (scaling out) } \\
\text { (Reed and Bruyneel 2010) alters the actor constellation in } \\
\text { place and might lead to the construction of privatized scales } \\
\text { of regulation. }\end{array}$ \\
\hline & $\begin{array}{l}\text { Agency and social } \\
\text { conflict can lead to } \\
\text { scalar change (Smith } \\
\text { 2008). }\end{array}$ & $\begin{array}{l}\text { Social actors are able to alter scales, to construct new scales } \\
\text { and scales structure and limit acitivities of social actors. } \\
\text { Village heads are able to expand the scales of regulation } \\
\text { through issuing village-scale land titles (Hein et al. 2015). }\end{array}$ \\
\hline \multirow{2}{*}{$\begin{array}{l}\text { Scalar change } \\
\text { and conflict }\end{array}$} & $\begin{array}{l}\text { Social conflicts can be } \\
\text { caused by conflictive } \\
\text { and overlapping scales } \\
\text { of meaning and } \\
\text { regulation (Towers } \\
2000 \text { ). }\end{array}$ & $\begin{array}{l}\text { Overlapping scales of regulation e.g. village scale of } \\
\text { regulation overlapps and competes with the national scale } \\
\text { (state forests) inducing conflicts on the legitimcy of property } \\
\text { rights. }\end{array}$ \\
\hline & $\begin{array}{l}\text { Scale structures } \\
\text { conflicts and scale is } \\
\text { the outcome of } \\
\text { conflicts (Towers 2000: } \\
\text { 26). }\end{array}$ & $\begin{array}{l}\text { Scale, according to Smith's understanding demarcates arenas } \\
\text { of political contest. Scale in this sense "[...] both contains } \\
\text { social acitivity, and at the same time provides already } \\
\text { partioned geography within which social acitivity takes } \\
\text { place" (Smith 1992: 66). }\end{array}$ \\
\hline
\end{tabular}




\begin{tabular}{|c|c|c|}
\hline & $\begin{array}{l}\text { Rescaling might led to } \\
\text { the exclusion of actors } \\
\text { (Zimmerer 2000: } 359 \text {; } \\
\text { Hall, Hirsch, and Li } \\
\text { 2011: 60; Cohen and } \\
\text { McCarthy 2015: 8). }\end{array}$ & $\begin{array}{l}\text { Establishment of protected area might restrict access for } \\
\text { peasants (as explained above) (Zelli et al. 2014). }\end{array}$ \\
\hline \multirow{4}{*}{$\begin{array}{l}\text { Scale/ spatial } \\
\text { relations }\end{array}$} & $\begin{array}{l}\text { Scales are often } \\
\text { structured in a } \\
\text { hierarchical way } \\
\text { (Swyngedouw 2010: } \\
\text { 13). }\end{array}$ & $\begin{array}{l}\text { Scale as socially contructed spatial unit e.g. village, province, } \\
\text { nation, globe. Expansion of a specific scale e.g. village scale } \\
\text { reflects human agency (Smith 2008; Swyngedouw 2010). }\end{array}$ \\
\hline & $\begin{array}{l}\text { Sucessful actors are } \\
\text { able to choose the } \\
\text { scale of political } \\
\text { struggle (scale } \\
\text { jumping) for achieving } \\
\text { their interests, this } \\
\text { might include the } \\
\text { deconstruction of } \\
\text { scales serving the } \\
\text { intests of political } \\
\text { oponents (Smith 2008: } \\
\text { 232). }\end{array}$ & $\begin{array}{l}\text { The Indonesian indigenous rights organization AMAN (Aliansi } \\
\text { Masyrakat Adat Nusantara, Indigenous Rights Movement of } \\
\text { the Archipelago) was able to shift local struggles on } \\
\text { customary land rights to the constitutional court (national } \\
\text { scale) (more in section 5.2.1.) (Rachman 2013). }\end{array}$ \\
\hline & $\begin{array}{l}\text { Active scale choices } \\
\text { can be used in order to } \\
\text { in-or exclude actors } \\
\text { from access to land } \\
\text { (Lebel, Garden, and } \\
\text { Imamura 2005: 1). }\end{array}$ & $\begin{array}{l}\text { Actors might actively shift political struggle to a specific } \\
\text { scale, e.g. PT REKI seeks to shift struggle to the national scale } \\
\text { highlighting that the conservation company is the only actor } \\
\text { with national-scale land title (e.g. conservation concession) } \\
\text { (more in chapter six and seven). }\end{array}$ \\
\hline & $\begin{array}{l}\text { Not all spatial relations } \\
\text { can be covered by the } \\
\text { scale concept, espcially } \\
\text { network relations } \\
\text { might be relevant as } \\
\text { well (Jessop, Brenner, } \\
\text { and Jones 2008; Hein et } \\
\text { al. 2015). }\end{array}$ & $\begin{array}{l}\text { For instance "multi-scalar networks" have proofed to be } \\
\text { important for legalizing customary land claims (Perreault } \\
\text { 2003: 68) and horizontal relations proofed to be relevant as } \\
\text { well (Hein et al. 2015). }\end{array}$ \\
\hline
\end{tabular}

Table 1: Guiding assumptions derived from the politics of scale literature (Source: by the author)

\subsection{Conceptualizing power and resistance for analyzing conflictive access and property relations across scales}

Power differentials and power alliances between different actors might be important explanatory factors for differing abilities of actors to access land and property, to employ multi-scalar resistance and to access benefits from REDD+ benefit sharing arrangements (Corbera and Brown 2010; Nuijten 2005; Ribot and Peluso 2003; Rodriguez de Francisco and Boelens 2014; Wynberg and Hauck 2014; 
Koch, Faust, and Barkmann 2008). Furthermore, power shifts might alter the scalar structure (Zulu 2009: 687; Swyngedouw 2004). For instance, power shifts might create the opportunity for actors to change actively the scalar structure in the first place. At the same time actors might change power relations through changing the scalar structure.

Consequently, understanding power, power differentials and power shifts is relevant for answering all three research questions of this study. In this section, I briefly discuss how the politics of scale and political ecology literature conceptualizes power and resistance and how I operationalize power and resistance. Different schools of thought have influenced both strands of literature. Post-war French Marxism, Gramsci's understanding of hegemony, post-structuralism based on Foucault and realism have been picked up and combined by different authors of the political ecology and politics of scale literature e.g. (Bryant 2001; Ekers, Loftus, and Mann 2009; Forsyth 2008; Mann 2009).

- For Michel Foucault (2006: 14-15) power is an ensemble of mechanisms and procedures, which is inherent in all social relationships. In his understanding, power is not attached to people and institutions, or class (Ribot and Peluso 2003: 156; Balan 2010: 38). Furthermore, Foucault links power intrinsically to knowledge and discourse (Gaventa 2003).

- Antonio Gramsci uses the term hegemony for describing unjust power relations between different social actors. Hegemony, as the dominance of one group over another, is achieved through social relations of coercion and consent (Karriem 2009: 317) and especially through "[...] active and moral and intellectual leadership" (Ekers and Loftus 2008: 702).

- In post-war French Structural Marxism, power is defined as the ability of social groups (e.g. classes) to achieve their (class-specific) interest. Power according to Nico Poulantzas (1978) is relational and not quantifiable. He argues that power emerges from a relational system of material positions that different social actors can hold (Poulantzas 1978: 136).

- In realism, power is conceptualized as the ability to achieve one's objectives (Keohane and Nye Jr 1998: 86). The ability to achieve objectives is determined by the ability to control the necessary resources (e.g. financial resources, weapons, organizational strength) (ibid. ).

\subsubsection{Politics of scale and power}

Early protagonists such as Smith $(2008,1992)$ argue explicitly that power asymmetries between specific actors, e.g. between classes, are inherent in capital-labor relations and reflected in the sociospatial organization or in other words in the scalar structure. The politics of scale literature focus on consequences of power asymmetries as explanations for scalar configuration. Most of the authors share the following arguments: scales are spatial manifestations of power, changing power relations may influence the scalar structure and scale-power relations are dialectical (Meadowcroft 2002; 
Swyngedouw 2004; Zulu 2009). Some authors frame power as a capacity and as based on material resources, e.g. as the ability of certain actors to accomplish certain activities (Allen 2003: 97; Ekers and Loftus 2008: 701; Swyngedouw 2004: 17; Zulu 2009). Lebel (2005) argues that powerful actors have the ability to influence social and political processes on different scales. Authors such as Swyngedouw and Zulu use rather realist framings of power and combine these implicitly with an understanding of power akin to Gramsci's concept of hegemony ${ }^{14}$.

\subsubsection{Political ecology and power}

Political ecologists argue that unequal power relations are an important explanatory factor for uneven access to natural resources including access to land. (Blaikie 2012; Bohle and Fünfgeld 2007; Bryant 1998; Forsyth 2008). Nevertheless, power is in many cases not explicitly conceptualized and the understandings of power within political ecology changed significantly over time. The early, often called first phase political ecology scholarship (Bryant 1998; Forsyth 2008) links structural Marxism with thoughts on the emergent environmental crisis (Forsyth 2008: 758) and consequently draw on rather Marxist power definitions (e.g. the ability of classes to achieve their class specific interests).

The second and third phase of political ecology have no singular theoretical reference. For some scholars structural Marxism's remained important while others increasingly shifted towards Foucault, Gramsci and others e.g. (Bryant 1998; Ekers, Loftus, and Mann 2009; Peet, Robbins, and Watts 2011). A political ecology based on Gramsci asks for instance "[...] how hegemony is achieved through particular spaces and natures" (Ekers, Loftus, and Mann 2009: 288). In the "Theory of Access" Jesse Ribot and Nancy Peluso define power in line with Foucault as "[...] embodied in and exercised through various mechanisms, processes, and social relations-that affect people's ability to benefit from resources" (Ribot and Peluso 2003: 154). In addition, they have a rather realist understanding and argue: "ability is akin to power". They cite Steven Lukes (1986:3 cited in ibid. 155) arguing that power is defined "[...] as the capacity of some actors to affect the practices and ideas of others" (ibid.).

\subsubsection{Three dimensional power}

The short literature review has shown that different authors in both strands of literature (politics of scale and political ecology) have different understandings of power. Furthermore, some authors use different conceptual understandings of power (e.g. realist, Gramscian and post-structuralist) or in

\footnotetext{
${ }^{14}$ In their case studies, they show how different actors reshape the politics of scale of the Spanish waterscape or of community forest management in Malawi for consolidating legitimacy (Ekers and Loftus 2008: 709, Swyngedouw 2010, Zulu 2009).
} 
other words different types of power within the same piece of research. A challenge is that in most cases authors have either not explicitly defined power or have defined power in ways that are almost not applicable for empirical research. Consequently, I argue for a rather pragmatic but empirically applicable conceptualization of power based on Steven Lukes (2005) and John Gaventa $(2006,1982)$ than for a theoretical sound one which would ignore certain forms of power or which would rank certain forms of power over others.

Lukes (2005) argues for a "three dimensional" view on power. Gaventa (2006) influenced by Lukes distinguishes three different types of power which have to be understood in relation to different socially produced political arenas and scales (Gaventa 2006: 25; Rodriguez de Francisco and Boelens 2014: 353). The three types of power reflect complementary ways of thinking about power. They are also used at least implicitly in the politics of scale and explicitly in some of the political ecology literature (Ribot and Peluso 2003; Rodriguez de Francisco and Boelens 2014; Rodríguez de Francisco, Budds, and Boelens 2013). Visible power (first dimension of power) according to Gaventa $(1982,2006)$ refers to material resources, capacities, organizational strength and to participation in decision-making processes and is akin to realist understandings of power. Visible power "[...] may be understood primarily by looking at who prevails in bargaining over the resolution of key issues" (Gaventa 1982: 14). In a more applied sense visible power ${ }^{15}$ refers to the capacity of an actor $A$ to get an actor $B$ to do things, which are against his own interest (Lukes 2005: 16-17). Visible power includes economic resources such as financial assets or land and political resources e.g. amount of members of a political organization.

Hidden power (second dimension of power) refers to the "rules of the game", e.g. according to Barach and Baratz (1970, cited in Gaventa 1982: 14) to "[...] a set of predominant values, beliefs, rituals and institutional procedures that operate systematically and consistently to the benefits of certain persons and groups at the expense of others". Hidden power also refers to the ability of actors to set the community agenda, to exclude certain actors and to mechanisms ensuring compliance with rules (Gaventa 2006: 29; Lukes 2005: 21). In Lukes (2005: 111) words hidden power refers to the "[...] power to decide what is decided".

Invisible power (third dimension of power) is akin to Gramsci's concept of hegemony. However, hegemony for Lukes (2005) refers to unconscious and internalized domination and subordination and to active and coordinated strategies to achieve or to resist against domination. Invisible power points to forms of power that "[...] prevent people, to whatever degree, from having grievances by shaping their perceptions, cognitions and preferences in such a way that they accept their role in the existing

\footnotetext{
${ }^{15}$ Visible power is also akin to Max Weber's power definition. Weber argues that men have power if they are able to achieve their objective against the will of others (Weber 1993: 20).
} 
order of things, either because they can see or imagine no alternative to it, or because they see it as natural and unchangeable, or because they value it as divinely and ordained and beneficial" (Lukes 2005: 28). Invisible power shapes in an important way how marginalized social actors perceive and accept the dominant social production of nature and space (Gaventa 1982: 16-19). Resistance and counter hegemonic struggle concerning the social production of nature and space have to modify the dominant social relations that constitute the production of nature and space (Ekers, Loftus, and Mann 2009: 290).

Gaventa (2006: 25) argues that Lukes' three power dimensions are rather an interrelated sets of dynamic relationships than static categories which operate across scales and spaces. Gaventa acknowledges that power and space are intrinsically linked. Powerful actors or successful resistance movements have to apply different forms of power across spaces and scales to maintain their interests or to change existing power relations significantly.

For identifying power empirically (table 2) and especially for identifying the role power has for the ability of different actors to access land and property this study builds on and extends a methodology developed by Gaventa (1982: 20-32). Visible power can be identified by investigating: the organizational strength of a specific organization (e.g. members), the material resources (e.g. land, financial resources), who prevails in formal decision-making and who holds formal or customary functions (e.g. village head, hamlet head, customary leader) (ibid.). Hidden power can be identified by investigating: non-involvement in decision-making (e.g. by investigating alternative developments facilitated by power-shifts), by observing resistance activities (e.g. land occupations), communication and the socialization of sub-ordinate actors (e.g. language used by sub-ordinate actors, and the historical development of specific legal orders (e.g. established by force in the context of colonization) (ibid). The identification of invisible power is mainly based on interpretation argues Gaventa (1982: 29), following questions such as what would have been of interest of an actor in a specific situation. Furthermore, the identification of believes of inferiority by actors and the explicit acceptance (e.g. through statements) of a certain legal order that acts against their interest might further support the identification of invisible power (ibid. 31).

\begin{tabular}{|l|l|l|}
\hline Type of power & Explanation & Criteria for identifying different types of power \\
\hline Visible Power & $\begin{array}{l}\text { Material resources, } \\
\text { organizational } \\
\text { strength, who } \\
\text { participates in } \\
\text { decision-making, the } \\
\text { power to affect others } \\
\text { (first dimension) }\end{array}$ & $\begin{array}{l}\text { Asset base e.g. land, financial resources, social } \\
\text { capital e.g. membership in groups, participation in } \\
\text { formal decision making bodies e.g. village meetings, } \\
\text { is holding a formal or customary function e.g. Kepala } \\
\text { Desa, Kepala Dusun, Ketua Adat. }\end{array}$ \\
\hline
\end{tabular}




\begin{tabular}{|l|l|l|}
\hline Hidden Power & $\begin{array}{l}\text { Rules of the game, } \\
\text { values, agenda setting, } \\
\text { exclusion of specific } \\
\text { actors by rule making, } \\
\text { mechanism of } \\
\text { compliance, coercion } \\
\text { and exclusion. }\end{array}$ & $\begin{array}{l}\text { Involvement and non-involvement in decision } \\
\text { making, communication and socialization of sub- } \\
\text { ordinate actors, identification of mechanisms of } \\
\text { exclusion (non-decision-making), ethnicity and social } \\
\text { identity existing state and customary regulations and } \\
\text { in how far their privilege specific actors over others, } \\
\text { altered rules of the game. }\end{array}$ \\
\hline Invisible Power & $\begin{array}{l}\text { Construction of } \\
\text { meanings, myths, } \\
\text { language, moral and } \\
\text { intellectual leadership. }\end{array}$ & $\begin{array}{l}\text { Based on interpretation, e.g. what would be of } \\
\text { interest for a certain actor, scales of meanings } \\
\text { constructed for legitimizing benefits for elites, } \\
\text { internalization of subordination, acceptance of } \\
\text { authority relations, internalization of development } \\
\text { and backwardness narratives of the New Order era, } \\
\text { privatization and commodification of land and } \\
\text { conservation. }\end{array}$ \\
\hline
\end{tabular}

Table 2: Overview of different power dimensions

(Source: Lukes (2005) and Gaventa $(1980,2006)$ )

\subsubsection{Resistance and power}

The concept of resistance is relevant for explaining conflicts over access and control of natural resources and especially land. Dominique Caouette and Sarah Turner (2009b: 9) argue that “[...] conceptualizations of resistance are situated within understandings of power; power being comprised of the relational interplay of dominance and subordination". Gaventa (1982: 23) has pointed out that resistance, in his words "[...] rebellion may develop if there is a shift in the power relationships - either owing to loss in the power of A or gain in the power of $\mathrm{B}^{\prime \prime}$. Peasant resistance occurs in open and rather collective forms or in hidden and rather individual forms (Turner and Caouette 2009; Chin and Mittelman 1997). Both forms are spatial and territorial practices (especially in the case of land conflicts) challenging the power constellations in place but also the pre-existing scalar structure and pre-existing scales of meaning and regulation (Moore 1998; Turner and Caouette 2009; Towers 2000). Hidden and open forms of resistance have to be understand in relation to the conceptualization of power introduced above and should be treated as other categories in social science, to be specific as dynamic, interrelated and overlapping.

Hidden resistance in James C. Scott words "every day peasant resistance" or "infrapolitics" are relatively safe and silent practices (Chin and Mittelman 1997: 31; Scott 1989: 34). "Every day peasant resistance" is characterized by resisting without openly contesting the existing political order. Every day peasant resistance is rather negotiated in the informal sphere: e.g. household, community and not openly challenging hegemony (Chin and Mittelman 1997: 31). Peasants prefer relatively safe resistance strategies to avoid open conflict with actors that are more powerful (Scott 1989: 34-35). Scott (1989: 35) and Turner and Caouette (2009: 11) argue that when power constellations change individual and 
hidden peasant resistance can turn into larger resistance activities e.g. silent encroachment of plantations or protected areas can turn into larger organized and open land occupations.

Power constellations change argues Gaventa (1982) when sub-ordinate or in his words "the powerless" are able to challenge all three dimensions of power (ibid. 24). For developing material resources (visible power), the powerless have to defeat invisible and hidden power (ibid.). For overcoming invisible power, the powerless have to develop an understanding of their sub-ordinate role in society. Moreover, they need to develop strategies for changing the existing political circumstances and intrinsically linked power constellations (ibid. 21). Strategies and the development of political objectives and issues of concerns allows for political mobilization thus for overcoming hidden power. In many cases, powerless actors employ clandestine strategies such as ignorance, smuggling, sabotage, or the silent encroachment of the state forestland (Gaventa, Pettit, and Cornish 2011; Scott 1989: 34). The different strategies might then allow for developing visible power and for engaging in open resistance (Gaventa 1982: 21-24). Peasant groups such as Serikat Petani Indonesia (SPI) have developed the means to employ open resistance strategies e.g. larger-scale occupation of state forestland and demonstrations (more in detail in chapter 6 and 7).

Resistance as a spatial strategy might also involve 'scale jumping' activities (term has been introduced in section 2.2). The term 'scale jumping' has been picked up by many authors for describing the attempts to shift political struggle of actors that are marginalized at a specific scale to higher or lower scales $^{16}$ (Hein and Faust 2014: 24; Smith 2008: 232; Zulu 2009: 687). Gaventa (2006: 31) argues that contemporary resistance movements need to build up strategic alliances with actors operating at different political scales for being successful. Scale jumping in other words the spatial expansion of protest to higher scales has been facilitated by the transnationalization of governance and the growing interrelations between different former national policy fields (Caouette and Turner 2009a; Smith 2008; Swyngedouw 2000).

\subsection{Conceptualizing Access and Property relations}

I argue that access and property relations in Jambi are embedded in and the result of significant rescaling processes and power asymmetries within the governance of land and forests (Cohen and McCarthy 2014; Ribot and Peluso 2003; Zulu 2009). According to Jesse Ribot's and Nancy Peluso's

\footnotetext{
${ }^{16}$ Keebet von Benda-Beckman (1981) has developed the concept of "forum shopping" for explaining the attempts of actors to choose between different conflict mediation institutions, she argues that their selection is based on the hope that the institution might support their interest (von Benda-Beckmann 1981).
} 
"Theory of Access" (2003: 155), access is defined as "[...] the ability to benefit from things - including material objects, persons, institutions, and symbols". Ability in their understanding is akin to visible power as defined by Lukes and Gaventa (see section 2.3.3.). Access refers to de jure and de facto options to benefit from given opportunities of any kind or, in this specific case, from land and community benefits ${ }^{17}$ from REDD+ and conservation projects (Corbera and Brown 2010: 1745). Rightsbased access, in other words property usually refers to access arrangements having been legitimized, sanctioned and enforced by a socially accepted institution (ibid.). In the next sections, I will first define property, second I will discuss the meaning of property, the constitution and the role of public authorities and scale for the formation of property, and finally I will shortly describe the role of social identity and ethnicity for accessing property.

\subsubsection{Defining property}

Property is one of the most contested concepts in social science, heavily loaded with different ideologies, ongoing and century old philosophical discussions on its meaning and its function, intrinsically linked to the constitution of social identify and often perceived as a fundamental legal basis of societies (Lund 2008: 3; von Benda-Beckmann, von Benda-Beckmann, and Wiber 2009: 1-2). For John Locke property is a transformative product emerging out of combining labor and nature (Macpherson 1978: 18). Locke argues that a contract between the state and individuals guarantees property (van Meijl and von Benda-Beckmann 1999: 2). Simply defined, property is a socially legitimate relationship to objects of value (Sikor and Lund 2010: 3-5). In other words, property is access or physical possession of material objects of value and the ability to benefit from these objects based on enforceable rights (Macpherson 1978: 3). Property can only be considered as such if a legitimate public authority sanctions it and vice versa.

The meanings of property differ between different social groups and change constantly over time. According to F. and K. von Benda-Beckmann (1999: 30) the meaning of property is heavily influenced by ideology and culture. The understanding of property in the Western societies is dominated by the argument that formalized private property is a fundamental requirement for the efficient use of (natural) resources and for "proper" market exchange (van Meijl and von Benda-Beckmann 1999: 6). According to the Indonesian state ideology, property should contribute to development, market

\footnotetext{
17 Community benefits are defined as benefits deriving from conservation projects and from market-based conservation initiatives such as REDD+ and PES. Community benefits and/or payments should incentivize local communities to accept and to comply with conservation regulations imposed by the initiatives. Furthermore, they should ideally compensate for any income-losses from the project interventions. Community benefits can be: monetary (e.g. direct cash payments), in-kind benefits for households (e.g. conditional land tenure, agricultural extension services, improved access to water and healthcare) and in-kind benefits for the whole community such as improved infrastructure (Greiner and Stanley 2013; Wunder 2005; Peskett 2011).
} 
exchange and welfare (von Benda-Beckmann and von Benda-Beckmann 1999: 30). In contrast, according to many indigenous ideologies such as adat, property should support and balance the livelihoods of and within a community (ibid.). Ideological diversity (e.g. state and adat ideology) constitutes legal pluralism contributing to different competing regulatory orders governing property relations (ibid.). The existence of conflicts over the "organizing ideology" (Alagappa 1995: 18) affect the legitimacy and universality of property relations within a given society. The necessity of force to ensure compliance with an existing regulatory order indicates that the "organizing ideology" is contested (ibid.).

As shown property can have different meanings, yet property may also have different temporal dimensions (von Benda-Beckmann and von Benda-Beckmann 1999: 27). Many property relations are bound to time-limited social relations. Examples are rights bound to marriage, forest concessions issued by the Ministry of Forestry (MoF), carbon credits, and rights of shifting cultivators (ibid.). For instances, the Indonesian MoF issues forest concessions for smallholders and companies only for a limited time (e.g. 35 years). The land rights of shifting cultivators are often bound to active land use and expire when the land is not used. Rights that are bound to marriages may expire if the marriage is dissolved (ibid.). For dissolving the temporal dimension of property rights social groups attach rights to groups "who do not die" (ibid. 27) e.g. to lineages, communities or states.

Figure 1: The property, authority and legitimacy nexus

(Source: compiled by the author)

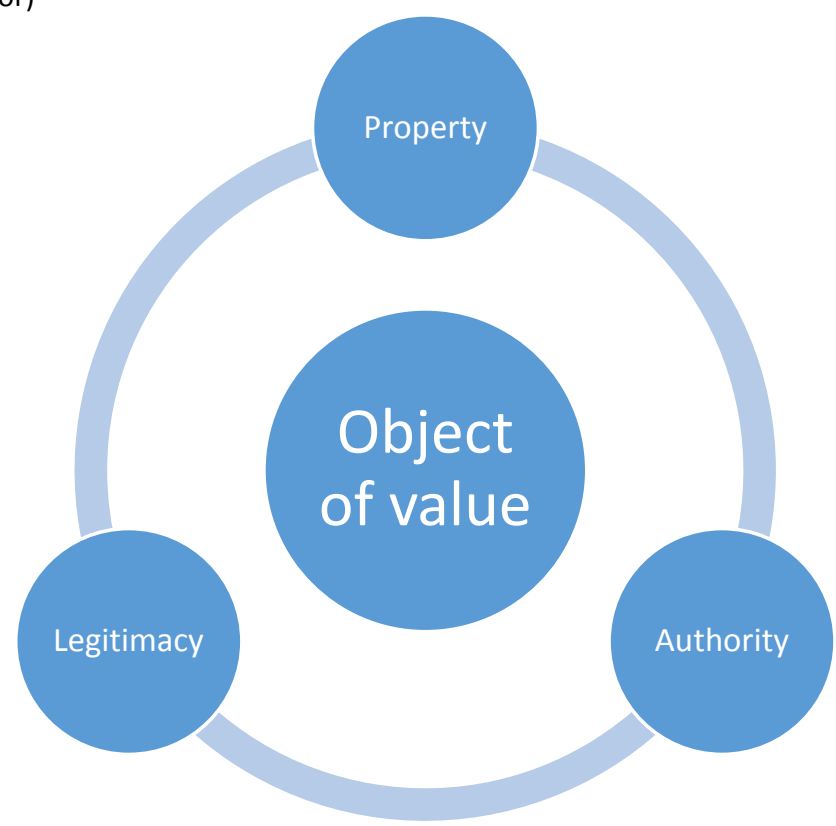




\subsubsection{Public authority, legitimacy and scale}

\subsubsection{Public authority and legitimacy}

Lund (2008: 7) defines public authority as "[...] a specific form of power exercised publicly and legitimated with reference to the state". Public authorities can only be considered as legitimated if actors show a minimum of voluntary compliance with rules imposed by the public authority (Alagappa 1995: 23; Lund 2008: 7; Sikor and Lund 2010: 1). Constituting elements of legitimacy are according to Muthiah Alagappa (1995: 14, 31) shared norms and values (ideology as universal truths) including the belief in sanctity and traditions, law (procedural legitimacy), and power. Hegemonic groups in society are seeking to establish universal truths and seek to turn them into the will of a larger community, of a society and into "national will" (ibid. 17). Though as Lund (2008: 5) points out, especially local politics in the global South reflect that different apparatuses of the state might act in contradictory ways, and might not fully reflect the will of apparently dominant groups e.g. indicated by overlapping land titles issued by different state apparatuses. As discussed in section 2.2.3, the state forms a contradictive unit with civil society. Consequently, analytical boundaries between state and non-state actors are blurred (ibid. 8). Local public authorities draw on the notion of the state for achieving legitimacy but operate not necessarily in line with the central state (ibid.). Local public authorities are even not necessarily state actors but they gain power and legitimacy through using symbols and languages of the state and through referring to the legal system of the state. But they are not necessarily complying with all rules imposed by the state (Lund 2006: 687).

What members of society consider as legitimate, changes over time and is subject to historical contingent and continuous struggles on concepts and truths within society (Sikor and Lund 2010: 6). Struggles over the constitution and legitimacy of public authority and on the legitimacy of a specific scale of regulation have direct influence on the legitimacy of the property relations in place. Power relations, in its invisible (as moral and intellectual leadership) and hidden (constructing the roles of the game/ laws) dimensions are structuring legitimization processes. The exercise of visible power (e.g. of force for ensuring the compliance with a land and forest tenure regulation) indicates conflicts over the "organizing ideology" (Alagappa 1995: 18). Furthermore, the legitimacy of a property relation and of the associated public authority cannot be described as a simple dichotomic relationship, "[...] legitimacy is likely to be a matter of degree (strong/ week rather than legitimate/illegitimate)" (Alagappa 1995: 30). 


\subsubsection{Public authorities, policies and regulations}

National laws, regulations and policies are structuring access and property relations. Local public authorities follow especially those policies and laws that support their own interest (Lund 2008: 4). National laws and policies are not necessarily fully implemented locally and fully obeyed by local public authorities and by the local population. But they often structure the agency of local actors (ibid.). The relevance of a specific national legislation in a local setting depends on the power structure in the political arena (ibid. 135). The result is "[...] neither coherent policy implementation nor complete disregard of law and policy" (ibid. ). Accordingly, what is perceived as legal or illegal is not only the result of changing laws it is the outcome of what powerful local actors consider as appropriate (ibid. 19). For legitimizing specific local activities, e.g. the issuance of a village-scale land title ${ }^{18}$ or of a forest conversion permit local public authorities might translate or transform fragments of national regulations and policies (e.g. land laws or land titling policies) which correspond to their objectives into locally relevant rules. This specific type of legitimation strategy can be considered as "mimicry of the legal ${ }^{19 \prime \prime}$ (Kunz et al. submitted), thus as a mimicry of legal texts, policies and symbols.

The dialectical relationship between local interpretation of laws and disregard of laws provides room for agency and room for rent seeking behavior, e.g. protection services for illegal activities (Lund 2008: $23,155)$. Especially in frontiers spaces are the boundaries between law and theft and between governance and violence blurred (Tsing 2005: 27). In some cases, local actors may have the ability to choose between rather legal or rather illegal ways to legitimize a land claim but in most cases the agency is limited since the political elites in the arena negotiate the "modes of regulation" (Etzold et al. 2009: 8).

\subsubsection{Public authority and scale}

The legitimacy of public authorities in local politics is in many cases characterized by "[...] endless chains of reference to bigger authorities" (Lund 2006: 693), and has consequently a direct scale component. Different public authorities entangled with different scales might compete over legitimizing property rights for the very same piece of land. For enhancing their respective legitimacies,

\footnotetext{
${ }^{18}$ Village heads in the different study villages are issuing documents used as land titles, officially only the National Land Title has the authority to issue land titles (more details on de-jure and de facto land titling procedures in chapter five and six).

19 The term „mimicry of the legal“ has been taken from scholars of international law (Bélanger 2011; Drumbl 2007) and from post-colonial studies (Bhabha 1994). The term is used y for adoption and translation processes of international or colonial law into national and sub-national laws and regulations. In this case, the term is used for describing the translation of fragments of national law into local regulations driven by local public authorities. A more in depth discussion of this term will be published in a paper by Yvonne Kunz, myself and colleagues (submitted to Austrian Journal of South-East Asian Studies (ASEAS).
} 
they seek to gain additional recognition from other institutions (Lund 2008: 2), in many cases from institutions at higher scales of governance. Political scales are relevant as reference points for local public authorities, but local public authorities actively produce and reproduce scales (e.g. village scale) as well and employ scalar strategies such as scale jumping for achieving their interests.

Public authorities such as village heads, district heads, provincial governments and the national government stabilize the scalar configurations through regular interaction with their citizens (and viceversa), e.g. through enforcing land claims (Lebel, Garden, and Imamura 2005). They channel social interaction and stabilize the social production of space and scales (Towers 2000: 26). Access to specific public authorities on higher or lower scales is an important factor in explaining socially differentiated abilities to benefit from resources (Leach, Mearns, and Scoones 1999: 233).

In particular, societies with plural land tenure systems have nested and plural legal authority arrangements (legal pluralism) with unequal ranges of validity and unequal abilities to enforce claims. Claims backed by high-level administrative authorities may have greater legitimacy than claims backed by a village official or vice versa. (Sikor and Lund 2010: 6f).

\subsubsection{Ethnicity and social identity mediating access to public authority and property}

In frontier regions, with their confusing and dynamic institutional landscapes social identity is a key factor shaping the ability to access public authority and to benefit from resources (Hein and Faust 2014: 23; Rhee 2009: 53; Ribot and Peluso 2003: 170). Ethnicity and kinship shape patron-client linkages and permit privileged access to state officials and, consequently, to formal or semi-formal processes facilitating resource access (Rhee 2009; Ribot and Peluso 2003). Ethnicity is contextdependent (Wimmer 2008: 977) and determines affiliation to groups with specific customary arrangements permitting resource access for their members. Classifications such as putra daerah (child of the region) or "first comers" and "late comers" serve as ethnic markers and as factors influencing access to natural resources and political power (Lund 2008: 16; Rhee 2009: 43).

\subsection{Conclusion}

As outlined above the conceptual frameworks of this thesis builds on different elements for investigating transnationalized conflicts on access and property in REDD+ target areas. In line with Swyngedouw (2010) I assume that questions of access to natural resources (including land) can be explained by analysing the socio-spatial configurations of scales. I argue that rescaling processes in the course of state transformations (e.g. colonization, nationalization, decentralization)) structure the 
abilities of different social actors to access land and property. Nevertheless, social actors also have the ability to shape actively the scalar structure for accessing or maintaining property rights by constructing new competing scales of meaning and regulation, or by expanding existing scales of meaning or by moving conflicts on property rights to higher or local scales. Scale and rescaling reflect the dialectical relationship between structure and agency. They structure and contain space and social practices within space and they are the outcome of social practices (Smith 1995: 60).

Socio-ecological scales such as the Berbak Carbon or the Harapan Rainforest Project are produced through social and physical processes. Social conflict and changing power relations have an impact on the structure, content and spatial extend of ecological and social scales (Swyngedouw 2010). The very same ecosystem or in other words the very same nature might be experienced differently depending on the social position of an actor (Escobar 1999:5). Successful protest of an environmental movement might lead to expansion of the borders of the Berbak Carbon Project, changing the characteristics and meanings of the ecosystem and of the social relations contained by the project area. The expansion of the project might restrict specific land-use practices thus changing land use practices and social positions towards the ecosystem of actors. This might also induce new social conflict. A changing ecosystem e.g. caused by sealevel rise or by more direct anthropogenic interventions (e.g. forest encroachment) might also change the meanings of relations social actors have vis-à-vis the ecosystem.

The work of Towers (2000) provides the opportunity to analyze the social construction of scales of meaning and scales of regulation seperately. This is of specific importance in the context of REDD+ and conservation debates where different scales of meaning such as carbon forests or customary forest overlap with local, national and transnational scales of regulation (Flitner and Görg 2008; Lebel, Garden, and Imamura 2005). Brenner stresses the central role of the state producing producing hierarchical scalar structures (Brenner 1997, 2001).

Political scales are also constituting the division of labor of the different apparatuses of the state. Public authorities control their respective scales of regulation. Especially in the context of rapid scalar restructuring (e.g. decentralization) scales of regulation might overlapp leading to competing access and property relations. The role of the state in the Indonesian context, the colonial state, the development state of the Suharto era and the Indonesian state of the Reformasi era have altered the socio-spatial configuration of Indonesia's forest and land tenure governance significantly and promoted foreign direct investment and commodification of natural resources, land and very recently of ecosystem services (Nevins and Peluso 2008). Public authorities legitimizing property rights construct scales of regulation, thus contain space and are at the same time part of the broader hierarchical scalar structure of the nation state. 
Public authorities have the ability to exercise power publicily building on symbols and legal texts of the state (Lund 2008: 7). For establishing legitimcay public authorities refer in many cases to authorities at higher ends of the hierarchy (Lund 2006: 693) or seek to scale back (Reed and Bruyneel 2010: 651) making reference to past authorities (e.g. imagined lineage chiefs). The legitimcay of a public authority and of a specific scale of regulations is a matter of degree (e.g. continium between strong and weak) and changes overtime while new public authorities emerge.

In Indonesia as in other parts of the global South different public authorities, in other words different apparatuses of the state might act in contradictory ways, thus might not reflect the will of apparently dominant groups in society. Scales of regulation constructed by public authorities and stabilized by interactions with citiziens e.g. through issuing land titles might overlapp or compete.

Furthermore, I argue that the ability to alter scales of meaning and regulation and consequently the ability to access land and property is linked to question of power. Social actors that are willing to change access and property relations have to make use of different forms of power across spaces and scales (Gaventa 2006). Social actors have to rely on material resources (visible power), have to have the capability to change formal and informal regulations (change the rules of the game, hidden power) and have to influence the "organizing ideology" (invisible power) (Alagappa 1995). 


\section{Methods, research design and locating the main sites of investigation}

This chapter outlines the research design, the methods used for answering the research questions and locates the main research sites. In the first section I will introduce the reflexive science model (Burawoy 1998). The model will be used for guiding the qualitative approach of this study. In the second section I will introduce the concept of multi-sited fieldwork developed by George E. Marcus (1995), Salle E. Merry (2000) and F. and K. Benda-Beckmann and colleagues (2005). Multi-sited fieldwork will be used for unraveling REDD+, forest and land politics on different scales. Based on the notion of REDD+ as a multi-sited arena of negotiation (Klepp 2011; Benda-Beckmann, Benda-Beckmann, and Griffiths 2005) and on the "follow the conflict" premises outlined by Marcus (1995: 90-94) I will justify the selection of my various sites of empirical investigation across scales. In the third section I will describe and justify the qualitative techniques and the data analyzes approaches I have used. In the fourth section I will discuss limitations of my approach, problems encountered during my research, and I will reflect my own and changing role and positionality within various research contexts (e.g. international climate change conferences, donor headquarters and informal settlements within REDD+ demonstration activities). In the last section I will introduce the main sites of empirical investigation, in particular five villages adjacent to Harapan Rainforest and Berbak Carbon project in Jambi, Indonesia.

\subsection{Reflexive science model, political ecology and qualitative research}

Political ecology aims to understand specific environmental problems embedded and caused by relations of production and not the identification of universal truths and laws by testing formalized hypothesis (Forsyth 2008; Cox 2013). Research in political ecology can be understand as an informed dialog between researcher and participants (Marin-Burgos 2014: 34). According to Michael Burawoy (1998: 5), the researcher is engaged in three different dialogs for investigating empirical phenomena. The first dialog he identifies, is taking place between the researcher and participants (e.g. through interviewing or participatory observation), the second is taking place between "local processes and external forces" and the third is taking place between the identified empirical patterns and theory (ibid.).

The reflexive science model developed by Burawoy (1998) which I will use as guidance for research design and methods of this study argues for an active conceptualization of the role of the researcher in the research process (ibid. 5). He argued to "[...] thematize our participation in the world we study" (ibid.). Burawoy developed his model as a critique towards positivistic approaches which handle data 
collection and analysis as clearly separate processes. In his approach, empirical investigation or fieldwork is intrinsically linked to the empirical reality and is characterized by continuous interactions between the researcher and the participants (e.g. interviewees) constituting the research topic. The researcher is actively engaging with the objects of the study and is embedded in the broader social context of the field sites (ibid.). In line with Burawoy, Kim V. L. England (1994: 84) argues that the "[...] researcher is a visible and integral part of the research setting". Consequently, the research process is characterized by direct interaction and not by attempts to isolate researcher and participants from each other (ibid.).

Burawoy's (1998:14-16) reflexive science model consists of four basic principles: intervention, process, structuration and reconstruction. Intervention refers to gathering data through interviews. Interviews are considered as perturbating (e.g. distracting the participants from their normal way of life) the social relations of the field site (Burawoy 1998: 14, England 1994: 85). Process refers to understanding the social context of the interview situation. First by bearing in mind that not all types of knowledge can be acquired by interviewing (ibid. 15). Second by understanding the different positions researcher and participants hold during different research situations (ibid.). Understanding positionality implies considering power imbalances and asymmetrical relationships between participants and researcher. England (1994: 85) argues that researchers should be aware of power imbalances and positionality and should be sensitive to them but should not try to remove them. Issues concerning positionality are especially relevant in multi-sited field research. Interview situations in different contexts e.g. interviews with high-level experts of the state bureaucracy or with people marginalized in a specific context are constituted by different power relations.

Structuration refers to the external contexts of the field situation and how external factors (e.g. the "everyday world") are shaping the field situation and vice versa (Burawoy 1998: 15). The external context of the field situation is constantly changing and explains why reflexive scientists argue that scientific qualitative investigations cannot be replicated (ibid.). Replicating research design and techniques of investigation can complement or improve research but will not produce the very same knowledge. Reconstruction refers to processes of generalization through engagement with existing theory (ibid. 16) or in Lund's (2014: 229) words: “[...] Generalization is an attempt to see resonance with events and processes, largely at the same level of abstraction but in different temporal and spatial contexts". 


\subsection{Doing multi-sited fieldwork for analyzing land conflicts in the context of REDD+ across scales}

REDD+, forest and land tenure are negotiated and regulated on different scales e.g. at the village scale by the village head, by the district head or in the case of forest land by the MoF in Jakarta or at through the third party standards or international safeguards. Thus I argue that research on conflicts over access and property in a REDD+ pilot province calls for "deterritorialized" (Merry 2000: 130) fieldwork or "multi-sited ethnography" (Marcus 1995: 80).

Multi-sited ethnography was first outlined by Marcus (1995) as a response to "empirical changes" (ibid. 80 ) in an increasingly globalized world. He argued, referring to Immanuel Wallersteins world system theory, that research which is "embedded in a world system [...] cannot be [...] focused on a single site of intensive investigation" (ibid. 79f). In multi-sited fieldwork is the so called "global" not external to the field of investigation, the global is part of the relationships constituting the field of research (ibid. 86). Multi-sited fieldwork is process-based and "[...] emerges from putting questions to an emergent object of study whose contours, sites, and relationships are not known beforehand" (ibid. 86). Researchers conducting multi-sited research have different opportunities for guiding their investigations. Marcus proposes to follow people, things (e.g. commodity chains), metaphors, plots, stories, life's, or conflicts (ibid. 90-94). This dissertation seeks to follow conflicts.

Multi-sited research according to Marcus and Merry should trace the networks of interaction between actors across field sites. This provides the researcher the opportunity to analyze scale jumping strategies (Smith 2008) of peasants affected by REDD+ activities or to investigate attempts of actors to alter the scalar configuration or to identify scales that actors preferably use for political struggle. By following scale jumping strategies the approach provides the opportunity to follow the "translators and intermediaries" and to investigate how they are acting at the translational scale and how they communicate outcomes to community members or to members of donor agencies (Merry 2000: 131). Translators and intermediaries are those actors that are able to link the different sites of investigation; this might include village heads, community representatives and members of NGOs (ibid.).

Multi-sited approaches also pose a number of challenges. As mentioned in the chapter on reflexive science is the positionality of researcher an important factor in qualitative research. Researchers using a multi-sited approach have to consider that positionality and power constellations (e.g. between researcher and participants) change across research sites. The researcher has to be aware of the fact that his identity is constantly negotiated affecting his ability to access relevant knowledge. Furthermore, the researcher has to consider that the questions he might ask have to be formulated in ways understandable for actors living in the different social fields investigated by the researcher. In 
the case of this dissertation an additional challenge has been the different lingual contexts. Interviews with German donor agencies and ministries were held in German, interviews at UNFCCC conferences and some of the expert interviews in Jakarta were held in English, and all other interviews (in Jambi city and in the research villages) were hold in Bahasa Indonesia with the support of an Indonesian field assistant. Moreover, multi-sited research is probably not able to investigate the full complexity of local processes since time at each location is much more limited in comparison to single-sited research.

\subsection{Selection of the main sites of investigation}

This dissertation follows the conflicts on access and property that are emerging in REDD+ target areas and which are negotiated across scales. The selection process has been influenced by different empirical and conceptual factors relevant at different levels. On the country level Indonesia has been selected because of different scientific and practical reasons.

First, a number of rather practical then "purely" scientific reasons have been relevant for doing research in Indonesia and Jambi in particular. I was familiar with the country and language since I did research for my diploma thesis on environmental change and rural migration ${ }^{20}$ in Indonesia from October 2008 to January 2009 (Hein and Faust 2010). In 2012 the University of Göttingen received a grant of the Deutsche Forschungsgesellschaft (DFG) for establishing a collaborative research center on "Ecological and Socioeconomic Functions of Tropical Lowland Rainforest Transformation Systems" (CRC 990) in Jambi. In March 2012 I had the chance to become associated member of the CRC 990 and the opportunity to get a PhD position at the German Development Institute in a research and advisory project on "Climate Change and Development" funded by the German Federal Ministry for Economic Cooperation and Development (Bundesministerium für wirtschaftliche Zusammenarbeit und Entwicklung, BMZ). The project provided funding for my fieldtrips. As an associated member of the CRC 990 I benefitted from the infrastructure of the project and from interdisciplinary dialogues in the project. My project became part of the human dimensions' group " $\mathrm{C}$ " and of the subproject $\mathrm{CO} 2$. The CO2 sub-project "A Geographical and Historical Analyzes of the Current Cultural Landscape Transformation" sought to identify socio-cultural and political factors explaining landscape transformation in two study landscapes ${ }^{21}$ of Jambi.

\footnotetext{
${ }^{20}$ Title of diploma thesis: „Rurale Migration in Zentral Sulawesi, Indonesien - Haushaltsstrategien im Kontext von Umweltveränderungen“, not published, publication of major findings together with Heiko Faust "Frontier Migration as response to environmental change - a case study from Central Sulawesi, Indonesia (STORMA Discussion Paper No. 31, July 2010).

${ }^{21}$ The two study landscapes of the CRC 990 are the "Bukit Duabelas Landscape" consisting of the Bukit Duabelas national park and surrounding villages and the "Harapan Landscape". The term Harapan Landscape has been
} 
During the early phase of my PhD I planned doing research in Jambi and at least in one other Indonesian province. At the beginning of the second field trip it became clear that for understanding the complex land conflicts ongoing in Jambi related to REDD+ implementation all my attention would be needed. Consequently, I skipped any field work on REDD+ projects in other Indonesian provinces.

Second I will outline the more "scientific" based reasons for selecting Indonesia, Jambi and the two landscapes within Jambi and the many other locations of this multi-sited study. Most of them have already been mentioned in the Introduction of this thesis. Indonesia has a long and violent history of land conflicts and ever postponed land reforms (Bakker and Moniaga 2010; Peluso, Afiff, and Rachman 2008). State transformation, mainly decentralization after regime change end of the 1990s and recentralization in the early 2000s induced rescaling of the governance of land and forests. Processes of rapid up-and down-scaling produced unclear and contested land and forest tenure (Hein et al. 2015; Barr et al. 2006: 2), making it a highly relevant case for investigating conflictive rescaling processes. Recently, after the UNFCCC conference in Bali in 2007 the archipelago has experienced a REDD+ boom or "REDD rush" (McGregor 2010: 23) again followed by scalar restructuring e.g. up-scaling of regulations to the global scale or by scaling-out of former state functions to non-state actors. Only three years later, in 2010, (CIFOR 2012) counted 30 REDD+ pilot initiatives and projects implemented by provincial governments, district governments, donor agencies, companies and transnational NGOs. Climate change pushed the land question back on the agenda of Indonesian politics, this is also demonstrated by the Indonesia's National REDD+ strategy which states that a land reform is "[...] prerequisite to create the conditions required for successful implementation of REDD+" (Indonesian REDD+ Task Force 2012: 18). The centrality of the land question within Indonesia's REDD+ policies makes Indonesia a very interesting location for a study on the scalar politics of access and property in the context of REDD+.

I have selected the province of Jambi because of the engagement of the German International Climate Initiative (IKI), because of the existence of provincial mitigation policies, because of being the host for five REDD+ pilot projects (or related initiatives combining mitigation and conservation), because of being a candidate for a national REDD pilot province (in 2013 Jambi became an official REDD+ pilot province, more details in chapter four) and because of land conflicts taking place within or at the margins of the REDD+ pilot projects ${ }^{22}$. Relevant conceptual criteria for selecting Jambi were especially the existence of competing modes of production, the existence of relevant multi-scalar networks

invented by the CRC 990 and refers to the Harapan Rainforest project and to the different research villages of the CRC 990 located at the margins of the Harapan Rainforest (Faust et al. 2013: 4).

${ }^{22}$ Interview with staff member of the German Federal Ministry for Environment, Nature Conservation, Building and Nuclear Safety in Bonn, 27.03.2012, Document ID: 7 and with staff member of KfW in Frankfurt, 19.04.2012, Document ID: 385 
involved in REDD+ implementation and in resistance against REDD+. The two REDD+ projects, the Harapan Rainforest and the Berbak Carbon Project have been selected as research sites based on first explorative interviews with donor agencies, NGOs, based on discussions with experts of the Agricultural University Bogor (IPB) and of the University of Jambi, with my supervisors and based on internet search. Relevant criteria for the selection have been:

- The REDD+ project has to cope with conflicts on access and control of the project area between different actors e.g. between smallholder and implementing agencies, or between different state agencies active at different scales;

- competing access and property relations are in place;

- competing modes of production e.g. large-scale oil palm plantation estates vs. shifting cultivation and/ or conservation;

- REDD+ project activities have started already e.g. demonstrated by new conservation regulations, incentive schemes or socialization of the population;

- the local population uses the project area e.g. for farming, fishing, hunting, timber;

- the REDD+ project receives support from international or transnational donors;

- the project area is accessible e.g. not hampered by the local security situation or lack of infrastructure.

\begin{tabular}{|l|l|l|}
\hline REDD+/ Conservation Project & Research village & District \\
\hline \multirow{3}{*}{ Harapan Rainforest } & Bungku & Batang Hari \\
\hline \multirow{3}{*}{ Berbak Carbon Project } & Tanjung Lebar & Muaro Jambi \\
\hline & Air Hitam Laut & Tanjung Jabung Timur \\
\cline { 2 - 3 } & Seponjen & Muaro Jambi \\
\cline { 2 - 3 } & & Muaro Jambi \\
\cline { 2 - 3 } & Sungai Aur & \\
\hline
\end{tabular}

Table 3: Research villages and REDD+/ conservation projects

For selecting the research villages within or adjacent to the two REDD+ projects I have built again on the "follow the conflict" premise. Furthermore, sites with conflictive access and property relations e.g. competing property rights systems where preferred over other potential sites. With the support of partners from the University of Jambi and based on interviews with NGOs (mainly with environmental NGOs, environmental justice groups and peasant organizations) staff of donor agencies (KfW) and with village heads I have identified five research villages (table 3 and details in section 3.9) located within and adjacent to the REDD+ projects. Each village, has its own specific conflict history e.g. with oil palm plantation companies as well as a shared history of conflicts related to broader rescaling processes e.g. 
colonization and decentralization. Within the villages I have focused in particular on conflicts that are affected by the implementation of protected areas and REDD+ pilot projects.

Additional field sites of this dissertation are the transnational, national and local nodes of REDD+, land and forest governance. Nodes of the transnational REDD+ governance are, for instance, the ministries and governmental institutions involved in REDD+ and located in Bonn, Jakarta and Jambi City, UNFCCC conferences and the headquarters of environmental organizations (head office of Burung Indonesia in Bogor), peasant movements (e.g. SPI head office in Jakarta) and donor agencies (e.g. offices in Jakarta and Germany) (Benda-Beckmann, Benda-Beckmann, and Griffiths 2005; Flitner and Görg 2008; Bulkeley 2005; Merry 2000). These different locations are linked through decision making processes, and resistance strategies. They are part of competing and contradictive scales of meaning and regulation. Following Benda-Beckmann and colleagues (2005: 9) I tried to follow "[...] the chains of interaction connecting transnational, national and local actors in multi-sited arenas of negotiation along with power relations that structure these interactions and are reproduced or changed by them".

\subsection{Description of research methods and field research}

In the next sections I will first describe the qualitative techniques I have used. Second I will outline the time frame of my empirical investigations. Third I will discuss challenges occurred during my fieldtrips, limitations of my approach and I will reflect on issues concerning positionality and power asymmetries in different field situations.

\subsubsection{Applied qualitative techniques}

In detail the study builds on different qualitative techniques such as semi-structured interviews with expert interviews and stakeholders, participatory observation, (informal) group interviews and document analyzes (Flick 2007).

Semi-structured interviews are combining "predetermined" questions and open conservation (Longhurst 2010: 103). According to Robyn Longhurst (2010: 113) they provide insights into "complex behaviors", opinions and experiences. They combine theory-oriented questions, standardized questions and open questions (Lamnek 2005: 364f). "Semi-structured" interviews had been conducted with stakeholders and experts directly involved in research topic and with those observing the research 
topic $^{23}$, e.g. researchers. "Semi-structured" interviews have been conducted using interview guides. For different stakeholder groups (e.g. smallholders, members of the village government or staff of NGOs) different interview guides have been used (examples in annex II). In general, the guides have been used in an open and context-dependent way for promoting an open conservation. The order of the questions, the amount of questions and the questions being asked has been adapted to the specific interview situation. Furthermore, at different stages of this dissertation different interview guides have been used, e.g. during the explorative phase interview guides focused rather on the general context and not on specific access and property regimes. All interview guides have been continuously updated by the latest empirical findings.

Group interviews had been conducted to gain semi-public knowledge (Faust et al. 2013: 11). Furthermore, they have been conducted in situations where a longer stay did not permit personal interviews. Most of the group interviews have also been recorded and transcripted.

Participatory observations have been an essential part of the field stays in the villages within and adjacent to the REDD+ projects and of the UNFCCC conference visits. During the field stays in the research villages, informal talks and discussions with villagers offered additional insights which would be hard to gain in formal interview situations. Furthermore, during the field stays I had the chance to participate in formal and informal village meetings, to participate in meetings of the peasant movements SPI and AGRA, to participate in patrolling activities of ZSL and national park rangers, and to discuss preliminary results with staff of the field camp of the conservation company PT REKI. During the UNFCCC conference visits I had been able to follow the negotiations during open meetings.

During most of the interviews conducted in Jambi province, including those conducted in the research villages, one Indonesian field assistant supported me. The field assistant facilitated access to the participants, provided translation if necessary and was in charge of taking notes. Most of the "semistructured" interviews had been recorded. Many of the interviews conducted in Bahasa Indonesia had been transcripted by Indonesian student assistants from the UNJA and IPB. Most of the interviews conducted in English or German had been transcripted by myself and by student assistants at the German Development Institute.

In addition to qualitative interviews as primary empirical sources I have analyzed different types of documents. Document analysis is according to Glenn A. Bowen (2009: 27) “[...] a systematic procedure for reviewing or evaluating documents [...]". The systematic analysis of documents consists of several steps, e.g. searching and selecting relevant documents and coding and summarizing important content

\footnotetext{
${ }^{23}$ In many cases it may not easy to distinguish between observers and active stakeholders, researchers who are observing a specific topic are also influencing the topics through publications etc.
} 
(ibid. 28). Documents can provide additional data and consequently the basis for triangulation (ibid. 29). Furthermore, documents such as laws, regulations or policies can provide relevant contextual information that might structure the livelihoods of social actors (ibid.). The selection of documents has been guided by the research questions and by the conceptual framework outlined in chapter two. Especially relevant for the empirical investigation have been documents describing the meaning, the scope and the content of property rights (e.g. forest and land tenure regulations), political strategies (e.g. REDD+ strategies), documents of different state authorities explaining the objectives and the means for achieving a political objective, documents that keep record of NGO campaigns (e.g. reports, project proposals, pamphlets) and newspaper articles that provided complementary insights on land conflicts in Jambi. In summary the following document types have been analyzed:

- Indonesian forestry and land tenure related laws and regulations,

- political strategies of national and sub-national state authorities related to land tenure, forest tenure, REDD+ and mitigation,

- decisions of the UNFCCC related to REDD+,

- newspaper articles on REDD+ and land conflicts in Jambi,

- NGO reports and design documents of the Berbak Carbon and the Harapan Rainforest project,

- documents of donors (e.g. reports, safeguards),

- scientific literature on REDD+, forest governance, land tenure, decentralization, colonization and decolonization especially those focusing on Jambi,

- and theoretical and conceptual literature (as outline in chapter 2)

\subsubsection{Time frame of empirical investigation}

REDD+ is an emerging policy field. Land conflicts in Jambi and everywhere in the world are constantly changing dynamic processes. This dissertation covers directly only a very limited time frame. But through asking participants about past events, about the historical context of conflicts and through document and literature review this dissertation covers events which were considered as relevant for understanding land conflicts dating back to the $19^{\text {th }}$ century. The dissertation covers events prior to colonization (e.g. customary governance mechanisms of indigenous groups), the colonial period (e.g. colonial forest and land tenure regulations) and post-colonial Indonesia (e.g. processes of de- and recentralization) that are relevant for explaining conflictive access and property relations. The climate change negotiations are covered after the first decision of the UNFCCC on REDD+ were made in 2005. Indonesia's national REDD+ process is covered from the publication of Indonesia's first REDD strategy in 2007 until the general elections in 2014. Thus the thesis covers the emergence of Indonesia's national REDD+ governance. 
Empirical research in Indonesia has been conducted from July 2012 to October 2012 and from June 2013 to October 2013. In total (2012 and 2013) I have stayed 33 days in the Harapan Landscape and 23 days in the Berbak Landscape ${ }^{24}$. UNFCCC conferences had been visited in May 2012, December 2012, 2013 and 2014. Other important nodes of decision making outside of Indonesia (donor headquarters) had been visited mainly between March 2012 and July 2012 (Table 4 provides a detailed overview).

\begin{tabular}{|c|c|c|c|}
\hline Period & Location & Tasks & Applied methods \\
\hline $03 / 12-07 / 12$ & $\begin{array}{l}\text { Bonn, Frankfurt, } \\
\text { Eschborn (Germany) }\end{array}$ & $\begin{array}{l}\text { Explorative } \\
\text { discussions and } \\
\text { interviews with } \\
\text { donor agencies and } \\
\text { German Ministries }\end{array}$ & $\begin{array}{l}\text { Semi-structured } \\
\text { interviews, informal } \\
\text { discussions }\end{array}$ \\
\hline $05 / 12$ & $\begin{array}{l}\text { Bonn Climate Change } \\
\text { Conference (Germany) }\end{array}$ & $\begin{array}{l}\text { Visiting different side } \\
\text { events on REDD+ }\end{array}$ & $\begin{array}{l}\text { Informal discussions, } \\
\text { participatory } \\
\text { observation }\end{array}$ \\
\hline $07 / 12-08 / 12$ & $\begin{array}{l}\text { Jakarta, Bogor, } \\
\text { Yogyakarta (Indonesia) }\end{array}$ & $\begin{array}{l}\text { Explorative } \\
\text { interviews with } \\
\text { donor agencies, } \\
\text { NGOs, Indonesian } \\
\text { Ministries and } \\
\text { academia, } \\
\text { discussions with } \\
\text { researchers from IPB }\end{array}$ & $\begin{array}{l}\text { Semi-structured } \\
\text { interviews }\end{array}$ \\
\hline $09 / 12-10 / 12$ & $\begin{array}{l}\text { Jambi city, Harapan } \\
\text { Rainforest, Berbak } \\
\text { Carbon project } \\
\text { (Indonesia) }\end{array}$ & $\begin{array}{l}\text { Explorative } \\
\text { interviews with } \\
\text { NGOs, discussions } \\
\text { with researchers } \\
\text { from UNJA, first } \\
\text { investigations in the } \\
\text { REDD+ project areas }\end{array}$ & $\begin{array}{l}\text { Semi-structured } \\
\text { interviews, open } \\
\text { interviews, informal } \\
\text { (group) discussions, } \\
\text { participatory } \\
\text { observation }\end{array}$ \\
\hline $12 / 12$ & COP 18, Doha (Qatar) & $\begin{array}{l}\text { Interviews, visiting } \\
\text { different side events, } \\
\text { following } \\
\text { negotiations }\end{array}$ & $\begin{array}{l}\text { Semi-structured } \\
\text { interviews, informal } \\
\text { discussions, } \\
\text { participatory } \\
\text { observation }\end{array}$ \\
\hline $06 / 13$ & Jakarta, Bogor (Indonesia) & $\begin{array}{l}\text { Interviews with } \\
\text { donor agencies, } \\
\text { NGOs, Indonesian } \\
\text { Ministries and } \\
\text { academia, } \\
\text { discussions with } \\
\text { researchers and } \\
\text { students from IPB }\end{array}$ & $\begin{array}{l}\text { Semi-structured } \\
\text { interviews, informal } \\
\text { discussions }\end{array}$ \\
\hline $06 / 13-09 / 13$ & $\begin{array}{l}\text { Jambi city, Harapan } \\
\text { Rainforest, Berbak } \\
\text { Carbon project } \\
\text { (Indonesia) }\end{array}$ & $\begin{array}{l}\text { Interviews with } \\
\text { NGOs and state } \\
\text { agencies in Jambi, } \\
\text { investigations in the } \\
\text { REDD+ project areas }\end{array}$ & $\begin{array}{l}\text { Semi-structured } \\
\text { interviews, open } \\
\text { interviews, informal } \\
\text { (group) discussions, } \\
\text { participatory } \\
\text { observation }\end{array}$ \\
\hline
\end{tabular}

\footnotetext{
${ }^{24}$ The term Berbak landscape has been introduced by conservationist and donors in order to promote an integrated spatial planning concept for the peat swamp ecosystems of the Berbak National Pak, and for the adjacent forest categories and villages (Millennium Challenge Account 2013).
} 


\begin{tabular}{|l|l|l|l|}
\hline $10 / 13$ & Jakarta, Bogor (Indonesia) & $\begin{array}{l}\text { Interviews with } \\
\text { NGOs }\end{array}$ & $\begin{array}{l}\text { Semi-structured } \\
\text { interviews }\end{array}$ \\
\hline $12 / 13$ & COP 19, Warsaw (Poland) & $\begin{array}{l}\text { visiting different side } \\
\text { events, following } \\
\text { negotiations, } \\
\text { presentation } \\
\text { together with ZSL }\end{array}$ & $\begin{array}{l}\text { Informal discussions, } \\
\text { participatory } \\
\text { observation }\end{array}$ \\
\hline $12 / 14$ & COP 20, Lima (Peru) & $\begin{array}{l}\text { visiting different side } \\
\text { events, following } \\
\text { negotiations }\end{array}$ & $\begin{array}{l}\text { Informal discussions, } \\
\text { participatory } \\
\text { observation }\end{array}$ \\
\hline
\end{tabular}

Table 4: Timetable and research locations

\subsection{Qualitative research with different actors at different field sites}

Different field sites (as mentioned in section 3.3) have been visited and different actor groups have been interviewed. Interviews have been conducted with: peasants, customary leaders, members of village governments, academia, staff of different governmental agencies (including the Ministry of Forestry, National Land Agency, National and Provincial REDD+ Taskforce), staff and activists of NGOs, staff of donors and staff of the NGOs and companies involved in the implementation of the Berbak Carbon and the Harapan Rainforest project (complete list of all interviews in the annex I). Through conducting interviews and participatory observations at different field sites different types of knowledge has been gained, power asymmetries and knowledge gaps have been identified and different interpretations of formal regulations, conservation practices and REDD+ have been captured. Furthermore, the approach facilitated the identification of different viewpoints, of contradictive local histories and different explanations for local conflicts.

In total 172 "semi-structured" interviews, group interviews and discussions had been conducted (figure 2). 65 interviews had been conducted with experts and stakeholders involved in or observing forest governance, REDD+ implementation, land tenure governance and land conflicts. 107 interviews had been conducted in the five study villages mainly with peasants, members of the village governments and customary leaders.

\subsubsection{Interviews at the village scale}

Accessing field sites was not possible without the support of the coordination office of the CRC 990 at UNJA and of my field assistants. UNJA provided formal letters for requesting a research permit and support for all my research activities from the village head. The formal letters with seal and signature are a very important instrument for accessing research sites and interview partners in hierarchical rural Indonesia. An official letter from a university as a document of a state institution provided legitimacy and authority for entering the field sites. Therefore, village heads to some extent felt obliged to 
support my research. The limitations and challenges related to this formal approach for accessing field sites will be discussed in the section on "Reflection, limitations and challenges" (section 3.7). Access to participants (or in other words key informants, interviewees or interview partners) was achieved by using the "snowball system" considering the follow the conflict premise. Most of the interviews have been conducted with the household heads (kepala keluarga) only. In a few interviews women and other household members participated.

Figure 2: Number of interviews at different field sites

(Source: sketched by the author)

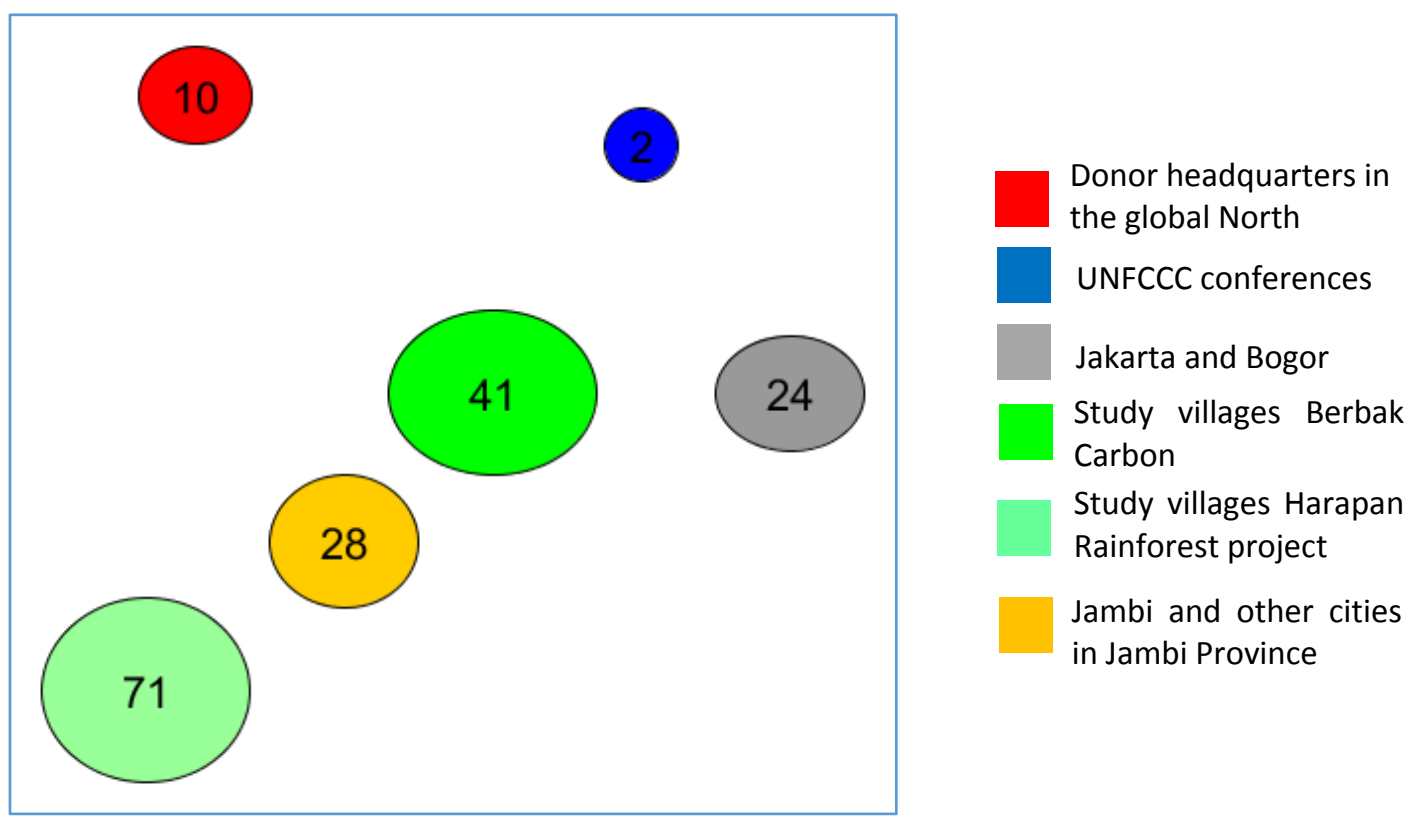

First mainly members of the village elites have been interviewed. The village elites include in general the different members of the village government (e.g. village head (Kepala Desa), hamlet head (Kepala Dusun), neighborhood head (Ketua RT), head of the village parliament (e.g., Ketua BPD), customary authorities (e.g. Ketua Adat) and members of the economic elite e.g. shop owners or owners of larger land holdings. Second, based on information and recommendations by the first group of participants additional interviewees have been selected. In order to gain specific information on land conflicts, customary land tenure regulations and local interpretations of national regulations specific actors with specific knowledge on these issues have been asked. For gaining knowledge on conflicts actors directly affected by conflicts or involved in conflicts have been interviewed. For gaining access on land tenure elders with knowledge on customary regulation and migrants with recent experience in land transactions have been interviewed. In almost all interviews the participants have been asked to outline and explain the history of their settlement, how they accessed their land, if they hold a land certificate and if they have knowledge on REDD+ and conservation regulations. Furthermore, participants have been asked to provide some basic information on their household characteristics, on 
livelihood strategies and their land use practices (e.g. number of household members, plot size, crops cultivated).

The group interviews have been conducted in very informal settings and some even on an ad hoc basis, e.g. when smaller groups have been met accidentally and agreed to be interviewed. In the SPI area a group interview on the history of the settlements facilitated by an SPI member has been performed. In Bungku a mapping exercise has been conducted. Invited villagers had been asked to draw a map of Bungku village. In the village of Sungai Aur a mapping exercise of the NGO Gita Buana was observed.

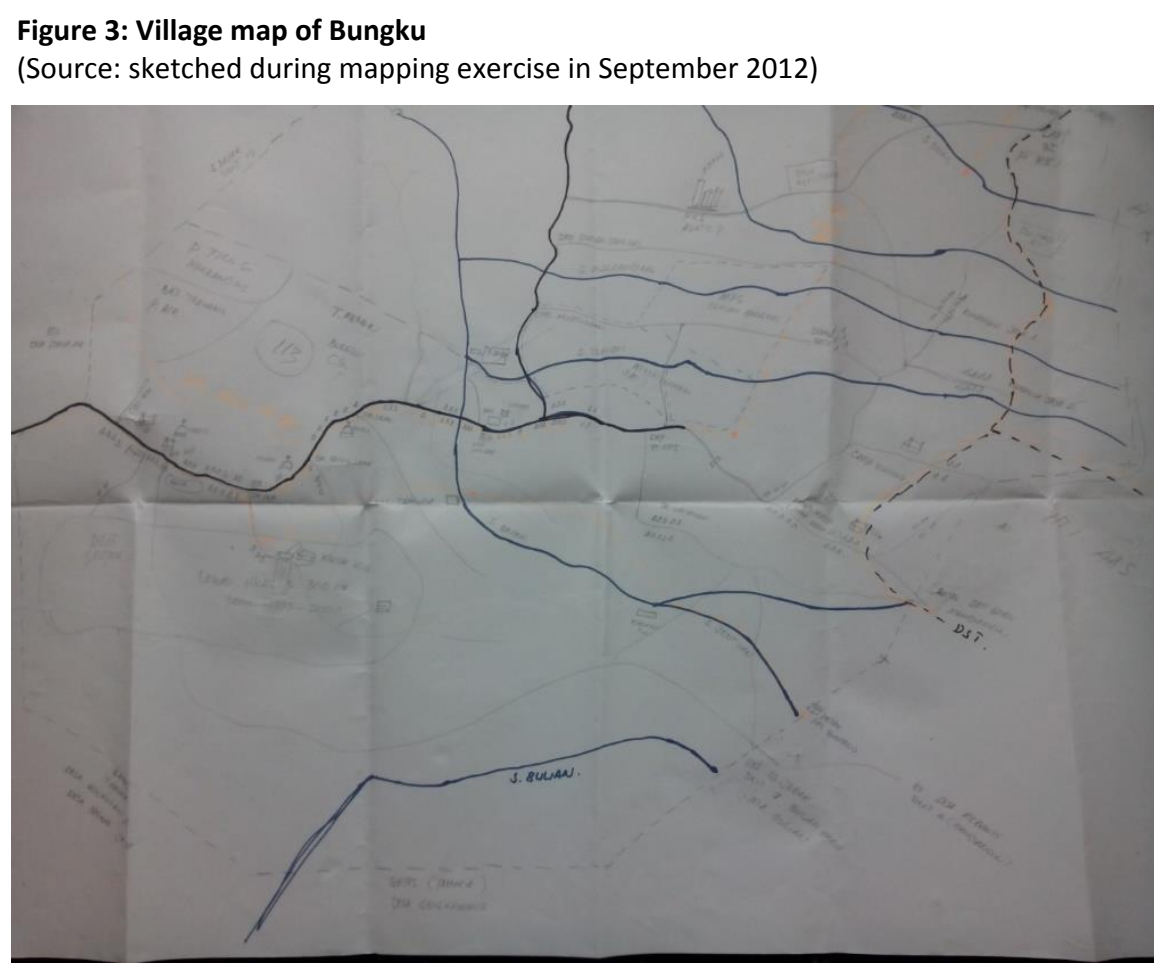

In the project area of the Harapan Rainforest, despite being part of the study area of the CRC 990 I received only limited support by the conservation company PT REKI. The company even attempted to prohibit research activities in parts of their concession (more in section 3.7) and tried to influence the selection of participants directly. In the Berbak Landscape my research was very much supported by ZSL, Berbak National Park agency and by the local NGO Gita Buana. The three organizations facilitated access to village authorities and to remote locations. Accommodation in the villages was facilitated either by the village head, by the coordination office of the CRC 990, by ZSL, SPI or by people met during this research. My research assistant and I stayed between three to eleven days per field trip in the villages. The village of Bungku had been visited one in 2012 and twice in 2013. Tanjung Lebar had been visited twice in 2013. The villages in the Berbak landscape had only been visited once either in 2012 or 2013. 


\subsubsection{Interviews with NGOs, companies, academia, staff of state agencies and donor} agencies

First explorative interviews with NGOs, companies, academia, staff of state agencies and donor agencies have been conducted in 2012. They have been conducted for gaining knowledge on Indonesia's forest governance, REDD+, land tenure, and for identifying influential actors involved in land conflicts in the Berbak and Harapan Landscapes. Questions focused for instance on the relevance of specific policies and on how should a specific law or regulation be read. Other questions aimed to explore common sources of land conflicts and on the implementation status of different REDD+ projects, policies and regulations. In 2013 interviews with actors directly involved in or observing the land conflicts in the two landscapes have been conducted. Questions shifted towards understanding the land conflicts in the Berbak and Harapan landscapes. NGOs (e.g. CAPPA, SPI, AGRA), companies (PT REKI) and forest authorities (provincial and district forest services) with an active role in the conflicts have been asked to explain the origins of the conflict, to describe the actor constellation and to describe their specific role in the conflict.

The selection of interview partners has been supported by alumni of the Managing Global Governance Network of DIE and GIZ, by the CRC 990 offices in Bogor and Jambi, by CIFOR, SPI and by project partners from UNJA and IPB Bogor. Additional interview partners have been selected according to the snow ball system. Moreover, access to governmental agencies and ministries was also facilitated by having a formal research permit issued by the Indonesian Ministry for Research and Technology (RISTEK).

\subsubsection{Role and background of research assistants}

Beside of assisting me during the interviews my field assistants supported me in explaining my research objectives to the village head and to all other participants in the field. They facilitated access to interview partners and taught me local customs. Moreover, they had previous experience in conducting qualitative research in rural settings. 


\subsection{Data analysis}

For analyzing transcripted interviews, field memos and documents this study builds to an important extend on the thematic coding technique developed by Christel Hopf and Christiane Schmidt (1993). Thematic coding has been developed for theory informed qualitative studies. Therefore, the technique seems appropriate for research guided by the reflexive science model.

The technique consists of five analytical steps. In a first step, based on in-depth reading of the textual data considering theoretical assumptions I have developed first analytical categories or code families. In a second step I have created a coding guide out of the developed code families. The coding guide has a nested structure. Terms such as "access", "land tenure" or "PT REKI" constitute important categories of the coding guide. Each category consists of a number of codes. In the case of "PT REKI" this includes codes such as "regulation", "community benefits" and "socialization". The code "community benefits" for instance consists of a number of sub-codes such as "elite capture" and "conditional land tenure". In a third step I have used the coding guide for coding the textual data. Fourth, I prepared code summaries and code memos based on the coded textual data. Code summaries and code memos have been prepared for important categories such as "land conflicts" or "access". In a last step I focused on cases of key relevance for answering the research questions (Schmidt 2008: 444-449). Additionally, village exposes have been prepared including all relevant codes, cases and actor mappings. For analyzing the interview data and the field memos I have used the software Atlas TI. Atlas Ti facilitates the management of larger textual data bases and the development of coding guides.

All interviews have been anonymized and numbered. The number or document ID was assigned automatically by the software Atlas TI. When citing interviews conducted in the study villages I only cite "interview with key informant", village name, date and the document ID (example: interview with key informant in Bungku, 08.09.2012, Document ID: 77). This keeps the interviewees as anonymous as possible. Many issues discussed in the interviews might be considered as illegal. Any reference such as member of the village government or shop owner could compromise the anonymity of the interviewees. When citing interviews conducted with NGOs, academia and staff members of state agencies I only state the name of the institution and not of the interviewee. Direct citations are translated to English, the original interview language of each interview is listed in annex I. 


\subsection{Reflection, limitations and challenges}

In this section I reflect on challenges occurred during the empirical investigation, on issues of positionality and power within different field situations and on general limitations of my qualitative enquiry. As England stated fieldwork is "[...] a dialogical process in which the research situation is structured by both the researcher and the person being researched" (England 1994: 84).

Research on conflicts, on illegal or semi-legal land occupations, and competing property right regimes creates specific challenges since the researcher might be perceived as a threat to the activities of the participants, as being part of the opponent conflict party or as a threat to the status quo (England 1994: 85). The conservation company PT REKI and RSPB as one of PT REKI's shareholders for instance argued from the very beginning that any research on land tenure would not be possible within the project area. A staff member of RSPB argued that research in the conflictive areas of the Harapan Rainforest would exaggerate the conflict. Furthermore, he argued that conducting interviews would not be possible adding, that settlers responses would give the impression of stronger tenure that is de jure the case (Manager of Royal Society for the Protection of Birds 2012). The RSPB manager tried not only to hinder research he even directly questioned the validity of the statements that the settlers would made. PT REKI staff based within the project area argued in the same direction and permitted only research with communities that agreed to cooperate with the conservation company. Research in the conflict areas of Bungku (Kunangan Jaya I and II) and Tanjung Lebar (Tanjung Mandiri and Sungai Jerad) was only possible because of permits and invitations of the respective village governments, the settler groups and peasant organizations. Despite having permits from the respective village governments the fact that PT REKI did not permit research in the conflict areas influenced my behavior at the field sites. Without official permit from PT REKI I felt unsafe as someone acting "illegally" and tried to limit overnight stays in PT REKIs project area.

In the Berbak Landscape the situation was different. The implementing agencies of the Berbak Carbon Project such as the Provincial Forest Agency, the Berbak National Park Agency, ZSL and the subcontracted NGO Gita Buana supported my research project from the very beginning. The context of my fieldwork in both landscape was consequently fundamentally different affecting my positionality in the field situations. In the Harapan Landscape my research was welcomed by village governments and informal settlers and rather rejected by the conservation company PT REKI. The informal settlers perceived my research as supportive for their concerns especially those that were aware that the Harapan Rainforest project received funding from the German government. Settlers hoped that a German researcher would convey their concerns to the decision makers in Germany and supported 
my fieldwork. In the Berbak Landscape implementing agencies hoped that research from an "independent" third party might help them to solve ongoing conflicts.

In all villages the village heads felt obliged to support my activities because of my formal letter of request from the University of Jambi. All village governments supported my fieldwork, and most facilitated accommodation and access to interview partners. This formal support from the political elite of the villages facilitated my research but might hinder the ability to cover marginalized actors within the political arena of my research villages. In the settlements of Sungai Jerad that are controlled and organized by the peasant movement SPI I have encountered similar problems. SPI supported my trips to the settlement and for all actors at the field site I was perceived as guest of SPI. This has probably hindered local opponents of SPI to raise criticism in interviews.

Additional challenges and limitations of my research are directly linked to my positionality and to power imbalances structuring interviews and field work. As a researcher from Europe I was highly visible in all field situation and struck attention. As being part of the "development world" I was often asked about how trade-offs between development and conservation are solved in the "West", why Germany is supporting a conservation project in their region or why should we conserve forest in Jambi for reducing Germany's greenhouse gas emissions. Questions of identity, of positionality and of being external to the community came up almost every day and where part of the field experience. The fact that a person from Europe is doing research in their village in Jambi made some villagers proud but also produced awestruck or fear in interview situations and face to face communication. Furthermore, as a guest of the village government some interview partners might felt obliged to participate and to respond to questions despite having fears to communicate semi-legal land use or land access practices to outsiders. A general weakness of this study is that because of being male access to female household members and interview partners was difficult and therefore only few women participated in my interviews.

In the context of interviews with high-level staff of the Ministry for Forestry and the Ministry of Finance positionality and power relations were different. I was just one of many researchers, PhD students or consultants willing to interview them and their full calendars allowed only relatively short conversations ( $30 \mathrm{~min}$ to $60 \mathrm{~min}$ ). As in the local context, questions of north-south relations and climate justice issues popped up in the conservations, especially when I asked questions about deforestation rates, greenhouse gas emissions and land conflicts. Changing roles and power relations across field sites (e.g. village and UNFCCC conference) were easy to feel. At the local level only very few people rejected an interview request whereas only very few high-level experts agreed to be interviewed. It was for instance not possible for me to interview staff from the forest agency of Muaro Jambi or from the provincial of district transmigration agency. 
Language barriers posed additional challenges. Despite of my intermediate Indonesian language skills I was not able to fully understand all field situations and all interview content. In these cases, my assistant tried to translate to English and to mediate between myself and interview partners. Any translation leads to loss of content. Interviews with some experts in Jakarta were conducted in English. English was neither their mother tongue nor mine increasing the potential for misunderstandings.

Some limitations of my research are directly linked to my research design. Multi-sited field research pose challenges such as language barriers and issues of positionality as already discussed above but may also come to the expense of unraveling local politics. Multi-sited research is time consuming giving the general time constraints of a PhD project. This implied balancing field stays at the forest margins and at the different nodes of decision making. Furthermore, again because of time constraints I was not able to follow all conflicts I have identified or to interview all actors involved in a specific conflict.

\subsection{Applying reflexive social science}

This study follows a multi-sited approach inspired by Burawoy's reflexive science model. Multi-sited research permits to follow the chains of interaction between different actors constituting transnationalized land conflicts. In conceptual terms, as outlined in chapter 2 , this study builds on the politics of scale and political ecology literature. The diversity of concepts and methods used in this study reflect that human-environmental interactions are too complex for relying only one theory or method (Doolittle 2010: 67). The four principles of the reflexive science model are implicitly reflected in the different four methodological and analytical steps of this study. In this research, the first step "intervention" refers to the multi-sited and deterritorialized fieldwork and qualitative interviews on REDD+, land conflicts and access and property relations. In other words, the term refers to the empirical investigations at different scales. The second principle "process", argues of understanding the broader social context of the interview situation. Therefore, this study is based on extended field work across time and space, and has relied on different interview techniques and on participatory observation and explicitly discusses issues of positionality (Burawoy 1998: 26). The third principle "structuration" argues for understanding the conditions and social forces that shape the local context (ibid.). In this sense was the development of the conceptual framework (chapter two) through active dialog between theory and empirics the first step of the structuration process. The fourth principle, "reconstruction" is constituted by an active dialog between theory e.g. political ecology and politics of scale and empirics while giving "[...] priority of the social situation [broader patterns] over the individual" (ibid. 16). This analytical dialog will inform the results chapters four, five, six and seven and in particular the discussion in chapter eight. 


\subsection{Locating the main sites of investigation}

In this section I will describe the main sites of field research. The description includes socio-economic (e.g. land use practices), demographic and physical geographical information on Indonesia, but mainly on the province of Jambi, and on the research villages located within or adjacent to the Harapan Rainforest project and to the Berbak Carbon project. Furthermore, some basic information on the two REDD+ projects will be given. A more in depth description and analysis of the history of the Harapan and Berbak landscapes and its settlements and Indonesia's forest, land tenure and REDD+ governance is part of the result section.

\subsubsection{Transnational, national and local nodes of decision making}

The important locations for qualitative investigation (interviews, informal discussions, participatory observation) outside of the REDD+ project areas were the UNFCCC conferences in Bonn and Doha, the donor headquarters in Germany, Ministries in Bonn and Jakarta, NGO offices in Jakarta, Bogor and Jambi city and governmental agencies in Jambi City, Muaro Bulian and Bogor (figure 2 and table 4).

\subsubsection{Indonesia}

Indonesia has with 252 million the fourth largest population in the world (United Nations Population Fund 2014: 111). The country consists of around 18.000 islands and has a landmass of $1.919 .440 \mathrm{~km}^{2}$. Approximately $60 \%$ of the Indonesian population lives on the island of Java which has a population density of approximately 1100 inhabitants per $\mathrm{km}^{2}$ (Badan Pusat Statistik 2014: 7). The island of Sumatra on which the province of Jambi is located has a population density of 113 inhabitants per km² (ibid.).

Indonesia is a middle income country experiencing growth rates in average of around $6 \%$ in recent years (Ufen 2014). Even though, especially rural Indonesia is highly dependent on the agricultural and forest sectors. The agricultural sector provides jobs for $41 \%$ of the total population and contributes to two-thirds to the rural household income (World Growth 2011: 2). Indonesia's key agricultural commodities are oil palm, rice, rubber and cocoa (ibid. 10). The country is the largest oil palm producer in the world (ibid. 11). Oil palm cultivation is an important direct and indirect income source in rural Indonesia. Directly in a sense that $41 \%$ of all Indonesian palm oil is produced by smallholders, indirectly through employment provided by large scale corporate plantations (ibid.). The forest sector supports the livelihood of least 6 million Indonesian directly (Indrarto et al. 2012: 1) and contributes to 2,9\% of the GDP (FAO 2014: 102). Furthermore, the FAO states that $38,5 \%$ of Indonesia's population are using wood fuel for cooking (ibid. 122). Despite or because of its high forest dependency Indonesia forests 
are at risk. Since 2000 the country has lost $6 \%$ of its primary forest and is currently the country with the fastest rate of primary forest loss (Margono et al. 2014: 731).

\subsubsection{The province of Jambi}

The province of Jambi is located on the island of Sumatra between $0^{\circ} 45^{\prime} \mathrm{S}$ and $2^{\circ} 45^{\prime} \mathrm{S}$ and $101^{\circ} 10^{\prime} \mathrm{E}$ and $104^{\circ} 55^{\prime}$ E. Jambi has an area of 53.435,92 $\mathrm{Km}^{2}$ and 3.2 million inhabitants (Badan Pusat Statistik Provinsi Jambi 2012). The province borders Riau and the Kepulauen Riau in the north, South Sumatra in the south, West Sumatra and Bengkulu in the west and Kepulauen Riau and Bangka Belitung in the east. In administrative terms Jambi is divided into nine districts (Kabupaten) and two independent cities (Kota).

Two third of the province are characterized by hilly lowlands first gently inclining then rampant towards the Bukit Barisan Range reaching $3819 \mathrm{~m}$. The hilly low lands or peneplain zone consist of tertiary sediments with an altitude of less than $100 \mathrm{~m}$ and of flood plains formed by Jambi's large river systems (Murdiyarso et al. 2002: 430). Most of Jambi's larger rivers have their headwaters in the Bukit Barisan Range and flow eastwards through the lowlands towards the coast. The coastal areas of Jambi are characterized by the Batang Hari River delta, flat marshlands and peat swamps, partly influenced by tidal streams (Murdiyarso et al. 2002: 430; Perbatakusuma et al. 2012: 32; Sevin and Benoît 1993: 95).

Schmidt and Ferguson, classify Jambi's highland areas as very wet tropical climate (Af) with 12 months above $100 \mathrm{~mm}$ precipitation and more than $3000 \mathrm{~mm}$ annual rainfall (Perbatakusuma et al. 2012: 38). The low land areas are classified as wet tropical climate (Am) with 10 months above $100 \mathrm{~mm}$ precipitation, 1 month below $60 \mathrm{~mm}$ precipitation and approximately $2000 \mathrm{~mm}$ annual rainfall (ibid.). The short dry season occurs between May and September. The natural vegetation of lowland Jambi has been evergreen rainforest, peat swamp forest and mangrove forest (Whitten 2000). The MoF (Ministry of Forestry) has classified $2.179 .440 \mathrm{Ha}$ or $42,73 \%$ of the provincial areas as state forest (Perbatakusuma et al. 2012: 40). 870.000 ha of the state forest are classified as protected areas (e.g. as national park, forest reserve or conservation forest) (ibid. 40). Anyhow in $2010,888.800 h a$, or $41 \%$ of the state forest including protected state forests have not been covered by trees (ibid. 41).

The corner stone of Jambi's economy is the agriculture sector contributing to $26,5 \%$ to the provincial GDP (ibid. 41). Other relevant pillars of Jambi's economy are the exploitation of black coal, oil and gas. The most important agricultural commodities are rubber, oil palm, and rice (Badan Pusat Statistik Provinsi Jambi 2012). As a result of agricultural expansion and open pit mining Jambi has lost $76.522 \mathrm{ha}$ of forest between 2006 and 2009 per year (Perbatakusuma et al. 2012: 55). Jambi's high deforestation 
rate and the conversion of peat swamps lead to annual GHG net emissions of $57 \mathrm{MtCO} 2 \mathrm{e}^{25}$ (Pemerintah Provinsi Jambi 2012).

Since 2013 Jambi is one of Indonesia's REDD+ pilot provinces. The two REDD+ pilot projects and the adjacent research villages which have been investigated are located in the districts of Batang Hari, Muaro Jambi and Tanjung Jabung Timur. The district of Batang Hari has an area of 5.180,35 $\mathrm{km}^{2} .81$ percent of the district area is characterized by lowlands and flood plains below 100m (Pemerintah Kabupaten Batang Hari 2010: 3). The district has been founded in 1948 by the first independent Indonesian government. Since 1948 Muaro Bulian is the capital of the district. In 2009 the district had a population of 222.841 and a population density of 38,39 inhabitants per $\mathrm{km}^{2}$ (Badan Pusat Statistik Provinsi Jambi 2010: 126). $215.936 \mathrm{Ha}, 42 \%$ of the district is designated as state forest (Pemerintah Kabupaten Batang Hari 2010: 5).

The district of Muaro Jambi dates back to an administrative reform. In 1999 the north-eastern parts of Batang Hari that are located close to the provincial capital of Jambi city became an independent district called Muaro Jambi with Kota Sengeti as its capital (Pemerintah Kabupaten Batang Hari 2012). Muaro Jambi, as Batang Hari is characterized by lowlands and floodplains. The northern parts of the district are characterized by tidal marshlands and peat swamps. The district had a population of 314.598 and a population density of 59.07 people per $\mathrm{km}^{2}$ in 2009 (Badan Pusat Statistik Provinsi Jambi 2010: 126). In 2013 Muaro Jambi became a pilot district of the provincial REDD+ program.

The district of Tanjung Jabung Timur with an area $5445 \mathrm{~km}^{2}$ and a population of 213.781 people is located in coastal Jambi (Badan Pusat Statistik Provinsi Jambi 2010: 126). Tanjung Jabung Timur was part of the former Tanjung Jabung district until 1999. In 1999 the districts were divided into Tajung Jabung Barat and Timur. The capital of the district is Muara Sabak. The district is characterized by peat swamps and tidal marshlands. $40 \%$ of the district area is designated as state forest (Pemerintah Kabupaten Tanjung Jabung Timur 2012).

\subsubsection{The Harapan Landscape}

The term Harapan Landscape has been invented by the CRC 990 and refers to the Harapan Rainforest project and to the different research villages of the CRC 990 located at the margins of the Harapan Rainforest (Faust et al. 2013: 4). The Harapan Landscape is located in the districts of Batang Hari and Muaro Jambi. The project area of the Harapan Rainforest project has 98.555 ha and is officially located in the district of Batang Hari and Sarolangun and in the neighboring province of South Sumatra. The

\footnotetext{
${ }^{25}$ The most recent figure is from 2005.
} 
north-eastern parts of the project area are claimed by the district of Muaro Jambi, but they are according to maps of the Ministry of Forestry part of Batang Hari district.

I have selected the villages of Bungku and Tanjung Lebar within the Harapan Landscape according to the "follow the conflict" premise.

Figure 4: Map of south-east Jambi showing the locations of the research villages and of the REDD+/ conservation projects

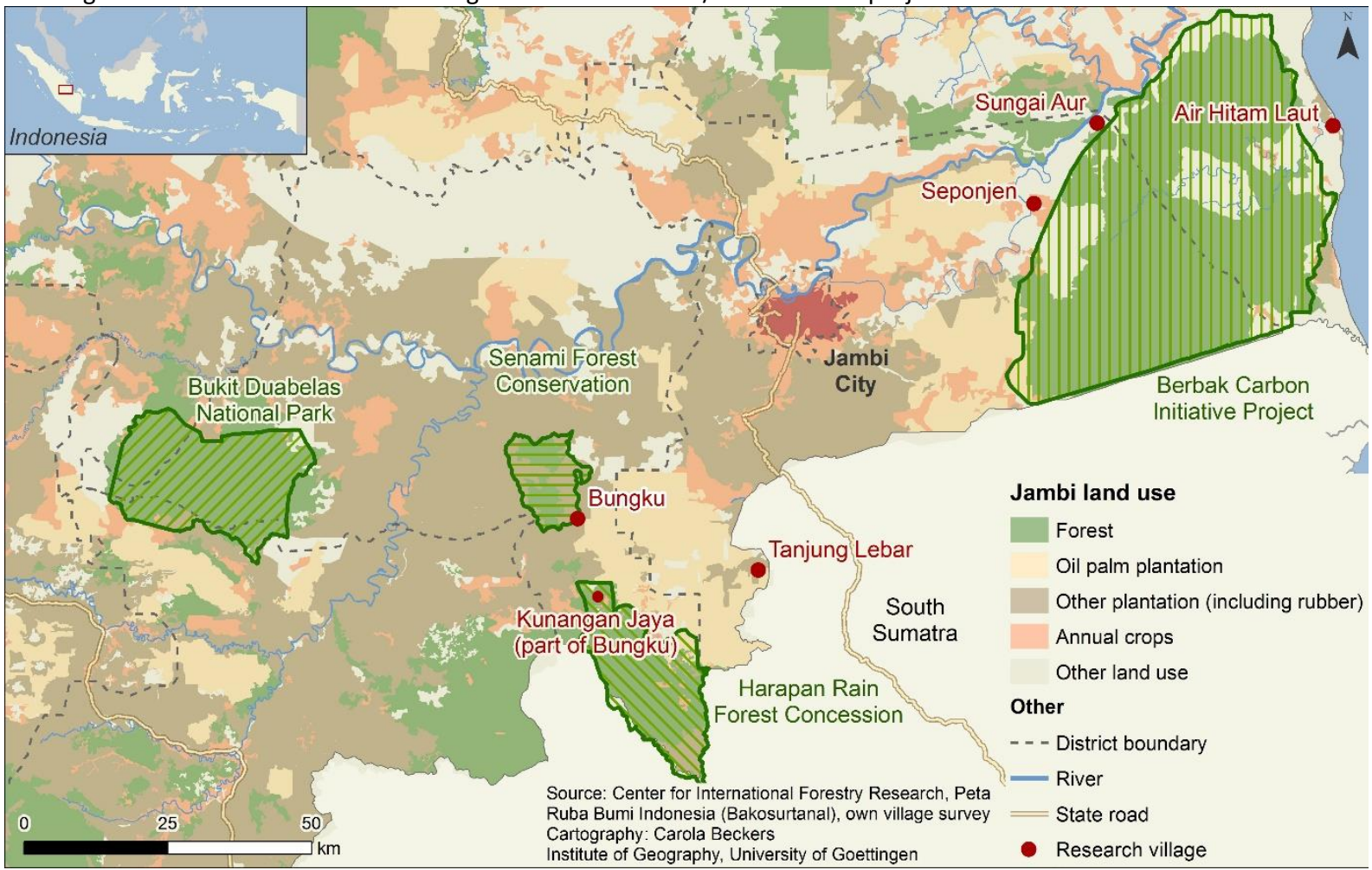

\subsubsection{Bungku}

The village of Bungku is part of the CRC 990 village sample. It is located in the district of Batang Hari and in the sub-district of Bajubang north of the Harapan Rainforest project and south of Senami Forest Reserve slightly south-east of the water divide between the Batang Hari watershed and Sungai BaharLalang watershed. The village arose from a resettlement scheme for local Batin Sembilan groups in 1972 (Faust et al. 2013: 9; Hein 2013b: 15). However, a number of pre-existent settlements in the area prove that the area has been populated since pre-colonial times (Zainuddin 2013: 6).

The village has approximately 10,215 inhabitants and a village territory of 77.000 ha (Faust et al. 2013). Bungku consists of five hamlets: Bungku Indah, Johor Baru I, Johor Baru II, Kunangan Jaya I and Kunangan Jaya II. Bungku Indah dates back to the resettlement schemes, Johor Baru I to a saw mill of 
the logging company PT Tanjung ASA existing in the 1980s. The hamlets of Johar Baru II and Kunangan Jaya I and II have been formed after $1999^{26}$.

Land use in Bungku is dominated by oil palm and rubber cultivation. Shifting cultivation is still practiced by some households in Kunangan Jaya I and II but is becoming less relevant. Anyhow, most of Bungku's village territory is either designated as state forest (e.g. part of the Harapan Rainforest project or of the Senami Forest reserve) or part of large plantation concessions hold by the oil palm company PT Asiatic Persada and by the timber companies PT Agro Alam Sejahtera and PT Wanakasita Nusantara. Batin Sembilan groups consider the areas designated as state forest and the concessions as being part of their Wilayah Adat (customary territory) ${ }^{27}$. As a consequence of overlapping land claims the village of Bungku is affected by a number of different long-lasting and violent land conflicts involving Batin Sembilan, migrants, state forest agencies and companies such as PT REKI and PT Asiatic Persada. Inhabitants described Bungku as "[...] the village with 1001 problems" in reference to the ongoing land conflicts $^{28}$.

\subsubsection{Tanjung Lebar}

The village of Tanjung Lebar is located in district of Muaro Jambi and in the sub-district of Bahar Selatan. Tanjung Lebar consists of five hamlets: Dusun 1, Dusun 2, Sungai Beruang, Pangkalan Ranjau and Tanjung Mandiri. The center of the village (Dusun 1 and 2) is located north-east of the Harapan Rainforest concession in a flat area were the waters of Sungai Bungin and Sungai Kandang meet. The village has officially 2,876 inhabitants; the population is probably much higher since official village data exists only for the hamlets located outside of the Harapan Rainforest (Polsek Sungai Bahar 2011). The autochthon population of the village consists of Batin Sembilan, Melayu Jambi and Melayu Palembang. Migrants are mainly Javanese second-generation transmigrants from other parts of Jambi, Kerinci people from south-west Jambi and Batak from North Sumatra. Land use is dominated by rubber and oil palm. Shifting cultivation is still practiced in the hamlets of Pangkalan Ranjau and Tanjung Mandiri ${ }^{29}$.

Tanjung Lebar dates back to the pre-colonial era. It is one of the oldest villages of the Sungai Bahar area. The village can be traced back to the small hamlets of Pangkalan Ranjau, Sungai Buruk and Sungai Beruang. Pangkalan Ranjau has been founded before 1908, given that it is marked on a map published in 1908 (Hagen 1908). The hamlets have been founded by different Batin Sembilan groups controlling

\footnotetext{
${ }^{26}$ Interview with key informant in Bungku, 08.09.2012, Document ID: 77 and 16.09.2012, Document ID: 85.

${ }^{27}$ Interview with key informant in Bungku, 08.09.2012, Document ID: 77.

${ }^{28}$ Interview with key informants in Bungku, 09.09.2012, Document ID: 38.

${ }^{29}$ Interviews with key informants in Tanjung Lebar, 25.07.2013, Document ID: 125 and 26.07.2013, Document ID: 127.
} 
the upper Sungai Bahar and Sungai Lalang watersheds (Hein and Faust 2014: 23). The officially village territory has an area of 6500 ha but again this number includes not the area within the Harapan Rainforest claimed by the village. Moreover, the Batin Sembilan of Tanjung Lebar lost large parts of their former Wilayah Adat to companies, to transmigration settlements established in the $1980 \mathrm{~s}$ and to the village of Bungku. Today the village territory is fragmented consisting of different dispersed and not connected hamlets located between transmigration settlements and between the oil palm plantations of PT Perkebunan Nusantara VI, PT Bahar Pasifik and PT Asiatic Persada. As Bungku, Tanjung Lebar is affected by a number of different land conflicts, again involving PT REKI and PT Asiatic Persada ${ }^{30}$.

\subsubsection{The Berbak Landscape}

The term Berbak landscape has been introduced by conservationist and donors in order to promote integrated spatial planning for the peat swamp ecosystems of the Berbak National Pak, and for the adjacent forest categories and villages (Millennium Challenge Account 2013). The Berbak Carbon Project can be considered as one of the latest and most advanced attempts to achieve this objective. In the Berbak landscape I focused my investigations on the villages of Air Hitam Laut, Sungai Aur and Seponjen following the conflict premise.

\subsubsection{Air Hitam Laut}

The village of Air Hitam Laut is part of the sub-district of Sadu and located in the district of Tanjung Jabung Timur. The village is directly located at the coast of the South China Sea, at the mouth of the river Air Hitam. In 2012 Air Hitam Laut was only accessible by boat or motor bike.

Air Hitam Laut is divided into four hamlets: Sejahtera, Tanel, Nelayan and Sejati (Alamsyah 2004: 5). The center of the village is located in Sejahtera (ibid.). The village territory has a size of 4320 ha (ibid. 27). In 2012 the village had a population of 2328 inhabitants, according to the village secretary. $75 \%$ of the population are Bugis and originally from South Sulawesi (ibid.9). Other relevant ethnic groups are Melayu Jambi, Javanese and Chinese (ibid.). Land use is dominated by coconut plantations. Oil palm has been introduced very recently in 2009. Important income sources, especially for the Malay population are fishing and gathering of nipa palm ${ }^{31}$ leaves. The Chinese population and increasingly

\footnotetext{
${ }^{30}$ Interviews with key informants in Tanjung Lebar, 26.07.2013, Document ID: 127 and 27.07.2013, Document ID: 113.

31 Nypa fruticans
} 
other ethnic groups are practicing swallow breeding and have built large nesting houses for that purpose.

Air Hitam Laut has been founded by Bugi seafarers from the Luwu district in South Sulawesi in 1965. The Bugi migrants constructed drainage channels, converted forest and reclaimed land for coconut cultivation and established a first settlement. In contrast to all other research villagers no plantation companies are operating in Air Hitam Laut. Conflicts between the local population and the different forest authorities are ongoing since the $1970 \mathrm{~s}^{32}$.

\subsubsection{Sungai Aur}

The village of Sungai Aur is located in the district of Muaro Jambi and in the sub-district of Kumpeh. The village is located on the south-eastern riverbank of the tidal influenced lower course of the Batang Hari River. Until end of the 1990s the Batang Hari River was the main transport route, since 1997 the village is accessible by car. The village had 1573 inhabitants in 2012 and has a village territory of 12.000ha (Kepala Desa Sungai Aur 2012). Most of the village territory is located south-east of the Batang Hari river and a small currently not used and not populated part of the village area is located at the opposite river bank. Sungai Aur consist of three hamlets which are all located at the southeastern river bank. Dusun 1 and 2 form the center of the village, dusun 3 also called Ketapang is located approximately $2 \mathrm{~km}$ further north were the Ketapang River runs into the Batang Hari River. During the rainy season large parts of the village are flooded. Almost all buildings are elevated on stilts. The less flood prone hamlets (dusun 1 and 2) are located on higher alluvial deposits (Sevin and Benoît 1993: 110) directly at the river shore.

Melayu Jambi people are the dominant ethnic group living in the less flood prone hamlets, whereas Javanese migrants live in the low-lying peat swamps of Ketapang (dusun 3) which are flooded first and which are flooded longer than the other hamlets ${ }^{33}$. Land use in Sungai Aur is more diverse than in the other research villages. Important crops are: oil palm, wet rice, rubber, cocoa and vegetables. Fishing, swallow breeding and logging are other important livelihood strategies. Furthermore a number of shipyards for the construction of small cargo ships are located in the village ${ }^{34}$.

The village has been founded in pre-colonial times according to interviewed village elders of Sungai Aur. During Dutch colonization a small Dutch military basis was located close to the village ${ }^{35}$. Since

\footnotetext{
32 Interview with key informants in Air Hitam Laut, 28.09.2012, Document ID: 56, 30.09.2012, Document ID: 67 and with staff member of ZSL in Air Hitam Laut, 29.09.2012, Document ID: 53.

${ }^{33}$ Interview with key informant in Sungai Aur, 31.08.2013, Document ID: 138.

${ }^{34}$ Interview with key informant in Sungai Aur, 02.09.2013, Document ID: 131.

35 Interview with key informant in Sungai Aur, 02.09.2013, Document ID: 131.
} 
1985 forests around Sungai Aur had been designated as conversion forests and became non forest land (areal penggunaan lain (APL)). In $1999^{36}$ the area 3-4km south-east of the Batang Hari River had been designated as forest reserve (Forest Reserve Sekitar Tanjung). In 2008 the Transmigration Agency of Muaro Jambi started to construct a transmigration settlement within the forest reserve inducing land conflicts between different state apparatuses ${ }^{37}$. Sungai Aur is one of the pilot sites for a community reforestation scheme which is part of the community benefit package of the Barbak Carbon Project.

\subsubsection{Seponjen}

The village of Seponjen has been founded in 1931 by Melayu Jambi people from the neighboring Sungai Bungur village (Kepala Desa Seponjen 2013: 6). Seponjen is part of the sub-district of Kumpeh and belongs to the district of Muaro Jambi. Seponjen is located at both sides of the tidal influenced Sungai Kumpeh River which is an arm of the Batang Hari River. Seponjen has a village territory of 16.000 ha and a population of 1315 people (ibid, 8). The village has officially four hamlets. The main two hamlets are located directly at both side of Sungai Kumpeh. They form the oldest part of Seponjen. The third hamlet, Pulau Tigo had been an independent village in the past and became part of Seponjen after a territorial reform. Hamlet four, called Sungai Lais has been established from 1997 onwards by Bugi migrants from South Sulawesi and coastal Jambi ${ }^{38}$.

Wet rice and oil palm are grown in the flood prone lower parts of Seponjen. On the higher lands rubber, cocoa, langsat ${ }^{39}$ and durian ${ }^{40}$ are grown. Commercial illegal logging was one of the most important income source until the former President Susilo Bambang Yudhoyono started anti-illegal logging campaigns in $2005^{41}$. The village has still one sawmill indicating the former importance of the timber sector. Since 1999 parts of the village territory are designated as forest reserve. Seponjen is also one of the pilot sites for a community reforestation scheme which is part of the Barbak Carbon Project's community benefit package.

A number of different land conflicts are taking place in Seponjen. The most intense involves the oil palm plantation company PT Bintang Bukit Sawit. Other relevant conflicts are taking place between

\footnotetext{
${ }^{36}$ The area had been designated as forest reserve in 1993, but only in 1999 the designation became legally binding through decision 421/KPTS-II/1999 of the Ministry of Forestry.

37 Interview with staff member of the sub-district administration (Kecamatan) of Kumpeh, in Sua Kandis, 02.09.2013, Document ID: 181.

${ }^{38}$ Interviews with key informants in Seponjen, 08.09.2013, Document ID: 175 and 11.09.2013, Document ID: 174.

${ }^{39}$ Lansium parasiticum

${ }^{40}$ Durio zibethinus

${ }^{41}$ Interview with key informant in Seponjen, 12.09.2013, Document ID: 316.
} 
villagers and the state forest agency on access and control of the forest reserve and between villages of Seponjen and Sungai Bungur over the border between the two villages ${ }^{42}$.

\footnotetext{
${ }^{42}$ Interviews with key informants in Seponjen, 13.09.2013, Document ID: 122 and 15.09.2013, Document ID: 172.
} 


\section{Background: REDD+ towards a global scale of forest governance?}

The main assumption guiding this chapter is that REDD+ has induced rescaling processes leading to the emergence of a transnational scale of regulation of forest and land tenure governance. REDD+ and forest carbon offsetting induced processes of tenure formalization (e.g. the Indonesian REDD+ strategy refers to a land reform), of commodification of ecosystem services and of international and transnational norms and regulations for involving local communities (FPIC) and for measuring forest carbon. The trading of forest carbon and the allocation of financial contributions of bilateral and multilateral donors to governments and forest owners and users requires homogenous rules for land tenure and for the involvement of local communities. Moreover, REDD+ produces a global scale of meaning for local forest conservation efforts since it links place-based forests to the global problem of climate change and it provides entry points for transnational resistance and climate justice campaigns (Hein et al. 2015).

In the following chapter I will first introduce REDD+, then I will give a short overview over commodification of forest carbon and the evolution of the REDD+ mechanisms. First, I will investigate the development of international norms, social safeguards, instruments for assuring the rights of local and indigenous communities and benefit sharing policies developed at the transnational and international level which are relevant for local struggles over land in REDD+ target areas. Second, I will describe Indonesia's national REDD+ policies with a specific attention to policy elements dedicated to the avoidance of land conflicts, to the mediation of land conflicts and to agrarian reform. Third, provincial REDD+ policies of Jambi and REDD+ pilot activities in Jambi will be described, again with specific attention to land and agrarian reform policies. Finally, a short mapping of different actors involved in REDD+ implementation and REDD+ related land conflicts in Jambi will be presented.

\subsection{Introducing REDD+}

REDD+ is an incentive-based instrument for reducing forest related greenhouse gas emissions (Zelli et al. 2014: 27). The basic idea of REDD+ is to provide monetary value for standing forest and to establish a mechanism for allocating payments from high emitting industrialized countries of the global North to countries with standing tropical forest in the global South (Hein, Meijer, and Rodriguez de Francisco 2015: 2; Zelli et al. 2014:19-20). REDD+ as an idea was heavily promoted by influential policy reports such as Nicholas Stern's "Review on the Economics of Climate Change" (2007) and Johan Eliasch's review "Climate Change: Financing Global Forests" (2008). These reports have framed REDD+ as a win- 
66

in mechanism that would reduce greenhouse gas emissions at very low costs, would generate alternative income for forest-dependent communities and would support

Critique on forest carbon offsets and REDD+ was raised from the very beginning especially by
indigenous rights and peasant movement (Fogel 2004: 116; Hein and Garrets 2014: 321). The raised critique focused mainly on three aspects of the offsetting idea. First, indigenous rights and peasant entangled transfer of responsibilities for avoiding emissions to the global South. Second, they criticized the framing of forests as empty carbon stocks highlighting that many indigenous groups and peasants
lived within and close to forests and have maintained the carbon storage capacity of forests since generations. Third, they have criticized the lack of a clear and legally binding acknowledgement of
indigenous land rights in the Kyoto Protocol and in early agreements of the UNFCCC on REDD+ such as the Bali Roadmap (Fogel 2004; Griffith 2007; Hin and Garrets 2014; Hall 2010). But so far the introduction of REDD+ and forest carbon offsetting has not only negative implications
for local and indigenous communities. REDD+ has created the much needed attention for forest conservation and for the structural inequality characterizing forest governance in many tropical frontier areas in the global South (Heine et al. 2015). Furthermore, REDD+ has provided new 2010: 325). The Warsaw Framework for REDD+ established in 2013 acknowledges the rights indigenous and local communities more concrete then earlier decisions of the UNFCCC.

RUMAL KAMI

BURAN "TOILET"

KARBON (EMISI PENCEMAR) megara kay 


\subsection{The emergence of REDD+ and the commodification of forest carbon ${ }^{43}$}

In the 1990's international environmental and development organizations (such as the World Bank) and environmental NGOs increasingly started to argue that environmental problems such as climate change and forest and ecosystem loss are caused either by policy failures (McAfee 1999, 2012a, 2012b; Hein 2013b) or by a failure to economically account for externalities (Corbera, Soberanis, and Brown 2009; Hein 2013b; McAfee 2012b). For coping with the prevalent environmental crisis in ways compatible with capitalist development, nature, or specific ecosystem services should be internalized into the economic and financial system (McAfee 2012b: 26). The idea of conserving forests to mitigate climate change came up in the late 1980s when first private companies and NGOs mainly from the United States started to engage in forest conservation for offsetting their emissions voluntarily thereby creating a market for forest carbon credits (Hein 2014: 508; Hein and Garrelts 2014: 320; Hein, Meijer, and Rodriguez de Francisco 2015: 2; Neeff et al. 2009: 8). Forest conservation as a potential threat to economic growth has been transformed to a new profit option through the invention of REDD+ and payment for ecosystem service schemes (McAfee 2012b; Smith 2008; McGregor 2010).

REDD+ and forest carbon offsets can be considered as an attempt to assign a price to the ability of forests to store and to sequester greenhouse gases. For transforming the carbon sequestration services of forests to tradable commodities a number of conditions have to be fullfilled. According to Noel Castree (2003: 279-282) (4) $^{4}$ the following requirements to commodify ecosystem services have to be fullfilled. First, clear property rights to ecosystem services (e.g. ability of forests and trees to capture greenhouse gases) have to be assigned (privatization). Second, ecosystem services have to be exchangeable in order to trade them (alienability) (ibid. 279). Third, ecosystem services should be seperated from their supporting context (individuation) (ibid. 280). Fourth, ecossystem services have to be homogenized (abstraction) in order to produce services which are exactly like any other service produced by a forest located elsewhere on the globe (ibid. 281). Fifth, prices have to be assigned (valuation). These rather theoretical steps involve practically several technical steps that are conducted by state agencies (e.g. MoF), carbon consulting companies and carbon certification bodies.

\footnotetext{
${ }^{43}$ Parts of this section have been published in Hein et al. (2015) "What is the Potential for a Climate, Forest and Community Friendly REDD+ in Paris?”, Briefing Paper 3/2015, German Development Institute/ Deutsches Institut für Entwicklungspolitik, Bonn and in Hein (2014) "Peripherie-Stichwort Politiken zur Reduktion von Emissionen aus Entwaldung und Schädigung von Wäldern (REDD+)" in Peripherie: Zeitschrift für Politik und Ökonomie in der Dritten Welt, 136/2014, 508-511, and in Hein and Garrelts (2014) „Ambiguous involvement: civil-society actors in forest carbon offsets: the case of the climate community and biodiversity standards (CCB) in: Matthias Dietz / Heiko Garrelts (eds.), Routledge Handbook of the Climate Change Movement, London: Routledge, 319-333.

${ }^{44}$ Noel Castree (2003: 282) mentions a seventh condition "displacements" arguing that market exchange hides the "socio-natural relations" of production hiding social and environmental consequences".
} 
Starting point is the projection of the amount of greenhouse gases sequestered by the forest ecosystem including emissions avoided through conserving the forest ecosystem. The amount of sequestered carbon and the emissions avoided by the project determine the amount of tradable emission permits (Hein and Garrelts 2014: 320). Emission permits or carbon credits then allow to trade the ability of forest ecosystem to sequester green house gases.

The Kyoto Protocol (KP), agreed on in 1997, introduced the Clean Development Mechanism (CDM) and Joint Implementation (JI) as first formal emission trading systems permitting the trade of emission rights produced by forest carbon offset projects (Hein 2014; Hein, Meijer, and Rodriguez de Francisco 2015). The CDM and the Jl allow companies to offset their emissions, for instance through investing in reforestation and afforestation projects (ibid). Forest conservation and avoidance of deforestation were not covered by the KP because of critique raised by the EU and NGOs regarding permanence and additionality of climate mitigation based on terrestrial carbon and forest conservation (Bäckstrand and Lövbrand 2006: 64; Hein, Meijer, and Rodriguez de Francisco 2015: 2). However they can be traded at the voluntary markets ${ }^{45}$.

In 2005 due to strong lobbying by Costa Rica and Papua New Guinea, the issue of forest conservation re-entered the UNFCCC negotiations (Hein, Meijer, and Rodriguez de Francisco 2015: 2). In a recently published briefing paper I argue together with my co-authors "[...] that the fact that the Kyoto Protocol finally came into force in 2005 (COP 11 in Montreal), gave a new momentum for forests in the climate negotiations" (Hein, Meijer, and Rodriguez de Francisco 2015: 2). The Kyoto Protocol increased the attractiveness of the UNFCCC and turned the convention into an attractive forum for actors mainly interested in finding global solutions for forest and biodiversity conservation after several failed attempts of other international forums such as the Convention on Biological Biodiversity (CBD) and United Nations Forum on Forests (UNFF) (Hein, Meijer, and Rodriguez de Francisco 2015: 2; Zelli et al. 2014: 19). Furthermore, this momentum created an influential discourse coalition for the inclusion of standing forests involving those interested in forest conservation (e.g. the big environmental NGOs such as Conservation International and WWF) and those interested in developing carbon markets and cheaper carbon offsetting options (e.g. companies such as British Petrol and Intel) for fossil fuel emissions from developed countries (Hein, Meijer, and Rodriguez de Francisco 2015: 2).

The first official decision of the UNFCCC referring REDD+ was made during the 13th conference of the parties (COP) on the island of Bali, Indonesia. The so called Bali Roadmap includes a decision (Decision 2/CP.13) on "Reducing emissions from deforestation in developing countries: approaches to stimulate

\footnotetext{
${ }^{45}$ Voluntary investments for compensating greenhouse gas emissions, in other words the offsetting of emissions and all transactions related to the exchange of carbon-related environmental services are known as the voluntary carbon market (VCS 2015).
} 
action" (UNFCCC 2007). The decision encourages developing countries to "[...] undertake efforts, including demonstration activities, to address the drivers of deforestation relevant to their national circumstances, with a view to reducing emissions from deforestation and forest degradation and thus enhancing forest carbon stocks due to sustainable management of forests; [...]" (UNFCCC 2007).

It is in fact not clear in how far the implementation of an international REDD+ scheme for financing forest conservation will require the full commodification of forest carbon as explained above. Since it is still open whether forest conservation should be financed through an emission trading system, result-based aid or common aid. This is part of the ongoing climate negotiations (Hein, Meijer, and Rodriguez de Francisco 2015). At the same time voluntary markets for forest carbon offsets are expanding significantly since the late 1980s reaching a market value of USD 126 million and a further expansion is projected (Peters-Stanley and Gonzalez 2014: 17, 42).

\subsection{REDD+ and the rights of local and indigenous communities ${ }^{46}$}

A first list of social safeguards referring to rights of local and indigenous communities was agreed on during COP 16 in Cancun, Mexico (Zelli et al. 2014: 20). The so called Cancun Safeguards are part of the appendix of the decision 1/CP.16. The safeguards should be considered for all REDD+ activities mentioned in the decision ${ }^{47}$. Relevant safeguards referring to the rights of local and indigenous communities are listed below (UNFCCC 2010). REDD+ activities should:

- "be undertaken in accordance with national development priorities, objectives and circumstances and capabilities and should respect sovereignty" (1.e);

- " "be consisted with the adaptation needs of the country" (1.h);

- "respect for the knowledge and rights of indigenous peoples and members of local communities, by taking into account relevant international obligations, national circumstances and laws, and noting that the United Nations General Assembly has adopted the United Nations Declaration on the Rights of Indigenous Peoples" (2.c);

\footnotetext{
${ }^{46}$ Parts of this section have been published in Hein et al. (2015) "What is the Potential for a Climate, Forest and Community Friendly REDD+ in Paris?”, Briefing Paper 3/2015, German Development Institute/ Deutsches Institut für Entwicklungspolitik, Bonn and in Hein (2014) "Peripherie-Stichwort Politiken zur Reduktion von Emissionen aus Entwaldung und Schädigung von Wäldern (REDD+)“ in Peripherie: Zeitschrift für Politik und Ökonomie in der Dritten Welt, 136/2014, 508-511, and in Hein and Garrelts (2014) „Ambiguous involvement: civil-society actors in forest carbon offsets: the case of the climate community and biodiversity standards (CCB), in: Matthias Dietz / Heiko Garrelts (eds.), Routledge Handbook of the Climate Change Movement, London: Routledge, 319-333.

47 According to Decision 1/CP.-16, article 70 refers to the following activities eligible for REDD+: a) Reducing emissions from deforestation, b) reducing emissions from forest degradation, c) conservation of forest carbon stocks, d) sustainable forest management of forests, and e) enhancement of forest carbon stocks.
} 
- guarantee "the full and effective participation of relevant stakeholders, in particular indigenous peoples and local communities, in the actions referred to in paragraphs 70 and 72 of this decision ${ }^{48 \prime}(2 . e)$.

The Cancun Safeguards state that REDD+ interventions should "promote and support" the rights of indigenous communities and "full and effective" stakeholder involvement. Anyhow the formulation of the safeguards is relatively weak e.g. the decision only "notes" that the UN Declaration on the Rights of Indigenous Peoples has been adopted, the decision does not stipulate that any REDD+ intervention have to follow the declaration. Despite of the progress in comparison to earlier UNFCCC agreements many NGOs and climate justice organizations have criticized the document as too weak, too general and for not having clarified the legal status of the safeguards as such (Spiller and Fuhr 2010; Lang 2010). The last relevant decisions of the UNFCCC on REDD+, the Warsaw Framework for REDD+ were made at COP 19 in 2013 in Warsaw. The framework restates the Cancun Safeguards and states that REDD+ activities in developing countries should be financed through result-based approaches (UNFCCC 2013).

Parallel to the formal UNFCCC REDD + negotiations a number of multilateral, bilateral, national, private and sub-national initiatives emerged. The probably most influential multilateral initiatives are the Forest Carbon Partnership Facility (FCPF), the Forest Investment Program (FIP) and the UNREDD initiative (Corbera and Schroeder 2011; Zelli et al. 2014). All three initiatives are active in Indonesia. Influential bilateral initiatives in Indonesia are the Norwegian Forest and Climate Initiative, the German International Climate Initiative, and the German-Indonesian "Forclime" Program. Simultaneously national, private and sub-national initiatives emerge. Indonesia has developed several national REDD+ policies (more in section 4.4) and at the sub-national level NGOs, provincial governments and district governments initiated smaller project-based REDD+ initiatives. Most sub-national private and public and private REDD+ initiatives such as the Berbak Carbon Project are aiming at the voluntary carbon markets. Bilateral and private REDD+ initiatives do not necessarily follow the Cancun Safeguards. Many have formulated own safeguards, do-no harm principles and social standards. The German bilateral initiatives funded by the BMZ are at least since 2011 committed to the "Human Rights-Based Approach in German Development Policy". The policy supports the UN Declaration on the Rights of Indigenous People, the Convention 169 of the International Labor Organization (ILO) and the implementation of free, prior and informed consent (FPIC) (Schielmann et al. 2013: 26).

\footnotetext{
${ }^{48}$ For article 70 consider the footnote above, article 72 requests that developing country parties "[...] when developing and implementing their national strategies or action plans, to address, inter alia, the drivers of deforestation and forest degradation, land tenure issues, forest governance issues, gender considerations and the safeguards identified in paragraph 2 of appendix I to this decision, ensuring the full and effective participation of relevant stakeholders, inter alia indigenous peoples and local communities".
} 
But it remains unclear in how far the human rights policy of the BMZ is binding for initiatives funded by the Federal Ministry for the Environment, Nature Conservation, Building and Nuclear Safety (Bundesministerium für Umwelt, Naturschutz, Bau und Reaktorsicherheit, BMUB) such as the German International Climate Initiative (IKI). According to a recent study conducted by Sabine Schielmann and colleagues (2013: 26) IKI will use the BMZ human rights policies as guidance for future projects. PT REKI, the implementing agency of the Harapan Rainforest project received funding from IKI from 2010 to 2013. At that time IKI had no coherent and detailed safeguards in place. IKIs funding guidelines only stipulate that implementing organizations have to outline potential consequences of the project to local and indigenous groups (Schielmann et al. 2013: 27). They have to explain how negative consequences might be avoided or minimized, how rights of indigenous group and local communities are respected, how groups are compensated and how a participatory approach is ensured. The guidelines do not include clear "do no harm guidelines", they do not clarify what is meant by a "participatory approach" and the guidelines only state that existing international standards might be helpful for project implementation (ibid.). PT REKI has been criticized by various actors for neither conducting FPIC nor other forms of participatory community involvement prior to project implementation ${ }^{49}$.

REDD+ projects aiming at the voluntary carbon markets such as the Berbak Carbon Project have to follow certain regulations formulated by transnational carbon certification bodies. Certification according to a carbon standard can be considered as a precondition for selling forest carbon credits (Hein and Garrelts 2014: 321). The Climate Community and Biodiversity Standard (CCBS) has been developed by the Climate Community and Biodiversity Alliance (CCBA). CCBA is an organization founded by the NGOs Care, Conservation International, The Nature Conservancy, Rainforest Alliance, the Wildlife Conservation Society and is supported by the companies BP, Intel, Weyerhauser and GFA Envest (CCBA 2015). The CCBS provides criteria for assessing REDD+ projects and other forest carbon offsets. A second, especially in Jambi relevant standard is the Planvivo Standard for community-based Payments for Ecosystem Services. Globally the Planvivo Standard is of minor importance (Estrada 2011: 1). The Planvivo standard has been developed by the Edinburgh Centre for Carbon Management and by El Colegio de La Frontera Sur in 1994 (Estrada 2011: 3). Planvivo stipulates that 60\% of the carbon revenues have to be allocated to the involved communities and stipulates FPIC (Estrada 2011: 3; Plan Vivo 2013: 22-23).

\footnotetext{
${ }^{49}$ Interviews with key informants in Bungku, 12.09.2012, Document ID: 79, and in Tanjung Leber, 21.07.2013, Document ID: 128, 129 and with CAPPA activists in Jambi, 18.07.2013, Document ID: 157 and unpublished document of KfW.
} 
Projects certified according to the CCBS should at least create no harm for local communities and in the best case they should provide benefits for them. Relevant criteria in the second edition of the standard referring to the rights of local and indigenous communities are the following. The project proponents have to

- "Demonstrate [...] that the project will not encroach uninvited on private property, community property [...] and has obtained the free, prior and informed consent of those whose rights will be affected by the project." (G5.3)

- Demonstrate that the project does not require the involuntary relocation of people or of the activities important for the livelihoods [...]. The project proponents must demonstrate that the agreement was made with the free, prior and informed consent of those concerned and includes provisions for just and fair compensation" ("including lands that communities have traditionally owned, occupied or otherwise used or acquired") (G5.4) (CCBA 2008: 16, 20, 22, 34 cited in Hein and Garrelts 2014: 324).

The CCBS stipulates FPIC and recognizes traditionally owned land and land occupied by local communities. CCBS provides far-reaching recognition of local community rights. But implementing the standards and especially conducting FPIC might be challenging at the local level and might raise the following questions: who is entitled to FPIC and who represents communities in the negotiations with implementing agencies? (Hein and Garrelts 2014: 327).

FPIC as an emerging principle in international law dates back to the ILO convention 169 from 1989, has been picked up by the Convention on Biological Diversity (CBD) in 1992, by the UN Declaration on the Rights of Indigenous Peoples in 2007 and by FAO in 2012. Today many different interpretations of FPIC exist and no general agreement on its meaning and its implications have been achieved yet (Sargent 2015: 88-89). Generally speaking, those communities are entitled to FPIC that are affected by an intervention (e.g. REDD+) that endangers the survival of the community. Especially entitled are indigenous communities or communities that share common characteristics with indigenous communities (UN-REDD 2013: 11-12). In 2013 UN REDD published guidelines for the application of FPIC in the context of REDD+. The guidelines stipulate FPIC for any REDD+ intervention especially in cases where indigenous populations have to be relocated, propose the mapping of rights before implementation and recommends the formulation of national FPIC guidelines. (UN-REDD 2013: 22-24). However, the UN REDD guidelines are voluntary and especially in countries that have not been effected by European settler colonialism such as Indonesia the entire population can be to some extend defined as indigenous. 
Despite or probably caused by the co-existence of many different approaches towards REDD+ (e.g. UNFCCC, bilateral approaches, voluntary carbon markets) no coherent global or transnational scale of forest governance has been formed yet. The current institutional structure of REDD+ remains fragmented (Zelli et al. 2014: 18). Many different actors e.g. UNFCCC, donor agencies, and non-state actors such as CCBA have formulated different standards, rules and safeguards and seek to construct their own scales of regulation.

\subsection{National REDD+ and land-based mitigation policies and land tenure ${ }^{50}$}

The highly fragmented global institutional structure of REDD+ is also reflected nationally and subnationally through different overlapping REDD+ related scales of meaning and regulation (Zelli et al. 2014; Indrarto et al. 2012). Today many different sub-national, national, bilateral, multilateral, private and transnational REDD+ initiatives are running across the country. Indonesia hosts 37 REDD+ pilot projects (Forest Climate Center 2012) and public donor initiatives from 11 countries are either contributing or committing more than 750 million USD for implementing REDD+ policies. Private sector initiatives (including private foundations and NGOs) are contributing more than 55 million USD towards REDD+ and good forest governance in Indonesia (Forest Trends 2014). Over the period from 2002-2012 different German donor initiatives contributed 33.4 million USD directly for the forest sector and additional 81.9 million USD for general environmental protection including forestry and climate change (Buergin 2014: 76)

The province of Jambi is simultaneously a REDD+ pilot province of the REDD+ Agency, a low carbon development pilot province of the National Council on Climate Change, and forms a REDD+ pilot province of the national greenhouse gas reduction strategy (RANGRK). Within Jambi the provincial REDD+ taskforce selected specific pilot districts. At the same time NGOs and conservation companies in cooperation with external donors and state forest agencies have established REDD+ pilot projects and landscape scale conservation initiatives including the Harapan Rainforest and the Berbak Carbon project (Hein 2013b: 12-13).

The first domestic Indonesian REDD+ policies have been outlined in the "REDDI" strategy (REDD Indonesia) of the MoF shortly before COP 13 (2007). The document contains first options for baseline development, monitoring of deforestation and benefit sharing (Ministry of Forestry 2007). In addition, it argues for first pilot activities that would test approaches that are able to formalize forest

\footnotetext{
${ }^{50}$ Parts of this section have been published in Hein (2013) "Climate Change Mitigation in Emerging Economies The Case of Indonesia - Hot Air or Leadership?", Briefing Paper 8/2013, German Development Institute/ Deutsches Institut für Entwicklungspolitik, Bonn.
} 
governance through gazettement, law enforcement and land tenure assessments (Ministry of Forestry 2007: 17, 33).

In 2008 and 2009 the Ministry of Forestry issued first REDD+ regulations. The first outlying procedures for the implementation of demonstration activities (Regulation 68/2008) and the second outlying procedures for licensing forest carbon projects in production and conservation forest including rules for benefit sharing between government, communities and the implementing company (Regulation 36/2009) (Menteri Kehutanan 2008b, 2009). And a third, regulation 30/2009 that further clarifies implementation procedures. Regulation 68/2008 remains very unspecific and does not even mention communities. Regulation 36/2009 states that implementing agencies have to indicate community benefits for receiving a license for implementing a REDD+ project (article 6) and have to support community empowerment (article 14). Furthermore, the regulation proposes the use of existing carbon and social environmental standards of the voluntary carbon market (e.g. CCBS and Planvivo) (article 14) and therefore indirectly suggests FPIC. Yet the regulation did not come into force since the Ministry of Finance opposes the regulation ${ }^{51}$. Regulation 30/2009 lists criteria for selecting REDD+ pilot sites e.g. data availability, deforestation risks, and the existence of land conflicts (Ministry of Forestry 2009). At the project-scale in Jambi the different REDD+ regulations did not seem to be very relevant, only ZSL staff argued that benefit sharing is pending because benefit sharing regulations went not into force ${ }^{52}$.

In 2009 Indonesia signed the Copenhagen Accord announcing as one of the first emerging economies an emission reduction target. The Indonesian government declared that it will reduce its emissions about $26 \%$ below business as usual by 2020 . Two years later President Susilo Bambang Yudhoyono (SBY) enacted Presidential Regulation No. 61/2011 providing a legal framework for Indonesia's mitigation targets (Hein 2013a: 2). The regulation includes a detailed work plan for emission reductions, called RANGRK (Rencana Aksi Nasional Pengurangan Emisi Gas Rumah Kaca) and refers to mitigation actions that are - in most instances - part of the already existing short- and mid-term national development plans. $80 \%$ of the overall emission reductions target are planned to be achieved through changes in land use (ibid). The policy proposes emission reductions through the development of plantations on degraded non-forest land, through development of timber plantations, through the issuance of additional ecosystem restoration concessions, expansion of community forest concessions and through the development of REDD+ demonstration activities in Jambi and Central Kalimantan (Republic of Indonesia 2011b). RANGRK consists of the above-mentioned national work plan and

\footnotetext{
${ }^{51}$ Interviews with staff member of the Ministry of Finance, Jakarta, 19.07.2012, Document ID: 89 and with staff member of CIFOR, Bogor, 26.07.2012, Document ID: 100.

52 Interview with staff member of ZSL, Bogor, 27.08.2012, Document ID: 120.
} 
provincial work plans (RADGRK), which have to be prepared by the provincial governors (Hein 2013a: 2).

An influential bilateral agreement that explicitly considers ongoing discussions on land tenure conflicts in the context of REDD+ is the Letter of Intent (LOI) between the Norwegian and Indonesian Governments on "Cooperation on reducing greenhouse gas emissions from deforestation and forest degradation". The agreement has been signed in 2010 and foresees payments of up to USD 1 billion if Indonesia would reach specific mitigation and policy goals outlined in the LOI (Government of the Kingdom of Norway and Government of the Republic of Indonesia 2010). The LOI forms the legal basis of the agreement, calls for "full and effective participation" by all stakeholders, including indigenous groups and local communities, and for the development of "[...] appropriate measures to address land tenure conflicts [...]" (ibid.). The development of appropriate measures to solve land conflicts is listed as one of the official deliverables of the result-based payments agreement, implying at least theoretically that Indonesia would only receive payments from Norway if measures are developed (ibid.). Anyhow Norway is not supporting policy measures aimed at solving land conflicts directly. "The agreement is result-based and therefore we do not provide technical assistance for the process" and "[...] we do not use specific social safeguards for the initiative we draw on Indonesia's domestic safeguards" stated an expert from the Norwegian Forest and Climate Initiative ${ }^{53}$. Other listed deliverables are inter alia, a two-year moratorium for new conversion concessions within peat and natural forest, the establishment of a special agency directly accountable to the President and the formulation of a national REDD+ strategy (Government of the Kingdom of Norway and Government of the Republic of Indonesia 2010). The moratorium went into force in 2011 and has been extended in 2013 and 2015. The national REDD+ strategy has been published in 2012 and the REDD agency has been established in 2013.

The moratorium bans new forest and land conversion business licenses (e.g. oil palm concessions) and protects 22.5 million hectares of additional forest and peatland (Murdiyarso et al. 2011). Moreover, the moratorium also fostered formalization and homogenization of spatial planning processes. The One Map Initiative initiated by the REDD+ Taskforce to monitor the moratorium is an attempt to develop one reference map for all state agencies (Hein 2013a). This might reduce the risk of overlapping concessions in future ${ }^{54}$.

\footnotetext{
53 Interview with staff member of the Norwegian Forest and Climate Initiative, via telephone, 11.12.2012, Document ID: 387.

${ }^{54}$ Interview with Greenpeace activist, Jakarta, 27.07.2012, Document ID: 121.
} 
The national REDD strategy has been developed by the Indonesian REDD+ Taskforce ${ }^{55}$ with the support of civil society organizations. The document summarizes different policies aiming at achieving Indonesia's emission reduction targets and at developing Indonesia's forests as a net carbon sink by 2030 (Indonesian REDD+ Task Force 2012: 5). The Indonesian REDD strategy can be considered as being part of RANGRK ${ }^{56}$ or as contributing to RANGRK ${ }^{57}$ and at the same time being a deliverable of the agreement with Norway. The strategy entails a framework for the development of social safeguards. Listed safeguards acknowledge land rights of indigenous and local communities based on historical use (Indonesian REDD+ Task Force 2012: 28), admit indigenous and local communities the right to object decisions related to REDD+ and stipulate conflict resolution measures and FPIC. Furthermore, the strategy contains a section on "land tenure reform" that refers to the "[...] constitutional right to certainty over boundaries and management rights for natural resources" (ibid. 18), considers a land reforms as "[...] an important prerequisite to create the conditions required for successful implementation of REDD+" and stipulates FPIC for any new natural resource management concessions (ibid.).

Yet the section on land reform does neither explicitly mention that the state forest will be subject to the reform nor that the MoF will be involved. Only the National Land Agency (Badan Pertanahan Nasional, BPN) and the Ministry of Home Affairs are mentioned as involved actors (Indonesian REDD+ Task Force 2012: 18). An interviewed expert of the MoF when asked about the land reform argued that "the land reform is meant to further clarify the status of land used by different actors [...]" adding that the existing regulations already permit community, smallholder and village forest concessions ${ }^{58}$ and implying that the reform will not change the status of the state forest. An interviewed CIFOR expert argued "[...] I don't think that any government will voluntarily conduct a land reform unless there is strong pressure from the society" ${ }^{\prime 2}$. An interviewed agrarian reform activist lauded the reference to a land reform in the REDD strategy but added that the REDD+ Taskforce has not the authority to implement a land reform ${ }^{60}$.

The introduced political strategies, policies, agreements and regulations can be considered as an attempt of specific apparatuses of the state to establish new national scales of meaning and regulation for implementing REDD+. And to use the political momentum for forest reform provided by REDD+ in order to formalize forest governance and spatial planning and at least to some extend also as an

\footnotetext{
${ }^{55}$ The Indonesian REDD+ Taskforce (SATGAS) was the precursor of the REDD+ Agency (Badan Pengelola REDD+), members are experts from relevant sector Ministries, state agencies and academia.

${ }^{56}$ Interview with staff member of the Ministry for Finance, Jakarta, 19.07.2012, Document ID: 89.

57 Interview with staff member of CIFOR, Bogor, 26.07.2012, Document ID: 101.

${ }^{58}$ Interview with staff member of the Ministry of Forestry, Jakarta, 23.07.2012, Document ID: 88.

${ }^{59}$ Interview with staff member of CIFOR, Bogor, 26.07.2012, Document ID: 100.

${ }^{60}$ Interview with staff member of Sajogyo Institute, Bogor, 13.08.2013, Document ID: 155
} 
attempt to strengthen the rights of local and indigenous communities. REDD+ and the high attention towards Indonesia's forests could have a positive influence on the constitutional court deciding on the release of adat forest from the state forest argued an activist of $A M A N^{61}$ prior to the court decision (more detailed information on the constitutional court decision in section 5.3.1). Furthermore, AMAN was able to map territories claimed by indigenous groups in cooperation with the REDD+ Taskforce. The One Map Initiative for monitoring the moratorium might lead to safer tenure for indigenous and local communities but will also facilitate the issuance of corporate concessions.

Yet the legal character of the new REDD+ related scales of regulation remain weak. It is for instance contested whether disregarding the presidential instruction, which is the legal foundation for the moratorium, implies legal consequences or not (Hein 2013a: 4; Murdiyarso et al. 2011: 2). Furthermore, the legal basis of the LOI and of the National REDD+ strategy is challenged by some actors. A CIFOR expert argued that, "[...] in the National REDD+ strategy, there is no explanation or no reference to a presidential decree or regulation"62. Above all REDD+ related scales of meaning and regulation are challenged by other far more influential policies such as the Master Plan for Acceleration and Expansion of Economic Development 2011-2025 (MP3EI) which refers to the expansion of mining and corporate oil palm and rubber plantations. Sumatra for instance is designated for oil palm, rubber and coal mining (Republic of Indonesia 2011a: 49). According to the plan the provinces of Jambi, North Sumatra, and Riau should become major "oil palm plantation nodes" (ibid. 51). Central and East Kalimantan are designated as "timber activity nodes". REDD+ is only mentioned as a potential source of non-timber related income. Moreover, timber plantations not natural forests are considered for absorbing additional carbon under an international REDD+ scheme (ibid. 112).

\subsection{Jambi's REDD+ policies $^{63}$}

Jambi was one of the first provinces in Indonesia that hosted conservation projects that linked local conservation efforts with climate change mitigation. The "Climate Change, Forest and Peatlands in Indonesia Berbak-Sembilang Project" (CCFPI), 2002-2005) in Jambi and South Sumatra linked explicitly forest and peat land conservation with mitigation and carbon sequestration objectives (Lubis and Suryadiputra 2004: 115). The project was funded by the Canadian Climate Change Development Fund. The initiative can be considered as a precursor of the Berbak Carbon Project. A first province-wide

\footnotetext{
${ }^{61}$ Interview with AMAN activist, Jakarta, 27.07.2012, Document ID: 92.

62 Interview with staff member of CIFOR, Bogor, 26.07.2012, Document ID: 101.

63 Parts of this section have been published in Hein (2013), "Reducing Emissions from Deforestation and Forest Degradation (REDD+), transnational conservation and access to land in Jambi, Indonesia, published on GeorgAugust-Universität Göttingen (EFForTS Discussion Paper Series 2).
} 
mitigation strategy with a strong focus on land-based activities (e.g. REDD+ and reforestation) was developed by the National Council on Climate Change and by the Provincial Government of Jambi (Purnomo et al. 2012: 75; Dewasan Nasional Perubahan Iklim 2010).

In 2010 the provincial government started a first attempt to become one of Indonesia's REDD+ pilot provinces. The government of Jambi prepared a draft REDD+ strategy. The document "Jambi Sebagai Provinsi Percontohan Untuk Mekansime REDD+" (Jambi as a pilot province for the REDD+ mechanism) was developed to outline Jambi's potential as a national REDD+ pilot province (Hein 2013b: 12; Pemerintah Provinsi Jambi 2011). The strategy supports the designation of new community forest concessions (e.g. village forests and community forests) in Jambi and argues for the acknowledgement of indigenous and local community rights to forest land. At that time Jambi's attempt to become a REDD+ pilot province was not successful. Central Kalimantan became the first pilot province.

In 2011 the province started a second attempt and established the Jambi Regional Commission for REDD+ (KOMDA REDD+) through Governor Decree No. 356/2011 (Hein 2013b: 12). The members of the commission were appointed by the provincial government ${ }^{64}$. In 2013 the commission consisted of the NGOs WARSI, ZSL, and Flora and Fauna International, of the conservation company PT REKI and of representatives of the provincial planning agency (BAPPEDA), the provincial forest agency and of the provincial environmental protection authority, and of experts from the University of Jambi and of the World Agroforestry Center (ICRAF). The commission has no regulatory authority and has been mainly formed to coordinate the formulation of the provincial REDD+ strategy. In 2013 Jambi finally became a REDD+ pilot province of the National REDD Agency.

The provincial REDD+ strategy covers the period from 2012 to 2030. In addition to providing technical details and data on the emission reduction potential of specific land-use policies, the strategy refers to potential pro-poor benefits of REDD. It also aims to strengthen the rights of local communities and includes plans to map forest land claimed by local communities and indigenous groups (Perbatakusuma et al. 2012: 4f). The strategy was written by the commission. Other NGOs were invited to focus group discussion for commenting the document ${ }^{65}$. The strategy designates the districts of Tebo, Muaro Jambi and Merangin as REDD+ pilot districts. The pilot districts have been selected since they represent three different landscapes ${ }^{66}$. Merangin is characterized by the upper Sungai Batang Asai watershed and the Bukit Barisan Range. Tebo is characterized by hilly low lands and low mountain ranges whereas Muaro Jambi consist of hilly low lands, tidal marshlands and peat swamps. In addition

\footnotetext{
${ }^{64}$ Interview with member of the KOMDA REDD+, Jambi, 15.08.2013, Document ID: 156.

${ }^{65}$ Interview with member of the KOMDA REDD+, Jambi, 15.08.2013, Document ID: 156.

${ }^{66}$ Interview with member of the KOMDA REDD+, Jambi, 15.08.2013, Document ID: 156.
} 
the districts have been selected because of their high numbers of land conflicts ${ }^{67}$. In these districts, land use and forest use permit procedures will be reviewed, and forest monitoring and law enforcement will be improved. Though in 2013, the village government of Tanjung Lebar and staff of the administration of the sub-district of Kumpeh in Muaro Jambi were neither aware of being located within a REDD+ pilot district nor of REDD+ related policy shifts at the district level ${ }^{68}$.

The provincial REDD+ strategy argues for strengthening the rights of local communities and indigenous communities. Anyhow, many of the suggested policies cannot be implemented by provincial or district governments alone since they involve national scale authorities such as the MoF. Furthermore, the provincial government of Jambi has recently acted in ways contradictive to the policies suggested in the REDD+ strategies. According to regional media the Governor of Jambi has refused to sign recommendations for nineteen village forests concessions in the province (JambiekspressNews 2013). Though, in comparison to other provinces Jambi, has with 54.978 ha of village forest concessions managed by 25 villages, the largest village forest area in Indonesia (Bakhori 2013). Through different strategies and policies, the provincial government has successfully constructed REDD+ as a new scale of meaning in order to attract donor investments but it has not the authority and probably not the political will to establish a complementary scale of regulation.

\subsubsection{REDD+ demonstration activities and donor interventions}

In parallel to REDD+ related strategies and activities formulated and coordinated by the provincial government a number of project-based REDD+ demonstration activities are based in Jambi. According to the Forest Climate Center (2012) Jambi hosts five REDD+ demonstration projects (table 5).

In the next sections the different demonstration activities will be introduced. The Harapan Rainforest Project and the Berbak Carbon Project as the main objects of investigation of this thesis will be described in detail in the section 4.5.2 and 4.5.3.

The Bukit Tigapuluh Ecosystem Conservation initiative was developed by the Frankfurt Zoological Society (FZS), the Bukit Tigapuluh National Park Agency, WWF, Yayasan Kehati and other NGOs. The NGOs ZGF, WWF and Yayasan Kehati have recently founded a conservation company and have applied for a private conservation concession (ERC). At the time of writing in May 2015 the application was still in process. In addition, the NGO consortium has applied for funding from Germany's international Climate Initiative (ICI). As in other projects, the NGOs are planning community benefit schemes to

\footnotetext{
${ }^{67}$ Interview with member of the KOMDA REDD+, Jambi, 15.08.2013, Document ID: 156.

68 Interview with staff member of the sub-district administration of Kumpeh, Tanjung/Suakandis, 02.09.2013, Document ID: 181 and with key informant in Tanjung Lebar, 25.07.2013, Document ID: 125.
} 
improve the livelihoods of local communities. Parts of the project area are occupied by local indigenous groups and by Javanese migrants. ZGF plans to finance the project activities in the future via carbon trade and has recently conducted a carbon pre-assessment (Hein 2013b: 14).

The Village Forest Community Carbon Pool is an initiative of Flora and Fauna International (FFI) with project sites in Jambi and West Kalimantan (Fauna\& Flora International 2012). FFI plans to support villages by implementing voluntary market REDD+ projects in their village forest concessions. In Jambi FFI collaborated with the village community of Durian Rambun in the Merangin district. The village holds a village forest concession of 4,484ha (ibid. 4). Anyhow, in May 2015 the status of the project remains unclear. Planvivo, the involved carbon standard, lists the project only as a project with approved "Project Idea Note" and has not issued certificates yet (Plan Vivo 2015).

The Community Forest Management Project in Jangkat Highland is implemented by the NGO Sumatra Sustainable Support Pundi (SSS Pundi Sumatra) in the villages of Pematang Pauh, Talang Tembago and Muara Madras in Merangin district (Pundi Sumatera 2014: 2). The Project Idea Note has been approved by Planvivo in 2014 (Plan Vivo 2015).

\begin{tabular}{|c|c|c|c|c|c|c|}
\hline Project & Ecosystem & Project status & $\begin{array}{l}\text { Land use } \\
\text { category/ } \\
\text { concession }\end{array}$ & Proponents & Funding & FPIC \\
\hline $\begin{array}{l}\text { Harapan } \\
\text { Rainforest }\end{array}$ & $\begin{array}{l}\text { dry lowland } \\
\text { rainforest }\end{array}$ & $\begin{array}{l}\text { Running, no tradable } \\
\text { certificates yet, pre- } \\
\text { carbon accounting } \\
\text { done }\end{array}$ & $\begin{array}{l}\text { Limited } \\
\text { production } \\
\text { forest/ ERC- } \\
\text { Concession }\end{array}$ & $\begin{array}{l}\text { Burung } \\
\text { Indonesia, } \\
\text { Birdlife } \\
\text { International, } \\
\text { RSPB, PT REKI }\end{array}$ & $\begin{array}{l}\text { KfW until 2013, } \\
\text { Danida, Harapan } \\
\text { Fund (e.g. } \\
\text { Singapore } \\
\text { Airlines), } \\
\text { Conservation } \\
\text { International }\end{array}$ & $\begin{array}{l}\text { No } \\
\text { formal } \\
\text { FPIC }\end{array}$ \\
\hline $\begin{array}{l}\text { Berbak } \\
\text { Carbon Value } \\
\text { Project }\end{array}$ & $\begin{array}{l}\text { peat swamp } \\
\text { forest, mangroves }\end{array}$ & $\begin{array}{l}\text { Running but only in } \\
\text { the national park, no } \\
\text { tradable certificates } \\
\text { yet. Verified Carbon } \\
\text { Standard (VCS) and } \\
\text { CCBS in preparation }\end{array}$ & $\begin{array}{l}\text { National park, } \\
\text { conservation } \\
\text { forest, forest } \\
\text { reserve and } \\
\text { limited } \\
\text { production } \\
\text { forest }\end{array}$ & $\begin{array}{l}\text { ZSL, Gita Buana, } \\
\text { National Park } \\
\text { Agency, Province } \\
\text { of Jambi, PT } \\
\text { Pesona } \\
\text { Belantara } \\
\text { Persada, PT } \\
\text { Putraduta Indah } \\
\text { Wood }\end{array}$ & $\begin{array}{l}\text { Darwin Initiative, } \\
\text { Clinton } \\
\text { Foundation, UK } \\
\text { Panthera Fund }\end{array}$ & Ongoing \\
\hline $\begin{array}{l}\text { Bukit Tiga } \\
\text { Puluh } \\
\text { Ecosystem } \\
\text { Conservation }\end{array}$ & $\begin{array}{l}\text { Dry lowland } \\
\text { rainforest and } \\
\text { mountain } \\
\text { rainforest }\end{array}$ & $\begin{array}{l}\text { Not running yet, pre- } \\
\text { carbon accounting } \\
\text { done }\end{array}$ & $\begin{array}{l}\text { Production } \\
\text { forest/ applied } \\
\text { for ERC- } \\
\text { Concession }\end{array}$ & $\begin{array}{l}\text { ZGF, WWF, } \\
\text { Yayasan Kehati, } \\
\text { The Orang Utan } \\
\text { Project, National } \\
\text { Park Agency, PT } \\
\text { Alam Bukit } \\
\text { Tigapuluh }\end{array}$ & KfW, TFCA & $\begin{array}{l}\text { No } \\
\text { informati } \\
\text { on }\end{array}$ \\
\hline
\end{tabular}




\begin{tabular}{|c|c|c|c|c|c|c|}
\hline $\begin{array}{l}\text { Village Forest } \\
\text { Community } \\
\text { Carbon Pool }\end{array}$ & $\begin{array}{l}\text { Mountain } \\
\text { rainforest }\end{array}$ & $\begin{array}{l}\text { Project Idea Note } \\
\text { approved by the } \\
\text { Plan Vivo carbon } \\
\text { standard }\end{array}$ & $\begin{array}{l}\text { Production } \\
\text { forest, village } \\
\text { forest } \\
\text { concession }\end{array}$ & $\begin{array}{l}\text { Flora and Fauna } \\
\text { International } \\
\text { (FFI), Village } \\
\text { Forest } \\
\text { Management } \\
\text { Institution }\end{array}$ & $\begin{array}{l}\text { Darwin Initiative, } \\
\text { International } \\
\text { Carbon Action } \\
\text { Partnership }\end{array}$ & $\begin{array}{l}\text { Yes } \\
\text { accordin } \\
\text { g to FFI }\end{array}$ \\
\hline $\begin{array}{l}\text { Community } \\
\text { Forest } \\
\text { Management } \\
\text { Project in } \\
\text { Jangkat } \\
\text { Highland }\end{array}$ & $\begin{array}{l}\text { Mountain } \\
\text { rainforest }\end{array}$ & $\begin{array}{l}\text { Project Idea Note } \\
\text { approved by the } \\
\text { Plan Vivo carbon } \\
\text { standard }\end{array}$ & $\begin{array}{l}\text { Production } \\
\text { forest, village } \\
\text { forest } \\
\text { concession }\end{array}$ & $\begin{array}{l}\text { SSS Pundi } \\
\text { Sumatera, } \\
\text { Village Forest } \\
\text { Managing } \\
\text { Agency }\end{array}$ & No information & $\begin{array}{l}\text { No } \\
\text { informati } \\
\text { on }\end{array}$ \\
\hline
\end{tabular}

Table 5: REDD+ demonstration projects in Jambi ${ }^{69}$

(Source:Badan Pengelola REDD+ 2015; Forest Climate Center 2012; Hein 2013b, own interviews)

In addition, Jambi is a target area of the Tropical Forest Conservation Action (TFCA) for Sumatra. TFCA is a US-Indonesian debt for nature swap administered by the Indonesian NGO Yayasan Kehati (TFCASumatera 2014). Its main focus is biodiversity conservation at the landscape level and contributing to Indonesia's emission reduction targets. TFCA supports currently village border demarcation in buffer zone villages of the Berbak Carbon Project ${ }^{70}$. TFCA provides also funding for the Bukit Tiga Puluh Ecosystem Conservation project. A second major donor initiative linking conservation and mitigation is funded through the US Millennium Challenge Cooperation (MCC). MCC is supporting land-use planning and alternative livelihood strategies in 32 villages surrounding the Berbak Carbon Project (Millennium Challenge Account 2015: 20).

\subsubsection{The Harapan Rainforest Project}

The conservation company PT REKI runs the Harapan Rainforest project. PT REKI is owned by a transnational NGO consortium consisting of Birdlife International, the Royal Society for the Protection of Birds (RSPB) and Burung Indonesia and has received funding, among others, from the German International Climate Initiative (IKI), the Danish Ministry of Foreign Affairs (DANIDA), the European Commission and Singapore Airlines. IKI provided 7.5 million EUR, DANIDA provided 9 million EUR and Singapore Airlines provided 3 million USD (Buergin 2014: 65). The project is implemented in an ecosystem restoration concession ${ }^{71}$. Its specific actor constellation e.g. operated by a conservation company founded by a transnational NGO consortium and the existence of multiple and diffuse land conflicts make the Harapan Rainforest a very specific and highly relevant conservation project for

\footnotetext{
69 Interviews with staff member of ZGF, Jambi, 31.08.2012, Document ID: 28, with staff of REKI, Jambi, 02.09.2012, Document ID: 33 and with staff member of Burung Indonesia, 11.10.2013, Document ID: 210.

${ }^{70}$ Interview with activists of Gita Buana, Jambi, 22.08.2013, Document ID: 207.

${ }^{71}$ The terms ecosystem restoration concession and private conservation concessions are used as synonyms.
} 
analyzing transnationalized land conflicts and conflictive access and property relations. The implementation of the project is challenged by a number of different ongoing conflicts involving the districts governments of Muaro Jambi and Batang Hari, different governmental agencies, peasant and indigenous groups living among others in the villages of Bungku and Tanjung Lebar (more details in chapter 6 and 7). Especially the conflict with the peasant movement Serikat Petani Indonesia (SPI, Indonesian Peasant Union) is notably violent. PT REKI and SPI accuse each other of kidnappings as well as for the destruction of houses, trees, and plantations. During field work in 2013 , the conflict was still ongoing and both parties had rejected mediation (Hein 2013b; Hein et al. 2015). The different conflicts will be discussed in detail in chapter seven.

The Indonesian REDD+ agency lists the Harapan Rainforest as a REDD+ demonstration project (Badan Pengelola REDD+ 2015). However, the question whether the Harapan Rainforest project is a REDD+ project has been answered differently by different stakeholders and more recently PT REKI seems to dissociate itself more and more from REDD+. A project manager from Burung Indonesia ${ }^{72}$ stated in October 2013 that “[...] we were from the very beginning not a REDD+ project, PT REKI is not REDD [...]". But in 2012 a project manager ${ }^{73}$ based in Jambi argued that the "[...] carbon market is long-term funding option, the baseline preparation is in process and we will base a carbon consultant in Palembang". PT REKI's main donors IKI, DANIDA and Singapore Airlines explicitly link climate mitigation, carbon sequestration or REDD+ piloting as the project objectives (DANIDA 2012; Internationale Klimaschutzinitiative 2015; Singapore Airlines 2015). PT REKIs recent attempts to disassociate itself from REDD+ might be considered as a strategy to avoid potential controversies on benefit sharing or as a response to SPIs climate justice and anti-REDD+ campaigns (Hein and Faust 2014: 24). Anyhow, PT REKI has not sold any carbon credits and has not been certified according to a carbon standard yet.

For mediating conflicts and for providing alternative sources of income PT REKI provides a number of community benefits and has negotiated conservation agreements and conditional land tenure agreements with some Batin Sembilan groups. The agreements allow families to use a plot of land in future, in accordance with guidelines developed by PT REKI (more details in section 6.4.1).

PT REKI has developed new conservation regulations, tree inventories, and a preliminary carbon assessment and has started border demarcation. Moreover, PT REKI has established a forest guard unit for protecting the conservation concession and for monitoring the compliance with the conservation regulations. PT REKIs activities can be considered an active attempt to construct a new scale of

\footnotetext{
72 Interview with staff member of Burung Indonesia, 11.10.2013, Bogor, Document ID: 210.

73 Interview with staff member of REKI, 02.09.2012, Jambi, Document ID: 33.
} 
meaning - linking local conservation efforts to global environmental problems such as biodiversity loss and climate change - and to establish the project area as a new scale of regulation. Batin Sembilan and migrant groups supported by the peasant movement, SPI, and others sought to construct alternative scales of meaning and regulation turning the Harapan Rainforest into a confused and contested arena (Hein et al. 2015) (detailed analysis of the different land conflicts in chapter seven).

\subsubsection{The Berbak Carbon Project}

The Berbak Carbon Project is also listed as a REDD+ demonstration project by the Indonesian REDD+ agency. The project is a collaborative initiative of the Zoological Society of London (ZSL), the Jambibased NGO Gita Buana, the Berbak National Park Agency and the Provincial Forest Service (Dinas Kehutanan Provinsi Jambi) and can be considered as the latest attempt to establish the Berbak (Carbon) Landscape as a scale of meaning and regulation. The project has to cope with informal forest conversion activities and with a transmigration settlement established by the Transmigration Agency of the district of Muaro Jambi. The transmigration settlement has been constructed within the state forest and within the borders of the Berbak Carbon Project violating regulations of the MoF.

Initial funding of 478883 USD (The REDD Desk 2015) for the project was provided by the Darwin Initiative of the UK Department for Food, Environment and Rural Affairs (DEFRA). The carbon credit broker Eco Securities announced its interest in purchasing credits from the project in 2008. Yet till today the project has not been certified and has not sold any carbon credits. ZSL is seeking for CCBS and Verified Carbon Standard (VCS) certification for the project ${ }^{74}$. The Indonesian-based carbon consultancy company Forest Carbon has conducted an "initial field and desktop assessment of carbon emission reduction potential for the Berbak Carbon Initiative" (Eickhoff, Salim, and Stanley 2010). The authors conclude that the initiative could led to emission reductions of approximately $\sim 75$ to 82 MtCO2e and is eligible for being certified according to the VCS standard (ibid. 7). The project is of specific interest since it is planned to be implemented in different forest categories (Berbak National Park, Forest Reserve Sekitar Tanjung, limited production forest (logging concessions) and conservation forest) permitting different types of land use.

However, at the time of field research only the Berbak National Park Agency and the Provincial Forest Service managing the Forest Reserve officially agreed to form part of the REDD+ initiative. Negotiations with the logging companies PT Putra Dutra Indahwood and PT Persona Belantara Persada were not

\footnotetext{
${ }^{74}$ Interview with ZSL staff member, Bogor 27.08.2012, Document ID: 120.
} 
finalized at the time of field research ${ }^{75}$. According to $\mathrm{ZSL}$, the two companies are interested in collaboration if income from carbon trade would compensate for income losses of low emission logging techniques (ZSL 2008: 4). Potential benefits for local communities from carbon trade profits were still under discussion. A ZSL project manager stated that benefit sharing is planned but its design will depend on national legislation ${ }^{76}$. A first community needs assessment for designing community benefits was conducted by the NGO WALESTRA (Wahana Pelestarian dan Advokasi Hutan Sumatera) and first pilot community reforestation and conditional land tenure schemes are running in Seponjen, Sungai Aur and few other villages in the Berbak Landscape ${ }^{77}$.

In 2013 the project proponents were conducting focus group discussions with the support of the subdistrict head (camat) of Kumpeh. Villages representatives from villages located adjacent to the project boundaries (representatives from Sungai Aur and Seponjen participated) were invited. The discussions were part of a FPIC process and were funded by the Clinton Foundation. Though, in spite of the focus group discussion the majority of the interviewees in Sungai Aur and Seponjen were not aware of the Berbak Carbon Project. A member of the village government argued that he has not disseminated information on REDD+ since he does not want to create high expectations in REDD+ as a potential income source ${ }^{78}$. Land conflicts associated with the Berbak Carbon Project are not as severe and violent as in the Harapan Rainforest project. Forest authorities are tolerating fishing and jelutung tapping in the National Park. Land conversion within the project occurs e.g. in east of Seponjen, in Sungai Cemara. Sungai Gelam, and as mentioned, initiated by the construction of the Transmigration settlement in Sungai Aur.

\subsubsection{Actor mapping: state and non-state actors involved in REDD+ in Jambi}

In this section I will briefly present a mapping of actors involved either in the implementation of REDD+, or in resistance campaigns against REDD+. The mapping (table 6) is mainly based on expert knowledge. Stakeholders from state and non-state organizations had been asked to state actors they consider as relevant in relation to the implementation of REDD+ in Jambi. In addition, the mapping and the selection of actors is based on document review and on my own judgement. Table 6 groups actors according to their involvement in either the Harapan Rainforest or the Berbak Carbon Project.

\footnotetext{
75 Interview with ZSL staff member, Bogor, 27.08.2012, Document ID: 120 and with staff member of the Dinas Kehutanan Provinsi (District Forest Agency), Jambi, 19.08.2013, Document ID: 147, 27.08.2013, Document ID: 137.

${ }^{76}$ Interview with ZSL staff member, Bogor, 27.08.2012, Document ID: 130.

${ }^{77}$ Interview with staff member of the Dinas Kehutanan Provinsi, Jambi, 27.08.2013, Document ID: 137.

78 Interview with key informant, Sungai Aur, 30.08.2013, Document ID: 123.
} 
Furthermore, I distinguish between state and non-state actors. I will only describe the role of the most relevant actors.

The most important state actors are as a matter of course the different forest authorities, more explicitly the MoF and the different district and provincial forest services. The MoF has authority over the state forest, has enacted different REDD+ regulations (as outlined in section 4.4) and has allocated the Meranti River-Kapuas River Forest Block ${ }^{79}$ to the conservation company PT REKI for implementing the Harapan Rainforest project. A second relevant national scale authority is the REDD+ Agency (Badan Pengelola REDD+). The REDD+ Agency is accountable to the President. Furthermore, the agency appointed Jambi to an official REDD+ pilot province. However, the agency has no regulatory power but authored the National REDD+ strategy and argued proactively for a land tenure reform and for the consideration of FPIC (as outline in section 4.4). The different district and provincial forest services are involved in managing forest reserves and conservation forests. They have not the authority to allocate concessions but they are involved in conflict mediation, forest monitoring and law enforcement. At the provincial level the Komda REDD+ (Provincial REDD+ commission) is in charge of coordinating REDD+ implementation. However, as the national REDD+ agency Komda REDD+ has no regulatory power. Komda REDD+ is a hybrid institution consisting of state and non-state actors. ZSL, the NGO leading the Berbak Carbon project, is member of Komda REDD+.

State actors challenging the implementation of REDD+ and conservation projects and the integrity of the state forest are different sectoral agencies of the district governments of Muaro Jambi and Batang Hari. The Transmigration Agency of Muaro Jambi for instance has developed transmigration settlements within the borders of Berbak Carbon project (more details in section 7.4). The Education Agencies (Dinas Pendidikan) of both districts are supporting and running schools within the Harapan Rainforest project. The Agricultural Agency of Batang Hari has provided extension services of settlers farming within the Harapan Rainforest (more details in section 6.3.3).

Relevant non-state actors are involved in the Berbak Carbon project. These are ZSL and Gita Buana. ZSL identifies itself as an international scientific, conservation and educational charity (ZSL 2015). ZSL is based in the United Kingdom (UK). The organization has started its Indonesia Field program in 2002 focusing on ecological research, core area protection and connectivity of conservation areas (CIRAD 2012). On the island of Sumatra ZSL's activities focus mainly on tiger conservation. ZSL seeks to develop mechanisms permitting rural development and conservation. Gita Buana is a Jambi-based NGO founded in 2001 by students from the Faculty of Agriculture from the University of Jambi. Gita Buana is involved in the implementation of FPIC for the Berbak Carbon Project. Gita Buana's donors are the

\footnotetext{
${ }^{79}$ Official name of the Ministry of Forestry for the production forest block located at both sides of the border region of Jambi and South Sumatra.
} 
Clinton Foundation, the Tropical Forest Conservation Action (TFCA) and Flora and Fauna International ${ }^{80}$.

Non-state actors are of key importance in the Harapan Rainforest project. PT REKI is owned by three NGOs (as outlined in section 4.5.2). Burung Indonesia has been founded in 2002. The organization focuses mainly on bird and bird habitat conservation. Burung Indonesia works mainly in Sumatra, Sumba, Gorontalo, Sangihe Taluad, Tanimbar, and Buru. Burung Indonesia is a member of Birdlife International. The Royal Society for the Protection of Birds (RSPB), also member of Birdlife International, was founded in 1889 in the UK. RSPB holds more than 200 bird reserves (RSPB 2015). In the accounting year 2014/ 2015 the organization had a net income of $f 99$ million (ibid.). Birdlife International is the transnational umbrella association of 120 bird conservation organizations. Birdlife International claims to be the world's largest conservation initiative and the world's leader in bird conservation (Birdlife International 2015). Birdlife members manage or own 1553 conservation areas covering 4.3 million ha land (ibid.). The different member organization employ 7400 staff and have a joint budget of USD 539 million (ibid.).

Peasants and indigenous groups living within the borders of the Harapan Rainforest project are supported by a number of non-state actors as well. The most relevant are: Serikat Petani Indonesia (Indonesian Peasant Union, SPI), and the grass root organizations Yayasan CAPPA, and Yayasan Setara. SPI is the largest Indonesian Peasant Movement being member of La Via Campesina. (Section 5.3.2 describes the history of SPI in detail.) La Via Campesina is an umbrella organization uniting 164 local and national peasant organizations from 73 countries. La Via Campesina claims to represent 200 million farmers from all continents. The main aims of the organization are the realization of food sovereignty and the implementation of agrarian reforms.

Yayasan CAPPA ${ }^{81}$ is a Jambi-based environmental justice organization. The organization supported first mainly peasants in conflicts with pulp and paper companies. Today the organization claims to support "victims of agrarian policies". Yayasan CAPPA supports peasants in defending and accessing property rights and argues for social transformation in order to end agrarian conflicts. Furthermore, Yayasan CAPPA is involved in conflict mediation, advocacy work and indigenous rights issues. Its main donors are Misereor, Ford Foundation and USAID. Yayasan SETARA ${ }^{82}$ is a Jambi-based NGO working on environmental justice issues, especially on the consequences of oil palm expansion. Yayasan SETARA supports small-scale oil palm cultivators and indigenous communities. SETARA is member of the

\footnotetext{
${ }^{80}$ Interview with activists of Gita Buana, 22.08.2013, Jambi, Document ID: 189.

${ }^{81}$ Interview with activists of CAPPA, 18.07.2013, Jambi. Document ID: 157.

82 Interview with activists of SETARA, 18.07.2013, Jambi, Document ID: 115.
} 
Roundtable for Sustainable Palm Oil (RSPO). The organization has a watch-dog function within RSPO and is struggling for the acknowledgement of peasant rights. Yayasan SETARA and CAPPA are cooperating intensively and are supporting Batin Sembilan communities in the land conflicts with the conservation company PT REKI and with the oil palm company PT Asiatic Persada. SETARA received financial support from Misereor.

The mapping indicates vertical linkages (across scales) between actors (e.g. SPI and La Via Campesina) and horizontal linkages (e.g. the cooperation between CAPPA and SETARA). In addition, the actor mapping shows coalitions involved in the construction of new scales of meaning and regulation e.g. actor coalition involved in the Berbak Carbon Project and in the Harapan Rainforest project. Actor coalitions across scales indicate a transnationalization of land conflicts in the context of REDD+. Actors promoting REDD+ and conservation and actors resisting against the expansion of conservation have established actor coalitions involving local, national NGOs, and transnational NGOs.

In chapter seven more detailed actor mappings for two conflicts sites within the Harapan Rainforest will be presented.

\begin{tabular}{|c|c|c|c|}
\hline Actor & Type & Activities & Donor (if applicable) \\
\hline Ministry of Forestry & GO, national scale & $\begin{array}{l}\text { Enacted different REDD+ regulations, } \\
\text { registered the Berbak Carbon Project as } \\
\text { official demonstration activity, issued } \\
\text { private conservation concession for the } \\
\text { Harapan Rainforest }\end{array}$ & \\
\hline $\begin{array}{l}\text { REDD+ Agency } \\
\text { (Badan Pengelola } \\
\text { REDD+) }\end{array}$ & GO, national scale & $\begin{array}{l}\text { Appointed Jambi to an official REDD+ pilot } \\
\text { province }\end{array}$ & $\begin{array}{l}\text { LOI (Norway- } \\
\text { Indonesia) }\end{array}$ \\
\hline Governor of Jambi & $\begin{array}{l}\text { GO, head of } \\
\text { provincial } \\
\text { government }\end{array}$ & $\begin{array}{l}\text { Issued provincial regulations e.g. } \\
\text { establishment of KOMDA REDD+, enactment } \\
\text { of REDD+ strategy and of the RADGRK, but } \\
\text { also approved the construction of a road } \\
\text { through the Harapan Rainforest }\end{array}$ & \\
\hline Komda REDD+ & $\begin{array}{l}\text { Hybrid (GO, NGO, } \\
\text { academia, private } \\
\text { sector) }\end{array}$ & Coordination of REDD+ strategy formulation & $\begin{array}{l}\text { LOI (Norway- } \\
\text { Indonesia) }\end{array}$ \\
\hline $\begin{array}{l}\text { Dinas Kehutanan } \\
\text { Provinsi }\end{array}$ & $\begin{array}{l}\text { GO, provincial forest } \\
\text { service }\end{array}$ & $\begin{array}{l}\text { Management of Forest Reserve „Sektitar } \\
\text { Tanjung“ information meetings on REDD } \\
\text { with village elites and community } \\
\text { reforestation in the Berbak Landscape, } \\
\text { member of Komda REDD+, not well } \\
\text { equipped has only seven staff members for } \\
\text { managing the Forest Reserve Sekitar } \\
\text { Tanjung, and only } 50 \text { forest police staff for } \\
\text { the whole province. }\end{array}$ & - \\
\hline
\end{tabular}




\begin{tabular}{|c|c|c|c|}
\hline $\begin{array}{l}\text { Dinas Kehutanan } \\
\text { Kabupaten (Batang } \\
\text { Hari, Muaro Jambi, } \\
\text { Tanjung Jabung } \\
\text { Timur) }\end{array}$ & $\begin{array}{l}\text { GO, district forest } \\
\text { service }\end{array}$ & $\begin{array}{l}\text { Management of district forest reserves (e.g. } \\
\text { TAHURA }{ }^{83} \text { Senami), conflict mediation (e.g. } \\
\text { Harapan Rainforest) }\end{array}$ & \\
\hline $\begin{array}{l}\text { Badan Lingkungan } \\
\text { Hidup Daerah }\end{array}$ & $\begin{array}{l}\text { GO, Provincial } \\
\text { Environmental } \\
\text { Protection Agency }\end{array}$ & $\begin{array}{l}\text { Member of Komda REDD+, environmental } \\
\text { aspects of spatial planning, environmental } \\
\text { impact assessments }\end{array}$ & \\
\hline $\begin{array}{l}\text { BAPPEDA (Provincial } \\
\text { Planning Agency) }\end{array}$ & $\begin{array}{l}\text { GO, Provincial } \\
\text { Planning Agency }\end{array}$ & $\begin{array}{l}\text { Member of Komda REDD+, responsible for } \\
\text { RADGRK, and focal point for donor } \\
\text { interventions }\end{array}$ & \\
\hline $\begin{array}{l}\text { Dinas Pertanian } \\
\text { Kabupaten (Batang } \\
\text { Hari) }\end{array}$ & $\begin{array}{l}\mathrm{GO}, \text { Agricultural } \\
\text { Agency of the } \\
\text { districts }\end{array}$ & $\begin{array}{l}\text { Allocated seeds, fertilizer etc. to settlers } \\
\text { within Harapan Rainforest }\end{array}$ & \\
\hline $\begin{array}{l}\text { Dinas Pendidikan } \\
\text { (Batang Hari, Muaro } \\
\text { Jambl) }\end{array}$ & $\begin{array}{l}\text { Go, Education } \\
\text { Agency of the } \\
\text { districts }\end{array}$ & $\begin{array}{l}\text { Supported schools located within Harapan } \\
\text { Rainforest }\end{array}$ & \\
\hline $\begin{array}{l}\text { Transmigration } \\
\text { Agency (Muaro } \\
\text { Jambi) }\end{array}$ & $\begin{array}{l}\text { GO, district } \\
\text { transmigration } \\
\text { agency }\end{array}$ & $\begin{array}{l}\text { Allocated land within the Berbak Carbon } \\
\text { Project to transmigrants }\end{array}$ & \\
\hline $\begin{array}{l}\text { Berbak National Park } \\
\text { Agency }\end{array}$ & $\begin{array}{l}\text { GO, accountable to } \\
\text { Ministry of Forestry }\end{array}$ & $\begin{array}{l}\text { Awareness raising sessions on climate } \\
\text { change and forest degradation, in } \\
\text { cooperation with ZSL, WARSI and Gita } \\
\text { Buana; focus group discussions with village } \\
\text { elites on REDD. Has } 102 \text { staff members. }\end{array}$ & \\
\hline ZSL & NGO & $\begin{array}{l}\text { Co-implementing agency of Berbak Carbon } \\
\text { Project, distributes information on climate } \\
\text { change and biodiversity to village elites, } \\
\text { member of KOMDA REDD+ }\end{array}$ & $\begin{array}{l}\text { Darwin initiative, } \\
\text { Clinton Foundation, }\end{array}$ \\
\hline Gita Buana & NGO & $\begin{array}{l}\text { Cooperates with ZSL, focus groups on REDD } \\
\text { with village elites in the Berbak Landscape, } \\
\text { needs assessments for Berbak project }\end{array}$ & $\begin{array}{l}\text { ZSL, Clinton } \\
\text { Foundation, Darwin } \\
\text { Initiate, TFCA, MCC }\end{array}$ \\
\hline Walestra & NGO & $\begin{array}{l}\text { Sub-contractor of ZSL, conducted socio- } \\
\text { economic baseline assessments in villages of } \\
\text { the Berbak Landscape }\end{array}$ & ZSL \\
\hline PINSE & NGO & $\begin{array}{l}\text { Supports community reforestation, e.g. HTR } \\
\text { project in the Berbak landscape }\end{array}$ & \\
\hline $\begin{array}{l}\text { PT Pesona Belantara } \\
\text { Persada }\end{array}$ & Logging company & $\begin{array}{l}\text { Holds logging concession which is part of } \\
\text { the Berbak Carbon Project }\end{array}$ & \\
\hline $\begin{array}{l}\text { PT Putraduta Indah } \\
\text { Wood }\end{array}$ & Logging company & $\begin{array}{l}\text { Holds logging concession which is part of } \\
\text { the Berbak Carbon Project }\end{array}$ & \\
\hline
\end{tabular}

${ }^{83}$ TAHURA, Taman Hutan Raya, forest reserve 


\begin{tabular}{|c|c|c|c|}
\hline ZGF & NGO & $\begin{array}{l}\text { Orangutan and elephant conservation in the } \\
\text { Bukit Tiga Puluh area, has applied for a } \\
\text { private conservation concession (ERC) }\end{array}$ & KfW (IKI) \\
\hline WWF & NGO & $\begin{array}{l}\text { Involved in the Bukit Tiga Puluh Ecosystem } \\
\text { Conservation project, cooperates with ZGF }\end{array}$ & \\
\hline $\begin{array}{l}\text { Flora and Fauna } \\
\text { International }\end{array}$ & NGO & $\begin{array}{l}\text { Member of KOMDA REDD+, and runs a } \\
\text { REDD+ demonstration project in Merangin }\end{array}$ & \\
\hline $\begin{array}{l}\text { PT Restorasi } \\
\text { Ekosistem Indonesia, } \\
\text { PT REKI }\end{array}$ & $\begin{array}{l}\text { Conservation } \\
\text { company }\end{array}$ & $\begin{array}{l}\text { Company implementing the Harapan } \\
\text { Rainforest project, holds a private } \\
\text { conservation concession in Jambi and South } \\
\text { Sumatra (ERC), member of KOMDA REDD+ }\end{array}$ & $\begin{array}{l}\text { Various sources, KfW } \\
\text { (until 2013), DANIDA, } \\
\text { Singapore Airlines }\end{array}$ \\
\hline $\begin{array}{l}\text { Burung Indonesia/ } \\
\text { Birdlife International }\end{array}$ & NGO & $\begin{array}{l}\text { Shareholder of PT REKI, involved in conflict } \\
\text { mediation of Harapan Rainforest conflict, }\end{array}$ & $\begin{array}{l}\text { Various sources, KfW } \\
\text { (until 2013), DANIDA }\end{array}$ \\
\hline $\begin{array}{l}\text { Royal Society for the } \\
\text { Protection of Birds } \\
\text { (RSPB) }\end{array}$ & NGO & Shareholder of PT REKI & \\
\hline WARSI & NGO & $\begin{array}{l}\text { Information meetings on REDD+ in selected } \\
\text { villages of Jambi, member KOMDA REDD+, } \\
\text { conducted, involved in community baseline } \\
\text { assessments in the Harapan Rainforest }\end{array}$ & $\begin{array}{l}\text { NORAD, JIKA, } \\
\text { Rainforest } \\
\text { Foundation }\end{array}$ \\
\hline AMAN & $\begin{array}{l}\text { NGO, association of } \\
\text { indigenous groups }\end{array}$ & $\begin{array}{l}\text { Plans to conduct information meetings on } \\
\text { REDD for communities, involved in } \\
\text { community baseline assessments in the } \\
\text { Harapan Rainforest, supports the } \\
\text { transnational "NO Rights NO REDD" } \\
\text { campaign }\end{array}$ & \\
\hline $\begin{array}{l}\text { Serikat Petani } \\
\text { Indonesia (SPI)/ La } \\
\text { Via Campesina }\end{array}$ & $\begin{array}{l}\text { NGO, peasant } \\
\text { movement }\end{array}$ & $\begin{array}{l}\text { Distributes information on REDD to its } \\
\text { members, actively use of REDD/ Anti-REDD } \\
\text { to legitimize land occupations, transnational } \\
\text { campaign against offsetting }\end{array}$ & $\begin{array}{l}\text { Financed by } \\
\text { members }\end{array}$ \\
\hline AGGRA & $\begin{array}{l}\text { NGO, peasant } \\
\text { movement }\end{array}$ & $\begin{array}{l}\text { Involved in mapping of land claimed by } \\
\text { indigenous groups in the Harapan Rainforest } \\
\text { area }\end{array}$ & \\
\hline CAPPA & NGO & $\begin{array}{l}\text { Distributes information on REDD to villagers } \\
\text { living in the Harapan Rainforest region, } \\
\text { involved in conflict mediation, also works on } \\
\text { REDD+ in Central Sulawesi (UN REDD) }\end{array}$ & $\begin{array}{l}\text { MISEREOR, Ford } \\
\text { Foundation, USAID }\end{array}$ \\
\hline $\begin{array}{l}\text { SINARMAS Forestry/ } \\
\text { PT WKS }\end{array}$ & $\begin{array}{l}\text { Pulp \& paper and } \\
\text { agribusiness } \\
\text { company }\end{array}$ & $\begin{array}{l}\text { Has applied for private conservation } \\
\text { concession (ERC), conducted forest fire and } \\
\text { climate change awareness workshops with } \\
\text { community representatives }\end{array}$ & - \\
\hline $\begin{array}{l}\text { Kreditanstalt für } \\
\text { Wiederaufbau (KfW) }\end{array}$ & $\begin{array}{l}\text { Donor, development } \\
\text { bank }\end{array}$ & $\begin{array}{l}\text { Manages and facilitates the financial } \\
\text { contributions of the German International } \\
\text { Climate Initiative including those for the } \\
\text { Harapan Rainforest project }\end{array}$ & $\begin{array}{l}\text { Donor of Harapan } \\
\text { Rainforest/ PT REKI }\end{array}$ \\
\hline
\end{tabular}




\begin{tabular}{|c|c|c|c|}
\hline $\begin{array}{l}\text { German } \\
\text { International Climate } \\
\text { Initiative (IKI/ICI) }\end{array}$ & Donor & $\begin{array}{l}\text { Funding instrument of the Federal German } \\
\text { Ministry for the Environment, Nature } \\
\text { Conservation, Building and Nuclear Safety } \\
\text { (BMUB), supports climate mitigation, } \\
\text { adaptation projects and projects protecting } \\
\text { biodiversity (IKI 2015), has supported the } \\
\text { Harapan Rainforest project from } 2009 \text { to } \\
2013 \text { (€7,575 million) }\end{array}$ & $\begin{array}{l}\text { Donor of Harapan } \\
\text { Rainforest/ PT REKI }\end{array}$ \\
\hline DANIDA & Donor & $\begin{array}{l}\text { Denmark's development cooperation, under } \\
\text { the authority of the Ministry of Foreign } \\
\text { Affairs, has supported the Harapan } \\
\text { Rainforest project from 2011-2014 (USD 8,4 } \\
\text { million). Recently DANIDA has extended the } \\
\text { support for the year of 2015. Support is part } \\
\text { of DANIDA's Special Climate Change Fast- } \\
\text { Start Fund. }\end{array}$ & $\begin{array}{l}\text { Donor of Harapan } \\
\text { Rainforest/ PT REKI }\end{array}$ \\
\hline Darwin Initiative & Donor & $\begin{array}{l}\text { Funding instrument of the UK Department } \\
\text { for Environment, Food and Rural Affairs, } \\
\text { provided initial support for the Berbak } \\
\text { Carbon Project. }\end{array}$ & $\begin{array}{l}\text { Donor of ZSL for } \\
\text { Berbak Carbon } \\
\text { Project }\end{array}$ \\
\hline \multicolumn{4}{|c|}{$\begin{array}{l}\text { Blue: state actors, light blue: state actors not directly involved in REDD+, green: NGOs involved in the Berbak Carbon } \\
\text { Project, pink: NGOs involved in the Bukit Tiga Puluh Ecosystem Conservation Project, orange: actors involved in } \\
\text { Harapan Rainforest project, yellow: actors involved in resistance campaigns, grey: donors, white: not grouped actors. }\end{array}$} \\
\hline
\end{tabular}

\subsection{Summary and preliminary conclusion}

The implementation of a global mechanism for mitigating climate change by protecting tropical forests supports the construction of a transnational scale of forest and land tenure governance. The production of forest carbon credits for global carbon markets or for bilateral result-based aid schemes such as Norwegian-Indonesian Forest and Climate Initiative foster the formalization and standardization of forest management, carbon quantification and of strategies for community participation and benefit sharing. But REDD+ has not yet led to coherent and uniform transnational rules yet. The current situation is rather characterized by a number of fragmented, sometimes competing scales of regulation. This is also reflected at the national and sub-national scale where many different forest-based mitigation initiatives exist in parallel to each other and some might even compete or contradict other ones. Even more important many of the new Indonesian REDD+ regulations, policies, strategies and letters of intent have not been implemented yet or have been challenged by other state apparatuses hindering the construction of a coherent scale of regulation. Furthermore, many of REDD+ regulations of the MoF remain unspecific and seemed to be irrelevant at the project-scale. 
Anyhow, REDD+ and forest carbon offsetting link emitters in the North to land conflicts in the global South thus contributing to the transnationalization of alleged local land tenure conflicts. REDD+ provides entry points for transnational resistance campaigns tackling questions of global climate justice (Hein et al. 2015). Different legal documents of the UNFCCC, criteria of transnational carbon standards (e.g. CCBS) and safeguards of donors (e.g. human rights policy of the BMZ) have at least potentially strengthen the rights of local and especially of indigenous communities, vis-à-vis national forest agencies, private companies, conservation NGOs and donors.

Moreover, REDD+ has probably changed the dialectical relationship between structure and agency. Indications for this changed relationship are AMAN's success at the constitutional court, the consideration of FPIC in forest carbon standards, the acknowledgements of customary land tenure in Indonesia's national REDD+ strategy, the Cancun Safeguards and probably also the ability of SPI to use the Harapan Rainforest project for SPIs and La Via Campesina's transnational campaigns against offsetting.

REDD+ and forest carbon offsetting have also strengthened the roles of non-state actors significantly. Civil-society organizations and conservation companies are directly involved in conservation, territorialization and in the construction of new conservation scales. 


\section{Findings-I: Rescaling of forest and land tenure governance}

The main assumption guiding this chapter is that broader rescaling processes in the course of state transformation e.g. colonization, de-colonization, democratization and decentralization change the abilities of different actor groups to access land and property. Moreover, I argue that scaling back, in other words understanding historical scalar arrangements and associated land and forest tenure regulations is a precondition for understanding land conflicts in REDD+ target areas. Chapter four has outlined the emergence of global scale of forest and REDD+ governance. But REDD+ and conservation initiatives are not implemented in a social and political vacuum. Land conflicts in the context of REDD+ implementation are embedded in historically contingent social and political dynamics.

In this chapter I investigate mainly the dynamic context of REDD+ implementation in Indonesia, namely processes of state transformation and intertwined reforms of forest and land tenure governance. The different political regimes mentioned above facilitated the construction of specific scales of meaning and regulation. Some of them outlived the historical conditions that led to their construction. They are still inscribed in the landscape. Others have been deconstructed and replaced over time. Aim of the chapter is to identify the framework conditions and inherent rescaling processes that structure local agency. First, I investigate the historical development of Indonesia's forest and land tenure governance. I start with Dutch colonization and with the early post-colonial period. Second, I proceed with the New Order period, the Democratization after the fall of Suharto and the emergence of resistance movements that seek to construct alternative scales of meaning and regulation. In the last section I will briefly describe the history of the province of Jambi and of the Berbak and Harapan Landscapes considering entangled rescaling processes.

\subsection{Development of Indonesia's forest and land tenure governance}

Formalized forest and land governance in Indonesia can be broadly divided into a pre-colonial phase, a colonial phase, a transitional phase of early independence, an autocratic and development oriented phase (New Order) and a contemporary phase characterized by decentralization, democratization and (neo-) liberalization. Each of the phases has its specific socio-spatial structure, was driven by different larger state projects and was influenced by broader and transnational narratives on how to use, manage and govern forest and land resources (Galudra and Sirait 2009). The different phases had no abrupt end, some elements of each phase persistent and influenced the following phase. Indonesia's dualistic land governance system based on forest and agricultural laws has been inherited from colonial authorities (Indrarto et al. 2012: 36). In the following a few examples are given. Protected 
areas in Jambi founded by the Dutch are colonial scales of meaning and regulation that are still in place (e.g. Berbak National Park and TAHURA Sultan Thaha Syaifudin). Authorities established by the Dutch colonial administration in Jambi such as the Pasirah have been relevant in legitimating property relations at least until the New Order regime enacted its village law in 1979 (Galudra et al. 2014: 723; Sevin and Benoît 1993: 97). First land titles issued by the Dutch colonial authorities are still used as source of legitimacy for stakeholders in land conflicts. These illustrations indicate that for understanding present-day conflictive access and property relations in REDD+ target areas the historical context and historical legal orders are relevant explanatory factors.

\subsubsection{Colonial forest and land tenure governance}

Colonial forms of forest and land tenure governance in Indonesia date back to the activities of the Dutch East Indian Company (VOC, Vereenigde Oost-Indische Compagnie) in the $17^{\text {th }}$ century (Galudra and Sirait 2009: 525). The activities of the VOC where mainly limited to timber extraction (ibid.). The first colonial regulations have been enacted for the island of Java in 1808 (Nurjaya 2005: 38). This first regulation defined any not privately owned forest areas as state domain, established a colonial forest service accountable to the Colonial General Governor and stated that the timber demand of the colonial government should be prioritized. Furthermore, the regulation stipulated logging permits for local communities (ibid.). Early colonial forest policies were dominated by forest extraction (Galudra and Sirait 2009: 525). During the mid-19 ${ }^{\text {th }}$ century colonial forest policies shifted towards conserving forests and maintaining associated environmental services e.g. water provision (ibid.).

Based on the believe that forests are the main determinant for the hydrological balance of watersheds colonial forest authorities argued that forest protection is of colonial interest (Galudra and Sirait 2009: 525; Barr et al. 2006: 19). The main argument of foresters at that time was that forests act as sponges that are able to assure water provision for irrigation agriculture during the dry season. According to the dominant scientific discourse of the $19^{\text {th }}$ century deforestation especially in the upper parts of watersheds would reduce the water availability in adjacent low lands significantly (Galudra and Sirait 2009: 525). The argument that deforestation would disturb the hydrological balance was used to legitimize first resettlements, to legitimize exclusion of local communities from forests and to legitimize the prohibition of shifting cultivation (Galudra and Sirait 2009: 530; Metzner 1981: 47). Watershed protection was constructed as new colonial scales of meaning and regulation restricting access to land and forest resources for safeguarding colonial interests.

Colonial forest policy has been developed further during the mid- $19^{\text {th }}$ century. The first colonial forest law (Boschordonatie) for the islands of Java and Maduro has been issued in 1865. At the same time the colonial government has introduced a formalized concession system for facilitating forest exploitation 
(Nurjaya 2005: 40). In 1870 the domein verklaring further strengthen colonial claims to the forests of Java and Maduro and the colonial forest agency initiated first forest zoning activities (ibid.). In the same year the colonial government enacted a second law the Agrarische Wet. The Agrarische Wet was a law aiming at regulating land ownership and promoting private investment. It introduced a western concept of private property, provided a framework for renting out land to private agricultural estate companies and declared again all unused land as property of the colonial state (Gamin et al. 2014: 55; Nurjaya 2005: 38; Szczepanski 2002: 235). Agrarische Wet and Boschordonatie established a dualistic legal structure for land declared as forests and for land declared for agriculture which continued in post-colonial Indonesia and which is still reflected in contemporary Indonesian forest and agrarian laws (Indrarto et al. 2012: 36).

Colonial authority over land and forests on the outer islands (e.g. Sumatra, Sulawesi) remained limited until the end of the $19^{\text {th }}$ century. Colonial rule on the outer islands was mainly based on indirect rule and self-governance (Barr 2006: 19). Dutch colonial authorities negotiated contracts with local Sultanates which forced them to accept the sovereignty of the colonial government and facilitated access to resources for Dutch and European companies (Locher-Scholten 1994: 95; 1996: 140-141). Forests remained under the authority of the Sultanates, of allied elites and local communities. End of the $19^{\text {th }}$ century, Dutch colonial policy shifted from indirect rule to attempts to fully subject the outer islands especially Sumatra (Locher-Scholten 1996: 142). In several military operations, the Dutch started to expand direct control and conquered most of Sumatra at the beginning of the $20^{\text {th }}$ century (Locher-Scholten 1996: 95). A first agrarian regulation, the Agrarische Reglement, was enacted for clarifying land use and forest management in Jambi and other parts of Sumatra. The regulation provided the legal basis for dividing forests into three categories: permanent forests, forest reserves and forests for the extraction of non-timber and timber forest products (Nurjaya 2005: 42).

In 1927 the colonial government enacted a new forest law that strengthens the role of the colonial forest service (Galudra and Sirait 2009: 530). Since 1927 the colonial forest service and its post-colonial successors (e.g. Ministry of Forestry, (MoF)) have the authority to designate land as state forest and to control the use of forest resources (Galudra and Sirait 2009: 530). Furthermore, forest zoning and the designation of the forest domain had been expanded towards the outer islands (ibid.). However, colonial authorities were not able to spatially extend the forest management approaches developed for the colonial core areas to the vast forest areas of Sumatra, Borneo and Papua. Different types of customary law ( $a d a t^{84}$ ) remained the most relevant legal order governing access to forest and

\footnotetext{
${ }^{84}$ Adat: According to David Henley and Jamie S. Davidson (2007:1) the Indonesian term adat refers to custom or tradition including notions of order and consensus. The term adat is often used for customary law and the term adat rights is often used for legitimizing land claims based on customary law, in other words land claims not based on colonial or formal state law (ibid.)
} 
agricultural land (Nurjaya 2005: 42). But in some areas of Jambi (and beyond) colonial land and forest authorities induced significant changes altering preexisting customary arrangements. Colonial authorities for instance established protected areas that exist till today. The Wildreservaat Berbak (today Berbak National Park and Berbak Carbon Project) has been established in 1935 and a watershed protection forests (today forest reserve TAHURA Sultan Thaha Syaifuddin) north of present-day Bungku village has been established in 1933 (Pemerintah Kabupaten Batang Hari 2010: 8).

In addition, colonial administrative reforms challenged pre-existing administrative structures and customary forms of regulating access and property. In 1903, after Dutch conquest, the former independent Sultanate of Jambi became part of the Residence of Palembang (today South Sumatra) (Locher-Scholten 2004: 239). Later Jambi became an independent residence but the jurisdictional system of the Sultanate based on twelve nations within the Sultanate was replaced by the administrative system used in Palembang (Guillaud 1994: 125). From 1919 onwards the Residence of Jambi received a hierarchical territorial structure divided into Onderafdeeling (departments), Margas (sub-districts) and dusuns (hamlets).

The construction of new colonial scales of meaning and regulation was not conflict-free. First conflicts on access and control of forest and land resources between villagers and the colonial forest service occurred in 1929 in West Sumatra (Galudra and Sirait 2009: 527). Conflicts occurred also within the colonial state. 'Liberals' within the colonial administration argued for the introduction of a private property based land and forest governance. They suggested to convert collective customary property to individual private property for facilitating private investments and forest exploitation (Galudra and Sirait 2009: 527). The so called 'conservatives' within the colonial administration criticized the conversion of indigenous rights into private property and some even questioned whether the colonial forest service is legitimate to control the colonial forest domain ${ }^{85}$ (ibid.).

The evolution of a colonial forest and land tenure policy end of the 19th century on the island of Sumatra had territorial and scalar consequences. Colonial forest authorities established a colonial scale of forest regulation that challenged pre-existing rules for accessing forest resources. Forest zoning, monitoring activities and border demarcations underpinned the territorial claims and the new scale of regulation. Moreover, colonial forest authorities constructed watershed protection and even climate protection (Galudra and Sirait 2009: 529) as scales of meaning for legitimizing colonial forest claims. In the Residences of Jambi the colonial administration introduced a new scale of land tenure regulation

\footnotetext{
${ }^{85}$ The colonial forest domain became the state forest (kawasan hutan) in post-colonial Indonesia.
} 
and established the Pasirah ${ }^{86}$ as a new public authority responsible for allocating land to Indonesian citizens (Guillaud 1994: 125; Sevin and Benoît 1993: 97).

\subsubsection{Nationalization: introduction of new laws and rescaling for development?}

\subsubsection{Early post-colonial period}

Indonesian independence induced no abrupt changes in forest and land tenure governance. The Indonesian forest service (Jawatan Kehutanan) started activities on Sumatra in 1947 (Barr 2006: 19; Nurjaya 2005: 45). Structure and political orientation of the service had been heavily influenced by its colonial precursor (Barr 2006: 19). At least until the 1950s most of the colonial forest regulations remained officially valid. In this transition period the police unit Pamong Praja was appointed by the post-colonial government to issue permits for the harvest of products in the provinces of Jambi, Palembang and Bengkulu (Nurjaya 2005: 46). Despite the establishment of a Sumatran forest service with specific management territories state forest management in Sumatra remained unspecific and forests remained largely under the authority of local rulers (Barr 2006: 19-20).

In 1957, Government Regulation 64/57 handed far reaching forest management competencies to provincial governments and provided significant timber revenues for provincial governments (Barr 2006: 21; Nurjaya 2005: 46). Christopher Barr (2006: 20) argued that the new regulation was a political commitment of the Soekarno government to the provincial governments in order to maintain the integrity of the just independent state. The regulation permitted provinces to issue logging concessions of up to 10.000 ha for up to 20 years. Furthermore, the regulation guaranteed the independence of the provincial forest services (ibid.). The regulation induced down scaling of forest management competencies but failed to define the forest estate on the outer islands in a clear way (ibid. 21). Consequently, the co-existence of customary law and formal law continued at least for the first two decades of independent Indonesia (ibid.).

\subsubsection{The Basic Agrarian Law towards social justice and agrarian reform?}

The Basic Agrarian Law (Undang-Undang Pokok Agraria) passed in 1960. The BAL still applies (at least for non-forest land) and is highly relevant for understanding contemporary land conflicts and especially agrarian reform movements such as Serikat Petani Indonesia (SPI) (Rachman 2011). The law was aimed at harmonizing customary law (adat) and formal law and at replacing still existing colonial laws and regulations such as the Agrarische Wet (Bachriadi and Wiradi 2011: 2; Bakker and Moniaga 2010: 188).

\footnotetext{
${ }^{86}$ The Pasirah was responsible for land tenure issues within a Marga (colonial sub-district in Jambi and Palembang (Guillaud 1994: 125; Sevin and Benoît 1993: 97).
} 
The Basic Agrarian Law (BAL) was designed as a holistic law encompassing all natural resources within land, water and air thus including forest land (Bachriadi and Wiradi 2011: 1; Presiden Republik Indonesia 1960b).

The BAL clearly reflects the populist and socialist-oriented zeitgeist of the Soekarno era. The law stresses the social function of land rights (Article 6), prohibits "excessive ownership" of land (Article 7), and postulates redistribution of land (Article 17 (3)), limits exploitation rights to 35 years (Article 29), guarantees equal opportunities in obtaining land rights (Article 9 (2)) and regulates different types of private property (Article 16, 20) (Presiden Republik Indonesia 1960b). The BAL recognizes customary rights (adat) as long as they are not contradictive to the interests of the state (Article 2 (4)) but it does not provide clear regulation on how to solve conflicts between adat and formal state law (Barr 2006: 21). Furthermore, for registering and certifying rights based on adat, the adat rights have to be transformed into one of the private property concepts stated in Article 16 (Bakker 2008: 3). However, according to a study conducted by the University of Palangkaraya cited by Sandra Moniaga (1993: 139) most of the indigenous communities at the forest margins had no knowledge of the law and were not informed about the necessity to formalize their land claims based on adat and consequently do not hold registered land titles(ibid.).

Broadly speaking two critical lines of interpretations of the BAL are common today (Bachriadi and Wiradi 2011: 4). A first line of interpretation argues that the law is dysfunctional because of missing implementing regulations. And it has been used in ways that have not been intended by the authors. A second line argues that the law has even increased inequality since it expands state control and therefore has been used for legitimating the dispossession of local communities (Bachriadi and Wiradi 2011: 4).

On the one hand, the wordings of the law, especially of the articles 4, 6, 7, 9, 17 indicate a strong commitment to policies that promote social and agrarian justice (Bachriadi and Wiradi 2011: 2). In an interview, one of the leading experts on the Indonesian agrarian movement argued that the law has “[...] an inclusive spirit, was socially balanced and gender sensitive and an attempt to abolish large land holdings ${ }^{\prime 87}$. The redistribution of land (e.g. land reform) as stipulated by the law was not implemented except for smalls scale pilot schemes on Java (Rachman 2011: 40). On the other hand, the law privileges western forms of private property over community property, aims to transform collective rights based on adat to individual property rights and strengthens the right of the state to control land (Bachriadi and Wiradi 2011: 2-3; Bakker and Moniaga 2010: 188).

\footnotetext{
${ }^{87}$ Interview with staff member of the Sajogyo Institute, Bogor, 08.10.2013, Document ID: 197
} 
The New Order regime limited the applicability of the BAL to non-forest land (Barr 2006: 23). Therefore, the BAL is relatively weak in legal terms today but is still used by NGOs, social and environmental justice movements and peasant organizations for underpinning political campaigns for a more equal distribution of agrarian resources (Bakker and Moniaga 2010: 88; Hein and Faust 2014: 25; Rachman 2011: 54). For instance, members of peasant organization Serikat Petani Indonesia (SPI) are referring to the BAL for legitimizing land occupations within the Harapan Rainforest project ${ }^{88}$ (in detail in section 6.3 and 7.2).

The BAL can also be understood as an attempt to construct a new national scale for governing natural resources and as an attempt to deconstruct pre-existing colonial scales. For instance, Craig C. Thorburn (2004: 36) stresses that the authors of the BAL "[...] envisioned an entire national community guided by an overarching sense of social function. The state, as the ultimate arbiter of 'national adat', was in effect granted beschikkingsrecht rights to all the land, sea and natural and economic resources in the country". The post-colonial state sought to legitimize the BAL as a new national scale of regulation by constructing a complementary scale of meaning based on nationalism and based on the key role of land for achieving welfare and social justice in rural areas.

\subsubsection{New Order}

The development and modernization-oriented New Order regime changed forest and agrarian politics significantly (Bachriadi and Wiradi 2011: 6). The regime established and stabilized political control over the outer islands, liberalized forest exploitation, uniformed and Javanized village administration, expanded the transmigration program and stopped land redistribution policies initiated by Soekarno (Bachriadi and Wiradi 2011; Barr 2006; Kato 1989; Levang and Sevin 1990). These political processes have changed scales of meaning and regulation (e.g. centralization of forest governance), induced far reaching landscape transformation processes (e.g. the island of Sumatra lost $25-30 \%$ of its forest cover (Barr 2006: 28)) and altered the ability of local actors to access forest land significantly. The farreaching consequences of the New Order are still inscribed in Jambi's post-frontier landscapes and will be discussed in detail in section 5.4 .

\subsubsection{Reestablishing dualistic land and forest governance}

In 1967 President Suharto enacted the Basic Forest Law. The law is according to Barr (2006: 23) the first comprehensive legal and administrative framework for managing Indonesia's forest estate.

\footnotetext{
${ }^{88}$ Interview with key informant in Tanjung Lebar, 22.07.2013, Document ID: 291 and interview with staff member of Sajogyo Institute, Bogor, 08.10.2013, Document ID: 197.
} 
Through the enactment of the Basic Forest Law Suharto's regime reestablished the dualistic structure of the colonial system - with two separate laws, one regulating forest management and access to the state forest and one regulating access and property outside of the state forest. First, the law defines state forest (Kawasan Hutan) as a forested territory or as a non-forested territory designated for reforestation (Article 4). It gives the Directorate General of Forestry within the Ministry of Agriculture (later up-graded towards the Ministry of Forestry (MoF)) the authority to designate approximately $70 \%$ of Indonesia's land mass as state forest (Article 7) (Presiden Republik Indonesia 1967). Second, the law delegates authority to conduct forest zoning to the Directorate General of Forestry and introduces four different forest categories: production forest, recreation forest, forest reserve and nature conservation forest. Third, the law provides the legal framework for commercial forest exploitation and for the economic liberalization of forest management (Hak Pengusahaan Hutan, HPH) (Article 14). Fourth, the law states that customary forest is part of the state forest and activities of customary (adat) communities that contradict the law (e.g. shifting cultivation) are prohibited (Article 17). Furthermore, only still existing adat communities have rights to forest with the important addition that the state decides which community is eligible and which not.

Forest management during the New Order era was aimed to achieve at least three major objectives. First, revenues from forest exploitation were necessary in order to stabilize the state and its different apparatuses (Barr 2006: 23). This was mainly achieved through establishing clientelistic networks creating mutual dependencies of actors of the civil and military bureaucracy from central government down to the village level (Barr 2006: 24; Barr 1998: 4). Second, revenues from forest exploitation were necessary for stabilizing the state budget and for enhancing the trade balance. Third, forest resources were used to attract foreign investments (Barr 2006: 27).

In the 1970s, the central government established full control over Indonesia's forest resources and allocation procedures for all types of forest concessions. The central government revoked any rights of sub-national governments to issue forest exploitation permits (Barr 2006: 25). The first logging concessions in the Harapan Landscape (e.g. PT Asialog ${ }^{89}$ and PT Tanjung ASA ${ }^{90}$ ) date back to this period. Through up-scaling the permit procedures for all concession types the central government sought to exclude sub-national elites and their patronage networks from accessing forest resources and sought to facilitate access to forest resources for the Jakarta-based elite (Barr 2006: 25-26). Up-scaling finally consolidated Jakarta's attempts to control the forest resources of the outer islands.

\footnotetext{
${ }^{89}$ SK. HPH No. 408/Kpts/Um/9/1971 tanggal 23 September 1971 tentang Pemberian Hak Pengusahaan Hutan kepada PT. ASIALOG Decision of the Ministry of Forestry to allocate a logging concession to the company PT Asialog, own translation) (Menteri Kehutanan 1995)

${ }^{90}$ Not detailed information available, according to key informant in Tanjung Lebar the company received a logging concession in 1974, 27.07.2013, Document ID: 113.
} 


\subsubsection{Adjusting village governance}

Indonesia's local governance and administrative structure remained highly diverse until end of the 1970s. Villages as the lowest administrative unit had different names, meanings and sizes and were led by local leaders with different names, sources of legitimacy, and different responsibilities in regard to the regulation of land and forest tenure (Kato 1989: 91). Indonesia's constitution of 1945 officially acknowledges the diversity of local administrative systems (Kato 1989: 114). In many parts of Sumatra, the colonial system of village administration remained in place until the enactment of the village law in 1979 (Galudra et al. 2014: 723). The village law (Undang-Undang tentang Pemerintahan Desa 5/1979) was aimed at standardizing the administrative structure of villages across the Archipelago (Burkard 2002: 5; Kato 1989: 91-94; Warren 1990: 1-2). It was aimed at replacing the pre-existing structures that were based on colonial concepts or customary law by imposing the Javanese village (Desa) concept (ibid.).

The new Javanized village concept introduced a new hierarchical socio-spatial organization undermining previous forms of socio-spatial organization. According to the law, the village (desa) as a jurisdiction should be led by a village head (Kepala Desa) as the executive body and by a village council (Lembaga Musyawarah Desa) as the legislative body of the village government. Village head and village council were rather pseudo-democratic institutions since village head candidates had to be approved by the district head (Bupati) and the sub-district head (camat) (Kato 1989: 108). Internal village institutions such as the village council were accountable to the village head. The village head was not accountable to the village population. He was only accountable to district and sub-district head. In other words, he was part of a chain of command which was aimed at connecting the central government in Jakarta with the local population across the archipelago (Kato 1989: 106). The village law stipulated the sub-division of the village territory into hamlets (dusuns) led by a Kepala Dusun. Hamlets are further divided into different neighborhood units ${ }^{91}$ (Rukun Tetangga) led by the Ketua RT (Bebbington et al. 2004: 192; Kato 1989: 94; Warren 1990: 3). All leaders of the different sub-divisions were appointed by the village head.

Through standardizing and formalizing village government and village administration the village law undermined the authority of traditional customary authorities, traditional income sources of villages (Kato 1989: 105) and imposed the village territory as a new scale of regulation contradicting previous scales of regulation such as the Wilayah Adat $^{92}$ (customary land) of the Batin Sembilan in Jambi. New

\footnotetext{
${ }^{91}$ Neighborhood units were not mentioned in the village law; they have been introduced in 1983 through an addition decree of the Ministry of Home Affairs (Warren 1990: 3).

${ }^{92}$ Customary land
} 
village boundaries disrupted previous forms of socio-spatial organization of the Batin Sembilan which were based on lineages and watersheds (in detail in section 5.4.2).

Furthermore, the village law decoupled traditional local leader's form their material basis to power and authority (Bebbington et al. 2004: 193). Their previous material power, in Steven Lukes words their visible power was based on the right to allocate land, fishing rights and to collect rubber taxes (Galudra et al. 2014: 725; Kato 1989: 108). In the Berbak area for instance, land was controlled by the Pasirah of the Marga of Berbak until the early $1980 \mathrm{~s}^{93}$. Today the village head is in charge of land allocation and drainage permits ${ }^{94}$. Galudra and colleagues (2014) identified similar transformations in the district of Tanjung Jabung Barat in north-west Jambi.

The village law was not only aimed to standardize scales of regulation the law was also part of a set of policies aimed at establishing national modernization and development as new scales of meaning replacing previous scales of meaning based on local adat (e.g. locally relevant cultural meanings of land use practices). The New Order regime regarded village diversity and non-Javanese forms of sociospatial organization as potential threats for development and as signs for underdevelopment (Bebbington et al. 2004: 192; Hoey 2003: 112; Kato 1989: 93). Village governments as the lowest administrative unit should act in line with national development targets and were at the same time the lowest end of the national surveillance and control network of the New Order regime (Kato 1989: 107-113).

Nevertheless, the New Order regime was not fully able to defeat customary authority. Many village governments were not fully operational and in many peripheral villages adat and traditional public authorities remained influential and rapidly regained importance during the Reformasi era (more in section 5.1.4, and 5.3) (Bebbington et al. 2004: 193).

\subsubsection{Transmigration, new property and modernization}

The transmigration program was also part of the New Order policy set to promote modernization and development and for exporting Javanese culture to the outer islands (Bebbington et al. 2004: 193). Transmigration is a government-led resettlement program and rural development initiative. The program received significant financial support from the World Bank ${ }^{96}$ (Kebschull 1986: 152-153). In many parts of the Archipelago the transmigration program contributed significantly to the expansion

\footnotetext{
93 Interview with key informant in Air Hitam Laut, 29.09.2102, Document ID: 70.

${ }^{94}$ Interview with key informant in Air Hitam Laut, 30.09.2012, Document ID: 67 and key informant in Sungai Aur, 30.08.2013, Document ID: 268.

${ }^{95}$ Land allocation by village heads is officially not backed by the village law but in practice are many village heads involved in issuing different types of land use permits.

${ }^{96}$ During 1976-1989 10\% of the transmigration budget was covered by the World Bank (Fernside, 1997: 6).
} 
of a Western and individualized concept of property, of cash crops, of wet rice production and of a modern bureaucracy (Armitage 2002: 211; Cramb et al. 2009; Li 2005: 14-15; Roth 2009: 202; Kebschull 1986: 37).

Transmigration that dates back to the colonial period. The Kolonosatie program resettled Javanese farmers mainly to Lampung but also to Jambi (Levang and Sevin 1990: 1,3). Rational of the transmigration program and of its colonial precursor was to reduce population pressure and land scarcity on Java and Maduro and to redistribute the population to the sparsely populated outer islands (ibid.). Resettlement was also driven by the imagination of the superiority of Javanese and Balinese culture and land-use practices (Fearnside 1997: 559; Levang and Sevin 1990: 4). Javanese and Balinese transmigrants were framed as model farmers that would persuade 'back warded' slash and burn farmers of the outer islands to use more modern land-use techniques (ibid.).

The transmigration program had its peak in the 1980s. Until 1989 five million people had been resettled to the outer islands (Fearnside 1997: 554). Numbers declined in the 1990s but remained substantial (e.g. 90.762 families in 1996-1997) (Potter 2012: 272). In the Reformasi period the relevance of the project has declined significantly (e.g. 2265 families in 2000) (Potter 2012: 272). The authority over the program had been transferred to district governments. Today potential sending districts and receiving districts are directly negotiating with each other (Potter 2012: 273) and candidates can select between different destinations using an online platform (Dinas Tenaga Kerja dan Transmigrasi Sumatera Barat 2015).

The transmigration program allocated between 1,75 ha to 3,5 ha land per household for crop production including official land titles issued by the National Land Agency (Badan Pertanahan Nasional, BPN) (The World Bank 1979: 33, 73). In addition, the transmigration authorities provided a 0,25 ha house lot, seeds and start-up funding (Fearnside 1997: 555). In Jambi, the first post-colonial projects had been developed in the peat swamps of the Batang Hari delta, north east of today's Berbak Carbon project (Levang and Sevin 1990: 6). The projects induced enormous landscape transformation processes caused by drainage and land reclamation activities. Descendants of settlers, in other words second generation transmigrants migrated for instance to Sungai Aur in the Berbak Landscape and to Bungku in the Harapan Landscape. Additional projects had been conducted in Jambi's hinterland for instance in the Sungai Bahar area north of the Harapan Rainforest project. The transmigration settlements overlap with the customary land of the Batin Sembilan (more in section 5.4.2 and in chapter 6.). In addition, transmigration and local resettlement schemes might have contributed to the transformation of lineage-based property concepts to individualistic and commodified property in the Harapan Landscape (c.f. Hauser-Schäublin and Steinebach 2014; Krishna, Pascual, and Qaim 2014). A 
member of the village parliament in Tanjung Lebar for instance stated that: "In the times before the settlement project was implemented we did not used land titles in the village [...] ${ }^{\prime 97}$.

The transmigration program and its sub-program Swakarsa Transmigration were also used as inspiration and as a source of legitimacy for organized land occupations in the Harapan Rainforest area. The name Transswakarsa Mandiri of an informal settlement within Harapan Rainforest makes direct reference to the state-based formal transmigration program (more in section 6.3). In the Berbak Landscape at least two district to district transmigration settlements have been established recently. Both projects overlap with the boundaries of the Forest Reserve TAHURA Sektitar Tanjung and with the Berbak Carbon project causing conflicts between different state agencies and settlers ${ }^{98}$. The case of Sungai Aur will be discussed in detail in seven (section 7.4).

\subsubsection{Reformasi: rescaling through democratization and decentralization}

On 21th of May 1998 President Suharto announced his resignation after two years of student protests calling for democracy, and after ethnic violence and sharp economic decline (Hofman and Kaiser 2002: 3). His successors President Habibie, President Wahid and President Megawati implemented far reaching democratic reforms and decentralization processes that transformed Indonesia's political landscape significantly. Indonesia's "big bang decentralization" was neither a controlled nor a planned process (Hofman and Kaiser 2002). First decentralization laws and regulations e.g. law 22/1999 on Regional Governance were formulated in an overhasty way reflecting the weak power base of the central state during the political transition period after the fall of Suharto (Barr et al. 2006: 2; Hofman and Kaiser 2002: 3). Decentralization and regional autonomy and new revenue sharing arrangements between the central government, provincial and district governments were rather an ad hoc response to separatist tendencies for maintaining the integrity of the nation state then following a stringent plan (McCarthy 2007: 96).

Regional governments including village heads and customary leaders took advantage of the confusion and of the political vacuum caused by the weak central state. They interpreted reforms to their advantage and started to assert far-reaching administrative authority over forests, land tenure and natural resources (Barr et al. 2006: 2; Hein et al. 2015). At the local level decentralization increased competition between different actors over the new profit options. In some areas of the archipelago (e.g. Central Sulawesi and the Maluku Islands) violent conflicts along ethnic and religious lines on access and control of natural resources and political power emerged (Acciaioli 2001: 87; Rhee 2009:

\footnotetext{
${ }^{97}$ Interview with key informant in Tanjung Lebar, 25.07.2013, Document ID: 124

${ }^{98}$ Interviews with key informant in Sungai Aur, 29.08.2013, Document ID: 135 and with staff member of Dinas Kehutanan Provinsi Jambi, 27.08.2013, Document ID: 137.
} 
46). Ethnicity and customary law reemerged as means to control land and natural resources (Barr et al. 2006: 12; Moeliono and Dermawan 2006: 109; Rhee 2009: 109). The reemergence of ethnicity and customary law are highly relevant for understanding contemporary conflicts on access and property in the Berbak and especially in the Harapan landscapes (Beckert, Dittrich, and Adiwibowo 2014; Hein and Faust 2014; Hein et al. 2015; Steinebach 2013b).

Reforms of forest, land and village governance induced a wide range of changes. However, in many cases and especially in the forest sector the reforms have only temporarily shifted de jure competencies. Most relevant competencies remained at the national level. Though the changed political context extended the agency of local public authorities including village governments, customary communities and agrarian reform movements (Barr et al. 2006: 11; Moeliono and Dermawan 2006: 109; Peluso, Afiff, and Rachman 2008: 388). Whereas de jure authority over the state forest shifted only temporarily especially district governments benefitted substantially from new forest revenue sharing arrangements. Districts in which forest concessions are located now receive a four times higher share of the concession license fee and receive $40 \%$ of the reforestation fund ${ }^{99}$ (Resosudarmo et al. 2006: 61, 67).

Decentralization of the forest sector was initiated through the enactment of the regulations 62/1998 on the Delegation of Partial Authority on the Forest Sector to Regions and regulation 6/1999 on Regional Governance (Resosudarmo et al. 2006: 88). These two regulations and a couple of following decrees issued by the MoF permitted district governments to issue small scale logging and forest conversion concessions in areas designated as conversion and production forest (Resosudarmo et al. 2006: 99; Indrarto et al. 2012: 27). Further legitimacy was provided through Law 22/1999 on Regional Governance. The law delegated authority over various governance functions such as health, education, agriculture, environmental protection and to some extend over agricultural land to district governments (Barr et al. 2006: 11; Indrarto et al. 2012: 27).

In Jambi, district governments issued Community Timber Extraction Permits (Ijin Pemungutan Kayu Rakyat, IPKR) within production and conversion forest (Resosudarmo et al. 2006: 89) inducing a short logging boom in the Berbak Landscape. In 2002 the central government withdraw the authority to issue small-scale logging and forest conversion concessions from district governments after lobbying of the Association of Indonesian Forest Concession holders and re-established full authority over the state forest estate (Resosudarmo et al. 2006: 90). With regulation 34/2002 the central government returned to a stricter reading of the forest law 41/1999 and abrogated small scale logging but gives provincial and district governments at least the opportunity to provide recommendations during the

\footnotetext{
${ }^{99}$ The reforestation fund (Dana Reboisasi) is volume based fee charge on harvested timber for supporting reforestation of logged over forest (Resosudarmo et al. 2006: 62).
} 
permit process for forest concessions (Resosudarmo et al. 2006: 90, 104; Indrarto et al. 2012: 28; McCarthy et al. 2006: 45). These seesaw changes of competencies led to uncertainty and confusions providing room for monetary and political rent-seeking behavior among actors (Moeliono and Dermawan 2006: 106; and c.f. Lund 2008: 152 for sub-saharian Africa).

Today some district governments are still issuing small scale forest conversion permits, according to an expert of the MoF in Jakarta. During the interview the expert explained: "[...] the authority was given to the local government actually with a hope to speed up the process, but the problem than the issued licenses were not used for timber but mostly for estate crop plantations. That's way the decision has been revoked, but they continue to release the license but mostly not for small scale timber [....] the local government mostly related to the issuance for oil palm plantation, small scale although this is not legal”100.

The forest law 41/1999 mostly resumes the forest policy of the New Order era e.g. the law declares that customary forests is part of the state forest and allows access to forests only for formally recognized adat communities (Bedner and Van Huis 2008: 184). However, for instance in its article 68 on community participation the law goes beyond New Order policies and provides room for implementing regulations on village forestry (hutan desa, Ministerial Regulation 49/2008), community forestry (hutan kemasyarakatan, Ministerial Regulation 37/2007) and smallholder forestry (hutan tanaman rakyat, Ministerial Regulation 55/2011).

On the one hand, district and provincial governments have de jure only few management competencies today e.g. management of forest reserves (Tanaman Hutan Raya also known as TAHURA) and conservation forests (Hutan Lindung) and they have neither the authority to issue concessions, nor to decide on the forest classification and forest designation. On the other hand, they gained significant influence outside the forest sector. This includes spatial planning, environmental impact assessments and the lucrative approval of agricultural plantation and mining permits on nonforest land (Paoli et al. 2013: 27-28; Indrarto et al. 2012: 31).

The reform of village administration as the forest sector reforms were characterized by seesaw changes. Law 22/1999 on Regional Governance describes villages not anymore as the lowest administrative unit but as "autonomous units" recognizing local customary law and regional characteristics (Moeliono and Dermawan 2006: 115). Only a few years later the revised decentralization law of 2004 and the regulation on village government (Government Regulation 76/2001) stipulates again that villages across the archipelago should have a uniform structure (ibid.). Despite of this drawback the reforms have democratized village governments. Villages head and village

\footnotetext{
${ }^{100}$ Interview with staff member of the Ministry of Forestry, Jakarta, 23.07.2012, Document ID: 88.
} 
parliament (Badan Permusyawaratan Desa, BPD) are elected for 6 years for maximum of two terms. BPD and village head can enact village regulations, prepare village development plans and have to be involved in spatial planning processes conducted by higher authorities (Bedner and Van Huis 2008: 174).

The new laws and regulations have not changed the spatial organization of village governance. Villages are still sub-divided into hamlets and neighborhoods. The reforms provided more room for selfdetermination for village governments but offer de jure no control over forest resources within state forest. Anyhow, de facto former village heads in Bungku and Tanjung Lebar have exercised authority over state forest after the fall of Suharto (ibid.). Village heads in both villages legitimize their control over state forest (e.g. demonstrated through issuing of village level land titles and supporting forest conversion and settlement within state forest) with reference to pre-existing customary territories. Furthermore, Governmental Regulation 24/1997 on land registration (Article 24) gives village heads a formal role in registering adat land rights and other rights based on oral history (Nurhaniah 2006: 74; Presiden Republik Indonesia 1997).

\subsection{Different types of de jure land and forest rights}

Indonesia's forest and land tenure regime is complex and governed through a wide set of laws and regulations. The development of the most relevant ones e.g. the Forest Law 41/1999, the Basic Agrarian Law 1/1960 and the Law on Regional Autonomy 22/1999 have been introduced in the previous sections. In this section I will assess different types of de jure land and forest rights eligible for different stakeholders. I will only refer to those rights that have been relevant in the study area or might be relevant in the context of REDD+ implementation. Furthermore, I will focus on rights eligible for smallholders.

First, it is relevant where the land is located. If land is located within the state forest, it is subject to the Forest Law and related regulations. Forest land is under the authority of the MoF. If land is located outside the state forest, also called areas for other use (APL, Areal Penggunaan Lain), it is subject to the Basic Agrarian Law. APL is under the authority of district governments and National Land Agency (BPN). Second, both regimes distinguish between land and forest rights for individuals (smallholders), communities (including formal villages), and corporate actors. Third, the forest regime permits only temporary use rights (hak pengusaha hutan) for all actor groups. Whereas the agricultural regime permits inheritable and alienable individual rights (hak milik) for smallholders with a maximum size of 
$20 a^{101}$, communal land rights (hak ulayat) for adat communities and temporary cultivation rights (hak gunah usaha) for larger corporate actors (Bedner and Van Huis 2008: 179-180; Presiden Republik Indonesia 1960b, 1960a, 1999). The de facto forest and land tenure regime in the Harapan and in the Berbak landscapes differs from village to village and will be discussed in chapter six.

The allocation of corporate forest concessions is a complex, intransparent and corruption prone process (Casson and Obidzinski 2002; Smith et al. 2003). For obtaining one of the different available forest concessions (HPH) actors have in general to approach the MoF or local branches of the Ministry ${ }^{102}$. The district governments are involved in the permit procedure but the final saying has the $\mathrm{MoF}^{103}$. The legal procedure for accessing ecosystem restoration concessions for instance is complex and long lasting (Walsh et al. 2012; Walsh, Asmui, and Utomo 2012). Ecosystem restoration concessions are private conservation concessions for habitat protection, habitat restoration and management (Ministry of Forestry 2008: 5). They permit the commercial exploitation of non-timber forest products and the commercial use of ecosystem services such as ecotourism, biodiversity and carbon capture and storage (ibid. 7). For selling carbon credits the specific REDD+ regulations of the MoF outlined in section 4.4 have to be considered. The conservation company PT REKI running the Harapan Rainforest project holds an ecosystem restoration concession. Thomas A. Walsh and colleagues (2012: 11) reported that the process takes between 14 to 36 months instead of the 132 days as announced in Ministerial Regulation 50/2010 (ibid.).

The forest regime provides different forest concessions for villages (hutan desa/ village forest concession) communities (hutan kemasyarakatan/ community forest concession) and individual smallholders (hutan tanaman rakyat/ smallholder forest concession). Though, it is usually difficult for village governments, communities and individual smallholders to access these concessions. Small holder forest concessions (hutan tanaman rakyat, HTR) are often allocated by forest authorities as a mean to solve conflicts between smallholders occupying land designated as state forest and forest authorities ${ }^{104}$. This has been the case in the village of Sungai Gelam in south eastern part of the Berbak Carbon Project ${ }^{105}$ and it is discussed as a conflict solution tool for solving conflicts between smallholders in Bungku and the conservation company PT REKI ${ }^{106}$. In other cases, in Jambi, HTR

\footnotetext{
${ }^{101}$ According to Governmental Regulation 56/1960, Article 1 the maximum land size permitted per individual depends on the population density and on the type of land (land for wet rice cultivation and dry land). 20 ha of dry land are permitted in areas with a low population density in areas with very high population densities only 6ha are permitted.

${ }^{103}$ Interview with member of the Working Group on Forest and Land Tenure, Bogor, 08.10.2013, Document ID: 198.

${ }^{104}$ Interview with Working Group on Forest and Land Tenure, Bogor, 08.10.2013, Document ID: 198 and with staff member of Burung Indonesia, Bogor, 11.10.2013, Document ID: 210.

${ }^{105}$ Interview with activists of the NGO PINSE, Sungai Gelam (Jambi), 05.09.2013, Document ID: 304.

${ }^{106}$ Interview with staff member of Burung Indonesia, Bogor, 11.10.2013, Document ID: 210.
} 
concessions are part of NGO or donor initiatives. For instance the NGO Amphal supported by the Finish Development Cooperation runs two smallholder agroforestry projects based on HTR concessions in the surroundings of Bukit Duabelas National Park in Jambi ${ }^{107}$.

Asked on how communities could obtain a village forest concession (hutan desa) experts from academia, donor agencies and NGOs interviewed in July 2012 mentioned that requirements such as the preparation of management plans and performance of forest inventories, and the levying of administrative charges represent significant barriers to local communities and smallholders that cannot be resolved without external support ${ }^{108}$. In addition, only forest land that is designated as production forest (hutan produksi) and which is not allocated yet is eligible for new community and smallholder forest concessions ${ }^{109}$. Village and community forest concessions can also be implemented in conservation forests (hutan linding). Furthermore, the respective regulation on village forests clearly links village forests to existing and formally recognized villages (Menteri Kehutanan 2008a). This excludes groups that settle informally or live nomadically inside the state forest ${ }^{110}$. The indigenous rights movement AMAN rejects community and village forest concessions and argues "[...] we do not agree with that, because actually the basis of this forest categories is wrong. Because the forestry law itself is wrong. [....] it doesn't recognize indigenous peoples rights, [...] the law is wrong and consequently are implementing regulation also wrong"111. Community forest concessions do not change state ownership. They only permit temporary use rights. AMAN consequently refuses concessions and demands full land ownership and the recognition of indigenous territories ${ }^{112}$. The recent constitutional court review declared that adat forest is no longer part of the state forest it is subject to rights of adat communities (Rachman 2013: 2). This might create specific rights for customary communities to forests in future (more in section 5.3).

Beyond that, in specific circumstances communities with the support of the district government can apply for an enclave. An enclave implies the release of a specific area from the state forest. The MoF assesses the request according to specific criteria which cover inter alia ethnicity, history of the area, existing evidence of community rights and ecological indicators ${ }^{113}$.

\footnotetext{
${ }^{107}$ Interview with staff member of the NGO Amphal, Jambi, 17.07.2013, Document ID: 146.

${ }^{108}$ Interview with GIZ advisor, Jakarta, 24.07.2012, Document ID: 18, Greenpeace Indonesia activist, Jakarta, 27.07.2012, Document ID: 121 and Forest Watch activist, Bogor, 20.07.2012, Document ID: 15.

109 Interview with staff member member of Dinas Kehutanan Provinsi Jambi, Jambi, 01.09.2012, Document ID: 72.

110 Interview with Forest Watch activists, Bogor, 20.07.2012, Document ID: 15.

${ }^{111}$ Interview with AMAN activist, Jakarta, 27.07.2012, Document ID: 92.

112 Interview with AMAN activist, Jakarta, 27.07.2012, Document ID: 92.

${ }^{113}$ Interview with staff member of Dinas Kehutanan Provinsi Jambi, Jambi, 19.09.2012, Document ID: 30.
} 
For obtaining land rights in areas designated as APL district governments and the National Land Agency (Badan Pertanahan Nasional, BPN) have the final voice. The role of village heads is mention in Governmental Regulation 24/1997 on land registration. Individual smallholders can request land rights (hak milik) from BPN. BPN distinguishes two procedures for accessing hak milik. The first called sistematik refers to government sponsored and government assisted land titling schemes conducted in specific area such as the Proyek Operasi Nasional Agraria (PRONA) for agricultural land. PRONA is a program of the BPN for certifying agricultural land. Village heads and civil servants from BPN are jointly conducting tenure mappings for identifying and certifying land.

The second is called sporadik and refers to the process of individual land registration. For getting a plot of land certified several documents are necessary including a declaration confirming that land taxes had been paid, a document that informs about the ownership history, a document that describes the location of the land and its borders (Surat Pernyataan Penguasan Fisik Bidang Tanah), and a declaration that the plot is not claimed by another party. For converting customary rights, a statement of the village head is necessary. Moreover, in peripheral areas without cadaster the village head is in charge of land deed. In both landscapes the term sporadic refers customarily to a village-scale land title. A sporadik is not a legal land title but according to a BPN officer ${ }^{114}$ it can be considered as a Surat Pernyataan Penguasan Fisik Bidang Tanah and can be accepted by BPN as a necessary document for a land title application (more details in section 6.3.2) (Presiden Republik Indonesia 1997; Wibisono 2012: 9-11).

For obtaining a concession for cultivation rights (hak gunah usaha (HGU)) corporate actors have to apply for a location permit (ijin lokasi) from the district government. Before issuing a location permit the district government has to consult local communities potentially affected by the concession ${ }^{115}$ (Paoli et al. 2013: 24). After holding the location permit the planned plantation estate is subject to an environmental impact assessment involving the environmental protection authority of the district (ibid. 28). In a last step BPN issues the HGU (ibid.). In some cases e.g. in Seponjen companies run plantation estates only based on the location permit ${ }^{116}$.

The different types of land and forest rights described above are subject to different laws and regulations and involve different authorities such as village governments, district governments, BPN and the MoF. Each authority has its specific scale of regulation which reflects the position and the different dimensions of power of the authority within the different apparatuses of the state. But as the previous sections have shown power constellation and scales of regulation are not stable, they are

\footnotetext{
${ }^{114}$ Interview with BPN officer, Jambi, 06.09.2013, Document ID: 184.

${ }^{115} \mathrm{Also}$ confirmed in an interview with BPN officer, Jambi, 06.09.2013, Document ID: 184.

${ }^{116}$ Interview with key informants, Seponjen, 15.09.2013, Document ID: 172 and 13.09.2013, Document ID: 122.
} 
continuously re-negotiated. The table 7 below overviews the different rights or in other words property types, their legal basis, limitations, involved authorities and lists of stakeholders eligible for each property type.

\begin{tabular}{|c|c|c|c|c|c|}
\hline Property type & $\begin{array}{l}\text { Regulation/ } \\
\text { law }\end{array}$ & Limitations & $\begin{array}{l}\text { Involved } \\
\text { Authority }\end{array}$ & $\begin{array}{l}\text { Eligible } \\
\text { stakeholder }\end{array}$ & $\begin{array}{l}\text { Eligible land } \\
\text { and forest } \\
\text { category }\end{array}$ \\
\hline $\begin{array}{l}\text { Collective } \\
\text { customary rights } \\
\text { (Hak Ulayat) }\end{array}$ & $\begin{array}{l}\text { Basic Agrarian } \\
\text { Law 1/1960 }\end{array}$ & $\begin{array}{l}\text { Communal land } \\
\text { title based on } \\
\text { customary rights }\end{array}$ & $\begin{array}{l}\text { District } \\
\text { government, } \\
\text { BPN }\end{array}$ & $\begin{array}{l}\text { Customary } \\
\text { communities }\end{array}$ & APL \\
\hline $\begin{array}{l}\text { Individual land } \\
\text { title (Hak Milik) }\end{array}$ & $\begin{array}{l}\text { Basic Agrarian } \\
\text { Law 1/1960, } \\
\text { Governmental } \\
\text { Regulation } \\
24 / 1997 \text { and } \\
56 / 1960\end{array}$ & $\begin{array}{l}\text { Agricultural land } \\
\text { with a maximum } \\
\text { size of } 20 \text { ha }\end{array}$ & $\begin{array}{l}\text { Village head } \\
\text { and BPN }\end{array}$ & $\begin{array}{l}\text { Individual } \\
\text { land users }\end{array}$ & APL \\
\hline $\begin{array}{l}\text { Cultivation } \\
\text { permit } \\
\text { (Hak Guna Usaha, } \\
\text { HGU) }\end{array}$ & $\begin{array}{l}\text { Basic Agrarian } \\
\text { Law 1/1960, } \\
\text { Governmental } \\
\text { Regulation } \\
26 / 2007\end{array}$ & $\begin{array}{l}\text { Concession for } \\
\text { agricultural } \\
\text { plantations (e.g. } \\
\text { oil palm), for } \\
\text { max } 60 \text { years }\end{array}$ & $\begin{array}{l}\text { District } \\
\text { government, } \\
\text { BPN }\end{array}$ & $\begin{array}{l}\text { Corporate } \\
\text { actors }\end{array}$ & APL \\
\hline $\begin{array}{l}\text { Smallholder } \\
\text { forest concession } \\
\text { (Hutan Tanaman } \\
\text { Rakyat, HTR) }\end{array}$ & $\begin{array}{l}\text { Ministerial } \\
\text { Regulation } \\
55 / 2011\end{array}$ & $\begin{array}{l}\text { Max land size of } \\
15 \text { ha per } \\
\text { household, for } \\
\max 60 \text { years }\end{array}$ & $\begin{array}{l}\text { Ministry of } \\
\text { Forestry }\end{array}$ & $\begin{array}{l}\text { Individual } \\
\text { land users }\end{array}$ & $\begin{array}{l}\text { Permanent } \\
\text { Production } \\
\text { Forest }\end{array}$ \\
\hline $\begin{array}{l}\text { Community } \\
\text { forest concession } \\
\text { (Hutan } \\
\text { kemasyarakatan) }\end{array}$ & $\begin{array}{l}\text { Ministerial } \\
\text { Regulation } \\
88 / 2014\end{array}$ & $\begin{array}{l}\text { Concession for } \\
\text { community } \\
\text { forestry, for max } \\
35 \text { years }\end{array}$ & $\begin{array}{l}\text { Ministry of } \\
\text { Forestry }\end{array}$ & $\begin{array}{l}\text { Community } \\
\text { with } \\
\text { community } \\
\text { association }\end{array}$ & $\begin{array}{l}\text { Production } \\
\text { and } \\
\text { Conservation } \\
\text { forest }\end{array}$ \\
\hline $\begin{array}{l}\text { Village forest } \\
\text { concession } \\
\text { (Hutan Desa) }\end{array}$ & $\begin{array}{l}\text { Ministerial } \\
\text { Regulation } \\
49 / 2008\end{array}$ & $\begin{array}{l}\text { Concessions for } \\
\text { community } \\
\text { forestry, for max } \\
35 \text { years }\end{array}$ & $\begin{array}{l}\text { Ministry of } \\
\text { Forestry }\end{array}$ & $\begin{array}{l}\text { Village } \\
\text { community }\end{array}$ & $\begin{array}{l}\text { Production } \\
\text { and } \\
\text { Conservation } \\
\text { forest }\end{array}$ \\
\hline $\begin{array}{l}\text { Customary forest } \\
\text { (Hutan Adat) }\end{array}$ & $\begin{array}{l}\text { Forest Law } \\
41 / 1999 \text { and } \\
\text { Putusan MK } \\
\text { No. 35/PUU- } \\
\text { X/2012 } \\
\text { tentang Hutan } \\
\text { Adat }\end{array}$ & $\begin{array}{l}\text { Implementing } \\
\text { regulation } \\
\text { pending }\end{array}$ & $\begin{array}{l}\text { Ministry of } \\
\text { Forestry and } \\
\text { Constitutional } \\
\text { Court }\end{array}$ & $\begin{array}{l}\text { Customary } \\
\text { communities }\end{array}$ & n. a. \\
\hline $\begin{array}{l}\text { Forest plantation } \\
\text { concession } \\
\text { (Hutan Tanaman } \\
\text { Industri, HTI) }\end{array}$ & $\begin{array}{l}\text { Forest Law } \\
41 / 1999, \\
\text { Government } \\
\text { Regulation } \\
7 / 1990\end{array}$ & $\begin{array}{l}\text { Concession for } \\
\text { timber } \\
\text { plantations, max } \\
35 \text { years }\end{array}$ & $\begin{array}{l}\text { Ministry of } \\
\text { Forestry }\end{array}$ & $\begin{array}{l}\text { Corporate } \\
\text { actors }\end{array}$ & $\begin{array}{l}\text { Permanent } \\
\text { Production } \\
\text { Forest }\end{array}$ \\
\hline
\end{tabular}




\begin{tabular}{|c|c|c|c|c|c|}
\hline $\begin{array}{l}\text { Logging } \\
\text { concession } \\
\text { (Pemanfaatan } \\
\text { Hasil Hutan Kayu) }\end{array}$ & $\begin{array}{l}\text { Forest Law } \\
41 / 1999\end{array}$ & $\begin{array}{l}\text { Logging } \\
\text { concession, max } \\
20 \text { years }\end{array}$ & $\begin{array}{l}\text { Ministry of } \\
\text { Forestry }\end{array}$ & $\begin{array}{l}\text { Corporate } \\
\text { actors }\end{array}$ & $\begin{array}{l}\text { (Limited) } \\
\text { Production } \\
\text { Forest }\end{array}$ \\
\hline $\begin{array}{l}\text { Ecosystem } \\
\text { restoration } \\
\text { concession/ } \\
\text { conservation } \\
\text { concession } \\
\text { (Restorasi } \\
\text { Ekosistem) }\end{array}$ & $\begin{array}{l}\text { Ministerial } \\
\text { Regulation } \\
\text { No. } \\
\text { P.61/Menhut- } \\
\text { II/2008 }\end{array}$ & $\begin{array}{l}\text { Concession for } \\
\text { ecosystem } \\
\text { restoration, for } \\
\text { max } 95 \text { years }\end{array}$ & $\begin{array}{l}\text { Ministry of } \\
\text { Forestry, } \\
\text { provincial } \\
\text { government }\end{array}$ & $\begin{array}{l}\text { Corporate } \\
\text { actors }\end{array}$ & $\begin{array}{l}\text { Production } \\
\text { Forest }\end{array}$ \\
\hline $\begin{array}{l}\text { Demand for } \\
\text { enclave/ release } \\
\text { from forest land }\end{array}$ & $\begin{array}{l}\text { Forest Law } \\
41 / 1999\end{array}$ & $\begin{array}{l}\text { Release from } \\
\text { state forest } \\
\text { (reclassification) }\end{array}$ & $\begin{array}{l}\text { Ministry of } \\
\text { Forestry, } \\
\text { district } \\
\text { government }\end{array}$ & $\begin{array}{l}\text { Local } \\
\text { communities }\end{array}$ & All types \\
\hline
\end{tabular}

Table 7: Land and property rights (de jure)

(Source: cited laws and regulations and Paoli et al. 2013; Rahmina et al. 2011)

\subsection{The formation of resistance movements and alternative scales of meaning and regulation}

Indigenous rights movement and the agrarian movements re-emerged after the fall of Suharto as a response to historical contingent structural marginalization and violence (Peluso, Afiff, and Rachman 2008: 379). Both movements cooperate but are based on fundamentally different ideological foundations. Aliansi Masyrakat Adat Nusantara, (AMAN, Indigenous Rights Movement of the Archipelago) as the largest groups of the indigenous rights movement clearly links land rights to ethnic identity. Agrarian organizations such as Serikat Petani Indonesia (SPI, Indonesian Peasant Union) link land rights to citizenship, to the Indonesian constitution and to rights guaranteed in the Basic Agrarian Law (Peluso, Afiff, and Rachman 2008: 387; Rachman 2011: 104; Tuong 2009: 183). Consequently, both movements refer to different scales, narratives and regulations. AMAN seeks to reestablish different locally and ethnic-specific scales of cultural meaning and scales of land tenure regulation based on preexisting ethnic territories. Agrarian organizations fight for a more social and environmental just national scale of regulation. In practice despite of ideological differences both movements cooperate. For instance, AMAN and SPI jointly called members to vote for President Jokowi in 2014 presidential elections (Alliansi Masyarakat Adat Nusantara (AMAN) Bengkulu 2014). 


\subsubsection{Reemergence of Adat}

After the fall of Suharto indigenous communities in Indonesia, in general known as adat (customary) communities, regained influence. Adat communities and their leaders increasingly started to claim land based on preexisting ancestral lands and preexisting larger adat territories (e.g. Wilayah Adat) (Barr et al. 2006: 2; McCarthy 2005b: 57). Members of the indigenous Batin Sembilan living within and adjacent to the Harapan Rainforest project for instance claim that almost the entire project area had been part of their former customary land ${ }^{117}$. Preexisting adat territories and customary law were also used by district governments to legitimate small scale timber and forest conversion concessions (Barr et al. 2006: 12; Rhee 2009: 46). In many areas a parallel village administration based on customary law appeared. Furthermore, ethnicity became a relevant category for the legitimation of political authority (Rhee 2009: 46). Categories such as putra daerah, literally child of the region became relevant and conflicts especially between migrant groups and the indigenous population spread over the Archipelago (Acciaioli 2001: 87; Rhee 2009: 46). In the Harapan and Berbak landscapes interviewed villagers reported only on smaller ethnic disputes and especially in the Harapan Landscape are interethnic marriages common (Hein 2013b: 17; Hein et al. 2015: 5).

Especially the occupation of state forest or regaining access to state forest was a mean to overcome historical structural injustice and political marginalization starting with Dutch conquest and aggravated during the New Order era (Barr et al. 2006: 2; Peluso, Afiff, and Rachman 2008: 386; Steinebach 2013b: 65). Furthermore, decentralization and shifting boundaries caused by jurisdictional reforms made visible that scales of regulation established by the Dutch colonial government and the Suharto regime did not necessarily fit with pre-existing settlement patterns and customary territories.

The reemergence of adat or in broader terms of ethnicity as mean to claim natural resources did not happen accidently. Decentralization laws such as law 22/1999 explicitly permitted more diverse local administration considering local customs (Moeliono and Dermawan 2006: 115). In 2001 the Indonesian parliament decided that land tenure and natural resource management laws have to "[...] recognize, respect and protect the rights of adat law communities" (Indonesian Supreme Parliament (MPR), cited in McCarthy 2005b: 58). Furthermore, the strong transnational indigenous rights movement and international agreements and conventions such as the Convention 169 of the International Labor Organization (ILO), the Convention on Biological Diversity (CBD) and the following UN Declaration on the Rights of Indigenous People enhanced the political context of adat groups in Indonesia significantly (Bedner and Van Huis 2008: 168-169). Indonesia has not signed the ILO Convention 169 but the

\footnotetext{
${ }^{117}$ Interview with Batin Sembilan leaders, Bungku, 12.09.2012, Document ID: 79, and Tanjung Lebar, 26.07.2013, Document ID: 127.
} 
convention has become increasingly influential since many donor agencies (such as DANIDA) stipulate free and prior informed consent (FPIC) (ibid. 169).

In this dynamic context indigenous groups started to organize and formed associations. Customary communities that have been displaced or dispossessed increasingly started to organize resistance activities and started identifying themselves as indigenous people (Peluso, Afiff, and Rachman 2008: 386). In 1999 approximately 500 indigenous people from different parts of the Archipelago met in Jakarta and founded the nationwide indigenous rights organization AMAN ${ }^{118}$. During their initial congress in 1999 their postulated the slogan: "we will not recognize the Nation, if the Nation does not recognize us" (Li 2001: 645). Today the organization is well integrated in transnational networks and well supported by international donors (Hauser-Schäublin 2013: 10). The organization claims to represent all indigenous communities of the archipelago (Bedner and Van Huis 2008: 167).

REDD+ further strengthen the influence of the organization. AMAN successfully used the current attention towards forests and the dominant public discourse that frames indigenous groups as forest stewards (Sammukri 2013: 121-123). With the support of the Norwegian government and the REDD+ Taskforce AMAN has been involved in a nation-wide mapping of indigenous territories and they participate in the transnational indigenous rights campaign "No Rights No REDD"119 (c.f. Hein and Garrelts 2014: 345).

In 2013 the organization achieved a major success. For achieving recognition of indigenous rights AMAN and partner organizations brought about a decision of the Indonesian Constitutional Court whether the MoF has the legitimacy to control adat forest (Keputusan MK 35/PUU-X-2012). The court strengthened the rights of adat communities vis-à-vis the MoF significantly declaring that adat forest is no longer under the authority of the MoF (Rachman 2013). At the time of writing implementing laws or regulations have not been enacted yet. According to agrarian conflict experts of the Sajogyo Institute the decision is far reaching and has the potential to end criminalization of customary communities but might also increase the probability of ethnic conflicts ${ }^{120}$.

AMAN successfully shifted political struggle on the recognition of indigenous territories from the local scale to the national scale and to the scale of global climate policy - the international climate change conferences. But despite of AMANs claim to represent customary communities across the archipelago and its commitment to self-identification the organization uses criteria and verification mechanism for accepting members. An AMAN activist responded to the question if any community that identifies itself

\footnotetext{
${ }^{118}$ Interview with AMAN activist, Jakarta, 27.07.2012, Document ID: 92.

${ }^{119}$ Interview with AMAN activist, Jakarta, 27.07.2012, Document ID: 92.

120 Interviews with staff member of the Sajogyo Institute, Bogor, 13.08.2013, Document ID: 155 and Bogor, 08.10.2013, Document ID: 193.
} 
as indigenous could be member as follows: "[...] yes, but they have to get a recommendation of other communities which know them and we [AMAN] have our own criteria and verification mechanism, before we accept new members ${ }^{121 "}$. Not all ethnic groups are members of AMAN and not all local communities were able to mobilize collective action, to establish links to NGOs and to benefit from the indigenous rights discourse. For instance AMAN is not fully recognizing territorial claims of the Batin Sembilan in the Harapan Landscape ${ }^{122}$.

\subsubsection{Re-emergence of the Agrarian Movement}

Contemporary agrarian organizations in Indonesia have their historic roots in different left-wing organizations formed after independence. The Indonesian Peasant Front (Barisan Tani Indonesia, BTI) for instance was formed in 1945 and was involved in land occupations on Java, Bali and Sumatra after independence (Peluso, Afiff, and Rachman 2008: 381; Tuong 2009: 181). During the New Order any resistance against national land allocation policies was suppressed using police and military force. Hundred thousand of BTI activists and members of Indonesia's Communist Party (Partai Komunis Indonesia) have been killed in the massacres of the 1960s. Consequently, any open peasant resistance came to an end (Peluso, Afiff, and Rachman 2008: 382).

First new underground movements came up in the early 1990s (Peluso, Afiff, and Rachman 2008: 387). Some cooperated with the environmental justice movement WALHI (Wahana Lingkungan Hidup Indonesia) and with Indonesian Legal Aid Foundation. Both organizations had been tolerated by the Suharto Regime and were able to start first multi-scalar campaigns through supporting local farmers and criticizing that the Basic Agrarian Law has not been implemented (ibid. 384-387). Directly after Suharto's fall landless people and smallholder occupied state forest and plantation estates (Peluso, Afiff, and Rachman 2008: 388; Tuong 2009: 182). Peasant and agrarian reform organizations reemerged in the late 1990s. The probably most influential ones are Serikat Petani Indonesia (SPI, Indonesian Peasant Union) and Konsortium Pembaruan Agraria (KPA, Consortium for Agrarian Reform $\left.^{123}\right)$. Both organizations share the same political views but KPA is rather urban-based and SPI has a stronger rural basis (Tuong 2009: 183).

SPI has been formed in North Sumatra by peasant activists started to organize in the late 1990s. Since 2003, SPI is member of the global peasant organization La Via Campesina. In early years SPI was mainly involved in advocacy work for peasant farmers, landless peasant and peasants negatively affected by activities of agribusinesses and state agencies (Purwanto 2013: 1). From the very beginning the

\footnotetext{
${ }^{121}$ Interview with AMAN activist, Jakarta, 27.07.2012, Document ID: 92.

${ }^{122}$ Interview with AMAN activist, Jambi, 02.08.2013, Document ID: 142.

${ }^{123}$ For more detailed information on KPA please consider Rachman, 2011.
} 
organization used the basic agrarian law as the legal basis for is campaigns (ibid. 2). SPI considers the law "[...] as a progressive law aiming to redress the unfair distribution of agrarian and economic resources [...]" (Purwanto 2013: 2).

SPI considers itself as anti-capitalistic organization arguing for a socially inclusive land, natural resource and trade policy (Tuong 2009: 182). At the global level the organization campaigns for fair north-south relations, food sovereignty and climate justice (Tuong 2009: 185; Purwanto 2013: 2; Hein and Faust 2014: 23). For reaching its goals SPI is organizing mass protests against state agencies and companies and is conducting land occupations (Purwanto 2013: 2). SPI not only campaigns for a land reform, through allocating occupied land to landless farmers they conduct to some extend their own informal land reform. At the global scale SPI is in most cases represented by La Via Campesina. Both organizations are organizing protests against forest carbon offsetting and REDD+ in the context of international climate change conferences (Hein and Faust 2014: 25).

SPI claims to be a community-based organization. SPI is funded by its members. The internal administration of the organization corresponds to the hierarchical Indonesian administrative system. In villages with more than 25 SPI members the organization establishes a basis. A basis is the smallest organizational unit led by an elected head. The elected head (ketua basis) represents the basis at the ranting, which is a roundtable where all ketua basis of the sub-district meet. The elected head of the ranting represents the organization at the district level. Central decision making bodies are the regional and national conferences. Decisions made at the national level are communicate as recommendations to the lower levels ${ }^{124}$.

In Jambi the organization has currently 15.000 to 20.000 members and operates in eight districts. In the Harapan Rainforest SPI members are involved in land occupations. SPI is also supporting farmers in a land conflict in the Kerinci National Park. 3200 famers are involved in forest conversion and land occupation (Tambunan 2015; Serikat Petani Indonesia 2012). More details on the SPIs activities in the Harapan Landscape and their role within the conflict with PT REKI will be given in chapter six and seven.

\subsubsection{Concluding remarks on peasant and indigenous rights movements.}

AMAN and SPI have been quite successful in challenging the state and its apparatuses. They benefitted from the regime change end of the 1990s and have probably contributed to the regime change, but that is beyond the scope of this study. Political turmoil and regime change reduced the power of the central state over sub-national public authorities, peasants and indigenous groups. AMAN, SPI and

\footnotetext{
${ }^{124}$ Interview with SPI activist in Jakarta, 20.06.2013, Document ID: 104 and with SPI activist in Jambi, 12.07.2013, Document ID: 140.
} 
other peasant organizations were able to develop counter narratives which were able to challenge the development narratives of the New Order era. In Lukes and Gaventas terms, they were able to challenge invisible power. Furthermore, they were able to mobilize communities across the Archipelago. In 2012, 1992 indigenous communities were members of AMAN (Alliansi Masyarakat Adat Nusantara (AMAN) 2015). SPI is now present in 14 Indonesian provinces ${ }^{125}$. Hence, both organizations have developed a remarkable organizational strength and are able to challenge visible power of state apparatuses such as the MoF. Furthermore, they have proofed to be able to jump scales and to expand political struggle from the individual household scale of their members to the national (e.g. constitutional court) and to the global scale (e.g. no rights no REDD+ campaign) (Alliansi Masyarakat Adat Nusantara (AMAN) 2015; Purwanto 2013).

\subsection{The province of Jambi: shifting scales of meaning and regulation inscribed in two frontier landscapes}

\subsubsection{A brief history of Jambi}

In pre-colonial times Jambi was one of a number of Sultanates on the island of Sumatra. Jambi's location close to the Strait of Malacca and the natural resources in its hinterland provided the basis for Jambi's ascent and its early involvement in international trade (Guillaud 1994: 114). In the $18^{\text {th }}$ century Jambi was one of the most prosperous trade ports on Sumatra (Guillaud 1994: 114; Locher-Scholten 2004: 39). Forest products such as beeswax, resin, gum, rattan, and timber were collected in the hinterlands and transported via the Batang Hari River and the Strait of Malacca to the outside world (Locher-Scholten 2004: 37). In the $19^{\text {th }}$ century pepper and gold became important export products and Singapore became the most important trading partner of the Sultanate (Locher-Scholten 2004: 42).

In 1852, Jambi had approximately 60.000 inhabitants (ibid. 36). Most of the settlements were located close to rivers. Rivers were the main transport hubs of the Sultanate (Locher-Scholten 2004: 36; Steinebach 2013a: 105). The population of the Sultanate of Jambi was in contrast to other Sumatran Sultanates relatively heterogeneous. The Malay population lived mainly on river banks of the Batang Hari River. The semi-nomadic Orang Laut lived along the coast (Locher-Scholten 2004: 48). Jambi's hinterland was home to different nomadic and semi-nomadic ethnic groups. The Orang Rimba lived in

\footnotetext{
${ }^{125}$ Interview with SPI activist in Jakarta, 20.06.2013, Document ID: 104 and with SPI activist in Jambi, 12.07.2013, Document ID: 140.
} 
the Bukit Duabelas Region. Batin ${ }^{126}$ and $K u b u^{127}$ tribes settled in the upper courses of the main rivers and in the borderlands between Jambi and Palembang along Batang Hari and Musi River tributaries (Andaya 2008: 205; Locher-Scholten 2004: 37; Steinebach 2013a: 126).

Elisabeth Locher-Scholten (2004: 45) describes the pre-colonial Malay state of Jambi (the Sultanate) as a state without "[...] precise borders or a powerful central authority, their central government had no monopoly on the use of force, their rulers had no well-defined constitutional powers, and there was not a trace of popular sovereignty". The pre-colonial Sultanate had nothing in common with modern Western states the "[...] ruler was more fluid in terms of territory and structure, and sacral and symbolic in nature" (ibid. 45). Successful ruling was a result of balancing earth and divine and was indicated through wealth and prosperity. The Sultan was in formal terms the highest authority of the state but he ceded most of his tasks to the pangeran ratu ${ }^{128}$, to ministers and to a council of nobles (ibid.).

Jambi's Sultanate had not a uniform administrative structure as modern Western states have. Jambi administration reflected its heterogeneous population (Locher-Scholten 2004: 48-49). In general, the Sultanate was divided into different jurisdictions called Kalbu. Each Kalbu consisted of a number of settlements called dusuns (hamlets) (Hidayat 2012: 29). But the Sultan had only direct authority over the Malay population. The Malay population had no tax obligations but were responsible for law and order and for the security of the Sultan. The Batin had to pay taxes and were responsible for border protection but were relatively independent from the Sultanate. The Batin had their own leaders ruling over their hamlets and over the surrounding forests (ibid.). Orang Laut and the Kubu were not under the authority of the Sultan (ibid.).

At the beginning of the $20^{\text {th }}$ century, the Dutch took control (Locher-Scholten 2004: 226; Steinebach 2013a: 108) and established a new uniform administrative structure with new jurisdictional boundaries (Sevin and Benoît 1993: 97; Steinebach 2013a: 108-109). In 1906 colonial authorities divided Jambi into 83 margas. Margas had the characteristics of today's sub-districts (kecamatan) and consisted of a number of hamlets (Sevin and Benoît 1993: 97; Steinebach 2013a: 108-109). The Margas were led by a Pasirah which was installed by the colonial administration. The Dutch not only changed the territorial structure they also introduced rubber and started oil drilling close to present day Bungku village.

\footnotetext{
${ }^{126}$ In other sources the term Batin refers to the leader of semi-nomadic non-muslim forest dwellers and not to a specific ethnic group (Andaya 1993: 14).

$127 \mathrm{Kubu}$ is derogatory term for many non-Muslim nomadic and semi-nomadic tribes used by the Malay population and colonial authorities on Sumatra.

${ }^{128}$ The pangeran ratu was chosen by nobles and was in charge of most government affairs (Locher-Scholten 2004: 45).
} 
Rubber became one of most important agricultural commodities of the province during the $20^{\text {th }}$ century.

After independence Jambi became initially part of a newly formed province of Central Sumatra consisting of West Sumatra, Riau and Jambi (Dinas Komunikas dan Informatika Provinsi Jambi 2013). In 1957 Jambi became an autonomous province. One year later Batang Hari, Merangin and the city of Jambi became districts (ibid.). Today the province consists of 9 districts and two cities. In one of the most recent administrative reforms in 1999 the district of Batang Hari has been divided. The northeastern parts of Batang Hari located close to the provincial capital of Jambi city became the independent district of Muaro Jambi with Kota Sengeti as its capital (Pemerintah Kabupaten Batang Hari 2012). The south-western part form the present district of Batang Hari. The border between the two districts remains contested. A number of hamlets of the village of Tanjung Lebar (which is part of Muaro Jambi) such as Sungai Beruang, Tanjung Mandiri and Pangkalan Ranjau remain part of Tanjung Lebar but are at the same time located within the official boundaries of the district of Batang Hari. The contested border between the two districts runs through the Harapan Rainforest project adding an additional dimension to the ongoing conflicts on access and control of the project area.

\subsubsection{Harapan landscape, the Batin Sembilan and processes of dispossession ${ }^{129}$}

In pre-colonial times, the Harapan Landscape has been the home of semi-nomadic Batin and Kubu tribes (Andaya 2008: 205; Hagen 1908: 19-20; Hein et al. 2015: 5). Leonard Y. Andaya (2008: 205) describes the Batin of the landscapes between Batang Hari and Musi Rivers "[...] as collectors of forest products for former Malayu Kingdoms, they filled a complementary niche that helped them to maintain a distinctive lifestyle and ethnic identity". According to colonial sources interethnic marriages between Batin and Malay were common and many Batin increasingly adopted the Jambi Malay language, lifestyle and religion during the colonial period (Andaya 2008: 205). Today most Batin Sembilan speak Malay and describe themselves as Muslims.

The Batin Sembilan groups living in the border land between Jambi and South Sumatra trace their origins back to these groups (Hein et al. 2015: 5; Steinebach 2013b: 71). The Batin Sembilan settlements of Tanjung Lebar village especially of the hamlets of Pangkalan Ranjau, (Hagen 1908) and Sungai Beruang ${ }^{130}$ confirm their pre-colonial presence in the area (table 8 lists other pre-colonial

\footnotetext{
${ }^{129}$ Parts of this section have been published in Hein et al. (2015) "Rescaling of access and property relations in a frontier landscape: insights from Jambi, Indonesia", The Professional Geographer.

${ }^{130}$ Interviews with key informants in Tanjung Lebar, 25.07.2013, Document ID: 176, 26.07.2013, Document ID: 125.
} 
settlements). The villages of Tanjung Lebar and the neighboring village of Markanding ${ }^{131}$ were the oldest settlements in the Harapan Landscape, explained a Batin Sembilan elder ${ }^{132}$. The settlements were cultural and socio-economic centers of the Batin Sembilan. During the year the Batin Sembilan stayed alternately in the settlements or in the forest shelters for hunting, gathering of forest products, taking care of fruit trees and for shifting cultivation practices (Hidayat 2012: 49).

The Batin Sembilan share a common myth of origin. According to their myth of origin they descend from nine sons of a legendary noble named Raden Nagosari. Each son settled on the shores of nine rivers (Bulian, Bahar, Jebak, Jangga, Pemusiran, Burung Antu, Telisak, Sekamis, Singoan) in the borderland between the Sultanates of Jambi and Palembang (c.f. Hidayat 2012: 3 ) 133 134. This myth of origin is reflected in the former and at least in part still relevant socio-spatial organization of the different lineages of the Batin Sembilan. In pre-colonial and colonial times different lineages of the Batin Sembilan controlled forests in the upper water-sheds of the Bulian, Bahar, and Lalang rivers (Figure $7 / A)^{135}$. Each lineage controlled the forests in a sub-watershed, permitting only members to establish fruit gardens and dry rice fields ${ }^{136}$ (c.f. Hein et al. 2015: 5). Access to land was regulated by customary law (adat).Today different lineages and sub-lineages of the Batin Sembilan still refer to rivers for explaining and legitimizing the borders of their ethnic territories (table 8).

\begin{tabular}{|l|l|l|}
\hline $\begin{array}{l}\text { Name of Batin sub-group } \\
\text { and river name }\end{array}$ & Old settlement & Official villages \\
\hline Bulian (Sungai Bulian) & Dusun Singkawang & $\begin{array}{l}\text { Kel. Bulian, Kel. Sridadi, Kel. Pasar, } \\
\text { Kilangan, Singkawang, Sungkai, Kel. } \\
\text { Bajubang, Petajin, Batin }\end{array}$ \\
\hline Bahar (Sungai Bahar) & $\begin{array}{l}\text { Dusun Pinang Tinggi, Dusun } \\
\text { Padang Salak, Susun Tanah } \\
\text { Menang, Dusun Mengkanding, } \\
\text { Dusun Tanjung Lebar }\end{array}$ & $\begin{array}{l}\text { Pelembang, Nyogan, Tanjung Lebar, } \\
\text { Tanjung Pauh Illir, Ladang Peris, Sungai } \\
\text { Landai, Dusun Baru, Bungku, and } \\
\text { transmigration villages in the Kec. Sungai } \\
\text { Bahar and Bahar Selatan }\end{array}$ \\
\hline \multicolumn{2}{|l|}{ Other sub-groups: Jebak, Pemusiran, Singoan, Jangga, Burung Antu, Sekamis, Telisak } \\
\hline
\end{tabular}

Table 8: Lineages of the Batin Sembilan and their settlements

(Source: Hidayat 2012: 33)

The traditional leader-ship structure of the Batin Sembilan and their socio-spatial organization has been transformed and overlaid by colonial and post-colonial administrative and jurisdictional reforms.

\footnotetext{
${ }^{131}$ The village of Markanding is part of the sub-district of Sungai Bahar, it is located approximately $10 \mathrm{~km}$ northeast of Bungku.

${ }^{132}$ Interview with key informant in Tanjung Lebar, 26.07.2013, Document ID: 125.

${ }^{133}$ According to Hidayat (2012: 20-27) at least two other version of a myth of origin of the Batin Sembilan exist, the second argues that the Batin Sembilan descent from leader from Palembang (South Sumatra) and the third consist of elements of the first and the second myth.

${ }^{134}$ Interview with key informant in Bungku, 12.09.2012, Document ID: 87.

135 Interview with key informants in Bungku, 12.09.2012, Document ID: 87 and in Tanjung Lebar, 23.07.2013, Document ID: 171.

${ }^{136}$ Interview with key informant in Bungku, 12.09.2012, Document ID: 87.
} 
In the villages of Bungku and Tanjung Lebar much of the knowledge on traditional authorities and on the traditional socio-spatial organization seemed to be lost. The remaining information on the role of traditional authorities and on the hierarchy of authorities is rather contradictive. Rian Hidayat (2012: 71) argues that the Depati was the highest authority of the Batin Sembilan during the Sultanate governing a dusun (hamlet). A Batin Sembilan leader in Tanjung Lebar argued that the Temenggung ${ }^{137}$ was the highest authority in a dusun positioned above the Depati ${ }^{138}$. The Temenggung was a cultural and political leader responsible for conflict mediation ${ }^{139}$. Other key informants argued in line with Hidayat, or they did not know a Depati at all or explained that the Depati was called Mangku in the settlements of the Harapan Landscape.

In the early 20th century, the Dutch took control, introduced rubber cultivation, started oil drilling in the Harapan Landscape and imposed new jurisdictions (Figure 7/A) (Hein et al. 2015: 5; Sevin and Benoît 1993: 97). As described earlier in this chapter, the Dutch introduced the administrative system of Palembang and established the Pasirah as a new authority governing a Marga and holding the authority to allocate land. The Harapan Landscape became part of the Marga of Pemajoeng Hoeloe and first roads were built linking the region with Jambi city (Tidemann 1938: 251). The Dutch colonial administration also sought to settle and to "civilize" the native population, therefore challenging the watershed as a relevant scale of regulation (Hagen 1908: 17; Steinebach 2013b: 72; Hein et al. 2015: 5). Colonial authorities also established a first conservation area for watershed protection northwest of the main road of present days Bungku village (Pemerintah Kabupaten Batang Hari 2010: 8). Today the area is designated as forest reserve and managed by the District Forest Agency (TAHURA Sultan Thaha Syaifuddin, sometimes also called TAHURA Senami).

After independence, the region remained first relatively stable. Fundamental transformation processes have been introduced by Colonel Suharto's autocratic New Order regime (1967-1998). The New Order government nationalized and privatized forest management in the 1970s and 1980s. Almost the entire region was classified as state forest area (Figure 7/B) (Hein et al. 2015: 5). To fight "backwardness" and "unproductiveness,", in other words for promoting "development" the central government allocated large forest areas claimed by the Batin Sembilan to logging in the 1970s and in the 1980s to oil palm companies (Figure 6). In the 1970s the Harapan Landscape was divided into three corporate logging concession. The southern part was assigned to PT Asialog, the northern part to PT

\footnotetext{
${ }^{137}$ The position of the Temenggung existed among the Orang Rimba of the Dua Belas Landscape, in how far the position of the Temenggung was known among the Batin Sembilan in colonial and pre-colonial times is at least debatable argues Steinebach (forthcoming). Probably, the Batin Sembilan only very recently started to call their leaders Temenggung.
} 
Tanjung ASA and the eastern part to PT Suka Rimba Raya (Badan Inventarisasi dan Tata Guna Hutan n.a.). The classification of the area as state forest and the allocation of forest land to logging companies illegalized the settlements and livelihood practices of the Batin Sembilan and led to de jure dispossession of the Batin Sembilan. De facto were many Batin Sembilan groups still able to practice shifting cultivation and domestic logging was tolerated but the companies restricted access to the concession for non-local groups ${ }^{140}$. A Batin Sembilan leader in Bungku even argued that the logging company PT Asialog accepted the land rights of the Batin Sembilan ${ }^{141}$. However, some Batin Sembilan had other experiences with the company and reported that shifting cultivation and crop cultivation were not allowed ${ }^{142}$ within PT Asialog's concession and first conflicts especially between Batin Sembilan and the PT Asialog have also been reported e.g. when staff of the company logged fruit trees of the Batin Sembilan ${ }^{143}$.

Furthermore, law No. 05/1979 on village governance imposed the Javanese village administration and jurisdictional system and established villages (desa), hamlets (dusun), and neighborhoods (rukun tetangga) as new scales of regulation (c.f. section 5.1.3 and Hein et al. 2015). The foundation of Bungku village for instance and the establishment of new jurisdictional boundaries between the villages superimposed the scales of regulation established by lineages of the Batin Sembilan and ignored the previous separation of various lineages living along the rivers of the Bulian River watershed (Batin Bulian) and those living along rivers of the Bahar and Lalang River watersheds (Batin Bahar) (c.f. Hidayat 2012: 28).

In the 1980s and early 1990s the allocation of large-scale oil palm concessions and the development of the state-sponsored transmigration resettlement scheme induced the most disruptive transformation process. The vast logging concession still provided the possibility for co-existence of commercial large-scale resource extraction and for the livelihood patterns of the Batin Sembilan. In 1980s a number of transmigration settlements have been established in the northern Harapan Landscape. Through the transmigration program land was allocated to Javanese farmers acting as out growers for the state-owned oil palm plantation company PT Perkebunan Nusantara VI (PTPNVI). Only very few Batin Sembilan were able to participate in the program and many of them had difficulties to earn a living in the settlements and moved back to their traditional settlements ${ }^{144}$. In 1986 (Figure 6) the establishment of the 20.000ha oil palm estate of PT Bangun Desa Utama (PT BDU), today named

\footnotetext{
${ }^{140}$ Interview with key informant, Bungku, 21.09.2012, Document ID: 76.

${ }^{141}$ Interview with key informant, Bungku, 12.09.2012, Document ID: 79.

${ }^{142}$ According to the forest laws shifting cultivation is prohibited within state forest.

${ }^{143}$ Interview with key informants, Bungku, 12.09.2012, Document ID: 87 and Tanjung Lebar, 21.07.2013, Document ID: 162.

${ }^{144}$ Interviews with key informants, Tanjung Lebar, 25.07.2013, Document ID: 125, Tanjung Lebar, 25.07.2013, Document ID: 124.
} 
as PT Asiatic Persada, led to the displacement of many Batin Sembilan and to a still unsolved violent land conflict (c.f. Steinebach 2013b; Beckert, Dittrich, and Adiwibowo 2014). The new transmigration settlements and the plantation estates led to the fragmentation of the customary land of the Batin Sembilan and especially of the territory claimed by the village elites of Tanjung Lebar. Today Tanjung Lebar has no contiguous village territory, its five hamlets are scattered over the northern Harapan Landscape. Settlement policies for Batin Sembilan groups ${ }^{145}$, such as the program for "underdeveloped villages" (Impress Desa Tertinggal), provided no or only very limited land for agriculture. ${ }^{146}$

Following regime change in 1998 political turmoil, decentralization, and democratization induced the most recent and conflictive rescaling processes that have been ongoing in the region (c.f. Hein et al. 2015). District heads (Bupati), village heads (Kepala Desa), and customary leaders took advantage of the political vacuum, interpreting the reforms to their advantage and asserting far-reaching administrative authority over forests (Barr et al. 2006: 2; Hein et al. 2015: 5). Within the areas in and around today's Harapan Rainforest, Batin Sembilan increasingly started to accentuate their social identity as an indigenous group. Hidayat (2012: 3) argues that the active reconstruction of the ethnic identity of the Batin Sembilan should be considered as a process of resistance against the fact that their rights to land and natural resources have been neglected especially by the New Order regime. Furthermore, customary leaders of the Batin Sembilan began using their agency for reestablishing their former customary land as a relevant scale of meaning and regulation (Hein et al. 2015: 5-6). Batin Sembilan elites started to collaborate with peasant organizations such as SPI and - with mainly Javese migrants- adopted their land-use practices (e.g., oil palm cultivation) and began allocating the forests of the 67,000 ha concession of PT Asialog (abandoned since 2003; Figure $7 / \mathrm{C}$ ) to arriving migrants (in detail in section 6.3.3). Interethnic marriages between Batin Sembilan and migrants gained importance as strategic alliances (Hein et al. 2015: 5). They enhanced the social status of the indigenous Batin Sembilan and provided migrants access to land, timber and non-timber forest products within the state forest. The assigning of land to migrants can be considered as socio-spatial resistance strategy of the Batin Sembilan elite to regain authority over state forest land lost during the New Order period and for reestablishing their customary land claims within the state forest (Hein et al. 2015: 5-6). Leaders of the formal village governments - in most cases Batin Sembilan or individuals with strong kin-ties to Batin Sembilan - legitimated the land transactions by allocating forest conversion permits and villagescale land titles (ibid.). In 2010 the MoF challenged land allocation of village and customary authorities and turned the abandoned logging concession of PT Asialog into a conservation concession ignoring

\footnotetext{
${ }^{145}$ Interview with key informants in Bungku, 08.09.2012, Document ID: 77 and in Tanjung Lebar, 27.07.2013, Document ID: 113, 127.

${ }^{146}$ Interview with key informants in Bungku, 08.09.2012, Document ID: 77 and in Tanjung Lebar, 27.07.2013, Document ID: 113, 127.
} 
the existence of settlements and farmland and assigned the area to the conservation company PT REKI

(Figures $7 / C, D$, ) (ibid.). The land conflicts emerging in the context of the implementation of the conservation concessions are described in chapter seven. 
Figure 6: Map of the planned concession of PT BDU/ PT Asiatic Persada and adjacent logging concessions in the 1980s (Source: Badan Inventarisasi dan Tata Guna Hutan n.a.)

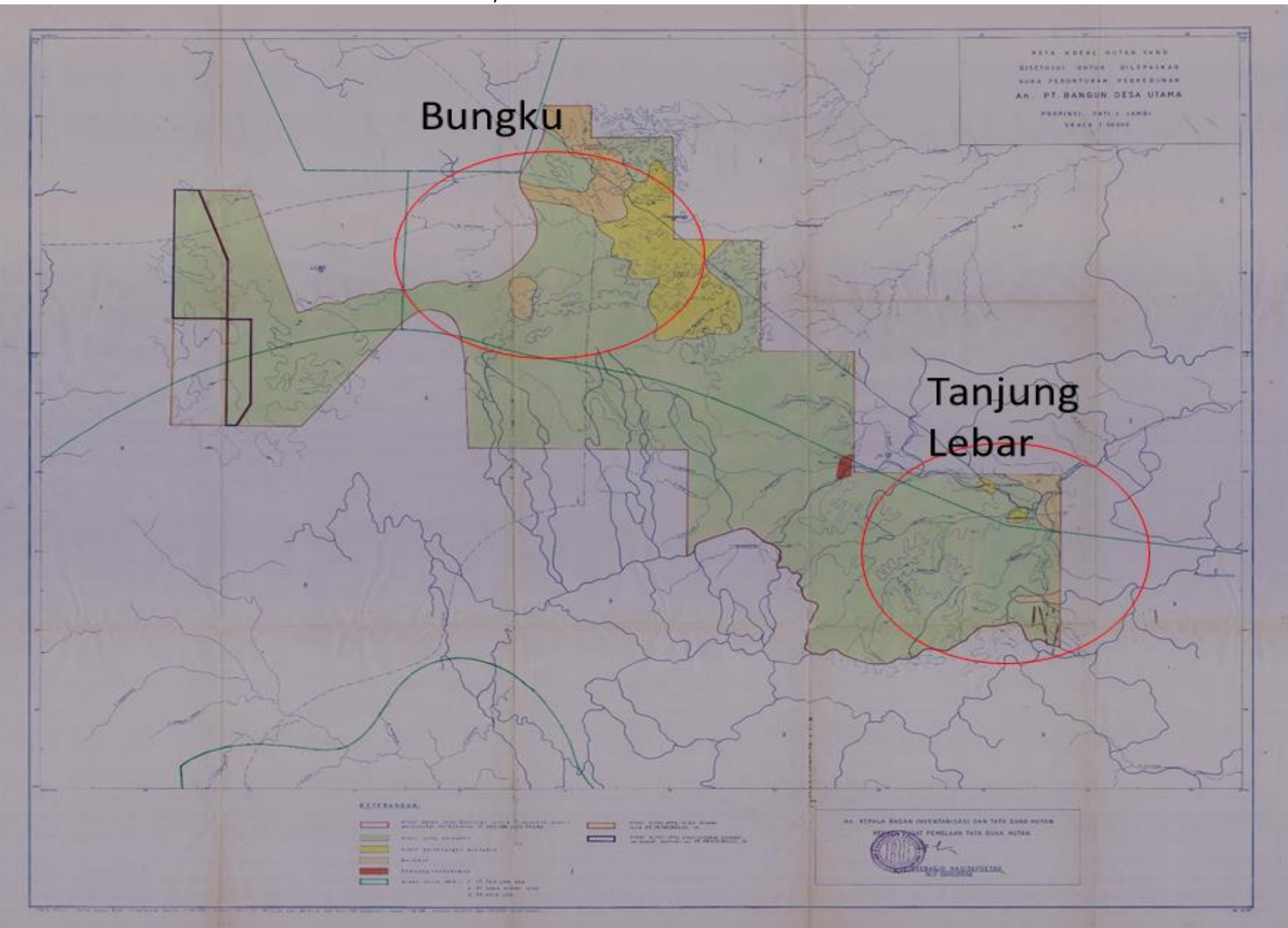


Figure 7: Different thematic maps of the Harapan Rainforest and its surroundings (Source: Hein et al. 2015: 4)

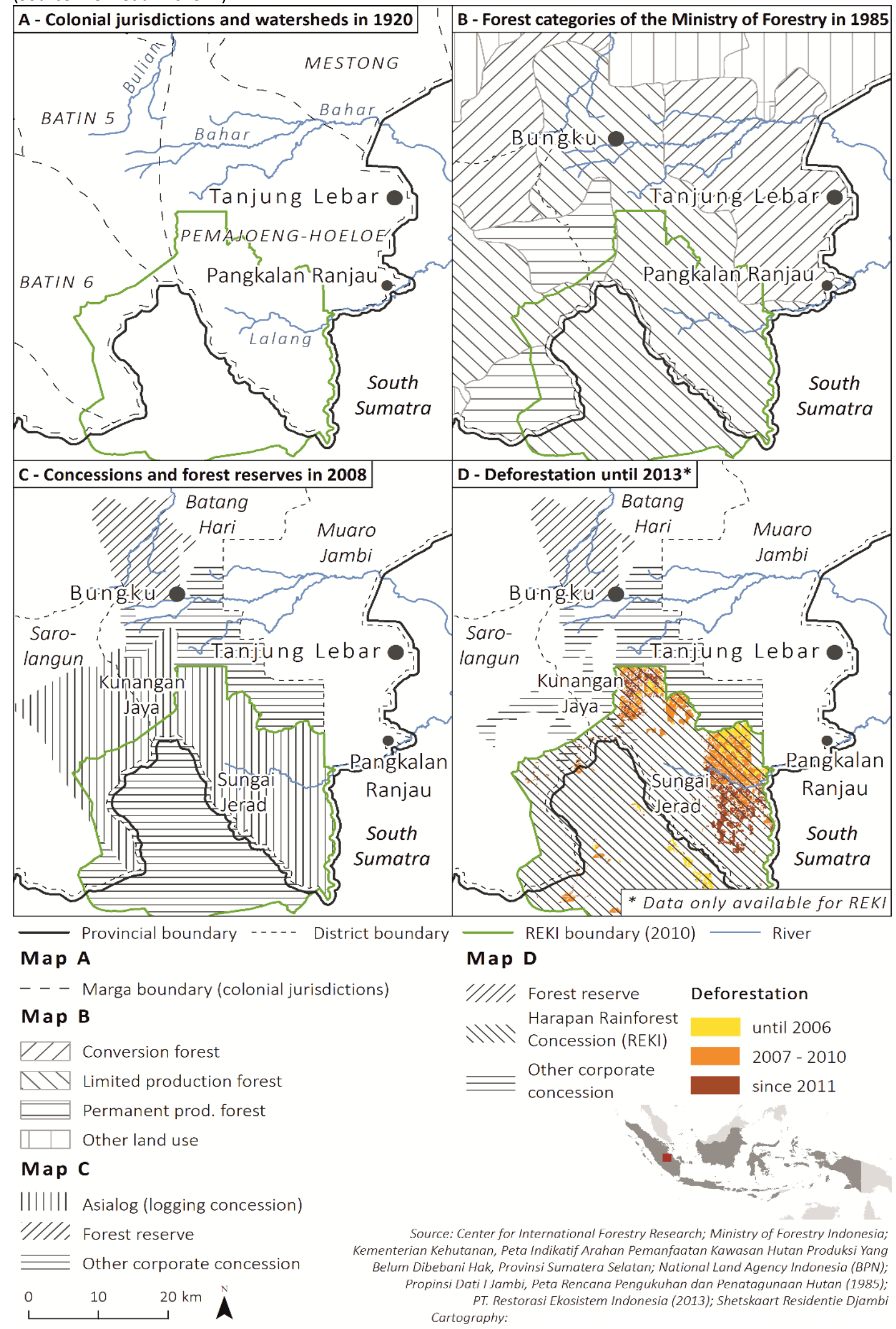




\subsubsection{Berbak landscape: in-migration, drainage and logging}

The Berbak landscape was sparsely populated until the beginning of the 20th century (Sevin and Benoît 1993: 95). A few small Malay settlements existed on the river banks of the lower Batang Hari River (Claridge 1994: 290; Sevin and Benoît 1993: 97). The coastal part of the region was home for Orang Laut tribes which were mainly involved in trading, fishing and piracy (Andaya 2008: 182; LocherScholten 2004: 58). The Malay villages in the delta consisted only of a few houses and interaction between the villages was limited (Sevin and Benoît 1993: 97). However, in contrast to the Batin people of Jambi's hinterland the Malay settlements were under the full authority of the Sultanate (LocherScholten 2004: 48). The villages of Seponjen and Sungai Air are probably pre-colonial Malay foundations ${ }^{147}$.

The influence of the colonial administration was relatively strong. A first colonial trade and military post dating back to the $17^{\text {th }}$ century (Tidemann 1938: 337) was located at the river banks of the Batang Hari River. The Berbak delta was even a target location for the colonial resettlement project Kolonosatie that started in 1905 (Sevin and Benoît 1993: 104). As in the Harapan Landscape the Dutch divided the landscape into Marga's led by a Pasirah (ibid. 97). The area of today's Air Hitam Laut was part of the Marga Berbak, Seponjen was part of the Marga Kompoe-Hilir and Sungai Aur of the Marga Djeboes (Tidemann 1938: 251). In 1935 the Berbak Wildreservaat as a precursor of the Berbak National Park was established by Dutch colonial authorities (Claridge 1994: 288). The protected area covered an area of 190.000 ha of peat swamp and mangrove forests (Balai Taman Nasional Berbak 2013).

In the 19th century Sumatra's east coast become a popular destination for Banjar from East Kalimantan and for Bugis from South Sulawesi (Benoit and Sevin 1993: 257). Banjar people were experienced hydraulic engineers having converted and drained peat swamp forest for crop production already in their areas of origin in East Kalimantan (Galudra et al. 2014: 722). They were active in the northern part of Jambi's coast. Bugi immigration intensified during a period of violence in South Sulawesi in the 1959s and 1960s. The Bugis adopted the drainage techniques of the Banjar engaged with local political authorities for accessing land and started peat conversion and settlement projects along the coast and in the Batang Hari delta. (Claridge 1994: 290; Sevin and Benoît 1993: 102).

More profound changes of landscape and socio-spatial organization started in 1960 and intensified during the New Order era. Transmigrants and the continuing influx of spontaneous migrants from Java and South Sulawesi induced rapid population growth in the Berbak Landscape (Claridge 1994: 292).

\footnotetext{
${ }^{147}$ Interview with key informants, Seponjen, 08.09.2013, Document ID: 175 and Sungai Aur, 30.08.2013, Document ID: 126.
} 
The village of Air Hitam Laut for instance has been founded by Bugi seafarers from the Luwu district in South Sulawesi in $1965^{148},{ }^{149}$.

The villages of Sungai Aur and Seponjen remained relatively stable until the 1990s. The Malay lived mainly from fishing, gathering of non-timber forest products (especially tapping of Dyera costulata, syn. D. laxiflora and gathering of rattan), rubber and fruit tree cultivation. The settlements and the fruit tree and rubber gardens were located on the higher alluvial deposits; the lower marshes were covered by peat swamp forests. Small areas were used for wet rice cultivation. In 1985 the MoF released large state forest areas on both sides of the Batang Hari River and of the Kumpeh River (which is a river arm of the Batang Hari) permitting the expansion of agricultural production (Badan Inventarisasi dan Tata Guna Hutan 1985). Yet the exact borders of the reclassified area remained unclear and a map of the MoF from 1993 indicates that at least parts of the released land were again reclassified to state forest despite of ongoing activities of the local population (e.g. logging and gathering of rattan). The forests east of the villages were designate as a forest reserve (TAHURA Sekitar Tanjung) (Badan Inventarisasi dan Tata Guna Hutan 1993). Few years later, in 1997 the Hutan Suaka Alam (former Wildreservaat) became the Berbak National Park, but the size of the protected area was reduced by almost 30.000 ha to 162.700 ha (Balai Taman Nasional Berbak 2013).

In Seponjen first larger forest conversion activities started in the 1990s. In 1992 Pak Hadji Pattimura ${ }^{150}$ a Jambi based business men born in the village of Seponjen received a forest conversion permit from the district government of Batang Hari (Izin dari Kabupaten Batang Hari Nomor: 593.3/5567/pem.tgl 22 desember 1992). In the following years a number of organized forest conversion, drainage and settlement projects were conducted in the lower and flood prone peat swaps, some of them overlapped with the borders of the forest reserve TAHURA Sekitar Tanjung. The largest of the forest conversion project started in 1997 and provided land for Bugi migrants (more details in section 6.3.4.1 $)^{151}$. Today the settlement is one of three hamlets of Seponjen. The hamlet is colloquially called dusun Bugis. In Sungai Aur village expansion started in the 2000s with the formation of the settlement Ketapang. The settlement has 500 ha agricultural land which was mostly sold to Javanese secondgeneration transmigrants from the northern Batang Hari delta.

The 1990s and the early 2000s saw an unprecedented logging boom in the Berbak Landscape. In Seponjen and Sungai Aur this was first partly induced by forest conversion associated with the

\footnotetext{
${ }^{148}$ Interview with key informant in Air Hitam Laut, 28.09.2012, Document ID: 51.

${ }^{149}$ Bugi migrants have conducted larger scale land drainage across Sumatra's east coast. According to Hanson and Koesoebione (1979, cited in Claridge 2004: 292) have Bugis converted as much forest as the government ledinitiatives in the period from 1969-1973.

150 fictitious name

${ }^{151}$ Interviews with key informants in Seponjen, 11.09.2013, Document ID: 174 and 13.09.2013, Document ID: 122 and 15.09.2013, Document ID: 317.
} 
settlement projects ${ }^{152}$. Later logging took also place within the forest reserve and the national park ${ }^{153}$. After the fall of Suharto, in the late 1990s and in the early 2000s villagers in Sungai Aur and Seponjen were able to receive IPKR's (small scale logging permits) issued by the Bupati of the district of Muaro Jambi ${ }^{154}$. Villagers in Seponjen had cooperative logging permits and formed logging groups that consisted of up to 10 individuals ${ }^{155}$. Logging occurred outside and within the state forest. In both villages logging was a very significant income source which attracted migrants and which led to the establishment of sawmills. In 2005, three years after the enactment of regulation 34/2002 that prohibited logging permits issued by district authorities' large anti-logging raids by the forest police stopped most commercial logging activities in the villages ${ }^{156}$. Anyhow, since approximately 2011 logging regained importance. At the time of field research in 2013 ships were produced in Sungai Aur. The shipyards (Figure 8) were owned by Bugis and according to key informants they used timber from the national park and from the forest reserve ${ }^{157}$.

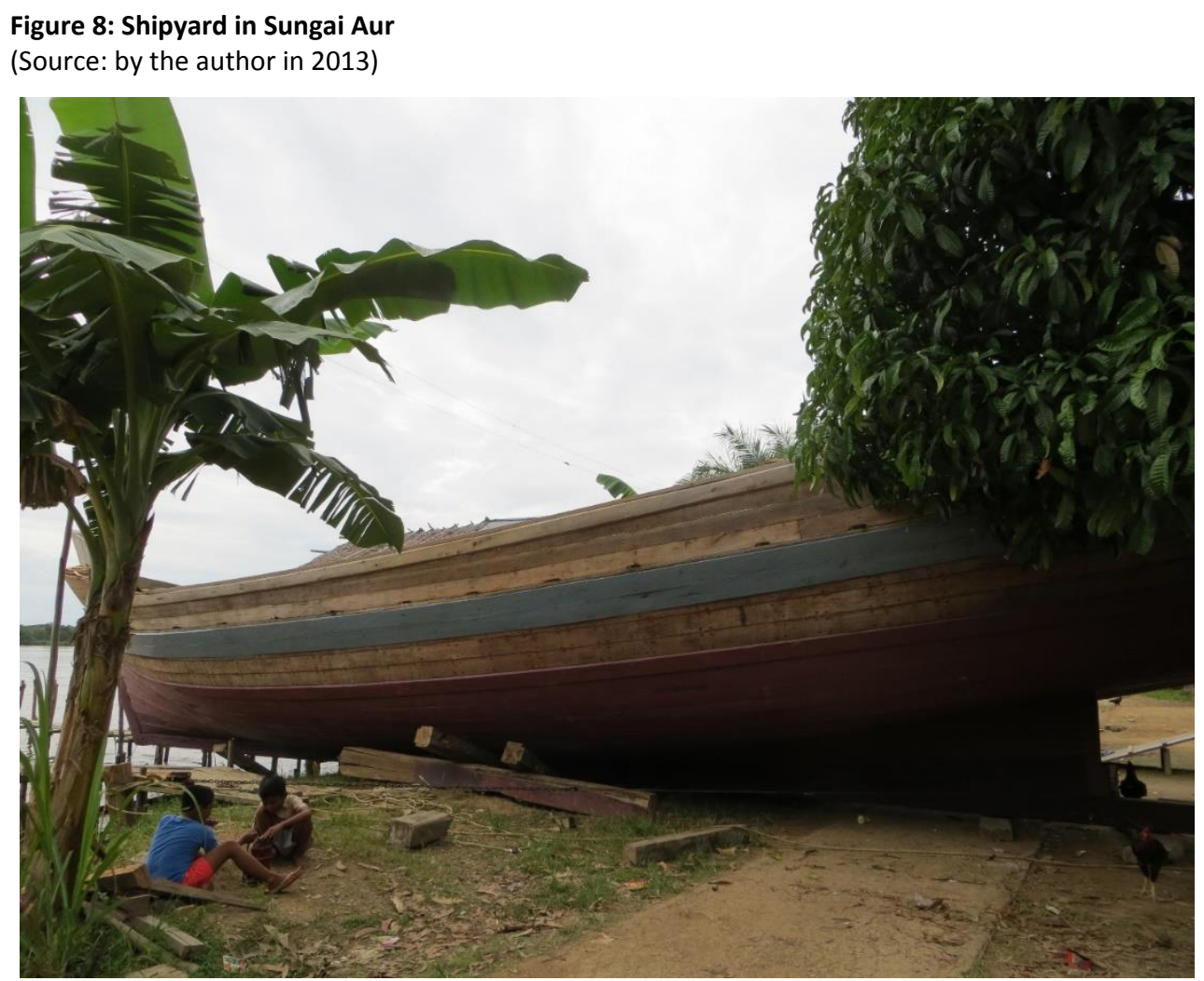

\footnotetext{
${ }^{152}$ Interviews with key informants in Seponjen, 08.09.2013, Document ID: 175 and 11.09.2013, Document ID: 173 and 13.09.2013, Document ID: 122.

${ }^{153}$ Interviews with key informants in Sungai Aur, 29.08.2013, Document ID: 132 and 01.09.2013, Document ID: 136.

154 Interviews with key informants in Sungai Aur, 28.08.2013, Document ID: 141 and 01.09.2013, Document ID: 136.

${ }^{155}$ Interview with key informants in Seponjen, 10.09.2013, Document ID: 205 and 12.09.2013, Document ID: 316.

${ }^{156}$ Interview with key informant in Seponjen, 12.09.2013, Document ID: 316.

${ }^{157}$ Interview with key informant in Sungai Air, 02.09.2013, Document ID: 131.
} 
Since the Hutan Suaka Alam Berbak became a Ramsar Site in 1991 and national park in 1997 the Berbak Landscape has been a target area for a number of conservation initiatives aiming at developing an integrated spatial planning concept for the different land use categories and jurisdictions of the landscape (Lubis and Suryadiputra 2004: 111-115). The first larger initiative was the Integrated Swamps Development Project (ISDP) running from 1997 - 2000. ISDP was funded by the Global Environmental Facility (GEF) and implemented among others by Wetland International, the Provincial Government of Jambi and by the MoF. The main output of the project was a management plan for the Berbak Landscape. The plan recommended not to extend the logging concessions south of the national park and to designate areas for community forest concessions (ibid. 113). The follow up project the GEF Berbak-Sembilang Project (2000-2004) was again an attempt to develop a more integrated spatial plan (ibid. 114). In parallel, a first initiative linking explicitly conservation and especially peat land conservation with climate change mitigation started in the early 2000s (ibid. 115). The three projects had components that involved local communities. In Sungai Aur, key informants mentioned that they received support for planting trees on idle village land outside of the state of forest ${ }^{158}$. Today most community reforestation activities are conducted in the TAHURA Sekitar Tanjung and in the southern part of the Berbak Landscape.

Anyhow, the different attempts to establish the Berbak Landscape as a new scale of regulation for protecting the different ecosystems have been challenged by many actors. The province of Jambi is developing an international seaport and industrial zone in the Batang Hari delta region, only a few kilometers north of the Berbak National Park ${ }^{159}$. The MoF, despite of the recommendations has extended the logging concessions and communities have not received community forest concessions. The Transmigration Agency of the District of Muaro Jambi has even developed transmigration settlements in Sungai Aur and Gedung Karya within the forest reserve TAHURA Sekitar Tanjung challenging the authority of the Provincial Forest Agency and of the MoF ${ }^{160}$. The establishment of the settlement in Sungai Aur induced conflicts between settlers, forest agencies and the district government. In section 7.4 the case will be analyzed in detail.

Conflicts between local communities and companies running plantation estates or between local communities and authorities of the central state were not as common and violent in the research sites of the Berbak Landscapes as in the sites of the Harapan Landscape. A potential explanation is that most of the land claimed as village land in Air Hitam Laut, Seponjen and Sungai Aur does not overlap with the state forest implying that the district government has the authority to issue corporate concessions.

\footnotetext{
${ }^{158}$ Interview with key informant in Sungai Aur, 31.08.2013, Document ID: 138.

${ }^{159}$ Interview with staff member of the Provincial Planning Agency of Jambi (BAPPEDA), Jambi, 02.08.2013, Document ID: 134.

160 Interview with key informants in Sungai Aur, 29.08.2013, Document ID: 132, 135, 273.
} 
Generally speaking, district governments seemed to accept traditional village lands and the reclassification of large forest tracts by the MoF in the surroundings of the villages. This might has reduced the potential for conflicts. Village governments had been directly involved in negotiations with companies and were in some cases even actively searching for investors ${ }^{161}$. Only recently, conflicts occurred but they were not associated with displacements or dispossession they were rather caused by controversies on the interpretation of benefit sharing agreements between oil palm plantation companies and local communities.

\subsection{Summary and preliminary conclusion}

This chapter mainly provided the empirical basis for responding to the first research question: In how far are rescaling processes altering the ability of different actors to access land and property? State transformation processes induced rescaling processes that altered the dialectical relationship between structure and agency and consequently changed the ability of actors to access land and property. State transformation and rescaling or in Swyngedouw's (2010: 12) words “[...] scalar reconfigurations also produce new socio-physical ecological scales that shape in important ways who will have access to what kind of nature" thus shaping societal relationships with nature (Brand, Görg, and Wissen 2011: 165). I argue that four subsequent state transformation processes have induced rescaling processes that have altered Indonesia's forest and land tenure governance, namely: colonization, independence, New Order and Reformasi. Each period has been characterized by specific land and forest tenure regulations providing different opportunities for different actors to access land and property.

In pre-colonial times watersheds have been main scales of meaning and regulation for Batin Sembilan groups in the Harapan Landscape. The different rivers were intertwined with the myth of origin of the Batin Sembilan and with the specific identity of the different lineages of the group. Through exercising different types of power, the Dutch colonial authorities were able to subject local elites (visible power), to establish new rules (hidden power) (e.g. new administrative system, sedentarization of nomadic and semi-nomadic groups, introduction of rubber) and to change the meanings of landscapes (e.g. establishment of protected areas for maintaining the hydrological balance) (invisible power).

Independence and post-colonial state transformations (e.g. from Soekarno's socialism to Colonel Suharto's autocratic regime to the reformasi era) changed societal relationships with nature and intertwined socio-ecological scales significantly. However, the path dependency and the relatively

\footnotetext{
${ }^{161}$ Interview with key informants in Sungai Aur, 30.08.2013, Document ID: 123, and Seponjen, 13.09.2013, Document ID: 122.
} 
stable forest and land tenure policies indicate that elites have been able to maintain or to take over specific scalar arrangements and rule systems that facilitate the exploitation of forest resources to their benefits. The dualistic governance structure for land designated for agriculture and land designated for forestry was established by the Dutch and persisted despite of state transformation and rescaling.

Nevertheless, three at least partly contradictive state projects of the post-colonial period impacted the scalar configuration and related access and property relations. First, the Basic Agrarian Law (BAL) as the first attempt to establish a new national scale of natural resource governance promoted (probably not intentionally) the commodifcation of land but at the same time the law imposed restrictions for large land holders and proposed a land reform. Today. the BAL is relatively weak in legal terms but is still used especially by peasant organizations such as SPI and KPA for underpinning political campaigns for a more equal distribution of agrarian resources (Bakker and Moniaga 2010: 188; Rachman 2011: 54; Hein and Faust 2014: 25). Second, the Basic Forest Law has led to the reestablishment of the dualistic governance structure, fostering the dispossession of local and indigenous communities and seeking to construct private-sector led economic growth as a new national scale of meaning. Third, the village law has further undermined traditional adat based scales of meaning and regulation. Moreover, the law has imposed new jurisdictional boundaries and creating a standardized and homogenous administrative structure across the archipelago.

Democratization and decentralization occurring after the fall of Suharto was the last and probably the most rapid rescaling process. But democratization and decentralization have not led to profound de jure changes of forest and land tenure polices relevant for peasants and indigenous groups but de facto the transformations were significant. Regime change altered the dialectical relationship between structure and agency provided the historical opportunity for peasant movements such as SPI and indigenous rights organization such as AMAN to turn hidden resistance e.g. hidden encroachment of the state forest into organized open and collective resistance. AMANs success at the Constitutional Court is a remarkable example showing how power constellations have changed in the Reformasi era.

Scaling back, in other words investigating past scalar arrangements demonstrated that historical contingent structural inequality is a persistent feature of land and forest tenure in Indonesia. The Reformasi era and democratization and decentralization provided additional agency for marginalized actors to construct alternative scales of meaning and regulation. This chapter illustrated state transformation processes and related changes of forest and land tenure governance. In the following chapter the actual in situ access and property relations will be analyzed. 


\section{Findings-II: Historically contingent access and property relations in REDD+ target areas}

In the previous chapter, I investigated state transformation and the entangled rescaling of forest and land tenure governance. Here I analyze the in-situ access and property relations in villages adjacent to the Berbak Carbon and Harapan Rainforest projects: These have been structured by rescaling processes that are changing the actors' ability to access land. While colonization and the New Order significantly reduced the opportunities for the Batin Sembilan and peasant groups to access land, they facilitated access to land and natural resources for corporate actors and transmigrants. Political regime change in the late 1990s altered the power constellation and enabled further rescaling, expanding the opportunities for Batin Sembilan groups and peasants to access land and property. The conflictive insitu access and property relations in the Berbak and Harapan Landscapes show that scales of regulation may overlap during rapid rescaling, and they show that REDD+ and conservation initiatives are not operating in a social and political vacuum.

Furthermore, as I argue in the conceptual framework of this thesis, actors' ability to alter scales of meaning and regulation - to access land and property - is linked to questions of power. The ability of local public authorities (village heads) to issue village-scale land titles (section 6.3.2) and of peasant organizations to establish settlements in the Harapan Rainforest (section 6.3.3.4) indicate that the power constellations have changed. Local public authorities in the Harapan and Berbak Landscapes have been able to challenge all three dimensions of power (Gaventa 1982: 24) vis-à-vis the Ministry of Forestry (MoF). They have changed the rules of the game (hidden power) by constructing scales of regulation and issuing land titles (see section 6.3). They have also developed political strategies, myths, and alternative scales of meanings to challenge invisible power - as shown by the narratives used to legitimize forest conversion in section 6.3.3 - and to legitimize land control. Furthermore, Batin Sembilan elites, village governments, and peasant organizations have been able to establish land claims (visible power). The changed power constellations have facilitated the construction of alternative scales of meaning and regulation that permit local public authorities to legitimize property rights, forest conversion, and settlement formation.

I begin by describing historical customary and colonial access and property before outlining the different actors and their strategies and limitations in terms of accessing land and property. This includes a detailed description of how the PT REKI conservation company was able to obtain its 100,000-ha conservation concession. Then I investigate the "making" of new property through larger forest conversion and settlement initiatives that challenge the scales of meaning and regulation of the Berbak Carbon and Harapan Rainforest projects. The fourth section examines new property rights such 
as conditional land tenure agreements and community benefits provided for peasants and indigenous groups by REDD+ and conservation initiatives. The fifth section presents four peasants' land access patterns, and the chapter closes with a preliminary conclusion about the role of power in accessing land and property.

\subsection{Customary and colonial access and property relations}

Today, large parts of the Harapan and Berbak Landscapes are either managed by private or stateowned companies (including conservation companies) or are designated for forest conservation. Until the late 1970s and still today (although to a lesser extent), access and property relations have been regulated by customary and colonial regulations. In both landscapes, colonization first induced the rescaling of access and property relations. The former lineage and watershed-based socio-spatial organization in the Harapan Landscape was replaced by new colonial jurisdictions, public authorities, and regulations (c.f. Hein et al. 2015). The pasirah, a public authority that legitimized access to land, was present in both landscapes until the 1970s. This section explores customary and colonial regulations, and outlines the different social constructions of property used by the indigenous population (Malayu Jambi in the Berbak Landscape and Batin Sembilan in the Harapan Landscape).

\subsubsection{The Harapan Landscape and the Batin Sembilan}

The Batin Sembilan of the Harapan Landscape mainly settled close to rivers in order to be near water, fish, and transport (see section 5.4.2). Different lineages and sub-lineages of the Batin Sembilan controlled the adjacent land and forests. The landscape's watersheds can be regarded as scales of meaning (they contain spiritual meanings and are linked to a lineage's specific origin myth) and as scales of regulation (each lineage has authority over land within its territory).

Land was generally owned by the first (extended) family to convert forest and establish a swidden in a specific area. ${ }^{162}$ Other families needed permits to establish swiddens in that area, and land rights continued after the forest had regrown. Batin Sembilan in the hamlet of Kunangan Jaya 1 (part of Bungku village) explain that only members of their lineage are allowed to live in their neighborhood (RT, rukun tetangga) and to convert forest along the upper Kandang River (a tributary of the Bahar

\footnotetext{
162 Interview with a key informant in Tanjung Lebar, 26.07.2013, Document ID: 127.
} 
River). ${ }^{163}$ Specific trees, watercourses, hills, and other landmarks demarcated the borders of land that was held by various extended families and lineages. ${ }^{164}$

Details regarding the traditional leadership structure are contradictory, making it difficult to assess the role of traditional Batin Sembilan public authorities in terms of land governance, and especially their role in granting access permits to non-lineage members and other outsiders (section 5.4.2). A key informant explained that when outsiders stopped using land for more than six months their rights to the land reverted to the Temenggung. ${ }^{165}$ The suggestion that the Temenggung had authority over land issues is confirmed by a study conducted by the Forest Peoples Program (FPP). Marcus Colchester and colleagues (2011: 10) state that the Temenggung "[...] had overall authority over adat territories". Key informants generally agreed that outsiders - migrants - needed permits from Batin Sembilan leaders to convert forests. ${ }^{166}$ This is confirmed by colonial sources. Tideman (1938: 78) explains that migrants had to pay rent to Batin Sembilan groups to access land rights. In cases of border disputes or violations, such as the destruction of another family's fruit tree, compensations were negotiated for any losses. ${ }^{167}$

Since the population density was very low in pre-colonial and colonial times, land was abundantly available. At that time, tree property (fruit trees and sialang trees ${ }^{168}$ with beehives) might have been more relevant than land rights, for instance, only the members of a family who owned the sialang trees were permitted to harvest the honey. ${ }^{169}$ The family who had planted the fruit trees usually owned them. Batin Sembilan families planted trees such as durian, langsat, and rubber on abandoned swiddens. ${ }^{170}$ Old fruit and rubber trees in the remaining forest patches of the Harapan Rainforest provide evidence of the historical presence of Batin Sembilan groups. Present-day jungle-rubber plantations can also be considered as relicts of Batin Sembilan forest gardens that existed before the deep transformation processes that began with the New Order.

As described in the previous chapter Dutch jurisdictional reforms for the Netherlands East Indies changed the pre-colonial scales of meaning and regulation (e.g. watershed scale) and the lineagebased access and property relations. A Batin Sembilan elder ${ }^{171}$ in the Harapan Landscape explained, "We were colonized by the Dutch. The Dutch formed a new government and we received a pasirah

\footnotetext{
163 Interviews with key informants in Bungku, 12.09.2012, Document ID: 79 and 09.07.2013, Document ID: 107 and in Tanjung Lebar, 23.07.2013, Document ID: 171.

164 Interview with a key informant in Tanjung Lebar, 27.07.2013, Document ID: 113.

165 Interview with a key informant in Tanjung Lebar, 23.07.2013, Document ID: 171.

166 Interview with key informants in Tanjung Lebar, 26.07.2013, Document ID: 127 and 27.07.2013, Document

ID: 113 and in Bungku, 08.09.2012, Document ID: 77.

167 Interview with a key informant in Tanjung Lebar, 27.07.2013, Document ID: 113.

${ }^{168}$ Koompassia excels, specific tree species that is often used by wild bees for beehives.

${ }^{169}$ Interview with key informants in Bungku, 12.09.2012, Document ID: 87 and 21.09.2012, Document ID: 76.

170 Interview with key informants in Bungku, 12.09.2012, Document ID: 79, 87.

${ }^{171}$ Interview with a key informant in Bungku, 12.09.2012, Document ID: 87.
} 
[...] replacing the authorities based on adat." In Bungku, the head of a Batin Sembilan family explained that to convert forest, a permit was required from a pasirah. ${ }^{172}$

In the late 1980s, the Batin Sembilan's customary regulations in the Harapan Landscape became less important; today, the land claims of different Batin Sembilan families, subgroups and lineages appear to be contested: their leaders and other public authorities interpret the borders between lineages and extended families in various ways. A Batin Sembilan elder in Tanjung Lebar argued, for instance, that all Batin Sembilan families in Tanjung Lebar, Bungku, and Markanding have the same ancestors but do not share the same territory. ${ }^{173} \mathrm{He}$ explained that the territory of the Batin Sembilan groups of Tanjung Lebar is located between the mouth of the Sungai Kandang River and the water divide of the daerah mandi angin, which is located west of the Harapan Rainforest in the district of Sarolangun ${ }^{174} 175$. A member of the Tanjung Lebar village government argued that the old border between the Markanding and Tanjung Lebar groups was located in the area of Kunangan Bawah, which is now part of the village of Bungku ${ }^{176}$ and claimed that the whole PT Asialog concession had been part of their territory. ${ }^{177} \mathrm{~A}$ Batin Sembilan elder in Bungku challenged these oral records and maintained that his family's territory was located between Sungai Kandang and Bahar: it was not part of the land controlled by the Batin groups from Markanding or Tanjung Lebar. ${ }^{178}$ Descendants of the former Batin Sembilan leader, Depati Jentikan, claimed that he had controlled the forests around the main hamlet of Bungku, reaching across watersheds to Air Hitam in the district of Sarolangun ${ }^{179}$. Members of the 113 group of Bungku, a local resistance group formed by the Batin Sembilan and Javanese migrants that occupies parts of the oil palm concession of PT Asiatic Persada (for more details on the conflict with 113 group consider: Steinebach 2013b; Beckert, Dittrich, and Adiwibowo 2014), argue that Bungku is located in the border area between two lineages (Batin Bulian and Batin Bahar).

In the Harapan Landscape, the New Order politics of dispossession transformed the Batin Sembilan from landowners to landless peasants, illegal settlers, squatters, and day laborers. The rescaling of forest and land governance facilitated resource exploitation by corporate actors but significantly reduced Batin Sembilan groups' abilities to access land and property. Only a few Batin Sembilan families, especially the elites and those who had adopted commercial farming, were able to benefit from the extra leeway provided by the rescaling processes of the Reformasi era. Spontaneous in-

\footnotetext{
172 Interview with a key informant in Bungku, 30.07.2013, Document ID: 117.

173 Interview with a key informant in Tanjung Lebar, 26.07.2013, Document ID: 127.

174 The district of Sarolangun is located south of the district of Batang Hari.

175 Interview with a key informant in Tanjung Lebar, 26.07.2013, Document ID: 127.

${ }^{176}$ Interview with a key informant in Tanjung Lebar, 25.07.2013, Document ID: 125.

177 Interview with a key informant in Tanjung Lebar, 25.07.2013, Document ID: 125.

178 Interview with a key informant in Bungku, 24.08.2013, Document ID: 2.

179 Interview with a key informant in Bungku, 08.09.2012, Document ID: 77.
} 
migration and the transmigration scheme further altered the landscape's demographic structure. Today, Batin Sembilan groups are minorities in Bungku and Tanjung Lebar. According to PT REKI data, only 10 percent of the population in the informal settlement of Transwakarsa Mandiri (part of Bungku) belong to local ethnic groups (REKI 2011a). A survey conducted by the Forest Agency of the Batang Hari district (2012) in the informal settlement of Bukit Sinjal (part of Tanjung Lebar) shows a similar situation.

\subsubsection{The Berbak Landscape}

In pre-colonial and colonial times, agriculture was of minor importance in the villages studied in the Berbak Landscape ${ }^{180}$ (Guillaud 1994: 177; Sevin and Benoît 1993: 96). The settlements had only small rice and sago ${ }^{181}$ plots; little forest gardens of durian and langsat were located in parts of the settlements that were less flood-prone. ${ }^{182}$ Fishing and extracting timber and non-timber forest products were much more important activities. Key informants in Seponjen claimed that the village has a community forest which their ancestors had exploited already. ${ }^{183}$ Community members did not need a permit from a customary leader to convert the community forest. Land was abundant and since agriculture was not important, it did not need to be regulated for community members. ${ }^{184}$

As in the Harapan Landscape, the colonial government imposed significant socio-spatial restructuring of the Berbak Landscape: authorities divided it into margas and transferred the authority to allocate land to the pasirah. In the late 1960s, for instance, the pasirah of the Marga Berbak facilitated the creation of the Air Hitam Laut village by permitting Buginese migrants to drain and convert peatswamp forest around the mouth of the Air Hitam Laut River. ${ }^{185}$ The drainage and settlement projects of Bugis migrants are described in detail in section 6.3.4.1.

Until the end of the 1990s, Malay families were allowed to convert forest according to their needs ${ }^{186}$ with decisions about forest conversion made at the household scale. Starting in the late 1990s, the government of Seponjen village restricted individual forest conversions. ${ }^{187}$ Decision-making about converting the community forest was rescaled, producing a village-scale of regulation. In the following years, the communities undertook more organized, cooperative initiatives for draining and converting

\footnotetext{
180 Interview with a key informant in Seponjen, 13.09.2013, Document ID: 122.

${ }^{181}$ Metroxylon sagu

182 Interviews with key informants in Seponjen, 09.09.2013, Document ID: 318 and 15.09.2013, Document ID:

172, and in Sungai Aur, 30.08.2013, Document ID: 126.

183 Interview with a key informant in Seponjen, 11.09.2012, Document ID: 173.

${ }^{184}$ Interview with a key informant in Seponjen, 13.09.2013, Document ID: 122.

185 Interview with a key informant in Air Hitam Laut, 29.09.2012, Document ID: 70.

${ }^{186}$ Interview with a key informant in Sungai Aur, 30.08.2013, Document ID: 126.

187 Interviews with key informants in Seponjen, 08.09.2013, Document ID: 175 and 09.09.2013, Document ID:
} 318. 
peat swamps. In Sungai Aur and Seponjen, the village governments required that farming groups be formed to convert the communities' traditionally owned peat-swamp forest ${ }^{188}$ (see section 6.3.4.2). The formation of farming groups and regulations restricting individual forest conversion permitted Malay elites to consolidate their control of village land and of timber resources. Moreover, the draining and conversion efforts were only possible through a farming group's collective labor.

Malay village communities in Seponjen and Sungai Aur, and Bugis in Air Hitam Laut have managed to keep control of most of their village territory. The village communities of Sungai Aur and Air Hitam Laut still possess larger tracts of fallow land and secondary forests. The village communities of Seponjen and Sungai Aur have allocated parts of their land to companies, thereby further strengthening the village-scale of land tenure regulation. However, as in the Harapan Landscape, the ethnic structure has changed: Javanese, Sundanese and Bugis now outnumber the Malay population in Seponjen and Sungai Aur.

\subsection{Different actors and different access patterns}

De facto access and property relation differ substantially from de jure land and forest rights. All the villages researched are located adjacent to or overlap with the state forest (figure 4). Peasants have very limited de jure opportunities to access agricultural land in the state forest (Hein 2013b). Nevertheless, peasant communities do use large parts of state forests, especially in the Harapan Landscape, which implies that peasant use of the state forests in the Harapan and Berbak Landscapes is not backed by the national forest law and must be governed by other mechanisms. In contrast, corporate actors, such as PT REKI and oil palm companies, have successfully accessed concessions issued by national-scale authorities. PT REKI even managed to change the existing forest governance framework. In the following section, I seek to unravel the pathways used by various actors to access land and property.

Section 6.2.1 unpacks the different de facto opportunities to access land for the purpose of conservation and REDD+. In 6.2.2, I investigate how oil palm companies gained access to land according to smallholders and village government officials. Oil palm companies are very relevant actors, whose large land holdings in both landscapes significantly limit the amount of land available to smallholders. Conflicts with oil palm companies in the Harapan Landscape are closely connected with

\footnotetext{
188 Interviews with key informants in Sungai Aur, 30.08.2013, Document ID: 126, 31.08.2013, Document ID: 138 and 01.09.2013, Document ID: 136, and in Seponjen, 08.09.2013, Document ID: 175, 09.09.2013, Document ID: 318 and 13.09.2013, Document ID: 122.
} 
conflicts regarding access to and control of PT REKI's conservation concession. Section 6.2.3 describes peasant migrant strategies for accessing land and property.

\subsubsection{Access to land and property for the purpose of conservation and REDD+}

PT REKI and ZSL used different approaches for establishing REDD+ and forest conservation initiatives. The conservation concession approach (used by PT REKI) provides full management rights and revenues from sustainable forest management, non-timber forest products and ecosystem services but requires financial resources. Obstacles to accessing conservation concessions include a lack of areas designated for ecosystem restoration, the requirement to obtain a letter of recommendation from the local governor, and a lack of guidance about what governors should recommend and the role of district governments (Walsh et al. 2012: 14 ). District governments have little interest in having an ecosystem restoration concession within their jurisdiction. ${ }^{189}$ An expert from the MoF argued, " $[. .$. Ecosystem restoration in the short term is a sacrifice [...] for all actors in all levels, including the company." ${ }^{190}$ Since ecosystem restoration concessions contribute less to the district's economy than other types, some districts seek to impede the issuance of ecosystem restoration concessions. ${ }^{191}$

The ZSL's approach is based on co-management and influencing state authorities and logging companies. ZSL participates in joint patrols and is involved in monitoring biodiversity and FPIC implementation. Although officially the NGO has no authority over land and no legal title to land, it has been able to implement conservation activities and undertake patrolling activities in protected areas of the Berbak Landscape. Even more important the NGO has established a new REDD+ based scale of meaning, the Berbak Carbon Project.

\subsubsection{Burung Indonesia, PT REKI, and the Harapan Rainforest}

Burung Indonesia claims that the introduction of regulations permitting private conservation concessions is due to its strong lobbying activities (Hein 2013b: 5; Hein et al. 2015: 6). In the early 2000s, Burung Indonesia and its national and transnational partners discussed new conservation and forest rehabilitation concepts, especially for areas designated as production forests. The Royal Society for the Protection of Birds (RPSB), in particular, was searching for areas to be used as privately financed and managed conservation areas. A key informant from Burung Indonesia explained, "At that time, the UK community over there, the members of RSPB, they wanted to share, for example, if you give money

\footnotetext{
189 Interview with staff member of an NGO applying for an ecosystem restoration concession, Jambi, 31.08.2102, Document ID: 28.

${ }^{190}$ Interview with staff member of the Ministry of Forestry, Jakarta, 23.07.2102, Document ID: 88
} 
you can conserve 1 hectare ${ }^{192}$." At that time, conservation and forest rehabilitation activities were limited to protected areas managed by state actors. Burung Indonesia argued that conservation regulations for protected areas were too restrictive for private initiatives ${ }^{193}$ and developed a proposal for a new concession type that would permit private actors to invest in conservation. According to a key informant of Burung Indonesia, at first the Ministry of Forestry (MoF) was skeptical, but after years of lobbying, it finally agreed: "Our CEO at that time, he was very persistent, [...] he lobbied here and there, also he wanted me to lobby here and there [...] I think the third minister finally agreed ${ }^{194}$." In 2004, the MoF enacted the first regulation on "Ecosystem Restoration in Production Forest" (SK 159/Menhut-II/2004) that permitted private conservation concessions. Three years later, the Indonesian parliament integrated private conservation concessions into the forest law (Birdlife International 2008: 21).

A key informant from the Carbon Synthesis consulting company who supported the lobbying campaign ${ }^{195}$ argued that Burung Indonesia's campaign was successful because of the reduced demand for logging concessions as a result of the post-Suharto boom in illegal logging. The MoF considers the new concession type mainly as a mechanism for recovering state forest production capacity ${ }^{196}$. Burung Indonesia and its national and transnational partners consider the new concession type to be a response to the failure of state-led conservation policies and an opportunity to finance conservation activities through sustainable forest exploitation, ecotourism, and carbon trade ${ }^{197}$.

In parallel to Burung Indonesia's lobbying campaigns, in 2000 the NGO started a site selection process with its partners. Biodiversity, urgency, administrative, and socio-economic criteria were used to study 14 sites across Indonesia ${ }^{198}$ (Birdlife International 2008: 13). Burung Indonesia conducted the first onsite investigations in Jambi and South Sumatra provinces between 2000 and $2004 .{ }^{199}$ The Meranti River-Kapuas River Forest Block ${ }^{200}$ in Jambi and South Sumatra was selected because it represents one of Sumatra's last patches of intact lowland rainforest. The area was also considered to be of great interest to timber and oil palm companies - and consequently at risk (ibid. 13). At that time, the southern part of the concession consisted of a retired logging concession formerly used by the stateowned company, PT Inhutani V. Although the northern part was still owned by PT Asialog, the company

\footnotetext{
192 Interview with staff member of Burung Indonesia, Bogor, 11.10.2012, Document ID: 99.

${ }^{193}$ Interview with staff member of Burung Indonesia, Bogor, 11.10.2012, Document ID: 99.

194 Interview with staff member of Burung Indonesia, Bogor, 11.10.2012, Document ID: 99.

195 Interview with staff member of Carbon Synthesis, Jakarta, 11.10.2012, Document ID: 19.

196 Interview with staff member of the Ministry of Forestry, Jakarta 19.07.2012, and Document ID: 90 and 23.07.2012, Document ID: 88.

197 Interview with staff member of Carbon Synthesis, Jakarta, 11.10.2012, Document ID: 19.

${ }^{198}$ Interview with staff member of Burung Indonesia, Bogor, 11.10.2013, Document ID: 210.

199 Interview with staff member of Burung Indonesia, Bogor, 11.10.2013, Document ID: 210.

200 Official name of the Ministry of Forestry for the production forest block located at both sides of the border region of Jambi and South Sumatra.
} 
had stopped logging in 1999, abandoned the concession in $2003,{ }^{201}$ and signed an agreement with Burung Indonesia about officially ending logging activities in the concession in 2006 (Birdlife International 2008: 22; Mardiana 2014: 14). In 2005, the MoF officially classified the forest block for ecosystem restoration ${ }^{202}$.

Initially, Jambi's local governments opposed the permit for the Harapan Rainforest project. Burung Indonesia was finally able to convince them, according to one of its board members ${ }^{203}$. One year later the NGO consortium won the public tender ${ }^{204}$ for the southern part of the concession and received letters of support from the district heads and governors of Jambi and South Sumatra (Birdlife International 2008: 22). The MoF officially revoked PT Asialog's logging concession in 2007 (Mardiana 2014: 14). In 2008, PT REKI, the company founded by the NGO consortium to manage the concession, received the southern part and two years later the northern part of the Meranti River-Kapuas River Forest Block. The concessions are valid for 100 years. The permit process for the conservation concession took eight years ${ }^{205}$ (Birdlife International 2008: 22).

\subsubsection{The Zoological Society of London and the Berbak Carbon Project}

The ZSL's approach to establishing the Berbak Carbon Project differs substantially from that of Burung Indonesia and its partners. The ZSL's basic idea is to harmonize the management of various concessions and protected areas - to establish a new scale of regulation for the Berbak Landscape: ZSL has not tried to gain full ownership or full control over its different land-use categories. ZSL's strategy is to influence the management of existing concessions and protected areas through negotiating cooperation agreements with concession owners and forest authorities ${ }^{206}$. A key informant working for ZSL argued that applying for a private conservation concession is not an option for the NGO because of the high upfront costs. He said, "It is too expensive for NGOs with no money. Because we have to have a very big investment [...] to get the concession area. Yeah, that's also, I think, the obstacle for an NGO who wants to get the restoration concession for REDD activity. Big investment [...] while to get the restoration area required the tax for the first 35 years, plus an extension of 60 years: 65 years must be paid in advance ${ }^{207}$." In addition to the financial barriers, only the logging concessions managed by PT Putra Dutra Indahwood and PT Persona Belantara Persada would be eligible to be reclassified as

\footnotetext{
201 Interview with key informant in Bungku, 31.07.2013, Document ID: 166.

202 Decree of the Minister of Forestry No. SK.83/Menhut-II/2005, dated April 1, 2005.

203 Interview with staff member of Burung Indonesia, Bogor, 11.10.2012, Document ID: 99.

${ }^{204}$ Interview with staff member of Burung Indonesia, Bogor, 11.10.2012, Document ID: 99.

205 Interview with staff member of Burung Indonesia, Bogor, 11.10.2012, Document ID: 99.

${ }^{206}$ Interview with staff member of ZSL, Bogor, 27.08.2012, Document ID: 120.

${ }^{207}$ Interview with ZSL staff member, Bogor, 27.08.2012, Document ID: 120.
} 
private conservation concessions. State forest that is already classified as a protected area, such as the Berbak National Park, is not eligible to become a private conservation concession.

The first discussions about establishing a REDD+ project between the ZSL and the Berbak National Park Agency started in 2008. The first cooperation agreement on establishing a REDD+ project in the Berbak Landscape was signed with the MoF in May 2011, and with the Berbak National Park Agency in October 2011. The agreement with the National Park Agency defines different areas of cooperation including the establishment of a measurement, reporting and verification system, support of the VCS and CCBS certification processes and the development of community benefits (Balai Taman Nasional Berbak and Zoological Society London 2011). The document states that potential income from carbon trade will be used to preserve biodiversity and maintain the peat-swamp forest's carbon storage capacity (ibid.). In 2013, the ZSL signed a third agreement with the Provincial Forest Agency on implementing a REDD+ initiative in the Sektitar Tanjung forest reserve. The agreement defines, inter alia, FPIC implementation, closure of illegal drainage canals, and the development of a benefit-sharing mechanism for carbon trade revenues (Dinas Kehutanan Provinsi Jambi 2013). Negotiations between the logging companies, PT Putra Dutra Indahwood and PT Persona Belantara Persada, and the district government of Muaro Jambi had not been finalized when field research was conducted in $2013^{208}$. According to a key informant who worked for ZSL, the companies were mainly concerned about the great uncertainties regarding carbon trade revenues ${ }^{209}$.

Existing forest regulations are an additional obstacle to harmonizing forest management in the Berbak Landscape. The forest reserve and national park had to be registered as separate REDD+ projects since it was not possible to register them as a single REDD+ project under current forest regulations ${ }^{210}$. The ZSL sought to circumvent the regulatory barriers by negotiating different cooperation agreements but has not yet been able to establish a coherent new scale of regulation for the Berbak Landscape. The various concessions and conservation areas are still governed by different authorities. A staff member of the Provincial Forest Agency argued that coordination was difficult since no authority wanted to lose influence to another ${ }^{211}$. Jumping to the transnational scale would still allow for the construction of the Berbak Landscape as a scale of regulation. Certification under VCS and CCBS would create a set of rules applicable to all land use categories. So far, the ZSL has only managed to establish REDD+ as a

\footnotetext{
208 Interviews with ZSL staff member, Bogor, 27.08.2012, Document ID: 1201 with staff of Dinas Kehutanan Provinsi Jambi, 27.08.2013, Document ID: 137, and with staff of the Berbak National Park Agency, Jambi, 19.08.2013, Document ID: 158.

${ }^{209}$ Interviews with ZSL staff member, Bogor, 27.08.2012, Document ID: 120119, and staff of the Berbak National Park Agency, Jambi, 19.08.2013, Document ID: 158.

${ }^{210}$ Interview with ZSL staff member, Bogor, 27.08.2012, Document ID: 120119.

${ }^{211}$ Interview with staff member of Dinas Kehutanan Provinsi Jambi, 27.08.2013, Document ID: 137.
} 
new scale of meaning for the landscape. Other actors (e.g. logging companies) are challenging the production of a complimentary scale of regulation.

\subsubsection{Access to land and property for oil palm companies}

Oil palm companies control vast areas of the Seponjen, Sungai Aur, Bungku, and Tanjung Lebar villages and thus are major players there. In many cases, the local population claims parts of the corporate concessions, and complains about unfair compensations and unjust benefit-sharing arrangements. Moreover, the land conflicts over access and control of the Harapan Rainforest (chapter 7) are deeply entangled with conflicts between the various oil palm companies and the local communities. The two lines of conflict involve the same actor groups, and the oil palm company PT Asiatic Persada has pushed the Batin Sembilan and other smallholders into the remaining forest patches of the Harapan Rainforest (Colchester et al. 2011: 15; Hein et al. 2015; Beckert, Dittrich, and Adiwibowo 2014: 86).

\begin{tabular}{|l|l|l|l|}
\hline Village & $\begin{array}{l}\text { “Official” village territory } \\
\text { (ha) }\end{array}$ & $\begin{array}{l}\text { Land allocated to } \\
\text { companies (ha) }\end{array}$ & Land used by farmers (ha) \\
\hline Air Hitam Laut & No data & No companies & No data \\
\hline Seponjen & 16,000 & $2,000^{212}$ & $1,600^{213}$ \\
\hline Sungai Aur & $12,000^{214}$ & $300^{215}$ & $825.4^{216}$ \\
\hline Bungku & $\sim 150,000^{217}$ & $105,205^{218}$ & No data \\
\hline Tanjung Lebar & $6,500^{219}$ & 3,000 & $1,500^{220}$ \\
\hline
\end{tabular}

Table 9: Land allocated to companies, total village territory, and land used by farmers in the study villages.

(Source: compiled by the author)

Most of the remaining land in Seponjen and Sungai Aur villages is designated as forest reserve, including bodies of water, settlement land, and land unsuitable for agriculture. Tanjung Lebar village's de facto territory is much larger and overlaps with the village territory of Bungku.

One of the most controversial plantation developments in Jambi province is the PT Asiatic Persada plantation, which for more than 20 years has caused a conflict over land between the company and

\footnotetext{
212 Based on interview with key informants in Seponjen, 09.09.2013, Document ID: 318, 11.09.2013, Document ID: 173 and 13.09.2013, Document ID: 121.

213 Based on village government documents, Seponjen (2013: 6).

${ }^{214}$ Based on village government, Sungai Aur (2012)

215 Based on an interview with a key informant in Sungai Aur, 02.09.2013, Document ID: 278.

${ }^{216}$ Based on Monografi Desa Sungai Aur (2012)

${ }^{217}$ Based on Zainuddin.

218 Ibid. and Mardiana (2014: 16)

${ }^{219}$ Based on Polsek Sungai Bahar (2011)

${ }^{220}$ Based on Polsek Sungai Bahar ((2011)
} 
the village communities of Bungku, Tanjung Lebar, Markanding, and Pompa Air (the latter two are not part of the village sample of this study).

It is likely that the Batin Sembilan and the populations of the affected hamlets had no say regarding the issuance of the HGU; according to a key informant in Bungku, they were not consulted prior to the plantation's implementation ${ }^{221}$. The same informant stated that the company destroyed rubber plots and fruit gardens: "Originally this was all community land. We had rubber, durian, and jernang ${ }^{222}$ (dragon blood). It was land of the people but the company destroyed it with bulldozers ${ }^{223}$." A Batin Sembilan elder explained that the plantation estate was constructed with support from the military and the police: resistance was impossible ${ }^{224}$. A significant part of the Batin Sembilan population that is now living in the Harapan Rainforest once lived in areas now used by PT Asiatic Persada ${ }^{225}$.

Although the conflict with PT Asiatic Persada has not yet been resolved, rescaling processes and scale jumping to the transnational scale facilitated by the NGO Setara ${ }^{226}$ has strengthened the position of local communities vis a vis the company. PT Asiatic Persada's owner, the Singapore-based agrobusiness group, Wilmar International, recently sold the company to avoid losing its certification from the Roundtable for Sustainable Palm Oil (RSPO) 227 (c.f. Beckert, Dittrich, and Adiwibowo 2014; Steinebach 2013b). At the time of my field research, members of the local community were occupying parts of the plantation (figure 9).

In more recent, smaller corporate plantations developments in the villages of Tanjung Lebar, Seponjen, and Sungai Aur, local public authorities were directly involved in the permit process - although conflicts and disputes also occurred. In Tanjung Lebar, for instance, PT Bahar Pasifik received a permit from the Lembaga Adat of Tanjung Lebar, which managed customary land that the Batin Sembilan community had received from the provincial government in the early $2000 \mathrm{~s}^{228}$. The Lembaga Adat's permit required the company to set aside land for a smallholder scheme but once the company received the HGU from the district government, it refused to allocate land to smallholders ${ }^{229}$. Some of the displaced smallholders then moved into the Harapan Rainforest concession. In this case, the company applied

\footnotetext{
${ }^{221}$ Interview with a key informant in Bungku, 13.09.2012, Document ID: 86.

222 Dragon blood, Daemonorops draco, is specific rattan species that produces a red resin.

223 Interview with a key informant in Bungku, 13.09.2012, Document ID: 86.

${ }^{224}$ Interview with a key informant in Bungku, 12.09.2012, Document ID: 87.

225 Interview with a key informant in Bungku, 21.09.2012, Document ID: 83.

226 Interview with a SETARA activist, 18.07.2013, Document ID: 115.

${ }^{227}$ RSPO is a transnational certification body that promotes sustainable oil palm plantations.

${ }^{228}$ Interview with a key informant in Tanjung Lebar, 27.07.2013, Document ID: 113.

${ }^{229}$ Interview with a key informants in Tanjung Lebar, 25.07.2013, Document ID 125 and 27.07.2013, Document ID: 113.
} 
scale jumping to the district scale of regulation to avoid the costs of running a smallholder scheme. Key informants have reported a similar case in Seponjen in the Berbak Landscape ${ }^{230}$.

Figure 9: A Batin Sembilan banner

welcomes visitors to their land behind a PT Asiatic Persada sign that prohibits entry (Source: by the author in 2012)

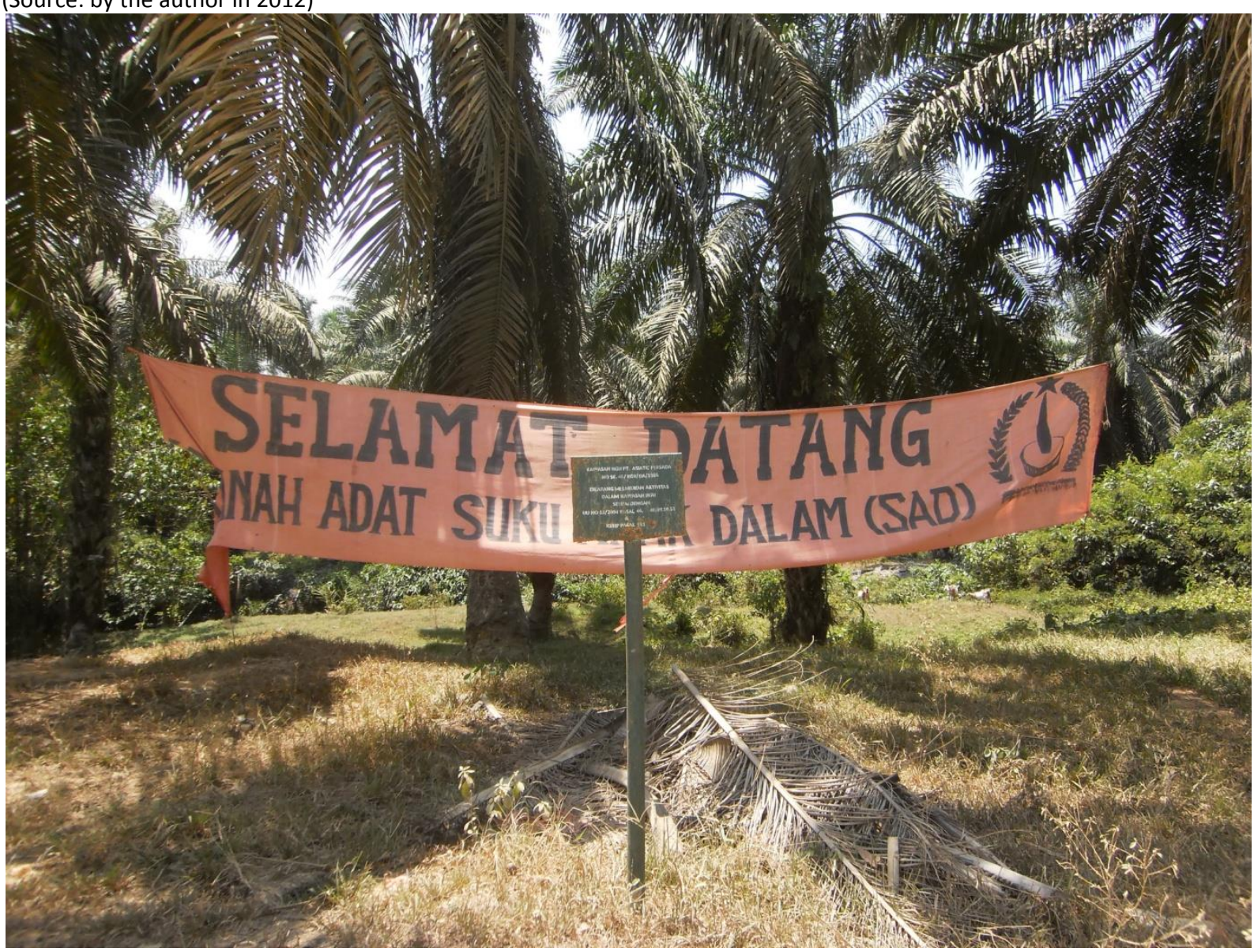

\subsubsection{Access to land and property for peasant migrants}

Rural migrants are very heterogeneous in both landscapes and have used many different strategies to access land. Some just migrated a few miles from a neighboring village while others came from areas as far as South Sulawesi in Indonesia's "Far East". The term 'migrant' is a rather blurred category in a dynamic rural frontier landscape. Especially in the Harapan Landscape, where semi-nomadic groups dominated until the 1970s, to some extent, many families are migrants. Most migrants who arrived were landless and managed to gain access to land with the support of family members (Hein and Faust 2010) and by engaging with the indigenous population and local public authorities. Rural migration makes access and property relations visible. Furthermore, the common and ongoing process of rural migration in dynamic tropical frontier landscapes is a major challenge for conservation initiatives

\footnotetext{
${ }^{230}$ Interview with a key informant in Seponjen, 13.09.2013, Document ID: 122.
} 
seeking to conserve a landscape's status quo (Carr 2009: 356; Zelli et al. 2014: 29; Hein and Faust 2010: 12).

Harapan and Berbak Landscapes are important destinations for spontaneous frontier migrants and participants of the state-led "transmigration" resettlement program. Here I focus my attention on how spontaneous frontier migrants have accessed land and property.

Figure 10: Migrants accessing land in the villages

(Source: Hein 2013b: 17)

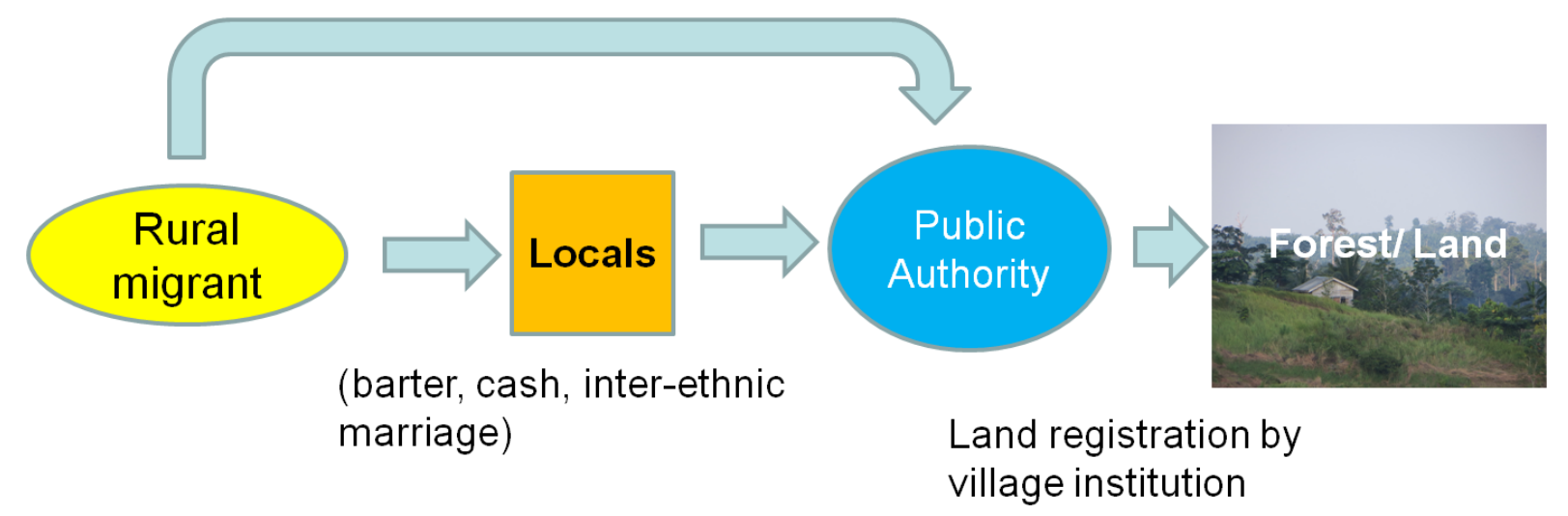

As in other frontier regions (Li 2005: 136; 2002: 429), migrants had to engage with the indigenous population and local public authorities in order to convert forest and access land (figure 10). A Javanese migrant who came to Bungku in the 1970s explained: "I have directly started to work together with the Orang $\mathrm{Kubu}^{231}$ in the forest. We were looking for jernang, ${ }^{232}$ rattan, timber, and other forest products. I worked for 12 years with them in the forest and in 1975 I have married my woman who is from here and we stayed in the village [...]. After, the forest products were getting scarcer [...] I have started farming in $1995^{233}$." Local customary regulation require all migrants to obtain permits from a local authority (a village head or customary leader), or at least from a member of the community. A former community leader in Bungku said, "Newcomers should first contact the village head or the ketua adat for a forest conversion permit ${ }^{234}$." A former community leader in Tanjung Lebar confirmed: "Forest conversion had to be reported to the village head or at least to an elder. [...] Migrants cannot just convert forest, the forests had been already used by our ancestors ${ }^{235}$." A migrant from Kerinci (located in the Bukit Barisan mountain range of western Jambi) said that he asked the Batin Sembilan before establishing his plots inside the borders of today's Harapan Rainforest project ${ }^{236}$. Various local

\footnotetext{
231 "Orang Kubu" refers here to the Batin Sembilan.

232 Daemonorops.

${ }^{233}$ Interview with a key informant in Bungku, 16.09.2012, Document ID: 85.

${ }^{234}$ Interview with a key informant in Bungku, 08.09.2012, Document ID: 77.

235 Interview with a key informant in Tanjung Lebar, 27.07.2013, Document ID: 113.

${ }^{236}$ Interview with a key informant in Tanjung Lebar, 27.07.2013, Document ID: 145.
} 
authorities complained that recently many migrants and outsiders had been converting forests without permits. A customary leader from Tanjung Lebar explained: "Those who convert two to three hectares still have a permit from us - from the Batin Sembilan - but those that have financial resources convert 20 to 50 hectares of land without asking us $^{237}$."

It is worth mentioning that migrants are well aware that by insisting that they had received a permit from a customary authority, their land claim would be considered more legitimate in conflicts with oil palm companies, conservation companies, and the forest agencies. Especially in the conflictive Harapan Landscape, migrants' statements should be treated with caution since it was impossible to verify all of them.

To access land in the Harapan Landscape, migrants usually had to compensate the land's previous user for his losses instead of buying the land outright, a transaction which was not considered to be a purchase: "The selling of land is actually not allowed, but migrants can obtain land through compensation payments ${ }^{238}$." In the past, cigarettes, rice, and other in-kind benefits were sufficient to access land and receive a forest conversion permit ${ }^{239}$. In most cases today, cash payments have to be made that are substantially larger than the earlier IDR 200,000 per ha - and can go up to IDR 70 million (equivalent to US\$ 14 to US\$5125) per ha for land planted with harvestable oil palms ${ }^{240}$. In recent years, migrants and locals have started to abandon the concept of compensation and describe the transactions as "purchases". A migrant from Kerinci who was farming inside a forest reserve stated: "I bought the land and converted the land and planted oil palms [...] I have paid IDR 4 million per hectare ${ }^{241}$." A Batin Sembilan woman said that she had sold land: "We sold 3 hectares to family members living in Jambi city because we had to cover the costs of a medical treatment ${ }^{242}$." Migrants who received land from one of the larger village-scale forest conversion and settlement initiatives reported that they had not to pay for the land but they did have to pay for the public infrastructure in the settlements, as well as for land measurement services and land titling (more details in section in 6.3.3 and c.f. Hein et al. 2015: 6).

Among the Berbak Landscape villages, only in Sungai Aur was the concept of compensation known. According to other informants land trade was even supported by the village government of Sungai Aur. In line with narratives used by the central state in Jakarta to legitimize the transmigration program, the village government officials argued that migrants promote village development ${ }^{243}$. There, land

\footnotetext{
${ }^{237}$ Interview with a key informant in Tanjung Lebar, 26.07.2013, Document ID: 127.

238 Interview with a key informant in Bungku, 08.09.2012, Document ID: 77.

239 Interview with a key informant in Bungku, 10.09.2012, Document ID: 73.

240 Interview with a key informant in Bungku, 10.09.2012, Document ID: 73.

${ }^{241}$ Interview with a key informant in Bungku, 16.09.2012, Document ID: 78.

242 Interview with a key informant in Bungku, 12.09.2012, Document ID: 84.

${ }^{243}$ Interview with a key informant in Sungai Aur, 31.08.2013, Document ID: 138.
} 
commodification seems generally more advanced than in the Harapan Landscape. Key informants in Sungai Aur and Seponjen confirmed that many native Malay have sold their land to migrants, companies, or outsiders ${ }^{244}$. In Air Hitam Laut, land trade is also common, but recently many landholders have leased land instead of selling $\mathrm{it}^{245}$.

In the Harapan Landscape, and to lesser extent in the Berbak Landscape, selling land to migrants accelerated processes that transformed large parts of the local indigenous population from landlords who controlled vast forest areas to marginalized smallholders or even to landless peasants. Tania Murray Li (2002) discovered similar dynamics in Central Sulawesi. Within the Harapan Rainforest, the Batin Sembilan facilitated forest conversion and land access for migrants, but as a PT REKI survey (2011a) shows, only a minority were able to maintain their land and only the elites benefited from land trade.

The reasons for selling land are hard to identify. One explanation might be that the owners lack economic resilience because they lack other assets and knowledge about how to act in a commodified, market-oriented environment. In some cases, land was sold to overcome shocks - the costs of medical treatment or to cover the costs for the children's education, to compensate for harvest failures or the destruction of a plantation by forest fires ${ }^{246}$. Another explanation might be that land had always been abundant and the Malay and Batin Sembilan groups were not yet able to adapt to the new scarcity.

\subsection{The "making" of new property challenging REDD+ and conservation: State policies, rescaling and legal mimicry}

Agricultural expansion is the main driver of deforestation and the main challenge to conservation and REDD+ projects in the Berbak and Harapan Landscapes. The rescaling of forest and land governance in the context of the decentralization processes of the Reformasi era provided the opportunity for local actors to expand their authority over forest and land tenure (Barr et al. 2006: 2 and section 5.1.4). In both landscapes, local public authorities (customary leaders, village governments, and district governments) have reinterpreted, reformulated, and reconceptualized national settlement and landtitling programs like those for transmigration and undeveloped villages (Impress Desa Tertingaal, IDT). Local public authorities have established a village-scale of regulation to legitimize land claims based on

\footnotetext{
${ }^{244}$ Interviews with key informants in Sungai Aur, 01.09.2013, Document ID: 136, 02.09.2013, Document ID: 1315, and in Seponjen, 10.09.2013, Document ID: 205 and 15.09.2013, Document ID: 172.

245 Interview with key informants in Air Hitam Laut, 29.09.2012, Document ID: 53.

246 Interview with key informants in Bungku, 12.09.2012, Document ID: 843, in Sungai Aur, 31.08.2013, Document

ID: 1387, and in Seponjen, 13.09.2013, Document ID: 1221.
} 
an informed choice of regulatory elements of Indonesian property law and started to issue village-level land titles, such as the sporadik (c.f. Kunz et al. submitted). Actor coalitions involving customary leaders, village governments, and district agents have reinterpreted, copied, and transplanted the transmigration program to the subnational scale - as in the Transwakarsa Mandiri settlement (section 6.3.3.1). Elements of Indonesian property regulations (e.g. Basic Agrarian Law), transmigration regulations, development policies, and the constitution have been used to underpin the legitimacy of local public authorities who formally and spatially exceed their competencies.

First, the various examples illustrated in this section show how rescaling has broadened the opportunities for local actors to access land and property. Second, they illustrate that different state apparatuses might act in contradictory ways and not directly reflect the will of dominant groups at the national scale. By using language and symbols of the central state such as sporadik and transwakarsa, and by referring to elements of the central state's legal system (legal mimicry), actors gain power and legitimacy (Lund 2006: 687). Local public authorities e.g. village governments follow the policies and regulations that specifically support their interests. The different informal settlement projects analyzed in section 6.3.3 indicate that specific rules or modes of regulation (Etzold et al. 2009: 8) are negotiated between the political elites (village leaders and customary authorities).

The examples illustrate how the power constellations have changed: local public authorities have been able to develop invisible, hidden, and visible power. The active reformulation of scalar narratives of the Suharto area has provided new meanings and legitimacy for agricultural expansion and settlement formation that indicate invisible power. Successful occupations of forest land, like those by the SPI (Serikat Petani Indonesia) peasant movement, show that the MoF and central state have lost hidden and visible powers - thus providing opportunities for alternative developments. In this sense, villagescale land-titling and the various village-scale settlements that violate forest law can be seen as active scalar resistance against the central state's land allocation policies, especially those of the MoF.

Land-allocation policies and forest law are considered as unjust - particularly in Bungku - and are actively challenged by local actors, as this former village head states: "My house is located within the state land. The state officials say that is state forest, my house is state forest. That means that myself, as a village leader, I am living within the state forest. There is no non-forest land (APL) available [...]. We cannot get a land certificate for the state forest. We live in this country but we cannot get land rights [....] According to the Forest Law 1999/41, we should be punished. This is unfair [...] Many people are living within the Asialog concession since the 1960s. Now the area [Harapan Rainforest] is designated for being the lungs of the world and for forest restoration. [....] There is no place for the 
rights of the people there. The communities are threatened by the application of the forest law. There is no social justice, no partnership: one of our community members was even sentenced ${ }^{247}$."

In this section, I investigate different processes of property-making, land-titling, legal mimicry, collective forest conversion, and settlement formation projects that challenge the integrity of the Harapan Rainforest and to a lesser extent, also that of the Berbak Carbon Project. First I describe the settlement, agricultural expansion, and land-titling schemes developed and implemented by state apparatuses and legitimized by national regulation, such as the transmigration and underdeveloped village programs. Then I unravel the local interpretations, that is, the mimicry of state-backed property regulations (c.f. Kunz and Hein et al., submitted), land allocation, settlement policies, and entangled scale relations. I include a detailed description of village-scale land-titling (6.3.2), and different examples of organized forest conversion and land allocation (6.3.3) that have been inspired and legitimized by elements of national regulations, laws, and policies.

\subsubsection{State-based settlement and land allocation schemes}

During the New Order era, transmigration settlements were established in the Sungai Bahar area. They overlap with land claimed by Batin Sembilan groups of Tanjung Lebar and later became independent villages. The settlements in the Sungai Bahar area (developed between 1983 and 1986) provided approximately 2 ha of agricultural land and a 0.25-ha plot for a house, yard, and garden. Participants received formal land titles from the National Land Agency. A member of the village government argued that the local population had difficulty joining the program. He reported that some Batin Sembilan households paid a fee to join but received no land from the transmigration authorities ${ }^{248}$. A Batin Sembilan household head said that a total of 56 Batin Sembilan households from Tanjung Lebar joined and received start-up credits and land titles issued by the National Land Agency ${ }^{249}$. Some of them later sold their land to migrants ${ }^{250}$.

In 2008, a district-to-district transmigration settlement for Javanese families was established in Sungai Aur - in the Sekitar Tanjung forest reserve and the Berbak Carbon Project. The transmigration program in Sungai Aur started in late 2008, with the district government selecting a location that is part of the Forest Reserve Sekitar Tanjung and the Berbak Carbon Project. Thus it was ineligible to become a transmigration site according to forest law, and the MoF and Provincial Forest Agency attempted to

\footnotetext{
${ }^{247}$ Interview with a key informant in Bungku, 08.09.2012, Document ID: 77.

248 Interview with a key informant in Tanjung Lebar, 25.07.2014, Document ID: 125.

249 Interview with a key informant in Tanjung Lebar, 25.07.2013, Document ID: 149, 292.

${ }^{250}$ Interview with a key informant in Tanjung Lebar, 25.07.2014, Document ID: 125.
} 
stop the settlement's formation ${ }^{251}$. A detailed description of this land conflict that involved different state apparatuses and settler is found in chapter seven.

\begin{tabular}{|c|c|c|c|c|}
\hline Program & Scope & Authority and scale & Land title & $\begin{array}{l}\text { Identified in } \\
\text { village? }\end{array}$ \\
\hline Transmigration & $\begin{array}{l}\text { Resettlement from } \\
\text { provinces with high } \\
\text { population density, } \\
\text { plot for home garden } \\
\text { and agriculture, } \\
\text { housing }\end{array}$ & $\begin{array}{l}\text { Since the Reformasi: } \\
\text { district government; } \\
\text { previously the } \\
\text { Ministry for } \\
\text { Transmigration }\end{array}$ & Yes & $\begin{array}{l}\text { Sungai Aur and } \\
\text { Tanjung } \\
\text { Lebar }^{252}\end{array}$ \\
\hline $\begin{array}{l}\text { Program for } \\
\text { underdeveloped } \\
\text { villages (Impress Desa } \\
\text { Tertinggal) }\end{array}$ & $\begin{array}{l}\text { Development support } \\
\text { for "backward } \\
\text { villages" }\end{array}$ & District government & $\begin{array}{l}\text { Not in all } \\
\text { projects }\end{array}$ & Tanjung Lebar \\
\hline $\begin{array}{l}\text { Social housing program } \\
\text { for nomadic groups } \\
\text { (Transsos) }\end{array}$ & $\begin{array}{l}\text { Sedentarization of } \\
\text { nomadic and semi- } \\
\text { nomadic groups }\end{array}$ & District government & $\begin{array}{l}\text { Only land } \\
\text { for house, } \\
\text { yard, and } \\
\text { garden }\end{array}$ & $\begin{array}{l}\text { Bungku, } \\
\text { Tanjung Lebar }\end{array}$ \\
\hline $\begin{array}{l}\text { National Agrarian } \\
\text { Operation (Proyek } \\
\text { Operasi Nasional } \\
\text { Agraria, PRONA) }\end{array}$ & $\begin{array}{l}\text { Collective land- titling } \\
\text { program }\end{array}$ & $\begin{array}{l}\text { Ministry for } \\
\text { Agriculture and Spatial } \\
\text { Planning and National } \\
\text { Land Agency }\end{array}$ & Yes & $\begin{array}{l}\text { Sungai Aur } \\
\text { (initial survey } \\
\text { conducted) }\end{array}$ \\
\hline Sporadik & $\begin{array}{l}\text { Individual land-title } \\
\text { application process }\end{array}$ & $\begin{array}{l}\text { Issued by village } \\
\text { government and } \\
\text { requested by the } \\
\text { National Land Agency } \\
\text { for obtaining a land } \\
\text { title }\end{array}$ & Yes & All study villages \\
\hline
\end{tabular}

Table 10: Different formal land allocation schemes

(Source: compiled by the author)

The program for underdeveloped villages (Impress Desa Tertinggal) and the Transsos settlement program were presented as social programs to develop the local population. They have been developed from the 1970s until the late 1990s. Aimed at sendentarizing the semi-nomadic Batin Sembilan families, the programs provided them with standardized wooden houses ${ }^{253}$. The program in Bungku provided no agricultural land; in Tanjung Lebar participating households received 1 ha of agricultural land ${ }^{254}$. In the late 1990s, a Transsos settlement was established in the hamlet of Pangkalan

\footnotetext{
${ }^{251}$ Interview with key informants in Sungai Aur, 29.08.2013, Document ID: 132, 135 and with the staff member of Dinas Kehutanan Provinsi Jambi, Jambi, 27.08.2013, Document ID: 137.

${ }^{252}$ Tanjung Lebar was not a transmigration village, but transmigration settlements were developed within the territory it claimed. Today those settlements are independent villages.

${ }^{253}$ Interview with key informants in Tanjung Lebar, 26.07.2013, Document ID: 127 and in Bungku, 08.09.2012, Document ID: 77.

${ }^{254}$ Interview with a key informant in Tanjung Lebar, 27.07.2013, Document ID: 113.
} 
Ranjau, but like the IDT settlement in Bungku, no agricultural land or land titles were allocated to the Batin Sembilan. ${ }^{255}$

\subsubsection{Village-scale land-titling and the role of local public authorities}

Although village-scale land titles have no clear legal basis, they are common all over Jambi and Indonesia (Kunz et al. submitted). Village-scale land titles are based on legal mimicry - a site-specific interpretation of elements and fragments of state laws and regulations (ibid.). Governmental Regulation 24/1997 is very relevant since it explicitly mentions the role of village governments in the land-titling process (see section 5.2). It gives village heads the authority to issue specific documents required for transforming customary land claims into a certificate of the National Land Agency (Badan Pertanahan Nasional). The regulation might thus provide legitimacy for local public authorities (e.g. village governments) to consolidate control over untitled customary land. Moreover, the regulation provides legitimacy to facilitate land transactions and room political and economic rent-seeking for village governments (c.f. Lund 2008: 23).

Conceptually, village-scale land titles might also be seen as the result of rescaling processes. The dayto-day interactions of smallholders seeking to get land certified by village governments and local banks' acceptance of some village-scale land titles as collateral for small loans consolidates the village scale of land tenure regulation. Moreover, I argue that the new village-scale of regulation reflects the requirements of a specific mode of production: smallholder oil palm cultivation. Village-scale land titles have facilitated the expansion of smallholder oil palm plantings and contributed to the commodification of former lineage-based property.

I have identified seven different documents issued by village governments or other village-based public authorities in the five villages (table 11), but discuss just two of them here: Sporadik (figure 12) and Surat Keterangan Tanaman Tumbuh (SKTT). Sporadik is the most common village-scale land title, found in all five study villages as well as in other parts of Jambi, such as the Bukit Duabelas Landscape (Kunz et al. submitted). The SKTT title is only issued by the village government of Bungku which certifies rights to an existing rubber or oil palm plantation ${ }^{256}$ - just crop ownership, not land. SKTT is probably a reinterpretation of the land registration letter (Surat Keterangan Pendaftaran Tanah, SKPT) introduced by Governmental Regulation 10/1961. According to the regulation the document must be issued by local offices of the National Land Agency. Key informants in Bungku explained that the village-

\footnotetext{
255 Interview with a key informant in Tanjung Lebar, 23.07.2013, Document ID: 171 and interview with Agra activist in Jambi, 18.09.2013, Document ID: 388.

${ }^{256}$ Interview with key informants in Bungku, 10.09.2012, Document ID: 75 and in Tanjung Lebar, 27.07.2013, Document ID: 113.
} 
scale SKTT may be issued for 2-ha plots for a fee of approximately IDR 200,000 to 250,000 (equivalent to US\$14 to US\$18). According to a key informant in Bungku, since this title only certifies the right to cultivate plants and trees, the village government also issues titles for land in the state forest ${ }^{257}$. The SKTT title is popular in Bungku, probably because large parts of the Bungku village territory are part of the state forest and are thus state-owned. When a village government issues cultivation rights, it does not challenge central state ownership per se and provides sufficient tenure clarity for facilitating land transactions between the various smallholders. SKTT titles are not used in the other villages studied. A key informant in Tanjung Lebar argued that the title is not "strong" and cannot resolve land disputes: for that reason, the village government decided against issuing the title. He further stressed that since the SKTT only certifies tree ownership, other parties can claim the land and create conflicts between SKTT holders and others (e.g. concession holders) ${ }^{258}$.

Figure 11: Village-scale land-titling in the villages and the changing meaning of sporadik across scales (Source: by the author)

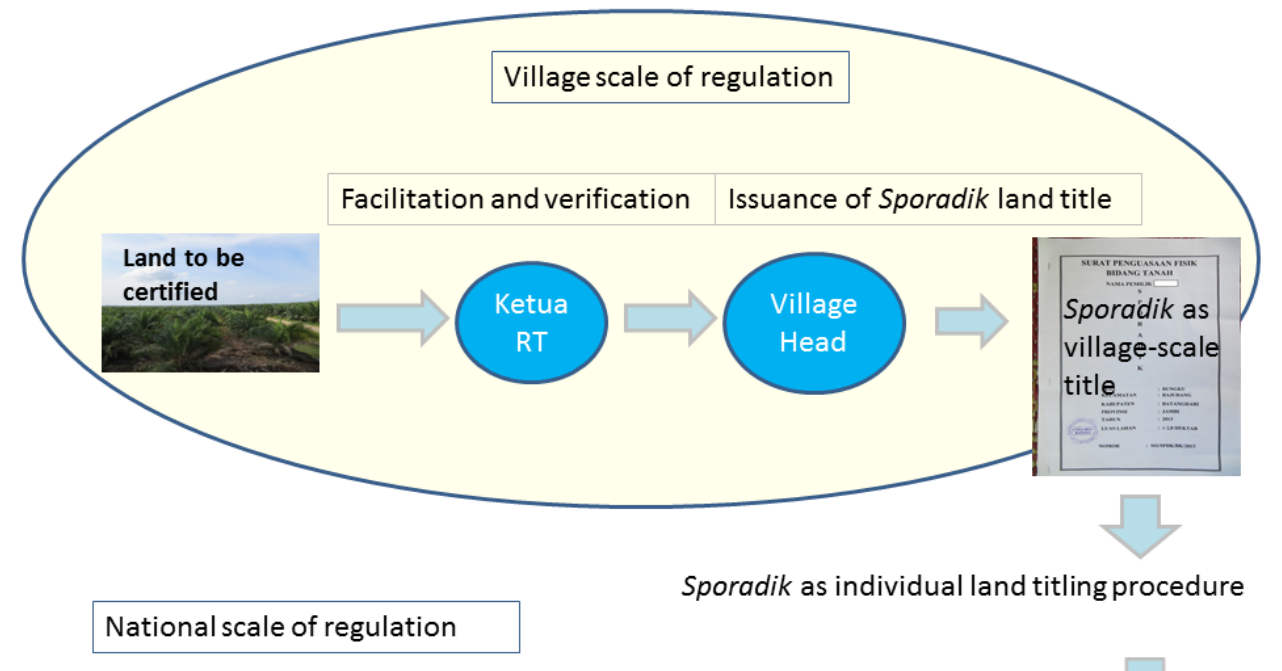

Hak Milik (Land title issued by National Land Agency)

According to Governmental Regulation 24/1997, sporadik is the National Land Agency's application procedure for an individual land title. However, in the villages I studied and in other parts of Jambi, sporadik refers to a village-scale land title and can be used for the National Land Agency's official sporadik titling procedure ${ }^{259}$. Sporadik has different meanings at different scales: at the village scale,

257 Interview with key informants in Bungku, 10.09.2012, Document ID: 75.
258 Interview with a key informant in Tanjung Lebar, 27.07.2013, Document ID: 113. 
the document is a land title that provides security of tenure; at the national scale, the National Land Agency considers it to be one of many documents required when applying for a land title through the sporadik titling procedure (figure 11 ).

The sporadik village-scale certification process is facilitated by the neighborhood head (Ketua Rukun tetangga $(R T)$ ), who organizes the certification process and appoints a team that usually consists of landowners of adjacent plots and village elders; in some cases, the head of the hamlet, village secretary, and customary leaders are also involved. The team approves the plot size and borders, and verifies that no other party claims $i^{260}$. Once the team has approved the ownership rights, the village head issues the sporadik title. This certification procedure is quite similar in the various villages. In Bungku, a key informant stated that the village government had issued sporadik titles without verifying the land claims ${ }^{261}$ and argued that the village is too large for its government to be able to verify all sporadik applications. Village government members in Tanjung Lebar, Seponjen and Sungai Aur stated that they do not issue sporadik titles for land in the state forest. However, the Bungku village government does issue sporadik land titles for plots in state forests and even for plots in the Harapan Rainforest (c.f. Mardiana 2014: 42). The head of the Kelurahan (lurah) ${ }^{262}$ of Tanjung (near Seponjen) also issues sporadik titles within the Forest Reserve Sekitar Tanjung, which is part of the Berbak Carbon Project. ${ }^{263}$ In Seponjen, two types of sporadik titles are in use: titles issued by the village government and those jointly issued by the head of the subdistrict (camat) of Kumpeh and the village government. Both types are considered to be equally strong, and both can be used as collateral for bank loans and the formal land-title application process ${ }^{264}$. The titled issued jointly by the subdistrict head and the village government might reflect Bugi migrants' higher expectations of formalized land-titling. As newcomers to the Berbak Landscape, Bugis do not belong to local kin networks that provide access to land and tenure security (c.f. von Benda-Beckmann and von Benda-Beckmann 1999: 18). They are therefore very interested in getting strong land titles. The document might also be traced back to the role of the pasirah in the margas of Berbak and Kumpeh, who allocated drainage and forest conversion permits to Bugi migrants. The position of a pasirah and the administrative unit of a marga were abolished through administrative reforms and replaced by the kecamatan (subdistrict), in which the camat replaced the pasirah. At least officially, the camat has no authority over land. However, as the

\footnotetext{
260 Interviews with key informants in Bungku, 10.09.2012, Document ID: 75, and 25.08.2013, Document ID: 3, in Tanjung Lebar, 25.07.2012, Document ID: 124, 177, and in Sungai Aur, 31.08.2013, Document ID: 138, and Seponjen, 08.09.2013, Document ID: 175.

261 Interview with a key informant in Bungku, 25.08.2013, Document ID: 3.

${ }^{262}$ An administrative entity of urban communities, same administrative level as a village but less autonomy, the head of the kelurahan is the lurah.

263 Interview with a key informant in Seponjen, 12.09.2013, Document ID: 312.

${ }^{264}$ Interview with a key informant in Seponjen, 08.09.2013, Document ID: 175.
} 
subdistrict's highest public authority who supervises village heads and the pasirah's successor, his signature might help to increase the legitimacy of sporadik titles.

Land certified with a sporadik title is registered in the village land registry. This is not the case for land certified with a SKTT title. ${ }^{265}$ In some villages, such as Bungku and Seponjen, the village government requested a fee for issuing sporadik titles. ${ }^{266}$ In Tanjung Lebar, a member of the village government said that issuance is free. ${ }^{267}$

\section{Figure 12: A sporadik land title}

issued by the village head of Bungku (left) and one issued by the Seponjen village government that was signed by the head (camat) of the Kumpeh subdistrict (right).

(Source: by the author in 2013)

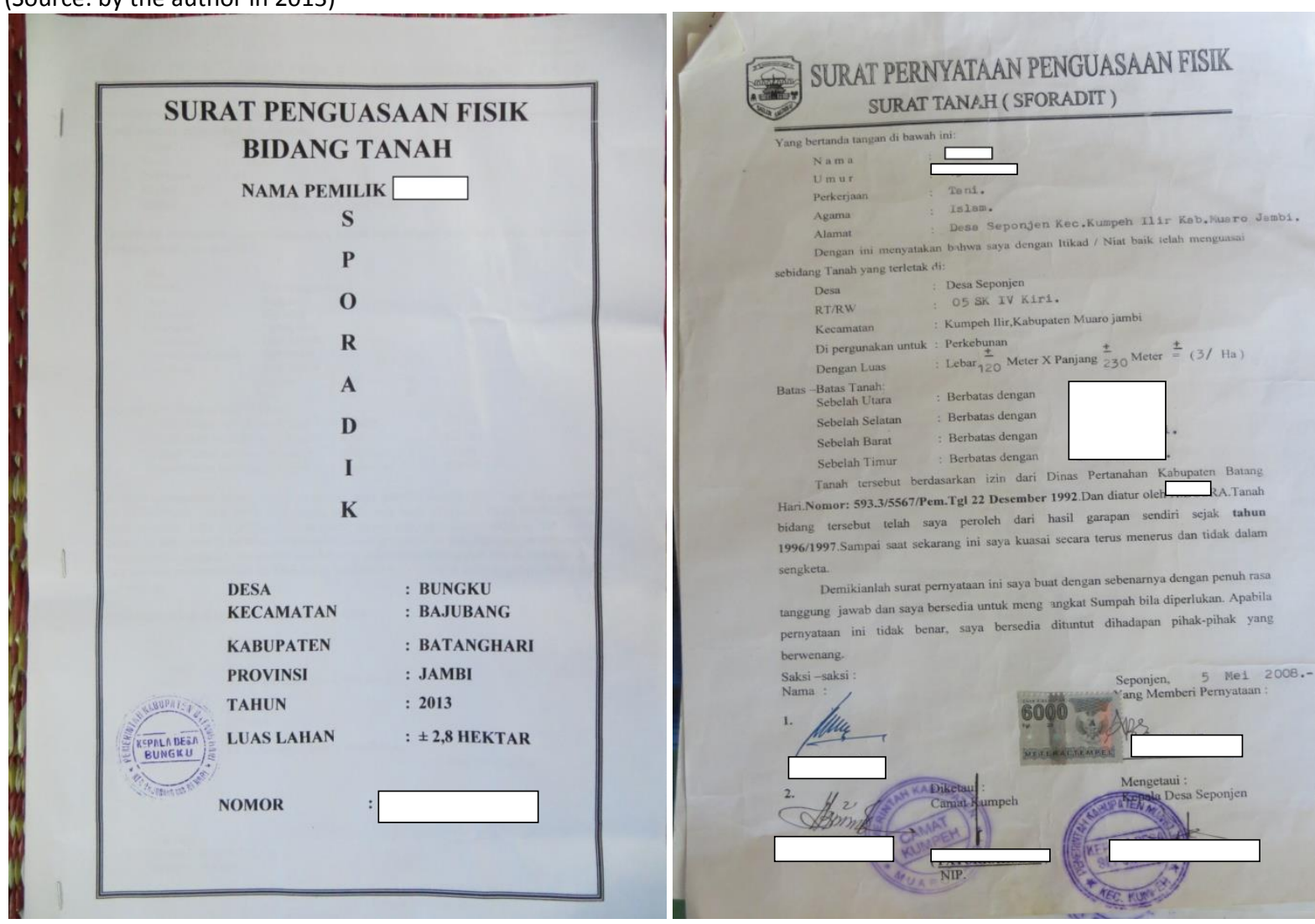

265 Interview with key informants in Bungku, 10.09.2012, Document ID: 75.

${ }^{266}$ Interviews with key informants in Bungku, 10.07.2013, Document ID: 105, 24.08.2013, Document ID: 152, and Seponjen, 15.09.2013, Document ID: 317.

${ }^{267}$ Interview with a key informant in Tanjung Lebar, 25.07.2013, Document ID: 125. 


\begin{tabular}{|c|c|c|c|c|c|}
\hline Land title & Used in: & Scope & Authorities involved & $\begin{array}{l}\text { Issued within } \\
\text { REDD+ project }\end{array}$ & $\begin{array}{l}\text { Scale of } \\
\text { regulation }\end{array}$ \\
\hline $\begin{array}{l}\text { Surat } \\
\text { Keterangan } \\
\text { Tanaman } \\
\text { Tumbuh } \\
\text { (SKTT) }\end{array}$ & Bungku & $\begin{array}{l}\text { Certifies } \\
\text { cultivation } \\
\text { rights/rights to } \\
\text { plantings }\end{array}$ & $\begin{array}{l}\text { Village head and village } \\
\text { secretary }\end{array}$ & $\begin{array}{l}\text { Yes, Harapan } \\
\text { Rainforest }\end{array}$ & Village \\
\hline $\begin{array}{l}\text { Surat } \\
\text { Warisi }\end{array}$ & Sungai Aur & $\begin{array}{l}\text { Certifies land } \\
\text { inheritance }\end{array}$ & Village head & N. A. & Village \\
\hline $\begin{array}{l}\text { Surat Jual } \\
\text { Beli }\end{array}$ & $\begin{array}{l}\text { Bungku, } \\
\text { Seponjen }\end{array}$ & $\begin{array}{l}\text { Certifies land } \\
\text { transactions }\end{array}$ & $\begin{array}{l}\text { Neighborhood head } \\
\text { (Ketua } R T \text { ) }\end{array}$ & N. A. & $\begin{array}{l}\text { Neighborh } \\
\text { ood (RT) }\end{array}$ \\
\hline $\begin{array}{l}\text { Surat } \\
\text { Tanah Hak } \\
\text { Milik }\end{array}$ & Bungku & $\begin{array}{l}\text { Certifies land } \\
\text { ownership }\end{array}$ & Village head & $\begin{array}{l}\text { Yes, Harapan } \\
\text { Rainforest }\end{array}$ & Village \\
\hline Segel & Sungai Aur & $\begin{array}{l}\text { Certifies land } \\
\text { ownership; } \\
\text { precursor of } \\
\text { sporadik }\end{array}$ & Village head & N. A. & Village \\
\hline $\begin{array}{l}\text { Sporadik } \\
\text { Desa }\end{array}$ & $\begin{array}{l}\text { Air Hitam Laut, } \\
\text { Bungku, } \\
\text { Seponjen, } \\
\text { Sungai Aur, } \\
\text { Tanjung Lebar }\end{array}$ & $\begin{array}{l}\text { Certifies land } \\
\text { ownership; } \\
\text { entered into } \\
\text { village land } \\
\text { registry }\end{array}$ & $\begin{array}{l}\text { Village head, } \\
\text { neighborhood head } \\
\text { (Ketua } R T \text { ), and/or } \\
\text { head of drainage canal } \\
\text { (Ketua Parit) }\end{array}$ & $\begin{array}{l}\text { Yes, Harapan } \\
\text { Rainforest and } \\
\text { Berbak Carbon } \\
\text { Project }\end{array}$ & Village \\
\hline $\begin{array}{l}\text { Sporadik } \\
\text { Kecamtan }\end{array}$ & Seponjen & $\begin{array}{l}\text { Certifies land } \\
\text { ownership; } \\
\text { entered into } \\
\text { village land } \\
\text { registry }\end{array}$ & $\begin{array}{l}\text { Subdistrict head } \\
\text { (camat), village head, } \\
\text { neighborhood head } \\
\text { (Ketua } R T \text { ), head of } \\
\text { drainage canal (Ketua } \\
\text { Parit) }\end{array}$ & No & Subdistrict \\
\hline
\end{tabular}

Table 11: Village-scale land titles used in the study villages

(Source: compiled by the author)

\subsubsection{Village-scale settlement schemes and land occupations in the Harapan Landscape ${ }^{268}$}

When PT Asialog abandoned its logging concession in the late 1990s and early 2000s, during the period of political turmoil and before the Harapan Rainforest project was started in 2010, at least four settlements were established within the borders of today's Harapan Rainforest (Figures 7/C, D and table 12). The settlements' formation was facilitated by actor coalitions involving Batin Sembilan elites, members of village governments, and migrants - most of whom were Javanese. The coalitions (figure 13) received support from local investors, members of district and subdistrict governments, and

\footnotetext{
268 Parts of this section are published in Hein, Jonas, Soeryo Adiwibowo, Christoph Dittrich, Rosyani, Endriatmo Soetarto, and Heiko Faust. 2015. Rescaling of Access and Property Relations in a Frontier Landscape: Insights from Jambi, Indonesia. The Professional Geographer: 1-10.
} 
peasant organizations such as SPI (c.f. Silalahi and Erwin 2013; Mardiana 2014; Hein et al. 2015). The formation of the settlements of Transwakarsa Mandiri (TSM) (Bungku), Camp Gunung (Bungku), Tanjung Mandiri (Tanjung Lebar), and Sungai Jerad (Tanjung Lebar) led to the conversion of approximately 14,000 ha of forest in the Harapan Rainforest by 2013 (REKI 2013). Especially in Bungku, settlement formation has been further legitimized through the issuance of village-scale land titles such as sporadik and SKTT.

The actor coalitions actively reproduced the New Order's development narratives to justify forest conversion and settlement formation in the state forest. Key informants emphasized that the settlements were intended to provide land for landless migrants and agricultural extension services for poor Batin Sembilan families to help them to overcome "backwardness" and achieve "development" ${ }^{269}$. The settlement projects mostly provided peasants with land. Regulations developed by Batin Sembilan elites, village governments, and Javanese migrants limit the maximum amount of land per household and stipulate that direct replanting must occur after forest conversion ${ }^{270}$.

\footnotetext{
269 Interview with a key informant in Bungku, 09.09.2012, Document ID: 96 and 10.07.2013, Document ID: 153.

270 Interview with key informants in Bungku, 09.07.2013, Document ID: 161, and in Tanjung Lebar, 21.07.2013, Document ID: 128 and 27.07.2013, Document ID: 167, 169.
} 
Figure 13: Schematic representation of settlement formation in the former PT Asialog concession (now the Harapan Rainforest).

(Source: by the author)

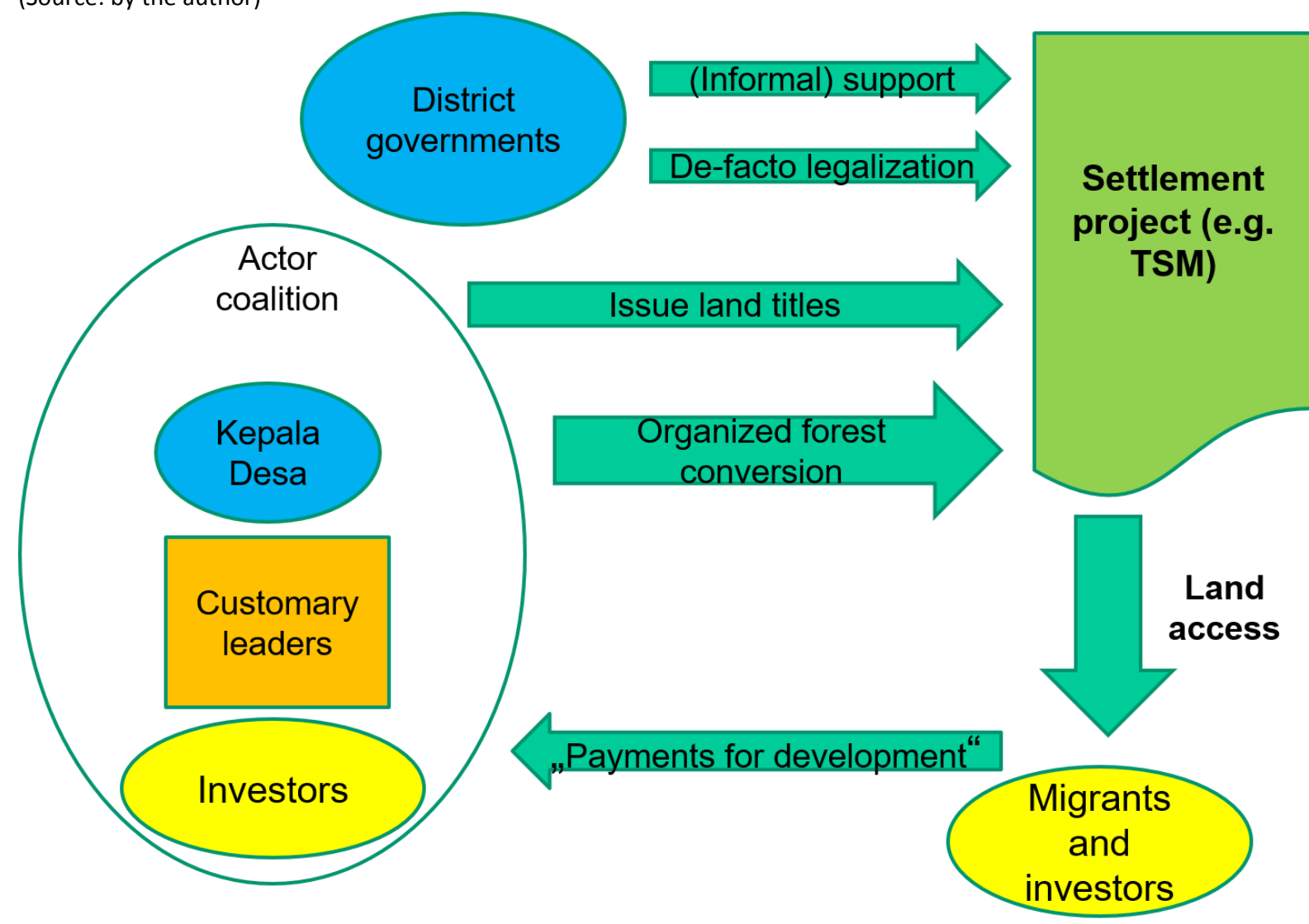

Village and Batin Sembilan authorities referred to "backwardness" and "development" to construct alternative scales of meaning and regain control over land appropriated by the New Order government. They also constructed complementary scales of regulation - by issuing village-scale land titles to settlers, and creating regulations to restrict the amount of land per household, stipulate direct replanting after forest conversion, and in at least one case, even restrict specific crops (e.g. oil palm cultivation). The regulations incorporate elements of formal state law, such as the Basic Agrarian Law (maximum amount of land) and the Forest Law (prohibition of oil palm cultivation in state forests), and customary regulations (replanting after forest conversion). The institutionalization of the settlements (establishing complex rules) and legal mimicry (using state language and elements of formal state law) further legitimized the settlements. Moreover, the settlements indicate different forms of scale jumping, for instance, village and Batin Sembilan elites jumped down to the district or subdistrict scale to obtain forest conversion permits and circumvent the MoF. For their part, migrants jumped down to the village-scale of regulation in order to access land and land titles, thus stabilizing the village-scale of regulation. 


\begin{tabular}{|c|c|c|c|c|}
\hline & $\begin{array}{l}\text { Transwakarsa } \\
\text { Mandiri (TSM) }\end{array}$ & Camp Gunung & Tanjung Mandiri & $\begin{array}{l}\text { SPI Settlements: } \\
\text { Sungai Jerad and } \\
\text { Bukit Sinyal }\end{array}$ \\
\hline Area (ha) & 1731 & 2073 & 6334 & 2500 \\
\hline Population* & 111 households & 302 households & $\begin{array}{l}\text { At least } 1500 \\
\text { households }\end{array}$ & $\begin{array}{l}508 \text { inhabitants } \\
\text { (only Bukit Sinyal, } \\
\text { no data for Sungai } \\
\text { Jeerad) }\end{array}$ \\
\hline Hamlet & Kunangan Jaya I & Kunangan Jaya II & Tanjung Mandiri & $\begin{array}{l}\text { Pangkalan Ranjau/ } \\
\text { Mangkubangan }\end{array}$ \\
\hline Village & Bungku & Bungku & Tanjung Lebar & Tanjung Lebar \\
\hline Subdistrict & Bajubang & Bajubang & Bahar Selatan & Bahar Selatan \\
\hline District & Batang Hari & Batang Hari & Muaro Jambi & Muaro Jambi \\
\hline Initiated in & $2003-2004$ & $2002-2004$ & $2003-2006$ & 2007-2009 \\
\hline Local authorities & $\begin{array}{l}\text { Village head, } \\
\text { customary leaders }\end{array}$ & $\begin{array}{l}\text { Village head, } \\
\text { customary leaders }\end{array}$ & $\begin{array}{l}\text { Village head, } \\
\text { customary leaders, } \\
\text { camat }\end{array}$ & $\begin{array}{l}\text { Hamlet head and } \\
\text { SPI leaders }\end{array}$ \\
\hline District authorities & $\begin{array}{l}\text { Agricultural } \\
\text { Agency, Education } \\
\text { Agency, Bupati** }\end{array}$ & $\begin{array}{l}\text { Agricultural } \\
\text { Agency, Education } \\
\text { Agency, Bupati** }\end{array}$ & $\begin{array}{l}\text { Agricultural } \\
\text { Agency, Education } \\
\text { Agency, Bupati }\end{array}$ & No \\
\hline $\begin{array}{l}\text { Settlers hold } \\
\text { village-scale land } \\
\text { titles }\end{array}$ & Yes & Yes & No & No \\
\hline $\begin{array}{l}\text { Regulation on } \\
\text { max. agricultural } \\
\text { land per } \\
\text { household }\end{array}$ & 5 ha & No & 3 ha & $\begin{array}{l}\text { Yes: In } 20074 \text { ha; } \\
\text { now 6-10 ha, } \\
\text { depending on } \\
\text { household size. }\end{array}$ \\
\hline $\begin{array}{l}\text { Rules for } \\
\text { cultivation } \\
\text { practices }\end{array}$ & $\begin{array}{l}\text { Direct replanting } \\
\text { after conversion }\end{array}$ & $\begin{array}{l}\text { Direct replanting } \\
\text { after conversion }\end{array}$ & $\begin{array}{l}\text { Direct replanting } \\
\text { after conversion }\end{array}$ & $\begin{array}{l}\text { Oil palm cultivation } \\
\text { prohibited, direct } \\
\text { replanting after } \\
\text { conversion }\end{array}$ \\
\hline \multicolumn{5}{|c|}{$\begin{array}{l}\text { * The demographic data is questionable, the official data on vill } \\
\text { population than village-scale data suggests. } \\
\text { ** The actors claim to have received a permit from the Bupati. }\end{array}$} \\
\hline
\end{tabular}

Table 12: Settlements within the Harapan Rainforest

(Sources: Dinas Kehutanan Kabupaten Batang Hari 2012; REKI 2011a, and own investigations; 2013) 
Figure 14: Location of settlements within the Harapan Rainforest

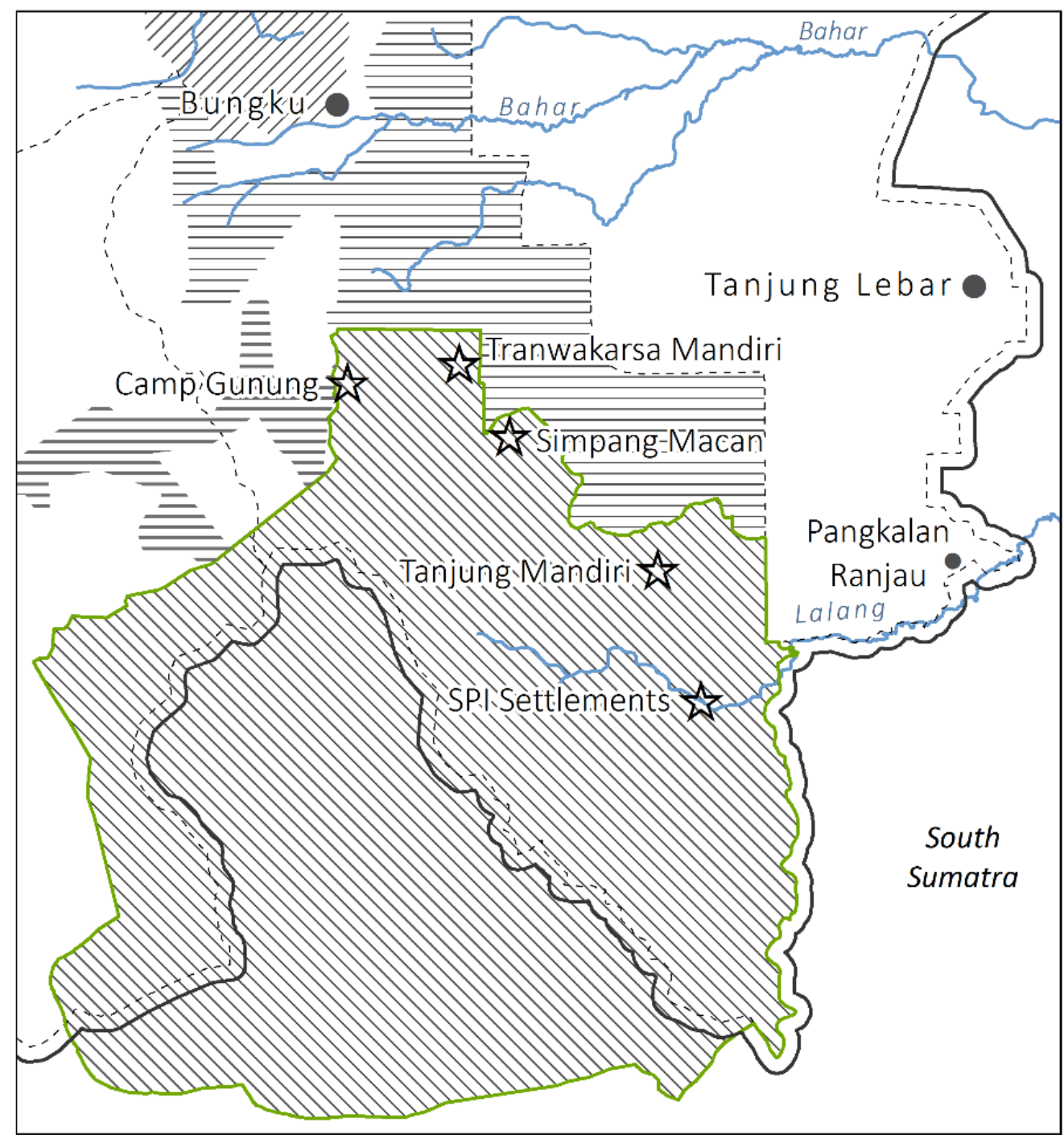

Provincial boundary

District boundary

REKI boundary (2010)

River

Forest reserve

Harapan Rainforest concession (REKI)

Other corporate concession

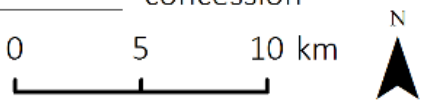

Source: Center for International Forestry Research; Ministry of Forestry Indonesia; Kementerian Kehutanan, Peta Indikatif Arahan Pemanfaatan Kawasan Hutan Produksi Yang Belum Dibebani Hak, Provinsi Sumatera Selatan; National Land Agency Indonesia (BPN); PT. Restorasi Ekosistem Indonesia (2013); Shetskaart Residentie Djambi Cartography: Carola Beckers, Institute of Geography, University of Goettingen 


\subsubsection{Transwakarsa Mandiri/Kunangan Jaya $I^{271}$}

As outlined in the conceptual framework of this thesis, national policies structure in-situ access and property relations and provide them legitimacy. The formation of the Transwakarsa Mandiri settlement in the hamlet of Kunangan Jaya I of Bungku village can be considered as legal mimicry of the national transmigration program (Kunz et al. submitted). The mimicry of policies, legal procedures, and narratives was used to legitimize and justify settlement formation and forest conversion (Hein et al. 2015; Kunz et al. submitted). The settlement name, Transwakarsa Mandiri (TSM), refers directly to the earlier central-state-backed Swakarsa transmigration subprogram. The New Order era Swakarsa program provides subsidies to relocate landless migrants from Java, Madura, and Bali, as well as land titles from the National Land Agency (Fearnside 1997: 555). However, the TSM settlement is not officially related to the Swakarsa program.

The TSM settlement was founded in 2004 by a Batin Sembilan leader living in Muaro Bulian, the district capital, a Javanese teacher named Pak Kumis ${ }^{272}$ and a former Bungku village head. The latter had married into a Batin Sembilan family and claims to represent formal village and customary authority (Hein et al. 2015; Kunz et al. submitted). First, the three leaders requested a permit from the PT Asialog logging company, which refused, arguing that that was the MoF's purview. However, the three leaders have never received a formal permit from the MoF, from the forest agency of the district of Batang Hari or from a transmigration authority ${ }^{273}$. Nevertheless, Pak Kumis claimed: “[...] in the past we had a rubber program [...]. We received a permit from the district head to plant rubber ${ }^{274}$." While it is impossible to verify his claim, it does appear likely that district officials supported the forest conversion and settlement formation. Since the Agricultural Agency and District Education Agency later de facto legalized the settlement it. The Agricultural Agency provided agricultural extension services such as allocating fertilizer, soy, and corn seeds for the settlers. Today the operational support that the settlement's elementary school receives from the District Education Agency further legitimizes the settlement ${ }^{275}$. The village government of Bungku issued village-scale land titles (sporadik and SKTT) to legalize individual land claims.

\footnotetext{
${ }^{271}$ Parts of this section have been published in Hein, Jonas, Soeryo Adiwibowo, Christoph Dittrich, Rosyani, Endriatmo Soetarto, and Heiko Faust. 2015. Rescaling of Access and Property Relations in a Frontier Landscape: Insights from Jambi, Indonesia. The Professional Geographer: 1-10. and will be published in Kunz et al. (submitted) "Mimicry of the legal: Translating de jure land formalization processes into de facto local action Experiences from Jambi province, Sumatra, Indonesia", submitted to the Austrian Journal for Southeast Asian Studies (ASEAS).

272 Fictitious name

273 Interview with a key informant in Bungku, 10.07.2013, Document ID: 153.

${ }^{274}$ Interview with a key informant in Bungku, 09.09.2012, Document ID: 96.

275 Interview with a key informant in Bungku, 10.07.2013, Document ID: 153.
} 
According to settlers I interviewed, the TSM settlement had three objectives which were perfectly in line with the objectives of the official transmigration program and with those of the program for underdeveloped villages. The settlement provided land, welfare, and employment for poor and landless peasants and aimed to support poor Batin Sembilan households. Pak Kumis said, "In 2004 we requested land for a farming group for supporting 52 Batin Sembilan households, building houses for them, educating them ${ }^{276}$." The programs also aimed to sedentarize the Batin Sembilan and teach them "modern farming techniques" which would support them to reach "development" 277 . As in the formal transmigration program, migrants participating in the TSM program were supposed to act like model farmers, thereby convincing the "backward" Batin Sembilan to abandon shifting cultivation. However, very few Batin Sembilan families were able to benefit from the program ${ }^{278}$.

To access land, migrants had to pay a development or administrative fee of approximately IDR 700,000 to $1,000,000$ per ha (equivalent to US\$ 55 to US\$ 80). Households were allowed to own a maximum of 5 ha of cropland. The development or administrative fee was intended to finance the settlement's infrastructure, including roads, electricity supply, housing for Batin Sembilan, and an elementary school. The organizers of the TSM settlement used the term "development fee" to obscure the fact that land was actually sold. Participating settlers reported that Pak Kumis promised them that, as in many other transmigration settlements, a plantation company would develop a smallholder scheme ${ }^{279}$ - but no plantation company ever started to operate there.

In 2007, the District Forest Agency and the forest police intervened. Pak Kumis was arrested for illegal logging and convicted by the Muaro Bulian district court to a prison sentence of one year. In 2010, the PT REKI conservation company received a conservation concession that overlapped the TSM settlement. The community's request to exclude the settlement from the state forest and from the conservation concession was refused by the Provincial Forest Service ${ }^{280}$. A detailed description of the subsequent land conflict involving the settlers, forest service, and the Harapan Rainforest project is given in chapter seven.

\subsubsection{Camp Gunung/ Kunangan Jaya II: Land for second-generation transmigrants}

The second and larger forest conversion and organized settlement project initiated by the government of Bungku village and Batin Sembilan elites that challenges the integrity of the Harapan Rainforest project is Camp Gunung. Like the TSM settlement, Camp Gunung predated the Harapan Rainforest.

\footnotetext{
${ }^{276}$ Interview with a key informant in Bungku, 10.07.2013, Document ID: 153.

277 Interview with a key informant in Bungku, 24.08.2013, Document ID: 152.

${ }^{278}$ Interview with key informants in Bungku, 10.07.2013, Document ID: 108 and 23.08.2013, Document ID: 202.

279 Interview with a key informant in Bungku, 23.08.2013, Document ID: 202.

${ }^{280}$ Interview with staff member of Dinas Kehutanan Provinsi Jambi, 19.09.2012, Document ID: 30.
} 
Camp Gunung is part of the hamlet of Kunangan Jaya II (part of Bungku village), and is located in a border triangle in the state forest between PT REKIs conservation concession (Harapan Rainforest) and the timber plantation concessions of PT Wanakasita Nusantara and PT Agronusa Alam Sejahtera (PT AAS). Formed between 2002 and 2004, Camp Gunung can be traced back to the deceased Batin Sembilan leader, Pak Yamin Almarhum, and the former village head of Bungku ${ }^{281}$. The village government permitted forest conversion within the former PT Asialog concession and supported the settlement's formation financially.

A key informant claimed that Pak Yamin Almarhum had a land conversion permit from the district government of Batang Hari ${ }^{282}$. As in the TSM case, it is impossible to verify this claim, but in the early 2000s, district governments did commonly issue forest conversion permits (Barr et al. 2006: 2 and section 5.1.4). Later, the settlement was legalized de facto through agricultural extension services provided by the Agricultural Agency of the District of Batang Hari. As well as through establishing a school and a kindergarten financed by the Education Agency of the District of Batang Hari ${ }^{283}$.

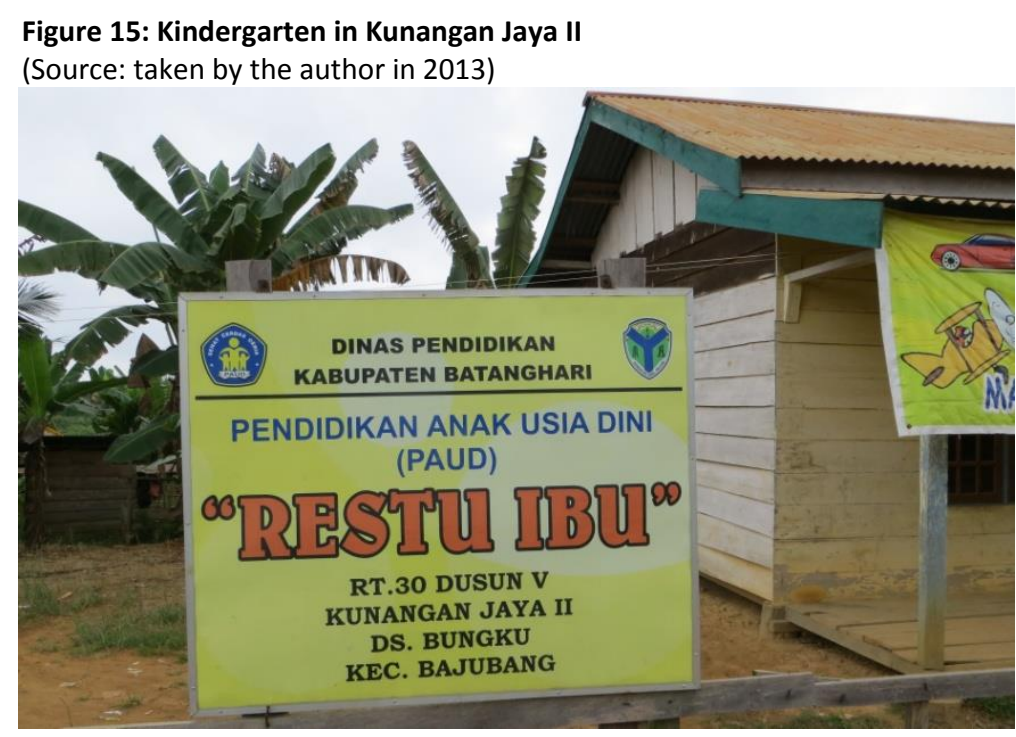

From the late 1990s to the early 2000s, Bungku became an important destination for secondgeneration, mostly Javanese transmigrants from the Batang Hari Delta transmigration settlements of Nipah Panjang and Ranto Rasau in the district of Tanjung Jabung Timur ${ }^{284}$ (c.f. Mardiana 2014: 41). The first group of second-generation transmigrants moved to the hamlet of Johor Baru II in the late 1990s. The Camp Gunung settlement was initiated in the early 2000s in order to satisfy the growing demand for land of the growing number of migrants from the coastal delta region (ibid.). Pak Yamin Almarhum

\footnotetext{
${ }^{281}$ Interview with key informants in Bungku, 14.09.2012, Document ID: 39, 44 and 09.07.2013, Document ID: 161.

282 Interview with a key informant in Bungku, conducted by Stefanie Steinebach, Document ID: 97.

283 Interview with a key informant in Bungku, 09.07.2013, Document ID: 107, 161.

${ }^{284}$ Interview with a key informant in Bungku, 11.09.2012, Document ID: 74.
} 
facilitated land transactions between migrants and Batin Sembilan families, and offered 5 ha parcels of land for IDR $750,000^{285}$. As for the TSM, the payment was considered to be a development and infrastructure fee not payment for land ${ }^{286}$. The village government of Bungku and Pak Yamin Almarhum organized the construction of roads and bridges, as well as a school, mosque, and rice mill. ${ }^{287}$ Key informants explained that land was only given to migrants who agreed to live there permanently and that settlers had to plant crops directly after converting forest ${ }^{288}$. I do not know whether or not customary leaders and the village government enforced the rules. When I visited the settlement in 2012 and 2013, many of the wooden houses and shelters looked abandoned.

PT AAS and PT REKI received their concessions in 2009 and 2010, respectively, and with the support of the police began to campaign against the settlers - reminiscent of the TSM case. According to a key informant, PT REKI and the forest police destroyed a settler camp with no warning ${ }^{289}$. In 2012, members of the settler community supported by the National Peasant Union (Serikat Tani Nasional, STN) and by the People's Democratic Party (Partai Rakyat Demokratik, PRD) started a protest march to the MoF in Jakarta ${ }^{290}$. Key informants considered the conflict with PT REKI as being solved but the conflict with PT AAS as still ongoing ${ }^{291}$. For a more detailed description of the conflict please consider a recently published working paper of Rina Mardiana (2014).

\subsubsection{Tanjung Mandiri: Migrants as model farmers and conflictive boundaries}

Tanjung Mandiri is the largest settlement in the Harapan Rainforest. Forest conversion and settlement formation started there in 2003; activities intensified in 2006 with the construction of houses and the establishment of the first plantations ${ }^{292}$. Today the settlement is one of five official hamlets of Tanjung Lebar. Like Camp Gunung and the TSM settlement, Tanjung Mandiri grew out of agreements between customary elites and the village government ${ }^{293}$. A key informant from neighboring Bungku stated that the subdistrict head (camat) of Sungai Bahar was also involved in the Tanjung Mandiri settlement project $^{294}$.

\footnotetext{
285 Interview with a key informant in Bungku, 11.09.2012, Document ID: 74, 14.09.2012, Document ID: 44, and 09.07.2013, Document ID: 161.

${ }^{286}$ Interview with key informants in Bungku, 11.09.2012, Document ID: 74

287 Interview with a key informant in Bungku, 11.09.2012, Document ID: 74, 14.09.2012, Document ID: 44, and 09.07.2013, Document ID: 161.

288 Interview with key informants in Bungku, 14.09.2012, Document ID: 39, 44.

289 Interview with a key informant in Bungku, 09.07.2013, Document ID: 107.

290 Interview with a key informant in Bungku, 09.07.2013, Document ID: 107.

291 Interview with key informants in Bungku, 09.07.2013, Document ID: 111, 161.

292 Interview with a key informant in Tanjung Lebar, 27.07.2013, Document ID: 169.

293 Interview with a key informant in Tanjung Lebar, 27.07.2013, Document ID: 113.

${ }^{294}$ Interview with a key informant in Bungku, 12.09.2012, Document ID: 87.
} 
As in Bungku the former village head of Tanjung Lebar, a Javanese migrant who had married into a Batin Sembilan family, claimed to represent both customary and village authority. The Tanjung Mandiri settlement, and especially the way in which the Tanjung Lebar village elites framed and legitimized it, has a lot in common with the TSM settlement of Bungku. Key informants in Tanjung Mandiri framed the settlement project as a "win-win" situation for migrants and the Batin Sembilan. Village elites in Tanjung Lebar also reproduced the narratives used by the New Order regime to legitimize the transmigration program and argued that Batin Sembilan would benefit from the commercial farming techniques introduced by migrants ${ }^{295}$. A key informant explained that Tanjung Mandiri "[...] is based on an agreement between $S A D^{296}$ and migrants with the aim of developing the SAD that have not understood how to farm yet. The settlement project provided the opportunity to meet migrants with modern farming techniques so they can work together on the land that has been already used by their ancestors ${ }^{297}$." Village and Batin Sembilan elites described Tanjung Mandiri as a settlement project jointly organized by Batin Sembilan and migrants ${ }^{298}$. A settler explained: “[...] The settlement was organized by Pak Adin ${ }^{299}$ acting on behalf of the SAD. Without involvement of the SAD, we have not dared to settle here because it is part of their land. He [Pak Adin] organized from the beginning that people settle here ${ }^{300 . "}$

Land settlers had to pay a "measurement fee" to access land. As in Bungku, key informants stressed that the land as such was gratis. The measurement fee and settlers' additional voluntary contributions were used for infrastructure development, especially to construct a school, village hall, mosque, and church. The first settlers received 2 ha of cropland and 1 ha for a house, yard, and garden. Settlers were not allowed to own more than 3 ha of land and land had to be planted right after forest conversion $^{301}$.

\footnotetext{
295 Interview with a key informant in Tanjung Lebar, 27.072013, Document ID: 113.

${ }^{296}$ SAD, refers to Suku Anak Dalam, a post-colonial and deprecatory term for indigenous communities, in this case the interviewee refers to the Batin Sembilan.

297 Interview with a key informant in Tanjung Lebar, 27.07.2013, Document ID: 113.

298 Interviews with key informants in Tanjung Lebar, 27.07.2013, Document ID: 113, 145, 169.

${ }^{299}$ Changed name to fictitious name.

${ }^{300}$ Interview with a key informant in Tanjung Lebar, 27.07.2013, Document ID: 169.

${ }^{301}$ Interviews with key informants in Tanjung Lebar, 27.07.2013, Document ID: 113, 167, 169.
} 


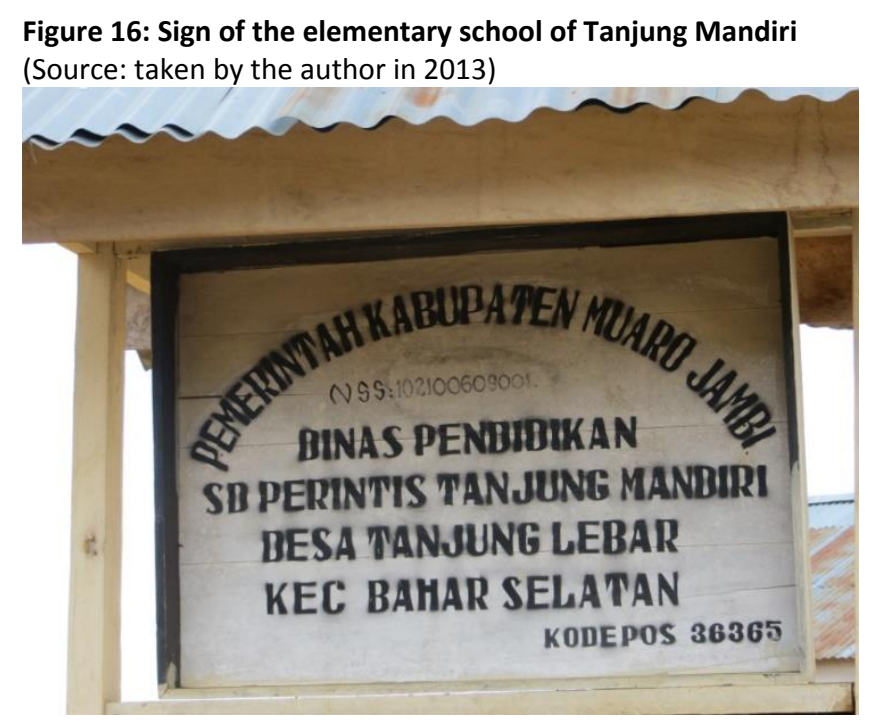

Today the settlement has been legalized de facto by the Education Agency of the District of Muaro Jambi, which supports its school ${ }^{302}$. In 2011, the head of Muaro Jambi district strengthened the settlers' position by celebrating the traditional rice harvest festival in Tanjung Mandiri and promising that the settlement would no longer be part of the Harapan Rainforest ${ }^{303}$. However, a district head has no formal authority to reclassify state forest, and the area is officially not even part of the district of Muaro Jambi. According to MoF maps, the Harapan Rainforest concession is located in the village of Bungku in the district of Batang Hari. Nevertheless, the northeast of the Harapan Rainforest concession is part of the customary land (wilayah adat) belonging to Batin Sembilan of Tanjung Lebar, which has been part of Muaro Jambi district since 1999. Consequently, most settlers identify as being from Tanjung Lebar - not from Bungku ${ }^{304}$. Batin Sembilan from Bungku and the village government of Bungku question the land claims of Batin Sembilan of Tanjung Lebar. Batin Sembilan in Bungku accuse Batin Sembilan elites in Tanjung Lebar of selling land that traditionally belongs to groups from around Bungku ${ }^{305}$.

Members of the village government of Tanjung Lebar interviewed in 2013 believed that the settlement had already been released from the Harapan Rainforest concession ${ }^{306}$. However, the settlement has not yet been released: mediation with PT REKI in summer 2013 failed to resolve the conflict ${ }^{307}$.

\footnotetext{
302 Interview with a key informant in Tanjung Lebar, 27.07.2013, Document ID: 167.

${ }^{303}$ Interview with key informants in Tanjung Lebar, 27.07.2013, Document ID: 113, 167.

${ }^{304}$ Interview with a key informant in Tanjung Lebar, 26.07.2013, Document ID: 127.

${ }^{305}$ Interview with key informants in Bungku, 12.09.2012, Document ID: 87 and 24.08.2013, Document ID: 2.

${ }^{306}$ Interview with a key informant in Tanjung Lebar, 25.07.2013, Document ID: 177.

307 Interview with REKI staff member in Bungku, 30.07.2013, Document ID: 1.
} 


\subsubsection{Land occupation by SPI: The settlements of Sungai Jerad and Bukit Sinjal}

The SPI settlement project is located south of the pre-colonial hamlet of Mangkubangan/ Pangkalan Ranjau and can be considered as being part of the organization's multi-scalar resistance strategy (see chapter seven). The settlement is the most recently founded settlement, and the most contested settlement in the Harapan Rainforest concession (Hein and Faust 2014; Hein et al. 2015). An SPI activist claimed that SPI members have been present in the area since the late $1990 \mathrm{~s}^{308}$. One of the first SPI members to live in the area was a teacher married into a Batin Sembilan family who swapped a motorcycle for land with the Temenggung Seman who controlled the area around Sungai Jerad ${ }^{309}$. Temenggung Seman and the teacher were also involved in initiating the SPI settlements. The formation of the SPI settlements started in 2007 after SPI's flag was symbolically hoisted in the presence of the hamlet head of Mangkubangan/Pangkalan Ranjau ${ }^{310}$. However some members of the village government complained that SPI started the settlement project without having formally asked the village head ${ }^{311}$.

As in the other village-scale settlement projects, reference was made to the transmigration program. The head of an SPI basis' argued: "[...] During the Suharto era we had the transmigration program paid by the government: trillions had been paid by the government for transmigration. Today it's different. [...] Today farmers like us, we have the problem that we do not have official permit from the government ${ }^{312}$." Today the area claimed by the SPI encompasses more than 2500 ha of PT REKI's concession and has as many as 18 smaller settlements, each inhabited by up to 40 households. The most important settlements are Sungai Jerad and Bukit Sinyal.

The settlements have a complex institutional structure established by SPI, which has divided its territory into blocks of land of 50 to 60 ha (figure 8), with each block used by approximately 10 households. Not all blocks have been converted yet. Four to five blocks form a 'basis', the lowest level of political organization in the SPI (see section 5.3.2). Each basis is led by an elected head (ketua basis) and has 2 ha of collective land that is planted with rubber. Every two weeks, meetings are held in each basis $^{313}$. The whole settlement project is part of the SPI section (Ranting) of Sungai Bahar.

\footnotetext{
308 Interview with an SPI activist in Jambi, 12.07.2013, Document ID: 140.

${ }^{309}$ Interview with an SPI activist in Jambi, 12.07.2013, Document ID: 140.

311 Interview with key informants in Tanjung Lebar, 25.07.2013, Document ID: 125, and 27.07.2013, Document ID: 113.

312 Interview with key informants in Tanjung Lebar, 22.07.2013, Document ID: 178, 291.

313 Interviews with key informants in Tanjung Lebar, 21.07.2013, Document ID: 128 and 22.07.2013, Document ID: 178.
} 
To access land, smallholders must have a residence permit issued by the village government of Tanjung Lebar, belong to SPI, be landless, and pay an IDR 300,000 (equivalent to US\$25) "measurement fee" for each hectare ${ }^{314}$. Land access is facilitated by the head of the Ranting of Sungai Bahar (Mardiana 2014: 36). Part of the measurement fee goes to Batin Sembilan elites (ibid. 51). SPI leaders claim that they only accept poor and non-commercial farmers, which is hard to verify. A local SPI leader stated: "[...] The poor farmer living in this neighborhood (RT) [...] came to survive. They have nothing outside, 99 percent of the farmers living here are really poor, they don't have another place of living [...] We don't have capitalist farmers living here [...] Those are the people I know, maybe there are others ${ }^{315}$."

SPI permits each household a maximum of 6 ha land; for larger households, up to 10 ha are permitted ${ }^{316}$. SPI leaders stated that a basic rule for all settlements is the three ' $T$ ' (tebang, tanam, tumbuh) rule: forest conversion, planting, and growing ${ }^{317}$. Around 2010, after PT REKI got the conservation concession, SPI leaders imposed a ban on oil palm cultivation in the settlements. The oil palm ban indicates that SPI leaders are willing to obey the forest law (cultivating oil palms is prohibited in the state forest), the conservation regulations of PT REKI and to act in line with the global anti-bio fuel and food sovereignty campaigns of La Via Campesina ${ }^{318}$. According to SPI leaders, settlers who violate the oil palm ban are expelled from the organization; settlers who had planted oil palms earlier are supposed to replace them with rubber. SPI claims that the households that are cultivating oil palms in the area are not SPI members ${ }^{319}$. The extent to which the SPI is enforcing the ban was impossible to verify during my fieldwork: I observed mostly rubber and dry rice cultivation.

Initially, the SPI settlement also aimed to provide benefits for Batin Sembilan families. Mardiana (2014: 51) found that Batin Sembilan elites had not fairly allocated the payments received from the SPI to other Batin Sembilan. Most Batin Sembilan families had not benefited from the land transactions. In July 2013, a Batin Sembilan leader living outside the SPI area said that his groups would like to cooperate with SPI to better understand modern farming techniques ${ }^{320}$. At the same time, he criticized the rapid expansion and forest destruction caused by SPI members ${ }^{321}$.

\footnotetext{
${ }^{314}$ Interview with a key informant in Tanjung Lebar, 21.07.2013, Document ID: 129.

315 Interview with a key informant, in Tanjung Lebar, 21.07.2013, Document ID: 128.

316 Interview with key informants in Tanjung Lebar, 22.07.2013, Document ID: 178.

317 Interviews with key informants in Tanjung Lebar, 21.07.2013, Document ID: 129 and 22.07.2013, Document

ID: 178, 291.

318 Interviews with key informants in Tanjung Lebar, 21.07.2013, Document ID: 128, 129 and 22.07.2013, Document ID: 178.

319 Interview with a key informant in Tanjung Lebar, 21.07.2013, Document ID: 129.

${ }^{320}$ Interview with a key informant in Tanjung Lebar, 23.07.2013, Document ID: 171.

${ }^{321}$ Interview with a key informant in Tanjung Lebar, 23.07.2013, Document ID: 171.
} 


\section{Figure 17: SPI settlements and surroundings}

The map shows the different settlements, roads, and rivers in the area claimed by SPI

(Source: sketched by local SPI leader).

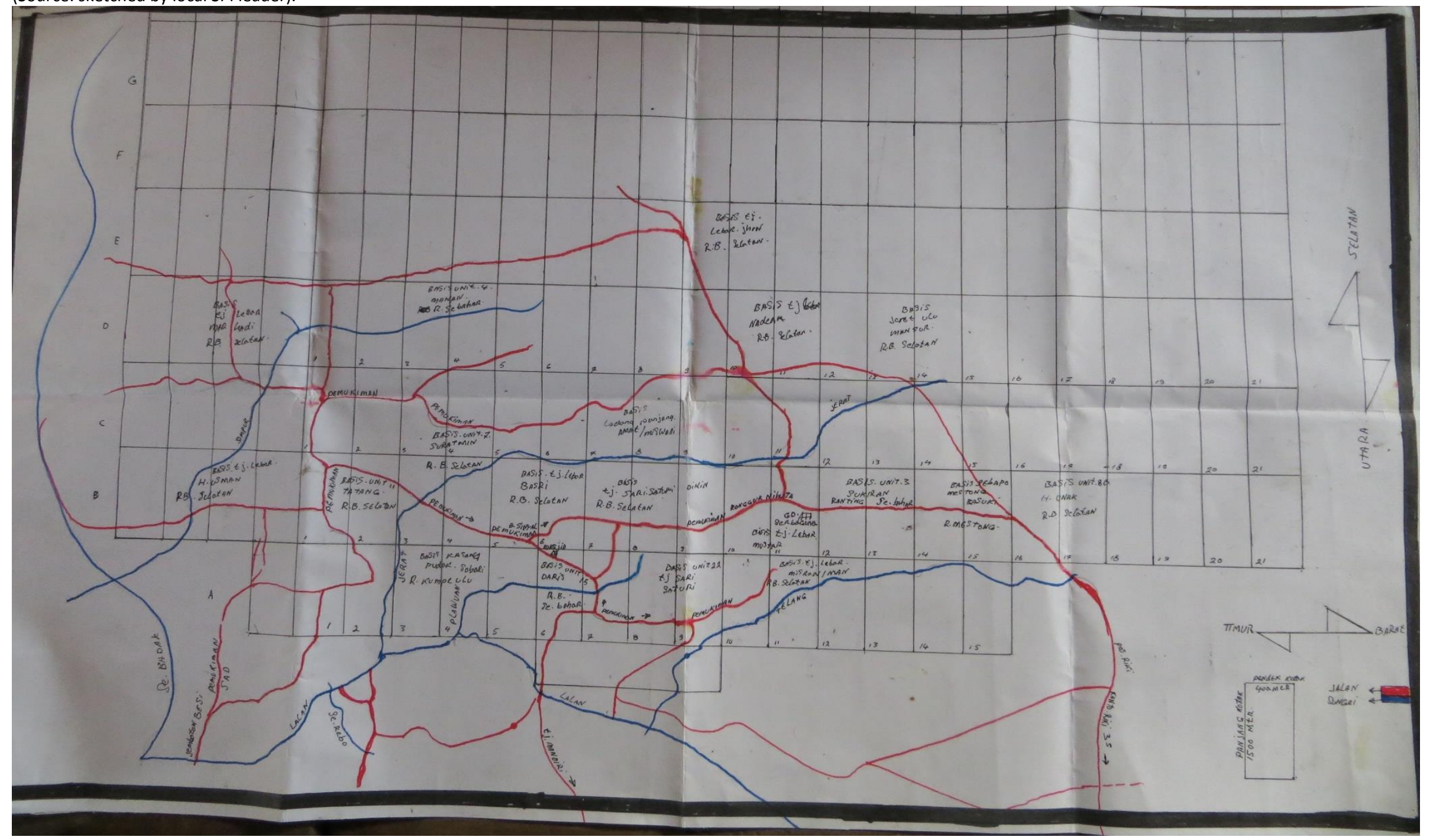




\subsubsection{Village-scale settlement schemes in the Berbak Landscape}

Village-scale peat swamp forest conversion and settlement projects in the Berbak Landscape mainly occurred outside of the state forest, that is, outside areas protected in the Berbak Carbon Project. However, some initiatives to convert peat-swamp forests extended beyond the border of Berbak National Park in the villages of Air Hitam Laut and Sungai Cemara ${ }^{322}$.In contrast to the settlement projects in the Harapan Landscape, the area used for agriculture within the Berbak Carbon Project is rather small with only a few households living permanently within the protected areas. The sole exception is the transmigration settlement in the forest reserve Sekitar Tanjung established by the Transmigration Agency of Muaro Jambi (see section 7.4).

Most of the key informants in Seponjen, Sungai Aur, and Air Hitam Laut said they accept the prohibition on planting crops in the state forest and most village governments considered new forest conversion that violated the borders of the Berbak Carbon Project to be illegal. A key informant in Sungai Aur said that the village government refused to issue the documents necessary for an identification card for a household that had settled in Berbak National Park ${ }^{323}$. Nevertheless, especially in Sungai Aur, villagers questioned why the forest reserve remains protected: “[...] the forest reserve is for protection, but what do they want to protect? There is no timber anymore and animals cannot live there anymore." ${ }^{324}$

One explanation for the broader acceptance of the state forest's border might be that after 1985 , the release of large areas from the state forest provided enough land for smallholders' agricultural needs. A second explanation might be that converting peat-swamp forest requires big investments that especially Bugi elites were only willing to make if the land's status guaranteed safe returns. A third explanation might be that enhanced law enforcement against illegal logging that was initiated by the former president Susilo Bambang Yudhoyono (SBY) stopped logged-over forest from being converted into agriculture plots. A fourth factor might be that for Malay groups in the area, agriculture was traditionally of minor importance and its relevance had only grown very recently. In the past, logging and gathering non-timber forest products was much more relevant. These activities are continuing -, also within the Berbak Carbon Project ${ }^{325}$.

I have identified two different types of organized, collective village-scale forest conversion and settlement initiatives in the villages of the Berbak Landscape that I studied. The first is directly

\footnotetext{
322 The village of Sungai Cemara is not part of the village sample, it is located south of Air Hitam Laut at the coast of the South China Sea. It is very remote and difficult to access.

${ }^{323}$ Interview with a key informant in Sungai Aur, 02.09.2013, Document ID: 270.

${ }^{324}$ Interview with a key informant in Sungai Aur, 29.08.2013, Document ID: 132.

325 Interviews with key informants in Air Hitam Laut, 29.09.2012, Document ID: 69, 70, 71, in Sungai Aur, 30.08.2013, Document ID: 179, 01.09.2013, Document ID: 136 and 02.09.2013, Document ID: 131 and in Seponjen, 12.09.2013, Document ID: 316.
} 
associated to the immigration of Bugis from South Sulawesi, and the second is driven by local Malay groups and Javanese migrants.

\begin{tabular}{|c|c|c|c|c|c|}
\hline & $\begin{array}{l}\text { Village of Air } \\
\text { Hitam Laut }\end{array}$ & Dusun ${ }^{326}$ Bugis & Ketapang & $\begin{array}{l}\text { Farming } \\
\text { groups in } \\
\text { Seponjen }\end{array}$ & $\begin{array}{l}\text { Farming } \\
\text { groups in } \\
\text { Sungai Aur }\end{array}$ \\
\hline Hamlet & All hamlets & Sungai Lais & Ketapang & Hamlets I+ II & All hamlets \\
\hline Village & Air Hitam Laut & Seponjen & Sungai Aur & Seponjen & Sungai Aur \\
\hline Subdistrict & Sadu & Kumpeh & Kumpeh & Kumpeh & Kumpeh \\
\hline District & $\begin{array}{l}\text { Tanjung Jabung } \\
\text { Timur }\end{array}$ & Muaro Jambi & Muaro Jambi & Muaro Jambi & Muaro Jambi \\
\hline Initiated in & 1965 & 1996-1997 & 2000 & 1995 & late 1990s \\
\hline $\begin{array}{l}\text { Overlapping } \\
\text { Berbak Carbon } \\
\text { Project and/ or } \\
\text { state forest }\end{array}$ & Until 1970s & No & No & $\begin{array}{l}\text { Only a few } \\
\text { plots }\end{array}$ & $\begin{array}{l}\text { Only a few } \\
\text { plots }\end{array}$ \\
\hline Local authorities & $\begin{array}{l}\text { Pasirah and Bugi } \\
\text { elites }\end{array}$ & $\begin{array}{l}\text { Camat, Bugi } \\
\text { elites, Malay } \\
\text { elites, village } \\
\text { government }\end{array}$ & $\begin{array}{l}\text { Village head, } \\
\text { customary } \\
\text { leader, head } \\
\text { of farming } \\
\text { group }\end{array}$ & $\begin{array}{l}\text { Village head, } \\
\text { customary } \\
\text { leader, head } \\
\text { of farming } \\
\text { group }\end{array}$ & $\begin{array}{l}\text { Village head, } \\
\text { customary } \\
\text { leader, head } \\
\text { of farming } \\
\text { group }\end{array}$ \\
\hline $\begin{array}{l}\text { Tenure } \\
\text { arrangement }\end{array}$ & Parit & Parit & $\begin{array}{l}\text { Tanah adat } \\
\text { and parit }\end{array}$ & Tanah adat & Tanah adat \\
\hline $\begin{array}{l}\text { Land access } \\
\text { facilitated by }\end{array}$ & $\begin{array}{l}\text { River head and } \\
\text { canal head }\end{array}$ & $\begin{array}{l}\text { River head and } \\
\text { canal head }\end{array}$ & $\begin{array}{l}\text { Head of } \\
\text { farming } \\
\text { group and } \\
\text { canal head }\end{array}$ & $\begin{array}{l}\text { Head of } \\
\text { farming } \\
\text { group }\end{array}$ & $\begin{array}{l}\text { Head of } \\
\text { farming } \\
\text { group }\end{array}$ \\
\hline $\begin{array}{l}\text { District } \\
\text { authorities }\end{array}$ & - & $\begin{array}{l}\text { Land Agency of } \\
\text { the district of } \\
\text { Batang Hari }\end{array}$ & $\begin{array}{l}\text { Agricultural } \\
\text { Agency }\end{array}$ & - & - \\
\hline $\begin{array}{l}\text { Settlers hold } \\
\text { village-scale land } \\
\text { titles }\end{array}$ & Yes & Yes & Yes & Yes & Yes \\
\hline $\begin{array}{l}\text { Regulation on } \\
\text { max. agricultural } \\
\text { land per } \\
\text { household }\end{array}$ & No & No & 2 ha & $\begin{array}{l}1.25 \text { ha per } \\
\text { farming } \\
\text { group } \\
\text { member }\end{array}$ & $\begin{array}{l}2 \text { ha per } \\
\text { farming } \\
\text { group } \\
\text { member }\end{array}$ \\
\hline
\end{tabular}

Table 13: Organized peat-swamp-forest conversion initiatives in Berbak Landscape villages

(Source: compiled by the author) 


\subsubsection{Bugi colonization in the Berbak Landscape: Commercial land reclamation and village- scale settlement projects}

In the 1950s, Bugi immigration grew; in the 1960s, they started to drain and found settlements in the Berbak Landscape (Claridge 1994: 290; Sevin and Benoît 1993: 102). The village of Air Hitam Laut dates back to a drainage and settlement initiative initiated by Bugis. In the 1970s, the pasirah of the Marga of Berbak gave them the right to drain and convert the peat-swamp forest around the mouth of the Air Hitam River. A key informant ${ }^{327}$ in the village explained: “The Bugi leader Pak Janggut ${ }^{328}$ obtained the right to drain and convert land from the pasirah. Part of the converted land was used to pay the pasirah afterwards." Pak Janggut, initiator and head of the project was appointed the "head of the river" (Kepala Sungai), who subdivided land received from the pasirah to his clients called "canal heads" (Kepala Parit). Usually the plots were divided by drainage canals. The canal heads were responsible for facilitating the drainage and conversion of the peat swamp in their plots. They also looked for Bugi migrants interested in land and let them convert the forest areas in their plots. A former kepala parit in Air Hitam Laut explained that for each 2 ha converted by the migrants he received 0.25 ha, part of which he paid to the river head and the pasirah ${ }^{329}$. In total, 24 main drainage canals were planned along the Air Hitam Laut coastline, partly overlapping the Berbak Wildreservaat (Hutan Suaka Alam). Only 10 of these have been realized ${ }^{330}$. The Directorate General of Forest Protection and Nature Conservation started forest management in the Berbak Wildreservaat in 1972 (Giesen 2004: 18). Drainage activities were stopped by the Governor of Jambi ${ }^{331}$ but drainage canals still impact the hydrological balance of the Berbak Carbon Project, increase the risk of peat fires, and facilitate access for illegal loggers ${ }^{332}$.

Figure 18: Canal (parit) system in Seponjen.

Blue lines illustrate the canals between the grey plots. The green plots were designated for local Malay. (Source: sketched by the author based own investigations).

\begin{tabular}{|c|c|}
\hline Canal head 1 & Canal head 6 \\
\hline Canal head 2 & Canal head 7 \\
\hline Canal head 3 & Canal head 8 \\
\hline Canal head 4 & Canal head 9 \\
\hline Canal head 5 & Canal head 10 \\
\hline
\end{tabular}

\footnotetext{
327 Interview with a key informant in Air Hitam Laut, 29.09.2012, Document ID: 69, 70.

328 fictitious name

329 Interview with key informants in Air Hitam Laut, 29.09.2012, Document ID: 69, 70, 71.

330 Interview with a key informant in Air Hitam Laut, 29.09.2012, Document ID: 69.

331 Interview with a key informant in Air Hitam Laut, 29.09.2012, Document ID: 69.

332 Interview with staff member of Dinas Kehutanan Jambi, Jambi 19.08.2013, Document ID: 147.
} 
Many Bugi settlements and forest conversion projects in the Berbak Landscape had land tenure arrangements based on various nested authorities, each equipped with a specific scale of regulation. In Seponjen, the hamlet of Sungai Lais, founded in 1997, is characterized by a similar arrangement: Pak Hadji Pattimura, a Malay businessman from Seponjen, held a land conversion permit from the land agency of the district of Batang Hari (Dinas Pertanahan Kabupaten Batang Hari). With the Bugi leader Pak Selang and the village government, he organized a peat-swamp conversion and settlement project for second-generation Bugi migrants and local Malay households. The leaders received land for investing in the project ${ }^{333}$. As in the Harapan Landscape, key informants stated that the settlement would contribute to village development and provide land for poor households ${ }^{334}$. Pak Selang acted as river head (Kepala Sungai) and allocated land to 10 canal heads, ${ }^{335}$ each of whom was authorized to regulate his own parcel of land. The land was converted by migrants - who were again mainly Bugis. Each migrant received half of the land that had been converted; the other half was divided between the canal and river heads, and Pak H. Pattimura. The land managed by the second and third canal heads (figure 18) was designated for local Malay households. Participating Malay households received all the land they had converted ${ }^{336}$. Many of them later sold it to Bugi or Javanese migrants. The hamlet of Sungai Lais was established outside of the Berbak Carbon Project.

\subsubsection{Farming groups for collective forest conversion}

In the 1990s, agriculture became more relevant in Seponjen and Sunga Aur. In addition, immigration of Javanese and Bugis increased. In order to meet rising demand for agricultural land, Malay elites started to convert the forests within the boundaries of their customary village land, called tanah adat.

Although this area overlaps the Berbak Carbon Project, only a few plots are located in the project ${ }^{337}$. Forest conversion was regulated and controlled by the local Malay elite. Community members who sought land first had to join a farming group. Such groups, each consisting of 20 to 60 farmers, were led by local Malay elites (the customary head, ketua adat) and were supported by the village governments - especially by the village heads ${ }^{338}$. Each participant received approximately 2 ha of land. In the early 2000s, the farming groups in Seponjen legitimized their activities by referring to community

\footnotetext{
${ }^{333}$ Interview with a key informant in Seponjen, 11.09.2013, Document ID: 174.

${ }^{334}$ Interviews with key informants in Seponjen, 11.09.2013, Document ID: 173, 174 and 15.09.2013, Document ID: 317.

335 Interview with a key informant in Seponjen, 10.09.2013, Document ID: 206

336 Interviews with key informants in Seponjen, 09.09.2013, Document ID: 315 and 15.09.2013, Document ID: 317.

${ }^{337}$ Interview with staff member of Gita Buana, 22.08.2013, Document ID: 207.

338 Interviews with key informants in Sungai Aur, 30.08.2013, Document ID: 126, 01.09.2013, Document ID: 136 and 02.09.2013, Document ID: 131 and in Seponjen, 08.09.2013, Document ID: 175, and 11.09.2013, Document ID: 173.
} 
timber extraction permits from the district government (see section 5.1.4) ${ }^{339}$. Farming groups reduced the cost of converting land for individuals and permitted the conversion and drainage of larger areas. In Seponjen, and beginning in the early 2000s in Sungai Aur, migrants, too, were allowed to access land by joining farming groups. In the Ketapang hamlet (in Sungai Aur), migrants and locals worked together to drain and convert land. Migrants had to pay to participate in farming groups and received the more flood-prone plots ${ }^{340}$.

\section{4. "Making" of new property and new regulations by REDD+ and conservation initiatives}

Rescaling, as a result of the construction of new REDD+ project scales, has induced exclusions, landuse restrictions, transnationalized land conflicts (see chapter 7) and changed the meanings of forests. But new project scales have also widened the agency of some actors providing new land access opportunities, especially for indigenous groups - as well as alternative income sources and community benefits (table 6). In addition, the construction of REDD+ project scales altered the pre-existing property-authority-legitimacy nexus. Especially in the Harapan Landscape, the PT REKI conservation company, a private actor, emerged as a new public authority for legitimizing new conditional land tenure agreements based on formalized conservation agreements.

\footnotetext{
${ }^{339}$ Interview with a key informant in Seponjen, 10.09.2013, Document ID: 205, 249.

${ }^{340}$ Interviews with key informants in Sungai Aur, 31.08.2013, Document ID: 138, 144.
} 


\begin{tabular}{|c|c|c|c|c|}
\hline \multirow{2}{*}{ Project } & \multirow{2}{*}{$\begin{array}{l}\text { Important } \\
\text { Regulations }\end{array}$} & \multirow{2}{*}{$\begin{array}{l}\text { Conditional land } \\
\text { tenure }\end{array}$} & \multicolumn{2}{|c|}{ Other community benefits } \\
\hline & & & Income-related & $\begin{array}{l}\text { Non-income- } \\
\text { related }\end{array}$ \\
\hline Harapan Rainforest & $\begin{array}{l}\text { Only forest } \\
\text { species (trees), } \\
\text { food-crop } \\
\text { cultivation is } \\
\text { permitted*, no } \\
\text { commercial } \\
\text { logging, no land } \\
\text { transactions }\end{array}$ & $\begin{array}{l}1-5 \text { ha per } \\
\text { household (planned) }\end{array}$ & $\begin{array}{l}\text { Employment (e.g. } \\
\text { in community } \\
\text { nurseries and as } \\
\text { forest rangers), } \\
\text { agricultural } \\
\text { extension services, } \\
\text { marketing }\end{array}$ & $\begin{array}{l}\text { Health services, } \\
\text { education, } \\
\text { sanitation, } \\
\text { electricity }\end{array}$ \\
\hline $\begin{array}{l}\text { Berbak Carbon } \\
\text { Project }\end{array}$ & $\begin{array}{l}\text { Only forest } \\
\text { species (trees), } \\
\text { logging is } \\
\text { prohibited, no } \\
\text { land transactions }\end{array}$ & $\begin{array}{l}1-5 \text { ha per } \\
\text { household (first plots } \\
\text { allocated in Seponjen } \\
\text { and Sungai Aur) }\end{array}$ & $\begin{array}{l}\text { Agricultural } \\
\text { extension services, } \\
\text { employment. } \\
\text { Further benefits } \\
\text { depend on } \\
\text { governmental } \\
\text { regulation. }\end{array}$ & Planned \\
\hline
\end{tabular}

Table 14: Conditional land tenure and community benefits of the Berbak Carbon and the Harapan Rainforest Project (Source: by the author)

\subsubsection{The Harapan Rainforest: New regulations and new properties and community benefits}

The conservation company PT REKI introduced new regulations, new types of property and benefits ("community benefits") for local communities, especially for Batin Sembilan living in Bungku and Sako Suban (South Sumatra). PT REKI's scales of meaning and regulation also directly compete with existing ones, especially those developed by the village governments, but also with those established by the Batin Sembilan. PT REKI's scale of meaning is based on the uniqueness of the Harapan Rainforest: it is one of the last patches of tropical dry-land rainforest on the island of Sumatra, a bird habitat of global importance, a habitat of the critically endangered Sumatran Tiger, and as potential carbon storage for a global REDD+ mechanism.

In this section, I briefly explain what interviewed members of the village communities of Tanjung Lebar and Bungku knew about PT REKI's conservation regulations and how they interpreted them.

De jure PT REKI has not enacted any relevant conservation regulations that go beyond the legal frameworks for state forest land and ecosystem restoration concession in particular (e.g. Forest Law 1999/41 and sub-ordinate implementing regulations). The existing legal framework for state forest prohibits the cultivation of non-tree and exotic species in conservation concessions. Though, the smallholders living in the informal settlements of Transwakarsa Mandiri, Tanjung Mandiri and Camp Gunung do not consider national forest law. Moreover, law enforcement was very limited after PT 
Asialog abandoned the concession and before PT REKI started the Harapan Rainforest project. As a private actor, PT REKI has de facto introduced new regulations to the area and promoted implementation of national laws, such as specific land use restrictions.

Local communities, advocacy groups like CAPPA, and members of the SPI peasant movement complain that PT REKI has not conducted FPIC, only started formal community consultation (socialisasi) in 2011, and has started project implementation before conducting formal consultations. According to key informants, the consultation sessions were mainly about the forest law (c.f. Wirasapeotra and Octavian 2012: 6). Some actors, such as SPI, considered them rather as an attempt to displace than to consult settlers ${ }^{341}$.

The rule most associated with PT REKI and its Harapan Rainforest project may be the prohibition of non-tree species such as oil palm. Most key informants in Bungku and Tanjung Lebar stated that PT REKI prohibits cultivation of oil palms. Many key informants reported that PT REKI had destroyed oil palm plantings in the Harapan Rainforest. A Batin Sembilan living in the conservation concession stated, for instance "[...] we had an oil palm plot in the past. The oil palms were sprayed with herbicides. They are dead now, $[\ldots]^{342}$."Most key informants consider that rubber cultivation is allowed but shifting cultivation is prohibited, and a number of them stated that PT REKI does not permit dry rice cultivation ${ }^{343}$. A customary head of the Batin Sembilan stated "REKI has still forest. There is still forest there, but protected: when we want to establish a rice plot we are not allowed to do that." ${ }^{344}$ In fact, an agreement between PT REKI and the TSM community in Bungku explicitly permits shifting cultivation and the use of fire for cultivating food crops (Kesepakatan Terhadap Prasyarat Mediasi Antara PT. REKI Dengan Warga RT 11 2012).

Villagers cited also other relevant regulations: the prohibition of commercial logging and hunting and restrictions on plot size. However, key informants did not agree that PT REKI had enacted a general hunting ban or that Batin Sembilan are excluded from the ban ${ }^{345}$. A key informant in the informal settlement of Tanjung Mandiri stated that PT REKI had restricted the size of land holdings: only 5 ha of agricultural land are permitted per household ${ }^{346}$.

\footnotetext{
341 Interview with CAPPA activists in Jambi, 18.07.2013, Document ID: 157, with an SPI activist in Jambi, 12.07.2013, Document ID: 140 and with key informants in Bungku, 10.07.2013, Document ID: 105 and in Tanjung Lebar, 22.07.2013 Document ID: 178 and 27.07.2013, Document ID: 169.

342 Interview with a key informant in Bungku, 12.09.2012, Document ID: 84.

343 Interviews with key informants in Bungku, 12.09.2012, Document ID: 84, 14.09.2012, Document ID: 44, 21.09.2012, Document ID: 76, 22.09.2012, Document ID: 95, and in Tanjung Lebar, 26.07.2013, Document ID: 127.

${ }^{344}$ Interview with a key informant in Tanjung Lebar, 26.07.2013, Document ID: 127.

${ }^{345}$ Interviews with key informants in Bungku, 21.09.2012, Document ID: 68, 24.08.2013, Document ID: 2 and in Tanjung Lebar, 23.07.2013, Document ID: 171.

${ }^{346}$ Interview with a key informant in Tanjung Lebar, 27.07.2013, Document ID: 167.
} 


\subsubsection{Conditional land tenure and conservation agreements}

In the Harapan Rainforest project, implementation of conditional land tenure agreements and conservation regulations is challenged by the ongoing conflicts over land. According to interviewed staff members, of PT REKI the conservation company is planning to develop two zones with specific access rights for smallholders and for the Batin Sembilan. The first, called tanaman kehidupan zone, should provide the Batin Sembilan opportunities to gather non-timber forest products and plant rubber. The second mitra zone should provide land for migrants who were living in the concession before the Harapan Rainforest project started. PT REKI only accepts the presence of migrants who were living in the settlement before 2010, (when the project was started in Jambi). A staff member of the conservation company explicitly stated, "Those that came after have to leave. We want to push them out ${ }^{347}$." Migrants living in the concession before 2010 should pay rent to REKI and have to follow existing regulations for state forest land e.g. implying that oil palm cultivation and shifting cultivation is prohibited ${ }^{348}$. PT REKI proposed a maximum plot size of 2 to 5 ha per migrant household for the cultivation of forest crops like rubber ${ }^{349}$. In 2013, the two zones had not yet been established.

Formalized conservation agreements (Village Resources Management Agreement) had only been negotiated with the Batin Sembilan community in Sako Suban (South Sumatra) and with a Batin Sembilan community resettled by PT REKI to a new settlement named mitra zone. PT REKI funded the construction of housing, wells, and toilets and promised to allocate land for rubber cultivation. The conservation agreement between PT REKI and the resettled Batin Sembilan community included only the latter's right to harvest non-timber forest products. The allocation land for rubber cultivation was not part of the agreement. In 2013, PT REKI had not yet allocated land and some Batin Sembilan households expressed displeasure about the delay ${ }^{350}$. According to PT REKI the allocation of land had to be postponed because of the ongoing land conflicts with informal settlers. In 2013 a PT REKI staff member explained that the company envisaged a location for the rubber plots and was investigating possible land claims by other Batin Sembilan groups ${ }^{351}$. A key informant living in the settlement stated that at least six families have agricultural land and REKI allows them to farm ${ }^{352}$.

\footnotetext{
${ }^{347}$ Interview with REKI staff member in Bungku, 30.07.2013, Document ID: 1.

${ }^{348}$ Interviews with REKI staff member in Jambi, 02.09.2012, Document ID: 33 and REKI staff member in Bungku, 30.07.2013, Document ID: 1.

349 Interviews with REKI staff member in Jambi, 02.09.2012, Document ID: 33 and with REKI staff member in Bungku, 23.09.2012, Document ID: 110, 30.07.2013, Document ID: 1 and 31.07.2013, Document ID: 148.

350 Interviews with key informants in Bungku, 30.07.2013, Document ID: 117, 151, 220, 221 and with CAPPA activists in Jambi, 18.07.2013, Document ID: 157.

${ }^{351}$ Interviews with REKI staff member in Bungku, 23.09.2012, Document ID: 110 and 31.07.2013, Document ID: 148.

352 Interview with a key informant, 21.09.2012, Document ID: 83.
} 
PT REKI has signed an agreement with Batin Sembilan in the settlement of Simpang Macan Dalam (part of Kunangan Jaya I, Bungku) that allows the households to harvest their rubber trees and gather nontimber forest products but prohibits land trades and forest conversion (REKI 2011b). The conservation agreement with the community of Sako Suban includes a conditional land tenure agreement permitting rubber cultivation. PT REKI has not yet signed any formalized conservation agreements with migrants or settler communities.

However, one outcome of conflict mediation with the TSM community in Kunangan Jaya 1 (part of Bungku) is a de facto conditional land tenure agreement involving the settlers, PT REKI, and the district forest agency. The agreed rules included, inter alia, the prohibition of land transactions, commercial logging, and land clearance outside the area identified in a participatory mapping conducted by PT REKI, the settlers, and the forest service (Kesepakatan Terhadap Prasyarat Mediasi Antara PT. REKI Dengan Warga RT 11 2012). The agreement permitted settlers to maintain their land but prohibited further agricultural expansion (ibid. ).

Key informants living in the informal settlements and some Batin Sembilan criticized the conditional land tenure and conservation agreements. A key informant in Tanjung Lebar argued that the settlers in Tanjung Mandiri did not want to sign any agreements since the Batin Sembilan who owned the land had invited them: there was no need for a permit from PT REK ${ }^{353}$. Additionally he stated that the conservation agreements would only provide access to land for a limited period. He further argued, that this is not attractive for the settlers since they claim to have rights granted by Batin Sembilan. A Batin Sembilan elder in the hamlet of Kunangan Jaya I (part of Bungku) said that he refused to be resettled and also refused the conservation agreements because he has rights based on customary law (adat) ${ }^{354}$. SPI members claimed that PT REKI had never informed them about the Village Resources Management Agreements (VRMA) or the possibility of obtaining land for rubber cultivation.

The current and planned conditional land tenure agreements and the de facto introduction of new conservation regulations indicate that PT REKI is becoming a new public authority in the Harapan Landscape. This process is conflictive since the boundary of the Harapan Rainforest project overlaps with land claimed by the villages of Tanjung Lebar and Bungku. PT REKI is competing with pre-existing public authorities such as village governments and customary leaders of the Batin Sembilan - over legitimizing property rights. All three actors have established rules for accessing land and property in the landscape and seek to maintain their scales of regulation.

\footnotetext{
353 Interview with a key informant in Tanjung Lebar, 27.07.2013, Document ID: 113.

${ }^{354}$ Interview with a key informant in Bungku, 12.09.2012, Document ID: 87.
} 


\subsubsection{Other rights and community benefits provided by the Harapan Rainforest project}

As part of the conservation agreements (VRMA) and beyond, REKI provides a number of direct incomerelated and non-income related benefits. The benefits are intended to provide alternative sources of income, stabilize household incomes, and compensate the opportunity costs of PT REKI's intervention ${ }^{355}$. Non-income-related benefits provided by PT REKI include elementary school services, free health care, clean water, electricity, and better sanitation. However, these benefits are de facto only accessible for the Batin-Sembilan-dominated settlements of Simpang Macan (Dalam and Luar) and the Batin Sembilan living in the mitra settlement. Direct income-related benefits provided by PT REKI include employment opportunities, agricultural extension services, and the joint marketing of non-timber forest products. PT REKI provides employment opportunities for local communities living in the Harapan Rainforest, the most important are community nurseries. Community nurseries have been established in the Batin Sembilan dominated settlements of Simpang Macan (Dalam and Luar, part of Kunangan Jaya I, Bungku), in the mitra (part of Kunangan Jaya I, Bungku), and in Sako Suban. Each community nursery provides employment for approximately seven families. The staff of the nurseries gets paid for each seedling, for the planting of the seedling at the reforestation site and if the seedling survives the first year ${ }^{356}$. The nurseries provide monthly incomes of IDR 300,000 to 700,000 per person ${ }^{357}$. Community nurseries have not yet been established in the village-scale settlements described in section 6.3.3 so migrants have de facto no access to this source of alternative income. Inhabitants of the mitra settlement have the additional opportunity to earn monthly payments of IDR 500,000 for providing information about incidences such as forest fires and new encroachers $^{358}$. PT REKI staff members claimed that if possible, full-time positions would be filled with local community members ${ }^{359}$. Nevertheless in July 2013, only two inhabitants of the mitra settlement had permanent jobs - as PT REKI forest guards ${ }^{360}$. PT REKI's reforestation efforts provide additional short-term employment opportunities: for example, PT REKI pays groups of planters up to IDR $1,600,000$ per ha ${ }^{361}$. Agricultural extension services provided by PT REKI consist mainly of the provision of rubber seeds and livestock. In the TSM settlement of Kunangan Jaya, rumors were circulating that Pak Kumis had received rubber seeds from REKI for the whole community but was refusing to allocate them. A key informant stated that Pak Kumis planted them on his own land ${ }^{362}$. Pak Kumis objected to

\footnotetext{
355 Interview with REKI staff member in Jambi, 02.09.2012, Document ID: 33.

356 Interview with REKI staff member in Jambi, 02.09.2012, Document ID: 33.

357 Interviews with REKI staff member in Jambi, 02.09.2012, Document ID: 33 and with REKI staff member in Bungku, 31.07.2013, Document ID: 148.

${ }^{358}$ Interview with REKI staff member in Bungku, 31.07.2013, Document ID: 148.

359 Interview with REKI staff member in Bungku, 23.09.2012, Document ID: 110.

${ }^{360}$ Interview with REKI staff member in Bungku, 31.07.2013, Document ID: 148.

${ }^{361}$ Interview with a key informant in Bungku, 12.09.2012, Document ID: 84.

362 Interviews with key informants in Bungku, 24.08.2013, Document ID: 2, 130.
} 
the allegations and claimed that his farming group had requested support from REKI but had not yet received any ${ }^{363}$.

An additional benefit that REKI aims to provide especially for Batin Sembilan is support for the marketing of forest products. REKI already organizes the marketing of honey for Batin Sembilan (Wardah 2013: 19) and plans to support the marketing of jelutung and dragon blood ${ }^{364}$.

\subsubsection{Berbak Carbon Project: New regulations and new property and access to community benefits}

The Berbak Carbon Project can be considered as the latest attempt to establish the Berbak Landscape as a new scale of meaning and regulation based on uniting different protected areas and productionforest concessions. The main idea of the project is to sell one specific ecosystem service of the Berbak Carbon Landscape, namely its capacity to store greenhouse gases and thereby save the entire landscape (ZSL 2009). The Berbak Carbon Project (see sections 4.5.3 and 6.2.1.2) is an initiative of different stakeholders, the most important of which are the ZSL, the Berbak National Park Agency, and the Forest Service of the Province of Jambi. Various actors run different community involvement programs, the most advanced of which is the community reforestation and conditional land tenure program run by Jambi's provincial forest service.

Since most forests in the project area have been protected for many years, project implementation has led to only a few changes. Furthermore, as outline in section 6.3.4, only few households are holding agricultural land within the boundaries of the Berbak Carbon project. In contrast to PT REKI ZSL and the project partners have started to conduct a formalized free prior and informed consent (FPIC) process in 32 villages of the Berbak Landscape. In 2013, the process was underway in 11 villages, including Seponjen and Sungai Aur ${ }^{365}$. However, the first consultation sessions in 2013 only involved members of the village elite and were conducted in the office of the subdistrict head - not in the villages. In the case of Seponjen, only the village head, the imam, the head of the village parliament, and the neighborhood heads participated ${ }^{366}$. The village population was not officially informed by its representatives about the outcome of the consultation meeting ${ }^{367}$. In Sungai Aur and Seponjen, therefore, knowledge about the Berbak Carbon Project and on REDD+ in general was relatively limited.

\footnotetext{
363 Interview with a key informant in Bungku, 10.07.2013, Document ID: 153.

364 Interviews with REKI staff member in Jambi, 02.09.2012, Document ID: 33, and in Bungku, 30.07.2013, Document ID: 1.

${ }^{365}$ Interview with REKI staff member Jambi. 22.08.2013, Document ID: 207.

366 Interviews with key informants in Seponjen, 10.09.2013, Document ID: 205 and 11.09.2013, Document ID: 122.

${ }^{367}$ Interviews with key informants in Seponjen, 10.09.2013, Document ID: 205 and 11.09.2013, Document ID:
} 122. 
In Sungai Aur, only three of 17 community members interviewed had heard about REDD+. A key informant who had participated in the meetings with Gita Buana, the NGO conducting the sessions, stated that they were informed about REDD+, especially that "the world will buy the carbon that is stored in our region ${ }^{368 \prime \prime}$. In a progress report, Gita Buana noted that the community representatives recognized the importance of the Berbak ecosystem and agreed to contribute to its protection (Gita Buana 2013). In addition to the FPIC process, a number of different community consultation sessions were conducted in the three study villages - mostly to inform about regulations for the protected areas and the conditional land tenure and community reforestation program ${ }^{369}$.

Like the Harapan Rainforest, the Berbak Carbon Project has de jure not established any additional landuse restrictions although it may have contributed to better enforcement and better acceptance of the existing legal framework for forestland. Additional regulations associated with the project rather promoting community involvement, such as FPIC implementation then further restricting access to land. Important land-use restrictions mentioned by key village informants were the prohibitions on oil palm cultivation, annual crops, and agricultural activities in the buffer zone (within $500 \mathrm{~m}$ of the project boundary), logging, and open fires ${ }^{370}$.

The main benefits provided by the various stakeholders implementing the Berbak Carbon Project are conditional land tenure schemes and employment opportunities in the community reforestation programs. Benefits for emission reductions are dependent on the planned benefit-sharing regulations for forest carbon projects, which are conditional on selling carbon credits. The ZSL and its partners have conducted a community needs assessment to design benefits for the community ${ }^{371}$.

The conditional land tenure and community reforestation initiative in the forest reserve is funded by the MoF's reforestation fund and through the provincial budget. It aims to allocate land to farming groups in eight villages of the Berbak Landscape and will privilege poor households and households that traditionally own land within the forest reserve. The allocated land rights are based on memorandums of understanding (MOU) between the farming groups and the Provincial Forest Service. The forest law prohibits the issuance of formal concessions e.g. smallholder forestry concessions (HTR) within forest reserves, but the Provincial Forest Service circumvents this legal barrier by negotiating MOUs. In Seponjen, the Provincial Forest Service has designated 150 ha of the forest reserve for farming groups. The farming groups have up to 25 members and receive 2 ha land per participant; this

\footnotetext{
368 Interview with a key informant in Sungai Aur, 30.08.2013, Document ID: 123.

369 Interviews with key informants in Air Hitam Laut, 28.09.2012, Document ID: 51, in Sungai Aur, 30.08.2013, Document ID: 123, and in Seponjen, Document ID: 172.

370 Interview with key informants in Seponjen, 08.09.2013, Document ID: 175, 12.09.2013, Document ID: 312 and 13.09.2013, Document ID: 122 and in Sungai Aur, 29.08.2012, Document ID: 132, 135 and 04.09.2013 Document ID: 139.

${ }^{371}$ Interview with staff member of the ZSL in Bogor, 27.08.2012, Document ID: 120.
} 
might be expanded to 5 ha in the future. Trading land is prohibited: the land can only be used for jelutung ${ }^{372}$, rubber, and rambutan ${ }^{373}$ cultivation $^{374}$.

In September 2013, 20 farming group members in Seponjen have received 1 ha of land and have been paid IDR 120,000 a day to prepare and plant the land. This is the first group to be officially registered by the Provincial Forest Service. According to a farming group member, not all interested community members had received land: many are on a waiting list. He explained that the households that are "ready" and those who need land have been selected first, but he added that the village government and the forest service had not used clear criteria to select participants ${ }^{375}$. Another farming group member stated that many community members were unaware that they could receive land free of charge from the forest service ${ }^{376}$. The information provided by key informants in Sungai Aur was partly contradictive. One key informant stated that land allocation had not yet started in Sungai Aur and explained that households interested in receiving land should form farming groups and prepare management plan proposals ${ }^{377}$. A second key informant said that he knew about the program but thought that it had not started yet ${ }^{378}$. A third key informant who is member of a farming group said that the program is already running: His farming group, which already had 37 members and an official permit from the Provincial Forest Service, had already started to plant jelutung trees ${ }^{379}$. A fourth informant stated that 50 ha of land would be allocated to farmers in Sungai Aur: the mapping and allocation of 2-ha plots had just started ${ }^{380}$.

The nontransparent dissemination of information on the conditional land tenure scheme and knowledge asymmetries between different community members permitted elite capture and rentseeking behavior. An example from an area of the forest reserve claimed by both the village of Seponjen and the subdistrict capital of Tanjung/ Suakandis is illustrative: a migrant from Lampung stated that he had bought land that was designated for the conditional land tenure scheme - from a field assistant of the Provincial Forest Service. He paid IDR 7,000,000 for 3 ha of land including a sporadik title issued by the head of the Kelurahan Tanjung/ Suakandis. In all, 30 ha of land designated for the scheme had been sold to 10 households ${ }^{381}$.

\footnotetext{
${ }^{372}$ Dyera costulata, syn. D. laxiflora

${ }^{373}$ Nephelium lappaceum

${ }^{374}$ Interview with the staff member of Dinas Kehutanan Jambi in Jambi, 27.08.2013, Document ID: 137.

375 Interview with a key informant in Seponjen, 09.09.2013, Document ID: 315.

376 Interview with a key informant in Seponjen, 10.09.2013, Document ID: 176.

377 Interview with a key informant in Sungai Aur, 30.09.2013, Document ID: 123.

378 Interview with a key informant in Sungai Aur, 01.09.2013, Document ID: 136.

379 Interview with a key informant in Sungai Aur, 29.08.2013, Document ID: 132.

${ }^{380}$ Interview with a key informant in Sungai Aur, 28.08.2013, Document ID: 141.

${ }^{381}$ Interview with key informant in Seponjen, 12.09.2013, Document ID: 312.
} 


\subsection{Introducing different settlers}

Historical contingent access and property relations are described in the first three sections of this chapter and various contemporary access and property relations investigated, starting with Batin Sembilan customary arrangements and colonial arrangements. This section describes the individual ways that four different households accessed land and their particular livelihood patterns.

\subsubsection{A migrant household in the TSM settlement within the Harapan Rainforest}

Pak Riadi ${ }^{382}$ and his wife migrated in 2005 from the Lubuk Linggau region in South Sumatra to the abandoned concession of PT Asialog. In Lubuk Linggau Pak Riadi had worked for an oil palm company. Then a friend told him about Pak Kumis' TSM settlement project and the chance to get land. After arriving in the Sungai Bahar area, he met Pak Kumis who promised him a 5 ha plot for IDR 5 million and said a plantation company would soon arrive in the area to develop a smallholder scheme. In 2007, Pak Kumis was arrested and Pak Riadi and his family were informed that they were living illegally in the state forest and had to leave. At the time of Pak Kumis' arrest, Pak Riadi had only received 0.25 ha of the promised 5 ha. In 2008, staff of PT REKI and Burung Indonesia visited the settlement but did not inform Pak Riadi and his family about the Harapan Rainforest project. He later managed to buy additional land from other family members who had participated in the TSM project but left the area. Today Pak Riadi has 2 ha of rubber trees and 3 ha of oil palms - land that is titled by the village government of Bungku. He feels betrayed by Pak Kumis and supports the mediation process with REKI. $^{383}$

\subsubsection{A migrant household in a SPI settlement in the Harapan Rainforest}

Pak Wadid ${ }^{384}$ and his wife migrated to the SPI settlement of Sungai Jerad in 2008 after a friend told him about the availability of land in the region. He had no information about the land's status and he did not know who owned the land at that time. To access land, they had to pay a fee of IDR 300,000 per ha and to join SPI. He also had to pay people to clear the land. Then they started to plant vegetables and sold them at the market in Tanjung Sari/Unit $22^{385}$. Two years later, PT REKI and the forest police appeared, claiming that the area belonged to PT REKI conservation concession. They did not force Pak Wadid and his wife to leave, but the conflict escalated as PT REKI and the forest police were trying to arrest SPI members involved in kidnapping PT REKI staff. In the course of the conflict some houses and

\footnotetext{
382 Fictitious name.

${ }^{383}$ Interview with key informant in Bungku, 24.08.2013, Document ID: 202.

${ }^{384}$ Fictitious name.

${ }^{385}$ Village located south of Tanjung Lebar's main hamlet, belongs to the sub-district of Bahar Selatan.
} 
plantations were burned. The conflict increased insecurity in the area e.g. motor cycles had been stolen stated Pak Wahid. He hopes that new police interventions will not cause more anarchy. ${ }^{386}$

\subsubsection{A Batin Sembilan household displaced by PT Asiatic Persada that lives in the mitra settlement of the Harapan Rainforest}

Previously, Ibu Legu ${ }^{387}$ and her husband were semi-nomads, practicing shifting cultivation in the area that is now part of the PT Asiatic Persada oil palm concession. Her family also had permanent fruit tree and rubber gardens. In the late 1990s, the oil palm company converted their land to an oil plantation and prohibited them to establish new swiddens. Although, PT Asiatic Persada promised them compensation and a smallholder scheme, they had not received any compensation or have been able to join a smallholder scheme. After losing their land, Ibu Legu worked as a day laborer for the oil palm company and earned additional income by selling oil palm fruits that she collected from the ground. In the early 2000s, they moved to the abandoned PT Asialog concession (now the Harapan Rainforest) and continued to work for PT Asiatic Persada. In 2007, Ibu Legu and her husband started to work for PT REKI. Her husband has a permanent position as a forest ranger and she works in the community nursery. Ibu Legu said that she is very concerned that the migrants will destroy the forest completely. She stated that some Batin Sembilan allow migrants to convert forest, but she does not agree with that: she wants to protect the forest. Since they started to convert the forest, it has become very difficult for them to earn additional income from gathering fruit, rattan, and jelutung in the forest. Today there is only enough fruit for them to eat, they cannot sell fruits anymore and rattan is becoming rare as well. ${ }^{388}$

\subsubsection{A Malay family in the transmigration settlement in the Berbak Carbon Project}

In 2009 Pak Budi ${ }^{389}$ and his wife were among the first settlers to move into the transmigration settlement of Sungai Aur. Previously they had lived in the hamlet of Ketapang (part of Sungai Aur). According to Pak Budi, he and his wife were able to participate in the transmigration project because of the quota for locals who were poor and married. Before moving, they had to participate in a weeklong preparation workshop in Sungai Aur, which was organized by the Transmigration Agency and the head of Muaro Jambi district. In April 2009, Pak Budi moved with his family and four others to the transmigration site. Before moving, they sold their house in Ketapang. Shortly thereafter, the Provincial Forest Service announced that the settlement had been constructed within the forest

\footnotetext{
${ }^{386}$ Interview with a key informant in Tanjung Lebar, 21.07.2013, Document ID: 129, 287.

${ }^{387}$ Fictitious name.

${ }^{388}$ Interview with key informant in Bungku, 21.09.2012, Document ID: 83, 63.

${ }^{389}$ Fictitious name.
} 
reserve and the Berbak Carbon Project thus in violation of the forest law. Pak Budi stated that at first, the Provincial Forest Service had planned to destroy the settlement, but with support from the district head and the village government, they were able to negotiate an agreement to stay. However, they are not allowed to plant oil palms or covert forest. Pak Budi has been waiting to receive the 2 ha of land he was promised when he moved in 2009 (thus so far he has only received $1 \mathrm{ha}$ ) and the agricultural extension services usually provided to transmigrants. ${ }^{390}$

\subsection{Summary and preliminary conclusion: Power and the scalar politics of de facto property rights and land titles}

This chapter has mainly provided the empirical basis to answer my second research question: Which historically contingent access and property relations explain the struggles over land in REDD+ target areas in Jambi? In addition, it helps answer the first research questions - how much are rescaling processes (e.g. decentralization and REDD+) altering the ability of different actors to access land and property, and how are actors shaping rescaling processes? - by unpacking the abilities of different actors (migrants and conservation companies) to access land and property. Chapter 5 described how processes of state transformation and rescaling processes changed the dialectical relationship between structure and agency, altering access and property relations in the study landscapes. In particular, the Reformasi era provided new opportunities to access land and property, along with greater leeway for the larger village-scale settlement projects in the state forest, especially in the Harapan Rainforest. The emerging scales of REDD+ and conservation projects (the Berbak Carbon Project and the Harapan Rainforest) are challenged by the village scales of regulation - and vice versa. Conservation initiatives imposed new conservation regulations restricting access and provided new conditional land tenure opportunities for peasants.

The results in this chapter show that in the study landscapes struggles over land are caused by overlapping property rights. In turn, competing and overlapping property rights are caused by competing authorities. Moreover, overlapping and competing property rights (e.g. property rights legitimized by village governments versus those backed by the MoF) indicate conflicts between different state apparatuses and struggles over the constitution and the legitimacy of public authorities. What members of society consider as legitimate property rights change over time and are subject to historically contingent and ongoing societal struggles over concepts and truth (Sikor and Lund 2010: 6). National laws and regulations structure access and property relations (chapter 5). In line with Lund

\footnotetext{
390 Interview with a key informant in Sungai Aur, 29.08.2013, Document ID: 132, 271.
} 
(2008: 4), chapter 6 shows that local public authorities follow the policies and laws that support their own interests (e.g. policies promoting rural development like the transmigration program and Governmental Regulation 24/1997). The legal mimicry of national regulations and policies (e.g. villagescale land-titling) and the construction of village scales of meaning and land tenure regulation can be considered as active scalar resistance strategies.

\begin{tabular}{|l|l|}
\hline Landscape & Access and property relations \\
\hline Harapan Landscape & $\begin{array}{l}\text { Property rights backed by village officials (legal mimicry) } \\
\text { Harapan Rainforest) }\end{array}$ \\
& National-scale regulation (including transmigration) \\
& Customary arrangements (customary authority and law) \\
\hline Berbak Landscape & Parit system (Bugi colonization) \\
& National-scale regulation (including transmigration) \\
Provincial-scale regulation (conditional land tenure/Berbak Carbon & Project) \\
& Property rights backed by village officials (legal mimicry)
\end{tabular}

Table 15: Access and property relations in the different study landscapes

(Source: author)

My investigation indicates that access and property relations are explicitly linked to specific scalar arrangements (table 16). Pre-colonial scales of regulation relevant for access and property relations were based on watersheds controlled by specific lineages. In the Harapan Landscape, the Depati and the Temmenggung were responsible for land tenure issues within specific watersheds, and kin relations regulated access to land and property. Rescaling induced by Dutch colonization changed the scalar structure and led to the establishment of a new authority (pasirah) that was in charge of recognizing land claims for the local population that challenged kinship-based property relations. Indonesian independence and the formation of the Indonesian nation-state have diversified access and property relations. Central state apparatuses constructed a national scale of meaning and regulations based on national development and narratives about economic growth in order to allocate exploitation and cultivation rights to corporate actors. Corporate actors actively reproduced the national scale of meaning and regulation by requesting these rights from national-scale authorities, such as the MoF. As a national scale of meaning and regulation, the state forest significantly reduced the abilities of peasants and indigenous groups to access land and property. 
The socio-spatial configuration changed again after Suharto: Village governments, local elites, and customary leaders constructed new village-scales for regulating access to land and property. These new village-scales have in turn have been reproduced by peasant farmers and especially by rural migrants who request land and village-scale land titles. Village scales of regulation - property rights that are based on unwritten village-scale tenure regulations - most notably overlap with the Harapan Rainforest, challenging the project's integrity and inducing land conflicts. Village governments, local elites, and customary leaders have not only legitimized individual land claims but - supported by district-scale state apparatuses - have also formed larger scale settlement projects that actively reproduce central state resettlement programs and development discourses (e.g. transmigration). Local public authorities translate and reinterpret central state policies and regulations to underpin the legitimacy of their actions (legal mimicry) and combat historically contingent structural inequality.

\begin{tabular}{|c|c|c|c|c|c|c|}
\hline \multirow{2}{*}{ Authority } & \multirow{2}{*}{$\begin{array}{l}\text { Scale of } \\
\text { regulation }\end{array}$} & \multirow{2}{*}{ Property } & \multicolumn{4}{|c|}{ Authority and scale of regulation in various periods } \\
\hline & & & $\begin{array}{l}\text { Pre- } \\
\text { colonial }\end{array}$ & Colonial & Independence & Reformasi \\
\hline $\begin{array}{l}\text { Lineage } \\
\text { leaders, } \\
\text { Depati, } \\
\text { Temeng- } \\
\text { gung }\end{array}$ & $\begin{array}{l}\text { Watershed, } \\
\text { customary } \\
\text { territory }\end{array}$ & $\begin{array}{l}\text { Rights to } \\
\text { establish } \\
\text { swiddens, } \\
\text { rights to gather } \\
\text { forest products }\end{array}$ & & & & \\
\hline $\begin{array}{l}\text { Descen- } \\
\text { dents of the } \\
\text { lineage } \\
\text { leaders, } \\
\text { depati, and } \\
\text { temengung }\end{array}$ & $\begin{array}{l}\text { Watershed, } \\
\text { customary } \\
\text { territory }\end{array}$ & $\begin{array}{l}\text { Land rights, } \\
\text { rights to gather } \\
\text { forest products }\end{array}$ & & & & \\
\hline Pasirah & Marga & $\begin{array}{l}\text { Land rights, } \\
\text { forest } \\
\text { conversion } \\
\text { rights, drainage } \\
\text { rights }\end{array}$ & & & $\begin{array}{l}\text { (until late } \\
\text { 1970s) }\end{array}$ & \\
\hline $\begin{array}{l}\text { Colonial } \\
\text { Forest } \\
\text { Service }\end{array}$ & $\begin{array}{l}\text { Dutch East } \\
\text { Indies }\end{array}$ & $\begin{array}{l}\text { Exploitation } \\
\text { rights }\end{array}$ & & & & \\
\hline $\begin{array}{l}\text { Ministry of } \\
\text { Forestry }\end{array}$ & State forest & $\begin{array}{l}\text { Exploitation } \\
\text { and cultivation } \\
\text { rights for } \\
\text { companies and } \\
\text { smallholders }\end{array}$ & & & & \\
\hline $\begin{array}{l}\text { National } \\
\text { Land } \\
\text { Agency }\end{array}$ & $\begin{array}{l}\text { Non-forest } \\
\text { land (APL) }\end{array}$ & $\begin{array}{l}\text { Land rights } \\
\text { (hak milik), } \\
\text { cultivation } \\
\text { rights for }\end{array}$ & & & & \\
\hline
\end{tabular}




\begin{tabular}{|c|c|c|c|c|}
\hline & & $\begin{array}{l}\text { companies } \\
\text { (HGU) }\end{array}$ & & \\
\hline $\begin{array}{l}\text { Ministry of } \\
\text { Transmi- } \\
\text { gration }\end{array}$ & Nation-state & $\begin{array}{l}\text { Land rights for } \\
\text { transmigrants }\end{array}$ & $\begin{array}{l}\text { (predecessor } \\
\text { Kolonisatie) }\end{array}$ & \\
\hline $\begin{array}{l}\text { Provincial } \\
\text { govern- } \\
\text { ments }\end{array}$ & Province & $\begin{array}{l}\text { Conditional } \\
\text { land tenure }\end{array}$ & & \\
\hline $\begin{array}{l}\text { District } \\
\text { govern- } \\
\text { ments }\end{array}$ & District & Land rights & & \\
\hline $\begin{array}{l}\text { Village } \\
\text { govern- } \\
\text { ments }\end{array}$ & Village & $\begin{array}{l}\text { Land rights } \\
\text { (village-scale } \\
\text { land titles) }\end{array}$ & & \\
\hline $\begin{array}{l}\text { River head } \\
\text { (Kepala } \\
\text { Sungai) }\end{array}$ & $\begin{array}{l}\text { Drainage and } \\
\text { settlement } \\
\text { project }\end{array}$ & $\begin{array}{l}\text { Land and } \\
\text { drainage rights }\end{array}$ & & \\
\hline $\begin{array}{l}\text { Peasant } \\
\text { movements }\end{array}$ & $\begin{array}{l}\text { Occupied } \\
\text { territory and } \\
\text { nation-state }\end{array}$ & Land rights & & \\
\hline $\begin{array}{l}\text { Conserva- } \\
\text { tion } \\
\text { companies/ } \\
\text { REDD+ } \\
\text { project }\end{array}$ & $\begin{array}{l}\text { Conservation } \\
\text { concession }\end{array}$ & $\begin{array}{l}\text { Conditional } \\
\text { land tenure }\end{array}$ & & \\
\hline
\end{tabular}

Table 16: De facto authority, property and scale relations in a historical perspective (Source: by the author)

To further unpack the various abilities of actors to access land and property, it might be helpful to engage more explicitly with power asymmetries. Political ecologists argue that unequal power relations help to explain uneven access to natural resources, including land (Blaikie 2012; Bohle and Fünfgeld 2007; Bryant 1998; Forsyth 2008). I argue that the ability of different actors to access land and property is mediated by the three dimensions of power (visible, hidden, and invisible) (Gaventa 2006; Lukes 2005), as I have outlined in my conceptual framework. The indigenous Batin Sembilan, rural migrants, elites, village governments, and companies such as PT REKI are differently positioned with regard to the three power dimensions.

In general, peasant farmers - including indigenous groups in the study villages - are poorly positioned with regard to the three dimensions of power. They hold fewer material resources then corporate actors (e.g. less land), often have no land titles from BPN, and are excluded through institutional procedures and regulations (Forest Law 41/1999). Invisible power, or the social construction of meanings or indirect power (Gaventa 1982: 15) and the internalization of subordination (ibid. 16), 
further marginalize peasant farmers and indigenous groups. The social construction of the backward shifting cultivator by the New Order regime also contributed to their marginalization, whiles changes in the New Order power constellations permitted new social constructions of meanings as well.

PT REKI's success in accessing its ecosystem restoration concession indicates that the conservation company is well-positioned with regard to the three power dimensions. Visible powers, especially the conservation company's material resources such as the ability to pay taxes in advance, were necessary for accessing the concession and establishing the Harapan Rainforest project. Furthermore, PT REKI was able to change the rules of the game (hidden power). The conservation company's active lobbying led to the MoF reforming the forest management, including introducing ecosystem restoration concessions that permit access to land in the first place. PT REKI also benefitted from its position with regard to the invisible dimension of power. Market-oriented conservation concepts such as private conservation concessions and REDD+, the internalization of the homo oeconomicus, and the neoliberal consensus of privatization (Harvey 2005; McAfee 1999, 2012a; Ong 2006; Rodríguez de Francisco 2013; Ellison 2003; Jenkins, Scherr, and Inbar 2004) laid the ground for PT REKI's successful lobbying activities. Moreover, the efforts of PT REKI and other conservation NGOs to construct a global scale of meaning to legitimize local conservation efforts has been internalized by some of the interviewed peasants in the study villages. Villagers for instances: "[...] The forest reserve is owned by the world" 391 and [...] this forest is the lung of the earth" 392 accepting the designation of conservation areas for maintaining planetary support services.

After Suharto's fall, village governments and Malay and Batin Sembilan elites were able to significantly expand their authority and establish new village scales to regulate access and property (hidden power). Village governments gained power by using symbols and language of the state. They control land in alliance with Malay or Batin Sembilan elites and can allocate land, one of most important means of production in rural landscapes (visible power). Especially Batin Sembilan elites in particular were able to change the rules of the game significantly through reintroducing customary regulations and making land claims based on social identity (hidden power). The Batin Sembilan elites' ability to change the rules of the game to their benefit was facilitated by their position in the invisible dimension of power. The rise of global discourses on indigeneity and the emerging indigenous rights movement may have changed the social construction of indigeneity from being associated with "backwardness" to being associated with "rights". It thus provided the opportunity to frame land and forest as indigenous territories or customary land (wilayah adat). Most migrants interviewed in the study villages in both landscapes did not question the authority or land claims of local and indigenous communities. Social

\footnotetext{
391 Interview with a key informant in Sungai Aur, 29.08.2013, Document ID: 135.

392 Interview with a key informant in Bungku, 08.09.2012, Document ID: 77.
} 
identity has become a relevant source of power in both landscapes, to the benefit of Batin Sembilan and Malay elites.

On one hand, migrants benefitted through alliances with Batin Sembilan elites because of Batin Sembilan land resources, while on the other, Batin Sembilan elites engaged with migrants in response to the social construction of the backwardness of shifting cultivators fostered by the Suharto regime. Interethnic marriages helped the Batin Sembilan to benefit from migrants' social capital. Moreover, the alliances provided significant benefits for both parties especially a better positionality in regard to the visible and invisible dimensions of power. However, Batin Sembilan without close ties to elites have probably been even further marginalized because they were not able to claim and allocate land (visible power) or to benefit from the altered notion of indigeneity.

The changed power balance of post-Suharto Indonesia - caused by shifting relationships between structure and agency - provided the opportunity for organizations such as SPI to openly resist (see chapter seven). SPI members in the Harapan Rainforest significantly benefitted from their alliances with Batin Sembilan elites. The ability to allocate material resources (land) increased the organization's attractiveness, and probably increased its organizational strength as well as its ability to occupy large parts of the Harapan Rainforest (Hein et al. 2015). 


\section{Findings-III: Transnational resistance and multi-scalar land conflicts in the context of REDD+}

This chapter focuses on the multi-scalar and transnational dimensions of land conflicts and peasant resistance. I argue that three specific dynamics have provided the extra leeway for resistance, for reclaiming customary land and for articulating alternative interpretations of national policies and regulations. First, state transformation, especially shifts towards democratization and decentralization changed the scalar structure and power relations. Second, the emergence of the indigenous rights discourse provided legitimacy for ethnicity-based land claims and entry points for transnational NGOs. Third, REDD+ has increased the international attention towards structural inequality in national forest governance in the tropics and has fostered the diffusion of international norms such as FPIC, strengthening the position of peasants and indigenous groups vis-à-vis forest authorities, companies and conservation project developers. Moreover, the idea of REDD+ as such transnationalizes local land conflicts linking emitters in the North with project implementers and forest owners in the South. Thus REDD+ links local struggles on access and control of forest land in Jambi to transnational activist networks that provide local land users the opportunity to resist against land claims of private or public conservation agencies and forest carbon offset developers (Hein and Faust 2014; Hein et al. 2015). While the debates on REDD+ might have widened the room for transnational resistance for some actors the simultaneous expansion of conservation areas and commercial large-scale agricultural estates have limited the land-use opportunities of peasant farmers significantly (Hall, Hirsch, and Li 2011; Hein and Faust 2014; Hein et al. 2015; Hein and Garrelts 2014; Osborne 2011; Kijazi 2015).

Chapter five has described broader patterns of state transformation and forest and land tenure reforms changing the dialectical relationship between structure and agency, chapter six has focused on in-situ access and property relations. Both chapters provide insights as such and relevant background information on the root causes of land conflicts in the study villages that become transnationalized in the context of REDD+.

This chapter provides first (7.1) a general overview and categorization (conflict mapping) of ongoing land conflicts in the research villages of the Berbak and Harapan Landscape. Second, I investigate three specific multi-scalar land conflicts characterized by different conflict histories, scalar arrangements and different actor constellations employing multiple strategies for legitimizing land claims. Section 7.2 illustrates the scalar dimensions of the land conflict between the peasant organization SPI and PT REKI on access and control of the Harapan Rainforest. Furthermore, the section sheds light on the role of transnational climate justice and national agrarian reform discourses for SPI's resistance activities. Section 7.3 focuses on the role of indigeneity and of transnational protest in a land conflict between 
Findings-III: Transnational resistance and multi-scalar land conflicts in the context of REDD+

peasants in Bungku and PT REKI. In section 7.4 I analyze a land conflict between different apparatuses of the state on a transmigration settlement within the Berbak Carbon Project.

\subsection{General overview of land conflicts in the research villages (conflict mapping)}

Land conflicts in the Berbak and Harapan Landscape are ongoing between different actors and in the context of different initiatives such as the formation of new protected areas, the implementation of REDD+ demonstration initiatives, the formation of new jurisdictions (e.g. of new villages or districts) and the establishment of new oil palm plantation estates by corporate actors (figure 19). Land conflicts involve peasants (indigenous groups and migrants), different apparatuses of the state (e.g. national government, district governments and village governments and sectoral agencies and ministries), corporate actors (e.g. conservation companies, oil palm companies and timber companies), NGOs and peasant organizations. Table 17 maps different land conflicts ongoing in the study villages.

Figure 19: Large trench as border fortification of the concession of PT Asiatic Persada in Bungku (Source: by the author, 2013)

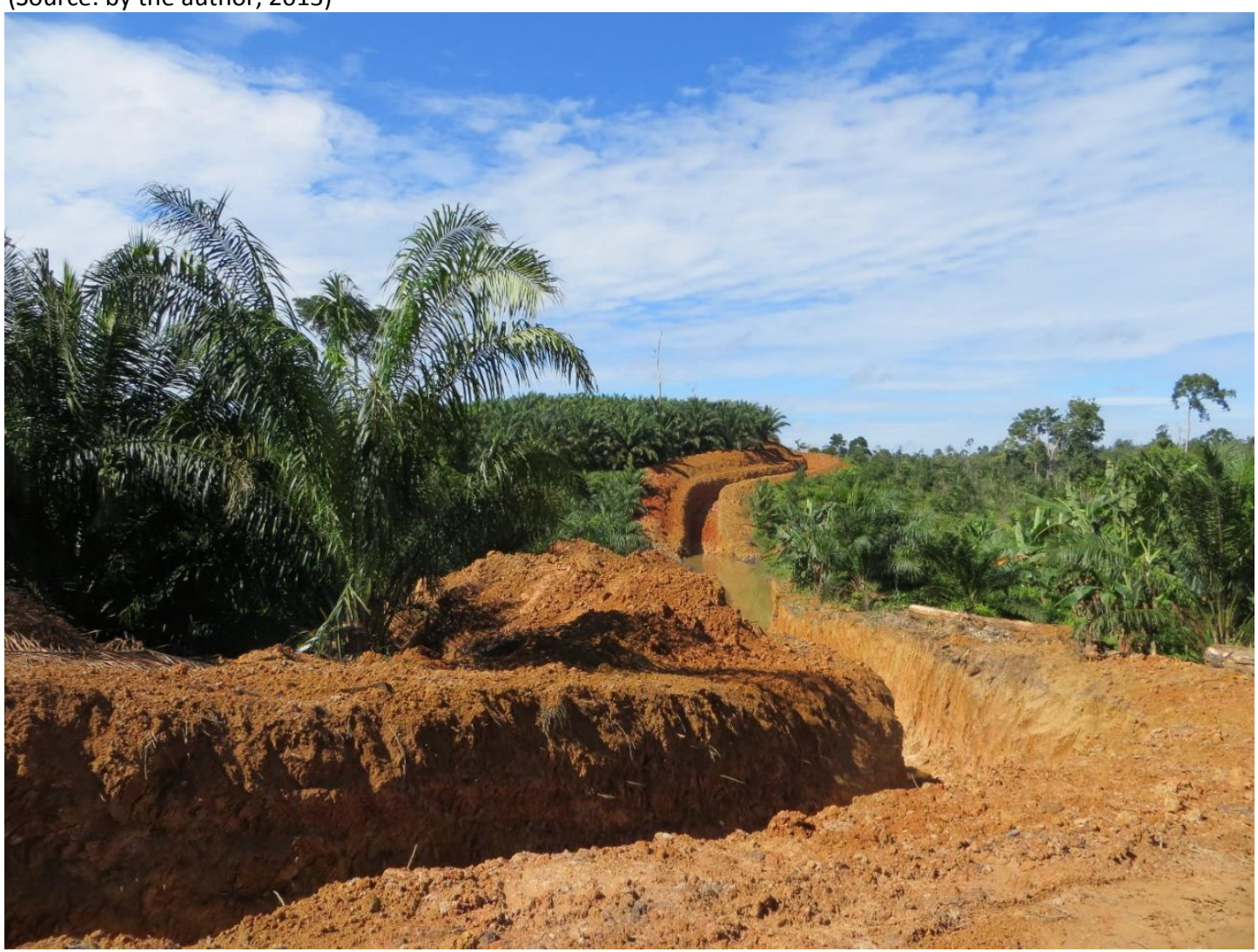




\begin{tabular}{|c|c|c|c|c|c|c|c|}
\hline $\begin{array}{l}\text { Conflict } \\
\text { type }\end{array}$ & Location & Land status & $\begin{array}{l}\text { Main conflict } \\
\text { parties }\end{array}$ & $\begin{array}{l}\text { Conflict } \\
\text { intensity }^{394}\end{array}$ & Conflict origins & $\begin{array}{l}\text { Conflict status } \\
(2013)\end{array}$ & $\begin{array}{l}\text { Transnationalized } \\
\text { conflicts }^{395}\end{array}$ \\
\hline \multirow{6}{*}{$\begin{array}{l}\text { Conservation } \\
\text { conflict }\end{array}$} & Air Hitam Laut & $\begin{array}{l}\text { National Park/ Berbak } \\
\text { Carbon Project }\end{array}$ & $\begin{array}{l}\text { Peasants }{ }^{396}, \\
\text { National Park } \\
\text { Agency }\end{array}$ & 1 & Overlapping property rights & n.a. & REDD+ \\
\hline & $\begin{array}{l}\text { Bungku } \\
\text { (Kunangan Jaya 1) }\end{array}$ & $\begin{array}{l}\text { Ecosystem restoration } \\
\text { concession/ Harapan } \\
\text { Rainforest }\end{array}$ & Peasants, PT REKI & 2 & $\begin{array}{l}\text { Overlapping property rights } \\
\text { and disagreement about } \\
\text { community involvement }\end{array}$ & Mediation ongoing & REDD+, indigenous rights \\
\hline & $\begin{array}{l}\text { Bungku } \\
\text { (Kunangan Jaya 2) }\end{array}$ & $\begin{array}{l}\text { Ecosystem restoration } \\
\text { concession/ Harapan } \\
\text { Rainforest }\end{array}$ & Peasants, PT REKI & 2 & Overlapping property rights & Mediation ongoing & REDD+, indigenous rights \\
\hline & $\begin{array}{l}\text { Bungku (Simpang } \\
\text { Macan, Kunangan } \\
\text { Jaya 1) and } \\
\text { Tanjung Lebar } \\
\text { (RT09) }\end{array}$ & $\begin{array}{l}\text { Ecosystem restoration } \\
\text { concession/ Harapan } \\
\text { Rainforest }\end{array}$ & Peasants, PT REKI & 2 & $\begin{array}{l}\text { Overlapping property rights } \\
\text { and disagreement about } \\
\text { community involvement }\end{array}$ & n.a. & REDD+, indigenous rights \\
\hline & $\begin{array}{l}\text { Bungku } \\
\text { (Kunangan Jaya 1) }\end{array}$ & $\begin{array}{l}\text { Ecosystem restoration } \\
\text { concession/ Harapan } \\
\text { Rainforest }\end{array}$ & $\begin{array}{l}\text { PT REKI, PT Asiatic } \\
\text { Persada }\end{array}$ & 1 & Overlapping property rights & n.a. & REDD+ \\
\hline & $\begin{array}{l}\text { Bungku (Bungku } \\
\text { Indah) }\end{array}$ & $\begin{array}{l}\text { Forest Reserve Senami/ } \\
\text { Sultan Sultan Thaha } \\
\text { Syaifuddin }\end{array}$ & $\begin{array}{l}\text { Peasants, District } \\
\text { Forest Service }\end{array}$ & 1 & Overlapping property rights & No mediation & No \\
\hline
\end{tabular}

${ }^{393}$ Conflict types: categorized according to land use type, conservation conflict refers to conflicts occurring between actors having authority over protected areas and actors interested in other land-uses; oil palm conflict refers to conflicts between oil palm plantation companies and peasants; forestry conflict refer to conflicts between timber companies and peasants; border conflict refers to conflicts between different jurisdictions e.g. between villagers or districts.

${ }^{394}$ Conflict intensity, based on Annabelle Houdret (2008: 9) and Houdret and colleagues (2010: 8), level of intensity: 1: articulated verbally, protest, public authorities involved in mediation; 2: active confrontation e.g. sabotage, road blocks, destruction of property; 3 : violent escalation: employ of physical violence by involved parties, forced displacements.

${ }^{395}$ Transnational linkages e.g. REDD+ demonstration initiative, plantation certified by a transnational standard (RSPO), actors have employed scale jumping to the transnational/ international scale, actors involved in the conflict explicitly refer to international law, REDD+/ UNFCCC or are supported by transnational NGOs in the conflict.

396 The category peasants includes indigenous groups and migrant communities. 


\begin{tabular}{|c|c|c|c|c|c|c|c|}
\hline & $\begin{array}{l}\text { Tanjung Lebar (T. } \\
\text { Mandiri) }\end{array}$ & $\begin{array}{l}\text { Ecosystem restoration } \\
\text { concession/ Harapan } \\
\text { Rainforest }\end{array}$ & Peasants, PT REKI & 2 & Overlapping property rights & Mediation failed & REDD+, indigenous rights \\
\hline & $\begin{array}{l}\text { Tanjung Lebar } \\
\text { (Sungai Jerad, P. } \\
\text { Ranjau) }\end{array}$ & $\begin{array}{l}\text { Ecosystem restoration } \\
\text { concession }\end{array}$ & Peasants, PT REKI & 3 & Overlapping property rights & Mediation failed & REDD+, human rights \\
\hline & Seponjen & $\begin{array}{l}\text { Forest Reserve Sekitar } \\
\text { Tanjung/ Berbak } \\
\text { Carbon Project }\end{array}$ & $\begin{array}{l}\text { Peasants and } \\
\text { Prov. Forest } \\
\text { Agency }\end{array}$ & 1 & Overlapping property rights & No mediation & REDD+ \\
\hline & Sungai Aur & $\begin{array}{l}\text { Forest Reserve Sekitar } \\
\text { Tanjung/ Berbak } \\
\text { Carbon Project }\end{array}$ & $\begin{array}{l}\text { District Gov. } \\
\text { Muaro Jambi, } \\
\text { Prov. Forest } \\
\text { Agency, Peasants }\end{array}$ & 1 & Overlapping property rights & Mediation ongoing & REDD+ \\
\hline \multirow{6}{*}{$\begin{array}{l}\text { Oil palm } \\
\text { conflicts }\end{array}$} & $\begin{array}{l}\text { Bungku (Bungku } \\
\text { Indah) }\end{array}$ & $\begin{array}{l}\text { HGU (oil palm } \\
\text { concession) }\end{array}$ & $\begin{array}{l}\text { Peasants, PT } \\
\text { Asiatic Persada }\end{array}$ & 3 & Overlapping property rights & Mediation ongoing & RSPO, indigenous rights \\
\hline & $\begin{array}{l}\text { Bungku (Johor } \\
\text { Baru) }\end{array}$ & $\begin{array}{l}\text { HGU (oil palm } \\
\text { concession) }\end{array}$ & $\begin{array}{l}\text { Peasants, PT } \\
\text { Asiatic Persada }\end{array}$ & 3 & Overlapping property rights & Mediation ongoing & RSPO, indigenous rights \\
\hline & Tanjung Lebar & $\begin{array}{l}\text { HGU (oil palm } \\
\text { concession) }\end{array}$ & $\begin{array}{l}\text { Peasants, PT } \\
\text { Asiatic Persada }\end{array}$ & 3 & Overlapping property rights & Mediation ongoing & RSPO, indigenous rights \\
\hline & Tanjung Lebar & $\begin{array}{l}\text { HGU (oil palm } \\
\text { concession) }\end{array}$ & $\begin{array}{l}\text { Peasants, PT } \\
\text { Bahar Pasifik }\end{array}$ & 1 & $\begin{array}{l}\text { Disagreement on smallholder } \\
\text { scheme }\end{array}$ & Mediation ongoing & no \\
\hline & Seponjen & $\begin{array}{l}\text { HGU (oil palm } \\
\text { concession) }\end{array}$ & $\begin{array}{l}\text { Peasants, PT } \\
\text { Bintang Bukit } \\
\text { Sawit }\end{array}$ & 2 & $\begin{array}{l}\text { Disagreement on smallholder } \\
\text { scheme }\end{array}$ & Mediation ongoing & no \\
\hline & Sungai Aur & HGU & $\begin{array}{l}\text { Peasants, PT } \\
\text { Jambi Batang Hari } \\
\text { Plantation }\end{array}$ & 1 & $\begin{array}{l}\text { Disagreement on smallholder } \\
\text { scheme }\end{array}$ & No mediation & no \\
\hline $\begin{array}{l}\text { Forestry } \\
\text { conflicts }\end{array}$ & $\begin{array}{l}\text { Bungku } \\
\text { (Kunangan Jaya 2) }\end{array}$ & $\begin{array}{l}\text { Forest plantation } \\
\text { concession (HTI) }\end{array}$ & $\begin{array}{l}\text { Peasants, PT AAS/ } \\
\text { Wanakasita } \\
\text { Nusantara }\end{array}$ & 3 & Overlapping property rights & Mediation ongoing & Indigenous rights \\
\hline
\end{tabular}




\begin{tabular}{|c|c|c|c|c|c|c|c|}
\hline & $\begin{array}{l}\text { Bungku and } \\
\text { Tanjung Lebar }\end{array}$ & $\begin{array}{l}\text { Logging concession } \\
\text { (Pemanfaatan Hasil } \\
\text { Hutan Kayu) }\end{array}$ & $\begin{array}{l}\text { Peasants, PT } \\
\text { Asialog }\end{array}$ & 1 & Overlapping property rights & $\begin{array}{l}\text { Stopped, PT Asialog } \\
\text { abandoned } \\
\text { concession }\end{array}$ & no \\
\hline \multirow{3}{*}{$\begin{array}{l}\text { Border } \\
\text { conflicts }\end{array}$} & $\begin{array}{l}\text { District of Muaro } \\
\text { Jambi and of } \\
\text { Batang Hari }\end{array}$ & Miscellaneous & $\begin{array}{l}\text { District gov. } \\
\text { Muaro Jambi and } \\
\text { of Batang Hari }\end{array}$ & 1 & $\begin{array}{l}\text { Different understanding of } \\
\text { district border }\end{array}$ & No mediation & no \\
\hline & $\begin{array}{l}\text { Bungku and } \\
\text { Tanjung Lebar }\end{array}$ & Miscellaneous & $\begin{array}{l}\text { Village gov. of } \\
\text { Bungku and } \\
\text { Tanjung Lebar }\end{array}$ & 1 & $\begin{array}{l}\text { Different understanding of } \\
\text { village border }\end{array}$ & No mediation & no \\
\hline & $\begin{array}{l}\text { Seponjen and } \\
\text { Sungai Bungur }\end{array}$ & APL and forest reserve & $\begin{array}{l}\text { Village gov. of } \\
\text { Seponjen and } \\
\text { Sungai Bungur }\end{array}$ & 1 & $\begin{array}{l}\text { Different understanding of } \\
\text { village border }\end{array}$ & Solved & no \\
\hline
\end{tabular}

Table 17: Land conflict mapping in the study villages

(Source: own investigations) 
The different conflicts have been identified in semi-structured interviews in the study villages and with NGOs, staff of state agencies and through the analysis of press articles and other documents. Conflicts are grouped according to the land-use type. The category conservation conflict refers to conflicts occurring between actors having authority over protected areas (including REDD+ demonstration initiatives) and actors interested in other activities. The categories oil palm and forestry conflicts refer to conflicts between corporate actors running oil palm and timber plantations or logging concessions. The fourth category "border conflict" refers to conflicts ongoing over the borders between different jurisdictions e.g. between villages and districts. In total, I have listed nineteen different land conflicts, nine of them occurred in the context of REDD+ demonstration/ private conservation initiatives such as the Berbak Carbon and the Harapan Rainforest Projects. Seven of them occurred in the context of oil palm and timber plantation estates. In fourteen conflicts, peasant farmers are a major conflict party. Overlapping and competing property rights can explain thirteen conflicts. It is important to note here that study villages have been selected according to the "follow the conflict" premise developed by Marcus (1995). Thus, only study villages characterized by ongoing conservation conflicts have been selected. Consequently, this leads to a selection bias explaining the higher amount of conservation conflicts in comparison to conflicts with oil palm or pulp and paper companies.

The mapped conflicts have different conflict intensities. The conflicts have been further categorized based on conflict intensity criteria developed for natural resource conflicts by Annabelle Houdret and colleagues (2008: 9; 2010: 8). They distinguish three levels of conflict intensity and conflict escalation. The first Intensity level refers to conflicts articulated verbally including protest. The second level of intensity refers to active confrontation between conflict parties (e.g. roadblocks, sabotage, and destruction of property). The third level refers to violent conflict escalation, thus to physical violence and forced displacements (ibid. ).

Examples for low intensity conflicts are the border conflicts between Tanjung Lebar and Bungku and between Seponjen and Sungai Bungur. The first was only articulated verbally by different key informants in both villagers and has not involved any open protest ${ }^{397}$. The latter was mediated and solved by public authorities, especially by elders of both villages ${ }^{398}$. Examples of conflicts of medium intensity are the land conflicts ongoing between settlers of the village-scale settlement schemes (e.g. Camp Gunung, Tanjung Mandiri and Transwakarsa Mandiri) within the Harapan Rainforest and PT REKI. In these conflicts, both parties accuse each other of having destroyed property (e.g. destruction of oil palm plantations, checkpoints, motor bikes and cars). Moreover, settlers supported by NGOs have

\footnotetext{
${ }^{397}$ Interview with key informant in Bungku, 24.08.2013, Document ID: 2 and in Tanjung Lebar, 25.07.2013, Document ID: 124.

${ }^{398}$ Interview with key informant in Seponjen, 15.09.2013, Document ID: 172.
} 
organized open protest ${ }^{399}$. The conflict between PT REKI and SPI and the different conflicts between the oil palm company PT Asiatic Persada and different peasant groups in Bungku and Tanjung Lebar can be considered as violent conflicts. PT REKI and SPI accuse each other for kidnappings. In addition, SPI accuses PT REKI for the destruction of farmsteads. The Indonesian National Commission on Human Rights (Komisi Nasional Hak Asasi Manusia, KOMNAS HAM) has found indications for the occurrence of human rights violations in the context of the conflict according to a local newspaper (Ferdiyal 2013). The conflict between peasants and PT Asiatic Persada led to a number of injuries, to at least one casualty and to the destruction of a number of farmsteads, old graveyards and forest gardens of the indigenous Batin Sembilan ${ }^{400}$ (Rettet den Regenwald 2014; Zainuddin 2013: 12).

At least eight conflicts can be considered as transnational conflicts involving transnational NGOs, donors, transnational standards or international law. Three ${ }^{401}$ of them will be discussed in details in the next sections (marked yellow in table 17).

\subsection{Peasant resistance, climate justice and agrarian reform: conflict between $\mathrm{SPI}$ and the Harapan Rainforest ${ }^{402}$}

The conflict between members of Serikat Petani Indonesia (SPI), the conservation company PT REKI and different apparatuses of the state (Ministry of Forestry, police and military) is probably the most intense conservation conflict in Jambi. Despite PT REKIs presence, peasants affiliated to SPI have been able to expand forest conversion and settlement formation. Peasant farmers in Sungai Jerad (figure 20) occupy and use land for agricultural purposes that the MoF has allocated to the conservation company PT REKI. Accordingly, SPI members openly challenge the hegemony of the MoF. SPI considers the occupation of state forest as legitimate response to colonial and post-colonial policies of dispossession (Hein et al. 2015). SPI members seek for the release of the claimed area out of PT REKIs conservation concession.

Peasant resistance in the context of the Harapan Rainforest project is a spatial and territorial practice that challenges scales of meaning and regulation constructed by PT REKI and by the MoF (Moore 1998;

\footnotetext{
${ }^{399}$ Interview with key informants in Bungku, 12.09.2012, Document ID: 84, 10.07.2013, Document ID: 105, 24.08.2013, Document ID: 152, 09.07.2013, Document ID: 107 and with staff member of PT REKI in Bungku, 30.07.2013, Document ID: 1.

${ }^{400}$ Interview with key informants in Bungku, 16.09.2012, Document ID: 85, 21.09.2012, Document ID: 68, 83, and with key informant in Tanjung Lebar, 25.07.2013, Document ID: 149.

${ }^{401}$ The table lists three different conflicts on Kunangan Jaya I alone, marked in light yellow, they will be discussed together in section 7.3.

${ }^{402}$ Parts of this section have been published in Hein, Jonas, Soeryo Adiwibowo, Christoph Dittrich, Rosyani, Endriatmo Soetarto, and Heiko Faust (2015)."Rescaling of Access and Property Relations in a Frontier Landscape: Insights from Jambi, Indonesia." The Professional Geographer.
} 
Turner and Caouette 2009; Towers 2000). Territorial in the sense, that SPI and PT REKI have established specific regulations and border demarcations for the spatial units they control. The conservation company has formulated, conservation regulations and SPI the three T rules (both explained in chapter 6). The territories, the actors control are marked with signs, turnpikes and flags and reflect power relations inscribed in the landscape (Peluso and Lund 2011: 673).

Peasant resistance facilitated by SPI is not only challenging the implementation of the Harapan Rainforest project, SPI's resistance can be considered as a multi-scalar resistance campaign. At the village-scale SPI seeks to tackle the local impacts of national land allocation policies through land occupations. At the national scale SPI seeks to change the national legal framework by organizing protest in urban centers. At the global scale SPI seeks to challenge the implementation of transnational forest carbon offsets (c.f. Hein and Faust 2014; Hein et al. 2015).

Figure 20: Deforestation in the northern Harapan Rainforest until 2013 (Source: Hein et al. 2015: 4)

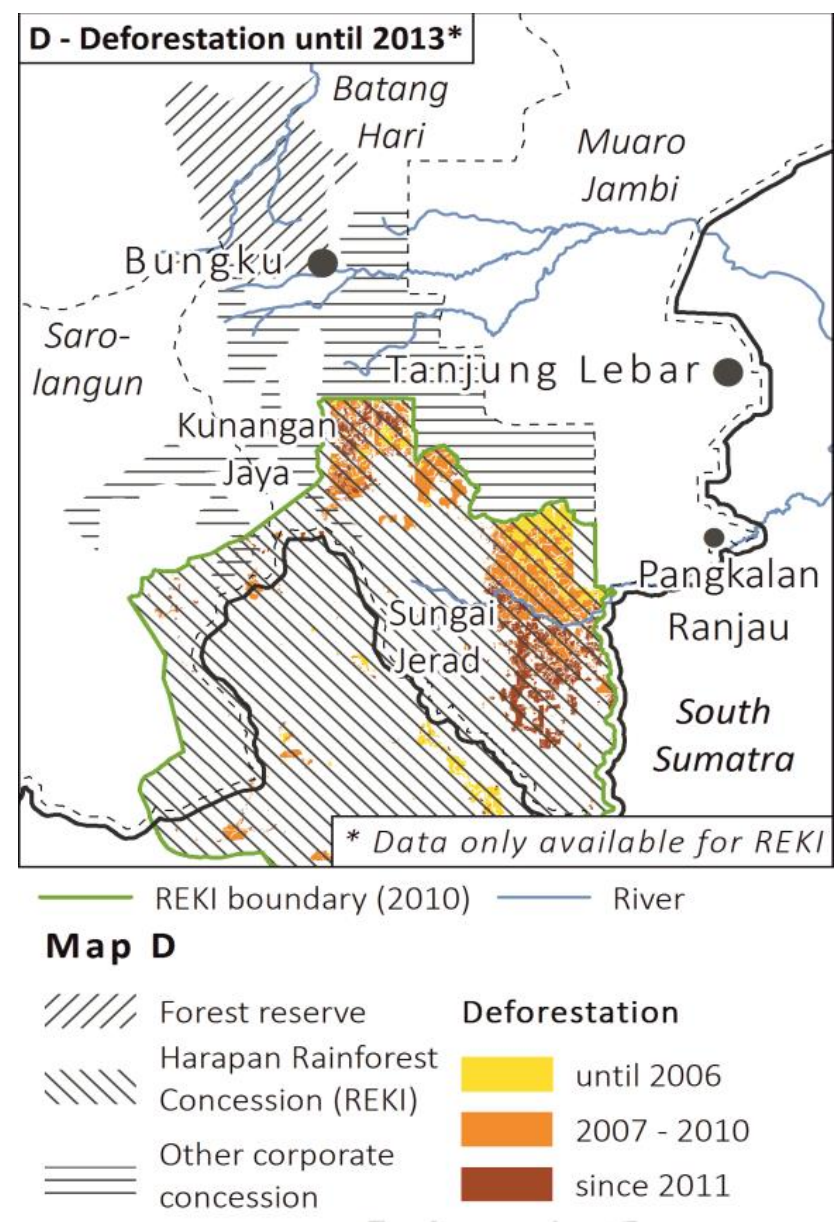




\subsubsection{Conflict history}

According to SPI members, the conflict started in 2008 and intensified in 2010. SPI members reported that in 2010 the forest police and staff of PT REKI started patrolling in the settlements and announced that the land is now under the concession of the conservation company ${ }^{403}$. SPI leaders argued that the conservation company has not conducted FPIC and has denunciated SPI members as encroachers and illegal loggers ${ }^{404}$ (c.f. Wirasapeotra and Octavian 2012: 6-13). In contrast, PT REKI argues that SPI members were not willing to participate in any consultations ${ }^{405}$. The conflict escalated in 2012. Both parties accuse each other for kidnappings and for the destruction of property. Especially, SPI members accuse the forest police, BRIMOB, the military and private informal security forces for having destroyed farmsteads $^{406}$ (c.f. Lang 2012a; Usman 2012; Wirasapeotra and Octavian 2012). Furthermore, SPI members complained that the raids of BRIMOB and forest police were only targeted at smallholders and not at the larger plantation estates hold by elites and politicians within the concession ${ }^{407}$. In 2013, during field research, the conflict was rather calm but not solved yet and both parties accuse each other for not willing to participate in conflict mediation.

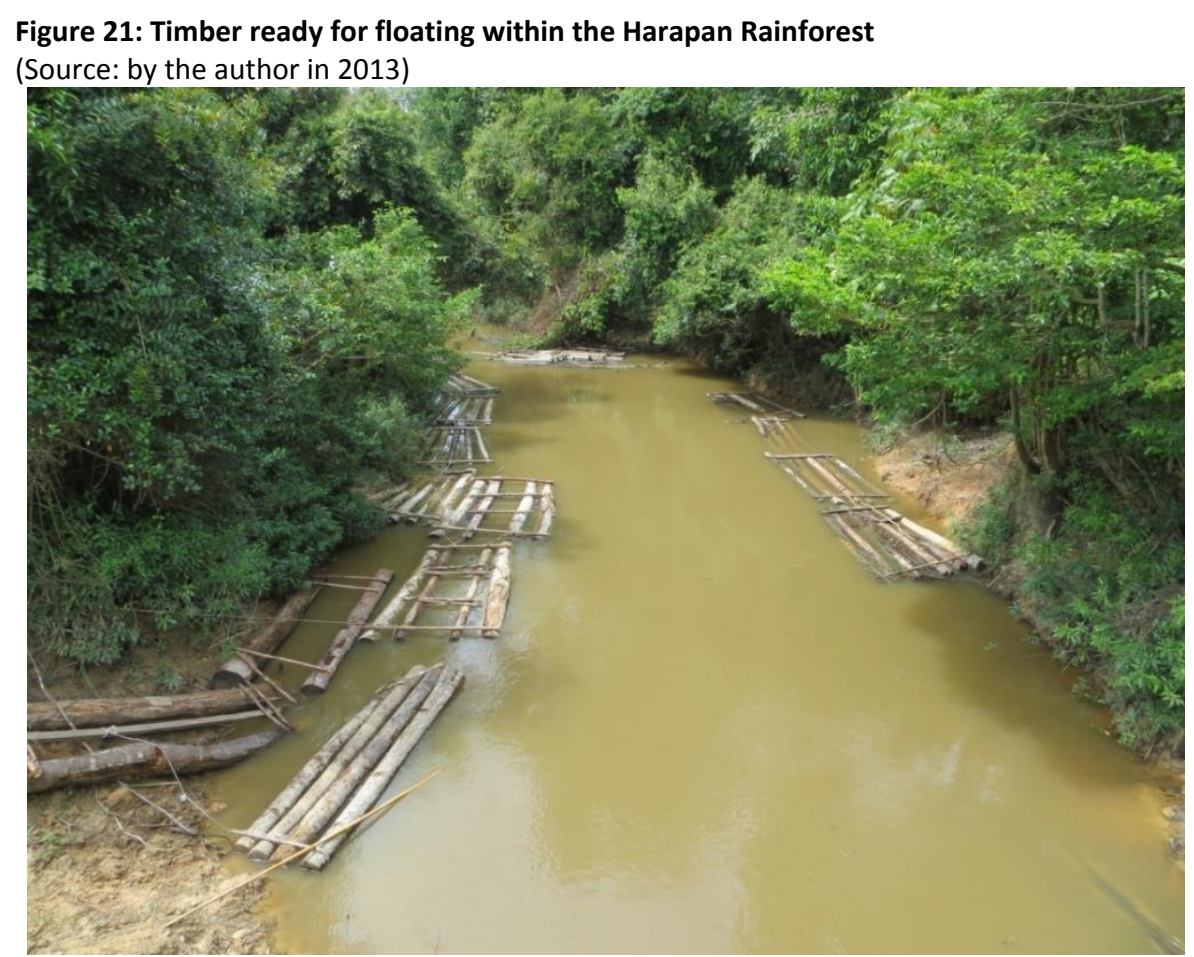

\footnotetext{
${ }^{403}$ Interviews with key informants in Tanjung Lebar, 21.07.2013, Document ID: 128, 129.

${ }^{404}$ Interview with SPI activist in Jambi, 12.07.2013, Document ID: 140.

${ }^{405}$ Interview with staff member of Burung Indonesia, 11.10.2013, Document ID: 210.

${ }^{406}$ Interviews with key informants in Tanjung Lebar, 21.07.2013, Document ID: 128, 129, 22.07. 2013, Document ID: 178 and with SPI activist in Jambi, 12.07.2013, Document ID: 140 and with KfW staff members in Frankfurt am Main, 04.02.2014. Document ID: 389.

${ }^{407}$ Interview with SPI activist in Jakarta, 20.06.2013, Document ID: 104.
} 
In how far specific actors are involved in organized forest crimes and in human rights violations is hard to assess and goes beyond the scope of this dissertation. Nevertheless, PT REKI accuses especially SPI members for being paid by logging companies for cutting valuable timber in the conservation concessions $^{408}$ (figure 21). SPI accuse PT REKI for paying informal security staff which has been involved in human rights violations ${ }^{409}$.

\subsubsection{Actor mapping}

The main actors in the conflict next to PT REKI and SPI (figure 22) are the MoF, different security apparatuses (e.g. police and the Indonesian Armed Forces), La Via Campesina as SPIs transnational partner, the transnational shareholders of PT REKI (Burung Indonesia, RSPB and Birdlife International) and PT REKIs foreign donors (e.g. Danida and KfW). Actors such as La Via Campesina, Singapore Airlines, Danida and KfW are of course not directly involved in the local confrontations. Although their involvement, constitutes, in one way or another, the transnational and multi-scalar dimension of this conflict. La Via Campesina facilitated scale jumping for SPI by organizing side events at UN climate change conferences. Scale jumping permitted SPI leaders to raise concerns about REDD+ and the Harapan Rainforest project at the global scale. In this specific case at the conference of the parties to the UNFCCC in Poznan in $2008^{410}$ (La Via Campesina 2008).

Singapore Airlines has contributed to a trust fund of the Harapan Rainforest project and labels itself as the "[...] exclusive airline partner for the Harapan Rainforest Initiative [...]" (Singapore Airlines 2015). In return Singapore Airlines has not received carbon credits but the carrier considers its support as being part of the carrier's commitment to improve its environmental performance (ibid.). Following this argument Singapore Airlines contribution to the trust fund can be at least considered as an indirect and not quantified environmental offset. An expert from $\mathrm{KfW}$ described the financial contributions to the trust fund as "virtual certificates" which do not lead to the production of regular carbon credits ${ }^{411}$. $\mathrm{KfW}$ as the implementing organization of the German International Climate Initiative (IKI) has not only funded the project but has also articulated verbal and written support for PT REKI in public debates on the conflict ${ }^{412}$ (c.f. Lang 2012a). Especially on the online platform REDD Monitor ${ }^{413}$ a debate between SPI and supporters of PT REKI was ongoing between 2008 and 2012 (Lang 2015). KfW has participated

\footnotetext{
${ }^{408}$ Interview with staff member of PT REKI in Bungku, 30.07.2013, Document ID: 1 and with staff members of KfW, Frankfurt am Main am Main, 04.02.2014, Document ID: 389.

${ }^{409}$ Interview with SPI activist in Jambi, 12.07.2013, Document ID: 140 and with KfW staff in Frankfurt am Main, 04.02.2014, Document ID: 389.

${ }^{410}$ Interview with SPI activist in Jambi, 12.07.2013, Document ID: 140.

${ }^{411}$ Interview with KfW staff member in Frankfurt am Main, 19.04.2012, Document ID: 385.

${ }^{412}$ Interview with KfW staff members in Frankfurt am Main, 04.02.2014, Document ID: 389.

${ }^{413} \mathrm{http}: / /$ www.redd-monitor.org (accessed 18.09.2015)
} 
in these debates supporting PT REKI. Important to consider is also that, as mentioned in chapter four, IKI had neither strict social safeguards in place nor has stipulated FPIC. The implementation of both policies would probably have helped to mediate the conflict in the first place.

Figure 22: Actor mapping of the conflict between SPI and PT REKI on access and control of the Harapan Rainforest concession

Green: SPI and partner, olive: other NGOs, orange: state actors, blue: PT REKI and partners, red: donors, grey: Batin Sembilan elites, black: illegal actors and informal security staff (Source: own draft, based on interviews with involved stakeholders).

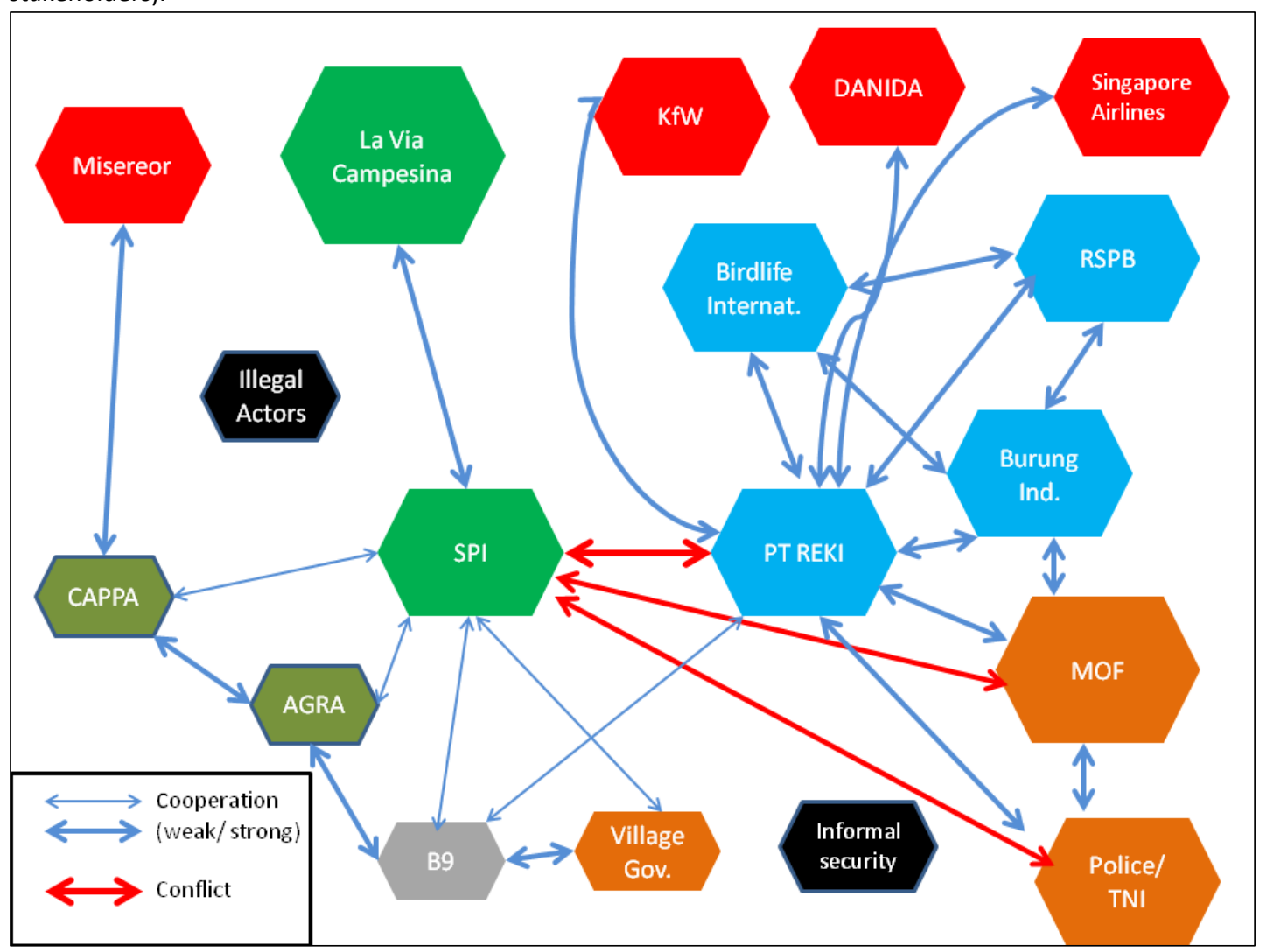

Other relevant actors in the conflict arena are the NGOs Yayasan CAPPA and AGRA and PT REKIs transnational shareholders Burung Indonesia, RSPB and Birdlife International. The NGO Yayasan CAPPA supports migrants and Batin Sembilan in land conflicts in Bungku and regularly coordinates campaigns with $\mathrm{SPI}^{414}$. AGRA is as SPI a peasant organization aiming at promoting agrarian reform. The organization has just started activities in Jambi and is closely collaborating with CAPPA and supports Batin Sembilan groups. In September 2013 the peasant organization AGRA planned to map the territorial claims of Batin Sembilan within the Harapan Rainforest ${ }^{415}$. AGRA highlighted that the Batin Sembilan became a minority in the Sungai Jerad area and that they need support in the negotiations with PT REKI and SPI ${ }^{416}$. The Batin Sembilan groups living close to the SPI settlements (B9 in the figure)

\footnotetext{
${ }^{414}$ Interview with CAPPA activist in Jambi, 18.07.2013, Document ID: 157.

415 Interview with activist of AGRA, Jambi, 18.09.2013, Document ID: 288

${ }^{416}$ Interview with activist of AGRA, Jambi, 18.09.2013, Document ID: 288
} 
are not directly involved in the conflict. But as described in chapter six (6.3.3.4) Batin Sembilan elites have granted access to land for SPI members in the first place. However, many non-elites were not able to benefit from the land transactions and some complained about the rapid expansion of SPI members. Others showed interest in expanding cooperation with SPI (e.g. for having access to agricultural trainings provided by SPI) ${ }^{417}$.

PT REKIs shareholders have slightly different positions in the conflict. RSPB was from the very beginning in favor of a strict fortress conservation approach aiming at relocating or displacing all settlers living in the concession ${ }^{418}$. Burung Indonesia in contrast is more in favor of a mediation based solution to the conflict $^{419}$ (Silalahi and Erwin 2013).

\subsubsection{A multi-scalar conflict on meanings, access and control of the Harapan Rainforest}

Although the main cause of the conflict are overlapping land rights legitimized by different public authorities and the interest in mutual exclusive land-use practices (e.g. farming vs. conservation), the transnational linkages and the strategies employed by the different conflict parties make the case even more complex. Both parties seek to situate their activities within broader scales of meaning and refer to competing scales of regulation. SPI seeks to construct explicit linkages between the confrontations in the Harapan Rainforest and national agrarian and global climate justice debates. SPI stands in the tradition of the socialist zeitgeist of the Soekarno era and is struggling for the reconstruction of national scales of meaning and of regulation based on the key role of land for achieving welfare and social justice in rural areas (Hein and Faust 2014). Interviewed SPI members settling in the Harapan Rainforest argued that the Basic Agrarian Law (BAL) and the constitution provides legitimacy for their land claims: "[...] the BAL from 1960, no. 5 clarifies the right of the people to land [...] we did not have a formal permit for the land here but we have a strong law on our side" ${ }^{420}$.

The settlements within the Harapan Rainforest provide land for SPI members hence they are strengthening the attractiveness of SPI and the political mobilization potential for national campaigns (Hein et al. 2015). At the transnational scale SPI and its ally La Via Campesina use the settlement and the associated land conflicts with PT REKI for underpinning transnational campaigns against carbon offsetting and REDD+ (Hein and Faust 2014; Hein et al. 2015; La Via Campesina 2012). SPI rejects the commodification of nature in the name of the "green economy", conservation and REDD+.

\footnotetext{
${ }^{417}$ Interview with key informant in Tanjung Lebar, 23.07.2013, Document ID: 171.

${ }^{418}$ Interview with staff members of KfW, Frankfurt am Main am Main, 04.02.2014, Document ID: 389.

${ }^{419}$ Interview with staff members of KfW, Frankfurt am Main am Main, 04.02.2014, Document ID: 389.

${ }^{420}$ Interview with key informants in Tanjung Lebar, 22.07.2013, Document ID: 178.
} 
Furthermore, SPI in line with La Via Campesina argues that developed countries should reduce emissions domestically and not through the enclosure of large forest areas in the global South ${ }^{421}$. The head of SPI Jambi stated in simple terms: "Traditional agriculture creates a healthy environment but instead displacements of farmers and [...] detention of farmers occur, thus REDD is equivalent to the displacement of farmers" ${ }^{422}$. SPI members settling in the Harapan Rainforest have argued: "PT REKI takes care of the lungs of the earth by re-greening, but who takes care of the lungs of the people?" 423 And "[...] I have just one question the carbon goes overseas, what is more important the carbon or the community living here? [...] When we have carbon we do not have people here, for who is the carbon then? $[\ldots]^{\prime \prime 424}$.

PT REKI and partners especially stress the global and local relevance of the Harapan Rainforest project. Birdlife International (2008: 4) as one of PT REKI shareholders stress in a project report that "[...] the lowland rainforests of Sumatra are of particular importance and rival the Amazon in terms of species" (ibid). Furthermore, the report highlights the "carbon value" of the project (ibid. 6). A former lobbyist of Burung Indonesia highlighted the singularity of the ecosystem and the presence of large mammals and asked "how can we commodify conservation to increase protection? [...]"425.

The project is locally relevant especially for the Batin Sembilan argue PT REKI and partners. The project area can be considered [...] as a last resort for Batin Sembilan" 426 providing "[...] them with the option of continuing to reside in a forest environment" (Birdlife International 2008: 5). In the direct stand-off between PT REKI and SPI the conservation company is rather employing a legalistic approach highlighting that SPIs activities and SPIs presence violates the forest law. A staff member of PT REKI for instance argued that "[...] SPI are bad guys, they are involved in illegal logging and land trade, they are criminals" adding that "fortress conservation is the only way to conserve this forest ${ }^{427 "}$. Figure 21 , indicates that illegal logging is ongoing in the area as the logs ready for floating show. Moreover, PT REKI stressed that the conservation concession is the only property right in place issued by a nationalscale authority. Thus, PT REKI challenges property rights issued by other public authorities (e.g. villagescale land titles) and reproduces the state forest and its concession system as scales of regulation.

\footnotetext{
${ }^{421}$ Interview with SPI activist in Jakarta, 20.06.2013, Document ID: 104.

${ }^{422}$ Interview with SPI activist in Jambi, 12.07.2013, Document ID: 140.

${ }^{423}$ Interview with key informant in Tanjung Lebar, 21.07.2013, Document ID: 129.

${ }^{424}$ Interview with key informant in Tanjung Lebar, 22.07.2013, Document ID: 178.

${ }^{425}$ Interview with staff member of Carbon Synthesis, 11.10.2012, Document ID: 19.

${ }^{426}$ Interview with staff member of PT REKI, Jambi, 02.09.2012, Document ID: 33.

${ }^{427}$ Interview with staff member of PT REKI in Bungku, 30.07.2013, Document ID: 1.
} 
In spite of all differences both parties reproduce putra daerah ${ }^{428}$ and indigeneity discourses (McCarthy 2004: 1206). SPI, as described in chapter six, claims to have received a permit from the hamlet head of Mangkubangan/ Pangkalan Ranjau and of Batin Sembilan leaders. PT REKI considers the land claims of Batin Sembilan as more legitimate then those of migrants ${ }^{429}$ (Hein 2013b; Hein and Faust 2014). In addition, PT REKI uses the presence of the Batin Sembilan and their alleged role as "forest-dependent people" (Birdlife International 2008: 5) for legitimizing forest conservation. SPI argues, as the conservation company does, that their activities are contributing to conservation. In this sense, the three ' $T$ ' rule and the oil palm ban can be considered as being part of SPI's strategy to increase the legitimacy of their activities. SPI members have argued that the forests of Sungai Jerad and Bukit Sinyal had been destroyed by PT Asialog. Following this argument, rubber agroforestry systems planted by the SPI settlers have even been contributing to forest rehabilitation. Furthermore, the head of a SPI basis argued that the area was "Iahan tidur" (which is a term describing degraded unproductive land) before SPI came to the area. SPI brings the land back to productivity he further argued ${ }^{430}$. The conservation company rejects these arguments and refers to Landsat and Rapid Eye images that indicate ongoing forest conversion and oil palm cultivation by SPI settlers ${ }^{431}$ (Lang 2012b).

\subsection{The conflict on Kunangan Jaya I}

The conflict on the hamlet of Kunangan Jaya I is again caused by overlapping property rights legitimized by different authorities. Even more important, the conflicts on Kunangan Jaya illustrate power shifts and the new fragile scalar structure of the post-Suharto period. The emergence of a village-scale of land tenure regulation and of attempts of Batin Sembilan groups to reestablish their customary territories after Suharto's fall has been challenged by the MoF through allocating the Meranti-RiverKapuas-River Forest Block to the conservation company PT REKI neglecting the presence of local communities and pre-existing access and property relations (Hein et al. 2015, section 6.1.1 and 6.3.3).

The hamlet of Kunangan Jaya I has more than 1200 inhabitants and consist of many dispersed settlements mainly located within the concessions of PT REKI and PT Asiatic Persada (Wirasapeotra and Octavian 2012: 7). Each settlement has its distinct history. This section focuses only on conflicts involving the TSM settler community (introduced in section 6.3.3.1) and different Batin Sembilan groups settling in the most northern part of the Harapan Rainforest concession. The conflict on

\footnotetext{
${ }^{428}$ English: child of the region

${ }^{429}$ Interview with staff member of PT REKI in Bungku, 30.07.2013, Document ID: 1.

${ }^{430}$ Interview with key informant in Tanjung Lebar, 21.07.2013, Document ID: 128.

${ }^{431}$ Interview with staff member of PT REKI, Bogor, 11.10.2013, Document ID: 210.
} 
Kunangan Jaya I has multiple dimensions and multiple strands. Depending on the perspective the conflict can be framed as conflict between different apparatuses of the state (e.g. involving village governments, MoF and sectoral agencies), as a transnational conflict on indigenous rights and as conflict between local communities and actors interested in conservation and climate change mitigation (e.g. PT REKI). Moreover, the different local communities involved in the project are very heterogeneous. Different community members and community leaders have different abilities, material resources and interest thus follow different strategies in the conflict with PT REKI. The TSM community and some of the Batin Sembilan communities seek for the release of their settlement out of the state forest (enclave). Others have accepted conditional land tenure agreements with PT REKI (PT REKIs conditional land tenure agreements have been discussed in section 6.4.1).

\subsubsection{Conflict history and conflict mediation}

First land conflicts on access and control of landscapes of Kunangan Jaya I date back to the period when the area was managed by the logging company PT Asialog. In the 1970s, in the course of the implementation of the logging concessions first Batin Sembilan families of Kunangan Jaya practicing shifting cultivation were forced to leave the concession ${ }^{432}$. The more recent conflicts related to the designation of the Meranti River-Kapuas-River Forest block for ecosystem restoration and to the allocation of the forest block to PT REKI started in 2007. In 2007 the District Forest Agency and the forest police started a first attempt to relocate the TSM community ${ }^{433}$. After first negotiations, the district forest agency accepted their presence tentatively and informed settlers that they should plant rubber instead of oil palms ${ }^{434}$. In 2010, the conservation company PT REKI supported by the heavily armed mobile police brigade (BRIMOB) and the forest police entered the community urging people to leave the concession and to abandon their farmsteads and plantations within two months ${ }^{435}$. In other parts of Kunangan Jaya I (e.g. area around Sungai Kandang and Simpang Macan) key informants complained that forest rangers of PT REKI destroyed their oil palm plantings ${ }^{436}$. In almost all settlements community members complained that PT REKI failed to conduct FPIC. The communities in Kunangan Jaya I were only informed in the course of the police interventions that agriculture and settlement within state forest is prohibited ${ }^{437}$. After the police intervention a farming group from

\footnotetext{
${ }^{432}$ Interview with key informant in Bungku, 12.09.2012, Document ID: 87.

${ }^{433}$ Interview with key informant in Bungku, 23.08.2013, Document ID: 202.

${ }^{434}$ Interview with key informant in Bungku, 23.08.2013, Document ID: 202.

${ }^{435}$ Interview with key informants in Bungku, 10.07.2013, Document ID: 105, 106, 108 and 25.08.2013, Document ID: 3.

${ }^{436}$ Interview with key informants in Bungku, 12.09.2012, Document ID: 79 and 84.

${ }^{437}$ Interview with key informants in Bungku, 12.09. 2012, Document ID: 79 and 10.07.2012, Document ID: 106, 108
} 
Kunangan Jaya I (PERTAMA, Persatuan Tani Mandiri) supported by the NGO Yayasan CAPPA organized demonstrations in front of the Governors Palace and in front of the provincial parliament in Jambi city ${ }^{438}$. Only after the demonstrations in Jambi City, PT REKI and forest authorities conducted first community consultations (socialisasi) in the TSM settlement ${ }^{439}$.

In 2011 pre-negotiations for conflict mediation started and a participatory land tenure mapping was conducted. The mapping involved community representatives, the District Forest Agency of Batang Hari, the Provincial Forest Agency of Jambi, activists of Yayasan CAPPA and staff of the conservation company PT REKI. Official mediation started in 2012 after PT REKI and representatives from Kunangan Jaya I agreed on 20 rules as a basis for mediation. The agreement includes rules that prohibit land trade, land swap, additional forest conversion, commercial logging, new oil palm plantings, intimidations, evictions and arrests (Kesepakatan Terhadap Prasyarat Mediasi Antara PT. REKI Dengan Warga RT 11 2012). Furthermore, the parties agreed to stop campaigning against each other (ibid.). The agreement and the participatory land tenure mapping can be considered as an unofficial conditional land tenure scheme since it provides tenure security if peasants accept the negotiated rules.

At the same time the Provincial Forest Agency handled a request from community members of Kunangan Jaya I and II for releasing the area out of the conservation concession and out of the state forest. The request was rejected by the Provincial Forest Agency. A staff member argued that the social and biophysical criteria ${ }^{440}$ were not met ${ }^{441}$. He stated explicitly that the multi-ethnic character of the settlement and the presence of non-indigenous communities was an important factor for the rejection. “[...] Most of the people in the area were not SAD ${ }^{442,}$ they are from Medan, they have Batak ${ }^{443}$ names, why they ask for an enclave they are outsiders, the area is still covered by forest, it's not their land"444,

For solving the conflict with the TSM community of Kunangan Jaya I two options have been suggested by the MoF in 2012. In the first option, the TSM settlement would remain within PT REKIs conservation concession. The area would be designated as community development zone (mitra zone). Settlers would receive conditional land tenure. The allocation of land rights of up to 5ha are under

\footnotetext{
${ }^{438}$ Interview with key informants in Bungku, 23.08.2013, Document ID: 202, and 25.08.2013, Document ID: 3, and with CAPPA activist in Jambi, 18.07.2013, Document ID: 157.

${ }^{439}$ Interview with key informant in Bungku, 23.08.2013, Document ID: 202.

${ }^{440}$ For the reclassification of forest land to non-forest land specific criteria have to be met. The criteria formulated by the General Director of Forest Planning in 1994, consist of biophysical criteria (e.g. soil type and altitude), and socio-economic criteria (e.g. land use, ethnicity of settlers, proof of land ownership).

${ }^{441}$ Interview with staff member of Dinas Kehutanan Provinsi Jambi, Jambi, 19.09.2012, Document ID: 30.

${ }^{442}$ Suku Anak Dalam term for indigenous people used in Jambi.

${ }^{443}$ Batak is an ethnic group from the Province of North Sumatra, Medan is the capital of North Sumatra.

${ }^{444}$ Interview with staff member of Dinas Kehutanan Provinsi Jambi, Jambi, 19.09.2012, Document ID: 30.
} 
discussion ${ }^{445}$. In the second option, the TSM settlement would be released out of the conservation concession but would remain part of the state forest. Settlers would receive smallholder forest concessions of 2 ha per household (HTR, Hutan Tanaman Rakyat). Later on, the MoF itself rejected the second option arguing that HTR schemes within a limited production forest (Hutan Produksi Terbatas) would violate the forest law urging PT REKI to implement the first option ${ }^{446}$.

The Batin Sembilan dominated settlements of Simpang Macan Luar and Dalam have not been targeted by the interventions of forest police and mobile police brigade. As outlined in the section on the conflict with SPI, PT REKI considers the land claims of Batin Sembilan communities as more legitimate then those of non-local ethnic groups. A staff member of PT REKI stated: “[...] REKI has never refused Batin Sembilan communities" ${ }^{\prime 47}$. The conflicts between PT REKI and Batin Sembilan have a much lower intensity than those with non-local ethnic groups. With the community in Simpang Macan Dalam, PT REKI has already negotiated conservation agreements (section 6.4.1.1). Negotiations with the community of Simpang Macan Luar were still ongoing in 2013 (Buletin Batin Sembilan 2013: 26). Parts of the Batin Sembilan community of KM $35^{448}$, located close to PT REKIs main camp reject negotiations with the conservation company arguing "[...] I do not want to participate in PT REKIs program, frankly speaking I do not participate, I might lose out, and I have customary rights to this land"449.

\subsubsection{Actor mapping}

An important feature of the conflict on Kunangan Jaya I is the fragmented character of the community. The community of Kunangan Jaya I consists of different fractions following different interests and strategies. Conflicts occur not only between community members and the conservation company PT REKI and state actors. Conflicts also occur between different fractions of the community of Kunangan Jaya I. The TSM settlement for instance consist of two opposing fractions: members of the farming group PERTAMA and peasants associated with Pak Kumis (one of the founding fathers of the settlement, as described in section 6.3.3.1.). Members of the farming group PERTAMA felt betrayed by Pak Kumis and the other organizers of the settlement. PERTAMA members argued that they were not aware that the TSM settlement is located within the state forest, thus within the Harapan Rainforest. Some settlers accused Pak Kumis for being involved in illegal logging and reported that he made high profits from land trade instead of building functional infrastructure and houses for Batin

\footnotetext{
${ }^{445}$ Interview with staff member of PT REKI, in Jambi, 02.09.2012, Document ID: 33 and 30.07.2013, Document ID: 1.

${ }^{446}$ Interview with staff member of PT REKI in Bungku, 30.07.2013, Document ID: 1.

${ }^{447}$ Interview with staff member of PT REKI in Bungku, 30.07.2013, Document ID: 1.

${ }^{448} \mathrm{KM} 35$ is a small settlement of Kunangan Jaya I located at a former logging road between Simpang Macan Luar and the airfield of PT REKI.

${ }^{449}$ Interview with key informant in Bungku, 12.09.2012, Document ID: 87.
} 
Sembilan families ${ }^{450}$. A Batin Sembilan elder complained that because of the formation of the TSM settlement his family lost large parts of their customary land (Wilayah Adat) to Javanese, Sundanese and Minangkabau migrants. The left over, he argues is too small for providing a safe livelihood for future generations ${ }^{451}$ (c.f. Kunz et al. submitted).

PERTAMA receives support from the NGOs Yayasan CAPPA and Yayasan SETARA. PERTAMA members are also participating in the conflict mediation meetings with PT REKI. In interviews, members of the farming group argued that their most important concern is to get their land released out of the conservation concession ${ }^{452}$. A member of PERTAMA pointed out: “[...] we reject the community development program (program kemitraan), [...] we just want to maintain our land” 453 .

Pak Kumis and peasants associated with him have no clear position in the negotiations with the conservation company. Interviewed in 2012 Pak Kumis argued that the conflict has to be solved by the government according to the existing legal framework. He argues that mediation is not necessary since the issuance of the conservation concession by the MoF was a failure because the ministry has ignored the presence of the TSM settlement. His group has rejected the support of NGOs but some members have participated in the mediation process ${ }^{454}$. His group supports PT REKIs community development zone $^{455}$

\footnotetext{
450 Interviews with key informants in Bungku, 10.07.2013, Document ID: 105, 106, 108 and 23.08, Document ID: 202 and 24.08, Document ID: 152.

451 Interview with key informant in Bungku, 24.08.2013, Document ID: 2.

${ }^{452}$ Interviews with key informants in Bungku, 10.07.2013, Document ID: 105, 106, 108.

${ }^{453}$ Interview with key informant in Bungku, 10.07.2013, Document ID: 106.

${ }^{454}$ Interviews with key informants in Bungku, 09.09.2012, Document ID: 96 and 10.07.2013, Document ID: 153.

${ }^{455}$ Interview with key informant in Bungku, 25.08.2013, Document ID: 3.
} 
Figure 23: Actor mapping of the conflict on Kunangan Jaya I

green: peasant groups, olive: NGOs supporting local communities, orange: state actors, blue: PT REKI and partners, red: donors, grey: Batin Sembilan groups, (Source: own draft, based on interviews with involved stakeholders).

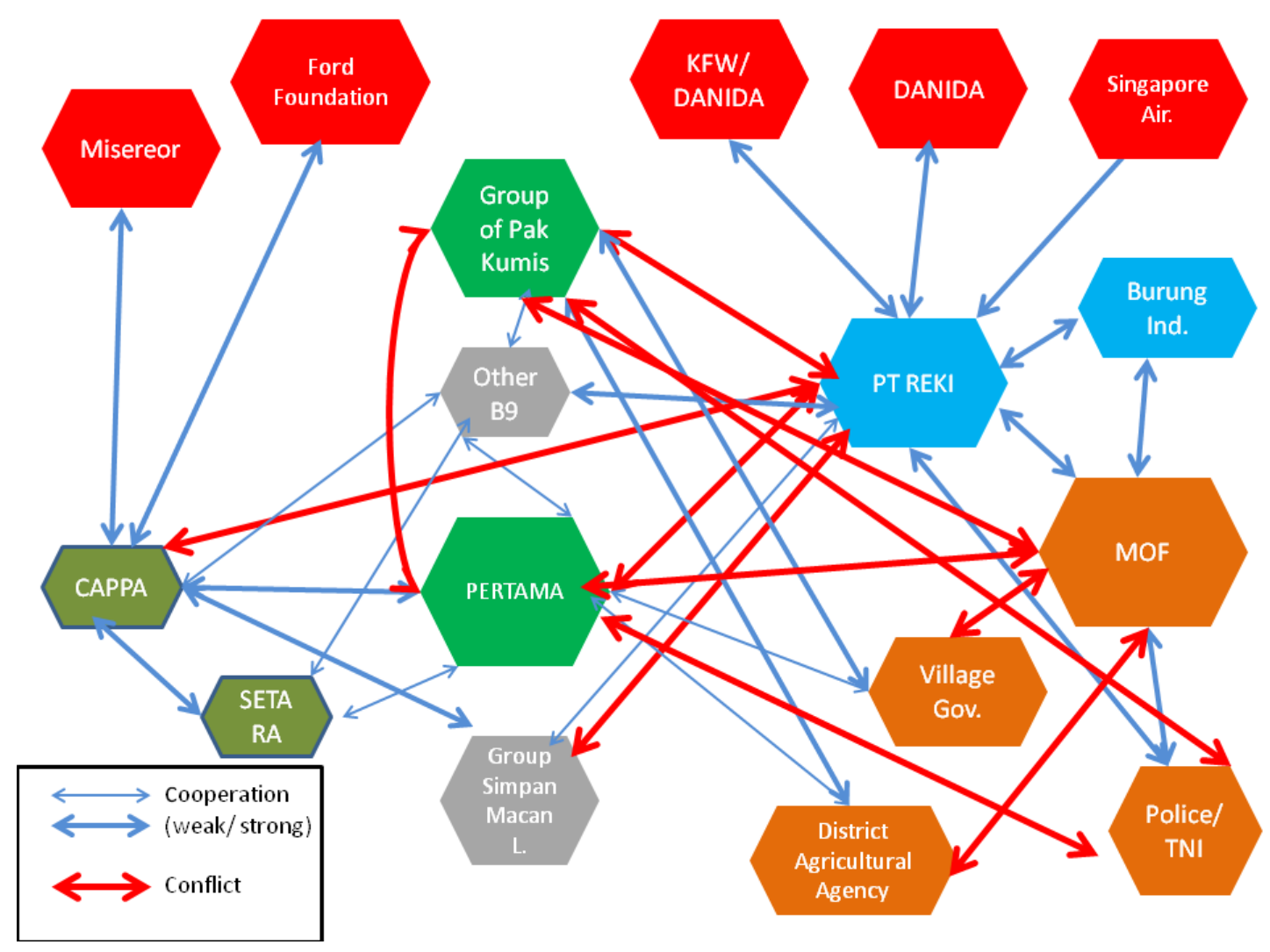

A third fraction of TSM settlers consist of those households that do not feel represented by the group of Pak Kumis nor by PERTAMA or are not following the mediation process ${ }^{456}$. A recently arrived Javanese household head for instance stated that he has no knowledge about PT REKI and the conflict at all 457 .

An important role in the conflict on Kunangan Jaya I has the NGO Yayasan CAPPA. First, the NGO has supported the TSM community and the community of Simpan Macan Luar in the mediation process. Second, the NGO has conducted workshops on REDD+ (socialization) in Kunangan Jaya I and II. Third, the NGO acted as an up- and downward translator (Pasgaard 2015: 113). The organization has translated global policies (e.g. REDD+) to local spaces and has aligned local concerns (e.g. risk of displacements) with transnational debates on the rights of local and indigenous communities (e.g. FPIC) (c.f. Mannell 2014: 2; Pasgaard 2015: 113). Through organizing demonstrations, posting of complaint letters of Batin Sembilan on REDD Monitor and contacting PT REKIs donors CAPPA's shifted the land conflict on Kunangan Jaya I to the provincial, national and transnational scale ${ }^{458}$. Yayasan

\footnotetext{
${ }^{456}$ Interview with key informant in Bungku, 25.08.2013, Document ID: 3.

${ }^{457}$ Interview with key informant in Bungku, 23.08.2013, Document ID: 208.

${ }^{458}$ Interviews with CAPPA activist in Jambi, 18.07.2013, Document ID: 157 and with key informant in Bungku, 10.07.2013, Document ID: 106.
} 
CAPPA receives funding from the Ford Foundation for mediating and solving land conflicts and from Misereor for explaining REDD+ to local communities ${ }^{459}$. In an allusion to Yayasan CAPPA's funding sources a staff member of PT REKI argued that the NGO is creating and exaggerating conflicts in order to get access to funding ${ }^{460}$.

Yayasan SETARA is the second NGO supporting the community of Kunangan Jaya I. SETARA, as a member of the transnational Roundtable on Sustainable Palm Oil (RSPO), supports mainly Batin Sembilan in the conflict with PT Asiatic Persada. SETARA criticizes especially PT REKIs approach of criminalizing the settlers as illegal encroachers ${ }^{461}$. SETARA cooperates intensively with CAPPA.

Burung Indonesia as one of PT REKIs shareholders has conducted additional meetings with community members in Kunangan Jaya I. The $\mathrm{KfW}$ is of course not directly involved in the conflict. However, staff of $\mathrm{KfW}$ stated that the development bank has advocated from the very beginning for the release of the hamlets of Kunangan Jaya I and II out of the Harapan Rainforest project ${ }^{462}$.

The conflict on Kunangan Jaya I is not only a transnationalized land conflict between peasants and the conservation company PT REKI. The conflict can also be considered as a conflict between different apparatuses of the state. As outlined in section 6.3.3, different settlement projects within the borders of the Harapan Rainforest (e.g. TSM in Kunangan Jaya I, Camp Gunung in Kunangan Jaya II, and Tanjung Mandiri in the village of Tanjung Lebar) have been actively supported by different state agencies. The formation of the settlements has been supported by village governments and by the agricultural agencies of Batang Hari and Muaro Jambi, and by the education agency of both districts. The allocation of corn and soy seeds to farming groups in Kunangan Jaya I by the Agricultural Agency of Batang Hari provided legitimacy for the settlers, provided in-kind start-up funding for the settlers but has violated the forest law 41/1999. The allocation of village-scale land titles by the village government of Bungku facilitated the transaction of land claimed by the MoF but again violates existing de jure regulations for forest land. Conflicts have also occurred within the forestry apparatus. The District Forest Agency of Batang Hari for instance has tolerated the TSM settlement after negations with settlers in 2007. Only a few years later, after PT REKI received the conservation concession, the forest police and the mobile police brigade sought to evict the settlers.

\footnotetext{
${ }^{459}$ Interview with CAPPA activist in Jambi, 18.07.2013, Document ID: 157.

${ }^{460}$ Interview with staff member of PT REKI un Bungku, 30.07.2013, Document ID: 1.

${ }^{461}$ Interview with SETARA activist in Jambi, 18.07.2013, Document ID: 115.

${ }^{462}$ Interview with staff of KfW in Frankfurt am Main, 04.02.2014, Document ID: 389.
} 


\subsubsection{Competing scales of regulation, conflicts between state apparatuses and the role of social identity and indigenous rights}

The village government of Bungku expanded its competencies formally and spatially through facilitating settlement formation within the state forest and through issuing village scale-land titles for the settlers (Hein et al. 2015). Migrants, village government and Batin Sembilan elites constructed alternative scales of meaning based on the reconstruction of the development narratives of the Suharto era and on the idea of re-establishing pre-colonial ethnic territories (ibid). Arriving migrants actively reproduced the authority of the village government and of the village scale of regulation through requesting land and land titles.

In contrast, PT REKIs conservation concession is located within the state forest and within the ethnic territory of the Batin Sembilan and has been issued by the MoF. Through requesting the concession, PT REKI contributed to the reproduction of the state forest as national scale of meaning and regulation controlled by the MoF challenging the alternative scales constructed by other actors (e.g. Batin Sembilan elites). This conflictive scalar arrangement is the starting point of the ongoing struggles on Kunangan Jaya. The struggle of the different actors involved in the conflict induced further scalar restructuring e.g. up-scaling through shifting the conflict to the emerging global scale of forest governance.

Moreover, the conflict highlights the relevance of transnational and multi-scalar resistance in the context of REDD+. The active use of global norms and regulations by different actors for solving land conflicts contributes to the construction of a global scale of regulation for governing the world's forests. In the context of an emerging global scale of forest governance, global norms such as FPIC are becoming increasingly relevant in local land conflicts. The NGO Yayasan CAPPA has a key role since the NGO has knowledge on relevant international debates, speaks the international development jargon and is able to communicate directly with donors. Consequently, Yayasan CAPPA is able to link local concerns to global norms such as FPIC, to the emerging debates on national and transnational safeguards for REDD+, to donor safeguards and to human rights. The right of FPIC for all natural resource concessions is stipulated in Indonesia's REDD+ strategy. In addition, the recent constitutional court decision (Keputusan MK 35/PUU-X-2012) might further strengthen the rights of local and indigenous communities. DANIDA and the "Human Rights-Based Approach in German Development Policy" acknowledge the UN Declaration for the Rights of Indigenous Peoples and the right to FPIC (DANIDA 2011: 2-3; Schielmann et al. 2013: 26). Peasants in Kunangan Jaya I explicitly stated that PT 
REKI failed to consult them adequately. This has been confirmed by other sources (Kreditanstalt für Wiederaufbau 2012; Wirasapeotra and Octavian 2012) and by activists of Yayasan CAPPA ${ }^{463}$.

PT REKIs failure to conduct FPIC in the settlements of Kunangan Jaya I provided an entry point for multiscalar campaigns against the conservation company. With the support of CAPPA, peasants were able to lift the conflict to the provincial scale (e.g. demonstration in front of the provincial parliament) and to the transnational scale (e.g. posting complaint letters on REDD Monitor, contacting PT REKIs donors). Multi-scalar resistance contributed probably to the at least tentative acceptance of land claims of the community of Kunangan Jaya I.

The conflict indicates that social identity is an important factor in the conflict on Kunangan Jaya I. PT REKI has so far only negotiated conservation agreements (as described in section 6.4.1) with the indigenous Batin Sembilan. The Provincial Forest Services has rejected the reclassification of Kunangan Jaya I to non-forest land arguing that most of the settlers are not members of local ethnic groups and consequently do not have customary rights to the land. Global norms such as FPIC, the Cancun Safeguards and decision of the Indonesian Constitutional Court have further increased the relevance of social identity and contribute to the construction of ethnicity as powerful mean to claim natural resources.

Ethnicity is a very dynamic category in the Harapan Landscape. Interethnic marriages between Batin Sembilan and migrants are common and most of the migrants claim to have received land from local ethnic groups (Hein 2013b; Hein et al. 2015; Hein and Faust 2014 and chapter six). Steinebach (2013b: 73-74) has shown for the conflict between peasants and the oil palm company of PT Asiatic Persada that becoming Batin Sembilan e.g. through interethnic marriages but also by just claiming to be Batin Sembilan is part of a set of strategies to re-claim land used by the company (ibid). Becoming Batin Sembilan seemed to be a relatively inclusive and conflict-free process in the Harapan Landscape. Migrants and Batin Sembilan actively cooperate as the history of the formation of the settlements TSM and Tanjung Mandiri has shown.

Finally, the conflict on Kunangan Jaya I confirms that local communities are heterogeneous. Different actors e.g. peasants associated with Pak Kumis and the members of PERTAMA or the Batin Sembilan groups of Simpan Macan Dalam and Luar have different interests and are part of different networks. It is important to consider that not all community members were involved in conflict mediation. Ten community members have been elected for representing the community in the negotiations. All community members have been invited to regular meetings on the mediation process, stated a key

\footnotetext{
${ }^{463}$ Interviews with CAPPA activist in Jambi, 18.07.2013, Document ID: 157.
} 
informant ${ }^{464}$.However, decisions have been made based on majority vote and not all villagers have followed the process ${ }^{465}$. Important to mention is that the large distance between the dispersed settlements of Kunangan Jaya I made it very complicated for community members to participate in community meetings.

\subsection{Conflicts between different state apparatuses: a transmigration site within the Berbak Carbon Project}

The third conflict investigated in this chapter is rather a conflict between different apparatuses of the state than a conflict caused by resisting peasants. The conflict shows that different apparatuses of the state might act in contradictive ways reflecting different views and interests in society. The divergent interests of different actors within the state become visible in the forest reserve Sektitar Tanjung which is part of the Berbak Carbon Project. Ongoing tensions between different state apparatuses aiming at facilitating rural development by promoting agricultural expansion and those aiming at fostering conservation are inscribed in Berbak's forest frontier. The forest reserve Sektitar Tanjung is located approximately $4 \mathrm{~km}$ east of the main hamlet of the village of Sungai Aur (District of Muaro Jambi). In 2008 (as described in section 4.3.3), the Zoological Society London, the Jambi-based NGO Gita Buana, the Berbak National Park Agency and the Provincial Forest Agency agreed to use the political momentum after the Bali Climate Change Conference (COP 13) to expanding protected areas in the Berbak Landscape. In other words, they have started a new attempt for establishing new scales of meaning and regulation for conserving the peat swamp forests of the Berbak Landscape - the Berbak Carbon Project. In the same year, the District Government of Muaro Jambi together with Javanese district governments started to establish a district to district transmigration program. One of the transmigration settlements has been established east of Sungai Aur within the borders of the forest reserve Sekitar Tanjung challenging the authority of the MoF and the integrity of the Berbak Carbon Project.

\footnotetext{
${ }^{464}$ Interview with key informant in Bungku, 25.08.2013, Document ID: 3.

${ }^{465}$ Interview with key informant in Bungku, 25.08.2013, Document ID: 3.
} 
Figure 24: Berbak Landscape and the location of the Transmigration Settlement of Sungai Aur

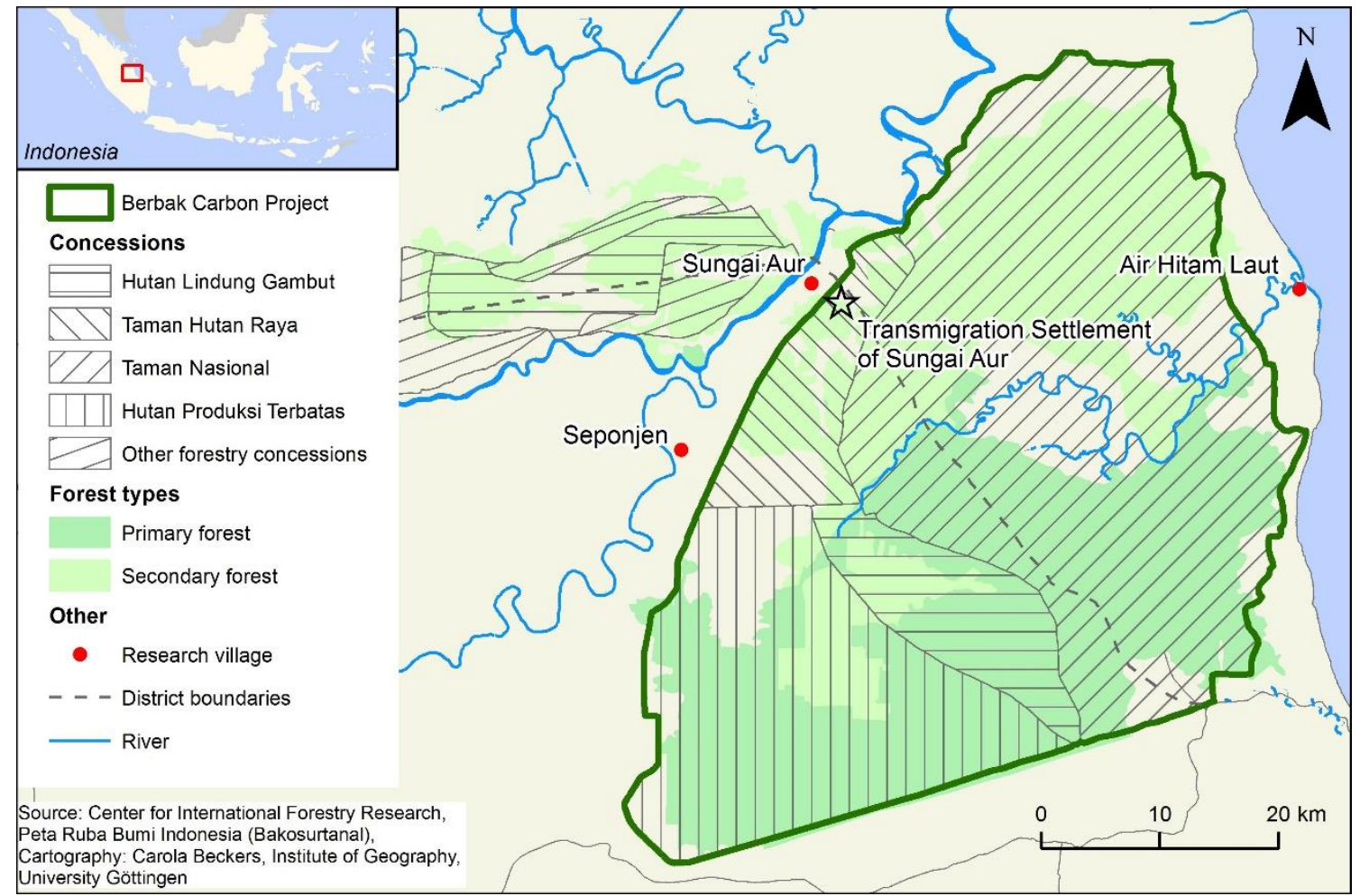

\subsubsection{Conflict history and the formation of the transmigration settlement}

In 2006 the district head of Muaro Jambi announced its interest in resettling Javanese farmers to Muaro Jambi for promoting rural development ${ }^{466}$. Two years later the Transmigration Agency of Muaro Jambi (Dinas Sosial, Tenaga Kerja dan Transmigrasi Kabupaten Muaro Jambi) conducted an initial survey in Sungai Aur. By the end of 2008 the first houses of the settlements were set up (see figure 24 for the location of the settlement). Only then, the district head of Muaro Jambi (Bupati $\mathrm{H}$. Burhanuddin) requested a formal permit from the Governor of Jambi for the conversion of state forest and for the establishment of a transmigration settlement (Surat 522/776/KANHUT Tanggal 10 Desember 2008) (WALHI Jambi 2009). However, according to the existing legal framework neither the district government nor the provincial government has the authority to permit the conversion of state forest, only the MoF has the authority to do so (as outlined in section 5.1 and 5.2). In 2009, without having received any de jure permit from forest authorities, the district head of Muaro Jambi announced that in 2009150 transmigrants will be resettled to Muaro Jambi (Republika Online 2009). The agreement between the district of Muaro Jambi and three East Javanese districts permitted the relocation of 225 households (ibid. ). Of the first 150 transmigrant households, 75 will be relocated to the village of Sungai Aur and 75 to neighboring village of Gedong Karya stated the district head in a

\footnotetext{
${ }^{466}$ Interview with staff member of the sub-district administration (Kecamatan) of Kumpeh, in SuaKandis, 02.09.2013, Document ID: 181.
} 
local newspaper (ibid.). The settlement in Sungai Aur was planned to provide land for settlers from East Java and for young, poor and landless Malay families from Sungai Aur. It was planned that each participant receives 2 ha agricultural land and 0,75 ha for house and house garden ${ }^{467}$. Furthermore, participants were told that they would receive further agricultural extension services ${ }^{468}$.

In 2009 the Provincial Forest Agency stopped the finalization of the settlement project, claiming that the project had been constructed illegally within the Forest Reserve Sekitar Tanjung violating the forest law $1999 / 41^{469}$. A few months earlier, the first local settlers from Sungai Aur have moved into their new houses in the transmigration settlement ${ }^{470}$. After the intervention of the Provincial Forest Agency rumors emerged that the settlement has to be deconstructed. Consequently, most of the Malay households from Sungai Aur that received land in the settlement sold their land to spontaneous migrants, mainly to second-generation transmigrants from the Batang Hari delta region ${ }^{471}$.The Provincial Forest Agency stopped only the formal settlement formation process. The agency did not try to evict the remaining Malay settlers and did not try to stop the influx of spontaneous migrants. Staff of the Provincial Forest Agency argued that eviction by force would exacerbate the situation and would lead to chaos $^{472}$.

Mediation between the different state actors involved in the process and community representatives from Sungai Aur have been long-lasting. In 2013, after negotiations facilitated by the Governor of Jambi, it was announced that the conflict is solved. According to the community representatives, the MoF decided to release 150 ha state forest land which had been mapped by representatives of the national parliament (Dewan Perwakilan Rakyat, DPR) ${ }^{473}$. This has been confirmed by staff of Provincial Forest Agency ${ }^{474}$. It was also announced by governmental officials (interviewed community members were not aware which governmental agency made the announcement) that in 2014 the first Javanese transmigrants will be relocated to Sungai Aur ${ }^{475}$. However, critical voices within the community argued

\footnotetext{
${ }^{469}$ Interview with staff member of the sub-district administration (Kecamatan) of Kumpeh, in SuaKandis, 02.09.2013, Document ID: 181, Interviews with key informants in Sungai Aur, 29.08.2013, Document ID: 132 and 30.08.2013, Document ID: 123 and with staff member of the Dinas Kehutanan Provinsi of Jambi in Jambi, 27.08.2013, Document ID: 137.

${ }^{470}$ Interviews with key informants in Sungai Aur, 29.08.2013, Document ID: 132 and 30.08.2013, Document ID: 123.

${ }^{471}$ Interviews with key informants in Sungai Aur, 29.08.2013, Document ID: 132, 135 and 30.08.2013, Document ID: 179.

${ }^{472}$ Interview with staff member of Dinas Kehutanan Provinsi of Jambi in Jambi, 27.08.2013, Document ID: 137.

${ }^{473}$ Interviews with key informants in Sungai Aur, 29.08.2013, Document ID: 132, 135 and 30.08.2013, Document ID: 123.

${ }^{474}$ Interview with staff member of Dinas Kehutanan Provinsi of Jambi in Jambi, 27.08.2013, Document ID: 137.

${ }^{475}$ Interviews with key informants in Sungai Aur, 29.08.2013, Document ID: 132, 135 and 30.08.2013, Document ID: 123.
} 
that the Provincial Forest Service has not made a final decision on the settlement yet and that the negotiations with the central government in Jakarta are ongoing ${ }^{476}$.

At the time of field research in 2013, at least two contradictive conflict solving processes were ongoing. The first foresees the release of the settlement from forest land and the formation of a new and independent village. This approach is favored by the District Government of Muaro Jambi. At the same time the Provincial Forest Agency started to implement a conditional land tenure scheme also involving the transmigrant community. The conditional land tenure scheme includes the allocation of forest land for the cultivation of jelutung and other forest species aiming at rehabilitating the forest cover of the Forest Reserve ${ }^{477}$.

\subsubsection{Competing state apparatuses, rent-seeking and new property}

The establishment of the transmigration settlement of Sungai Aur challenges not only the authority of the MoF, it also provides rent-seeking opportunities for village-scale and district-scale actors. The district head sought to legitimize and to justify his initiative referring to two well-known policy narratives of the new order era. He argued that Javanese transmigrants will act as model farmers augmenting the agrarian potential of the region leading to economic growth. He secondly referred to rural development and economic growth for justifying forest conversion. Muaro Jambi's long-term development plan (RPJPD, Rencana Pembangunan Jangka Panjang Daerah 2006-2025) highlights the relevance of the transmigration program for developing intensive agricultural systems (Pemerintah Kabupaten Muaro Jambi 2012: (2) 157).

Detailed information on the intention of the district government to establish the settlement beyond the references to rural development and economic growth was not available. However it is worthwhile to mention that the circumstance of the establishment of the transmigration settlement are investigated by the police of Jambi following accusations of corruption against staff members of the districts transmigration agency and of the involved construction company ${ }^{478}$ (JambiekspressNews 2014). Furthermore, the formation of the settlement and the allocation of land to local famers have probably provided political rents (e.g. popularity and votes in sub-district and district elections for himself and his allies). Interviewed community members in Sungai Aur described the district head $\mathrm{H}$. Burhanuddin as very supportive for the matter of the village community. He visited the village three times and talked directly to community members. Moreover, during one of his visits he permitted first

\footnotetext{
${ }^{476}$ Interviews with key informants in Sungai Aur, 29.08.2013, Document ID: 132 and 04.09.2013, Document ID: 139.

${ }^{477477}$ Interviews with key informants in Sungai Aur, 28.08.2013, Document ID: 141, 29.08.2013, Document ID: 132 and 31.08.2013, Document ID: 144.

${ }^{478}$ Interview with staff member of Dinas Kehutanan Provinsi of Jambi in Jambi, 27.08.2013, Document ID: 137.
} 
local transmigrants to move into the transmigration settlement prior to the official finalization of the settlement ${ }^{479}$. In addition, it is important to consider that district head $\mathrm{H}$. Burhaniddin seems to be an active advocate for land rights of peasants within the state forest. For instance, he has also supported the community of the settlement of Tanjung Mandiri in the Harapan Landscape (settlement formation described in section 6.3.3.3). He legitimized their presence within the PT REKIs conservation concession by celebrating the annual rice harvest ceremony (Panen Raya) in the settlement and promised that the Tanjung Mandiri will be released out of the Harapan Rainforest Project (without having the de jure competency to do so $)^{480}$.

The transmigration settlement provided significant benefits for the village government of Sungai Aur. Since the village government, especially the neighborhood heads (Ketua Rukun Tetangga, (Ketua RT)) were in charge of selecting the local participants. In interviews project participants mentioned that only poor, landless and married couples were able to participate ${ }^{481}$. Anyhow in informal conversations key informants stated that also villagers not fitting into the categories received land within the settlement. Consequently, the formation of the settlement provided room for rent-seeking at the village scale. The authority of the village government to select local participants thus to allocate land within the state forest provided significant benefits for the village elite.

Moreover, the conflict transformed the transmigration settlement in two different ways. First, the settlement has been transformed from a district-backed initiative aiming at providing land for Javanese migrants and local households to a destination for spontaneous migrants. Second, local project participants transformed themselves into land traders in order to cope with the conflictive situation. In 2013, 38 households lived in the settlement, only 5 of them were initial local project participants from Sungai Aur. All other local participants have sold their land. Official transmigrants from East Java have never arrived in the settlement according to key informants in Sungai Aur ${ }^{482}$.

The conflict on access and control of the forest reserve altered access and property relations. The conflict provided local Malay the ability to expand their village land and thus to create additional income through selling land to spontaneous migrants. The spontaneous migrants became new land owners holding property rights legitimized by local Malay and indirectly by the district head of Muaro Jambi. At the same time new types of properties have emerged. The conditional land tenure schemes

\footnotetext{
${ }^{479}$ Interviews with key informants in Sungai Aur, 28.08.2013, Document ID: 307 and 29.08.2013, Document ID: $132,125$.

${ }^{480}$ Interviews with key informants in Tanjung Lebar, 27.07.2013, Document ID: 113, 167, 169.

${ }^{481}$ Interviews with key informant in Sungai Aur, 29.08.2013, Document ID: 132, 30.08.2013, Document ID: 123 and 04.09.2013, Document ID: 139.

${ }^{482}$ Interview with key informant in Sungai Aur, 29.08.2013, Document ID: 135.
} 
introduced as a conflict solving mechanism by the Provincial Forest Agency for instance provide land use rights bound to conservation regulations.

\subsubsection{Competing state apparatuses and implications for REDD+}

Settlers and the village community of Sungai Aur experienced the conflict mostly as a conflict between different state apparatuses. Key informants stated for instance that the Transmigration Agency was not aware of the boundaries of the Forest Reserve and complained that the Provincial Forest Agency intervened only after the construction started ${ }^{483}$. Staff members of the Provincial Forest Agency challenge the legitimacy of the scheme and argue that the transmigration settlement as such is not an "official scheme" 484 . Gita Buana, the local NGO involved in the Berbak Carbon Project highlighted that the settlement is further increasing the risk of disturbance of the National Park. Staff of Gita Buana wondered about the contradictive policies of different state apparatuses ${ }^{485}$. Here, the implementation of Berbak Carbon Project has added an additional conflict layer. This additional conflict layer has also been recognized by some community members indicated by statements such as "[...] the Tahura is owned by the world" 486 .

The agreement between ZSL and the Provincial Forest Agency states that the forest reserve could supply carbon credits with a value of more than 200 million USD within 30 years (Dinas Kehutanan Provinsi Jambi 2013). The exact value would of course depend on the carbon price on the voluntary or on future binding carbon markets. Even more important, the production of carbon credits requires the integrity of the project boundaries and especially the effective avoidance of deforestation, forest fires and of further peat conversion. However exactly these objectives have been challenged by the district government through the implementation of the transmigration settlement. The case shows that apparently local conflicts between different state actors at Berbak's forest frontier might challenge the production of forest carbon credits and the permanence of avoided greenhouse gas emissions. Consequently, they become globally relevant. For producing carbon credits the seller (e.g. the project developer, in this case ZSL and partners) has to guarantee that the forest remains at least for a certain period. The buyer of the carbon credits uses the credits for compensating already emitted greenhouse gases (in other words to offset). In the case that a conflict between different apparatuses of the state challenges the permanence of the avoided greenhouse gas emission (e.g. because of a forest conversion) this would undermine offsetting and could create conflicts between the local sellers and

\footnotetext{
${ }^{483}$ Interview with key informants in Sungai Aur, 29.08.2013, Document ID: 132, 135 and 30.08.2013, Document ID: 123.

${ }^{484}$ Interview with staff member of the Dinas Kehutanan Provinsi, 27.08.2013, Document ID: 137.

${ }^{485}$ Interview with staff member of Gita Buana, 22.08.2013, Document ID: 207.

${ }^{486}$ Interview with key informant in Sungai Aur, 29.08.2013, Document ID: 135.
} 
the transnational buyer of a carbon credit. Consequently, the emergence of REDD+ and forest carbon offset arrangements transnationalizes apparently local land conflicts.

\subsection{Summary and preliminary conclusion}

This chapter contributes to the overarching research question of this thesis on how multi-scalar conflicts on access and property in REDD+ target areas are structured and to the third research question on which multi-scalar resistance strategies local actors employ to defend claims over land and natural resources. First, the chapter provided a general mapping of land conflicts in the study villages of the Berbak and Harapan Landscapes. Second, the chapter provided an in-depth analysis of three multi-scalar land conflicts challenging the implementation of the Harapan Rainforest and the Berbak Carbon Project. Especially the Harapan Rainforest cases show that peasants supported by NGOs were able to resist against PT REKI and were able to defend their land claims. Successful peasant resistance relied on scale jumping and on the construction of scales of meaning and regulation. Scales shape resistance opportunities, for instance they permit scale jumping to pre-existing higher scales, and alliances with actors that are able to raise protests at higher scales. At the same time resistance activities can also change existing scales (e.g. expansion of village scale of regulation) or produce new scales (e.g. SPI territory).

The Berbak Carbon Project case shows that different apparatuses of the state follow different interests reflecting different interest groups within society. All three cases indicate (and probably many of the land conflicts mapped in section 7.1) that rescaling of access and property relations, in other words the spatial expansion or reduction of regulation and authority is not a conflict-free process. Scales of regulation reflect power relations between different authorities, they are maintained and reproduced by actors requesting land titles and they are challenged by other actors requesting land titles from a competing authority. The scales of tenure regulations in place represent a fragile stand-off or compromise between different public authorities including customary leaders and different apparatuses of the state.

Furthermore, the illustrated cases show that rescaling provided the extra lee-way for successful peasant resistance. Especially REDD+ created attention of structural inequality at the forest margins (Hein et al. 2015). International norms such as FPIC and the Cancun Safeguards strengthened the position of peasants and especially of indigenous groups. As the Harapan Rainforest case illustrates, the failure of conducting - FPIC provided entry points for transnational resistance campaigns. Peasants used different multi-scalar resistance strategies. They build alliances with customary leaders, village 
governments and with NGOs and transnational peasant organizations. Especially peasants affiliated with SPI were able to raise concerns about the Harapan Rainforest project at the global scale. Peasants supported by CAPPA were able to send protest notes to donors and to organize protest at the provincial scale. Nevertheless, not only scale relations proofed to be relevant for successful resistance (Hein et al. 2015: 8). Especially network relations e.g. linking up with indigenous groups, or cooperation among local NGOs proofed to be relevant for successful peasant resistance as well (ibid.).

The ability to resist against PT REKIs land claims or from PT REKIs perspective to defend the integrity of the Harapan Rainforest is also a matter of power. As described in chapter six, PT REKI is well positioned in regard to the three power dimensions. Especially its visible power, in other words the financial resources of the conservation company to employ forest rangers and to pay the mobile police brigade (BRIMOB) facilitated the control of large parts of the project area. According to Gaventa (1982: 23) rebellion or the challenge of power "[...] may develop if there is a shift in the power relationships - either owing to loss in power of $A$ or gain in power of $B^{\prime \prime}$. In the first place changed power relations after the fall of Suharto provided the opportunity to organize and to transform hidden resistance into larger and open resistance actively challenging hegemony. Following Gaventa (2006: 31) it is argued that strategic alliances and multi-scalar strategies paved the way for successful resistance of the peasants of Kunangan Jaya 1 and of SPI. The ability to form alliances with actors on different scales and to construct political campaigns tailored for different scales (e.g. land distribution at the local scale, agrarian reform at the national scale and anti REDD+ and the global scale) contributed to their success. Peasant organizations became a relevant force in Jambi. SPI for instance has developed visible power. The organization has 15000 to 20000 members in Jambi and financial resources from membership fees. Moreover, SPI members hold approximately 2500ha land within the Harapan Rainforest concessions ${ }^{487}$. Yayasan CAPPA as the main NGO supporting peasants in Kunangan Jaya I relies on a transnational network and has received significant support from donors (e.g. Misereor and Ford Foundation). Yayasan CAPPA has the capacity to organize protest and to act as an up-and downward translator. The organizational strength of SPI and the capacities of Yayasan CAPPA have contributed to the ability of the different peasant groups to resist against PT REKI, against the MoF and the mobile police brigades.

\footnotetext{
${ }^{487}$ Interviews with SPI activists in Jakarta, 20.06.2013, Document ID: 104 and in Jambi 12.07.2013, Document ID: 140 and with key informants in Tanjung Lebar, 22.07.2013, Document ID: 178.
} 


\section{Discussion and conclusion}

REDD+ has transnationalized alleged local land conflicts. It links greenhouse gas emitters in the global North to peasants and indigenous groups struggling for land and property in the global South. REDD+ pilot projects in Jambi financed by private and public donors changed the dialectical relationships between structure and agency. They reduced the ability to access land for some actors, provided additional opportunities for others and provided entry points for transnational resistance campaigns of peasant movements and climate justice organizations. Moreover, the results have shown that transnational conservation initiatives and market-based conservation instruments such as REDD+ are not acting in a social and political vacuum. Understanding the historical context is of key importance for understanding land conflicts in the context of conservation interventions.

In response to the overarching research question, how are multi-scalar land conflicts on access and property in REDD+ target areas structured and how can this be explained, I argue that historical contingent structural inequality, rapid rescaling in the context of state transformation, overlapping property rights legitimized by competing authorities and competing scales of meaning and regulation are important explanations for land conflicts in the Berbak and Harapan Landscapes. Land conflicts are rather caused by historically contingent structural inequality and by the non-recognition of customary rights than by the conservation intervention itself (c.f. Hein and Faust 2014: 25).

The sub-ordinated research questions one and two are closely linked. The first (sub-ordinated) research question focused on the role of rescaling processes for accessing land and property, whereas the second focuses on in-situ access and property relations in a historical perspective. In other words the first question aims at identifying rather processes of structural change e.g. state transformation and the second rather local agency and the formation of property rights.

\section{In how far are rescaling processes (e.g. decentralization, REDD+) altering the ability of different actors to access land and property and it how far are actors shaping rescaling processes?}

The results of this study show that scales of meaning and regulation shape access to land and property. Rescaling in the course of state transformation has changed them. I argue that property rights, the notion of a state and especially scales of regulation are inseparably linked. In Indonesia specific scalar arrangements led to specific access and property relations. Colonial scales of meaning and regulation facilitated access to land and natural resources for extracting benefits for Dutch colonial authorities and corporate actors challenging pre-existing scalar arrangements of customary communities. The autocratic Suharto regime established a national scale of meaning based on modernization narratives. And a complementary national scale of regulation facilitating access to land for his cronies. In the late 
1990s political struggle induced, also triggered by the objective to reallocate land and natural resources, far reaching scalar restructuring changing dialectical relationships between structure and agency. Decentralization and changed power constellations have widened the opportunities for local actors to access land significantly as the informal settlements within the Harapan Rainforest indicate. Recently, donors, NGOs, and international organizations started to establish a global scale of forest regulation including regulations on the rights of local communities and indigenous people. This ongoing process is again changing the dialectical relationships between structure and agency. The formalization of land and forest tenure in the context of REDD+ and globalized forest governance widens access to natural resources for some actors, for instance for conservation companies and potentially for indigenous groups but limits access abilities for those actors that do not get their rights formalized.

\section{Which historical contingent access and property relations explain struggles over land in REDD+ target areas in Jambi?}

Access and property relations in the Berbak and Harapan Landscape are complex, conflictive and highly dynamic. They are the outcome of competing property rights evolved across time and regulated on different scales and issued by competing authorities. The legitimacy of specific property rights and authorities is dynamic and subject to ongoing change. Recently village governments supported by customary authorities have been able to establish village-scales of land and forest tenure regulation overlapping with national-scales of regulations. In the past customary and colonial authorities, and the MoF have been more relevant. Village governments gained power by using symbols and the language of the state. Furthermore, allied with customary authorities' village governments control land and are able to allocate land which is one of most important means of production in rural landscapes thus a source of visible power. Village-scales of land tenure regulation compete not only with national scales of regulation; they also compete with new REDD+ project scales. Authorities implementing the conservation projects have implemented conditional land tenure schemes, in consequence they become a new authority legitimizing property.

\section{Which multi-scalar resistance strategies do local actors employ to defend claims over land and natural resources?}

The third (sub-ordinated) research question focused on multi-scalar resistance and conflict. Successful peasant resistance, as the Harapan Rainforest case shows, has relied on scale jumping and on transnational support networks. Peasant movements and indigenous peoples have gained agency in the course of recent attempts to establish a global scale of forest governance. REDD+ provided entry 
points for a spatial expansion of resistance. Resistance activities have changed scales of meaning and regulation and led to the construction of new scales (e.g. village scales and the SPI territory). Multiscalar resistance was made possible because of a changing power constellation after regime change and has further changed the power constellation.

In the following, I will first relate the above general findings to my conceptual framework. I will argue for a political ecology that explicitly conceptualizes the role of scale and power for unraveling access and property relations. In the second section limitations, challenges and open issues will be outlined. The third section highlights the relevance and implications for practical politics regarding REDD+ implementation, climate justice and rural development.

\subsection{Elements of a political ecology of scale and property in the context of REDD+}

In the following section different explanations and interpretations of the main results of this study will be outlined as a starting point to draft a political ecology of scale and property. Explanations and interpretations will be mainly based on the core analytical categories of the conceptual framework, namely scale, power, and access and property relations. Moreover, the guiding assumptions of the conceptual framework will be revisited in order to identify limits and potentials for improvements. The section starts with explanations and interpretations of land conflicts based on socio-spatial theory and the politics of scale literature explicitly considering power and resistance. Since not all relevant social relations are spatial I will also draw on the political ecology-oriented access and property literature. In the last section I will outline the elements of a political ecology that explicitly considers scale, power and state transformation as factors explaining conflictive access and property relations.

\subsubsection{Spatial implications of conflictive modes of production}

The different ways land is used influences scalar arrangements and property relations (Zulu 2009: 690). I argue that conservation, corporate oil palm cultivation, smallholder oil palm and rubber cultivation and shifting cultivation as mutually exclusive modes of production produce different socio-spatial arrangements and competing access and property relations.

Shifting cultivation, hunting and gathering practices have been important modes of production in Jambi until the 1980s. Today they have become less relevant in the Berbak and Harapan landscapes as well as in other frontier landscapes in the global South (Li 2002: 421; Hall, Hirsch, and Li 2011: 106; Mertz 2009). Shifting cultivation in the Harapan Landscape is deeply entangled with a pre-existing 
watershed and lineage based socio-spatial organization. Shifting cultivation but also hunting and gathering practices require vast land areas controlled by lineage and sub-lineage leaders. Corporate and smallholder expansion of oil palm and rubber cultivation and the expansion of conservation areas have limited the land available for shifting cultivators significantly. At the same time and as consequence, of changing modes of production access and property relations, and entangled scalar arrangements have changed. Watershed and lineage scales have been replaced by village, district, national and transnational scales that facilitate especially oil palm cultivation and conservation as new modes of production. However, these replacements as the results outlined in the previous chapters have shown to be highly conflictive.

The introduction of rubber by Dutch colonial authorities, the promotion of oil palm cultivation by the Indonesian government and the reputation of oil palm as a modern crop (Schwarze et al. 2015; LocherScholten 2004; Hein et al. 2015), incentivized peasant farmers to convert former swiddens to permanent rubber and oil palm plantations ${ }^{488}$ (Schwarze et al. 2015: 1). Local communities cultivate oil palm also within the Harapan Rainforest and to lesser extend within the Berbak Carbon Project. In many cases the expansion of smallholder oil palm and rubber plantations has been promoted by customary, village and district authorities. As in other parts of Indonesia they consider the conversion of state forest as a legitimate response to colonial and post-colonial dispossessions (Lukas 2014; Peluso, Afiff, and Rachman 2008; Tuong 2009). Land allocation and forest conversion has been facilitated by village governments and customary leaders. For providing a minimum of tenure security for peasants cultivating oil palm and for permitting land trade, village governments started to issue different types of land titles, thus establishing a village-scale of land tenure regulation. By requesting village-scale land titles peasants reproduced and maintained the new scale of regulation. Moreover, I argue that the new village- scale of land tenure regulation reflects the requirements of a specific mode of production: smallholder oil palm cultivation. Village-scale land titles have facilitated the expansion of smallholder oil palm plantings, the commodification of former family or lineage-based property and the formation of a land market within the studied conservation areas.

Corporate oil palm cultivation has transformed rural Indonesia significantly in recent years. More than 6 million ha land are used for oil palm cultivation in Indonesia, approximately two-third by large-scale corporate oil palm plantation estates (Brad et al. 2015: 103). Since decentralization access to plantation concessions (HGU) is regulated mainly at the district scale. Commercial oil palm plantations require large land holdings, full land control and labor (Hall, Hirsch, and Li 2011: 92). Oil palm companies are usually well-positioned in regard to the three dimension of power. In consequence they

488 Today smallholders account approximately for $37 \%$ of Indonesia's annual oil palm production (Schwarze et al. 2015: 1) 
have been quite successful in accessing land rights for vast areas. Especially in the Harapan landscape oil palm concessions overlap with land claimed by local and indigenous communities. Previous commercial modes of production such as logging still permitted the co-existence of hunting and gathering and in some cases even of shifting cultivation. Commercial large-scale oil palm cultivation in contrast requires full land control and do not permits any co-existing land use practices. In consequence the introduction of commercial large-scale oil palm cultivation led to displacements and to conflicts with other right holders involved in other modes of production.

Another mode of production that requires large land resources is conservation and REDD+. In how far conservation and REDD+ can be fully considered as modes of production is part of heated debates. Especially political ecologists consider them as being intrinsically linked to specific modes and relations of production related to the commodification of ecosystem services (Castree 2003; Corbera and Brown 2010; Escobar 1996; Fairhead, Leach, and Scoones 2012; Kelly 2011; McAfee 1999; Zimmerer 2000). In contrast many conservationists do consider their interventions rather as a counter movement aiming at protecting the non-commodity status of wildness and at hindering the commodification of forest products such as timber (Li 2008: 125).

PT REKI and actors involved in the Berbak Carbon project both support specific so called biodiversityfriendly and low carbon land-use practices. But as many other conservation initiatives they also produce specific "fictitious commodities" (Nevins and Peluso 2008: 19) as well as specific tradable commodities such as sustainable products, ecotourism and forest carbon credits. Fictitious commodities, in other words symbolic commodities produced by the conservation company PT REKI in the Harapan Rainforest, include biodiversity hotspots, the last remaining patches of lowland rainforests of global importance and a refuge for the indigenous Batin Sembilan. Tradable commodities produced by PT REKI include ecotourism and sustainably produced non-timber forest products (REKI 2014).

Following Massé and Lunstrum (2015: 2) I argue that the social practices of PT REKI and actors involved in the Berbak Carbon project aim rather at securitizing their project areas than at accumulating capital. Processes of (fictitious) commodification of nature, and new "green" modes of production such as offsetting are elements of the ecological phase of capitalism (Escobar 1996: 326). In the Harapan Landscape as well as in the Berbak Landscape they encounter pre-existing and competing modes of production (especially smallholder and corporate oil palm cultivation) associated with different scalar arrangements, or in terms used by Karl S. Zimmerer and Thomas J. Basset (2003b: 288) with different geographies of resource access. The establishment of conservation projects involves the containing of space, thus the construction of conservation scales that fix social relations of conflict and cooperation (Zimmerer 2000: 360). The formation of the Harapan Rainforest and Berbak Carbon conservation 
scales has changed the meaning of the contained space and has transformed them to objects of environmental governance (Cohen and McCarthy 2014: 2). They have been produced by rescaling to a physical space for which no direct state authority or jurisdiction existed a priori (ibid.).

It is important to highlight that the state and its different apparatuses have a key role in the described socio-spatial processes. A number of subsequent state interventions have facilitated the expansion of capitalist modes of production which have changed access and property relations (Beckert, Dittrich, and Adiwibowo 2014; Brad et al. 2015; Fold and Hirsch 2009; Nevins and Peluso 2008; Hein et al. 2015; Faust 2007). The formation of the specific scalar arrangements facilitating privatized conservation, corporate oil palm and smallholder oil palm cultivation have been actively promoted by state actors responding to discourses of market environmentalism, neoliberalism and development. Conflictive access and property relations and conflictive scalar arrangements as discussed above can also be considered as conflicts between different apparatuses of the state over societal relationships with nature. The promotion of settlement and agricultural production within the Harapan Rainforest by village and district governments are one example. The transmigration settlement as a mean to promote rural development within the Berbak Carbon Project is an even more astonishing case. Both cases indicate that conflicts between different state apparatuses, especially between conservation and development agencies (Brand, Görg, and Wissen 2011: 150) are additional explanations for conflictive access and property relations thus for land conflicts.

\subsubsection{Rescaling}

As described throughout the thesis, rescaling caused by state transformation is another relevant explanation for changing and conflictive access and property relations. Based on Reed and Bruyneel (2010) I have identified three relevant scalar processes caused by state transformation processes (as outlined in section 2.2.3), namely up-scaling towards transnational or international state apparatuses, down-scaling towards sub-national state apparatuses and scaling-out towards non-state actors (e.g. conservation companies). State transformation from the colonial state, via the interventionist development state to the decentralized national competition state are main causes for scalar restructuring and rescaling in Indonesia. In other words causes of up-, down- and out-scaling have been regime change and policy shifts.

Up-scaling is taking place in the context of REDD+. Even though REDD+ has not led to a coherent scale of global forest governance yet. So far, the process has rather produced a number of fragmented international and transnational rules (Zelli et al. 2014: 23). But the so called Cancun Safeguards of the UNFCCC and transnational carbon standards such as the Climate, Change, Community and Biodiversity Standard (CCBS) indicate that specific rights for local and indigenous communities have been up-scaled 
to the emerging global scale of forest governance. Yet the application of global norms for community involvement (such as free, prior and informed consent) is still contested in many countries implementing REDD+ policies (Díaz 2014; McCarthy 2012; Delgado-Pugley 2013). As in the Harapan Rainforest case, many local and indigenous communities living within or adjacent to REDD+ pilot projects have not been involved in project planning, have not been informed about REDD+ or have not been asked to give their consent (Zelli et al. 2014: 104-106; Hein and Garrelts 2014: 326; Mcculloch 2010).

Down-scaling of land and natural resource governance in Indonesia has mainly taking place as a result of decentralization after the fall of Suharto. Indonesia's big bang decentralization can be considered as a response to changing power relations and as a process that further changed power relations. The decision to decentralize Indonesia was taken in the context of a relatively week central state and of reappearing separatist tendencies (Hofman and Kaiser 2002: 2). As explained in the chapters five and six, the decentralization policies have only led to limited permanent de jure change of Indonesia's forest governance but de facto changes have been significant as the informal settlements within the Harapan Rainforest, village-scale land titles and numerous studies on land tenure and conflict across the Archipelago indicate (Adiwibowo 2005; Lukas 2014; Peluso, Afiff, and Rachman 2008; Galudra et al. 2011). Down-scaling has increased the power of local state apparatuses, and local and customary elites at the expense of national apparatuses. In the Harapan and Berbak landscapes power gains (e.g. mainly visible power) have been mainly absorbed by local elites indicating that more decentralized or customary forms of environmental governance arrangements are not necessarily more favorable to social equality than more centralized ones. Studies focusing on the impacts of decentralization on access to land and forest resources on Indonesia and beyond indicate similar patterns of elite capture (McCarthy 2004; Resosudarmo 2004; Larson and Soto 2008).

Scaling-out refers to the delegation of former state functions to non-state actors (Cohen and McCarthy 2014: 13-14; Reed and Bruyneel 2010: 648). Especially in the Americas non-state actors have played a greater role in conservation since the 1990s through their involvement in payment for ecosystem service schemes (PES) and conservation concessions (Wolman 2004; Ellison 2003; Langholz, Lassoie, and Schelhas 2000). Indonesia started relatively late to privatize conservation and to implement PES (Heyde et al. 2012: 1). Not before the 2000s the Indonesian government introduced privately managed ecosystem restoration concessions after successful lobbing of PT REKIs shareholder Burung Indonesia. The concession delegated for the very first time protected area management within the state forest to non-state actors. Holding an ecosystem restoration concession provided PT REKI the authority to take over other state-functions such as law enforcement and even important the legitimation of property rights by running a conditional land tenure scheme. By scaling-out the management of the 
Meranti River-Kapuas River Forest Block to PT REKI the Indonesian MoF delegated a whole bundle of rights to the conservation company including the (de facto) right to exclude other land-users such as peasants.

\subsubsection{Agency and power and the production of scale}

Neil Smith and other scholars noticed that the production of scale is not only the outcome of modes of production and state interventions but also of human agency and social and cultural practices (Smith 1992; Marston 2000). The results of this study confirm especially the relevance of agency for scale production. Peasant and indigenous rights movements used the extended room for maneuver of the Reformasi era for organizing multi-scalar resistance campaigns against land and forest allocation policies of different state apparatuses. And they have constructed alternative scales of meaning and regulations for legitimizing forest conversion and land allocation as the different settlement and forest conversion projects organized by specific individuals supported by village governments and peasant movements in the Harapan and Berbak Landscapes show. SPI and AMAN have challenged existing scalar arrangements through scaling-up protest and land conflicts to the national and transnational scale.

Political scales are spatial delimitations of political power argues James Meadowcroft (2002: 170). In consequence, changing power relations are an important explanation for rescaling. The above mentioned resistance activities challenged power relations and scalar structures. Initially regime change, democratic freedom and subsequent decentralization decreased power of the central state providing the opportunity to transform hidden resistance into open resistance actively challenging hegemonic actors such as the MoF. Gaventa (1982: 24) argues that for changing power constellations in a specific arena "the powerless" have to challenge all three dimensions of power. Taking again the example of the Harapan Rainforest actors such as SPI have been able to challenge invisible power by formulating political aims (e.g. implementation of an agrarian reform based on the basic agrarian law, environmental justice), hidden power by mobilizing peasants and political allies (e.g. migrants in search for land and customary leaders), visible power by developing material resources and organizational strength (e.g. land resources and members). Visible power permitted SPI to engage in open conflict with PT REKI and the MoF. SPI challenged the MoF and PT REKI on different scales and constructed and defended successfully their settlements within the Harapan Rainforest as a new scale of meaning and regulation. 


\subsubsection{Network-relations}

It is worthwhile to mention that not all facets of land conflicts can be explained by using the concept of scale. Bop Jessop and colleagues (2008) stressed that a one-sided focus on scalar relations might be too narrow for understanding the complexity of socio-spatial relations. For explaining land conflicts in the context of REDD+ especially network relations proofed to be relevant as well. The mappings of actors involved in different land conflicts on access and control of the Harapan Rainforest project (sections 7.2.2 and 7.3.2) indicate that horizontal relations between actors, especially linking different NGOs or village governments and customary leaders have been relevant. La Via Campesina for instance facilitated scale jumping for SPI, the NGOs CAPPA and SETARA are supporting each other's lobbing activities and alliances of village governments and customary leaders raised the legitimacy of forest conversion activities. The Harapan Rainforest project as such has been formed by a NGO network with three core members, Burung Indonesia, Royal Society of Birds and Birdlife International and other supporting members such as the German NABU (Naturschutzbund Deutschland). The network of actors involved in the implementation of the Berbak Carbon Project consists of NGOs e.g. ZSL, Gita Buana and state actors such as the Berbak National Park Agency and the Provincial Forest Agency of Jambi.

\subsubsection{The nexus between property, authority and legitimacy}

Access to natural resources including land is shaped by socio-spatial relations (Swyngedouw 2010). But especially for understanding the nexus between property, authority and legitimacy other non-spatial social relations are relevant as well. Property as outlined in the conceptual chapter is a contested concept. The different meanings of property encountered in the Berbak and Harapan Landscapes illustrate how changing ideologies and in particular a Western understanding of property have transformed property rights over time. Lineage-based property has been gradually replaced by individual forms of property that facilitate market exchange.

Conflictive or overlapping property rights can also be explained by unraveling conflicts over the "organizing ideology" of a society (Alagappa 1995: 18; von Benda-Beckmann and von Benda-Beckmann 1999: 30). The organizing ideology can be defined as shared norms and truths of a society. In the case study regions and in other parts of Indonesia the organizing ideology is contested. In particular, adat ideology and different interpretations of Indonesia's state ideology clash in the Berbak and Harapan Landscapes. Actors seek to legitimize property rights by referring to different elements of the competing ideologies. The social practices of Batin Sembilan for instance have been in the past, and to a lesser extent, still are structured by adat ideologies. Benda-Beckmann et al. (1999: 30) argue that in many adat ideologies property rights over land should support and balance the livelihood of a 
community across generations. These elements are also reflected in the norms and beliefs of the Batin Sembilan in the Harapan Landscape. Property rights of the Batin Sembilan have been attached to lineages and sub-lineages providing access for all lineage members. For legitimizing recent attempts to reestablish their former customary land (wilayah adat) the Batin Sembilan refer to adat and to powerful ancestors of the different lineages. In contrast, members of the peasant movement SPI, different apparatuses of the state (e.g. MoF, district and village governments) and the conservation company PT REKI base their arguments for legitimizing land claims on different interpretations of Indonesia's state ideology and on related laws and discourses. The peasant movement stresses the social function of land stated in the Basic Agrarian Law formulated during the socialist-oriented Soekarno era. The MoF stresses rather the state ownership over forest land and the importance of forests to promote growth. The district head of Muaro Jambi highlighted the importance of Javanese "model farmers" promoting rural development in order to legitimize the formation of a transmigration settlement within the Berbak Carbon Project. He relates the allocation of land to nation building and to a development model dominated by a belief in the superiority of Javanese land use practices. The conservation company PT REKI refers to market-environmentalism, in particular to the belief that state-based conservation approaches have failed. Therefore, conservation needs to be privatized for maintaining the carbon and biodiversity value of the Harapan Rainforest. The different legitimation strategies and entangled ideologies illustrate different meanings and functions of property: customary property as a source of community wealth, property as mean to promote socially inclusive rural development, property for promoting growth or property as mean to protect ecosystems.

In spite of a contested organizing ideology or indeed for this reason the state or reference to the state is an important source of legitimacy as Lund (2006: 690) has shown for Ghana and Niger. This is also the case in the study villages and in other parts of Jambi (Kunz et al. submitted). Many actors refer to apparatuses of the state, to symbols of the state, to language used by the state including laws, regulations and policies formulated by the state or its apparatuses to legitimize land claims as property. National regulation structures local agency. Local elites choose and pick certain state regulations that support their interests e.g. the Basic Agrarian Law or the Governmental Regulation 24/1997. The relevance of a certain land tenure regulation depends on the power structure in the arena. For example, in the area occupied by SPI regulations formulated by the peasant movement are more relevant than regulations of the MoF.

Property is the enforceable right to objects of value. In consequence property can only be considered as such if a legitimate public authority is able to sanction it. An important source of legitimacy for public authorities is again the state. At the village-scale the state is represented by a number of actors: by the elected village head, by hamlet heads, neighborhood heads and other members of the village 
government (apparat desa). Other important sources of legitimacy are state regulations but also customary law, social identity and kinship. As Lund has shown for Ghana (Lund 2008: 8) boundaries between the state and non-state actors are blurred. The village head in Bungku for instance claim to represent the state and to be a customary leader since he has kinship ties to Batin Sembilan. The conservation company PT REKI is enforcing the forest law, has formulated additional conservation regulation and is issuing land titles thus the company has taken over a number of state functions. The legitimacy of property depends on the acceptance of the authority in issuing property rights. The acceptance of village-scale land titles across study villages and the acceptance of village-scale land titles as a collateral for accessing bank loans and as documents for accessing national-scale land titles indicates the legitimacy of the authority of village heads over land irrespective of opposing laws and regulations.

Finally, an important source of legitimacy for public authorities is scale (Lund 2006: 693). A number of different actors in both landscapes made reference to bigger authorities at higher scales for legitimizing property or their authority to issue property rights. In some case this again refers to the state and its different apparatuses, laws and regulations. In other cases, reference was made to "higher" customary authorities and even to international organizations and international law.

\subsubsection{Contributions to political ecology: revisiting guiding assumptions and analytical criteria}

For investigating explanations for transnationalized land conflicts in REDD+ target areas this study was guided by a number of assumptions and analytical criteria derived through an informed dialog between researcher, participants (interviewees), and conceptual literature. I argue that the results of this study indicate that an explicit conceptualization of scale, resistance and power is beneficial for political ecology. The politics of scale literature and the broader socio-spatial theory proved to be meaningful for explaining historically contingent conflictive access and property relations. As I have stated in the conceptual chapter of this thesis, political ecology and politics of scale literature share many theoretical and empirical concerns. Authors such as Neumann $(2009)$, Zimmerer $(2006,2000)$ and Swyngedouw $(2010,2004,2000)$ have helped to bridge both stands of literature. In the following table 18 I will revisit the assumptions and analytical criteria that have guided this research. 


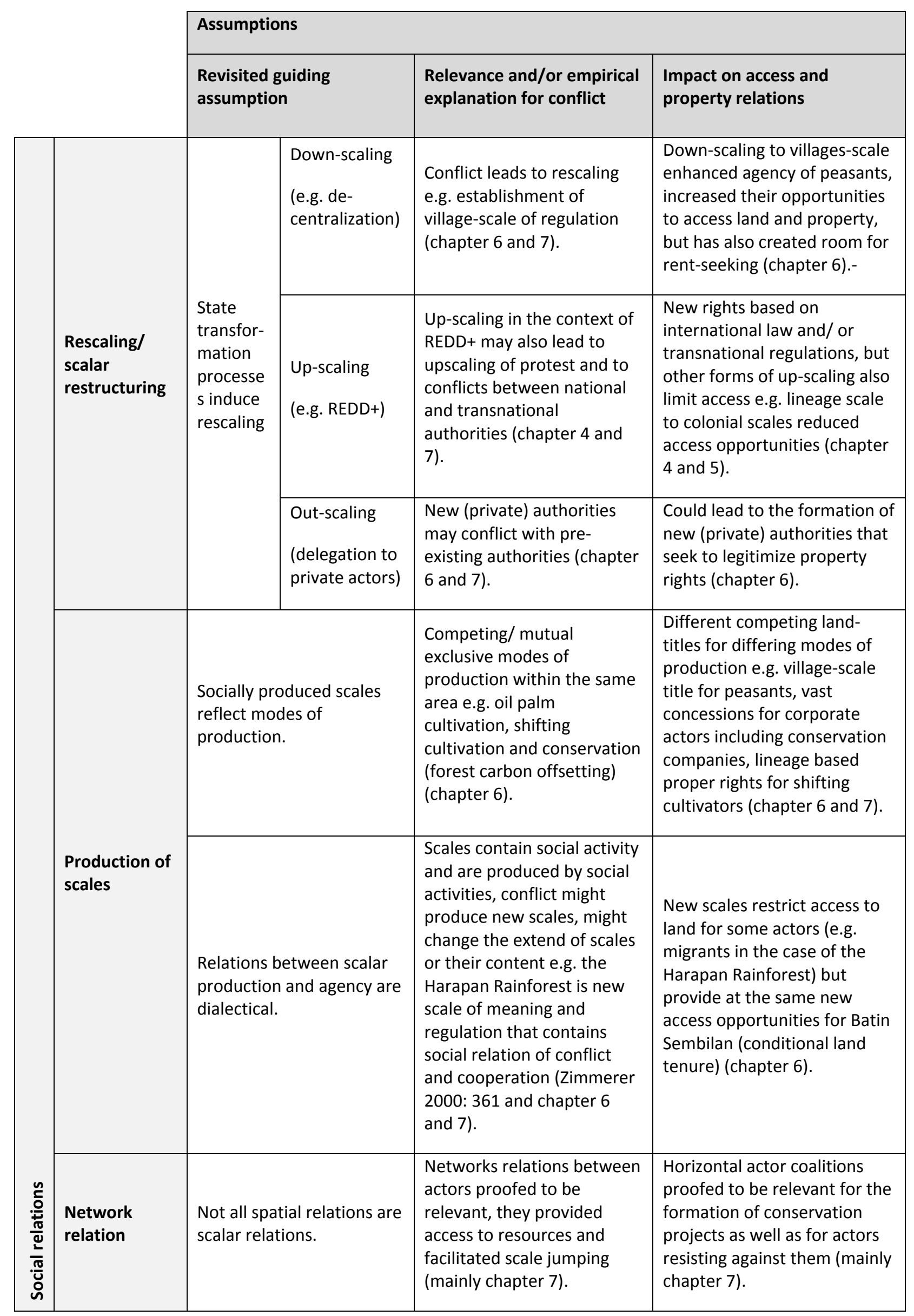




\begin{tabular}{|c|c|c|c|}
\hline \multirow{3}{*}{$\begin{array}{l}\text { Power } \\
\text { relations, } \\
\text { agency and } \\
\text { resistance }\end{array}$} & $\begin{array}{l}\text { Power differentials } \\
\text { between different actors } \\
\text { might be important } \\
\text { explanatory factors for } \\
\text { differing abilities of actors } \\
\text { to access land and } \\
\text { property. }\end{array}$ & $\begin{array}{l}\text { Shifting power relations } \\
\text { may explain conflicts, actors } \\
\text { need to develop visible } \\
\text { power (material resources } \\
\text { and organizational strength) } \\
\text { to engage in open conflict } \\
\text { on resources. Peasant (SPI) } \\
\text { and indigenous rights } \\
\text { (AMAN) movements } \\
\text { employed hidden resistance } \\
\text { before engaging in open } \\
\text { conflict with the state } \\
\text { (chapter } 5 \text { and } 7 \text { ). }\end{array}$ & \multirow{2}{*}{$\begin{array}{l}\text { All three power dimensions } \\
\text { are relevant for accessing and } \\
\text { maintaining property (e.g. PT } \\
\text { REKI), visible power provides } \\
\text { resources to access and } \\
\text { defend property, hidden } \\
\text { power relevant for mobilizing } \\
\text { support, invisible power for } \\
\text { framing discourses and ideas } \\
\text { that legitimize land claims: } \\
\text { (e.g. market } \\
\text { environmentalism, customary } \\
\text { land) (chapter } 6 \text { and } 7 \text { ). }\end{array}$} \\
\hline & $\begin{array}{l}\text { When power constellation } \\
\text { changes hidden resistance } \\
\text { may turn into open } \\
\text { resistance. }\end{array}$ & $\begin{array}{l}\text { Regime change altered } \\
\text { power constellations and } \\
\text { permitted actors such as SPI } \\
\text { to develop power in its } \\
\text { three dimensions thus to } \\
\text { engage in open conflict } \\
\text { (chapter } 5 \text { and } 7 \text { ). }\end{array}$ & \\
\hline & $\begin{array}{l}\text { Scales are manifestations } \\
\text { of power relations. }\end{array}$ & $\begin{array}{l}\text { Scalar arrangements are } \\
\text { produced by social conflict } \\
\text { and cooperation, scalar } \\
\text { arrangements in place } \\
\text { reflect power constellations } \\
\text { between different actors } \\
\text { involved in scalar } \\
\text { construction (e.g. relations } \\
\text { between village } \\
\text { governments and Ministry } \\
\text { of Forestry) (chapter 5, } 6 \\
\text { and 7) }\end{array}$ & $\begin{array}{l}\text { As explained above, specific } \\
\text { scalar arrangements facilitate } \\
\text { access to resources for some } \\
\text { actors and restrict access for } \\
\text { others (e.g. concession } \\
\text { system facilitates access for } \\
\text { corporate actors, village-scale } \\
\text { facilitates access for peasants) } \\
\text { (chapter } 5 \text { and } 6 \text { ). }\end{array}$ \\
\hline \multirow{3}{*}{$\begin{array}{l}\text { Property, } \\
\text { authority } \\
\text { legitimacy } \\
\text { nexus }\end{array}$} & $\begin{array}{l}\text { Relationship between } \\
\text { authority, legitimacy and } \\
\text { property. Property is only } \\
\text { property if legitimate and } \\
\text { sanctioned by a legitimate } \\
\text { authority (Sikor and Lund } \\
\text { 2010). }\end{array}$ & $\begin{array}{l}\text { Legitimacy of authorities } \\
\text { and of property rights by } \\
\text { authorities may change over } \\
\text { time, is context-depend and } \\
\text { may be a result of conflict } \\
\text { and might induce conflict } \\
\text { between different right } \\
\text { holders (chapter } 5 \text { and } 6 \text { ). }\end{array}$ & $\begin{array}{l}\text { Lineage-based property is } \\
\text { today considered as less } \\
\text { legitimate than in pre-colonial } \\
\text { times (chapter } 6 \text { ). Not all } \\
\text { actors consider the Ministry } \\
\text { of Forestry as legitimate actor } \\
\text { thus concessions (e.g. } \\
\text { Harapan Rainforest) are not } \\
\text { accepted by all actors } \\
\text { (chapter } 6 \text { and } 7 \text { ). }\end{array}$ \\
\hline & $\begin{array}{l}\text { Conflictive property } \\
\text { relations can be explained } \\
\text { by unraveling conflicts on } \\
\text { the "organizing ideology" } \\
\text { (Alagappa 1995: 18). }\end{array}$ & $\begin{array}{l}\text { The organizing ideology } \\
\text { influences scope and } \\
\text { meaning of property. } \\
\text { Conflict over the organizing } \\
\text { ideology is associated with } \\
\text { legal pluralism and may lead } \\
\text { to competing/ overlapping } \\
\text { property rights (chapter } 5 \\
\text { and 6). }\end{array}$ & $\begin{array}{l}\text { Scope and meaning of } \\
\text { property influences the ability } \\
\text { of actors to benefit from } \\
\text { property: lineage property } \\
\text { provides benefits for lineage } \\
\text { members, individualized } \\
\text { property only for the } \\
\text { household (chapter } 5 \text { and } 6 \text { ). }\end{array}$ \\
\hline & $\begin{array}{l}\text { Actors seek to legitimize } \\
\text { property by using symbols } \\
\text { and language of the state }\end{array}$ & & $\begin{array}{l}\text { Local public authorities } \\
\text { legitimize local regulations on } \\
\text { property through legal }\end{array}$ \\
\hline
\end{tabular}




\begin{tabular}{|l|l|l|l|}
\hline & $\begin{array}{l}\text { (Lund 2006: 690). Legal } \\
\text { mimicry for legitimizing } \\
\text { land claims (Kunz et al. } \\
\text { submitted). }\end{array}$ & $\begin{array}{l}\text { mimicry (e.g. imitating } \\
\text { national policies and } \\
\text { regulations) (chapter 6). }\end{array}$ \\
\cline { 2 - 4 } & $\begin{array}{l}\text { The legitimacy of public } \\
\text { authorities in local politics } \\
\text { is in many cases } \\
\text { characterized by “[...] } \\
\text { endless chains of } \\
\text { reference to bigger } \\
\text { authorities" (Lund, 2006: } \\
\text { 693). }\end{array}$ & $\begin{array}{l}\text { Local public authorities made } \\
\text { reference to "higher" } \\
\text { authorities e.g. village } \\
\text { government referred to a } \\
\text { permit from district } \\
\text { authorities (chapter 6). }\end{array}$ \\
\hline
\end{tabular}

Table 18: Revisited guiding assumptions and analytical criteria as elements of a political ecology of scale for investigating land conflicts

(Source: compiled by the author)

Table 18 lists different assumptions, analytical criteria and aggregated empirical explanations for conflict and links them to access and property relations. The list should not be considered as exhaustive. The table should rather be considered as an attempt to further bridging politics of scale, political ecology and the access and property literature. Listed assumptions and criteria might be used as a starting point for future empirical research. As other categories in social science the different assumptions and criteria have to be treated as dynamic, interrelated and overlapping. State transformation for instance may not only affect the scalar structure, but it may also affect the organizing ideology and the legitimacy of public authorities in issuing property rights. Moreover, conflicts over the organizing ideology are not only impacting property rights, but they may also change scales of meaning and regulation and modes and relations of production. Furthermore, it is important to consider that the different socio-spatial and non-spatial relations are characterized by at least three different dialectical relationships:

\section{- Between scalar structure and agency;}

- between power and scalar structure;

- between de jure and de factor land and forest tenure regulations and their spatial dimensions.

Finally, the different assumptions and core analytical categories (e.g. scale, power and access and property relations) provide different entry points for investigating land conflicts. Depending on the context it may be useful to rather focus on power or scale than on all three categories or vice versa. 


\subsection{Limitations, challenges and open issues}

This study has a number of conceptual and methodological limitations. First, using the politics of scale literature as the main theoretical reference might have hindered the identification of other non-scalar socio-spatial relations. Network relations have been identified for being as relevant. However, their genesis, their relevance for changing power constellations and their relations to scale have not been fully understood yet.

Second, it was not possible to fully assess the role of the different power dimensions for securing access and property as well as within land conflicts. A possible explanation is that especially hidden and invisible dimensions of power are fluid and may overlap. Moreover, it is difficult to unravel the implications of invisible power e.g. the power of meanings and discourses in rather short field stays.

Third, by using a multi-sighted approach the study was able to follow causes of conflicts, to identify interpretations of conflicts at different scales and different locations. However, research at different locations is time-consuming and makes it more difficult to access more in-depth information at each location.

Fourth, the research questions guiding this study are rather broad. This provided the opportunity to gather a huge amount of interrelated findings on different conflicts in the Berbak and Harapan Landscape. On the one hand, rather narrow research questions might have improved the in-depth understanding of certain issues. On the other hand, however, too narrow research questions might have limited the ability to de-contextualize the results.

Fifth, research on land conflicts in Indonesia is a politically sensitive issue. Actors such as PT REKI and shareholders of PT REKI such as the Royal Society of Birds (RSPB) felt rather threatened by research on the roots of conflicts within their concessions. Settlements and forest conversion within the state forest are considered as crimes by the MoF and other forest authorities. Thus, the researcher might be perceived as a threat to the possibly illegal activities of research participants (e.g. interviewed smallholders). In general, it is also worthwhile to mention that most interviewed actors also have direct interests in the conflicts. In consequence they also have an interest in influencing the results of the research that later might influence conflict mediation or the positionality of actors vis-á-vis each other.

Sixth, the selection of research participants (interview partner) in the study villages was conducted by the snowball method and has relied on support from the village governments. This might have hindered access to political opponents and worst-off members of the different villages. 
Finally, while focusing on village-scale dynamics and national and transnational-scale dynamics the district scale was not fully covered.

In spite of the constraints the results of this study provide relevant insights on how conflictive access and property rights in REDD+ target areas in Jambi are socially produced. Furthermore, they contribute to the de-construction of REDD+ and conservation as win-win narratives and show that forest governance is rather dominated by trade-offs between local development and conservation objectives than by win-win outcomes.

\subsection{Concluding remarks: relevance for REDD+ and climate justice and future directions of research for development geography}

REDD+ has often been discussed as "win-win" mechanism for mitigating climate change, promoting forest conservation and rural development. However, the results of this study indicate that the specific local historical conditions for REDD+ are far more complex than the simple rhetoric of market-based conservation allows for. As other scholars have shown for other parts of the tropical South, marketbased conservation instruments create significant trade-offs. Most initiatives have not been able to align climate change mitigation, conservation and rural development (Phelps, Friess, and Webb 2012; Gupta 2012; Muradian et al. 2013; Pokorny et al. 2012; Zelli et al. 2014). The Berbak Carbon Project and the Harapan Rainforest indicate that the ability of actors to benefit from REDD+, forest governance reforms and investments of public and private donors in forest conservation depends mainly on the national and local institutional setting. In landscapes characterized by historically contingent structural inequality caused by the neglectance of customary land rights conservation initiatives might reinforce inequality, existing power asymmetries and social conflict.

In the context of REDD+ the basic agrarian questions of who owns what and who gets what (Fairhead, Leach, and Scoones 2012: 241) have gained importance in at least three different ways. First, one of the probably most common arguments raised by REDD+ scholars is the requirement of having "clear" land and forest tenure for a successful implementation of REDD+ (Galudra et al., 2014, NaughtonTreves and Wendland, 2014, Larson et al., 2013). But what is meant by "clear" land and forest tenure? Indonesia's national REDD+ strategy refers to land tenure reform and to the "[...] constitutional rights to certainty over boundaries and management rights for natural resources" (Indonesian REDD+ Task Force, 2012: 18). At the village-scale clear tenure might have different meaning then at the district or national scale. A land tenure reform would formalize certain customary rights but certainly not all right holders will get their rights formalized. Consequently, a land tenure reform creates winners and losers. 
Second, a major success of the indigenous rights movement is their strong involvement in global debates on REDD+. Transnational safeguards for REDD+ projects acknowledge the rights of indigenous people and local communities but the rights of non-local ethnic groups are in many cases left out. Conservation and REDD+ initiatives such as the Harapan Rainforest that consider the land rights of migrants as less legitimate might foster ethnic tensions. Third, it is argued that clear rights are relevant for selling forest carbon credits. Since the seller of carbon credits has to guarantee that the forest cover will remain for an agreed period (e.g. 30 years). If other actors claim the same forest area for other purposes this could undermine the permanence of the avoided greenhouse gas emissions. The ongoing land conflicts on access and control of the Harapan Rainforest and the Berbak Carbon project as well as experiences from other countries implementing REDD+ such as Peru (Zelli et al. 2014) indicate that forest carbon offsetting is a very risky strategy to mitigate climate change. Instead of avoiding emissions, forest carbon offsetting could lead to additional greenhouse gas emissions if land conflictive access and property relations undermine the integrity of forest areas designated for carbon offsetting.

Debates on the implementation of REDD+ as part of the Paris climate agreement are linked to questions of rural development and climate justice. REDD+ transfers part of the responsibility to reduce greenhouse gas emissions to rural areas of the global South. The expansion of forest conservation may limit the development opportunities of those actors that have emitted least fossil fuel based greenhouse gas emissions (e.g. Irfany and Klasen 2015 for emissions at household level in Indonesia). REDD+ and forest carbon offsetting are considered as cheap mitigation options. However, the main reason why they are considered as cheap are lower opportunity costs of climate protection measures (such as REDD+) in the global South (Hein 2014: 510; McAfee 2012b: 30). Thus the success of REDD+ as an idea is based on uneven development and could even contribute to the persistence of uneven development.

Many development geographers and political ecologists have conducted studies on the vulnerability of the local population in the context of climate change, climate variability and environmental change (Binternagel 2011; Few 2003; Bohle 2011; Cutter, Boruff, and Shirley 2003; Bohle, Downing, and Watts 1994). The amount of studies focusing on the impacts of climate mitigation policies on rural development and on the vulnerability of the local population is still limited and a rather new and so far neglected field of research (Cannon and Müller-Mahn 2010; Hoch et al. 2015; Hoch et al. forthcoming). REDD+ and other climate protection policies should not increase the vulnerability to external shocks of the worst-off members of society. Many climate adaptation and mitigation measures are built on the assumption that development e.g. the transformation to a low carbon economy is a dirigible technical process and one that creates benefits for all actors. It is assumed that policy interventions e.g. investments in REDD+ lead to an anticipated outcome, e.g. to reduced 
deforestation rates. It is often left out that any policy shift creates winners and losers. A critical engagement of development geographers and political ecologists with climate protection instruments and with scalar dimensions of global climate governance could open up a relevant new frontier for geographical research. Development geography could help to unravel the interests of actors investing in climate protection, power asymmetries between actors and the legitimacy of private actors taking over former state functions. They could help supporting the design of policies that reduce greenhouse gas emissions and reduce the vulnerability of the worst-off members of society. 


\section{References}

Acciaioli, G. 2001. Grounds of conflict, idioms of harmony: custom, religion, and nationalism in violence avoidance at the Lindu Plain, Central Sulawesi. Indonesia (72):81-114.

Adiwibowo, S. 2005. Dongi-Dongi-Culmination of a multi-dimensional ecological crisis: A political ecology perspective. PhD-thesis, Fachbereich Ökologische Agrarwissenschaften, Universität Kassel, Kassel, Germany.

Agius, P., T. Jenkin, S. Jarvis, R. Howitt, and R. Williams. 2007. (Re) asserting Indigenous rights and jurisdictions within a politics of place: transformative nature of Native title negotiations in South Australia. Geographical Research 45 (2):194-202.

Alagappa, M. 1995. Political legitimacy in Southeast Asia: The quest for moral authority. Stanford, California, USA: Stanford University Press.

Alamsyah, Z. 2004. Socio-economic conditions in communities in the vicinity of Berbak National Park, A rapid appraisal in Air Hitam Laut village and Sungai Gelam village. Wageningen, The Netherlands Water for Food and Ecosystems Programme, Wageningen University.

Alavi, H. 1972. The state in post-colonial societies: Pakistan and Bangladesh. New Left Review 74 (1):5981.

Allen, J. 2003. Power. In A Companion to Political Geoghraphy, edited by J. Agnew and G. Toal. 95-108, Malden, Massachusettes, USA: Blackwell Publishing.

Alliansi Masyarakat Adat Nusantara (AMAN). 2015. Profil Organisasi [accessed 27.11 2015]. Available from http://www.aman.or.id/wp-content/uploads/2015/11/Profile-AMAN_2015.pdf.

Alliansi Masyarakat Adat Nusantara (AMAN) Bengkulu. 2014. AMAN dan SPI Klaim Sumbang 33 Ribu Suara [accessed 15.11. 2015]. Available from http://amanbengkulu.or.id/aman-dan-spi-klaimsumbang-33-ribu-suara/.

Allianz. 2014. Aktiver Waldschutz durch Klimainvestitionen [cited 11.11 2015]. Available from https://www.allianz.com/de/nachhaltigkeit/unser_engagement/leuchtturmprojekte/mittlere r_osten_afrika/redd.html/.

Amin, A. 2008. Post-Fordism: Models, Fantasies and Phantoms of Transition. In Post-Fordism A Reader, edited by A. Amin. 1-39, Oxford, UK and Cambridge, Massachusettes, USA: Blackwell Publishers Ltd.

Andaya, L. Y. 2008. Leaves of the Same Tree. Ethnicity and trade in the Straits of Melaka. Honolulu. Honolulu, USA: The University of Hawai'i Press.

Angelsen, A., M. Brockhaus, W. D. Sunderlin, and L. Verchot. 2012. Introduction. In Analysing REDD+: Challenges and choices, edited by A. Angelsen, M. Brockhaus, W. D. Sunderlin and L. Verchot. 1-12, Bogor, Indonesia: Center for International Forestry Research (CIFOR).

Armitage, D. 2002. Socio-institutional dynamics and the political ecology of mangrove forest conservation in Central Sulawesi, Indonesia. Global Environmental Change 12 (3):203-217.

Astuti, R., and A. McGregor. 2015. REDD+ governmentality in Indonesia: Governing forest carbon through the REDD+ Task Force. Asia Pacific Viewpoint 56 (1):21-36.

Atela, J. 2015. Implementing REDD+ Evidence from Kenya. In Carbon Conflicts and Forest Landscapes in Africa, edited by M. Leach and I. Scoones. 109-123, London and New York: Routledge.

Awono, A., O. A. Somorin, R. E. a. Atyi, and P. Levang. 2014. Tenure and participation in local REDD+ projects: Insights from southern Cameroon. Environmental Science \& Policy 35:76-86.

Bachriadi, D., and G. Wiradi. 2011. Six Decades of Inequality. Bandung, Indonesia: Agrarian Resource Centre, Bina Desa, Konsortium Pembaruan Agraria

Bäckstrand, K., and E. Lövbrand. 2006. Planting trees to mitigate climate change: Contested discourses of ecological modernization, green governmentality and civic environmentalism. Global Environmental Politics 6 (1):50-75.

Badan Inventarisasi dan Tata Guna Hutan. 1985. Peta Rencana Pengukuhan dan Penatagunaan Hutan, Propinsi Dati I Jambi. Jakarta, Indonesia Departemen Kehutanan. 
- - . 1993. Rencana Struktur Tata Ruang Propinsi, Propinsi Jambi. Jakarta, Indonesia: Departemen Kehutanan

- - - n.a. Peta Areal Hutan Yang Disetujui untuk Dilepaskan Guna Peruntukan Perkebunan An. PT Bangun Desa Utama Jakarta, Indonesia: Departemen Kehutanan.

Badan Pengelola REDD+. 2014. Kegiatan DA REDD+ di Jambi [accessed 11.02. 2015]. Available from http://kc.reddplusid.org/kegiatan-dan-program/provinsi-prioritas/jambi/480-kegiatan-da-.

Badan Pusat Statistik. 2014. Indikator Kesejahteraan Rakyat - Welfare Indicators Jakarta: Badan Pusat Statistik.

Badan Pusat Statistik Provinsi Jambi. 2010. Jambi Dalam Angka (Jambi in Figures). Jambi, Indonesia: Badan Pusat Statistik Provinsi Jambi.

---. 2012. Jambi Dalam Angka (Jambi in Figures). Jambi, Indonesia: Badan Pusat Statistik Provinsi Jambi.

Bakhori, S. 2013. 853.430 Hektare Hutan di Jambi Dikuasai HTI [accessed 29.05.2016]. Available from https://m.tempo.co/read/news/2013/08/16/058504870/853-430-hektare-hutan-di-jambidikuasai-hti.

Bakker, L. 2008. "Can We Get Hak Ulayat?": Land and Community in Pasir and Nunukan, East Kalimantan. In UC Berkeley-UCLA Joint Conference on Southeast Asia, "Ten Years After: Reformasi and New Social Movements in Indonesia, 1998-2008. Berkeley, California: Center for Southeast Asia Studies, UC Berkeley.

Bakker, L., and S. Moniaga. 2010. The Space Between: Land Claims and the Law in Indonesia. Asian Jorunal of Social Science (2):187-203.

Balai Taman Nasional Berbak. 2013. Sejarah Pembentukan Taman Nasional Berbak. Jambi, Indonesia.

Balai Taman Nasional Berbak and Zoological Society London. 2011. Perjanjian Kerjasama antara Balai Taman Nasional Berbak (BTNB) and the Zoological Society London (ZSL). In SP 427/BTNB$1 / 2011$.

Balan, S. 2010. M. Foucault's view on Power Relations. Revista Cogito 2 (2):1-6.

Barr, C. 2006. Forest Administration and Forestry Sector Development Prior to 1998. In Decentralization of Forest Administration in Indonesia. Implications for Forest Sustainability, Economic Development and Community Livelihoods, edited by C. Barr, I. A. P. Resosudarmo, A. Dermawan and J. McCarthy. 18-30, Bogor, Indonesia: Center for international Forestry Research (CIFOR).

Barr, C., I. Resosudarmo, J. McCarthy, and A. Dermawan. 2006. Forests and decentralization in Indonesia: an overview. In Decentralization of Forest Administration. Implications for Forest Sustainability, Economic Development and Community Livelihoods. , edited by C. R. Barr, IAP, Dermawan, A. and McCarthy, J. 1-17, Bogor, Indonesia: Center for international Forestry Research (CIFOR).

Barr, C. M. 1998. Bob Hasan, the rise of APKINDO, and the shifting dynamics of control in Indonesia's timber sector. Indonesia (65):1-36.

Barrow, C. W. 1993. Critical Theories of the State: Marxist, Neomarxist, Postmarxist. Madison, Wisconsin, USA: The University of Wisconsin Press.

Bebbington, A., L. Dharmawan, E. Fahmi, and S. Guggenheim. 2004. Village politics, culture and community-driven development: insights from Indonesia. Progress in Development Studies 4 (3):187-205.

Beckert, B., C. Dittrich, and S. Adiwibowo. 2014. Contested Land: An Analysis of Multi-Layered Conflicts in Jambi Province, Sumatra, Indonesia. Austrian Journal of South-East Asian Studies 7 (1):7592.

Bedner, A., and S. Van Huis. 2008. The return of the native in Indonesian law: indigenous communities in Indonesian legislation. Bijdragen tot de taal-, land-en volkenkunde/Journal of the Humanities and Social Sciences of Southeast Asia 164 (2-3):165-193.

Bélanger, M. 2011. Global Health Law: an Introduction. Paris, France: Editions des Archives Contemporaines.

Benda-Beckmann, F., K. Benda-Beckmann, and A. Griffiths. 2005. Mobile People, Mobile Law: An Introduction. In Mobile people, mobile law: expanding legal relations in a contracting world, 
edited by F. Benda-Beckmann, K. Benda-Beckmann and A. Griffiths. 1-25, Aldershot, UK: Ashgate.

Benoit, D., and O. Sevin. 1993. L'émigration javanaise: mythes et réalités. Annales de géographie 102 (571):255-276.

Bhabha, H. K. 1994. The location of culture. London, UK and New York, USA: Routledge.

Binternagel, N. 2011. Adaptation to natural hazards in Central Sulawesi, Indonesia-strategies of rural households. PhD-thesis, Department of Human Geography, Niedersächsische Staats-und Universitätsbibliothek Göttingen, Göttingen, Germany.

Birdlife International. 2008. Long term conservation of the Harapan rainforest in Sumatra, Final report to The Nando Peretti Foundation. Cambridge, UK and Jakarta, Indonesia: Birdlife International.

--- 2015. About Birdlife [accessed 04.12. 2015]. Available from http://www.birdlife.org/worldwide/partnership/about-birdlife.

Blaikie, P. 2012. Should some political ecology be useful? The Inaugural Lecture for the Cultural and Political Ecology Specialty Group, Annual Meeting of the Association of American Geographers, April 2010. Geoforum 43 (2):231-239.

Blaikie, P., and H. Brookfield. 1987. Land degradation and society. London: Methuen.

Bohle, H. G. 2011. Geographische Entwicklungsforschung In Geographie, Physissche Geographie und Humangeographie, edited by H. Gebhardt, R. Glaser, U. Radtke and P. Reuber. 745-763\& 779783, München: Spektrum Akademischer Verlag.

Bohle, H. G., T. E. Downing, and M. J. Watts. 1994. Climate change and social vulnerability: toward a sociology and geography of food insecurity. Global Environmental Change 4 (1):37-48.

Bohle, H. G., and H. Fünfgeld. 2007. The political ecology of violence in eastern Sri Lanka. Development and Change 38 (4):665-687.

Bowen, G. A. 2009. Document analysis as a qualitative research method. Qualitative research journal $9(2): 27-40$.

Brad, A., A. Schaffartzik, M. Pichler, and C. Plank. 2015. Contested territorialization and biophysical expansion of oil palm plantations in Indonesia. Geoforum 64:100-111.

Brand, U., and C. Görg. 2003. The state and the regulation of biodiversity: international biopolitics and the case of Mexico. Geoforum 34 (2):221-233.

Brand, U., C. Görg, J. Hirsch, and M. Wissen. 2008. The regulation of nature in post-Fordism. In Conflicts in Environmental Regulation and the Internationalisation of the State, edited by U. Brand, C. Görg, J. Hirsch and M. Wissen. 9-52, Milton Park: Routledge.

Brand, U., C. Görg, and M. Wissen. 2011. Second-Order Condensations of Societal Power Relations: Environmental Politics and the Internationalization of the State from a Neo-Poulantzian Perspective. Antipode 43 (1):149-175.

Brenner, N. 1997. Global, fragmented, hierarchical: Henri Lefebvre's geographies of globalization. Public Culture 10 (1):135-167.

---. 1998. Between fixity and motion: accumulation, territorial organization and the historical geography of spatial scales. Environment and planning D 16:459-482.

- - - 2001. The limits to scale? Methodological reflections on scalar structuration. Progress in Human Geography 25 (4):591-614.

Brockhaus, M., K. Obidzinski, A. Dermawan, Y. Laumonier, and C. Luttrell. 2012. An overview of forest and land allocation policies in Indonesia: Is the current framework sufficient to meet the needs of REDD+? Forest policy and economics 18:30-37.

Bryant, R. L. 1998. Power, knowledge and political ecology in the third world: a review. Progress in physical geography 22 (1):79-94.

---. 2001. Political Ecology: A Critical Agenda for Change? In Social nature: theory, practice, and politics, edited by N. Castree and B. Braun. 151-169, Malden und Oxford: Blackwell Publishers Ltd.

Buergin, R. 2014. Forest problematic and bilateral forest related German development cooperation in the case study country Indonesia. Freiburg im Breisgau, Germany: Institute of Forest Sciences, University of Freiburg. 
Buletin Batin Sembilan. 2013. A New Round in the Meeting between PT. REKI and the Communities of Simpang Macan Luar dan Bawah Bedaro. Jambi: Yayasan Cappa, Setara, AGRA, Perkumpulan Hijau.

Bulkeley, H. 2005. Reconfiguring environmental governance: Towards a politics of scales and networks. Political geography 24 (8):875-902.

Burawoy, M. 1998. The extended case method. Sociological theory 16 (1):4-33.

Burkard, G. 2002. Stability or sustainability? Dimensions of socio-economic security in a rain forest margin. Vol. No. 7 (September 2002), STORMA Discussion Paper Series. Göttingen, Germany: STORMA Discussion Paper Series.

Burlando, C. 2012. Land use planning policy in the Far North Region of Ontario: Conservation targets, politics of scale, and the role of civil society organizations in Aboriginal-state relations. PhD, Faculty of Graduate Studies, University of Manitoba, Winnipeg.

Cannon, T., and D. Müller-Mahn. 2010. Vulnerability, resilience and development discourses in context of climate change. Natural hazards 55 (3):621-635.

Caouette, D., and S. Turner. 2009a. Rural resistance and the art of domination. In Agrarian angst and rural resistance in contemporary Southeast Asia, edited by D. Caouette and S. Turner. 25-44, Abingdon, UK: Routledge.

---. 2009b. Shifting fields of rural resistance in Southeast Asia. In Agrarian angst and rural resistance in contemporary Southeast Asia, edited by D. Caouette and S. Turner. 1-24, Abingdon, UK: Routledge.

Carr, D. 2009. Population and deforestation: why rural migration matters. Progress in Human Geography 33 (3):355-378.

Casson, A., and K. Obidzinski. 2002. From New Order to Regional Autonomy: Shifting Dynamics of "Illegal" Logging in Kalimantan, Indonesia. World Development 30 (12):2133-2151.

Castree, N. 2001. Socializing Nature: Theory, Practice, and Politics. In Social nature: theory, practice, and politics, edited by N. Castree and B. Braun. 1-21, Oxford, UK: Blackwell Publishers.

Castree, N. 2003. Commodifying what nature? Progress in Human Geography 27 (3):273-297.

- - . 2008. Neoliberalising nature: processes, effects, and evaluations. Environment and planning. A 40 (1):153.

CCBA, Climate, Community \& Biodiversity Alliance. 2008. Climate, Community and Biodiversity Project Design Standards, Second Edition Arlington, VA, USA: CCBA.

---. 2015. About the CCBA [accessed 04.12. 2015]. Available from http://www.climatestandards.org/about-ccba/.

Chatterton, P., D. Featherstone, and P. Routledge. 2013. Articulating climate justice in Copenhagen: Antagonism, the commons, and solidarity. Antipode 45 (3):602-620.

Chin, C. B. N., and J. H. Mittelman. 1997. Conceptualising Resistance to Globalisation. New Political Economy 2 (1):25-37.

CIFOR. REDD+ project sites in Indonesia 2012 [accessed. Available from http://www.forestsclimatechange.org/global-comparative-study-on-redd/redd-projectsites/redd-project-sites-in-indonesia.html.

CIRAD, French Agricultural Research Centre for International Development. 2012. ZSL Indonesia Field Programme [accessed 04.12. 2015]. Available from http://spop.cirad.fr/project/documents/project-benchmarking/zsl-field-programme.

Claridge, G. 1994. Management of coastal ecosystems in eastern Sumatra: the case of Berbak Wildlife Reserve, Jambi Province. Hydrobiologia 285 (1-3):287-302.

Cohen, A., and J. McCarthy. 2014. Reviewing rescaling: Strengthening the case for environmental considerations. Progress in Human Geography.

Colchester, M., P. Anderson, A. Y. Firdaus, F. Hasibuan, and S. Chao. 2011. Human Rights Abuses and Land Conflicts in the PT Asiatic Persada Concession in Jambi: Report of an Independent Investigation Into Land Disputes and Forced Evictions in a Palm Oil Estate: Independent Investigation of PT AP. Moreton-in-Marsh, UK, Bogor and Jakarta, Indonesia: HuMa, Sawit Watch, Forest Peoples Programme. 
Corbera, E., and K. Brown. 2010. Offsetting benefits? Analyzing access to forest carbon. Environment and planning. A 42 (7):1739-1761.

Corbera, E., and H. Schroeder. 2011. Governing and implementing REDD+. Environmental science \& policy $14(2): 89-99$.

Corbera, E., C. G. Soberanis, and K. Brown. 2009. Institutional dimensions of Payments for Ecosystem Services: An analysis of Mexico's carbon forestry programme. Ecological Economics 68 (3):743761.

Cox, K. R. 1998. Spaces of dependence, spaces of engagement and the politics of scale, or: looking for local politics. Political geography 17 (1):1-23.

-- - 2013. Making human geography. New York, USA: Guilford Publications.

Cramb, R. A., C. J. P. Colfer, W. Dressler, P. Laungaramsri, Q. T. Le, E. Mulyoutami, N. L. Peluso, and R. L. Wadley. 2009. Swidden transformations and rural livelihoods in Southeast Asia. Human Ecology 37 (3):323-346.

Cutter, S. L., B. J. Boruff, and W. L. Shirley. 2003. Social vulnerability to environmental hazards*. Social science quarterly 84 (2):242-261.

DANIDA. 2011. How to Note Indigenous Peoples. Copenhagen: Ministry of Foreign Affairs of Denmark.

---. 2012. Harapan Rainforest Project in Indonesia [accessed 24.07. 2015]. Available from http://um.dk/en/danida-en/activities/annual-report-2012/programmes-and-projects/greengrowth-harapan-rainforest-project-in-indonesia/.

Delgado-Pugley, D. 2013. Contesting the Limits of Consultation in the Amazon Region: On Indigenous Peoples' Demands for Free, Prior and Informed Consent in Bolivia and Peru. Revue générale de droit 43:151-181.

Demeritt, D. 2001. Being constructive about nature. In Social nature: Theory, practice, and politics, edited by N. Castree and B. Braun. 22-40, Oxford, UK: Blackwell Publishers.

Dewasan Nasional Perubahan Iklim. 2010. Creating low carbon prosperity in Jambi. Jambi and Jakarta, Indonesia.

Díaz, C. A. B. 2014. Contested Lands, Contested Laws. Americas Quarterly 8 (2):106.

Dinas Kehutanan Kabupaten Batang Hari. 2012. Laporan Hasil Identifikasi dan Inventarisasi Masyarakat penggarap Wilayah Bukit Sinyak, Areal Kerja PT. Restorasi Ekosistem Indonesia. Muaro Bulian, Jambi, Indonesia: Kabupaten Batang Hari.

Dinas Kehutanan Provinsi Jambi. 2013. Persetujuan Lokasi Demonstration Activities Reducing Emission from Deforestation and Forest Degradation (DA-REDD+) di Taman Hutan Raya Tanjung. In 81/A/ZSL/II/2013 Jambi, Indonesia.

Dinas Komunikas dan Informatika Provinsi Jambi. 2013. Sejarah Berdirinya Provinsi Jambi [accessed 03.12.2015]. Available from http://jambiprov.go.id/index.php?sejarah.

Dinas Tenaga Kerja dan Transmigrasi Sumatera Barat. 2015. Bursa Transmigrasi [accessed 29.04 2015]. Available from http://bto-sumbar.com/index.php/en/.

Dittrich, C. 2012. Der globalisierte ländliche Raum im Entwicklungskontext. Geographische Rundschau (9):4-10.

Doherty, E., and H. Schroeder. 2011. Forest tenure and multi-level governance in avoiding deforestation under REDD+. Global Environmental Politics 11 (4):66-88.

Doolittle, A. A. 2010. Stories and maps, images and archives: Multimethod approach to the political ecology of native property rights and natural resource management in Sabah, Malaysia. Environmental management 45 (1):67-81.

Drumbl, M. A. 2007. Atrocity, punishment, and international law. Cambridge, UK: Cambridge University Press.

Duncan, J. 1995. Landscape geography, 1993-94. Progress in Human Geography 19 (3):414-422.

Eickhoff, G., A. Salim, and S. A. Stanley. 2010. Initial Field and Desktop Assessment of Carbon Emission Reduction Potential for the Berbak Carbon Initiative. Jakarta, Indonesia: Forest Carbon.

Eilenberg, M. 2015. Shades of green and REDD: Local and global contestations over the value of forest versus plantation development on the Indonesian forest frontier. Asia Pacific Viewpoint 56 (1):48-61. 
Ekers, M., and A. Loftus. 2008. The power of water: developing dialogues between Foucault and Gramsci. Environment and Planning D: Society and Space 26 (4):698-718.

Ekers, M., A. Loftus, and G. Mann. 2009. Gramsci Lives! Geoforum 40 (3):287-291.

Eliasch, J. 2008. The Eliasch Review-climate change: financing global forests. Commissioned by The Office of Climate Change, UK. Richmond, UK: The Stationery Office Limited on behalf of the Controller of Her Majesty's Stationery Office.

Ellison, K. 2003. Renting biodiversity: The conservation concessions approach. Conservation in Practice 4 (4):20-29.

Elmhirst, R. 2001. Resource struggles and the politics of place in North Lampung, Indonesia. Singapore Journal of Tropical Geography 22 (3):284-306.

England, K. V. 1994. Getting personal: Reflexivity, positionality, and feminist research*. The Professional Geographer 46 (1):80-89.

Escobar, A. 1996. Construction nature: Elements for a post-structuralist political ecology. Futures 28 (4):325-343.

---. 1999. After nature: steps to an antiessentialist political ecology 1. Current anthropology 40 (1):1-30.

Estrada, M. 2011. Standards and methods available for estimating project-level REDD+ carbon benefits: Reference guide for project developers. Bogor, Indonesia: Center for International Forestry Research (CIFOR).

Etzold, B., M. Keck, H.-G. Bohle, and W.-P. Zingel. 2009. Informality as agency-negotiating food security in Dhaka. Die Erde 140 (1):3-24.

Fairhead, J., M. Leach, and I. Scoones. 2012. Green Grabbing: a new appropriation of nature? Journal of Peasant Studies 39 (2):237-261.

FAO. 2014. State of the World's Forests - Enhancing the socioeconomic benefits from forests. Rome: FAO.

Fauna\& Flora International. 2012. Community Forest Ecosystem Services, Indonesia Plan Vivo Project Idea Note (PIN). Jakarta, Indonesia: FFI Indonesia Programme.

Faust, H. 2007. Vergleichende Kulturgeographie : empirische Befunde regionaler Integrationsprozesse in tropischen Agrarkolonisationsräumen Boliviens, der Elfenbeinküste und Indonesiens. Göttingen, Germany: Goltze.

Faust, H., and W. Kreisel. 2006. Humanökologie tropischer Regenwälder. Einführung in das Themenheft. Geographica Helvetica 61 (4):234-236.

Faust, H., S. Schwarze, B. Beckert, B. Brümmer, C. Dittrich, M. Euler, M. Gatto, B. Hauser-Schäublin, J. Hein, and A. Holtkamp. 2013. Assessment of socio-economic functions of tropical lowland transformation systems in Indonesia. Vol. No. 1, EFForts Discussion Paper Series. Göttingen, Germany: University of Göttingen.

Fearnside, P. M. 1997. Transmigration in Indonesia: Lessons from Its Environmental and Social Impacts. Environmental management 21 (4):553-570.

Ferdiyal, I. 2013. Pengusiran Petani REKI, Komnas HAM Temukan Indikasi Pelanggaran HAM [accessed 15.09 2015]. Available from http://www.metrojambi.com/v1/daerah/13893-pengusiranpetani-reki-komnas-ham-temukan-indikasi-pelanggaran-ham.html.

Few, R. 2003. Flooding, vulnerability and coping strategies: local responses to a global threat. Progress in Development Studies 3 (1):43-58.

Finlayson, R. 2014. REDD ready or not? Agroforestry World Blog [accessed 11.11 2015]. Available from http://blog.worldagroforestry.org/index.php/2014/06/19/redd-ready-or-not/.

Flick, U. 2007. Qualitative Sozialforschung: Eine Einführung. Reinbek bei Hamburg: Rowohlt Taschenbuch Verlag.

Flitner, M., and C. Görg. 2008. Politik im Globalen Wandel-räumliche Maßstäbe und Knoten der Macht. In Mit mehr Ebenen zu mehr Gestaltung? Multi-Level-Governance in der transnationalen Sozialund Umweltpolitik, edited by A. Brunnengräber, H.-J. Burchardt and C. Görg. 163-181, BadenBaden, Germany: Nomos Verlag. 
Fogel, C. 2004. The local, the global, and the Kyoto Protocol. In Earthly politics: Local and global in environmental governance, edited by S. Jasanoff and M. L. Martello. 103-125, Cambridge, USA: MIT Press.

Fold, N., and P. Hirsch. 2009. Re-thinking frontiers in Southeast Asia. The Geographical Journal 175 (2):95-97.

Forest Climate Center. 2012. REDD Project List - Indonesia (March 2012 Version) [accessed 04.12. 2015]. Available from http://forestclimatecenter.org/files/2012-03-26\%20Indonesia\%20\%20REDD\%20Demonstration\%20Activities.pdf.

Forest Trends. 2014. REDDX Tracking Forest Finance, Indonesia [accessed 04.12. 2015]. Available from http://reddx.forest-trends.org/country/indonesia/overview.

Forsyth, T. 2008. Political ecology and the epistemology of social justice. Geoforum 39 (2):756-764.

Foucault, M. 2006. Sicherheit, Territorium, Bevölkerung. Geschichte der Gouvernementalität I. Vorlesungen am Collège de France 1977-1978, Geschichte der Governementalität Frankfurt am Main, Germany: Suhrkamp.

Fürst, E. 2001. Global Resource Consumption, Environmental Space and Ecological Structural Change: Implications for Sustainable Development from the Perspective of North-South Relations. International Journal of Economic Development 3 (2).

Galudra, G., and M. Sirait. 2009. A discourse on Dutch colonial forest policy and science in Indonesia at the beginning of the 20th century. International Forestry Review 11 (4):524-533.

Galudra, G., M. van Noordwijk, P. Agung, S. Suyanto, and U. Pradhan. 2014. Migrants, land markets and carbon emissions in Jambi, Indonesia: land tenure change and the prospect of emission reduction. Mitigation and Adaptation Strategies for Global Change 19 (6):715-731.

Galudra, G., M. Van Noordwijk, S. Suyanto, I. Sardi, U. Pradhan, and D. Catacutan. 2011. Hot spots of confusion: contested policies and competing carbon claims in the peatlands of Central Kalimantan, Indonesia. International Forestry Review 13 (4):431-441.

Gamin, B. N., H. Kartodihardjo, L. M. Kolopaking, and R. Boer. 2014. Forest Land Tenure Conflicts and Their Resolutions: A Case Study from Musi Rawas Regency, South Sumatera Province*. Journal of Islamic Perspective on Science, Technology and Society 2 (1):53-64.

Gaventa, J. 1982. Power and powerlessness: Quiescence and rebellion in an Appalachian valley. Champaign, USA: University of Illinois Press.

- - . 2003. Power after Lukes: an overview of theories of power since Lukes and their application to development. Brighton, UK: Institute of Development Studies.

- - . 2006. Finding the spaces for change: a power analysis. IDS bulletin 37 (6):23-33.

Gaventa, J., J. Pettit, and L. Cornish. 2011. Scott: resistance [accessed 14.10. 2015]. Available from http://www.powercube.net/other-forms-of-power/scott-resistance/.

Gezon, L. L., and S. Paulson. 2004. Place, power, difference: multiscale research at the dawn of the twenty-first century. In Political Ecology Across Spaces, Scales and Social Groups. Rutgers University Press, New Brunswick. 1-16, New Brunswick, USA: Rutgers University Press.

Giesen, W. 2004. Causes of peat swamp forest degradation in Berbak NP, Indonesia, and recommendations for restoration, Water for Food and Ecosystems Programme Project on:"Promoting the river basin and ecosystem approach for sustainable management of SE Asian lowland peat swamp forests: case study Air Hitam Laut River basin, Jambi Province, Sumatra, Indonesia". Arnheim, The Netherlands: ARCADIS Euroconsult.

Gita Buana. 2013. Progres Kegiatan FGD-FPIC di Kecamatan Kumpeh, Kabupaten Muaro Jambi (unpublished document). Jambi, Indonesia.

Görg, C. 1999. Gesellschaftliche Naturverhältnisse. Münster: Westfälisches Dampfboot.

- - . 2007. Landscape governance: The "politics of scale" and the "natural" conditions of places. Geoforum 38 (5):954-966.

-- - 2011. Shaping Relationships with Nature - Adaptation to Climate Change as a Challenge for Society. Die Erde 142 (4):411-428.

Government of the Kingdom of Norway and Government of the Republic of Indonesia. 2010. Letter of Intent between the Government of the Kingdom of Norway and Government of the Republic 
of Indonesia on "Cooperation on reducing greenhouse gas emissions from deforestation and forest degradation" Oslo, Norway.

Greiner, R., and O. Stanley. 2013. More than money for conservation: exploring social co-benefits from PES schemes. Land Use Policy 31:4-10.

Griffiths, T. 2007. Seeing 'RED' ? Avoided deforestation' and the rights of Indigenous Peoples and local communities. Moreton-in-Marsh, UK: Forest Peoples Programme.

Guillaud, D. 1994. Les douze ventres du sultan: la permanence des territoires à Jambi (Sumatra, Indonésie). Géographie et Cultures 12:109-130.

Gupta, J. 2012. Glocal forest and REDD+ governance: win-win or lose-lose? Current Opinion in Environmental Sustainability 4 (6):620-627.

Hagen, B. 1908. Die Orang Kubu auf Sumatra. Frankfurt am Main: Joseph Baer\& CO.

Hall, D., P. Hirsch, and T. M. Li. 2011. Powers of Exclusion: Land Dilemmas in Southeast Asia. Honolulu: University of Hawai'i Press.

Hall, R. 2010. REDD: the realities in black and white. Amsterdam, The Netherlands: Friends of the Earth International.

Harvey, D. 2005. A brief history of neoliberalism. Oxford: Oxford University Press.

Hauser-Schäublin, B. 2013. Introduction. The Power of Indigeneity: Reparation, Readjustments and Repositioning. In Adat and Indigeneity in Indonesia: Culture and Entitlements between Heteronomy and Self-Ascription, edited by B. Hauser-Schäublin. 5-15, Göttingen, Germany: Universitätsverlag Göttingen.

Hauser-Schäublin, B., and S. Steinebach. 2014. Harapan: a" no man's land" turned into a contested agro-industrial Zone. Vol. No. 3, EFForts Discussion Paper Series. Göttingen, Germany: University Göttingen

Heigl, M. C. 2011. Social Conflict and Competing State Projects in the Semi-Periphery: A StrategicRelational Analysis of the Transformation of the Mexican State into an Internationalized Competition State. Antipode 43 (1):129-148.

Hein, J. 2013a. Climate change mitigation in emerging economies: the case of Indonesia: hot air or leadership? DIE Briefing Paper 8/2013.

- - . 2013b. Reducing Emissions from Deforestation and Forest Degradation (REDD+), Transnational Conservation and Access to Land in Jambi, Indonesia. Vol. No. 2, EFForts Discussion Paper Series. Göttingen, Germany: University of Göttingen.

- - . 2014. Politiken zur Reduktion von Emissionen aus Entwaldung und Schädigung von Wäldern (REDD+). Peripherie: Zeitschrift für Politik und Ökonomie in der Dritten Welt (136):508-511.

Hein, J., S. Adiwibowo, C. Dittrich, Rosyani, E. Soetarto, and H. Faust. 2015. Rescaling of Access and Property Relations in a Frontier Landscape: Insights from Jambi, Indonesia. The Professional Geographer:1-10.

Hein, J., and H. Faust. 2010. Frontier Migration as response to environmental change. Vol. No. 31 (July 2010), STORMA Discussion Paper. Göttingen, Germany: University of Göttingen

- - - 2014. Conservation, REDD+ and the struggle for land in Jambi, Indonesia. Pacific Geographies 41:20-25.

Hein, J., and H. Garrelts. 2014. Ambiguous involvement: Civil-Society Actors in Forest Carbon Offsets. The case of the Climate Community and Biodiversity Standards (CCB). In Routledge Handbook of the Climate Change Movement., edited by H. Garrelts and M. Dietz. 319-333, New York: Routledge.

Hein, J., K. Meijer, and J. C. Rodriguez de Francisco. 2015. What is the potential for a climate, forest and community friendly REDD+ in Paris? DIE Briefing Paper 3/2015.

Hidayat, R. 2012. Membangkitkan Batang Terendam. Sejarah Asal Usl Kebudayaan dan Perjuangan Hak SAD Batin 9. Jambi, Indonesia: Yayasan Setara Jambi.

Hirsch, J., and J. Kannankulam. 2011. The Spaces of Capital: The Political Form of Capitalism and the Internationalization of the State. Antipode 43 (1):12-37.

Heyde, Jill, Martin C. Lukas, and Michael Flitner 2012. Payments for Environmental Services in Indonesia: A Review of Watershed-related Schemes. Artec-paper Nr. 186. Bremen, Germany: Artec - Forschungszentrum Nachhaltigkeit. 
Hoey, B. A. 2003. Nationalism in Indonesia: Building Imagined and Intentional Communities through Transmigration. Ethnology 42 (2):109-126.

Hofman, B., and K. Kaiser. 2002. The Making of the Big Bang and its Aftermath, a Political Economy Perspective. In A Conference Sponsored by the International Studies Program, Andrew Young School of Policy Studies. Atlanta, Georgia: Georgia State University.

Hoch, S., B. Horstmann, A. Michaelowa, J. Hein. 2015. New climate investments must strenghten sustainable development and minimize trade-offs. DIE Briefing Paper 22/2015.

Hoch, S., B. Horstmann, J. Hein, A. Michaelowa. Forthcoming. Sustainable Development Impacts of mitigation measures: Lessons from the CDM, GCF, and REDD+. Reseach report for the German Development Institute/ Deutsches Institut für Entwicklungspolitik (DIE): Bonn.

Hopf, C., and C. Schmidt. 1993. Zum Verhältnis von innerfamilialen sozialen Erfahrungen, Persönlichkeitsentwicklung und politischen Orientierungen. Dokumentation und Erörterung des methodischen Vorgehens in einer Studie zu diesem Thema: Hildesheim: Institut für Sozialwissenschaften der Universität Hildesheim.

Houdret, A. 2008. Scarce water, plenty of conflicts, Local Water Conflicts and the Role of Development Cooperation. INEF Policy Brief 3.

Houdret, A., I. Dombrowsky, and L. Horlemann. 2014. The institutionalization of River Basin Management as politics of scale - Insights from Mongolia. Journal of Hydrology 519, Part C: 2392-2404.

Houdret, A., A. Kramer, and A. Carius. 2010. The water security nexus: challenges and opportunities for development cooperation. Eschborn, Germany: Gesellschaft für Technische Zusammenarbeit (GTZ).

Howson, P., and S. Kindon. 2015. Analysing access to the local REDD+ benefits of Sungai Lamandau, Central Kalimantan, Indonesia. Asia Pacific Viewpoint 56 (1):96-110.

Indonesian REDD+ Task Force. 2012. REDD+ National Strategy. Jakarta, Indonesia.

Indrarto, G. B., P. Murharjanti, J. Khatarina, I. Pulungan, F. Ivalerina, J. Rahman, M. N. Prana, I. A. P. Resosudarmo, and E. Muharrom. 2012. The context of REDD+ in Indonesia. Bogor, Indonesia: Center for International Forestry Research (CIFOR).

Internationale Klimaschutzinitiative. 2015. Harapan Rainforest - Pilothafte Restauration eines Degradierten Waldökosystems auf Sumatra [accessed 04.12. 2015]. Available from https://www.international-climate-initiative.com/de/projekte/weltkarte-undprojektliste/details/272/.

Irfany, M. I., and S. Klasen. 2015. Inequality in emissions: evidence from Indonesian household. Environmental Economics and Policy Studies:1-25.

JambiekspressNews. 2013. 19 SK Hutan Desa di Jambi Terancam Dicabut [accessed 04.12. 2015]. Available from http://www.jambiekspresnews.com/berita-6661-19-sk-hutan-desa-di-jambiterancam-dicabut.html.

---. 2014. Kajati : Tahura Ditangani Polda [accessed 28.10. 2015]. Available from http://www.jambiekspres.co.id/berita-13758-kajati---tahura-ditangani-polda.html.

Jenkins, M., S. J. Scherr, and M. Inbar. 2004. Markets for biodiversity services: potential roles and challenges. Environment: Science and Policy for Sustainable Development 46 (6):32-42.

Jessop, B., N. Brenner, and M. Jones. 2008. Theorizing sociospatial relations. Environment and Planning. D, Society and space 26 (3):389.

Karriem, A. 2009. The rise and transformation of the Brazilian landless movement into a counterhegemonic political actor: A Gramscian analysis. Geoforum 40 (3):316-325.

Kato, T. 1989. Different fields, similar locusts: Adat communities and the village law of 1979 in Indonesia. Indonesia (47):89-114.

Kebschull, D. 1986. Transmigration in Indonesia: An empirical analysis of motivation, expectations and experiences. Hamburg: Verlag Weltarchiv $\mathrm{GmbH}$.

Kelly, A. B. 2011. Conservation practice as primitive accumulation. Journal of Peasant Studies 38 (4):683-701.

Kelly, P. F. 1997. Globalization, power and the politics of scale in the Philippines. Geoforum 28 (2):151171. 
Keohane, R. O., and J. S. Nye Jr. 1998. Power and interdependence in the information age. Foreign affairs:81-94.

Kepala Desa Seponjen. 2013. Rencana Pembangunan Jangka Menengah Desa (RPJM-DES) Seponjen. Seponjen, Jambi, Indonesia: Pemerintah Kabupaten Muaro Jambi.

Kepala Desa Sungai Aur. 2012. Monografi Desa. Sungai Aur, Jambi, Indonesia: Pemerintah Kabupaten Muaro Jambi.

Kesepakatan Terhadap Prasyarat Mediasi Antara PT. REKI Dengan Warga RT 11. 2012. (unpublished document). Jambi, Indonesia.

Kijazi, M. 2015. Climate Emergency, Carbon Capture and Coercive Conservation on Mt. Kilimanjaro. In Carbon Conflicts and Forest Landscapes in Africa, edited by M. Leach and I. Scoones. 58-78, London and New York: Routledge.

Klepp, S. 2011. A Double Bind: Malta and the Rescue of Unwanted Migrants at Sea, a Legal Anthropological Perspective on the Humanitarian Law of the Sea. International Journal of Refugee Law 23 (3):538-557.

Koch, S., H. Faust, and J. Barkmann. 2008. Differences in power structures regarding access to natural resources at the village level in Central Sulawesi (Indonesia). Austrian Journal of South-East Asian Studies 1 (2):59-81.

Köhler, B. 2008. Die Materialität von Rescaling-Prozessen. Zum Verhälltnis von politics of scale und political ecology. In Politics of scale: Räume der Globalisierung und Perspektiven emanzipatorischer Politik, edited by M. Wissen, B. Röttger and S. Heeg. 208-223, Münster: Westfälisches Dampfboot.

Konsorsium Pembaruan Agraria. 2013. Laporan Akhir Tahun 2013. Jakarta Selatan, Indonesia: Sekretariat Nasional Konsorsium Pembaruan Agraria (KPA).

Kosoy, N., and E. Corbera. 2010. Payments for ecosystem services as commodity fetishism. Ecological economics 69 (6):1228-1236.

Kreditanstalt für Wiederaufbau. 2012. Financial Cooperation with Indonesia (unpublished document).

Krishna, V. V., U. Pascual, and M. Qaim. 2014. Do emerging land markets promote forestland appropriation? Evidence from Indonesia. Vol. No. 7, EFForTS Discussion Paper Series. Göttingen, Germany: University of Göttingen.

Kunz, Y., J. Hein, R. Mardiana, and H. Faust. submitted. Mimicry of the legal: Translating de jure land formalization processes into de facto local action - Experiences from Jambi province, Sumatra, Indonesia. Austrian Journal of South-East Asian Studies (ASEAS).

La Via Campesina. 2008. Small farmers victims of forest carbon trading [accessed 27.10. 2015]. Available from http://www.viacampesina.org/en/index.php/actions-and-events-mainmenu26/-climate-change-and-agrofuels-mainmenu-75/629-small-farmers-victims-of-forestcarbon-trading.

---. 2012. Bangkok, UN Climate negotiations move towards burning the planet [accessed 27.10 2015]. Available from http://www.viacampesina.org/en/index.php/actions-and-eventsmainmenu-26/-climate-change-and-agrofuels-mainmenu-75/1296-bangkok-un-climatenegotiations-move-towards-burning-the-planet.

Lambini, C. K., and T. T. Nguyen. 2014. A comparative analysis of the effects of institutional property rights on forest livelihoods and forest conditions: Evidence from Ghana and Vietnam. Forest Policy and Economics 38:178-190.

Lamnek, S. 2005. Qualitative Sozialforschung Basel: Beltz Verlag.

Lang, C. 2010. The Cancun agreement on REDD: Four questions and four answers [accessed 03.12. 2015]. Available from http://www.redd-monitor.org/2010/12/18/the-cancun-agreement-onredd-four-questions-and-four-answers/.

---. 2012a. Response from Germany's International Climate Initiative: The mediation and consultation process at Harapan "has been rejected by the groups claiming affiliation to SPI" [accessed 29.05.2016]. Available from http://www.redd-monitor.org/2012/12/21/responsefrom-germanys-international-climate-initiative/.

- - . 2012b. Response from Harapan Rainforest Project: "The SPI settlement is deep inside Harapan, on a scale large enough to compromise the ecological integrity of the forest" [accessed 
29.05.2016]. Available from http://www.redd-monitor.org/2012/04/30/response-fromharapan-rainforest-project-the-spi-settlement-is-deep-inside-harapan-on-a-scale-largeenough-to-compromise-the-ecological-integrity-of-the-forest/.

---. 2015. Harapan Rainforest [accessed 29.05.2016]. Available from http://www.reddmonitor.org/?s=Harapan+Rainforest.

Langholz, J., J. Lassoie, and J. Schelhas. 2000. Incentives for biological conservation: Costa Rica's private wildlife refuge program. Conservation Biology 14 (6):1735-1743.

Larson, A., and J. Ribot. 2004. Democratic decentralisation through a natural resource lens: an introduction. The European Journal of Development Research 16 (1):1-25.

Larson, A. M., M. Brockhaus, W. D. Sunderlin, A. Duchelle, A. Babon, T. Dokken, T. T. Pham, I. Resosudarmo, G. Selaya, and A. Awono. 2013. Land tenure and REDD+: the good, the bad and the ugly. Global Environmental Change 23 (3):678-689.

Larson, A. M., and F. Soto. 2008. Decentralization of natural resource governance regimes. Annual review of environment and resources 33 (1):213.

Leach, M., R. Mearns, and I. Scoones. 1999. Environmental entitlements: dynamics and institutions in community-based natural resource management. World development 27 (2):225-247.

Lebel, L., P. Garden, and M. Imamura. 2005. The politics of scale, position, and place in the governance of water resources in the Mekong region. Ecology and Society 10 (2):18.

Lefebvre, H. 1976a. Reflections on the Politics of Space (translated by Enders, Michael J). Antipode 8 (2):30-37.

- - . 1976b. The survival of capitalism. London: Allison and Busby.

- - . 1991. The production of space. Vol. 142: Oxford Blackwell.

Levang, P., and O. Sevin. 1990. 80 years of transmigration in Indonesia 1905-1985. Jakarta: Departemen Transmigrasi and Institut Francais de Recherche Scientifique pour le Developpement en Cooperation (ORSTOM).

Li, T. M. 2001. Masyarakat adat, difference, and the limits of recognition in Indonesia's forest zone. Modern Asian Studies 35 (03):645-676.

- - . 2002. Local histories, global markets: cocoa and class in upland Sulawesi. Development and Change 33 (3):415-437.

-- - 2005. Transforming the Indonesian uplands. Amsterdam, The Netherlands: Harwood academic publishers.

- - . 2008. Contested commodifications: struggles over nature in a national park. In Taking Southeast Asia to Market. Commodtities, Nature and People in the Neoliberal Age, edited by J. Nevins and N. L. Peluso. 124-139, Ithaca, USA: Cornell University Press.

Locher-Scholten, E. 1994. Dutch expansion in the Indonesian archipelago around 1900 and the imperialism debate. Journal of Southeast Asian Studies 25 (01):91-111.

- - . 1996. The establishment of colonial rule in Jambi: The dual strand of politics and economics. Paper read at Colloquium, Historical foundations of a national economy in Indonesia, 1890s1990s, at Amsterdam, New York, USA.

-- - 2004. Sumatran sultanate and colonial state: Jambi and the rise of Dutch imperialism, 18301907. Ithaca, New York: SEAP Publications.

Lohmann, L. 2008. Carbon trading, climate justice and the production of ignorance: ten examples. Development 51 (3):359-365.

Longhurst, R. 2010. Semi-structured interviews and focus groups. In Key Methods in Geography, edited by N. Clifford, S. French and G. Valentine. 103-115, London, UK: SAGE.

Lubis, R., and I. Suryadiputra. 2004. Upaya pengelolaan terpadu hutan rawa gambut bekas terbakar diwilayah Berbak-Sembilang. In Prosiding Semiloka "Kebakaran di Lahan Rawa/Gambut di Sumatera: Masalah dan Solusi", edited by S. Suyanto, U. Chokkalingam and P. Wibowo. 105119, Bogor, Indonesia: Center for International Forestry Research (CIFOR).

Lukas, M. C. 2014. Eroding battlefields: Land degradation in Java reconsidered. Geoforum 56:87-100.

Lukes, S. 2005. Power, Second Edition: A Radical View. New York: Palgrave.

Lund, C. 2006. Twilight institutions: public authority and local politics in Africa. Development and Change 37 (4):685-705. 
---. 2008. Local politics and the dynamics of property in Africa. Cambridge, UK: Cambridge University Press.

- - . 2014. Of what is this a case?: analytical movements in qualitative social science research. Human Organization 73 (3):224-234.

Macpherson, C. B. 1978. Property Mainstream and Crtitical Positions. Oxford, UK: Basil Blackwell.

Makamah Konstitusi Republik Indonesia. 2012. Putusan Nomor 35/PUU-X/2012. Jakarta, Indonesia.

Manager of Royal Society for the Protection of Birds, R. 2012. Personal Communication, 08.07.2012.

Mann, G. 2009. Should political ecology be Marxist? A case for Gramsci's historical materialism. Geoforum 40 (3):335-344.

Mannell, J. 2014. Adopting, manipulating, transforming: Tactics used by gender practitioners in South African NGOs to translate international gender policies into local practice. Health \& place 30:412.

Marcus, G. E. 1995. Ethnography in/of the world system: the emergence of multi-sited ethnography. Annual Review of Anthropology 25:95-117.

Mardiana, R. 2014. Kehendak Merestorasi Ekosistem Tersandera di Pusaran Sengkarut Agraria: Konflik dan Perjuangan Kedaulatan Agraria di Wilayah Restorasi Ekosistem Hutan Harapan Provinsi Jambi. Vol. 14, Sayogyo Institute Working Paper. Bogor, Indonesia: Sayogyo Institute.

Margono, B. A., P. V. Potapov, S. Turubanova, F. Stolle, and M. C. Hansen. 2014. Primary forest cover loss in Indonesia over 2000-2012. Nature Climate Change 4:730-735.

Marin-Burgos, V. 2014. Access, power and justice in commodity frontiers: The political ecology of access to land and palm oil expansion in Colombia. PhD-thesis, Institute for Innovation and Governance Studies, Universiteit Twente, Twente, The Netherlands.

Marston, S. A. 2000. The social construction of scale. Progress in Human Geography 24 (2):219-242.

Massé, F., and E. Lunstrum. 2015. Accumulation by securitization: Commercial poaching, neoliberal conservation, and the creation of new wildlife frontiers. Geoforum, in Press, Corrected Proof.

McAfee, K. 1999. Selling nature to save it? Biodiversity and green developmentalism. Environment and Planning 17:133-154.

- - . 2012a. The Contradictory Logic of Global Ecosystem Services Markets. Development and Change 43 (1):105-131.

- - . 2012b. Nature in the Market-World: Ecosystem services and inequality. Development 55 (1):25-33.

McCarthy, J. 2005a. Scale, sovereignty, and strategy in environmental governance. Antipode 37 (4):731-753.

McCarthy, J. 2007. Shifting resource entitlements and governance reform during the agrarian transition in Sumatra, Indonesia. Journal of Legal Pluralism 39 (55):95-121.

McCarthy, J., C. Barr, I. A. P. Resosudarmo, and A. Dermawan. 2006. Origins and Scope of Indonesia's Decentralization Laws. In Decentralization of Forest Administration. Implications for Forest Sustainability, Economic Development and Community Livelihoods, edited by C. Barr, I. A. P. Resosudarmo and A. Dermawan. 31-57, Bogor, Indonesia: Center for International Forestry Research (CIFOR).

McCarthy, J. F. 2004. Changing to gray: decentralization and the emergence of volatile socio-legal configurations in Central Kalimantan, Indonesia. World development 32 (7):1199-1223.

- - . 2005b. Between adat and state: institutional arrangements on Sumatra's forest frontier. Human Ecology 33 (1):57-82.

- - . 2005c. Contesting Decentralization: Transnational Policy Narratives and the Emergence of Volatile Socio-Legal Configuration in Central Kalimantan, Indonesia. Mobile People, Mobile Law, Expanding Legal Relations in a Contracting World, edited by F. von Benda-Beckmann and K. von Benda-Beckmann. 153-175, Aldershot: Ashgate Publishing Limited.

-- - 2006. The fourth circle: a political ecology of Sumatra's rainforest frontier: Stanford University Press.

- - . 2012. Certifying in Contested Spaces: Private regulation in Indonesian forestry and palm oil. Third World Quarterly 33 (10):1871-1888. 
Mcculloch, L. 2010. Ulu Masen REDD Demonstration Project-The challenges of Tackling Market Policy and Governance Failures that Underlie Deforestation and Forest Degradation. Forest Conservation Team Occasional Papers, Kamiyamaguchi, Japan: Institute for Global Environmental Strategies.

McGregor, A. 2010. Green and REDD? Towards a political ecology of deforestation in Aceh, Indonesia. Human Geograpy 3 (2):21-34.

Meadowcroft, J. 2002. Politics and scale: some implications for environmental governance. Landscape and urban planning 61 (2):169-179.

Menteri Kehutanan. 1995. Keputusan Menteri Kehutanan Nomor: 592/Kpts-IV/1995 Tentang Pengesahan Rencana Karya Pengusahaan Hutan Yang Meliputi Seluruh Jangka Waktu Pengusahaan Hutan (Sementara) Atas Nama PT. Asialog Provinsi Jambi. In No. 592/KptsIV/1995. Jakarta, Indonesia.

---. 2008a. Peraturan Menteri Kehutanan Tentang Hutan Desa. In No. P. 49/Menhut-II/2008. Jakarta, Indonesia.

- - . 2008b. Peraturan Menteri Kehutanan, Nomor: P.68/Menhut-II/2008 tentang Penyelenggaraan Demonstration Activities Pengurangan Emisi Karbon Dari Deforestatsi Dan Degradasi Hutan. In P.68/Menhut-II/2008. Jakarta, Indonesia.

-- - 2009. Peraturan Menteri Kehutanan Republik Indonesia Nomor P.36/Menhut-II/2009 Tentang Tata Cara Perizinan Usaha Pemanfaatan Penserapan Dan/Atau Penyimpanan Karbon Pada Hutan Produksi dan Hutan Lindung. In P.36/Menhut-II/2009. Jakarta, Indonesia.

- - . 2011. Peraturan Menteri Kehutanan Republik Indonesia Nomor: P55/Menhut-II/2011 Tentang Tata Cara Permohonan Izin Usaha Pemanfaatan Hasil Hutan Kayu Pada Hutan Tanaman Rakyat Dalam Hutan Tanaman. In No. P.55/Menhut-II/2011. Jakarta, Indonesia.

---. 2014. Peraturan Menteri Kehutanan Republik Indonesia Tentang Hutan Kemasyarakatan. In No. P. 88/Menhut-II/2014. Jakarta, Indonesia.

Menteri Pertanian. 2007. Peraturan Menteri Pertanian Tentang Pedoman Perizinan Usaha Perkebunan. In No. 26/Permentan/OT.140/2/2007. Jakarta, Indonesia.

Merry, S. E. 2000. Crossing Boundaries: Ethnography in the Twenty-First Century. PoLAR: Political and Legal Anthropology Review 23 (2):127-133.

Mertz, O. 2009. Trends in shifting cultivation and the REDD mechanism. Current Opinion in Environmental Sustainability 1 (2):156-160.

Metzner, J. 1981. Palu (Sulawesi): Problematik der Landnutzung in einem klimatischen Trockental am Äquator. Erdkunde 35 (1):42-54.

Millennium Challenge Account. 2013. Berbak Landscape, Muaro Jambi District [accessed 08.10 2015]. Available from http://gp.mca-indonesia.go.id/en/project-landscape/our-landscape-inglance/berbak-landscape-muaro-jambi-district/.

--- . 2015. Consolidation and Partnership for Progress Acceleration, Executive Summary MCAIndonesia, Annual Report, April 2013 - December 2014. Jakarta, Indonesia.

Ministry of Forestry, I. 2007. REDDI, Reducing Emissions from Deforestation and Forest Degradation in Indonesia Jakarta, Indonesia: Indonesia Forest Climate Alliance and Ministry of Forestry.

- - . 2008. Ministry of Forestry Regulation No. P.61/Menhut-II/2008 on Provisions and Pocedures for Issuing Ecosystem Restoration Forest Timber Utilisation Permits for Natural Forests in Production Forests through Applications. In No. P61/Menhut-II/2008. Jakarta, Indonesia.

---. 2009. Ministry of Forestry Republic of Indonesia Decree Number P. 36/Menhut-II/2009 (unofficial translation) In P.36/Menhut-II/2009.

Mochtar, P. 1995. Indonesia: Historizing the New Order's Legitimacy Dilemma. In Political legitimacy in Southeast Asia: The quest for moral authority, edited by M. Alagappa. 224-526, Stanford, USA: Stanford University Press.

Moeliono, M., and A. Dermawan. 2006. The Impacts of Decentralization on Tenure and Livelihoods. In Decentralization of Forest Administration. Implications for Forest Sustainability, Economic Development and Community Livelihoods, edited by C. Barr, I. A. P. Resosudarmo, A. Dermawan and J. McCarthy. 108-120, Bogor, Indonesia: Center for International Forestry Research (CIFOR). 
Moniaga, S. 1993. Toward Community-Based Forestry and Recognition of Adat Property Rights in the Outer Islands of Indonesia. In Legal Frameworks for Forest Management in Asia. Case Studies of Community/State Relations, edited by J. Fox, Occasional Paper No. 16, East-West Center, Honol Honolulu: East-West Center.

Moore, D. S. 1998. Subaltern struggles and the politics of place: Remapping resistance in Zimbabwe's eastern highlands. Cultural anthropology 13 (3):344-381.

Müller-Mahn, D., and J. Verne. 2011. Post-development: Geographische Entwicklungsforschung jenseits binärer Raumbilder. In Geographie, Physische Geographie und Humangeographie, edited by H. Gebhardt, R. Glaser, U. Radtke and P. Reuber. 775-778, München: Spektrum Verlag.

Muradian, R., M. Arsel, L. Pellegrini, F. Adaman, B. Aguilar, B. Agarwal, E. Corbera, D. Ezzine de Blas, J. Farley, G. Froger, E. Garcia-Frapolli, E. Gómez-Baggethun, J. Gowdy, N. Kosoy, J. F. Le Coq, P. Leroy, P. May, P. Méral, P. Mibielli, R. Norgaard, B. Ozkaynak, U. Pascual, W. Pengue, M. Perez, D. Pesche, R. Pirard, J. Ramos-Martin, L. Rival, F. Saenz, G. Van Hecken, A. Vatn, B. Vira, and K. Urama. 2013. Payments for ecosystem services and the fatal attraction of win-win solutions. Conservation Letters 6 (4):274-279.

Murdiyarso, D., S. Dewi, D. Lawrence, and F. Seymour. 2011. Indonesia's forest moratorium: A stepping stone to better forest governance? Bogor, Indonesia: Center for International Forestry Research (CIFOR).

Murdiyarso, D., M. V. Noordwijk, U. R. Wasrin, T. P. Tomich, and A. Gillison. 2002. Environmental benefits and sustainable land-use options in the Jambi transect, Sumatra. Journal of Vegetation Science 13 (3):429-438.

Naughton-Treves, L., and K. Wendland. 2014. Land Tenure and Tropical Forest Carbon Management. World Development 55:1-6.

Neeff, T., L. Ashford, J. Calvert, C. Davey, J. Durbin, J. Ebeling, T. Herrera, T. Janson-Smith, B. Lazo, R. Mountain, S. O'Keeffe, S. Panfil, N. Thorburn, C. Tuite, M. Wheeland, and S. Young. 2009. The forest carbon offsetting survey 2009: Eco Securitas, Conservation International, The Climate, Community\& Biodiversity Alliance, ClimateBiz.

Neumann, R. P. 2009. Political ecology: theorizing scale. Progress in Human Geography 33 (3):398-406.

Nevins, J., and N. L. Peluso. 2008. Introdution: Commoditization in Southeast Asia. In Taking Southeast Asia to Market, edited by J. Nevins and N. L. Peluso. 1-24, Ithaca, USA: Cornell University Press.

Nuijten, M. 2005. Power in practice: a force field approach to natural resource management. The Journal of Transdisciplinary Environmental Studies 4 (2):1-14.

Nurhaniah. 2006. Peran Kepala Desa Dalam Pendaftaran Hak Milik Atas Tanah Setelah Berlakunya PP NO. 24 Tahun 1997 Di Kecamatan Tanah Grogot Kabupaten Pasir Kalimantan Timur, Program Pascasarjana Magister Kenotariatan Universitas Diponegoro, Semarang.

Nurjaya, I. N. 2005. Sejarah Hukum Pengelolaan Hutan di Indonesia. Jurisprudence 2 (1):35-55.

Ong, A. 2006. Neoliberalism as exception: Mutations in citizenship and sovereignty: Duke University Press.

Osborne, T. M. 2011. Carbon forestry and agrarian change: access and land control in a Mexican rainforest. Journal of Peasant Studies 38 (4):859-883.

Pagiola, S. 2011. Using PES to implement REDD, PES Learning Paper 2011-1. Washington DC, USA: The World Bank.

Paoli, G. D., P. Gillespie, P. L. Wells, L. Hovani, A. Sileuw, N. Franklin, and J. Schweithelm. 2013. Oil Palm in Indonesia. Governance, Decision Making, \&Implications for Sustainable Development Jakarta, Indonesia: The Nature Conservancy.

Pasgaard, M. 2015. Lost in translation? How project actors shape REDD+ policy and outcomes in Cambodia. Asia Pacific Viewpoint 56 (1):111-127.

Peet, R., P. Robbins, and M. Watts. 2011. Global nature. In Global political ecology, edited by R. Peet, P. Robbins and M. Watts. 1-47, Milton Park: Routledge.

Peluso, N. L., S. Afiff, and N. F. Rachman. 2008. Claiming the grounds for reform: agrarian and environmental movements in Indonesia. Journal of Agrarian Change 8 (2-3):377-407. 
Peluso, N. L., and C. Lund. 2011. New frontiers of land control: Introduction. Journal of Peasant Studies 38 (4):667-681.

Peluso, N. L., and P. Vandergeest. 2001. Genealogies of the political forest and customary rights in Indonesia, Malaysia, and Thailand. The Journal of Asian Studies 60 (03):761-812.

Pemerintah Kabupaten Batang Hari. 2010. Rencana Strategi Penerapan Good Forestry Governance Kabupaten Batang Hari. Muaro Bulian, Indonesia: Pemerintah Kabupaten Batang Hari.

---. 2012. Sejarah Singkat Kabupaten Batang Hari [accessed 08.10.2015]. Available from http://www.batangharikab.go.id/bat/statis-7-sejarahberdirinyakabupatenbatanghari.html

Pemerintah Kabupaten Muaro Jambi. 2012. Rencana Pembangunan JangkaPanjang Daerah (RPJPD) KabupatenMuaro Jambi, Tahun 2006-2025. Sengeti, Jambi, Indonesia: BAPPEDA Muaro Jambi.

Pemerintah Kabupaten Tanjung Jabung Timur. 2012. Potensi Daerah dan Peluang Investasi Kabupaten Tanjung Jabung Timur Dektor Kehutanan [accessed 13.03.2015]. Available from http://tanjabtimkab.go.id/profil-

investasi/index.php?option=com_content $\&$ view=article\&id=73\&/temid=82.

Pemerintah Provinsi Jambi. 2011. Jambi Sebagai Provinsi Percontohan Untuk Mekanisme REDD+. Jambi, Indonesia.

-- - 2012. Rencana Aksi Daerah Penurunan Emisi Gas Rumah Kaca (RAD GRK) Provinsi Jambi Jambi, Indonesia Pemerintah Provinsi Jambi.

Perbatakusuma, E. A., M. Ridwansyah, A. Akiefnawati, R. Widolo, W. Kurniawan, D. Primadona, M. Shakti, I. Andrian, D. Lindawati, and Alfiansyah. 2012. Strategi dan Rencana Aksi Provinsi Jambi 2012-2030. Dokumen Risalah Eksekutif. Jambi, Indonesia: Komisi Daerah REDD+ Jambi.

Perreault, T. 2003. Changing places: transnational networks, ethnic politics, and community development in the Ecuadorian Amazon. Political geography 22 (1):61-88.

Peskett, L. 2011. Benefit sharing in REDD+: exploring the implications for poor and vulnerable people. Washington, D.C., USA: The World Bank and REDD-net.

Peters-Stanley, M., and G. Gonzalez. 2014. Sharing the Stage State of the Voluntary Carbon Markets 2014. Washington, DC, USA: Forest Treds' Ecosystem Marketplace.

Phelps, J., D. Friess, and E. Webb. 2012. Win-win REDD+ approaches belie carbon-biodiversity tradeoffs. Biological Conservation 154:53-60.

Phelps, J., M. C. Guerrero, D. A. Dalabajan, B. Young, and E. Webb. 2010. What makes a 'REDD'country? Global Environmental Change 20 (2):322-332.

Pichler, M. 2014. Politische Ökologie der Palmöl- und Agrartreibstoffproduktion in Südostasien. Münster: Westfälisches Dampfboot.

Plan Vivo. 2013. The Plan Vivo Standard for Community Payment for Ecosystem Services Programmes: Plan Vivo Foundation

---. 2015. Project Pipeline [accessed 04.12. 2015]. Available from http://www.planvivo.org/project-network/project-pipeline/.

Pokorny, B., J. Johnson, G. Medina, and L. Hoch. 2012. Market-based conservation of the Amazonian forests: Revisiting win-win expectations. Geoforum 43 (3):387-401.

Polsek Sungai Bahar. 2011. Data Profil Desa Dalam Wilayahm Sungai Bahar, Desa Tanjung Lebar. Bahar Selatan, Jambi, Indonesia.

Potschin, M., and R. Haines-Young. 2006. "Rio+ 10", sustainability science and Landscape Ecology. Landscape and Urban Planning 75 (3):162-174.

Potter, L. 2012. New transmigration 'paradigm'in Indonesia: Examples from Kalimantan. Asia Pacific Viewpoint 53 (3):272-287.

Poulantzas, N. 1978. Staatstheorie, Politischer Überbau, Ideologie, Sozialistische Demokratie. Hamburg: VSA-Verlag.

Presiden Republik Indonesia. 1960a. Peraturan Pemerintah Pengganti Undang-Undang Nomor 56 Tahun 1960. In No 56/1960. Jakarta, Indonesia.

-- . 1960b. Undang-Undang No.5 Tahun 1960 Tentang Peraturan Dasar Pokok-Pokok Agraria. In No.5 1960. Jakarta, Indonesia.

---. 1967. Undang-Undang Nomor 5 Tahun 1967 Tentang Ketentuan-Ketentuan Pokok Kehutanan. In No. 5/1967. Jakarta, Indonesia. 
- - . 1990. Peraturan Pemerintah Republik Indonesia Tentang Hak Pengusahaan Hutan Tanaman Industri. In No. 7/1990. Jakarta, Indonesia.

-- - 1997. Peraturan Pemerintah Republik Indonesia. In No. 24/ 1997 Jakarta, Indonesia.

-- . 1999. Undang-Undang Republik Indonesia Nomor 41 Tahun 1999 Tentang Kehutanan. In No 41/1999. Jakarta, Indonesia.

Pundi Sumatera. 2014. Project Identification Note (PIN) Community Forest Management Project in Jangkat Highland, JAMBI, Sumatra, Merangin, Jambi, Indonesia: SSS-PUNDI.

Purcell, M. 2002. Excavating Lefebvre: The right to the city and its urban politics of the inhabitant. GeoJournal 58 (2):99-108.

Purnomo, H., D. Suyamto, L. Abdullah, and R. Irawati. 2012. REDD+ actor analysis and political mapping: an Indonesian case study. International Forestry Review 14 (1):74-89.

Purwanto, H. 2013. Local To Global ; How Serikat Petani Indonesia Has Accelerated The Movement For Agrarian Reform. In La Via Campesina's Open Book: Celebrating 20 Years of Struggle and Hope, edited by La Via Campesina. 1-12, Jakarta, Indonesia: La Via Campesina.

Pye, O. 2012. Changing Socio-Natures in South-East Asia. Austrian Journal of South-East Asian Studies 5 (2):198.

Rachman, N. F. 2011. The Resurgence of Land Reform Policy and Agrarian Movements in Indonesia. PhD-thesis, Environmental Science, Policy and Management, University of California, Berkeley, Berkeley.

Rachman, N. F. 2013. Undoing Categorical Inequality Masyarakat Adat, Agrarian Conflicts, and Struggle for Inclusive Citizenship in Indonesia, Paper Sajogyo Institute. Bogor, Indonesia: Sajogyo Institute.

Rahmina, H., Y. Sofia, E. Marbyanto, and A. Mustofa. 2011. Tata Cara dan Prosedur Pengembangan Program Pengelolaan Hutan Berbasis Masyarakat dalam Kerangka Undang-Undang No. 41 Tahun 1999. Jakarta, Indonesia: Gesellschaft für Internationale Zusammenarbeit (GIZ) and Ministry of Forestry.

Reed, M. G., and S. Bruyneel. 2010. Rescaling environmental governance, rethinking the state: A threedimensional review. Progress in Human Geography 34 (5):646-653.

REKI, PT Restorasi Ekosistem Indonesia. 2011a. Profil Masyarakat Desa di Sekitar Kawasan PT. Restorasi Ekosistem Indonesia-Desa Bungku, Durian Dangkal (unpublished document). Bungku, Jambi, Indonesia.

- - . 2011b. Surat Pernyataan, edited by Kepala Desa Bungku, PT REKI, Pemerintah Kabupaten Batanghari.

---. 2013. Map of Encroachment 2005-2013 (unpublished document). Bungku, Jambi, Indonesia.

- - . 2014. Nature Tourism in the Harapan Rainforest. Harapan Rainforest is a paradise for wildlife adventurers. [accessed 18.11. 2015]. Available from http://harapanrainforest.org/harapan/subprogram/Nature\%20Tourism\%20in\%20the\%20Har apan\%20Rainforest\#.Vkxz_OLY5zk.

Republic of Indonesia. 2011a. Masterplan Acceleration and Expansion of Indonesia, Economic Development 2011-2025. Jakarta, Indonesia: Coordinating Ministry for Economic Affairs.

---. 2011b. Presidential Regulation of The Republic of Indonesia No. 61 Year 2011 on The National Action Plan for Greenhouse Gas Emissions Reductions. In No.61/2011. Jakarta, Indonesia.

Republika Online. 2009. 150 KK Transmigrasi Segera Ditempatkan di Muarojambi [accessed 20.01. 2014]. Available from http://www.republika.co.id/berita/breakingnews/nusantara/09/09/07/74563-150-kk-transmigrasi-segera-ditempatkan-di-muarojambi.

Resosudarmo, I. A. P. 2004. Closer to people and trees: will decentralisation work for the people and the forests of Indonesia? The European Journal of Development Research 16 (1):110-132.

Resosudarmo, I. A. P., S. Atmadja, A. D. Ekaputri, D. Y. Intarini, Y. Indriatmoko, and P. Astri. 2014. Does tenure security lead to REDD+ project effectiveness? Reflections from five emerging sites in Indonesia. World Development 55:68-83.

Resosudarmo, I. A. P., C. Barr, A. Dermawan, and J. McCarthy. 2006. Fiscal Balancing and the Redistribution of Forest Revenues. In Decentralization of Forest Administration in Indonesia. Implications for Forest Sustainability, Economic Development and Community Livelihoods., 
edited by C. Barr, I. A. P. Resosudarmo, A. Dermawan and J. McCarthy. 58-86, Bogor, Indonesia: Center for International Forest Research (CIFOR).

Rettet den Regenwald. 2014. Palmölfirma PT Asiatic Persada 3 Jahrzehnte Landraub, Vertreibung, Menschenrechtsverletzungen, Gewalt und Mord. Eine Chronologie [accessed 27.10 2015]. Available from https://www.regenwald.org/files/de/Chronic-Asiatic-Persada.pdf.

Rhee, S. 2009. The cultural politics of collaboration to control and access forest resources in Malinau, East Kalimantan. In The Decentralization of Forest Governance - Politics, Economics and the Fight for Control of Forests in Indonesian Borneo, edited by M. Moeliono, E. Wollenberg and G. Limberg. 43-59, London, UK: Earthscan.

Ribot, J. C., and N. L. Peluso. 2003. A Theory of Access*. Rural sociology 68 (2):153-181.

Rodríguez de Francisco, J. C. 2013. PES, peasants and power in Andean watersheds: power relations and payment for environmental services in Colombia and Ecuador. PhD-thesis, Wageningen School of Social Science, Wageningen University, Wageningen, The Netherlands.

Rodriguez de Francisco, J. C., and R. Boelens. 2014. Payment for environmental services and power in the Chamachán watershed, Ecuador. Human Organization 73 (4):351-362.

Rodríguez de Francisco, J. C., J. Budds, and R. Boelens. 2013. Payment for environmental services and unequal resource control in Pimampiro, Ecuador. Society \& Natural Resources 26 (10):12171233.

Roth, D. 2009. Property and authority in a migrant society: Balinese irrigators in Sulawesi, Indonesia. Development and Change 40 (1):195-217.

RSPB, Royal Society for the Protection of Birds. 2015. Annual Review 2014-2015 [accessed 04.12 2015]. Available from http://www.rspb.org.uk/about/run/annualreview/2015/index.html.

Sammukri, M. H. 2013. Mobilities of Indigeneity: Intermediary NGOs and Indigenous Peoples in Indonesia. In Adat and Indigeneity in Indonesia: Culture and Entitlements between Heteronomy and Self-Ascription edited by B. Hauser-Schäublin. 115-131, Göttingen, Germany: Universitätsverlag Göttingen.

Sargent, S. 2015. The contested meaning of free, prior and informed consent in international financial law and Indigenous rights. In Culture and International Economic Law, edited by V. Vadi and D. B. Witte. 87-103, London and New York: Routledge.

Sayer, J., T. Sunderland, J. Ghazoul, J.-L. Pfund, D. Sheil, E. Meijaard, M. Venter, A. K. Boedhihartono, M. Day, and C. Garcia. 2013. Ten principles for a landscape approach to reconciling agriculture, conservation, and other competing land uses. Proceedings of the national academy of sciences $110(21): 8349-8356$.

Sayre, N. F. 2005. Ecological and geographical scale: parallels and potential for integration. Progress in Human Geography 29 (3):276-290.

Sayre, N. F., and A. D. Vittorio. 2009. Scale. In International Encyclopedia of Human Geography, edited by R. Kitchin and N. Thrift. 19-28, Oxford: Elsevier.

Schiel, T. 2001. Stände, Klassen, strategische Gruppen:(noch) eingebettete und ausgebettete Gesellschaften. In Markt, Kultur und Gesellschaft. Zur Aktualität von 25 Jahren Entwicklungsforschung, edited by H. Schrader, M. Kaiser and R. Korff. 97-112, Hamburg, Germany: LIT Verlag.

Schielmann, S., M. Degawan, E. Falley-Rothkopf, B. Henneberger, K. Mantzel, and U. Nolte. 2013. Waldschutzvorhaben im Rahmen der Klimapolitik und die Rechte indigener Völker. Cologne, Germany: Institut für Ökologie und Aktions-Ethnologie e.V.

Schmidt, C. 2008. Analyse von Leitfadeninterviews. In Qualitative Forschung, edited by U. Flick, E. von Kardorff and I. Steinke. 447-456, Reinbek bei Hamburg: Rowohlt Taschenbuch Verlag.

Schroeder, H. 2010. Agency in international climate negotiations: the case of indigenous peoples and avoided deforestation. International Environmental Agreements: Politics, Law and Economics 10 (4):317-332.

Schwarze, S., M. Euler, M. Gatto, J. Hein, E. Hettig, A. M. Holtkamp, L. Izhar, Y. Kunz, J. Lay, and J. Merten. 2015. Rubber vs. oil palm: an analysis of factors influencing smallholders' crop choice in Jambi, Indonesia. Vol. No. 11, EFForTS Discussion Paper Series. Göttingen, Germany: University of Göttingen. 
Scott, J. C. 1989. Everyday Forms of Resistance. Copenhagen Journal of Asian Studies 4:33-62.

Serikat Petani Indonesia. 2012. Dana Pengalihan Hutang Untuk Mengusir Petani [accessed 27.11 2015]. Available from http://www.spi.or.id/dana-pengalihan-hutang-untuk-mengusir-petani/.

Sevin, O., and D. Benoît. 1993. Techniques d'encadrement et Terres-Neuves: les enseignements du delta du Batang Hari (Jambi-Indonésie). Géographie et Cultures (7):93-112.

Sikor, T., and C. Lund. 2009. Access and property: a question of power and authority. Development and change 40 (1):1-22.

-- . 2010. Access and Property: A Question of Power and Authority. In The Politics of Possession: Property, Authority, and Access to Natural Resources, edited by T. Sikor and C. Lund. 1-22, West Sussex, UK: Wiley-Blackwell.

Silalahi, M., and D. Erwin. 2013. Collaborative conflict management on ecosystem restoration (ER) area: Lessons learnt from Harapan Rainforest (HRF) Jambi. Paper read at International Conference of Indonesia Forestry Researchers, 2nd INAFOR, at Menara Peninsula, Jakarta, Indonesia.

Simmel, G. 2007. The Philosophy of Landscape. Theory, Culture \& Society 24 (7-8):20-29.

Singapore Airlines. 2015. Our Commitment to the Environment [accessed 27.10. 2015]. Available from https://www.singaporeair.com/en_UK/about-us/sia-history/sia-environment/.

Smith, J., K. Obidzinski, S. Subarudi, and I. Suramenggala. 2003. Illegal logging, collusive corruption and fragmented governments in Kalimantan, Indonesia. International Forestry Review 5 (3):293302.

Smith, N. 1992. Contours of a spatialized politics: homeless vehicles and the production of geographical scale. Social Text (33):55-81.

---. 2008. Uneven development: Nature, capital, and the production of space. Athens, USA: University of Georgia Press.

Soja, E. W. 1980. The socio-spatial dialectic. Annals of the Association of American Geographers 70 (2):207-225.

Spiller, I., and L. Fuhr. 2010. Wo steht die internationale Klimapolitik nach Cancun? Heinrich Böll Stiftung [accessed 03.12. 2015]. Available from https://www.boell.de/de/navigation/klimaenergie-analyse-klimagipfel-cancun-10814.html.

Steinebach, S. 2013a. Der Regenwald ist unser Haus: die Orang Rimba auf Sumatra zwischen Autonomie und Fremdbestimmung. Göttingen, Germany: Universitätsverlag Göttingen.

- - . 2013b. "Today we Occupy the Plantation-Tomorrow Jakarta": Indigeneity, Land and Oil Palm Plantations in Jambi. In Adat and Indigeneity in Indonesia - Culture and Entitlements between Heteronomy and Self-Ascription, edited by B. Hauser-Schäublin. 63-70, Göttingen, Germany Universitätsverlag Göttingen.

- - - forthcoming. Reproduction of ethninized territories.

Stern, N. 2007. Stern Review: The Economics of Climate Change. Cambridge, UK: Cambridge University Press.

Sunderlin, W. D., A. M. Larson, A. E. Duchelle, I. A. P. Resosudarmo, T. B. Huynh, A. Awono, and T. Dokken. 2014. How are REDD+ Proponents Addressing Tenure Problems? Evidence from Brazil, Cameroon, Tanzania, Indonesia, and Vietnam. World Development 55:37-52.

Swyngedouw, E. 2000. Authoritarian governance, power, and the politics of rescaling. Environment and Planning $D 18$ (1):63-76.

- - . 2004. Globalisation or 'glocalisation'? Networks, territories and rescaling. Cambridge review of international affairs 17 (1):25-48.

---. 2010. Place, nature and the question of scale: interrogating the production of nature: BerlinBrandenburgische Akademie der Wissenschaften.

Szczepanski, K. 2002. Land Policy and Adat Law in Indonesia's Forests. Pacific Rim Law\& Policy Journal $11: 231-255$

Tambunan, I. 2015. 3.200 Perambah Liar di TN Kerinci Seblat Tuntut Akomodasi Hak Kependudukan. Kompas 
TFCA-Sumatera, Tropical Forest Conservation Action-Sumatra. 2014. Selamat Datang di TFCA Sumatera [accessed 04.12. 2015]. Available from http://www.tfcasumatera.org/2014/?lang=en.

The REDD Desk. 2015. Financing agreement RD3412 [accessed 29.05.2016]. Available from http://theredddesk.org/countries/agreements/financing-agreement-rd3412.

The World Bank. 1979. Indonesia Transmigration II Staff Appraisal Report: Regional Projects Department East Asia and Pacific Regional Office.

Thorburn, C. C. 2004. The plot thickens: land administration and policy in post-new order Indonesia. Asia Pacific Viewpoint 45 (1):33-49.

Tidemann, J. 1938. Djambi. Amsterdam: Koloniaal Instituut.

Toumbourou, T. 2015. Fires spark hope for improved law enforcement [accessed 11.11 2015]. Available from http://indonesiaatmelbourne.unimelb.edu.au/fires-spark-hope-for-improved-lawenforcement/.

Towers, G. 2000. Applying the political geography of scale: Grassroots strategies and environmental justice. The Professional Geographer 52 (1):23-36.

Tsing, A. L. 2000. The global situation. Cultural anthropology 15 (3):327-360.

-- - 2005. Friction: An ethnography of global connection. Princenton, USA: Princeton University Press.

Tuong, V. 2009. Indonesia's agrarian movement: Anti-capitalism at a crossroads. In Agrarian angst and rural resistance in contemporary Southeast Asia, edited by D. Caouette and S. Turner. 180-205, Abingdon, UK: Routledge.

Turner, S., and D. Caouette. 2009. Shifting fields of rural resistance in Southeast Asia. In Agrarian angst and rural resistance in contemporary Southeast Asia, edited by D. Caouette and S. Turner. 124, Abingdon: Routledge.

Ufen, A. 2002. Herrschaftsfiguration und Demokratisierung in Indonesien (1965-2000). Hamburg, Germany: Institut für Asienkunde.

- - - 2014. Indonesien: Aufbruchstimmung im Inselreich. Welt Sichten 4/2014.

UN-REDD. 2013. Guidelines on Free, Prior and Informed Consent. Geneva, Switzerland.

UNFCCC, United Nations Framework Convention on Climate Change. 2007. Decision 2/ CP.13 Reducing emissions from deforestati on in developing countries: approaches to stimulate action. Bonn, Germany.

- - . 2010. Decision 1/CP.16 The Cancun Agreements: Outcome of the work of the Ad Hoc Working Group on Long-term Cooperative Action under the Convention. Bonn, Germany.

---. 2013. Warsaw Framework for REDD-plus [accessed 03.12. 2015]. Available from http://unfccc.int/land_use_and_climate_change/redd/items/8180.php.

United Nations Population Fund. 2014. State of World Population 2014. New York, USA: UNFPA.

Usman, M. 2012. Pengusiran Petani REKI Dimulai, 3 Rumah Dirobohkan [accessed 18.09 2015]. Available from http://www.metrojambi.com/v1/daerah/13120-pengusiran-petani-rekidimulai-3-rumah-dirobohkan.html.

Van der Werf, G. R., D. C. Morton, R. S. Defries, J. G. Olivier, P. S. Kasibhatla, R. B. Jackson, G. J. Collatz, and J. Randerson. 2009. CO2 emissions from forest loss. Nature geoscience 2 (11):737-738.

van Meijl, T., and F. von Benda-Beckmann. 1999. Introduction. In Property Rights and Economic Development Land and Natural Resources in Southeast Asia and Oceania edited by T. van Meijl and F. von Benda-Beckmann. 1-14, London, UK: Kegan Paul International.

VCS, Verified Carbon Standard. 2015. What is the voluntary carbon market [accessed 11.12. 2015]. Available from http://www.v-c-s.org/faqs/what-voluntary-carbon-market.

Virgilio, N. R., S. Marshall, O. Zerbock, and C. Holmes. 2010. Reducing Emissions from Deforestation and Degradation (REDD): A Casebook of On-the-Ground Experience. 2010. Arlington, Virginia, USA: The Nature Conservancy, Conservation International and Wildlife Conservation Society.

von Benda-Beckmann, F., and K. von Benda-Beckmann. 1999. A Functional Analysis of Property Rights, with Special Reference to Indonesia. In Property Rights and Economic Development Land and Natural Resources in Sotheast Asia and Oceania edited by T. van Meijl and F. von BendaBeckmann. 15-56, London, UK: Kegan Paul International. 
von Benda-Beckmann, F., K. von Benda-Beckmann, and M. Wiber. 2009. The Properties of Property. In Changing properties of property, edited by F. von Benda-Beckmann, K. von Benda-Beckmann and M. Wiber. 1-39, New York and Oxford: Berghahn Books.

von Benda-Beckmann, K. 1981. Forum shopping and shopping forums: Dispute processing in a Minangkabau village in West Sumatra. The Journal of Legal Pluralism and Unofficial Law 13 (19):117-159.

Vorlaufer, M., M. Ibanez, B. Juanda, and M. Wollni. 2015. Conservation vs. equity: Can payments for environmental services achieve both? Vol. No. 18, EFForTS Discussion Paper Series. Göttingen, Germany: University of Göttingen.

WALHI Jambi. 2009. Alihfungsi Tahura Sungai Aur Jadi Trans dan kebun sawit [accessed 20.01.2014]. Available from http://walhi-jambi.blogspot.de/2009/02/alihfungsi-tahura-sungai-aur-jaditrans.html.

Wallerstein, I. 1974. Dependence in an interdependent world: the limited possibilities of transformation within the capitalist world economy. African Studies Review 17 (01):1-26.

Walsh, T. A., Asmui, Y. Hidayanto, and A. Utomo. 2012. Supporting Ecosystem Restoration Concessions in Indonesia's Production Forests: A Review of the Licensing Framework 2004-2012: Burung Indonesia-Climate and Land Use Alliance.

Walsh, T. A., Y. H. Asmui, and A. B. Utomo. 2012. 1.5 Ecosystem restoration in Indonesia's production forests: towards financial feasibility. ETERN NEWS (54):35-41.

Wardah, N. 2013. Harapan Rainforest: Cultivating or Ignoring Hopes. Msc-thesis, Rural Development Sociology Group, Wageningen University, Wagenigen, The Netherlands.

Warren, C. 1990. The bureaucratisation of local government in Indonesia. Vol. 66, Working Paper. Clayton, Australia The Centre of Southeast Asian Studies Monash University.

Weber, M. 1993. Basic concepts in sociology. New York, USA: Citadel Press.

Weisse, M., and R. Petersen. 2015. Brazil and Indonesia Struggling to Reduce Deforestation [accessed 10.12. 2015]. Available from http://www.wri.org/blog/2015/09/brazil-and-indonesiastruggling-reduce-deforestation.

While, A., A. E. Jonas, and D. Gibbs. 2010. From sustainable development to carbon control: eco-state restructuring and the politics of urban and regional development. Transactions of the Institute of British Geographers 35 (1):76-93.

Whitten, T. 2000. The ecology of Sumatra. Oxford, UK: Oxford University Press.

Wibisono, A. R. 2012. Pelaksanaan Pendaftaran Tanah Pertama Kali Secara Sporadik Menjadi Sertifkat Hak Milik Berdasarkan Surat Segel Fakultas Hukum Unversitas Brawijaya Malang, Indonesia.

Wimmer, A. 2008. The Making and Unmaking of Ethnic Boundaries: A Multilevel Process Theory. American Journal of Sociology 113 (4):970-1022.

Wirasapeotra, K., and H. Octavian. 2012. Ringkasan Hasil Studi Identifikasi dan Analisa Konflik Para Pihak di Proyek Restorasi Ekosistem. Pekanbaru, Riau, Indonesia: Scale-Up.

Wissen, M. 2008. Zur räumlichen Dimensionierung sozialer Prozesse. Die Scale-Debatte in der angloamerikanischen Radical Geography - eine Einleitung. In Politics of Scale: Räume der Globalisierung und Perspektiven emanzipatorischer Politik, edited by M. Wissen, B. Röttger and S. Heeg. 8-32, Münser: Westfälisches Dampfboot.

Wolman, A. 2004. Review of conservation payment initiatives in Latin America: Conservation concessions, conservation incentive agreements and permit retirement schemes. Wm. \& Mary Envtl. L. \& Pol'y Rev. 28:859-981.

World Growth. 2011. The Economic Benefit of Palm Oil to Indonesia. Arlington, USA: World Growth.

Wunder, S. 2005. Payments for environmental services: some nuts and bolts. Vol. No. 42, CIFOR Occasional Paper. Bogor, Indonesia: Center for international Forestry Research (CIFOR).

Wynberg, R., and M. Hauck. 2014. People, Power, and the Coast: a Conceptual Framework for Understanding and Implementing Benefit Sharing. Ecology and Society 19 (1).

Zainuddin. 2013. PT Asiatic Persada dan Permasalahannya. Jambi, Indonesia: KKI Warsi and Wilmar.

Zelli, F., D. Erler, S. Frank, J. Hein, H. Hotz, and A.-M. Santa Cruz Melgarejo. 2014. Reducing Emissions from Deforesttaion and Degradation in Peru - A challenge to social inclusion and multi-level governance. DIE Studies. Bonn: DIE. 
Zimmerer, K. S. 2000. The reworking of conservation geographies: nonequilibrium landscapes and nature-society hybrids. Annals of the Association of American Geographers 90 (2):356-369.

- - . 2006. Cultural ecology: at the interface with political ecology-the new geographies of environmental conservation and globalization. Progress in Human Geography 30 (1):63.

Zimmerer, K. S., and T. J. Bassett. 2003a. Approaching Political Ecology, Society, Nature, and Scale in Human-Environment Studies. In Political ecology: an integrative approach to geography and environment-development studies, edited by K. S. Zimmerer and T. J. Bassett. 1-25, New York, USA: Guilford Press.

- - . 2003b. Future directions in political ecology: nature-society fusions and scales of interaction. In Political ecology: An integrative approach to geography and environment-development studies, edited by K. S. Zimmerer and T. J. Bassett. 275-296, New York, USA: Guilford Press.

ZSL, The Zoological Society of London. 2008. Darwin Initiative Application for Grant for Round 16: Stage 2. London, UK: Darwin Initiative and Department for Environment, Food and Rural Affairs.

---. 2009. Berbak Carbon Initiative - Harnessing carbon to conserve biodiversity [accessed 29.05.2016]. Available from http://static.zsl.org/files/berbak-info-sheet-may-2010-1113.pdf.

- - . 2011. Darwin Initiative Annual Report. London, UK: Darwin Initiative and Department for Environment, Food and Rural Affairs.

---. 2015. About the Zoological Society of London [accessed 04.12. 2015]. Available from http://www.zsl.org/about-us.

Zulu, L. C. 2009. Politics of scale and community-based forest management in southern Malawi. Geoforum 40 (4):686-699. 


\section{Acknowledgments}

As researcher at the German Development Institute (DIE) and associated member of the Collaborative Research Centre 990 (CRC 990) I had the opportunity to benefit from two great and supportive working environments. I am really thankful for that experience created by scientists at administrative staff from both DIE and CRC 990.

Over the last four years many colleagues and friends helped me to complete this thesis. First of all, I like to thank Heiko Faust. I am really thankful for your support, for engaged discussions, for the cordial admission into the $\mathrm{CO} 2$ team, and your supportive pragmatism. I also would like to thank Fariborz Zelli. Fari it was a pleasure working with you. I have really benefitted from your knowledge, your ideas and your constant advice.

Furthermore, I would like to thank Christoph Dittrich for his supervision, constructive feedback and for creating an encouraging research environment at the Department of Human Geography.

At German Development Institute I like to thank especially Carmen Richerzhagen. Thank you Carmen for your critical and encouraging feedback, commenting on draft chapters, manuscripts, presentations and proposals. Furthermore, I would like to express my gratitude to Ines Dombrowsky. Thank you Ines for your trust and for providing me the freedom to develop my own ideas over the last four years. Special thanks to Jean Carlo Rodriguez. I really benefitted from our critical discussions, extended coffee breaks, from your knowledge and your feedback. It is a pleasure having the opportunity to work with you.

This research would not have been possible without the support of Endriatmo Soetarto, Soeryo Adiwibowo and Rina Mardiana from IPB and Rosyani from UNJA. I am really grateful for your advice, for the opportunity to benefit from your great networks, for engaging with RISTEK and for your inspiration.

A very huge "thank you" to all my student and research assistants from IPB, UNJA, University of Göttingen and DIE especially to Arie Perdana, Syakir Muhaimin and Niklas Rehkopp. Thanks Arie and Syakir for your company, for traveling with me, for your energy and your efforts. It was a great time. Thanks Niklas for your patience during endless phone calls and for preparing most of my maps for papers, conference presentations and this thesis.

Moreover, I am thankful to the project coordinators Wolfram Lorenz in Bogor, Bambang Irawan in Jambi and Anette Koehler-Rahm in Bonn. You did a great job! 
Thank you Yvonne Kunz and Barbara Beckert for your constant support, intense discussions, and for finding answers to my almost daily questions via phone. It was a pleasure to be part of your team! I wish you all the best for your own PhD's! I also would like to thank Stefanie Steinebach. Thanks Steffi for introducing me to Bungku, for your great literature hints and for explaining essential elements of Jambi's history. Furthermore, I like to thank Siti Nissa Mardiah and Alina Brad for helping accessing interview partners.

On a personal note I like to thank my friends and family. First of all, to my dearest Marie, your love gave me the force for staying on track during this long way. I would also like to thank my friends Thorsten, Björn, Alex, and Florian for all your personal support. I am especially grateful to my family, to Wolfgang, Jamin and Brigitte for all your care and trust.

Last but not least I like to thank all the people that I interviewed, the village communities of Air Hitam Laut, Bungku, Tanjung Lebar, Seponjen and Sungai Aur and SPI and ZSL for supporting my field stays. Terimas Kasih Banyak!!! 
Annex I: List of interviews, meetings and discussions

List of interviews, meetings and discussions conducted at the village-scale

\begin{tabular}{|c|c|c|c|c|c|c|c|}
\hline Village & $\begin{array}{l}\text { Document } \\
\text { ID, assigned } \\
\text { by ATLAS TI } \\
\text { (transcript) }\end{array}$ & \begin{tabular}{|r|} 
Document \\
ID, assigned \\
by ATLAS TI \\
(Memo)
\end{tabular} & Date & $\begin{array}{l}\text { Inside } \\
\text { REDD+/ } \\
\text { conservation } \\
\text { project }\end{array}$ & Memo & Transcript & Language \\
\hline Air Hitam Laut & no & 51 & 28.09.2012 & no & yes & no & Bahasa Indonesia \\
\hline Air Hitam Laut & no & 59 & 29.09.2012 & no & yes & no & Bahasa Indonesia \\
\hline Air Hitam Laut & 67 & 56 & 30.09 .2012 & no & yes & yes & Bahasa Indonesia \\
\hline Air Hitam Laut & 71 & 57 & 29.09 .2012 & no & yes & yes & Bahasa Indonesia \\
\hline Air Hitam Laut & 70 & 58 & 29.09 .2012 & no & yes & yes & Bahasa Indonesia \\
\hline Air Hitam Laut & no & 53 & 29.09 .2012 & no & yes & no & Bahasa Indonesia \\
\hline Air Hitam Laut & 69 & no & 29.09.2012 & no & no & yes & Bahasa Indonesia \\
\hline Bungku & 96 & 41 & 09.09 .2012 & yes & yes & yes & Bahasa Indonesia \\
\hline Bungku & 85 & 42 & 16.09 .2012 & no & yes & yes & Bahasa Indonesia \\
\hline Bungku & 86 & 43 & 13.09 .2012 & no & yes & yes & Bahasa Indonesia \\
\hline Bungku & no & 44 & 14.09 .2012 & no & yes & no & Bahasa Indonesia \\
\hline Bungku & 78 & 45 & 16.09 .2012 & no & yes & yes & Bahasa Indonesia \\
\hline Bungku & no & 46 & 10.09 .2012 & no & yes & no & Bahasa Indonesia \\
\hline Bungku & 73 & 47 & 10.09 .2012 & no & yes & yes & Bahasa Indonesia \\
\hline Bungku & 74 & 48 & 11.09 .2012 & no & yes & yes & Bahasa Indonesia \\
\hline Bungku & 75 & 49 & 10.09 .2012 & no & yes & yes & Bahasa Indonesia \\
\hline Bungku & no & 50 & 13.09 .2012 & no & yes & no & Bahasa Indonesia \\
\hline Bungku & 95 & 60 & 22.09 .2012 & yes & yes & yes & Bahasa Indonesia \\
\hline Bungku & 66 & 61 & 21.09 .2012 & yes & yes & yes & Bahasa Indonesia \\
\hline Bungku & 68 & 62 & 21.09 .2012 & yes & yes & yes & Bahasa Indonesia \\
\hline Bungku & 83 & 63 & 21.09 .2012 & yes & yes & yes & Bahasa Indonesia \\
\hline Bungku & 76 & 64 & 21.09 .2012 & yes & yes & yes & Bahasa Indonesia \\
\hline Bungku & 116 & 211 & 08.07.2013 & no & yes & yes & Bahasa Indonesia \\
\hline Bungku & 164 & 212 & 07.07 .2013 & no & yes & yes & Bahasa Indonesia \\
\hline Bungku & 130 & 200 & 24.08 .2013 & yes & yes & yes & Bahasa Indonesia \\
\hline Bungku & 3 & 201 & 25.08 .2013 & yes & yes & yes & Bahasa Indonesia \\
\hline Bungku & 150 & 215 & 08.07 .2013 & no & yes & yes & Bahasa Indonesia \\
\hline Bungku & 153 & 216 & 10.07 .2013 & yes & yes & yes & Bahasa Indonesia \\
\hline Bungku & no & 202 & 23.08 .2013 & yes & yes & no & Bahasa Indonesia \\
\hline Bungku & 161 & 218 & 09.07 .2013 & not clear & yes & yes & Bahasa Indonesia \\
\hline Bungku & 108 & 219 & 10.07.2013 & yes & yes & yes & Bahasa Indonesia \\
\hline Bungku & 2 & 220 & 24.08 .2013 & yes & yes & yes & Bahasa Indonesia \\
\hline Bungku & 117 & 221 & 30.07 .2013 & yes & yes & yes & Bahasa Indonesia \\
\hline Bungku & 151 & 222 & 30.07 .2013 & yes & yes & yes & Bahasa Indonesia \\
\hline Bungku & 105 & 223 & 10.07.2013 & yes & yes & yes & Bahasa Indonesia \\
\hline Bungku & 152 & no & 24.08 .2013 & yes & no & yes & Bahasa Indonesia \\
\hline Bungku & 106 & 224 & 10.07.2013 & yes & yes & yes & Bahasa Indonesia \\
\hline Bungku & 107 & 225 & 09.07 .2013 & yes & yes & yes & Bahasa Indonesia \\
\hline Bungku & 166 & 226 & 31.07 .2013 & yes & yes & yes & Bahasa Indonesia \\
\hline Bungku & 208 & 227 & 23.08 .2013 & yes & yes & yes & Bahasa Indonesia \\
\hline
\end{tabular}




\begin{tabular}{|c|c|c|c|c|c|c|c|}
\hline Bungku & 160 & 228 & 08.07.2013 & no & yes & yes & Bahasa Indonesia \\
\hline Bungku & 165 & 229 & 08.07.2013 & no & yes & yes & Bahasa Indonesia \\
\hline Bungku & no & 230 & 09.07.2013 & no & yes & no & Bahasa Indonesia \\
\hline Bungku & 112 & no & 07.07.2013 & no & no & yes & Bahasa Indonesia \\
\hline Bungku & $94^{489}$ & no & n.a. & not clear & no & yes & Bahasa Indonesia \\
\hline Bungku & $97^{490}$ & no & n.a. & no & no & yes & Bahasa Indonesia \\
\hline Bungku & 111 & no & 09.07.2013 & yes & no & yes & Bahasa Indonesia \\
\hline Seponjen & no & 248 & 10.09 .2013 & no & yes & no & Bahasa Indonesia \\
\hline Seponjen & 205 & 249 & 10.09 .2013 & no & yes & yes & Bahasa Indonesia \\
\hline Seponjen & 204 & 250 & 15.09 .2013 & no & yes & yes & Bahasa Indonesia \\
\hline Seponjen & 206 & 251 & 10.09 .2013 & no & yes & yes & Bahasa Indonesia \\
\hline Seponjen & 313 & 252 & 12.09 .2013 & no & yes & yes & Bahasa Indonesia \\
\hline Seponjen & 122 & 253 & 13.09 .2013 & no & yes & yes & Bahasa Indonesia \\
\hline Seponjen & 174 & 254 & 11.09 .2013 & no & yes & yes & Bahasa Indonesia \\
\hline Seponjen & 175 & 255 & 08.09.2013 & no & yes & yes & Bahasa Indonesia \\
\hline Seponjen & 314 & 256 & 09.09 .2013 & no & yes & yes & Bahasa Indonesia \\
\hline Seponjen & 315 & 257 & 09.09.2013 & yes & yes & yes & Bahasa Indonesia \\
\hline Seponjen & 173 & 258 & 11.09 .2013 & no & yes & yes & Bahasa Indonesia \\
\hline Seponjen & 172 & 259 & 15.09 .2013 & no & yes & yes & Bahasa Indonesia \\
\hline Seponjen & 176 & 260 & 10.09 .2013 & yes & yes & yes & Bahasa Indonesia \\
\hline Seponjen & 317 & 261 & 15.09.2013 & no & yes & yes & Bahasa Indonesia \\
\hline Seponjen & 318 & 262 & 09.09.2013 & no & yes & yes & Bahasa Indonesia \\
\hline Seponjen & 316 & no & 12.09 .2013 & yes & yes & no & Bahasa Indonesia \\
\hline Seponjen & 312 & no & 12.09 .2013 & yes & no & yes & Bahasa Indonesia \\
\hline Sungai Aur & 138 & 263 & 31.08 .2013 & no & yes & yes & Bahasa Indonesia \\
\hline Sungai Aur & 139 & 279 & 04.09.2013 & no & yes & no & Bahasa Indonesia \\
\hline Sungai Aur & 123 & 265 & 30.08 .2013 & no & yes & yes & Bahasa Indonesia \\
\hline Sungai Aur & no & 266 & 28.08 .2013 & no & yes & no & Bahasa Indonesia \\
\hline Sungai Aur & 307 & 267 & 28.08 .2013 & no & yes & yes & Bahasa Indonesia \\
\hline Sungai Aur & 126 & 268 & 30.08 .2013 & no & yes & yes & Bahasa Indonesia \\
\hline Sungai Aur & no & 269 & 01.09 .2013 & no & yes & no & Bahasa Indonesia \\
\hline Sungai Aur & 131 & 270 & 02.09.2013 & no & yes & yes & Bahasa Indonesia \\
\hline Sungai Aur & 132 & 271 & 29.08.2013 & yes & yes & yes & Bahasa Indonesia \\
\hline Sungai Aur & 135 & 272 & 29.08.2013 & yes & yes & yes & Bahasa Indonesia \\
\hline Sungai Aur & 136 & 273 & 01.09 .2013 & no & yes & yes & Bahasa Indonesia \\
\hline Sungai Aur & 143 & 274 & 02.09 .2013 & no & yes & yes & Bahasa Indonesia \\
\hline Sungai Aur & 141 & 275 & 28.08.2013 & yes & yes & yes & Bahasa Indonesia \\
\hline Sungai Aur & 144 & 276 & 31.08 .2013 & yes & yes & yes & Bahasa Indonesia \\
\hline Sungai Aur & no & 277 & 30.08 .2013 & no & yes & no & Bahasa Indonesia \\
\hline Sungai Aur & no & 278 & 02.09 .2013 & no & yes & no & Bahasa Indonesia \\
\hline Sungai Aur & 179 & 280 & 30.08 .2013 & yes & yes & yes & Bahasa Indonesia \\
\hline Tanjung Lebar & 159 & 281 & 21.07.2013 & yes & yes & yes & Bahasa Indonesia \\
\hline Tanjung Lebar & 124 & 283 & 25.07.2013 & no & yes & yes & Bahasa Indonesia \\
\hline
\end{tabular}

${ }^{489}$ This interview has been conducted by Stefanie Steinebach, she was so kind to share the transcript with me.

490 This interview has been conducted by Stefanie Steinebach, she was so kind to share the transcript with me. 


\begin{tabular}{|l|l|l|l|l|l|l|l|}
\hline Tanjung Lebar & 125 & 284 & 25.07 .2013 & no & yes & yes & Bahasa Indonesia \\
\hline Tanjung Lebar & 128 & 285 & 21.07 .2013 & yes & yes & yes & Bahasa Indonesia \\
\hline Tanjung Lebar & 128 & 286 & 21.07 .2013 & yes & yes & yes & Bahasa Indonesia \\
\hline Tanjung Lebar & 129 & 287 & 21.07 .2013 & yes & yes & yes & Bahasa Indonesia \\
\hline Tanjung Lebar & 178 & 288 & 22.07 .2013 & yes & yes & yes & Bahasa Indonesia \\
\hline Tanjung Lebar & 145 & 289 & 27.07 .2013 & yes & yes & yes & Bahasa Indonesia \\
\hline Tanjung Lebar & 127 & 290 & 26.07 .2013 & no & yes & yes & Bahasa Indonesia \\
\hline Tanjung Lebar & no & 291 & 22.07 .2013 & yes & yes & no & Bahasa Indonesia \\
\hline Tanjung Lebar & 118 & no & 21.07 .2013 & yes & No & yes & Bahasa Indonesia \\
\hline Tanjung Lebar & 149 & 292 & 25.07 .2013 & no & yes & yes & Bahasa Indonesia \\
\hline Tanjung Lebar & 171 & 293 & 23.07 .2013 & yes & yes & yes & Bahasa Indonesia \\
\hline Tanjung Lebar & 113 & 294 & 27.07 .2013 & no & yes & yes & Bahasa Indonesia \\
\hline Tanjung Lebar & 162 & 295 & 21.07 .2013 & yes & yes & yes & Bahasa Indonesia \\
\hline Tanjung Lebar & 163 & 296 & 21.07 .2013 & yes & yes & yes & Bahasa Indonesia \\
\hline Tanjung Lebar & 167 & 297 & 27.07 .2013 & yes & yes & yes & Bahasa Indonesia \\
\hline Tanjung Lebar & 168 & 298 & 21.07 .2013 & yes & yes & yes & Bahasa Indonesia \\
\hline Tanjung Lebar & 169 & 299 & 27.07 .2013 & yes & yes & yes & Bahasa Indonesia \\
\hline Tanjung Lebar & 170 & 300 & 26.07 .2013 & no & yes & yes & Bahasa Indonesia \\
\hline Tanjung Lebar & 177 & 301 & 25.07 .2013 & no & yes & yes & Bahasa Indonesia \\
\hline
\end{tabular}

\begin{tabular}{|c|c|c|c|c|c|c|c|}
\hline \multicolumn{8}{|c|}{$\begin{array}{l}\text { List of Interviews conducted with NGOs, companies, academia, staff of state agencies } \\
\text { and donor agencies }\end{array}$} \\
\hline Institution & $\begin{array}{r}\text { Document } \\
\text { ID } \\
\text { (transcript) }\end{array}$ & $\begin{array}{l}\text { Document } \\
\text { ID (Memo) }\end{array}$ & Location & Date & Memo & Transcript & Language \\
\hline Agra & 288 & 182 & Jambi & 18.09 .2013 & yes & no & \begin{tabular}{|l|} 
Bahasa Indonesia \\
\end{tabular} \\
\hline AMAN & 92 & 12 & Jakarta & 27.07 .2012 & yes & yes & \begin{tabular}{|l|} 
English \\
\end{tabular} \\
\hline AMAN & 142 & 180 & Jambi & 02.08 .2013 & yes & yes & Bahasa Indonesia \\
\hline Amphal & 146 & 233 & Jambi & 17.07.2013 & yes & yes & Bahasa Indonesia \\
\hline $\begin{array}{l}\text { Bappeda } \\
\text { Jambi }\end{array}$ & 134 & 243 & Jambi & 02.08 .2013 & yes & yes & Bahasa Indonesia \\
\hline $\begin{array}{l}\text { Berbak } \\
\text { National Park } \\
\text { Agency }\end{array}$ & no & 54 & $\begin{array}{l}\text { Air Hitam } \\
\text { Laut }\end{array}$ & 29.09 .2012 & yes & no & Bahasa Indonesia \\
\hline $\begin{array}{l}\text { Berbak } \\
\text { National Park } \\
\text { Agency }\end{array}$ & no & 191 & Jambi & 19.08.2013 & yes & no & Bahasa Indonesia \\
\hline $\begin{array}{l}\text { Berbak } \\
\text { National Park } \\
\text { Agency }\end{array}$ & 158 & 192 & Jambi & 19.08.2013 & yes & yes & Bahasa Indonesia \\
\hline BLHD Jambi & 109 & 183 & Jambi & 04.09 .2013 & yes & yes & Bahasa Indonesia \\
\hline $\begin{array}{l}\text { BMU } \\
\text { (German } \\
\text { Federal } \\
\text { Ministry for } \\
\text { the } \\
\text { Environment, } \\
\text { Nature } \\
\text { Conservation, } \\
\text { Building and } \\
\text { Nuclear } \\
\text { Safety) }\end{array}$ & no & 7 & Bonn & 27.03.2012 & yes & no & German \\
\hline
\end{tabular}




\begin{tabular}{|c|c|c|c|c|c|c|c|}
\hline $\begin{array}{l}\text { BMZ (German } \\
\text { Federal } \\
\text { Ministry for } \\
\text { Development } \\
\text { and } \\
\text { Cooperation) }\end{array}$ & no & 4 & Bonn & 30.03 .2012 & yes & no & German \\
\hline $\mathrm{BMZ}$ & no & 5 & Bonn & 10.07 .2012 & yes & no & German \\
\hline $\mathrm{BMZ}$ & no & 6 & Bonn & 20.06 .2012 & yes & no & German \\
\hline $\begin{array}{l}\text { BMZ at the } \\
\text { Federal } \\
\text { German } \\
\text { Embassy } \\
\text { Jakarta }\end{array}$ & no & 9 & Jakarta & 16.07.2012 & yes & no & German \\
\hline BPN Jambi & no & 184 & Jambi & 06.09 .2013 & yes & no & Bahasa Indonesia \\
\hline BPN Jambi & 209 & 193 & Jambi & 22.08 .2013 & yes & yes & Bahasa Indonesia \\
\hline $\begin{array}{l}\text { Burung } \\
\text { Indonesia }\end{array}$ & 99 & 10 & Bogor & 11.10 .2012 & yes & yes & $\begin{array}{l}\text { English and } \\
\text { Bahasa Indonesia }\end{array}$ \\
\hline CAPPA & 157 & 236 & Jambi & 18.07.2013 & yes & yes & Bahasa Indonesia \\
\hline $\begin{array}{l}\text { Carbon } \\
\text { Synthesis/ } \\
\text { Burung } \\
\text { Indonesia }\end{array}$ & no & 19 & Jakarta & 11.10 .2012 & yes & no & $\begin{array}{l}\text { English and } \\
\text { Bahasa Indonesia }\end{array}$ \\
\hline CIFOR & 100 & 11 & Bogor & 27.07 .2012 & yes & yes & English \\
\hline CIFOR & 101 & 13 & Bogor & 27.07 .2012 & yes & yes & English \\
\hline CIFOR & 103 & 23 & Bogor & 26.07 .2012 & yes & yes & English \\
\hline $\begin{array}{l}\text { Conservation } \\
\text { International }\end{array}$ & 392 & no & Doha & 30.11 .2012 & No & yes & English \\
\hline $\begin{array}{l}\text { Dinas } \\
\text { Kehutanan } \\
\text { Batang Hari }\end{array}$ & 80 & 29 & Muaro Bulian & 17.09 .2012 & yes & yes & Bahasa Indonesia \\
\hline $\begin{array}{l}\text { Dinas } \\
\text { Kehutanan } \\
\text { Jambi }\end{array}$ & no & 30 & Jambi & 19.09 .2012 & yes & no & Bahasa Indonesia \\
\hline $\begin{array}{l}\text { Dinas } \\
\text { Kehutanan } \\
\text { Jambi }\end{array}$ & 137 & 187 & Jambi & 27.08 .2013 & yes & yes & Bahasa Indonesia \\
\hline $\begin{array}{l}\text { Dinas } \\
\text { Kehutanan } \\
\text { Jambi }\end{array}$ & 147 & 186 & Jambi & 19.08 .2013 & yes & yes & Bahasa Indonesia \\
\hline $\begin{array}{l}\text { Dinas } \\
\text { Kehutanan } \\
\text { Jambi }\end{array}$ & 72 & 31 & Jambi & 01.09 .2012 & yes & yes & $\begin{array}{l}\text { English and } \\
\text { Bahasa Indonesia }\end{array}$ \\
\hline $\begin{array}{l}\text { Dinas } \\
\text { Kehutanan } \\
\text { Jambi (head) }\end{array}$ & 154 & 188 & Jambi & 15.08 .2013 & yes & yes & Bahasa Indonesia \\
\hline DNPI & no & 27 & Jakarta & 23.07 .2012 & yes & no & English \\
\hline Forest Watch & no & 15 & Bogor & 20.07.2012 & yes & no & English \\
\hline Gita Buana & 207 & 189 & Jambi & 22.08 .2013 & yes & yes & Bahasa Indonesia \\
\hline $\mathrm{GIZ}$ & no & 24 & Jakarta & 23.07 .2012 & yes & no & German \\
\hline $\mathrm{GIZ}$ & 386 & 18 & Jakarta & 24.07 .2012 & yes & no & German \\
\hline GIZ & no & 26 & Eschborn & 19.04 .2012 & \begin{tabular}{|l|} 
yes \\
\end{tabular} & no & German \\
\hline GIZ Forclime & no & 14 & Jakarta & 18.07 .2012 & yes & no & German \\
\hline Greenpeace & 121 & 21 & Jakarta & 19.07.2012 & yes & yes & English \\
\hline $\begin{array}{l}\text { Institute for } \\
\text { Global } \\
\text { Environment } \\
\text { al Strategies } \\
\text { (IGES) }\end{array}$ & 391 & no & Doha & 06.12 .2012 & yes & no & German \\
\hline $\begin{array}{l}\text { Kecamatan } \\
\text { Kumpeh }\end{array}$ & no & 181 & Sua Kandis & 02.09 .2013 & yes & no & Bahasa Indonesia \\
\hline KfW & 385 & 8 & Frankfurt & 19.04 .2012 & \begin{tabular}{|l|} 
yes \\
\end{tabular} & no & German \\
\hline KfW & no & 389 & Frankfurt & 04.02 .2014 & yes & no & German \\
\hline
\end{tabular}




\begin{tabular}{|c|c|c|c|c|c|c|c|}
\hline $\begin{array}{l}\text { Komda } \\
\text { REDD+ }\end{array}$ & no & 34 & Jambi & 31.08 .2012 & yes & no & Bahasa Indonesia \\
\hline $\begin{array}{l}\text { Komda } \\
\text { REDD+ }\end{array}$ & 156 & 190 & Jambi & 15.08 .2013 & yes & yes & Bahasa Indonesia \\
\hline $\begin{array}{l}\text { Ministry for } \\
\text { Finance }\end{array}$ & 89 & 20 & Jakarta & 19.07.2012 & yes & yes & English \\
\hline $\begin{array}{l}\text { Ministry of } \\
\text { Forestry }\end{array}$ & 88 & 25 & Jakarta & 23.07.2012 & yes & yes & English \\
\hline $\begin{array}{l}\text { Ministry of } \\
\text { Forestry }\end{array}$ & 90 & 17 & Jakarta & 19.07.2012 & yes & yes & English \\
\hline $\begin{array}{l}\text { Norwegian } \\
\text { Forest and } \\
\text { Climate } \\
\text { Initiative }\end{array}$ & no & 387 & via Telefone & 11.12 .2012 & yes & no & English \\
\hline PUSKLIM & 102 & 16 & Bogor & 26.07 .2012 & yes & yes & English \\
\hline PT REKI & 148 & 241 & Bungku & 31.07 .2013 & yes & yes & Bahasa Indonesia \\
\hline PT REKI & 110 & 65 & Bungku & 23.09 .2012 & yes & yes & $\begin{array}{l}\text { English and } \\
\text { Bahasa Indonesia }\end{array}$ \\
\hline PT REKI & no & 1 & Bungku & 30.07 .2013 & yes & no & English \\
\hline PT REKI & 210 & 199 & Bogor & 11.10 .2013 & yes & yes & Bahasa Indonesia \\
\hline $\begin{array}{l}\text { Royal Society } \\
\text { for the } \\
\text { Protection of } \\
\text { Birds }\end{array}$ & no & 33 & Jambi & 02.09 .2012 & yes & no & English \\
\hline $\begin{array}{l}\text { Sajogyo } \\
\text { Institute }\end{array}$ & 155 & 196 & Bogor & 13.08 .2013 & yes & yes & English \\
\hline $\begin{array}{l}\text { Sajogyo } \\
\text { Institute }\end{array}$ & no & 197 & Bogor & 08.10 .2013 & yes & no & Bahasa Indonesia \\
\hline $\begin{array}{l}\text { SATGAS } \\
\text { REDD+ (REDD } \\
\text { Taskforce) }\end{array}$ & 133 & 195 & Bogor & 13.08 .2013 & yes & yes & Bahasa Indonesia \\
\hline SETARA & 115 & 238 & Jambi & 18.07 .2013 & yes & yes & Bahasa Indonesia \\
\hline $\begin{array}{l}\text { Sinarmas } \\
\text { Forestry/ } \\
\text { WKS }\end{array}$ & no & 194 & Jambi & 18.09 .2013 & yes & no & Bahasa Indonesia \\
\hline SPI & 104 & 239 & Jakarta & 20.06 .2013 & yes & yes & Bahasa Indonesia \\
\hline SPI & 140 & 240 & Jambi & 12.07 .2013 & yes & yes & Bahasa Indonesia \\
\hline SPI & no & 185 & Jambi & 18.09 .2013 & yes & no & Bahasa Indonesia \\
\hline WARSI & 114 & 237 & Jambi & 29.07.2013 & yes & yes & Bahasa Indonesia \\
\hline $\begin{array}{l}\text { Working } \\
\text { Group on } \\
\text { Forest and } \\
\text { Land Tenure }\end{array}$ & no & 198 & Bogor & 08.10 .2013 & yes & no & Bahasa Indonesia \\
\hline ZGF & no & 28 & Jambi & 31.08 .2012 & yes & no & German \\
\hline ZSL & no & 32 & Jambi & 01.09 .2012 & yes & no & Bahasa Indonesia \\
\hline ZSL & 120 & 22 & Bogor & 27.08 .2012 & yes & yes & English \\
\hline
\end{tabular}




\section{Annex II: Interview guides}

1) Berbak Landscape interview guide (Sequence of questions is depending on interview situation, not all questions will be asked in all interviews)

\section{A) Household characteristics:}

- How many household members do you have? B

- Which profession do you and your household members have?

- Do you have household members living not inside your house? Where are you born?

- $\quad$ Since when are you living in the village?

- Why are you moved to you actual living place?

- Profession at your former living place?

- Did you own or still own land at that place?

\section{B) Land use}

- Which crops are you cultivating?

- $\quad$ Are you cultivating oil palms?

- Since when are you cultivating the crops you grow now?

- What were you growing before?

- Why are you growing these crops?

- $\quad$ Are you using shifting cultivation?

- Do you have any regulations (ADAT regulations/ customary regulations) on land use?

- Has the village regulations for land use?

- Do you follow land use regulations?

\section{C) Forest and natural resources}

- Which meaning do forests have for you?

- Who owns the forest in the region?

- Did the landscape around your village changed during the last 15 years?

- Can you describe me this change and can you explain me the causes? Has this change consequence for your livelihood?

- Which importance do forests have for your livelihood?

- How do you use the forests and forests that are part of the Tahura or the National Park?

- For what do you need forest resources? (E.g. for cooking?)

- Do you sell forest products?

- Which resources do you use (e.g. Nibung, Rattan)?

- What do think about forest conservation?

- What do you think about the National Park and about the Tahura?

- During which season do you harvest forest resources?

\section{D) Rules}


- How do you secure that the forest resources you use do not disappear?

- Do you have any rules for the use of forest resources in your community? Which part of the forest are you using?

- $\quad$ Are you aware of any governmental regulations concerning forest resources or land use in general?

- Which plants are allowed in the kawasan hutan? Is it allowed to gather forest products?

- Do you discuss issues regarding the use of the forests in your community?

- Do you discuss issues regarding the use of the forests in your household?

- What is adat for you?

\section{E) Village and village politics:}

- Do you know of any adat related to forest or land-use?

- Is adat important for getting land or for using land?

- Can you tell me something about the history of this village?

- When the village was founded?

- Do you have a Kepala Parit in your village?

- Tasks\& Responsibilities?

- Can you tell me something about the ethnic structure of the village?

- Since when which ethnic group is living in the village?

- What changed in the village in the last 5- 15 years? And in the last 30 years?

- Which companies are operating in the village and in the surrounding today and before?

- What changes after the company arrived?

- Have people lost their land because of these companies?

- Are people of this village working for these companies? Which benefits are these companies providing for you?

- Do you have problems with one of the companies?

- $\quad$ Are there protected areas (hutan lindung, TAHURA, Taman Nasionl) close to the village?

- Since when there is a TAHURA, Taman Nasional, REDD project?

- Is the village or parts (Dusuns) located in the kawasan hutan or inside the REDD project?

- Do you have meetings in your village?

- Which topics are discussed in village meetings? Which forest issues are discussed in village meetings?

- Are land issues discussed in the village meetings?

- Companies?

- When/ how often village meetings take place? Who is participating in the village meetings?

\section{F) Land tenure}

- Do you own the land that you use?

- Size of the plots you use for agricultural purposes?

- How do you get the land that you use?

- Do you inherit the land? Did you buy the land or did you opened by yourself?

- From whom did you buy or get the land?

- Did you ever open land for some else? Do you want to use more land? Who owned the land before you?

- Do you ever lose land?

- Why do you lose land?

- Is the land you use located inside the Tahura, National Park, REDD project (kawasan hutan)?

- Do you have a certificate for your land? Which certificate do you have?

- Is your land registered by the Kepala Desa or by another authority?

- Do you have land titles isuued by the Kepala Desa in your village?

- What do you have to do for getting a BPN certificate?

- Who owns the not used land in the village? 
- How get newcomers get land in the village or in the region? Role of the Kepala Parit in accessing and distributing land?

- Do you know of any regulations of the kepala desa or kepala adat for getting access to land and for using land?

- $\quad$ Are there conflicts between people on land?

Who is responsible for mediating land conflicts in the village?

- What is tanah hukum adat?

- What us tanah ulayat?

- Is the land you use claimed by someone else, for example by a company or part of a conservation area?

- Do the village have community land?

- Which rules do exist for the community land?

\section{G) Berbak Project-}

- Are you aware that you are living close to a/ in a forest conservation project area?

- Did you ever hear about REDD?

- Who told you about REDD?

What is REDD?

- Do you know that the Tahura is part of a REDD project?

- Did you participate in any meetings organized by the National Park or by NGOs related to REDD?

- Did the project staff or national part staff introduce new rules concerning the use of natural resources?

What do you think about the new rules?

- $\quad$ Are there different regulations for using Tahura and for using the land within the National Park?

2) Harapan Landscape interview guide (Sequence of questions is depending on interview situation, not all questions will be asked in all interviews)

\section{A) Household characteristics:}

- How many household members do you have?

- Which profession do you have?

- Which profession do you and your household members have?

- Are your children in school?

- Do you have household members living not inside your house?

- Where are you born?

- Since when are you living in the village?

\section{B) Land use}

- Which crops are you cultivating?

- Are you cultivating oil palms?

- Since when are you cultivating the crops you grow now?

- Why are you growing these crops?

- Are you using shifting cultivation??

- Are you growing tree crops?

- Do you employ daily laborers?

- Has the village regulations for land use? 
C) Forest and natural resources

- Who owns the forest in the region?

- Did the landscape around your village changed during the last 15 years?

- Can you describe me this change and can you explain me the causes?

- Which importance do forests have for your livelihood?

- How do you use the forests in the Harapan area?

- For what do you need forest resources?

- What are the most important forest resources for your livelihood?

- What do think about forest conservation?

- During which season do you harvest forest resources?

\section{D) Rules}

- How do you secure that the forest resources you use do not disappear?

- Do you have any rules for the use of forest resources in your community?

- Which part of the forest are you using?

- $\quad$ Are you aware of any governmental regulations concerning forest resources or land use in general?

Which plants are allowed in the kawasan hutan?

- Do you discuss issues regarding the use of the forests in your community?

- What is adat for you?

- Do you know of any adat related to forest or land-use?

$\circ \quad$ Is adat important for getting land or for using land?

\section{E) Village and village politics:}

- Can you tell me something about the history of this village?

- When the village was founded?

- Can you tell me something about the ethnic structure of the village?

- Since when which ethnic group is living in the village?

- What changed in the village in the last 5- 15 years? And in the last 30 years?

- Which companies are operating in the village and in the surrounding today and before?

- What changes after the company arrived?

- Have people lost their land because of these companies? Are people of this village working for these companies?

- Which benefits are these companies providing for you? Do you have problems with one of the companies?

- $\quad$ Are there protected areas (hutan lindung, TAHURA, Taman Nasionl) close to the village?

- Is the village or parts (Dusuns) located in the kawasan hutan?

- Do you have meetings in your village?

- Which topics are discussed in village meetings? Which forest issues are discussed in village meetings?

- Companies?

- When/ how often village meetings take place? Who is participating in the village meetings?

\section{F) Land tenure}

- Do you own the land that you use?

- Size of the plots you use for agricultural purposes?

- How do you get the land that you use?

- From whom did you buy or get the land?

- Do you want to use more land? Apakah bapak mau menambah lahan?

- Who owned the land before you? 
- Do you ever lose land?

- Why do you lose land?

- Do you have a certificate for your land? Which certificate do you have?

- Is your land registered by the Kepala Desa or by another authority?

- What do you have to do for getting a BPN certificate?

- Who owns the not used land in the village?

- How get newcomers get land in the village or in the region?

- Do you know of any regulations of the kepala desa or kepala adat for getting access to land and for using land?

- $\quad$ Are there conflicts between people on land?

- Who is responsible for mediating land conflicts in the village?

- What is tanah hukum adat?

- What is tanah ulayat?

- Is the land you use claimed by someone else, for example by REKI or by an oil palm company? Do the village have community land?

- Which rules do exist for the community land?

\section{G) Harapan Rainforest Project-}

- $\quad$ Are you aware that you are living close to a/ in a forest conservation project area?

- What do you know about forests and climate change?

- Did you ever hear about REDD?

- Who told you about REDD?

- What is REDD? Apa itu REDD?

O Who will benefit from REDD?

- Do you know what REKI is?

- Do you know what an ERC concession is?

- Which role has the Harapan/ REKI forest for your livelihood? Did you already get in contact with staff of the Harapan project/REKI?

W What do you think of the Harapan project?

- $\quad$ Did you use the forest or land belonging to REKI? Are you aware of the community activities such as beekeeping/ nurseries of the Harapan project?

- Did you participate in the community development activities of the Harapan project?

- Did you participate in any meetings of the Harapan project?

- Did the project staff introduce new rules concerning the use of natural resources?

- What do you think about the new rules?

- What do you think about the conflict between famers and REKI?

- What are the causes of that conflict in your opinion?

- Did you hear of the mediation process?

- What do you think about the mediation process?

- Did you participate in any mediation meeting?

3) Interview guide for Interviews conducted with NGOs, companies, academia, staff of state agencies and donor agencies (example, some interviews have been conducted without formal guide)

\section{Interview guide on REDD+ related issues (English)}

1) General questions on REDD

a. What are the major challenges for the implementation of REDD in Indonesia?

b. Which influence has REDD on Indonesia's forest policies?

c. What are major critics on REDD stated by NGOS, private sector and governmental institutions? 
d. Who is promoting and who is opposing REDD from your point of view?

e. Will Indonesia reach its emission reduction targets?

f. In how far are ecosystem services (REDD and others) perceived as an income source on the national, provincial and district level? And if so for whom/ for which actors at which levels?

g. Which role has the voluntary carbon market and the CDM A/R (forest carbon projects) in Indonesia?

h. Which role has your institution in the REDD process?

i. What are the most important drivers of deforestation in Indonesia?

2) Regulatory Framework

a. Which REDD related laws and acts were developed by governmental agencies which relevance do they have?

b. Which relevance have the different regulations developed from 2008 onwards of the MOF concerning REDD?

C. Which other ministerial regulations or presidential decrees are relevant for the Indonesian REDD process?

d. Which relevance has the forest delineation process for REDD?

e. Why the forest delineation process proceeds so slowly?

f. Which relevance has Adat law for forest resource management?

g. Which relevance has the palm-oil moratorium for the REDD process?

i. In how far does the moratorium exceed existing laws and regulations?

h. Which social-environmental safeguards exist for forest carbon projects in Indonesia?

i. What does the REDD pilot province status implicate?

j. Which concession types are handed-out by which governmental institution and at which level?

k. I read in various publications and press articles that the establishment of forest concessions leads often to social conflicts, could you explain me the causes of these conflicts?

I. Which formal competencies have the districts in forest management?

$\mathrm{m}$. Which division of competencies exist between districts and national governments regarding forest management?

n. Which community land titles for forest land exist

i. Who can apply for a land title?

ii. How can communities apply?

o. Which forest land titles exist for indigenous communities or adat groups?

i. How can they apply for such titles?

p. The REDD strategy from June $\mathbf{2 0 1 2}$ mentions a land reform, how might this reform look like?

q. Why a land reform is mentioned as prerequisite for REDD in Indonesia?

$r$. The REDD strategy mentions fairness and benefits for the most vulnerable - what does this mean?

s. What do you think on Free and prior informed consent (FPIC) and REDD in Indonesia?

t. Who can apply for ERC concessions?

u. Who applies for ERC concessions?

v. How is demand for ERC concessions developing?

w. What are the strengths and weaknesses of the ERC concession concept?

3) REDD Strategies/ Policies

a. In which stage is the FCPF funded Readiness process?

b. Which relevance has Indonesia's Roadmap for bio fuel production for REDD?

c. What is a conservation district?

d. The conservation of which ecosystem services is the objective of a conservation district? 
e. How can rural development objectives be met considering emission reduction targets?

4) Spatial planning

a. Which criteria does the MOF use for classifying forest land?

b. Are sub-national governments considering revenues from ecosystem services in spatial planning?

c. Which competencies have sub-national governments regarding spatial planning?

d. Which criteria does the national Government use for evaluating spatial planning proposals of sub national governments?

e. Is the amount of carbon stored in different ecosystems already considered in spatial planning? And in law enforcement? e.g. stricter law enforcement in peatlands?

5) Actors

a. Which governmental institutions are important for the Indonesian REDD process?

b. What do think about the establishment of a new REDD and forest related institution such as the REDD+ Agency?

c. Which role has the Ministry for Finance in the REDD process?

d. Which responsibilities and duties do have sub-regional governments in the REDD process?

e. Which role has UPK4 in the REDD process?

f. Which role has the REDD+ Task Force?

i. Who is member of the task force?

ii. Which issues are discussed in the task force?

g. Role of MOF?

h. Role of Ministry for Environment?

i. Which role had the civil society in the formulation of the readiness strategy?

j. Which NGOs are actively promoting REDD?

k. Which NGOS are opposing REDD and why?

I. Which role has Bappenas in the REDD process?

m. Who is responsible for the initial land use classification process?

n. Which role has the private sector in REDD?

6) Distribution

a. Which relevance has the Menhut-II/36/2009 for the distribution of REDD revenues?

b. For which purposes are revenues of the reforestation fund used?

c. In how far can local governments (village, district, and province) benefit from ERC concessions?

d. How can sub-national governments benefit from REDD?

e. Could you explain me the planned Regional Incentive Mechanism promoting greenhouse gas mitigation?

f. Could you please explain me the Dana Alokasi Khusus fund, its purpose and its role for climate change finance?

g. Which incentives exist for sub national entities to abide the moratorium? 


\section{Annex III: CV}

\section{$\underline{\text { CV }}$}

ACADEMIC BACKGROUND:

05/2012$04 / 2016$

09/2010$05 / 2011$

10/2004$12 / 2009$
PhD-Student at the Department of Human Geography, Faculty of Geo Science and Geography, University of Göttingen, Göttingen, Germany.

Supervisors: Prof. Dr. Heiko Faust, Dr. Fariborz Zelli, Prof. Dr. Christoph Dittrich

- Title of thesis: "Rescaling conflictive access and property relations in the context of REDD+ in Jambi, Indonesia"

Postgraduate Training Program on Development Cooperation at German Development Institute/ Deutsches Institut für Entwicklungspolitik (DIE), Germany

Studies of Geography, Cultural Anthropology and Political Science at University of Göttingen, Göttingen, Germany and Université Joseph Fourier, Grenoble, France.

- Diploma thesis on: "Rural Migration in Central Sulawesi, Indonesia - Household strategies as an adaptation strategy to environmental change", based on interviews with rural households and quantitative census data.

WORKING EXPERIENCE:

Since 03/2012 Research Fellow at German Development Institute/ Deutsches Institut für Entwicklungspolitik (DIE), Bonn, Germany.

07/2011- Research Fellow at Research Center for Sustainability Studies (artec) University of 02/2012 Bremen, joint appointment with Leibnitz Center for Tropical Marine Ecology (ZMT), Bremen, Germany.

05/2010- Intern at AGEG International Consulting Services, Kirchheim Teck, Germany.

$07 / 2010$

01/2010- Intern at GIGA Institute for Asian Studies, Hamburg, Germany.

$04 / 2010$

08/2008- Student Assistant at University of Göttingen, Göttingen, Germany

$06 / 2009$ 